\title{
Research in Radiobiology
}

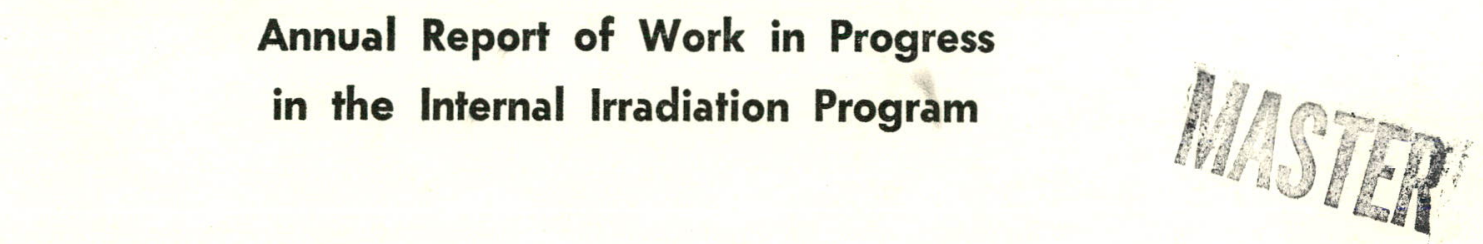

RADIOBIOLOGY DIVISION OF THE DEPARTMENT OF ANATOMY, UNIVERSITY OF UTAH COLLEGE OF MEDICINE

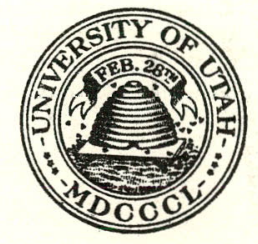

Respectfully Submitted by:

THOMAS F. DOUGHERTY, Director

MARCH 31, 1971

CONTRACT No. AT (11-1)-119 


\section{DISCLAIMER}

This report was prepared as an account of work sponsored by an agency of the United States Government. Neither the United States Government nor any agency Thereof, nor any of their employees, makes any warranty, express or implied, or assumes any legal liability or responsibility for the accuracy, completeness, or usefulness of any information, apparatus, product, or process disclosed, or represents that its use would not infringe privately owned rights. Reference herein to any specific commercial product, process, or service by trade name, trademark, manufacturer, or otherwise does not necessarily constitute or imply its endorsement, recommendation, or favoring by the United States Government or any agency thereof. The views and opinions of authors expressed herein do not necessarily state or reflect those of the United States Government or any agency thereof. 


\section{DISCLAIMER}

Portions of this document may be illegible in electronic image products. Images are produced from the best available original document. 
RESEARCH IN RADIOBIOLOGY.

Annual Report of Work in Progress

in the Internal Irradiation Program

\author{
Radiobiology Division of the Department of Anatomy \\ University of Utah College of Medicine
}

Respectfully Submitted by:

Thnmac. F. Mnuahertv. Director

This report $\cdots$ was prepared as an account of work sponisored by the United States Government. Neither the United:States nor the United States Atomic Energy Cominission, nor any of their employees, nor any of their contractors, subcontractors, or their employees, makes any warranty, express or implied, or assumes any legal liability or responsibility for the accuracy, completeness or usefulness of any information, apparatus, product or process -disclosed, or represents that its use would not infringe privately owned rights.

\title{
March 31, 1971
}

Contract No. AT(11-1)-119 
TABLE OF CONTENTS

$\begin{array}{lr}\text { Group Leaders and Sections } & 5 \\ \text { Availability of Previous Reports } & 6 \\ \text { Current Census of the Beagle Colony } & 8 \\ \text { Preface to Injection Tables } & 9 \\ \quad \text { Dosimetry } & 11\end{array}$

Injection Tables

1. Toxicity Animals

A. Radium-226 14

B. Plutonium-239 24

C. Radium-228 (Mesothorium) 36

D. Thor ium-228 (Radiothorium) 42

E. Strontium-90 48

F. Americium-241 54

G. Californium-252 60

H. Californium-249 62

11. Test Animals 64

A. Radium-226 64

B. Plutonium-239 $\quad 70$

C. Radium-228 (Mesothorium) 78

D. Thorium-228 (Radiothorium) 80

$\begin{array}{ll}\text { E. Strontium-90 } & 82\end{array}$

F. Radium-224 (Quickradium) 86

G. Americium-241 90

H. Lead-210 92

I. Californium-249 94

J. Ancillary $\quad \therefore 6$ 
TABLE OF CONTENTS (Con't.)

Special Topics

Page

Californium Retention, Excretion and Distribution in Beagles Soon After Injection

Early Hematologic Effects of Californium in The Beagle

Distribution of Californium-249 and Berkelium-249 in the Soft Tissues of Beagles

Intracellular Distribution of $249 \mathrm{Cf}$ in Canine Liver

The Disappearance of Californium-249 and Californium252 from the Blood of Beagles

Distribution of Injected ${ }^{24 I} \mathrm{Am}$ in the Beagle Skeleton

Subcellular Distribution of ${ }^{241} \mathrm{Am}(111)$ and $239 \mathrm{Pu}(\mathrm{IV})$ in Livers Studied Serially

Retention of ${ }^{239} \mathrm{Pu}(\mathrm{IV})$ by the Young Adult Beagle

Early Skeletal Distribution and Retention of $239 \mathrm{Pu}$ (IV) at an Intermediate and Low Dose Level in the Beagle

The Interaction of Some Actinide Elements with Blood Constituents

Interaction Between Blood Constituents and Some Actinides

Accumulation of Macrophages Labelled with Plutonium-239 in Marrow Spaces of Lumbar Vertebral Bodies

High Resolution Neutron-Induced Autoradiography of Bone Containing Plutonium-239

240

Electron Microscopy of Radiation Damage in Bone

Autoradiographic Study of the Early Distribution of

${ }^{45} \mathrm{Ca}$ in Alveolar Bone of Dogs

270

Effect of Cortisol on Bone Accretion, ${ }^{4}{ }^{5} \mathrm{Ca}$ Efflux, and Trabecular Bone Resorption

Interrelated Effects of Glucocorticoid and Parathyroid Hormone upon Bone Remodelling

Effect of Cortisol on Incorporation of Tritiated-Tetracycline into Bone 
TABLE OF CONTENTS (Con' $t$. )

The Distribution of ${ }^{3} \mathrm{H}$-Tetracycline in Young-Adult Mouse Bone - A Rapid Method for the Quantitation of New Bone Formation

Page

319

Structural Activity Relationship of Corticosteroids to Growing Bones: Comparison of Activities of Cortisol, Prednisolone, Betamethasone and Dexamethasone

Kidney Function in Aging Control Beagle Dogs

Genetics of Canine Blood Group "A" and Hypothetical Grouping of the Blood Antigens According to their Serological Properties

Growth Dynamics of Osteosarcomas Induced in Beagles by Bone-Seeking Radionuclides

Retention and Distribution of Injected $210 \mathrm{~Pb}$ in Beagles

The Association of $210 \mathrm{~Pb}$ with Constituents of Erythrocytes

A Non-linear Interpretation to the "Doubling Dose" Concept

Additions to Bibliography (April I 1970 through March 31 1971)

Comparative Effects of ${ }^{239} \mathrm{Pu}$ and ${ }^{241} \mathrm{Am}$ on Biochemical Parameters Effects of Dose and Radionuclide Burden Time 
GROUP LEADERS AND SECTIONS

Division of Radiobiology, Department of Anatomy, University of Utah College of Medicine

Section

Director

Prof. Thomas F: Dougherty

Biochemistry

Dr. Charles.J. Nabors, Jr.

Bone

Dr. Webster S.S. Jee

Chemistry

Dr. Walter Stevens

Clinic \& Pathology

Dr. Glenn N. Taylor

3

Hematology

Dr. Jean $H$. Dougherty

Instrumentation

Mr. Garth D. Westenkow

Physics

Dr. Charles W. Mays

Radiology

Dr. William R. Christensen 


\section{AVAILABILITY OF PREVIOUS REPORTS}

Copies of our reports may be obtained from the Clearinghouse for

Federal Scientific and Technical Information, Springfield, Virginia.

Paper copies $\$ 3.00$ each; microfiche copies $\$ 0.65$ each.

\begin{tabular}{|c|c|c|}
\hline Report & Date & Title \\
\hline TID-7639 & Jun 1954 & Consultants Meeting \\
\hline$A E C U-3418$ & Mar 1955 & Annual Report \\
\hline AECU-3109 & Sep 1955 & Semi-Annual Report \\
\hline TID- 16458 & Mar 1956 & Annual Report \\
\hline TID- 16459 & Sep 1956 & Semi-Annual Report \\
\hline AECU -3522 & Mar 1957 & Annual Report \\
\hline AECU -3583 & Sep 1957 & Semi-Annual Report \\
\hline $\operatorname{coo}-215$ & Mar 1958 & Annual Report \\
\hline$c 00-216 *$ & Mar 1958 & Escape of Radon and Thoron \\
\hline $\mathrm{COO}-217$ & Sep 1958 & Semi-Annual Report \\
\hline AECU -4.112 & Feb 1959 & Radioactive Fallout \\
\hline $\mathrm{C} 00-218$ & Mar 1959 & Annual Report \\
\hline $\operatorname{coo}-219 *$ & Sep 1959 & Semi-Annual Report \\
\hline $\mathrm{co0}-220$ & Mar 1960 & Research in Radiobiology \\
\hline$c 00-221$ & Aug 1960 & Interim Report of ${ }^{90} \mathrm{Sr}$ \\
\hline $\mathrm{COO}-222$ & Sep 1960 & Research in Radiobiology \\
\hline $\mathrm{COO}-223$ & Mar 1961 & Research in Radiobiology \\
\hline$c 00-224 \%$ & Sep 1961 & Research in Radiobiology \\
\hline $\mathrm{co0}-225$ & Mar 1962 & Research in Radiobiology \\
\hline $\mathrm{co0}-226$ & Sep 1962 & Research in Radiobiology \\
\hline
\end{tabular}


AVAILABILITY OF PREVIOUS REPORTS (CON't.)

$l_{3}^{1}$

$\frac{\text { Report }}{\cos -227 *}$
$\operatorname{co0}-228 *$
$\cos -119-229$

c00-119-230.

coo-119-231:

c00-119-232*

c00-119-233*

coo-119-234:

c00-119-235

c00-119-236*

COO-119-237*

C00-119-238*

c00-119-239

c00-119-240:

COO-119-241:

c00-119-242*

COO-119-243:

C0O-119-244:

c00-119-245*
Date

Mar 1963

Sep 1963

Mar 1964

Jul 1964

Sep 1964

Mar 1965

Sep 1965

Mar 1966

Sep 1966

Mar 1967

Mar 1968

Aug 1968

Dec 1968

Mar 1969

Mar 1970

Mar 1970

Jan 1971

Mar 1971

May 1971
Title

Research in Radiobiology

Research in Radiobiology

Research in Radiobiology

Safety Manual (replace by C00-119-245)

Research in Radiobiology

Research in Radiobiology

Research in Radiobiology

Research in Radiobiology

Research in Radiobiology

Research in Radiobiology

Research in Radiobiology

$\mathrm{Rb}$ in RBC, Plasma and Urine

$\mathrm{Cs}, \mathrm{Rb}$ and $\mathrm{K} \cdot$ Metabolism

Research in Radiobiology

Retention and Dosimetry

Research in Radiobiology

Osteosarcoma Growth Dynamics

Research in Radiobiology

Radiobiology Safety Manual

* Also available on request from this laboratory. 
CURRENT CENSUS OF THE BEAGLE COLONY

March 31, 1971

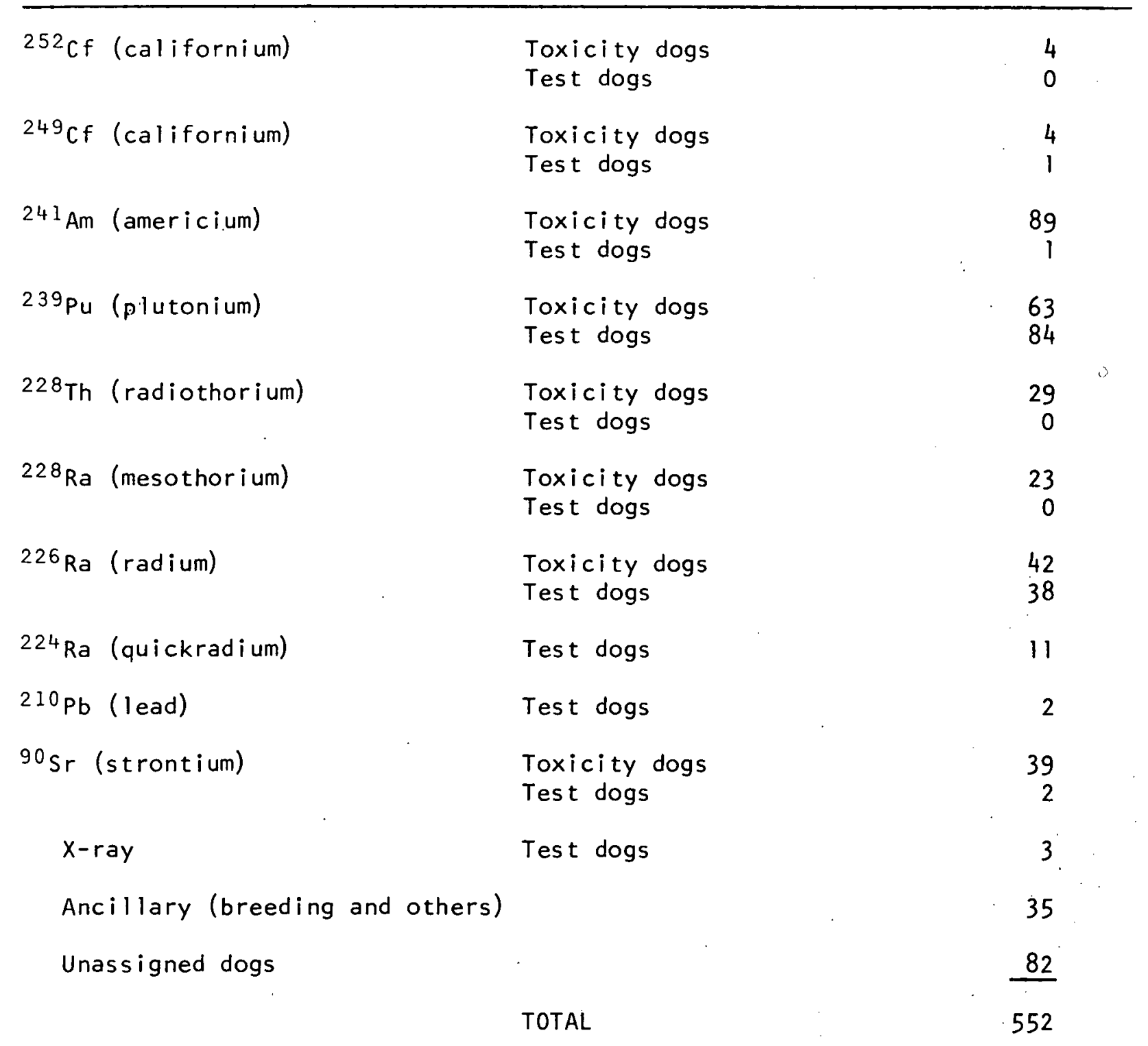




\section{INJECTION TABLES}

Tables $I$ and $\Pi$ list the toxicity and test animals, respectively. Toxicity animals are those animals which will be maintained until sacrifice becomes a clinical necessity; test animals may be sacrificed as needed for special studies.

Dogs are put into the toxicity study at graded injection levels. At each level, about half the dogs are male and half female. Litter mates are used whenever posisible. Each animal receives the designated dose of one radionuclide in a single i.v. injection at approximately 17 months of age. At this age the skeleton is mature with all epiphyses fused except those of the ribs. Twelve such groups have been injected for each of the six radionuclides, ${ }^{226} \mathrm{Ra},{ }^{239} \mathrm{Pu},{ }^{228} \mathrm{Ra},{ }^{228} \mathrm{Th},{ }^{90} \mathrm{Sr}$ and $241 \mathrm{Am}$. The current injection program involves ${ }^{226} \mathrm{Ra}$ and $239 \mathrm{Pu}$ at lower dose levels, ${ }^{249} \mathrm{Cf}$ and $252 \mathrm{Cf}$, and test animals receiving various radionuclides of current interest.

The five injection levels designated by integers are those specified at the early meetings of the consultants, and those designated by nonintegers have been added by the laboratory staff. Since those injection levels were originally specified in "retained" activities, the actual injections are four times the desired "retained" levels of ${ }^{226} \mathrm{Ra},{ }^{228} \mathrm{Ra}$ (Mesothoriund, and $90 \mathrm{Sr}$, and 1.11 times the desired "retained" levels of $239 \mathrm{Pu}$ and $228 \mathrm{Th}$ (Radiothorium).* The desired "retained activities are the same for all the radionuclides except ${ }^{90} \mathrm{Sr}$, in which case they are greater by a factor of 10 . Injection

*Since radioactive decay and excretion occur continuously, the term "retained" dose is obviously meaningless unless the time after injection is specified. Our present measurements indicate that

$$
\begin{aligned}
& \text { average } 226 \mathrm{Ra} \text { retention }=0.25 \text { after } 271 \text { days } \\
& \text { average } 239 \mathrm{Pu} \text { retention }=0.90 \text { after } 6 \text { days } \\
& \text { average } 228 \mathrm{Ra} \text { retention }=0.25 \text { after } 214 \text { days } \\
& \text { average } 228 \mathrm{Th} \text { retention }=0.90 \text { after } 6 \text { days } \\
& \text { average } 90 \mathrm{Sr} \text { retention }=0.25 \text { after } 134 \text { days }
\end{aligned}
$$


level 1 is the basis of the scheme, and is 10 times the maximum permissible concentration of ${ }^{226} \mathrm{Ra}$ in man. Level $1=10 \times \frac{0.1 \mu \mathrm{Ci} 226 \mathrm{Ra}}{70 \mathrm{~kg} \mathrm{man}}=0.0143$ "retained" $\mu \mathrm{Ci} / \mathrm{kg}$. All other injection levels are simple multiples of level 1 as shown below.

\begin{tabular}{|c|c|c|c|c|c|}
\hline Level & 0.1 & is & $1 / 27$ & . & e l \\
\hline Level & 0.2 & is & $1 / 9$ & o & vel \\
\hline Level & 0.5 & is & $1 / 3$ & 0 & level \\
\hline Level & 1.5 & is & 2 & times & S level \\
\hline Level & 1.7 & is & 3 & times & $5 \mathrm{lev}$ \\
\hline Level & 2 & is & 6 & time & 5 leve \\
\hline Level & 3 & is & 18 & time & level \\
\hline Level & 4 & is & 54 & time & 1 \\
\hline Level & 4.5 & is & 94 & time & ; leve \\
\hline Level & 5 & is & 162 & time & \\
\hline
\end{tabular}

The numbering system for the dogs has been built around the injection program and serves as a code to describe each dog's place in the experiment. The first letter tells the sex of toxicity animals $(M=$ male, $F=$ female $)$. When the first letter is $T$, the dog is a test animal. $M, F$, or $T$ is followed by a number which denotes chronological order of groups in the case of toxicity dogs and of individual test dogs.

Next comes a code letter for the radionuclide: $R=226 \mathrm{Ra}, P=239 \mathrm{Pu}$, $M=228 \mathrm{Ra}, T=228 \mathrm{Th}, \mathrm{S}={ }^{90} \mathrm{Sr}, J={ }^{85} \mathrm{Sr}, Q=224 \mathrm{Ra}, W=241 \mathrm{Am}, \mathrm{L}=210 \mathrm{~Pb}$, $G=249 \mathrm{Cf}, F=25.2 \mathrm{Cf}$, and $A=$ Ancillary.

"A" following the regular dog number means that the dog is a replacement. "H" following the regular dog number means that the dog received its dose in more than one injection. "B", "C", or "D" denotes assignment to serial sacrifice schedule. "E" in the final position is used to denote that the dog listed is not a Beagle from our colony. Any of the above letters denoting a radionuclide may follow the final number, in which case the letter indicates that two radionuclides were given. The injection level refers to the radionuclide appearing first in the identifying code. 
Example: MIR5 is a male animal in the first radium group at the highest injection level.

Al though MIR5, MIR4, MIR3, MIR2, MIRI, and MIRO constitute a group and were injected at the same time; the tables are arranged according to injection level to facilitate comparison of all the R5 animals, all the R4 animals, etc.

The conditions listed in the injection tables under "Comments on Dead Dogs" present the lesions or factors that had the most prominent effect on the clinical status of the animal. For example, multiple rib fractures, which seldom produced symptoms, are not listed, even though their incidence was usually much higher than the crippling fractures involving the limb bones or mandible. The hematological changes have been omitted unless they were extreme. Increased rate of tooth. loss, hepatic changes, eye lesicns, and many other factors in the various syndromes have not been included because of space limitations. Over the years many soft tissue tumors have been removed surgically; these tumors were the subject of a separate report, Research in Radiobiology, September $30,1963(000-228)$, pp. 95-108. In many instances, the conditions that have been listed were the reasons for sacrifice of the animal but they were not the immediate cause of death. Most of the animals were euthanized when death appeared imminent or when life could no longer be humanely prolonged.

\section{DOSIMETRY}

The injection tables include the calculated dose in rads to the skeleton at death. ${ }^{226} \mathrm{Ra},{ }^{228} \mathrm{Ra}$, and ${ }^{90} \mathrm{Sr}$ doses are calculated for each dog using his individually observed retention values: $239 \mathrm{Pu}$ and ${ }^{228} \mathrm{Th}$ doses are from our average skeletal retention equations. For our standard beagle, the following equations were used for the EFFECTIVE: skeletal retention at.( $t$ ) days after injection: 
$226 \mathrm{Ra}=0.412 \mathrm{e}^{-0.558 t}+0.105 \mathrm{e}^{-0.0730 t}+0.196 \mathrm{e}^{0.00488 t}+0.287 \mathrm{e}^{0.000299 t}$

(5-level only)

${ }^{226} \mathrm{Ra}=0.251 \mathrm{e}^{-0.982 t}+0.211 \mathrm{e}^{-0.269 t}+0.210 \mathrm{e}^{-0.0155 t}+0.177 \mathrm{e}^{-00204 t}+151 \mathrm{e}^{-0.000150 \mathrm{t}}$

(lower levels)

$$
{ }^{222} \mathrm{Rn} /{ }^{226} \mathrm{Ra}=0.075\left(1-\mathrm{e}^{-0.181 \mathrm{t}}\right) \mathrm{t}^{0.158}
$$

(all levels)

$239 \mathrm{pu}=0.72 \mathrm{t}^{-0.040}$

$228 \mathrm{Ra}=0.251 \mathrm{e}^{-0.982 t}+0.211 \mathrm{e}^{-0.269 t}+2.10 \mathrm{e}^{-0.0158 t}+0.177 \mathrm{e}^{-0.00237 t}+0.151 \mathrm{e}^{-0.000479 t}$
(pure at $\mathrm{t}=0$ )

$84 \%$ retention of in vivo produced ${ }^{228} \mathrm{Th}$ and daughters.

$$
\begin{aligned}
& 228 \mathrm{Th}=0.69 \mathrm{e}^{-0.00113 \mathrm{t}} \\
& { }^{224} \mathrm{Ra} /{ }^{228} \mathrm{Th}=0.895 \\
& 212 \mathrm{~Pb} / 228 \mathrm{Th}=0.866
\end{aligned}
$$

$90 \mathrm{Sr}=0.36 \mathrm{e}^{-0.95 t}+0.29 \mathrm{e}^{-0.12 t}+0.10 \mathrm{e}^{-0.0092 t}+0.12 \mathrm{e}^{-0.0020 t}+0.13 \mathrm{e}^{-0.00022 t}$

* Effective retention is decreased by both radioactive decay and biological elimination.

Detailed retention data and dosimetric analyses have been presented in a special report C00-119-241 (March 1970).

$228 \mathrm{Ra}$ doses deserve special comment. The dose from "pure" $228 \mathrm{Ra}$ and its in vivo produced daughters is based on our best evaluation of $5.77 \pm$ $0.02 \mathrm{yr}$ for the ${ }^{228} \mathrm{Ra}$ half-period. The tabulated total doses include the contributions from ${ }^{228}$ Th contamination in the injection solutions. For example, ${ }^{228}$ Th contaminations of $0.6 \% ; 3 \%$, and $15 \%$, respectively, account for $2.8 \%$, $13 \%$, and $42 \%$ of the total dose in rads at 1000 days. If injected ${ }^{228} \mathrm{Th}$ is 4 times more toxic rad-for-rad than is in vivo produced ${ }^{228} \mathrm{Th}$, these injected 
${ }^{228}$ Th contaminations would account for $10 \%, 37 \%$ and $74 \%$ of the total biological damage at 1000 days. Therefore, it may be desirable to use only results from the slightly contaminated $\left(0.6 \%{ }^{228} \mathrm{Th}\right)$ dogs in evaluation of $228 \mathrm{Ra}$ toxicity.

The careful reader will note that we have extended our toxicity studies to two californium isotopes: ${ }^{249} \mathrm{C} f$ which deays by $\alpha$-particle emission and ${ }^{252} \mathrm{Cf}$ which decays both by $\alpha$-emission and spontaneous fission. To our knowledge, this is the first time that a study has been started to evaluate the cancer-inducing efficiency of fission fragments within tissue. The extremely high linear energy transfer (LET) of this type of radiation makes it especially interesting. Preliminary observations on Cf retention, distribution, binding and hematological effects appear in the first articles of this report, and we anticipate additional new and exciting findings in future years. 
TABLE I.TOXICITY ANIMALS (MAR, 31 1971)

A. RADIUM-226

OOG

NUMEER

MOU1RO.O

MOU2R0.0

FOUJR0.0

$M 004 R 0.0$

MO05R0.0

F006R0.0

MUOTR0.0

FOU $8 R 0.0$

FUO9R0.0

MO1ORO.0

F011R0.0

FO12R0.0

M013R0.0

F014R0.0

MO15R0.0

FO16R0.0

M017R0.0

F018R0.0

F019R0.0

MO20R0.0

F021R0.U

M022R0.0

FO31RO.OR

F031R0.OC

F031R0.0D

F032R0.0B

F032R0. OC

FO32R0.0D

F033RO.OB

F033R0. OC

FOJ3R0.0D

F034R0.0B

F034R0.0C

F034R0.OD

FOSSRO. OB

FO $35 R 0.0 \mathrm{C}$

FO35RO. OD

F036R0.0B

F036R0. OC

F036R0.0D

FOJ7R0.0B

FO37R0.0C

F037R0.0D
AT INUECTION AGE WEIGHT (DAYS) (KG)

$\begin{array}{rr}558 & 8.03 \\ 487 & 14.60 \\ 601 & 11.40 \\ 461 & 11.00 \\ 460 & 6.57 \\ 483 & 8.43 \\ 511 & 11.00 \\ 638 & 8.21 \\ 700 & 11.70 \\ 522 & 10.90 \\ 544 & 10.20 \\ 501 & 8.68 \\ 515 & 12.30 \\ 536 & 10.80 \\ 564 & 12.80 \\ 469 & 10.00 \\ 469 & 12.50 \\ 497 & 12.00 \\ 533 & 8.42 \\ 536 & 9.70 \\ 549 & 9.90 \\ 533 & 12.10 \\ 536 & 10.60 \\ 536 & 9.88 \\ 542 & 9.90 \\ 542 & 7.80 \\ 532 & 11.70 \\ 532 & 9.70 \\ 532 & 9.80 \\ 496 & 9.50 \\ 496 & 11.80 \\ 525 & 8.20 \\ 520 & 8.90 \\ 484 & 9.90 \\ 502 & 9.41 \\ 502 & 9.38 \\ 552 & 8.86 \\ 467 & 10.10 \\ 467 & 9.17 \\ 467 & 9.08 \\ 801 & 11.10 \\ 501 & 10.40 \\ 501 & 10.90 \\ & \\ & \end{array}$

DATE

INUECTED

$(H C i / K G)$

INJECTEO

D MO YR

$\begin{array}{lll}20 & 4 & 53\end{array}$

$\begin{array}{lll}16 & 11 \quad 53\end{array}$

10354

$\begin{array}{lll}7 & 4 & 54\end{array}$

$22 \quad 654$

$\begin{array}{lll}27 & 754\end{array}$

$24 \quad 854$

$21 \quad 1254$

11455

27755

$20 \quad 1255$

17156

4364

231064

$\begin{array}{lll}4 & 2 & 65\end{array}$

$\begin{array}{lll}74 & 65\end{array}$

27466

25566

131066

291266

$\begin{array}{lll}26 & 1 & 67\end{array}$

$\begin{array}{lll}22 & 3 & 67\end{array}$

$\begin{array}{lll}23 & 10 & 64\end{array}$

$\begin{array}{lll}23 & 10 & 64\end{array}$

21965

21965

21965

21965

$\begin{array}{lll}21 & 9 & 65\end{array}$

25566

$25 \quad 566$

$\begin{array}{lll}26 & 1 & 67\end{array}$

$\begin{array}{lll}22 & 3 & 67\end{array}$

$\begin{array}{lll}22 & 3 & 67\end{array}$

1268

1268

$\begin{array}{lll}9 & 1 & 69\end{array}$

2768

2768

2768

20569

23970

23970
DAYS SINCE

INJECTION 31/3/71 DEATH

3116

3675

2139

5284

4018

3182

3360

3361

1550

4698

4575

4283

2583

2350

2246

2184

1799

1771

1630

1553

1525

1470

2350

2350

2017

2017

2017

2017

2017

1771

1771

1525

1470

1470

1154

1154

811

1002

1002

1002

680

189

189
DOSE TO

SKELETON

(RADS) 
DOG

NUMBER

MUOLRO.O MOUZRO.O FOU 3RO.U MOU 4RO.O MUOSRO.O F006RO.O MOOTRO.O F008R0.0 FOOGRO.O MOLORO.O FULLKO.U F012R0.U MO13R0.0 FU14RO.U MO15RO.O FO16RO . U MOL TRO.O FO18RO .U FOLIRO.O MO2ORO.O FOC1RO.O $M O \angle 2 R O . O$

FO31KO.UB FO31RO.0C FU31R0.0U F032R0.0B FOJ2RO.OC FO32RO.OD FOS3RO.OB FO33RO. OC F033RO . D D F034RO.UB F034RO.LC FOS4RO.UU FOS5RO. OU FOJSRO.UC FOS5RO. OD FOS6RO . UB FONGRO.UC F036R0.UD F037RO.UB FU37RO.UC FU37RO.UD
COMMENTS ON DEAD DOGS

SEMINOMA, LYMPHOSARCOMA

TRANSITIONAL CELL CARCINOMA

STATUS EPILEPTICUS

CHRONIC INTERSTITIAL NEPHRITIS: THROMBOSIS OBTURATING PULMONARY EMBOLISM

STATUS EPILEPTICUS

STATUS EPILEPTICUS. NEPHRITIS

PANCREATIC ADENOCARCINOMA

AORTIC BODY TUMOR

NEPHRITIS

VAGINAL FIBROMA

UNDETERMINED 
DOG

NUMBER

FO3URO.OB $501 \quad 11.50$

F042RO.GB $338 \quad 8.00$ AGE WEIGHT (DAYS) (KG)
AT INJECTION

INJECTED $(\mu C \mathrm{i} / K G)$

DATE INUECTED

$D$ MO YR

23970

$25 \quad 469$

189

DAYS SINCE INJECTION 31/3/71 DEATH

DOSE TO SKELETON (RADS)

$\begin{array}{lrrrrrrr}\text { MO13RO.Z } & 529 & 9.77 & 0.00577 & 4 & 3 & 64 & 2583 \\ \text { F014R0.2 } & 460 & 8.10 & 0.00836 & 23 & 10 & 64 & 2350 \\ \text { MO15RO.2 } & 504 & 10.80 & 0.00873 & 4 & 2,65 & 2246 \\ \text { FU16R0.2 } & 486 & 8.90 & 0.00665 & 7 & 4 & 65 & 2184 \\ \text { MO17R0.2 } & 494 & 11.80 & 0.00711 & 27 & 4 & 66 & 1799 \\ \text { F018R0.2 } & 497 & 9.30 & 0.00652 & 25 & 5 & 66 & 1771 \\ \text { FO19R0.2 } & 533 & 10.60 & 0.00785 & 13 & 10 & 66 & 1630 \\ \text { MOZORO.2 } & 546 & 11.40 & 0.00676 & 29 & 12 & 66 & 1553 \\ \text { FU21RO.2 } & 549 & 11.50 & 0.00687 & 26 & 1 & 67 & 1525 \\ \text { MO22RO.2 } & 533 & 12.90 & 0.00961 & 22 & 3 & 67 & 1470\end{array}$

\begin{tabular}{|c|c|c|c|c|c|c|c|}
\hline $\begin{array}{l}M O 13 K 0.5 \\
F 014 R 0.5 \\
M 015 R 0.5 \\
F O 16 R 0.5 \\
M O 17 R 0.5 \\
F 016 R 0.5 \\
F O 19 R 0.5 \\
M 020 R 0.5 \\
F 021 R 0.5 \\
M 022 R 0.5 \\
M 031 R 0.5 B \\
F 031 R 0.5 C \\
F 031 R 0.5 D \\
M 032 R 0.5 B \\
F 032 R 0.5 C \\
F 032 R 0.5 D \\
M 033 R 0.5 B \\
F 033 R 0.5 C \\
F 033 R 0.50 \\
M 034 R 0.5 B \\
F 034 R 0.5 C \\
F 034 R 0.50 \\
M 035 R 0.5 B \\
F 035 R 0.5 C \\
F 035 R 0.50\end{array}$ & $\begin{array}{l}529 \\
510 \\
490 \\
500 \\
494 \\
496 \\
533 \\
536 \\
538 \\
520 \\
508 \\
537 \\
537 \\
496 \\
519 \\
509 \\
497 \\
527 \\
527 \\
496 \\
524 \\
508 \\
536 \\
532 \\
532\end{array}$ & $\begin{array}{r}11.00 \\
9.75 \\
10.40 \\
11.40 \\
9.20 \\
9.10 \\
10.00 \\
13.20 \\
8.80 \\
12.30 \\
11.40 \\
9.40 \\
11.70 \\
13.40 \\
10.10 \\
10.10 \\
12.90 \\
10.60 \\
8.70 \\
10.50 \\
9.90 \\
9.70 \\
10.40 \\
9.00 \\
10.20\end{array}$ & $\begin{array}{l}0.0171 \\
0.022 \\
0.0263 \\
0.0205 \\
0.0215 \\
0.0197 \\
0.023 \\
0.0206 \\
0.0208 \\
0.029 \\
0.021 \\
0.0235 \\
0.0238 \\
0.0196 \\
0.0239 \\
0.024 \\
0.0194 \\
0.0212 \\
0.0217 \\
0.0196 \\
0.0215 \\
0.0212 \\
0.0205 \\
0.0201 \\
0.0202\end{array}$ & $\begin{array}{r}4 \\
23 \\
4 \\
7 \\
27 \\
25 \\
13 \\
29 \\
26 \\
22 \\
27 \\
22 \\
22 \\
25 \\
22 \\
22 \\
25 \\
27 \\
27 \\
25 \\
27 \\
27 \\
29 \\
29 \\
29\end{array}$ & $\begin{array}{r}3 \\
10 \\
2 \\
4 \\
4 \\
5 \\
10 \\
12 \\
1 \\
3 \\
4 \\
12 \\
12 \\
5 \\
12 \\
12 \\
5 \\
4 \\
4 \\
5 \\
4 \\
4 \\
12 \\
12 \\
12\end{array}$ & $\begin{array}{l}64 \\
64 \\
65 \\
65 \\
66 \\
66 \\
66 \\
66 \\
67 \\
67 \\
66 \\
65 \\
65 \\
66 \\
65 \\
65 \\
66 \\
66 \\
66 \\
66 \\
66 \\
66 \\
66 \\
66 \\
66\end{array}$ & $\begin{array}{l}2583 \\
2350 \\
2246 \\
2184 \\
1799 \\
1771 \\
1630 \\
1553 \\
1525 \\
1470 \\
1799 \\
1925 \\
1925 \\
1771 \\
1925 \\
1925 \\
1771 \\
1799 \\
1799 \\
1771 \\
1799 \\
1799 \\
1553 \\
1553 \\
1553\end{array}$ \\
\hline
\end{tabular}


DOG

NUMBER

COMMENTS ON DEAD DOGS

FOSBRO.0B

F042R0.0B

SPECIAL STUDY

$M 013 R 0.2$

F014R0.2

MO15RO.2

FO16R0.2

MO17R0.2

FO18RO.C

F019R0.2

M020R0.2

F021R0.2

$M 022 R 0.2$

$M 013 R 0.5$

F014R0.5

MO15R0.5

F016R0.5

MO17R0.5

F018R0.5

F019R0.5

MUZORO.S

FOĊRO.S

MO22R0.5

MO31R0.5B

F031R0.5C

F031R0.SU

M032R0.SB

$\mathrm{F} 032 \mathrm{RO} .5 \mathrm{C}$

F032R0.50

MO33R0.5B

F033K0.5C

F033R0.SO

M034R0.5B

F034R0.5C

F034R0.50

M035RO.5B

F035R0.5C

F035RO.5D 
DOG

NUMBER

MOUIRI.U

MOU2R1.U

FOU 3R1 . U

MOO4K1.0

MOUSR1.O

FUU6R1.U

MO07R1.U

FOUBR1. O

FOU9R1.0

M010R1.U

FO11R1.U

F012R1.0

M013R1.U

F014R1.0

M015R1.0

F016R1.0

M017R1.0

F018R1.0

F019R1.0

MOCOR1.O

F021R1.0

MO22R1.0

F031R1. OB
AT INJECTION AGE WEIGHT

(DAYS) (KG)

$\begin{array}{rrr}471 & 8.48 & 0.0618 \\ 627 & 10.00 & 0.0876 \\ 706 & 8.68 & 0.0576 \\ 414 & 8.60 & 0.0642 \\ 490 & 11.70 & 0.0436 \\ 483 & 7.23 & 0.0584 \\ 511 & 11.40 & 0.0651 \\ 861 & 8.98 & 0.0559 \\ 781 & 9.88 & 0.0521 \\ 523 & 11.50 & 0.0573 \\ 511 & 11.20 & 0.0522 \\ 501 & 9.71 & 0.0444 \\ 529 & 11.70 & 0.0527 \\ 510 & 10.50 & 0.0701 \\ 490 & 8.88 & 0.0797 \\ 501 & 8.99 & 0.0611 \\ 494 & 11.40 & 0.0639 \\ 496 & 10.00 & 0.0589 \\ 526 & 11.60 & 0.0682 \\ 536 & 10.00 & 0.061 \\ 525 & 8.10 & 0.0633 \\ 484 & 10.90 & 0.0861 \\ 509 & 10.40 & 0.0712\end{array}$

471

414

490

483

511

861

781

523

511

529

510

490

501

494

496

526

536

484

509
INJECTED

( $\mu \mathrm{Ci} / K G$ )
DATE

INJECTED

D MO YR

$20 \quad 453$

161153

10354

$\begin{array}{lll}7 & 4 & 54\end{array}$

22654

$27 \quad 754$

$24 \quad 854$

$\begin{array}{lll}21 & 12 & 54\end{array}$

11455

27755

$20 \quad 12 \quad 55$

17156

4364

231064

4265

$\begin{array}{lll}7 & 4 & 65\end{array}$

$27 \quad 4 \quad 66$

25. 566

131066

$\begin{array}{lll}29 & 12 & 66\end{array}$

$\begin{array}{lll}26 & 1 & 67\end{array}$

$\begin{array}{lll}22 & 3 & 67\end{array}$

$\begin{array}{lll}22 & 12 \quad 65\end{array}$
DAYS SINCE

INJECTION

31/3/71 DEATH
DOSE TO

SKELETON

(RADS)

170

237

151

108

112

187

167

93

99

157

5580

2583

3978

124

148

82

1729

893
2184

1799

1771

1630

1553

1525

1470

1925
17156

$\begin{array}{lll}30 & 1156\end{array}$

6363

$\begin{array}{lll}20 & 12 & 55\end{array}$

$20 \quad 12 \quad 55$

$20 \quad 12 \quad 55$

$\begin{array}{lll}20 & 12 & 55\end{array}$

$30 \quad 1156$

$\begin{array}{lll}20 & 12 & 55\end{array}$

$\begin{array}{lll}30 & 11 & 56\end{array}$

$30 \quad 1156$

7159

$\begin{array}{llll}30 & 11 & 56\end{array}$

301156 .

$\begin{array}{rr} & 4438 \\ & 1273 \\ 2947 & \\ & 3267 \\ & 5495 \\ & 4107 \\ & 3432 \\ & 3142 \\ & 2577 \\ & 3914 \\ & 557 \\ 4466 & \\ 5234 & \\ & 2399\end{array}$

341

116

385

513

488

417

309

378

262

109

$\begin{array}{rr}10.60 & 0.183 \\ 8.17 & 0.165 \\ 8.95 & 0.167\end{array}$

2399

210 
DOG

NUMBER

MOO1R1.0

MOU2R1.0

FOU3R1.0

MUO4R1.U

MOU5R1.U

FOU6K1.U

M007R1 . U

FOUBR1.U

FOU9R1:U

MO1OR1.U

F011R1.0

F012R1.0

MO13R1.U

F014R1.0

M015R1.0

F016R1.0

MO17R1.O

FO18R1.U

F019R1.0

M020R1.0

F021R1.0

M022R1.U

FO31R1. OB

MOO1R1.7

MOUZR 1.7

MOO2R1.7A

FOO3R1.7

M004R1.7

MOOSR1.7

F0U6R1.7

MOU7R1.7

FOO $8 R 1.7$

FOUGR1.7

MOLUR1.7

MO1OR1.7A

F011R1.7

F012R1.7
COMMENTS ON DEAD DOGS

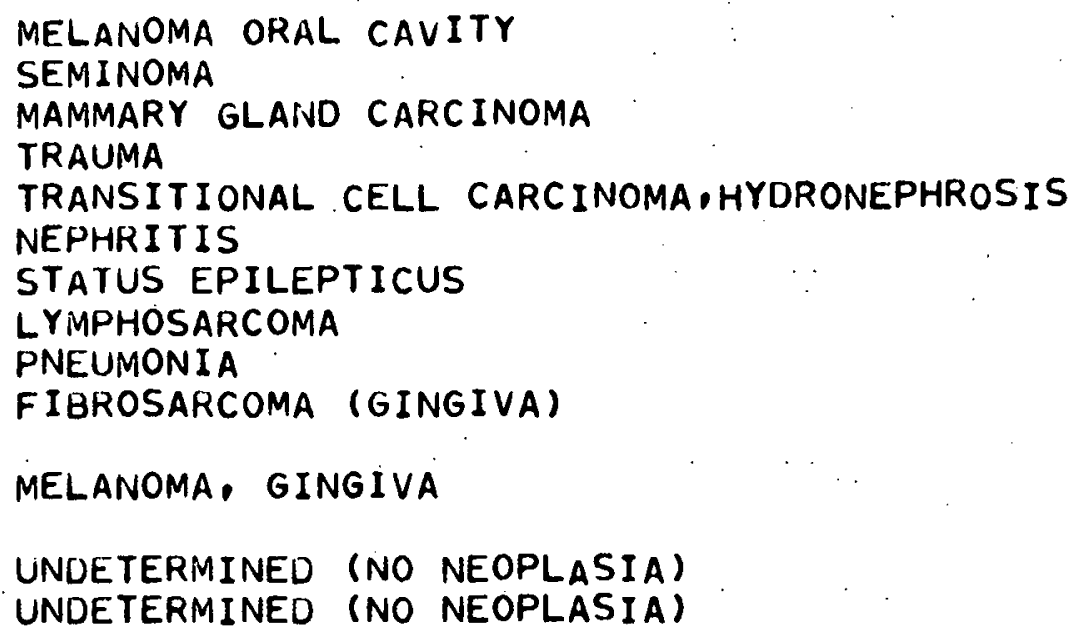

OBTURATING ABDOMINAL AORTA AND PULMONARY EMROLISM LYMPHOSARCOMA

MIAMMARY GLAND CARCINOMA

NEPHRITIS

OSTEOSARCOMA

BACTERIAL TOXEMIA. INTERSTITIAL CELL ADENOMA DRUG ALLERGY PYOMETRA

TRAUMA

UNOETERMINED (NO BONE TUMOR) 
DOG

NUMBER

MOO1R2. 0

MOO2R2.U

F003R2.O

$M 004 R 2.0$

MOU4R2.UA

MOOSR2. 0

F006R2. O

MOOTR2.0

F008R2.0

F009R2.0

MOLOR2.U

FO11R2.U

F012R2.0
AT INJECTION AGE WEIGHT (DAYS) (KG)
INJECTED

$\left({ }^{\prime} \mathrm{C} i / K G\right)$
OATE

INJECTED

D MO YR

0.382

0.387

$592 \quad 8.21$

541

414

8.53

10.50

0.347

0.361

0.306

461

486

514

572

592

523

495

497
10.60

11.50

10.60

11.10

6.95

9.38

9.95

9.30

10.30
0.267

0.36

0.413

0.331

0.317

0.345

0.31

0.281
$20 \quad 4 \quad 53$

$16 \quad 1153$

10354

7454

11455

$22 \quad 654$

27754

24854

$\begin{array}{lll}21 & 12 & 54\end{array}$

11455

27755

$\begin{array}{lll}20 & 12 \quad 55\end{array}$

17156
DAYS SINCE INJECTION $31 / 3 / 71$ DEATH
DOSE TO

SKELETON

(RADS)
MOO1R3.U

M002R3.0

F003R3.0

MOO4R3.0

MUUSR3.0

F006R3.0

M007R3.0

F008R3.0

FOO9R3.0

MOLOR3.0

F011R3.0

F012R3.0
473

470

386

412

461

486

514

542

551

525

495

497
$8.91 \quad 1.2$

9.02

7.74

11.70

13.00

9.75

12.30

7.76

8.02

10.10

12.90

11.40
1.21

1.11

1.16

0.846

1.14

1.29

1.03

0.987

1.06

0.938

0.883
$20 \quad 453$

$\begin{array}{lll}16 & 11 & 53\end{array}$

10354

7454

$22 \quad 654$

27754

$24 \quad 854$

$\begin{array}{lll}21 & 12 & 54\end{array}$

11455

27755

$\begin{array}{lll}20 & 12 & 55\end{array}$

17156
3440

3775

4459

325

4368

4703

4615

3425

4781

3998

3569

3297

2948
860

625

872

189

1142

994

1264

922

996

1016

1220

728

742
MOO1R4.0

MOO2R4.O

FUU3R4.O

FOU3R4.UA

MO0 4R4. 0

MOUSR4.0

F006R4.0

MOOTR4.O

FOOBR4.O

FOO9R4.0

MO1OR4.O

F011R4.0

$\begin{array}{rrl}471 & 9.08 & 3.51 \\ 470 & 9.53 & 3.55 \\ 384 & 8.65 & 3.33 \\ 598 & 7.20 & 3.1 \\ 408 & 8.83 & 3.47 \\ 461 & 13.20 & 2.42 \\ 486 & 8.55 & 3.44 \\ 453 & 9.55 & 3.88 \\ 474 & 8.94 & 3.14 \\ 542 & 8.53 & 3.02 \\ 527 & 10.80 & 3.28 \\ 491 & 10.40 & 2.84\end{array}$

$\begin{array}{rrr}20 & 4 & 53 \\ 16 & 11 & 53 \\ 10 & 3 & 54 \\ 30 & 11 & 56 \\ 7 & 4 & 54 \\ 22 & 6 & 54 \\ 27 & 7 & 54 \\ 24 & 8 & 54 \\ 21 & 12 & 54 \\ 11 & 4 & 55 \\ 27 & 7 & 55 \\ 20 & 12 & 55\end{array}$

1606

1884

490

1614

1518

1659

1939

1647

1324

1471

1553

1469
2395

1727

2323

2361

2317

2246

3029

1916

1839

2336

1333

1639 
DOG

NUMBER

COMMENTS ON DEAD DOGS

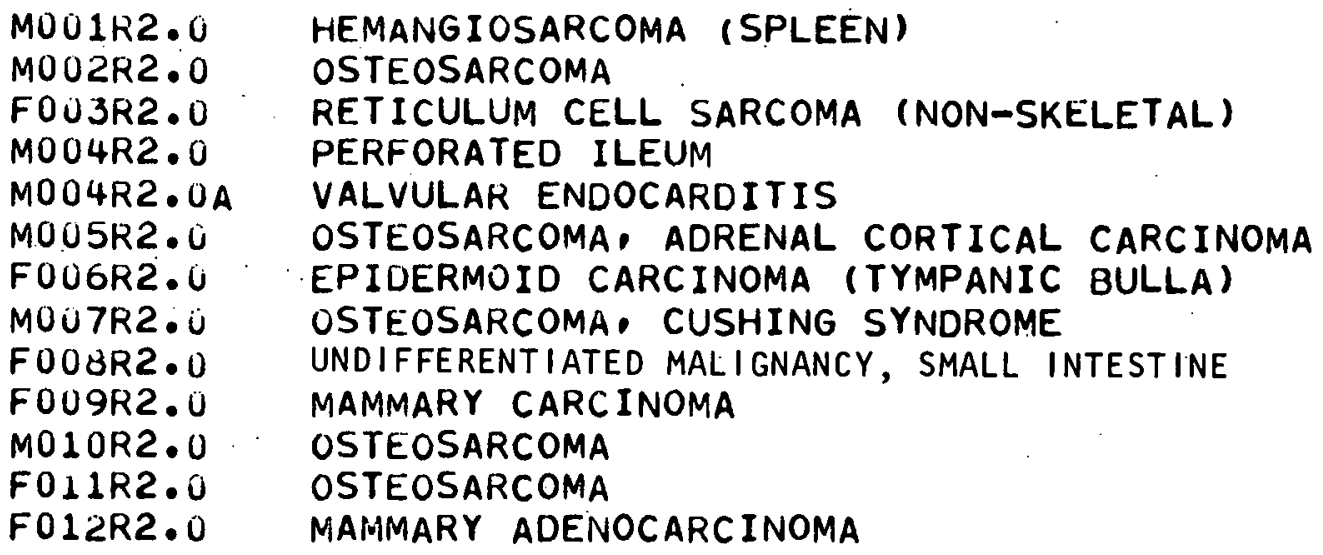

2

MOU1R3.0

OSTEOSARCOMA

MOO2R3.

OSTEOSARCOMA

F003R3.0

MO04R3.U

MOUSR3.U

FOU6R3.U

OSTEOSARCOMA

OSTEOSARCOMA

OSTEOSARCOMA

OSTEOSARCOMA

MUUTR3.U

OSTEOSARCOMA

F0O8R3.U

F0O9K3.U

MOLUR3.0

OSTEOSARCOMA

OSTEOSARCOMA

OSTEOSARCOMA

FO11R3.0

F012R3.0

PYOMETRITIS + SECONDARY PERITONITIS

OSTEOSARCOMA

$\begin{array}{ll}\text { MOU1R4.U } & \text { OSTEOSARCOMA } \\ \text { MOU2R4.0 } & \text { OSTEOSARCOMA } \\ \text { FOU3R4.0 } & \text { CANINE DISTEMPER } \\ \text { FOU3R4.UA } & \text { OSTEOSARCOMA } \\ \text { MOU4R4.0 } & \text { OSTEOSARCOMA } \\ \text { MOUSR4.0 } & \text { OSTEOSARCOMA } \\ \text { FUO6R4.0 } & \text { OSTEOSARCOMA } \\ \text { MOU7R4.U } & \text { OSTEOSARCOMA } \\ \text { FOU8R4.0 } & \text { OSTEOSARCOMA } \\ \text { F0U9R4.0 } & \text { OSTEOSARCOMA } \\ \text { MO1OR4.U } & \text { OSTEOSARCOMA } \\ \text { FO11R4.0 } & \text { OSTEOSARCOMA }\end{array}$




\begin{tabular}{|c|c|c|c|c|c|c|c|}
\hline \multirow{2}{*}{$\begin{array}{l}\text { DOG } \\
\text { NUMBER } \\
\text { FO12R4.0 }\end{array}$} & \multicolumn{2}{|c|}{$\begin{array}{l}\text { AT INJECTION } \\
\text { AGE WEIGHT } \\
\text { (DAYS) (KG) }\end{array}$} & \multirow{2}{*}{$\begin{array}{l}\text { INJECTED } \\
\left({ }_{\mu} \mathrm{Ci} / K G\right) \\
2.81\end{array}$} & \multicolumn{2}{|c|}{$\begin{array}{c}\text { DATE } \\
\text { INJECTED }\end{array}$} & $\begin{array}{c}\text { DAYS SINCE } \\
\text { INJECTION } \\
31 / 3 / 71 \text { DEATH }\end{array}$ & $\begin{array}{l}\text { DOSE TO } \\
\text { SKELETON } \\
\text { (RADS) }\end{array}$ \\
\hline & 496 & 9.61 & & 17 & 156 & 1435 & 3877 \\
\hline 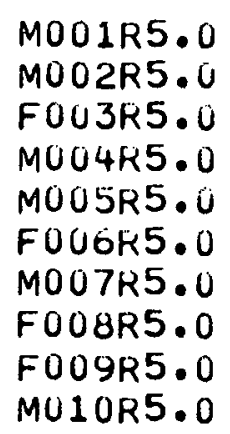 & $\begin{array}{l}473 \\
470 \\
380 \\
408 \\
458 \\
486 \\
453 \\
474 \\
420 \\
527\end{array}$ & $\begin{array}{r}9.87 \\
8.85 \\
7.82 \\
8.90 \\
10.90 \\
9.66 \\
8.85 \\
7.76 \\
9.16 \\
10.70\end{array}$ & $\begin{array}{l}10.5 \\
10.8 \\
10.1 \\
10.6 \\
10.1 \\
10.2 \\
11.9 \\
9.68 \\
9.48 \\
10.2\end{array}$ & $\begin{array}{l}20 \\
16 \\
10 \\
7 \\
22 \\
27 \\
24 \\
21 \\
11 \\
27\end{array}$ & $\begin{array}{rl}4 & 53 \\
11 & 53 \\
3 & 54 \\
4 & 54 \\
6 & 54 \\
7 & 54 \\
8 & 54 \\
12 & 54 \\
4 & 55 \\
7 & 55\end{array}$ & $\begin{array}{r}908 \\
1380 \\
481 \\
1091 \\
1220 \\
1015 \\
1288 \\
968 \\
1288 \\
825\end{array}$ & $\begin{array}{r}14943 \\
18071 \\
7147 \\
16417 \\
15433 \\
15414 \\
16708 \\
11564 \\
15941 \\
11179\end{array}$ \\
\hline
\end{tabular}


DOG

NUMBER

COMMENTS ON DEAD DOGS

FO12R4.0 OSTEOSARCOMA

$\begin{array}{ll}\text { MOO1R5.0 } & \text { OSTEOSARCOMA } \\ \text { MO02R5.0 } & \text { OSTEOSARCOMA } \\ \text { F003R5.0 } & \text { CANINE DISTEMPER } \\ \text { MO04R5.0 } & \text { OSTEOSARCOMA } \\ \text { MOOSR5.0 } & \text { OSTEOSARCOMA } \\ \text { F006R5.0 } & \text { OSTEOSARCOMA } \\ \text { MO07R5.0 } & \text { OSTEOSARCOMA } \\ \text { F008R5.0 } & \text { OSTEOSARCOMA } \\ \text { FO09R5.0 } & \text { OSTEOSARCOMA + ANEMIA } \\ \text { M010R5.0 } & \text { OSTEOSARCOMA + FRACTURED MANDIBLE }\end{array}$ 
B. PLUTONIUM-239

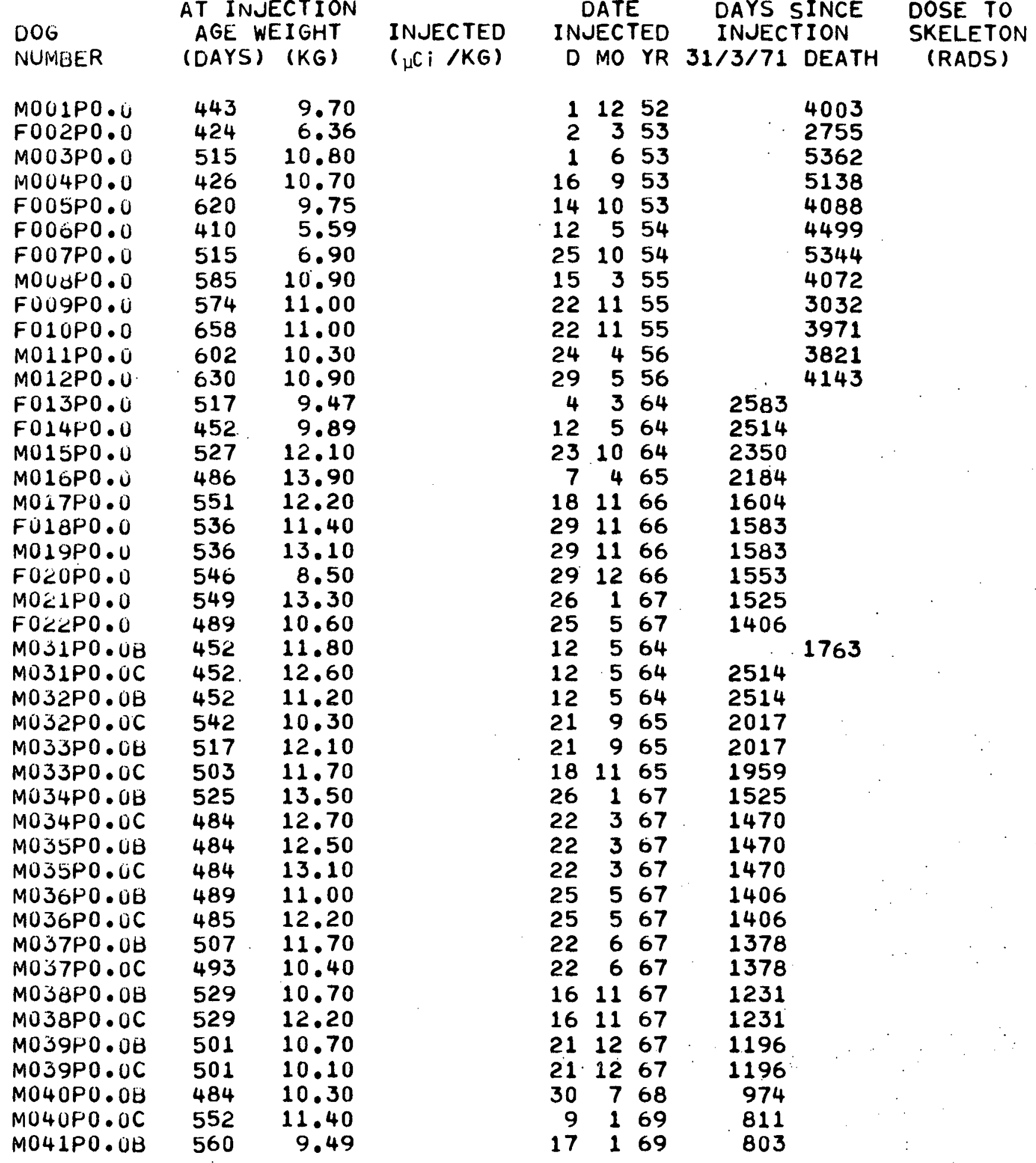

AT INJECTION (DAYS) (KG)

\section{DOG}
DATE
DAYS SINCE
DOSE TO INJECTED INUECTION

4003

2755

5362

5138

4088

4072

3821

2583

2514

2184

1604

1583

1583

1553

1525

2514

2514

2017

2017

1959

1470

1470

1406

1306

1378

1231

1231

1196

803 
DOG

NUMBER

MOO1PO.O

F002P0.O

MUO3PO. $U$

MOU 4PO.O

FOUSPO.O

F0U6P0.0

F007P0.0

MOOBPO. 0

FOU 9P0. 0

F010P0.O

MO11P0.O

MO12P0.0

F013P0.0

F014P0.0

MO15PO.L

MO16P0.O

M017P0.0

F018P0.U

MOLIPO.U

F020PO.U

MO21P0.O

F022P0.O

MOJ1PO.OH

MO31PO.OC

M032PO. OB

MO32PO.OC

M033P0.OB

MOS3PO.OC

MO34PO.OB

MO34P0.0C

MOJ5PO.CB

MOS5PO.OC

MOS6PO.UB

MOJ6PO.UC

M037PO.UB

MOS7PO.UC

MOJ\&PO.UB

MOS\&PO.UC

MOS9PO.UB

M039P0.0C

M040P0.08

MO40PO.0C

M041PO.0B
COMMENTS ON DEAD DOGS

SPLENIC RUPTURE, METASTATIC SEMINOMA

ANESTHETIC ACCIUENT

PAINCREATIC ADENOCARCINOMA

THYROID CARCINOMA. NEPHRITIS

ADRENAL CORTICAL CARCINOMA

OBTURATING PULMONARY EMROLISM

RHABDOMYOSARCOMA

CIRCULATORY FAILURE

PULMONARY EMBOLISM. NEPHRITIS

LEUKEMIA

FIBROSARCOMA (SPLEEN)

TESTICULAR CARCINOMA

STATUS EPILEPTICUS: BILE DUCT OBSTRUCTION 
DOG
NUMBER

$M 042 P 0.0 B$
AT INJECTION AGE WEIGHT (OAYS) (KG)
INJECTED $(\mu C i / K G)$
DATE INJECTED D MO YR 25
469
DAYS SINCE DOSE TO INJECTION 31/3/71 DEATH SKELETON (RADS)
0.00068

0.00055

0.00071

0.00059

0.00057

0.0007

0.00063

0.00075

0.00059

0.00059

0.00068

0.00059

0.00079

0.00058

0.00059

0.0006

0.00059

0.00057

0.00058

0.00072
4364

12564

$2310 \quad 64$

7465

$\begin{array}{lll}18 & 11 & 66\end{array}$

291166

291166

$\begin{array}{lll}29 & 12 \quad 66\end{array}$

$\begin{array}{lll}26 & 1 & 67\end{array}$

$\begin{array}{lll}25 & 5 & 67\end{array}$

$\begin{array}{lll}4 & 3 & 64\end{array}$

$\begin{array}{lll}18 & 11 & 65\end{array}$

$\begin{array}{lll}18 & 11 & 65\end{array}$

181166

$\begin{array}{lll}25 & 5 & 67\end{array}$

$\begin{array}{lll}22 & 6 & 67\end{array}$

$\begin{array}{lll}22 & 6 & 67\end{array}$

$\begin{array}{lll}21 & 12 & 67\end{array}$

$\begin{array}{lll}21 & 12 & 67\end{array}$

$\begin{array}{lll}2 & 1270\end{array}$
32
2583

2514

2350

2184

1604

1583

1583

1553

1525

1406

2583

1959

1959

1604

1406

1378

1378

1196

1196

119

$\begin{array}{lrrlrrrr}F U 13 P 0.2 & 517 & 9.44 & 0.00206 & 4 & 3 & 64 & 2583 \\ F 014 P 0.2 & 516 & 7.44 & 0.00173 & 12 & 5 & 64 & 2514 \\ M 015 P 0.2 & 505 & 10.90 & 0.00201 & 23 & 10 & 64 & 2350 \\ M 016 P 0.2 & 500 & 11.40 & 0.00163 & 7 & 4 & 65 & 2184 \\ M 017 P 0.2 & 533 & 11.80 & 0.00171 & 18 & 11 & 66 & 1604 \\ F 018 P 0.2 & 530 & 9.46 & 0.002 & 29 & 11 & 66 & 1583 \\ M 019 P 0.2 & 530 & 12.10 & 0.00198 & 29 & 11 & 66 & 1583 \\ F 020 P 0.2 & 532 & 8.30 & 0.00224 & 29 & 12 & 66 & 1553 \\ M 021 P 0.2 & 538 & 12.10 & 0.00181 & 26 & 1 & 67 & 1525 \\ F 022 P 0.2 & 485 & 8.30 & 0.00176 & 25 & 5 & 67 & 1406 \\ M 031 P 0.2 B & 515 & 10.70 & 0.00185 & 4 & 3 & 64 & 2583 \\ F U 31 P 0.2 C & 452 & 11.90 & 0.00169 & 12 & 5 & 64 & 2514 \\ F 031 P 0.2 D & 429 & 9.35 & 0.00186 & 12 & 564 & 2514 \\ M O 32 P 0.2 B & 549 & 13.60 & 0.00178 & 18 & 1165 & 1959 \\ F 032 P 0.2 C & 494 & 10.10 & 0.00183 & 4 & 2 & 65 & 2246 \\ F 032 P 0.2 D & 490 & 8.04 & 0.00193 & 4 & 2 & 65 & 2246\end{array}$


DOG

NUMEER

M042P0.0B SPECIAL STUDY
COMMENTS ON DEAD DOGS

\section{F013P0.1}

F014P0.1

MO15PO.1

MO16P0.1

MO17P0.1

F018P0.1

M019P0.1

F0 $20 P 0.1$

$M 021 P 0.1$

F022P0.1

i

MU31P0.1B

F032P0.1B

M033P0.16

FO34P0.18

MO35P0.1B

FU36P0.1B

M037P0.1B

F038P0.1B

MU39P0.1B

F044P0.1C

F013P0.2

F014P0.2

MO15PO.2

MO16P0.2

MO17P0.С

F018P0.2

MO19P0.Z

F020P0.2

MO¿1PO.2.

FO2'2PO.Z

MU31P0.2B

FUS1P0.2C

FU31P0.20

M032PO. $2 B$

F032P0.2C

F032P0. 20 
NOG
NUINBEER

MO33P0.2B

FO3 $3 P 0 . \angle C$

F033P0.2D

$M 034 P 0.28$

F034P0.2C

F034P0.2D

MO35PO. $2 B$

F0S5P0.2C

F035P0.20

M036P0.2B

F036P0.2C

F036P0. 20

MO37PO • $\angle B$

F037P0.2C

F037P0.20

MO38P0.2H

F038P0.2C

F038P0.20

MU39P0.2B

F039P0.2C

F039P0.20

F042P0.2C

F043PO. $2 \mathrm{C}$
AT INJECTION AGE WEIGHT

(DAYS) (KG)

$\begin{array}{rrl}513 & 14.50 & 0.00178 \\ 549 & 12.50 & 0.00176 \\ 513 & 12.70 & 0.00178 \\ 533 & 12.70 & 0.0017 \\ 533 & 11.50 & 0.00172 \\ 519 & 9.92 & 0.00167 \\ 489 & 11.20 & 0.00173 \\ 507 & 10.50 & 0.00175 \\ 507 & 9.10 & 0.00175 \\ 479 & 12.90 & 0.00177 \\ 493 & 10.40 & 0.00177 \\ 569 & 8.74 & 0.00146 \\ 529 & 10.60 & 0.00149 \\ 529 & 10.10 & 0.0015 \\ 529 & 7.14 & 0.00153 \\ 517 & 10.00 & 0.00152 \\ 501 & 7.95 & 0.00211 \\ 499 & 9.08 & 0.00176 \\ 542 & 11.60 & 0.00214 \\ 499 & 9.46 & 0.00173 \\ 499 & 9.34 & 0.00176 \\ 589 & 9.55 & 0.00176 \\ 542 & 9.50 & 0.00239\end{array}$

INJECTED

( $\mu \mathrm{Ci} / K G)$
DATE
INUECTED

D MO YR
DAYS SINCE INUECTION 31/3/71 DEATH
DOSE TO

SKELETON

(RADS)

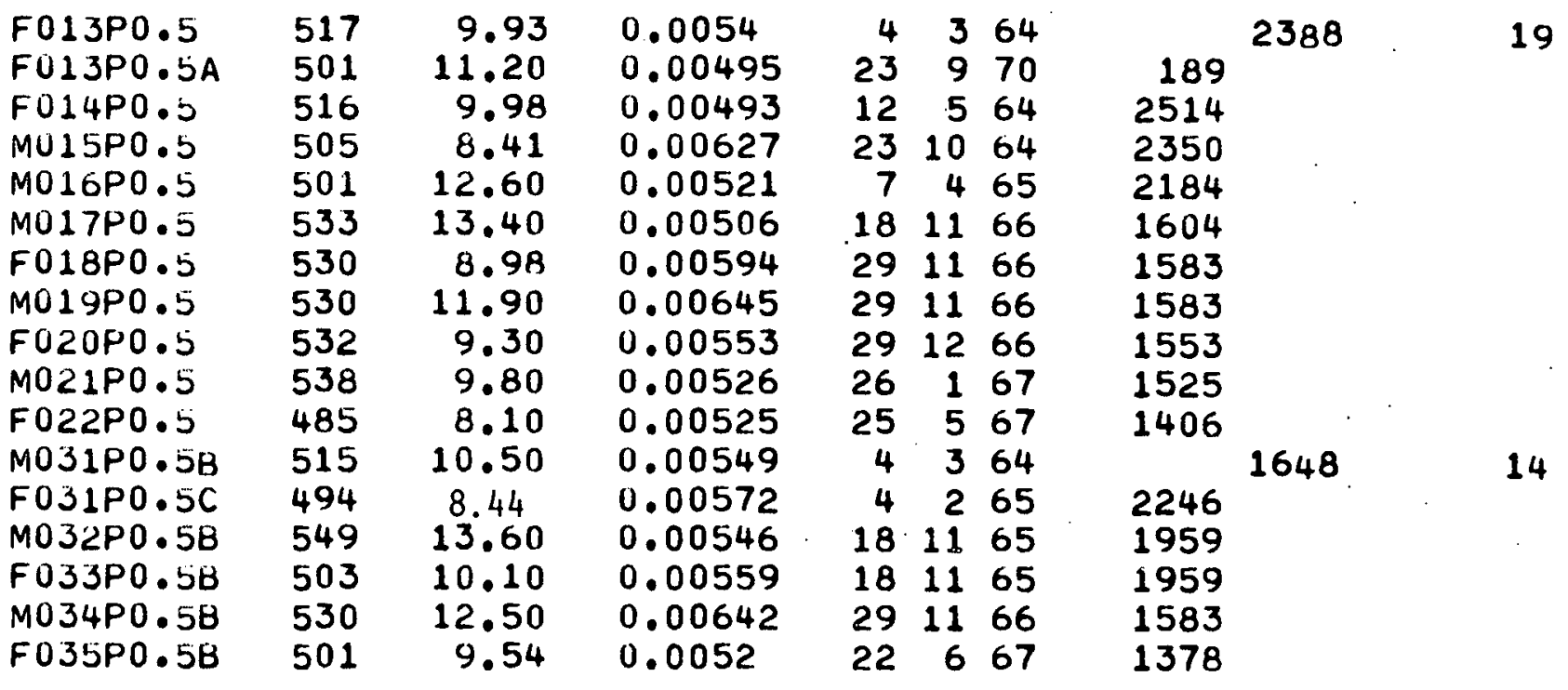


DOG

NUMEER

COMMENTS ON DEAD DOGS

M033P0.2B

F033PO.2C

FOSSPO.ZU

M034P0.2B

F034PO.2C

F034P0.20

M035PO.2E

F035P0. $\angle C$

F035P0.20

M036P0.2B

F036PO . $\angle \mathrm{C}$

F036PO.20

MO37PO.ZB

F037P0.2C

F037P0.20

MO38P0.28

F038P0.2C

F038P0.2D

MU 39P0 . $\angle B$

F039P0 . $2 \mathrm{C}$

FU39P0 . $\angle D$

F042P0. $2 \mathrm{C}$

F043PO. $2 \mathrm{C}$

F013P0.5

F0 13P0.5A

F014P0.5

MO15P0.S

M016P0.5

M017P0.5

F018P0.5

MO19P0.5

F02UPO.5

MOL1PO.b

$F 0<2 P 0.5$

MOJ1PO.SB

F0J1P0.5C

MO32PO.5B

FOJ3PO.5B

MOS4PO.5B

F035P0.58
MAMMARY CARCINOMA

STATUS EPILEPTICUS 
OOG

NUNiBER

M036P0.5B

F037P0.5B

M038PO.5B

F039P0.58

$\mathrm{M042P0.5 \textrm {B }}$

MU42P0.5C

F042P0.5D

F043P0. 58

F043P0.5C

$\mathrm{M044P0.5B}$

$\mathrm{M045P0.5B}$

M046P0.5B
AT INJECTION AGE WEIGHT (DAYS) (KG)
INJECTED

( $\mu \mathrm{C} i / K G)$
DATE

INUECTED

D MO YR

$\begin{array}{lll}25 & 5 & 67\end{array}$

$\begin{array}{lll}16 & 11 & 67\end{array}$

$\begin{array}{lll}16 & 11 & 67\end{array}$

$\begin{array}{lll}21 & 12 & 67\end{array}$

$\begin{array}{lll}2 & 12 & 70\end{array}$

$\begin{array}{lll}2 & 12 & 70\end{array}$

$\begin{array}{lll}2 & 12 & 70\end{array}$

$\begin{array}{lll}3 & 10 & 69\end{array}$

31069

3669

3669

472

484
9.71

11.60

10.70

11.50

10.30

11.80
0.0048

0.0036

0.00336
DAYS SINCE

INUECTION

31/3/71 DEATH

1406

1231

1231

1196

119

119

119

544

544

$\begin{array}{rl}99 & 1 \\ 42 & 1 \\ 7 & 1\end{array}$

DOSE TO

SKELETON

(RADS)

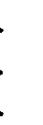

$\begin{array}{lrrlrrrr}\text { F014P0.7 } & 533 & 8.98 & 0.00947 & 22 & 769 & 617 \\ M 015 P 0.7 & 533 & 10.30 & 0.00941 & 22 & 7 & 69 & 617 \\ M 016 P 0.7 & 516 & 11.90 & 0.0102 & 4 & 9 & 69 & 573 \\ M 017 P 0.7 & 540 & 8.04 & 0.0103 & 3 & 10 & 69 & 544 \\ F 018 P 0.7 & 521 & 9.66 & 0.00942 & 22 & 7 & 69 & 617 \\ M 019 P 0.7 & 501 & 11.60 & 0.0104 & 23 & 9 & 70 & 189 \\ F 020 P 0.7 & 521 & 9.18 & 0.00926 & 22 & 7 & 69 & 617 \\ M 021 P 0.7 & 499 & 11.10 & 0.0104 & 23 & 970 & 189 \\ F 022 P 0.7 & 538 & 9.69 & 0.0108 & 4 & 969 & 573 \\ F 023 P 0.7 & 538 & 9.56 & 0.0108 & 4 & 969 & 573 \\ F 024 P 0.7 & 516 & 8.90 & 0.011 & 4 & 969 & 573\end{array}$

M001P1.0

FOU2P1.0

MO03P1.0

M004P1.0

F005P1.0

F00SP1.0A

F006P1.0

F007P1.0

M008P1.0

F009P 1.0

FO1OP1.0

MO1 $1 P 1.0$

MO12P1.0

MU13P1.0

$\begin{array}{rrl}443 & 9.41 & 0.015 \\ 422 & 6.85 & 0.0163 \\ 515 & 8.00 & 0.0165 \\ 608 & 9.97 & 0.0139 \\ 620 & 8.80 & 0.0142 \\ 472 & 11.00 & 0.0168 \\ 410 & 7.38 & 0.014 \\ 510 & 6.36 & 0.0167 \\ 453 & 10.60 & 0.0172 \\ 556 & 7.87 & 0.0168 \\ 641 & 12.00 & 0.0152 \\ 602 & 8.90 & 0.0157 \\ 629 & 9.67 & 0.0167 \\ 504 & 12.70 & 0.0153\end{array}$

$1 \quad 1252$

2353

1653

16953

141053

3958

12554

$\begin{array}{lll}25 & 10 & 54\end{array}$

15355

9955

$22 \quad 1155$

24456

29556

3958
617

617

573

544

617

189

617

189

573

573 
DOG

NUMBER

M036P0.5B F037P0.5B M038PO.5B FO39P0 . 5B M042PO . $5 B$ $\mathrm{MO} 42 \mathrm{PO} .5 \mathrm{C}$ F042P0.5D F043P0. $5 B$ F043PO. $5 \mathrm{C}$ MO44PO . 5B M045PO.5B M046P0.5B

F014P0.7 MO15P0.7 M016P0.7 M017P0.7 F018P0.7 MO19P0.7 F020P0. 7 MO21P0.7 F0 $22 P 0.7$ F023PO.7 F024P0.7

MOU1P1.0 F0U2P1.0 MOOJP1.0 MUO4P1.U FU05P1.0 F0OSP1.UA F006P1.O F007P1.0 M008P1.0 FOC9P1.0 F010P1.U M011P1.0 M012P1.0 M013P1.0
SPECIAL STUDY SPECIAL STUDY SPECIAL STUDY

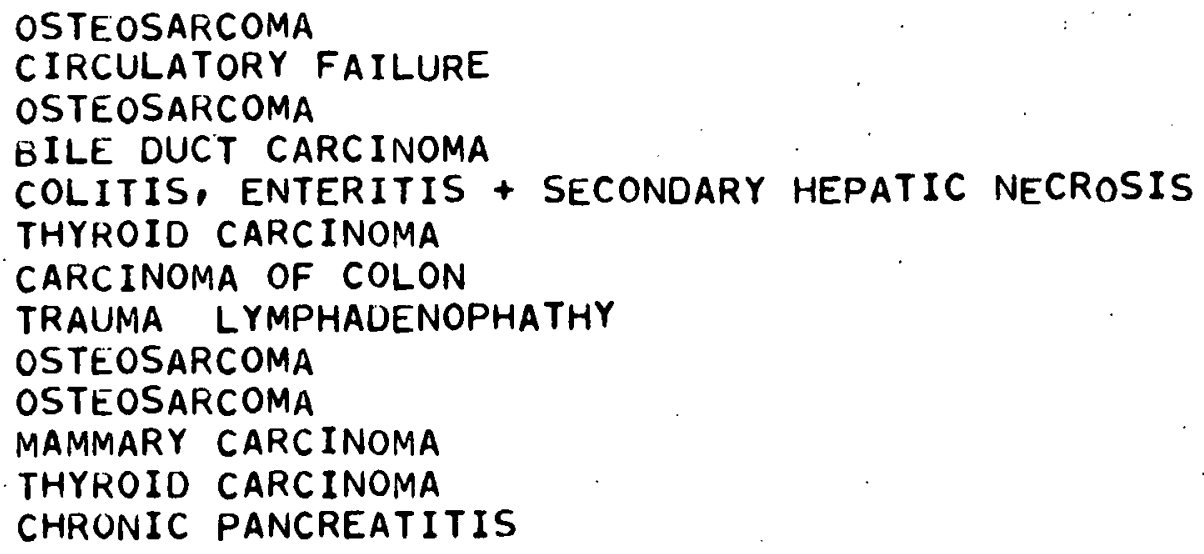


DOG

NUNIBER

F014P1.0

MO1SP1.U

MO16P1.U

M017P1.0

F018P1.0

MO19P1.0

F020P1.0

M021P1.U

F022P1.0

F023P1.0

F024P1.0
AT INJECTION AGE WEIGHT (DAYS) (KG)

$\begin{array}{rr}533 & 10.40 \\ 516 & 12.80 \\ 516 & 10.60 \\ 537 & 10.90 \\ 531 & 9.89 \\ 501 & 9.82 \\ 521 & 10.40 \\ 499 & 10.00 \\ 531 & 9.04 \\ 538 & 11.20 \\ 516 & 10.40\end{array}$

INJECTED

$(\mu \mathrm{Ci} / K G)$

0.0141
0.0159
0.0165
0.0151
0.014
0.0159
0.0141
0.0156
0.0139
0.0163
0.0163

0.0141

$\begin{array}{rrr}22 & 7 & 69 \\ 4 & 9 & 69 \\ 4 & 9 & 69 \\ 3 & 10 & 69 \\ 22 & 7 & 69 \\ 23 & 9 & 70 \\ 22 & 7 & 69 \\ 23 & 9 & 70 \\ 22 & 7 & 69 \\ 4 & 9 & 69 \\ 4 & 9 & 69\end{array}$

617

573

573

544

617

189

617

189

617

573

573
M001P1.7

F002P1.7

M003P1.7

M004P1.7

F005P1.7

F006P1.7

F007P1.7

M008P1.7

F009P1.7

F010P1.7

F010P1.7A

MO11P1.7

M012P1.7

MO13P1.7

$\begin{array}{rr}657 & 8.72 \\ 527 & 8.62 \\ 642 & 8.63 \\ 673 & 8.37 \\ 642 & 11.60 \\ 642 & 10.30 \\ 756 & 9.73 \\ 673 & 13.60 \\ 756 & 9.72 \\ 739 & 10.60 \\ 472 & 8.07 \\ 599 & 11.60 \\ 673 & 9.41 \\ 504 & 10.60\end{array}$

0.0475

0.0431

0.0495

0.0484

0.0493

0.0459

0.0481

0.0479

0.0485

0.0495

0.0457

0.0486

0.0491

0.0473
$26 \quad 6 \quad 56$

$\begin{array}{lll}22 & 11 & 55\end{array}$

$26 \quad 656$

$\begin{array}{lll}10 & 10 & 56\end{array}$

$26 \quad 656$

$26 \quad 6 \quad 56$

$10 \quad 10 \quad 56$

101056

$10 \quad 10 \quad 56$

$10 \quad 10 \quad 56$

3958

$24 \quad 456$

$1010 \quad 56$

3958
3025

3430

3430

3312

2659

2221

3353

3282

2500

467

4214

2777

2973

4375
210

215

246

233

190

170

234

229

180

40

277

200

213

297

\begin{tabular}{|c|c|c|c|c|c|}
\hline $\begin{array}{l}M 001 P 2.0 \\
F 002 P 2 . U \\
M 003 P 2.0 \\
M 004 P 2.0 \\
F 0 U 5 P 2 . U \\
F 006 P 2 . U \\
F 0 U 7 P 2.0 \\
M O 08 P 2.0 \\
F 009 P 2.0 \\
F 010 P 2.0 \\
M 011 P 2.0 \\
M O 12 P 2.0\end{array}$ & $\begin{array}{l}443 \\
422 \\
485 \\
608 \\
594 \\
417 \\
485 \\
406 \\
552 \\
551 \\
599 \\
622\end{array}$ & $\begin{array}{r}7.61 \\
7.73 \\
10.50 \\
9.84 \\
8.12 \\
7.54 \\
8.40 \\
9.73 \\
9.72 \\
7.94 \\
10.30 \\
9.98\end{array}$ & $\begin{array}{l}0.0853 \\
0.112 \\
0.094 \\
0.0862 \\
0.0846 \\
0.0902 \\
0.0996 \\
0.0957 \\
0.101 \\
0.0968 \\
0.0961 \\
0.1\end{array}$ & $\begin{array}{r}1 \\
2 \\
1 \\
16 \\
14 \\
12 \\
25 \\
15 \\
9 \\
22 \\
24 \\
29\end{array}$ & $\begin{array}{r}12 \\
3 \\
6 \\
9 \\
10 \\
5 \\
10 \\
3 \\
9 \\
11\end{array}$ \\
\hline
\end{tabular}

2985

3185

420

2948

380

2423

310

2947

370

2093

310

1761

250

2014

300

2912

410

1617

230

2284

370 
DOG

NUMEER

COMMENTS ON DEAD DOGS

F014P1.0

MOLSP1.0

MOL LP1.0

MO 17P1:0

F018P1.U

M019P1.U

F020P1.0 M021P1.U

F022P1.0

F023P 1.0

F024P1.0

MOU1P1.7
FO02P1.7
MOU3P1.7
MO04P1.7
F005P1:7
FOU6P1.7
F007P1.7
MOUOP1.7
FOU9P1.7
F01UP1.7
F010P1.7A
MU11P1.7
M012P1.7
M013P1.7

M001P2.U

F002P2. 0 .

MOO3P2. 0

MOO4P2.O

F005P2.U

F006P2.0

F007P2.U

M0U8P2.U

FUUYP2.U

F010P2.0

MU11P2.U

MU12P2.U
OSTEOSARCOMA

OSTEOSARCOMA

CHROMOPHOBE ADENOMA OF PITUITARY. PROSTATE CARCINOMA OSTEOSARCOMA

OSTEOSARCOMA

OSTEOSARCOMA

OSTEOSARCOMA

OSTEOSARCOMA

OSTEOSARCOMA

ACUTE ENTERITIS

OSTEOSARCOMA

BILE DUCT CARCINOMA

LEUKEMIA

CHONDROSARCOMA

OSTEOSARCOMA

OSTEOSARCOMA

OSTEOSARCOMA

OSTEOSARCOMA

OSTEOSARCOMA

OSTEOSARCOMA

SQUAMOUS CELL CARCINOMA (FRONTAL SINUS)

ASPIRATION PNEUMONIA

OSTEOSARCOMA

OSTEOSARCOMA

OSTEOSARCOMA

OSTEOSARCOMA 
DOG

NUMBER

M001P3.0

F002P3.0

MO03P3.0

M004P3.0

F005P3.0

F006P3.0

F007P3.0

MOO BP3.0

F009P3.0

F010P3.O

M011P3.0

MO12P3.0

M0O1P4.0

FOU2P4.O

$M 003 P 4.0$

MO04P4.O

F005P4.0

F006P4.0

F007P4.0

$M 008 P 4.0$

F009P4.0

F010P4.0

$M 011 P 4.0$

M012P4.0
AT INUECTION AGE WEIGHT

(DAYS) (KG)

$\begin{array}{lrl}443 & 8.00 & 0.261 \\ 422 & 6.85 & 0.312 \\ 485 & 8.74 & 0.291 \\ 608 & 8.51 & 0.292 \\ 650 & 8.22 & 0.288 \\ 415 & 8.38 & 0.282 \\ 485 & 9.00 & 0.314 \\ 406 & 9.73 & 0.3 \\ 552 & 7.67 & 0.3 \\ 533 & 8.94 & 0.298 \\ 599 & 10.50 & 0.309 \\ 622 & 10.20 & 0.308\end{array}$

DATE

INJECTED

$\left({ }_{\mu} \mathrm{Ci} / \mathrm{KG}\right)$

INJECTED

D MO YR

11252

2353

1653

16953

$14 \quad 10 \quad 53$

$12 \quad 554$

$\begin{array}{lll}25 & 10 & 54\end{array}$

15355

9955

$22 \quad 1155$

$24 \quad 456$

29556
DAYS SINCE

INJECTION

$31 / 3 / 71$ DEATH
DOSE TO

SKELETON

(RADS)

580

900

700

840

630

670

750

780

840

700

550

1198

1659

760

$\begin{array}{rrlrrr}443 & 7.61 & 0.823 & 1 & 12 & 52 \\ 568 & 8.65 & 1.03 & 2 & 3 & 53 \\ 485 & 9.36 & 0.929 & 1 & 6 & 53 \\ 566 & 8.74 & 0.974 & 16 & 9 & 53 \\ 650 & 7.05 & 0.872 & 14 & 10 & 53 \\ 420 & 9.26 & 0.811 & 12 & 5 & 54 \\ 485 & 8.45 & 0.963 & 25 & 10 & 54 \\ 651 & 9.22 & 0.887 & 15 & 3 & 55 \\ 552 & 8.58 & 0.96 & 9 & 9 & 55 \\ 527 & 6.48 & 0.868 & 22 & 11 & 55 \\ 596 & 9.56 & 0.927 & 24 & 4 & 56 \\ 598 & 11.40 & 0.838 & 29 & 5 & 56\end{array}$

1724

1556

1198

1066

1245

1357

1198

1157

1343

1241

1288

1463

2100

2380

1680

1560

1650

1660

1730

1560

1920

1660

1790

1840

$\begin{array}{lrll}\text { MO01P5.0 } & 418 & 8.86 & 2.67 \\ \text { FO02P5.0 } & 1151 & 8.75 & 3.3 \\ \text { MOU3P5.U } & 515 & 8.10 & 3.0 \\ \text { MO04P5.0 } & 566 & 9.18 & 3.17 \\ \text { FO05P5.0 } & 691 & 8.77 & 2.77 \\ \text { F006P5.0 } & 407 & 7.90 & 2.57 \\ \text { F007P5.0 } & 482 & 8.33 & 2.99 \\ \text { M008P5.0 } & 497 & 9.55 & 2.69 \\ \text { FOOSP5.0 } & 552 & 9.45 & 2.73\end{array}$

$\begin{array}{rrr}1 & 12 & 52 \\ 2 & 3 & 53 \\ 1 & 6 & 53 \\ 16 & 9 & 53 \\ 14 & 10 & 53 \\ 12 & 5 & 54 \\ 25 & 10 & 54 \\ 15 & 3 & 55 \\ 9 & 9 & 55\end{array}$

$\begin{array}{rr}1324 & 5370 \\ 1576 & 7830 \\ 499 & 2340 \\ 1562 & 7380 \\ 2059 & 8690 \\ 1194 & 4620 \\ 1491 & 6630 \\ 1192 & 4840 \\ 1145 & 4750\end{array}$


DOG

NUMBER

COMMENTS ON DEAD DOGS

$\begin{array}{ll}\text { MOU1P3.0 } & \text { OSTEOSARCOMA } \\ \text { FOO2P3.0 } & \text { OSTEOSARCOMA } \\ \text { MOU3P3.0 } & \text { OSTEOSARCOMA } \\ \text { MUO4P3.0 } & \text { OSTEOSARCOMA } \\ F 005 P 3.0 & \text { OSTEOSARCOMA } \\ \text { F006P3.U } & \text { OSTEOSARCOMA } \\ F 007 P 3.0 & \text { OSTEOSARCOMA } \\ \text { MOO8P3.0 } & \text { OSTEOSARCOMA } \\ \text { F009P3.0 } & \text { OSTEOSARCOMA } \\ \text { FO10P3.0 } & \text { OSTEOSARCOMA } \\ \text { MO11P3.0 } & \text { OSTEOSARCOMA } \\ \text { MO12P3.0 } & \text { OSTEOSARCOMA }\end{array}$

$M 001 P 4.0$

OSTEOSARCOMA

F002P4.0

OSTEOSARCOMA

MOO3P4.U

OSTEOSARCOMA

MOO4P4.U

OSTEOSARCOMA

F005P4.0

OSTEOSARCOMA

F006P4.0

OSTEOSARCOMA

F0U7P4.0

OSTEOSARCOMA

M008P4.0

OSTEOSARCOMA

F009P4.U

OSTEOSARCOMA

F010P4.0

OSTEOSARCOMA

$M 011 P 4.0$

$M 012 P 4.0$

OSTEOSARCOMA

OSTEOSARCOMA

MOOLP5.U F002P5.0

M003P5.O

MOO4P5.U

FOUSP5.U

F006P5.0

FUU7P5.U

MOOBP5.0

F009P5.0
OSTEOSARCOMA

OSTEOSARCOMA + FRACTURED MANDIBLE

LIVER DEGENERATION + ASCITES

OSTEOSARCOMA

OSTEOSARCOMA, LIVER DEGENERATION + HEPATIC HEMORRHAGE OSTEOSARCOMA

OSTEOSARCOMA + CRIPPLING FRACTURE

GINGIVITIS

OSTEOSARCOMA. EPISTAXIS + CIRCULATORY COLLAPSE 
C. RAOIUM-228 (MESOTHORIUM) *

\begin{tabular}{|c|c|c|}
\hline $\begin{array}{l}\text { OUG } \\
\text { NUMBER }\end{array}$ & $\begin{array}{l}\text { AT INJ } \\
\text { AGE W } \\
\text { (DAYS) }\end{array}$ & $\begin{array}{l}\text { ECTION } \\
\text { EIGHT } \\
(K G)\end{array}$ \\
\hline $\begin{array}{l}F 001 M O .0 \\
F 002 M 0 . U \\
M 003 M 0.0 \\
M 004 M 0.0 \\
F 005 M 0.0 \\
M 006 M 0.0 \\
F 007 M 0.0 \\
F 007 M 0.0 A \\
F 008 M 0.0 \\
M O 09 M 0.0 \\
M 010 M 0.0 \\
F 011 M 0.0 \\
M O 12 M 0.0\end{array}$ & $\begin{array}{l}732 \\
545 \\
579 \\
601 \\
671 \\
492 \\
395 \\
594 \\
654 \\
575 \\
581 \\
475 \\
695\end{array}$ & $\begin{array}{r}7.33 \\
6.94 \\
13.00 \\
10.30 \\
11.20 \\
7.56 \\
8.71 \\
10.90 \\
11.60 \\
12.40 \\
13.30 \\
9.31 \\
10.00\end{array}$ \\
\hline
\end{tabular}

INJECTED

( $\mu(V K G)$
DATE INJECTED

D MO YR

4154

291154

13356

$\begin{array}{lll}15 & 1 & 57\end{array}$

$\begin{array}{lll}5 & 3 & 57\end{array}$

$23 \quad 457$

$\begin{array}{lll}4 & 6 & 57\end{array}$

15163

9360

13460

17762

18962

221260
DAYS SINCE INJECTION

$31 / 3 / 71$ DEATH
DOSE TO

SKELETON

(RADS)
F001M0.5

F002MO.5 MOO 3MO. 5 $M 004 M 0.5$ F005MO.5 MO06MO. 5

F007M0.5 F008MO. 5 M009MO.5 MO1OMO.5 F011MO.5 MO12MO.5

$\begin{array}{rr}492 & 9.47 \\ 492 & 9.15 \\ 493 & 10.80 \\ 475 & 12.80 \\ 534 & 7.83 \\ 510 & 10.30 \\ 492 & 8.87 \\ 654 & 12.60 \\ 485 & 11.90 \\ 492 & 10.60 \\ 505 & 7.82 \\ 510 & 10.60\end{array}$

0.0173

0.0173

0.0199

0.0199

0.0172

0.0171

0.0172

0.0159

0.017

0.0174

0.0202

0.0165 $\begin{array}{lll}17 & 762\end{array}$

17762

$\begin{array}{lll}189 & 9 & 62\end{array}$

$\begin{array}{lll}18 & 9 & 62\end{array}$

$\begin{array}{lll}23 & 10 & 62\end{array}$

$\begin{array}{lll}23 & 10 & 62\end{array}$

17762

9360

13460

17762

18962

$2310 \quad 62$
3451

5966

5056

4816

4581

4934

1414

2997

4039

4004

3116

3751

2991
3179

3179

3116

3116

3081

3179

3019

4039

4004

3179

3116

3081

\begin{tabular}{|c|c|c|c|c|c|}
\hline $\begin{array}{l}F 001 M 1.0 \\
F 001 M 1.0 A \\
F 002 M 1.0 \\
M 003 M 1.0 \\
M 004 M 1.0 \\
F 005 M 1.0 \\
M 006 M 1.0 \\
F 007 M 1.0 \\
F 008 M 1.0 \\
M 009 M 1.0 \\
M 010 M 1.0 \\
F 011 M 1.0\end{array}$ & $\begin{array}{l}718 \\
590 \\
459 \\
575 \\
601 \\
658 \\
521 \\
534 \\
654 \\
485 \\
492 \\
505\end{array}$ & $\begin{array}{r}7.75 \\
8.07 \\
8.25 \\
13.80 \\
9.90 \\
8.80 \\
10.60 \\
9.89 \\
12.40 \\
10.10 \\
9.43 \\
8.91\end{array}$ & $\begin{array}{l}0.0463 \\
0.0512 \\
0.0324 \\
0.0589 \\
0.0481 \\
0.049 \\
0.0468 \\
0.0489 \\
0.0491 \\
0.0504 \\
0.0501 \\
0.0613\end{array}$ & $\begin{array}{r}4 \\
23 \\
29 \\
13 \\
15 \\
5 \\
23 \\
4 \\
9 \\
13 \\
17 \\
18\end{array}$ & $\begin{array}{r}1 \\
10 \\
11 \\
3 \\
1 \\
3 \\
4 \\
6 \\
3 \\
4 \\
7 \\
9\end{array}$ \\
\hline
\end{tabular}

3081

2952

196

5267

3157

213

4260

306

4565

131

3402

192

2159

272

149

240

MOO9M1.O

F011M1.0

505

8.91

0.0613

3886

4004

2966

213 
DOG

NUMBER

FOU1MO.U FUU2MO.O

MOOZMO.O

MOO4MO.U

FOUSMO.U

MOUOMO.O

FUU7M0.0

FUO7MO.UA

FOU8MO.O

MOO9MO.U

MO10MO.O

F011M0.0

MO12MO.O

F001M0.5

F002MO.S

MOO3MO.S

M004M0.5

F005MO.b

MO06MO.5

FOU7MO.S

FOU8MO.5

MOO9MO.5

MO1OMO.5

FOL1MO.5

MO12MO.S

FOU1M1.U

F0O1M1.0A

F002M1.0

M003M1.O

MOO4M1.U

F005M1.0

M006M1.0

F007M1.0

F0U8M1.U

MOU9M1.U

MOLOM1.O

F011M1.U
COMMENTS ON DEAD DOGS

PURULENT MENINGOENCEPHALITIS

BRAIN INFARCTION

VALVULAR ENDOCARDITIS\& MYOCARDIAL INFARCTION MAMMARY CARCINOMA

NEPHRITIS

STATUS EPILEPTICUS

MALIGNANT MELANOMA (ORAL)

MALIGNANT MELANOMA (EYE)

SARCOMA (SPLEEN)

OSTEOSARCOMA

OSTEOSARCOMA

PNEUMONIA: PANCREATITIS

MALIGNANT MELANOMA (EYE)

EPIUERMOID CARC INOMA (PENIS)

SARCOMA (HEART)

MALIGNANT MELANOMA (EYE)

MALIGNANT MELANOMA (EYE) 
DUG

NUNIBER

MU12M1.U
AT INJECTION AGE WEIGHT (DAYS) (KG)
INJECTED ( $\mu$ CVKG)

0.0498
DATE INJECTED

D MO YR

$23 \quad 10 \quad 62$
DAYS SINCE INJECTION $31 / 3 / 71$ DEATH
DOSE TO SKELETON (RADS)

$\begin{array}{lrrlrrr}\text { FOO1M1.7 } & 510 & 7.52 & 0.151 & 23 & 10 & 62 \\ \text { FOU2M1.7 } & 560 & 9.90 & 0.183 & 13 & 3 & 56 \\ \text { MOO3M1.7 } & 576 & 11.00 & 0.18 & 13 & 3 & 56 \\ \text { MOO4M1.7 } & 601 & 8.94 & 0.143 & 15 & 1 & 57 \\ \text { FOUSM1.7 } & 658 & 12.80 & 0.141 & 5 & 3 & 57 \\ \text { MOU6M1.7 } & 521 & 10.00 & 0.144 & 23 & 4 & 57 \\ \text { F007M1.7 } & 534 & 10.20 & 0.146 & 4 & 6 & 57 \\ \text { FOO8M1.7 } & 654 & 10.80 & 0.148 & 9 & 360 \\ \text { MOO9M1.7 } & 485 & 12.60 & 0.149 & 13 & 460 \\ \text { MO1OM1.7 } & 492 & 10.10 & 0.124 & 17 & 762 \\ \text { FO11M1.7 } & 505 & 10.70 & 0.179 & 18 & 962 \\ \text { MO12M1.7 } & 524 & 9.28 & 0.153 & 23 & 1062\end{array}$

3081

\begin{tabular}{|c|c|c|c|c|c|c|c|c|}
\hline 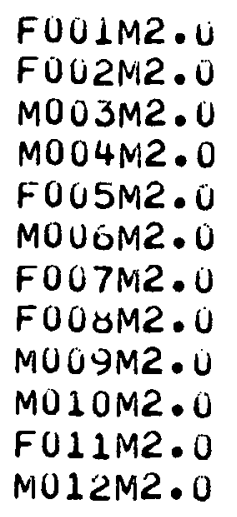 & $\begin{array}{l}676 \\
517 \\
576 \\
601 \\
509 \\
502 \\
534 \\
654 \\
630 \\
430 \\
505 \\
524\end{array}$ & $\begin{array}{r}7.60 \\
8.25 \\
11.00 \\
9.88 \\
8.30 \\
12.40 \\
10.10 \\
12.40 \\
9.99 \\
11.20 \\
7.03 \\
9.47\end{array}$ & $\begin{array}{l}0.276 \\
0.194 \\
0.358 \\
0.282 \\
0.295 \\
0.306 \\
0.298 \\
0.3 \\
0.302 \\
0.311 \\
0.381 \\
0.306\end{array}$ & $\begin{array}{r}4 \\
29 \\
13 \\
15 \\
5 \\
23 \\
4 \\
9 \\
13 \\
17 \\
18 \\
23\end{array}$ & $\begin{array}{r}1 \\
11 \\
3 \\
1 \\
3 \\
4 \\
6 \\
3 \\
4 \\
7 \\
9 \\
10\end{array}$ & $\begin{array}{l}54 \\
54 \\
56 \\
57 \\
57 \\
57 \\
57 \\
60 \\
60 \\
62 \\
62 \\
62\end{array}$ & $\begin{array}{r}1780 \\
965 \\
619 \\
2282 \\
2688 \\
2674 \\
2239 \\
2386 \\
1254 \\
2373 \\
2878 \\
2471\end{array}$ & $\begin{array}{r}870 \\
198 \\
355 \\
1033 \\
928 \\
1382 \\
1064 \\
928 \\
561 \\
1448 \\
1096 \\
1494\end{array}$ \\
\hline $\begin{array}{l}F O U 1 M 3.0 \\
F 002 M 3.0 \\
M O O 3 M 3.0 \\
M 004 M 3.0 \\
F 005 M 3.0 \\
M O O 6 M 3.0 \\
F O 07 M 3.0 \\
F O O 8 M 3.0 \\
M O O 9 M 3.0\end{array}$ & $\begin{array}{l}519 \\
460 \\
579 \\
601 \\
531 \\
502 \\
534 \\
633 \\
630\end{array}$ & $\begin{array}{r}10.40 \\
6.70 \\
10.40 \\
10.20 \\
8.51 \\
9.09 \\
9.94 \\
11.80 \\
9.83\end{array}$ & $\begin{array}{l}0.858 \\
0.612 \\
0.965 \\
0.916 \\
0.94 \\
0.953 \\
0.907 \\
0.95 \\
0.918\end{array}$ & $\begin{array}{r}4 \\
29 \\
13 \\
15 \\
5 \\
23 \\
4 \\
9 \\
13\end{array}$ & $\begin{array}{r}1 \\
11 \\
3 \\
1 \\
3 \\
4 \\
6 \\
3 \\
4\end{array}$ & $\begin{array}{l}54 \\
54 \\
56 \\
57 \\
57 \\
57 \\
57 \\
60 \\
60\end{array}$ & $\begin{array}{l}918 \\
1856 \\
1185 \\
1176 \\
1869 \\
1421 \\
1463 \\
1447 \\
1570\end{array}$ & $\begin{array}{l}1833 \\
2075 \\
2464 \\
1592 \\
2148 \\
1906 \\
3145 \\
2158 \\
2277\end{array}$ \\
\hline
\end{tabular}

3081

$\begin{array}{rl}2383 & 733 \\ 2709 & 723 \\ 2864 & 424 \\ 3234 & 625 \\ 3424 & 393 \\ 2646 & 600 \\ 2486 & 386 \\ 2799 & 672 \\ 3101 & 748 \\ 3017 & 718\end{array}$

3116 
UOG

NUMBER

COMMENTS ON DEAD DOGS

MO12M1.O

F0O1M1:7

FOU2M1.7 . OSTEOSARCOMA

MOU3M1.7: OSTEOSARCOMA

MO04M1.7 CARCINOMA SMALL INTESTINE.

FOOSM1.7 OSTEOSARCOMA

MO06M1.7 OSTEOSARCOMA

F007M1.7 OSTEOSARCOMA

F008M1.7 . OSTEOSARCOMA

MO09M1.7. OSTEOSARCOMA

MO1OM1.7 . OSTEOSARCOMA

$F 011 M 1 \cdot 7$

M012M1. 7

UNKNOWN

\begin{tabular}{|c|c|}
\hline $\begin{array}{l}F O U 1 M 2.0 \\
F 002 M 2.0 \\
M U O 3 M 2.0 \\
M 004 M 2.0 \\
F 005 M 2 . U \\
M 006 M 2.0 \\
F 007 M 2.0 \\
F 008 M 2.0 \\
M 009 M 2.0 \\
M 010 M 2.0 \\
F 011 M 2.0 \\
M O 12 M 2.0\end{array}$ & $\begin{array}{l}\text { OSTEOSARCOMA } \\
\text { INTESTINAL } \\
\text { PNEUMONIA } \\
\text { OSTEOSARCOMA } \\
\text { OSTEOSARCOMA } \\
\text { OSTEOSARCOMA } \\
\text { CHRONIC PANC } \\
\text { OSTEOSARCOMA } \\
\text { OSTEOSARCOMA } \\
\text { OSTEOSARCOMA } \\
\text { OSTEOSARCOMA } \\
\text { OSTEOSARCOMA }\end{array}$ \\
\hline $\begin{array}{l}F O U 1 M 3.0 \\
F 0 \cup 2 M 3.0 \\
M O U 3 M 3.0 \\
M 0 \cup 4 M 3.0 \\
F O U 5 M 3.0 \\
M 0 \cup 6 M 3.0 \\
F 007 M 3.0 \\
F O U 8 M 3.0 \\
M O U 9 M 3.0\end{array}$ & $\begin{array}{l}\text { OSTEOSARCOMA } \\
\text { OSTEOSARCOMA } \\
\text { OSTEOSARCOMA } \\
\text { OSTEOSARCOMA } \\
\text { OSTEOSARCOMA } \\
\text { OSTEOSARCOMA } \\
\text { OSTEOSARCOMA } \\
\text { OSTEOSARCOMA } \\
\text { OSTEOSARCOMA }\end{array}$ \\
\hline
\end{tabular}


DOG

NUMBER

MO1UM3.0

F011M3.0

MO12M3.U
AT INJECTION AGE WEIGHT (DAYS) (KG)
INJECTED

( $\mu^{C i / K G)}$
DATE

INJECTED

D MO YR

$\begin{array}{lll}17 & 7 & 62\end{array}$

18962

231062
DAYS SINCE INJECTION

$31 / 3 / 71$ DEATH
DOSE TO

SKELETON

(RADS)

2318

2467

2365

\begin{tabular}{|c|c|c|c|c|c|c|c|c|}
\hline $\begin{array}{l}F 001 M 4.0 \\
F 002 M 4.0 \\
M 003 M 4.0 \\
M 003 M 4.0 A \\
M 004 M 4.0 \\
F 005 M 4.0 \\
M 006 M 4.0 \\
F 007 M 4.0\end{array}$ & $\begin{array}{l}510 \\
460 \\
579 \\
494 \\
609 \\
509 \\
502 \\
544\end{array}$ & $\begin{array}{l}7.56 \\
6.95 \\
9.65 \\
7.34 \\
7.84 \\
9.63 \\
9.49 \\
8.40\end{array}$ & $\begin{array}{l}2.6 \\
1.86 \\
3.37 \\
2.64 \\
2.47 \\
2.67 \\
2.66 \\
2.67\end{array}$ & $\begin{array}{r}4 \\
29 \\
13 \\
4 \\
15 \\
5 \\
23 \\
4\end{array}$ & $\begin{array}{r}1 \\
11 \\
3 \\
6 \\
1 \\
3 \\
4 \\
6\end{array}$ & $\begin{array}{l}54 \\
54 \\
56 \\
57 \\
57 \\
57 \\
57 \\
57\end{array}$ & $\begin{array}{r}841 \\
778 \\
418 \\
1063 \\
896 \\
1064 \\
1121 \\
1253\end{array}$ & $\begin{array}{l}5614 \\
2272 \\
1795 \\
5604 \\
2680 \\
4358 \\
4784 \\
4636\end{array}$ \\
\hline
\end{tabular}

$\begin{array}{rrrrrrrrr}\text { F0O1M5.0 } & 494 & 7.77 & 8.11 & 4 & 1 & 54 & 232 & 3854 \\ \text { FOO2M5.0 } & 460 & 7.35 & 5.46 & 29 & 1154 & 780 & 7666 \\ \text { M003M5.0 } & 579 & 8.87 & 10.4 & 13 & 3 & 56 & 688 & 14151 \\ \text { M004M5.0 } & 482 & 7.29 & 7.89 & 15 & 157 & 561 & 5662 \\ \text { F005M5.0 } & 658 & 11.10 & 8.48 & 5 & 3 & 57 & 770 & 9559 \\ \text { M006M5.0 } & 580 & 7.53 & 8.67 & 23 & 4 & 57 & 792 & 6761 \\ \text { F007M5.0 } & 494 & 7.35 & 8.92 & 4 & 6 & 57 & 966 & 18094\end{array}$

\footnotetext{
$*\left(\mu \mathrm{C} i^{228} \mathrm{Th} / \mu \mathrm{Ci}{ }^{228} \mathrm{Ra}\right)$ injected $=0.15$ for $\mathrm{FIMI} .0,2.0,3.0,4.0,5.0$.

$=0.03$ for $\mathrm{F} 2 \mathrm{MI} .0,1.7,2.0,3.0,4.0,5.0$, M3MI.0, $1.7,2.0,3.0,4.0,5.0$.

$=0.006$ for groups $4,5,6,7,8,9,10,11$, 12 , and dogS FIMO.5, F2MO.5, M3MO.5, FIMIA, FIMI.7 and M3M4.0A.
} 
DOG

NUMBER

MO10N3.0

F011M3.

MO12M3.U

F001M4.U FO02M4.0 MOO3M4.O MOO3Ni4.0A $M 004 M 4.0$ F005M4.0 MOŨ 6M4.O F.007M4.0

FOUIM5.O F002M5. $U$ MOU3M5. 0 MOO4MS.O FOUSMS.O MUUGMS.O F007M5.0
OSTEOSARCOMA + CRIPPLING FRACTURE OSTEOSARCOMA

STRANGULATED INGUINAL HERNIA OSTEOSARCOMA, NEPHRITIS, ULCERATIVE GINGIVITIS + PNEUMONIA FRACTURED MANDIBLE + ULCERATIVE GINGIVITIS OSTEOSARCOMA OSTEOSARCOMA OSTEOSARCOMA.

NEPHRITIS + SEVERE ANEMIA

CRIPPLING FRACTURES

ULCERATIVE GINGIVITIS

CRIPPLING FRACTURE

ULCERATIVE GINGIVITIS

OSTEOSARCOMA +CRIPPLING FRACTURE

ULCERATIVE GINGIVITIS, MYOCARDIAL INFARCTION + GLAUCOMA 
D. THORIUM-228 (RADIOTHORIUM)

DOG

NUMBER

MOO1TO.0

MOU2TO.0

F0U3T0.O

M004TO.0

M005T0.0

F006T0.0

FOOGTO.UA

MOU7T0.0

MOOSTO.0

F009T0.0

F010T0.0

F011T0.0

F012T0.0
AT INJECTION AGE WEIGHT (DAYS) (KG)

$\begin{array}{rr}493 & 8.24 \\ 488 & 7.28 \\ 797 & 11.60 \\ 591 & 8.10 \\ 458 & 10.40 \\ 489 & 9.64 \\ 688 & 8.61 \\ 517 & 10.50 \\ 533 & 10.80 \\ 569 & 8.28 \\ 536 & 10.40 \\ 530 & 9.45 \\ 492 & 9.09\end{array}$

DATE

INJECTED

$(\mu \mathrm{C} / K G)$

INJECTED

D MO YR

8254

$\begin{array}{lll}28 & 9 & 54\end{array}$

$6 \quad 6 \quad 55$

181055

$14 \quad 1058$

10161

$\begin{array}{lll}15 & 12 & 60\end{array}$

$\begin{array}{lll}7 & 2 & 61\end{array}$

$24 \quad 561$

$29 \quad 6 \quad 61$

$\begin{array}{lll}28 & 7 & 61\end{array}$

4663

9763
DAYS SINCE

INJECTION

31/3/71 DEATH
DOSE TO

SKELETON

(RADS)
MOO1T0.2 M002T0.2 F003T0.2 M004TO.2 MOOSTO.2 M0U5TO.2A F006T0.Z M007T0.2 M008T0.2 FOU9T0.2 F010T0.2 F011T0.2 F012T0.2
682

682

478

478

625

530

489

532

494

569

508

530

492

$\begin{array}{rl}11.40 & 0.00164 \\ 10.40 & 0.00166 \\ 9.86 & 0.00163 \\ 10.00 & 0.00166 \\ 13.80 & 0.00162 \\ 13.40 & 0.00173 \\ 8.85 & 0.00176 \\ 10.50 & 0.00159 \\ 13.90 & 0.00189 \\ 7.82 & 0.00171 \\ 10.50 & 0.0017 \\ 9.76 & 0.00171 \\ 7.37 & 0.0019\end{array}$

$\begin{array}{lll}27 & 3 & 62\end{array}$

27362

$\begin{array}{lll}27 & 3 & 62\end{array}$

$\begin{array}{lll}27 & 3 & 62\end{array}$

9260

4663

$10 \quad 161$

$\begin{array}{lll}7 & 2 & 61\end{array}$

24561

29661

28761

4663

9763
3291

3291

3291

3291

2857

3732

3704

3598

3562

3533

2857

2822
4895

5510

2592

3072

171

1412

889

10

\begin{tabular}{|c|c|c|c|c|c|c|c|}
\hline 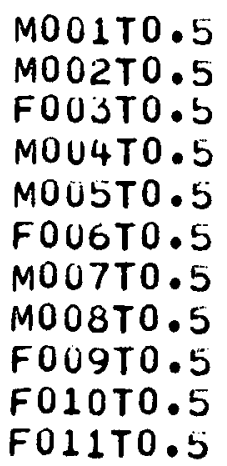 & $\begin{array}{l}699 \\
455 \\
659 \\
516 \\
513 \\
489 \\
532 \\
533 \\
569 \\
508 \\
530\end{array}$ & $\begin{array}{r}14.30 \\
10.50 \\
8.59 \\
8.58 \\
8.46 \\
9.66 \\
9.11 \\
9.53 \\
8.62 \\
10.20 \\
7.78\end{array}$ & $\begin{array}{l}0.00496 \\
0.0049 \\
0.00485 \\
0.0054 \\
0.00522 \\
0.0051 \\
0.00491 \\
0.00562 \\
0.00529 \\
0.0051 \\
0.00518\end{array}$ & $\begin{array}{r}7 \\
28 \\
6 \\
18 \\
14 \\
10 \\
7 \\
24 \\
29 \\
28 \\
4\end{array}$ & $\begin{array}{r}9 \\
9 \\
6 \\
10 \\
10 \\
1 \\
2 \\
5 \\
6 \\
7 \\
6\end{array}$ & $\begin{array}{l}56 \\
54 \\
55 \\
55 \\
58 \\
61 \\
61 \\
61 \\
61 \\
61 \\
63\end{array}$ & $\begin{array}{l}4551 \\
3732 \\
3704 \\
3598 \\
3562 \\
3533 \\
2857\end{array}$ \\
\hline
\end{tabular}

$3471 \quad 45$

$1976 \quad 41$

$3032 \quad 44$

2159 . 46 
000

NUMBER

MOUITO.U

M002T0.0

F003TO.O

M004TO.O

M005T0.0

F006T0.0

F006T0.0A

MO07.TO.O

MOU8T0.0

F009T0.0

F010T0.0

F011T0.0

F012T0.0

M001T0.2

MOO2TO.Z

FOU3T0.2

M004TO.L

MUU5TO.2

M005T0.2A

F006TO.

MOU7TO.Z

M008T0.2

F009T0.2

F010T0.2

F011T0.2

F012T0.2

MOU1T0.5

M002T0.5

FUUSTO.S

MOU4T0.3

MUUST0.5

FOU6TO.S

MO07TO.S

MOU४T0.5

FOOGTO.D

F010T0.ל

F011T0.S
COMMENTS ON DEAD DOGS

RETICULUM CELL SARCOMA (SOFT TISSUE)

NEPHRITIS

BRAIN HEMORRHAGE

LYMPHOSARCOMA

TRAUMA

BRAIN HEMORRHAGE

STRANGULATION ON VOMITUS + GRAND MAL
CERFBRAL INFARCTION HEMORRHAGE STRANGULATION ON VOMITUS + GRAND MAL PYOMETRITIS + SECONDARY PERITONITIS STATUS EPILEPTICUS + PNFUMONIA 
DOG

NUMGER

F012T0.5
AT INJECTION AGE WEIGHT

(DAYS) (KG)
INJECTED

( ${ } \mathrm{C} i / K G)$
DATE INJECTED

D MO YR

9763

0.00567

$\begin{array}{rl}9.36 & 0.0146 \\ 9.27 & 0.0146 \\ 8.84 & 0.0145 \\ 8.27 & 0.0146 \\ 11.90 & 0.0146 \\ 8.81 & 0.015 \\ 9.18 & 0.0147 \\ 8.69 & 0.0166 \\ 10.00 & 0.016 \\ 10.20 & 0.015 \\ 7.55 & 0.0154 \\ 9.96 & 0.0167\end{array}$

493

699

723

699

513

489

532

533

527

508

521

472

9.96

9.94

9763

$\begin{array}{rrr}8 & 2 & 54 \\ 7 & 9 & 56 \\ 7 & 9 & 56 \\ 7 & 9 & 56 \\ 14 & 10 & 58 \\ 10 & 1 & 61 \\ 7 & 2 & 61 \\ 24 & 5 & 61 \\ 29 & 6 & 61 \\ 28 & 7 & 61 \\ 4 & 6 & 63 \\ 9 & 7 & 63\end{array}$

DAYS SINCE INUECTION

31/3/71 DEATH

DOSE TO

(RADS)

45

F011T1.0

F012T1.U
699

458

609

591

598

489

517

521

494

527

508

518

465

$$
\begin{array}{r}
7.95 \\
10.00 \\
10.30 \\
8.59 \\
9.65 \\
8.14 \\
8.83 \\
9.08 \\
11.60 \\
8.80 \\
11.60 \\
11.40 \\
7.56
\end{array}
$$

0.0289

0.0293

0.0303

0.0299

0.0286

0.0292

0.0292

0.0311

0.0324

0.0306

0.0296

0.0305

0.0329 $\begin{array}{rrr}7 & 9 & 56 \\ 28 & 9 & 54\end{array}$

$6 \quad 655$

$1810 \quad 55$

9260

10161

7261

4663

24561

29661

$\begin{array}{lll}28 & 7 & 61\end{array}$

4663

9763

1682

132

135

133

132

130

136

134

3598

3538

140

136

2857

2546

3420

1263

118
2894

2576

1921

2309

1624

2373

384

2857

2665

2983

1859

2408

2120
258

257

249

257

223

252

95

286

274

241

281

278
M001T2.0

M002T2.0

F003T2.0

M004T2.0

M004T2.0A

M005T2.0

F006T2.0

M007T2.0

$\begin{array}{rrl}491 & 10.20 & 0.0976 \\ 483 & 9.16 & 0.0875 \\ 474 & 7.87 & 0.0908 \\ 553 & 13.00 & 0.09 \\ 650 & 10.60 & 0.0899 \\ 598 & 9.12 & 0.0848 \\ 451 & 8.65 & 0.0879 \\ 517 & 8.85 & 0.0881\end{array}$

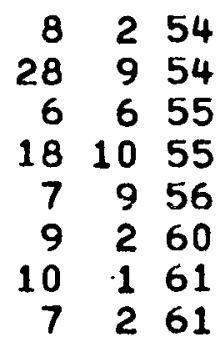

1282

1234

1541

78

1222

1085

1108

1015
693

611

695

70

625

556

583

558 
DOG

NUMBER

COMMENTS ON DEAD DOGS

F012T0.5 LIVER DEGENERATION. ANESTHETIC REACTION

M001T1.U

MO02T1.0.

F003T1.0

M004T1.0

MOOST1.0

F006T1.0

MOU7T1.0

M008T1.0

F009T1.0

F010T1.0

F011T1.0

F012T1.0

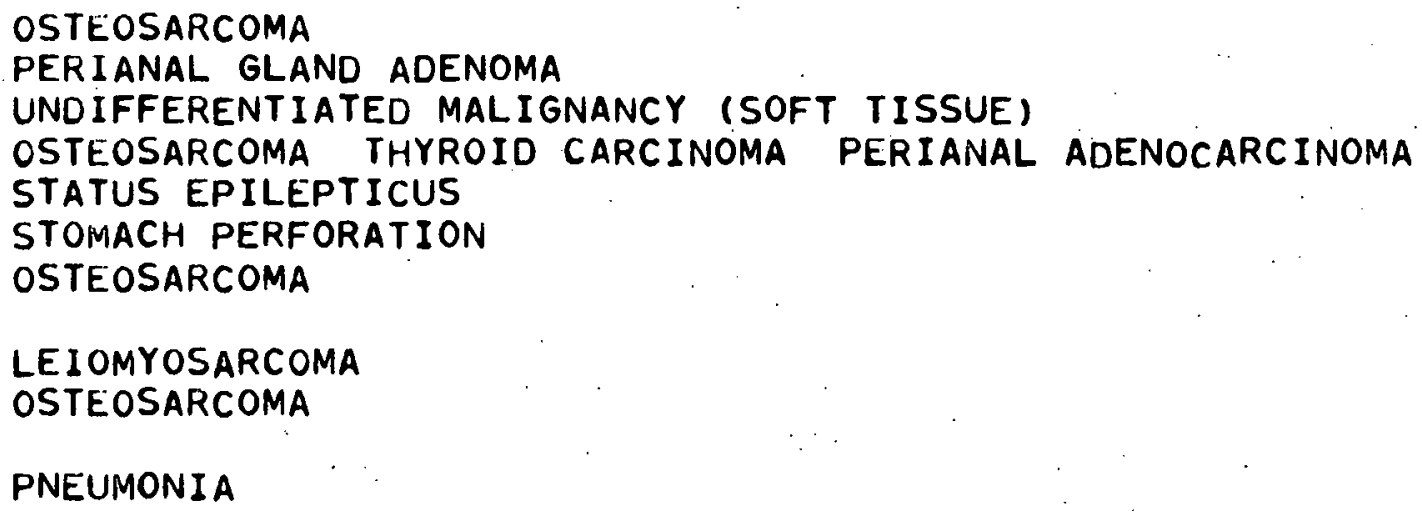

PNEUMONIA

MUO1T1.5

M002T1.5

F003T1.5

MOU 4T1.S

MOOST1.3

F006T1.5

M007T1.5

M007T1.5A

MO08T1.5

F009T1.5

F01UT1.D

F011T1.5

F012T1.S

MUU1T2.O

MO02T2.0

F003T2.0

$M 004 T 2.0$

M004T2.0A

M005T2.0

F006T2.U

M007T2.0
OSTEOSARCOMA

OSTEOSARCOMA

COMA OF UNKNOWN ETIOLOGY (NO BONE TUMOR) OSTEOSARCOMA

OSTEOSARCOMA

OSTEOSARCOMA

LEPTOSPIROSIS

OSTEOSARCOMA

OSTEOSARCOMA

OSTEOSARCOMA

OSTEOSARCOMA

USTEOSARCOMA

OSTËOSARCOMA

OSTEOSARCOMA

OSTEOSARCOMA

TRAUMA

OSTEOSARCOMA

OSTEOSARCOMA

OSTEOSARCOMA

OSTEOSARCOMA 
DOG

NUMBER

M008T2.0

FOU9T2.0

F010T2.0

F011T2.0

F012T2.0
AT INJECTION AGE WEIGHT

(DAYS) (KG)

533

527

508

518

464

$\begin{array}{rl}10.70 & 0.0981 \\ 8.09 & 0.0979 \\ 10.70 & 0.0919 \\ 10.80 & 0.0904 \\ 8.92 & 0.1\end{array}$

8.92
INJECTED

$(\mu \mathrm{Ci} / K G)$
DATE

INJECTED

D MO YR

$\begin{array}{rrr}24 & 5 & 61 \\ 29 & 6 & 61 \\ 28 & 7 & 61 \\ 4 & 6 & 63 \\ 9 & 7 & 63\end{array}$

8254

$\begin{array}{lll}28 & 9 & 54\end{array}$

$\begin{array}{lll}6 & 655\end{array}$

$18 \quad 1055$

9260

10161

$\begin{array}{lll}7 & 2 & 61\end{array}$

24561

$\begin{array}{lll}29 & 6 & 61\end{array}$

28761

$\begin{array}{lll}46 & 63\end{array}$

9763
DAYS SINCE INJECTION

31/3/71 DEATH
DOSE TO

SKELETON

(RADS)

641

677

584

579

748

F009T3.0

F010T3.0

Fo11T3.0

F012T3.0

518

459

9.26

0.28

0.29

$11.50 \quad 0.32$

MOO1T4.0

MOO2T4.0

FOU 314.0

MUO4T4.O

480

458

461

606

8.32

0.882

$8 \quad 254$

645

4237

833

5185

7.25

0.8

6655

$\begin{array}{lll}18 & 10 \quad 55\end{array}$

763

793

4290

4587

MOU1T5.U

480

9.48

2.76

8254

$\begin{array}{lll}28 & 9 & 54\end{array}$

212

97

5457

2535 
DOG

NUMBER

COMMENTS ON DEAD DOGS

$\begin{array}{ll}\text { MOO8T2.0 } & \text { OSTEOSARCOMA } \\ \text { F009T2.0 } & \text { OSTEOSARCOMA } \\ \text { F010T2.0 } & \text { OSTEOSARCOMA } \\ \text { F011T2.0 } & \text { OSTEOSARCOMA } \\ \text { F012T2.0 } & \text { OSTEOSARCOMA }\end{array}$

MOO1T3.0

MUO2T3.0

OSTEOSARCOMA + SEVERE ANEMIA

F003T3.0

OSTEOSARCOMA + TRAUMA

OSTEOSARCOMA

$M 004 T 3.0$

M005T3.0

FOUOT3.U

MOOTT3.0

MOU8T3.U

F00.9T3.0

F010T3.0

F011T3.0

F012T3.0

OSTEOSARCOMA

OSTEOSARCOMA

OSTEOSARCOMA

OSTEOSARCOMA

OSTEOSARCOMA

OSTEOSARCOMA

OSTEOSARCOMA

OSTEOSARCOMA

HEMANGIOSARCOMA (HUMERUS)

MOU1T4.0 OSTEOSARCOMA + CRIPPLING FRACTURE

MO02T4.0 OSTEOSARCOMA. CRIPPLING FRACTURE + NEPHRITIS

FOU3T4.0

MOO4T4.U

ULCERATIVE GINGIVITIS + NEPHRITIS

ULCERATIVE GINGIVITIS

MOU1T5.0 NEPHRITIS

MOU2T5.0. PANCYTOPENIA 
E. STRONTIUM-90

DOG

NUMBER

F00150.0

M00250.0

MO0 350.0

F00450.U

MO0550.0

MOUGSO.O

FOUTSO.OA

F00050.0

F009S0.U

FOU9SO.0A

MOLOSO.U

F01150.0

M01250.0
AT INJECTION AGE WEIGHT

(DAYS) (KG)

$\begin{array}{rr}502 & 8.48 \\ 600 & 11.10 \\ 493 & 9.03 \\ 520 & 8.19 \\ 542 & 10.60 \\ 466 & 9.68 \\ 462 & 9.46 \\ 483 & 9.29 \\ 549 & 12.40 \\ 535 & 11.20 \\ 522 & 13.90 \\ 541 & 9.60 \\ 605 & 8.99\end{array}$

INUECTED

( $K \mathrm{C} i / K G)$
DATE

INJECTED

D MO YR

18155

14256

11957

$\begin{array}{lll}15 & 10 & 57\end{array}$

$\begin{array}{lll}19 & 11 & 57\end{array}$

27558

7159

$19 \quad 5 \quad 59$

11859

4663

$29 \quad 959$

$\begin{array}{lll}3 & 11 & 59\end{array}$

6160
DAYS SINCE

INJECTION

$31 / 3 / 71$ DEATH

5484

3838

3516

4915

4158

4691

4334

3303

708

2857

4201

4166

4102

DOSE TO

SKELETON

(RADS)

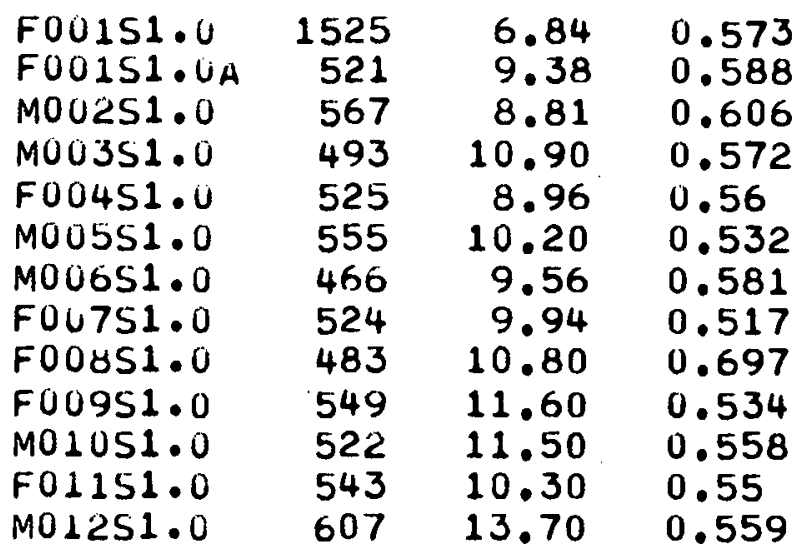

$18 \quad 155$

14256

14256

$\begin{array}{lll}11 & 9 & 57\end{array}$

$\begin{array}{lll}15 & 10 & 57\end{array}$

$\begin{array}{lll}19 & 11 & 57\end{array}$

$27 \quad 5 \quad 58$

$\begin{array}{lll}11 & 11 & 58\end{array}$

19559

11859

$\begin{array}{lll}29 & 9 & 59\end{array}$

31159

6160

308

21

5524

5077

90

4949

4915

4691

2705

71

4523

2783

3601

79

4201

4166

4102

87

\begin{tabular}{|c|c|c|c|c|c|}
\hline $\begin{array}{l}F 00151.7 \\
\text { M00251.7 } \\
M 00351.7 \\
F 004 S 1.7 \\
\text { M005S1.7 } \\
\text { MOOSS1.7A } \\
\text { MOU6S1.7 } \\
\text { F00751.7 } \\
\text { MO08S1.7 } \\
F 00951.7 \\
\text { M010S1.7 }\end{array}$ & $\begin{array}{l}526 \\
567 \\
493 \\
522 \\
560 \\
493 \\
466 \\
488 \\
472 \\
549 \\
519\end{array}$ & $\begin{array}{r}7.41 \\
11.60 \\
9.19 \\
9.60 \\
9.85 \\
11.40 \\
10.60 \\
10.20 \\
8.47 \\
10.00 \\
13.60\end{array}$ & $\begin{array}{l}1.78 \\
1.84 \\
1.69 \\
1.68 \\
1.6 \\
1.78 \\
1.72 \\
1.6 \\
2.03 \\
1.62 \\
1.66\end{array}$ & $\begin{array}{r}14 \\
14 \\
11 \\
15 \\
19 \\
6 \\
27 \\
11 \\
19 \\
11 \\
29\end{array}$ & $\begin{array}{r}2 \\
2 \\
9 \\
10 \\
11 \\
3 \\
5 \\
11 \\
5\end{array}$ \\
\hline
\end{tabular}

5524

$\begin{array}{ll}4297 & 405 \\ 4846 & 338 \\ 4628 & 279 \\ 1715 & 165\end{array}$

2947

4691

\begin{tabular}{|c|c|}
\hline & $\begin{array}{l}3990 \\
1973\end{array}$ \\
\hline - & 2947 \\
\hline
\end{tabular}


DOO

NUMBER

FoU150.U

MOU2SO.0

MO0350.0

F004S0.O

MOUSSO.O

M006S0.0

F00750.0A

F00850.U

FOU9SO.0

FUU9SO.UA

MO10SO.0

F01150.0

MO1250.0

F001S1.0

FUO1S1.0A

M002S1.0

MOU351.0

F00451.U

MOU5S1.0

M00651.0

F00751.0

FOU 851.U

F0ÜS1.0

MOLOS1.U

F011S1.0

MO12S1.0
COMMENTS ON DEAD DOGS

ADRENAL CORTICAL CARCINOMA: MAMMARY CARCINOMA BRONCHOGENIC CARCINOMA

OBTURATING AORTIC EMBOLISM. NEPHRITIS

TRANSITIONAL CELL CARCINOMA

DIABETES MELLITUS

TRAUMA

SACRIFICED - IMPROPER INJECTION AGE-

AORTIC BODY TUMOR

STATUS EPILEPTICUS

PANCREATIC ISLET CELL CARCINOMA

FOREIGN BODY PNEUMONIA: ENTERITIS
F00151.7 MOU2S1.7 MO03S1.7. F004S1.7 M005S1.7 M00551.7A MUUOSS1.7 F00751.7 F008S1.7 FU09S1.7 MU10S1.7
HEMANGIOSARCOMA (SOFT TISSUE ORIGIN) OBTURATING THROMBOEMBOLISM. AORTA PANCREATIC CARCINOMA COMA OF UNKNOWN ETIOLOGY (NO BONE TUMOR)

ARTHRITIS: MAMMARY CARCINOMA

STATUS EPILEPTICUS, CHRONIC PANCREATITIS

ORTURATING PULMONARY EMBOLISM. NEPHRITIS 
DOG

NUMIBER

F011S1.7

MO1251.7 $\triangle T$ INJECTION AGE WEIGHT

(DAYS) (KG)
INUECTED

$(\mu \mathrm{C} / K G)$

$\begin{array}{lll}543 & 11.00 & 1.68 \\ 607 & 11.90 & 1.68\end{array}$

DATE INJECTED

D MO YR

31159

6160
DAYS SINCE INJECTION 31/3/71 DEATH
DOSE TO

SKELETON

(RADS)

239

$\begin{array}{lrrl}\text { F0U1S2.0 } & 502 & 5.59 & 3.7 \\ \text { MOU2S2.0 } & 567 & 8.97 & 3.42 \\ \text { MOU3S2.0 } & 494 & 7.82 & 3.39 \\ \text { F004S2.U } & 522 & 9.68 & 3.41 \\ \text { MOOSS2.0 } & 560 & 8.72 & 3.24 \\ \text { MOU6S2.0 } & 466 & 9.19 & 3.5 \\ F 00752.0 & 488 & 11.20 & 3.19 \\ \text { FOU8S2.U } & 465 & 9.49 & 4.14 \\ \text { FOU9S2.0 } & 473 & 14.10 & 3.28 \\ \text { MO10S2.0 } & 508 & 10.70 & 3.34 \\ F 01152.0 & 543 & 10.40 & 3.41 \\ \text { MO12S2.0 } & 607 & 11.60 & 3.49\end{array}$

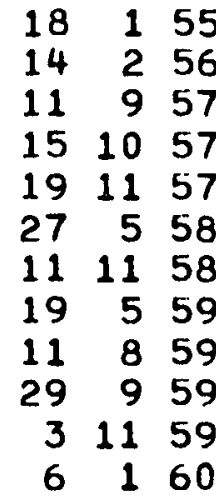

3269

3768

4295

4775

3253

4691

3421

3955

2467

3436

4166

4102

$\begin{array}{lrrr}F 001 S 3.0 & 468 & 7.36 & 11.6 \\ M 00253.0 & 565 & 9.62 & 11.6 \\ M 00353.0 & 494 & 11.40 & 10.8 \\ F 00453.0 & 527 & 9.17 & 10.6 \\ M O U 5 S 3.0 & 557 & 8.90 & 10.1 \\ M 00653.0 & 466 & 9.44 & 10.9 \\ F 00753.0 & 486 & 9.80 & 10.1 \\ F 00853.0 & 465 & 12.50 & 12.9 \\ F 00953.0 & 468 & 10.00 & 10.1 \\ M 010 S 3.0 & 519 & 12.50 & 10.3 \\ F 01153.0 & 541 & 9.00 & 10.8 \\ M 01253.0 & 605 & 8.43 & 10.2\end{array}$

F00154.0 M00254.0 M00354.0

F004S4.0 MO05S4.0 M00654.0 F0U754.0 F00854.0

$\begin{array}{rrr}468 & 8.74 & 33.3 \\ 567 & 11.20 & 32.6 \\ 593 & 9.83 & 32.1 \\ 528 & 8.24 & 32.1 \\ 562 & 9.65 & 30.6 \\ 504 & 16.00 & 32.7 \\ 478 & 10.90 & 30.9 \\ 465 & 10.90 & 40.6\end{array}$

$18 \quad 155$

14256

11957

$\begin{array}{lll}15 & 10 & 57\end{array}$

$\begin{array}{lll}19 & 1157\end{array}$

$27 \quad 5 \quad 58$

111158

19559

11859

29959

$\begin{array}{lll}3 & 1159\end{array}$

6160
477

631

670

736

531

457

685

566

593

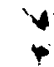


DOO

NUMGER

FU11S1.7 M012S1.7

F001S2.0 MOU2S2.0 MOU352:0 F004S2.0 M0U5S2.0 M00652.0 F00752.U FOU8S2.0 FUO9S2.0 MOLUS2.0 F011S2. C MO12S2.0

F00153.0 M00253.0 M00353.0 F004S3.0 M005S3.0 M00653.0 F00753.0 F00853.0 F0.0953.0 M010S3.0 F011S3.0 MO1253.O

F00154.0 MUO254.U MUO3S4.U FUU4S4.0 MOUSS4.U M00654.U F00754.0 F008S4.U
COMMENTS ON DEAD DOGS

AORTIC THROMBUS; METASTATIC CALCIFICATION OF LUNGS

BACTERIAL PINEUMONIA UNDETERMINED SOFT TISSUE. SARCOMA +BRONCHIOGENIC CARCINOMA STATUS EPILEPTICUS: THYROID CARCINOMA MAMMARY CARCINOMA ULCERATIVE STOMATITIS

PANCREATIC ISLET CELL ADENOMA PNEUMONIA UNDETERMINED (NO BONE TUMOR) BACTERIAL VALVULAR ENDOCARDITIS

UNDETERMINED (NO BONE TUMOR) NEPHRITIS SEMINOMA: HYDROCEPHALUS MAMMARY CARCINOMA SERTOLI CELL TUMOR

MAMMARY CARCINOMA: THYROID CARCINOMA

FIBROSARCOMA (GINGIVA)

NOT DETERMINED (NO OSTEOSARCOMA) SQUAMOUS CELL CARCINOMA - GINGIVAOBTURATING PULMONARY EMROLISM SQUAMOUS CELL CARCINOMA: ECTOPIC THYROID CARCINOMA HEMANG IOSARCOMA (SPLEEN) SEMINOMA

UNDETERMINEU (NO BONE TUMOR) 
DOO

NUMBER

F00954.0

MU1US4.U

F01154.0

M012S4.0
AT INJECTION AGE WEIGHT (DAYS) (KG)
INJECTED

( $\mu C V K G)$
DATE

INJECTED

D MO YR
DOSE TO

SKELETON

(RADS)

3324

$\begin{array}{lll}542 & 8.86 & 32.7\end{array}$

$\begin{array}{lll}605 & 10.90 \quad 32.3\end{array}$

$\begin{array}{rrrr}F 001 S 4.5 & 530 & 9.00 & 64.2 \\ M 002 S 4.5 & 530 & 12.20 & 63.6 \\ M 00354.5 & 530 & 11.90 & 63.8 \\ F 00454.5 & 530 & 9.80 & 64.5 \\ M 005 S 4.5 & 496 & 13.30 & 61.3 \\ M 00654.5 & 496 & 12.00 & 63.8 \\ F 00754.5 & 511 & 9.90 & 64.5 \\ F 008 S 4.5 & 511 & 9.90 & 64.5 \\ F 009 S 4.5 & 511 & 10.30 & 64.0 \\ M 010 S 4.5 & 496 & 14.00 & 60.9 \\ F 011 S 4.5 & 496 & 11.90 & 63.8 \\ M 012 S 4.5 & 485 & 11.40 & 63.7\end{array}$

F001S5.0

$M 00255.0$

MO0255.UA

M00355.0

F004S5.0

M00555.0

M006S5.0

M00655.0A

F00755.O

F00855.0

F009S5.0

M010S5.0

F011S5.0

M01255.0

$\begin{array}{rrr}434 & 9.38 & 103.0 \\ 551 & 12.20 & 102.0 \\ 545 & 11.40 & 96.6 \\ 507 & 10.30 & 102.0 \\ 528 & 11.40 & 105.0 \\ 621 & 8.53 & 95.2 \\ 504 & 9.33 & 98.8 \\ 462 & 11.20 & 94.2 \\ 478 & 10.20 & 92.7 \\ 535 & 11.20 & 90.5 \\ 459 & 8.82 & 93.5 \\ 517 & 8.55 & 95.9 \\ 542 & 8.97 & 102.0 \\ 606 & 12.50 & 99.2\end{array}$

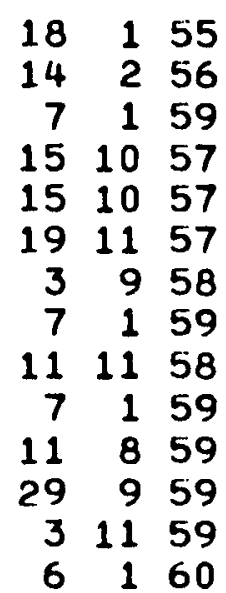

$\begin{array}{llllll}16 & 3 & 66 & 1841 & & \\ 16 & 3 & 66 & 1841 & & \\ 16 & 3 & 66 & & 1493 & 5949 \\ 16 & 3 & 66 & 1841 & & \\ 16 & 3 & 66 & & 993 & 5424 \\ 16 & 3 & 66 & 1841 & & \\ 16 & 3 & 66 & 1841 & & \\ 16 & 3 & 66 & 1841 & & \\ 16 & 3 & 66 & & 1028 & 5201 \\ 16 & 3 & 66 & 1841 & & \\ 16 & 3 & 66 & & 1758 & 6434 \\ 16 & 3 & 66 & 1841 & & \end{array}$

$\begin{array}{rr}960 & 8384 \\ 255 & 3213 \\ 1740 & 12295 \\ 2256 & 16559 \\ 1448 & 9527 \\ 1285 & 10243 \\ 35 & 652 \\ 1021 & 11538 \\ 1129 & 10899 \\ 1469 & 11132 \\ 1982 & 13607 \\ 990 & 7657 \\ 1667 & 10016 \\ 1165 & 8128\end{array}$


DOG

NUMBER

COMMENTS ON DEAD DOGS

Fou954.0

MO1054.0

FO1154.0

$\mathrm{MO} 1254.0$

BLOOD DYSCRASIA,PYOMETRA

F0u154.5

$M 00254.5$

MOU354.3

F0ن454.5

MUO554.5

MUU654.5

F00754.b

F00854.5

F00954.5

M010S4.5

FO1154.5

MU1254.5

F001S5.0

MO0255.0

MOOZS5.UA

MOU3S5.0

FU0455.0

MOU5S5.0

MOÜ655.0

MOUGS5.UA

F00755.U

FUU855.0

FU0955.U

MU10S5.0

F01155.U

M01255.O
SEVERE ANEMIA. INFARCTION, MYELOID METAPLASIA

OSTEOSARCOMA

OSTEOSARCOMA

OSTEOSARCOMA

OSTEOSARCOMA

STRANGULATED INGUINAL HERNIA

OSTEOSARCOMA

OSTEOSARCOMA

OSTEOSARCOMA

SEVERE ANEMIA, AUTOAGGLUTINATION, INFARCTION, SPLENOMEGALY INTESTINAL HEMORRHAGE

OSTEOSARCOMA. INFARCTION + THROMBOCYTOPENIA

STATUS EPILEPTICUS

OSTEOSARCOMA

SQUAMOUS CELL CARCINOMA ARISING FROM FRONTAL SINUS

SEVERE ANEMIA + THROMBOCYTOPENIA

HEMANGIOSARCOMA (LEFT MANDIBLE)

HEMANGIOSARCOMA (RIB) 
F. $\because$ AMERICIUM-241

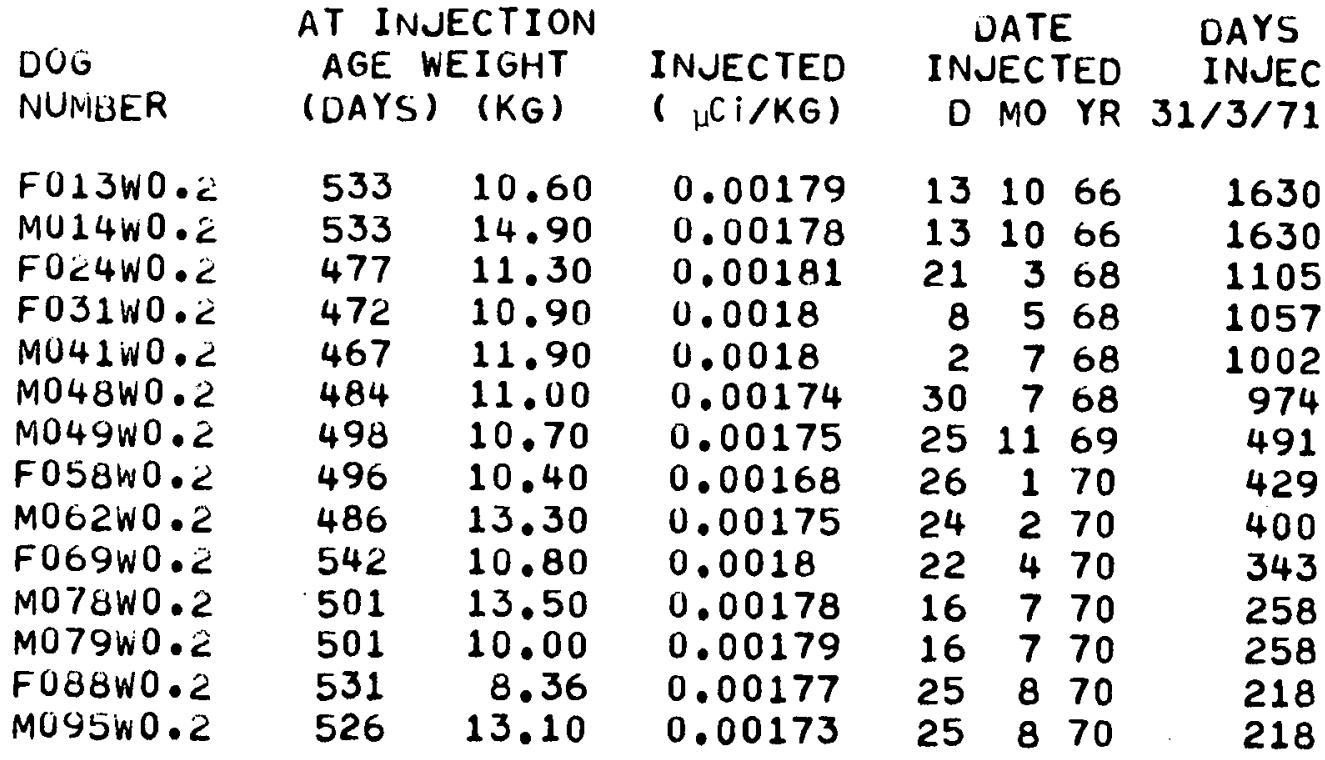

$\begin{array}{lrrlrrrr}\text { F011W0.5 } & 533 & 8.17 & 0.00532 & 13 & 10 & 66 & 1630 \\ \text { M012W0.5 } & 533 & 11.90 & 0.00539 & 13 & 10 & 66 & 1630 \\ \text { M023W0.5 } & 487 & 12.20 & 0.0053 & 21 & 3 & 68 & 1105 \\ \text { MO29W0.5 } & 472 & 10.40 & 0.00548 & 8 & 5 & 68 & 1057 \\ \text { F030W0.5 } & 472 & 10.60 & 0.00538 & 8 & 5 & 68 & 1057 \\ \text { F040W0.5 } & 467 & 9.40 & 0.00528 & 2 & 768 & 1002 \\ \text { M050W0.5 } & 552 & 11.80 & 0.00526 & 25 & 11 & 69 & 491 \\ \text { M059W0.5 } & 496 & 11.50 & 0.00503 & 26 & 1 & 70 & 429 \\ \text { M063W0.5 } & 486 & 11.40 & 0.00524 & 24 & 270 & 400 \\ \text { M070W0.5 } & 497 & 12.80 & 0.00531 & 22 & 470 & 343 \\ \text { F080W0.5 } & 501 & 11.90 & 0.00545 & 16 & 770 & 258 \\ \text { FO\&1W0.5 } & 501 & 12.10 & 0.00548 & 16 & 770 & 258 \\ \text { F089W0.5 } & 531 & 9.66 & 0.00527 & 25 & 870 & 218 \\ \text { M096W0.5 } & 490 & 12.00 & 0.00533 & 25 & 870 & 218\end{array}$

$\begin{array}{lrrlrrrr}\text { F009W1.0 } & 517 & 8.60 & 0.016 & 15 & 966 & 1658 \\ \text { F010W1.0 } & 517 & 9.90 & 0.0162 & 15 & 966 & 1658 \\ \text { M020W1.0 } & 513 & 10.80 & 0.0161 & 21 & 3 & 68 & 1105 \\ \text { F021W1.0 } & 513 & 9.36 & 0.0166 & 21 & 3 & 68 & \\ \text { F021W1.0A } & 552 & 11.40 & 0.0159 & 25 & 1169 & 491 \\ \text { M022W1.0 } & 487 & 11.60 & 0.0164 & 21 & 368 & 1105 \\ \text { M028W1.0 } & 472 & 12.10 & 0.0158 & 8 & 568 & 1057 \\ \text { F051W1.0 } & 552 & 8.25 & 0.0163 & 25 & 11 & 69 & 491 \\ \text { M00OW1.0 } & 496 & 10.00 & 0.0157 & 26 & 1 & 70 & 429\end{array}$


DOG

NUMBER

F013W0.2 MO14W0.2 F024W0.2 F031W0.2 MU41W0.2 M048W0.2 MO49W0.2 F058W0.2 M0oZW0.2 F009w0.2 M078W0.2 M079W0.2 F088W0.2 MU95W0.Z

FU11W0.5 MO12WO.5 MU23WO.5 M029W0.5 FU30W0.5 F040W0.5 M050W0.S MOS9W0.S MOGSW0.J MO70W0.5 Fo80W0.5 F0ல1W0.5 F009W0.5 M096rio. 5

F009W1.0 F010W1.U M020W1.0 FUट̇1W1.0 F0̈1W1.UA M022W1.0 M028W1.0 F051W1.0 M060W1.0

\section{COMMENTS. ON DEAD DOGS}


DOG

NUMBER

M064W1.0

F071W1.0

M082W 1.0

F090W1.0

M097W1.0
AT INJECTION AGE WEIGHT (DAYS) (KG)

$\begin{array}{lll}486 & 10.40 & 0.0158 \\ 485 & 12.10 & 0.0157 \\ 501 & 12.40 & 0.0163 \\ 526 & 10.90 & 0.016 \\ 490 & 10.40 & 0.016\end{array}$

INJECTED

$\left({ }_{\mu} \mathrm{C} i / K G\right)$ $\begin{array}{ccc}\text { DATE } & \text { DAYS SINCE } & \text { DOSE TO } \\ \text { INJECTED } & \text { INJECTION } & \text { SKELETON } \\ \text { D MO YR } & 31 / 3 / 71 \text { DEATH } & \text { (RADS) }\end{array}$

$\begin{array}{llll}24 & 2 & 70 & 400 \\ 22 & 4 & 70 & 343 \\ 16 & 7 & 70 & 258 \\ 25 & 8 & 70 & 218 \\ 25 & 8 & 70 & 218\end{array}$

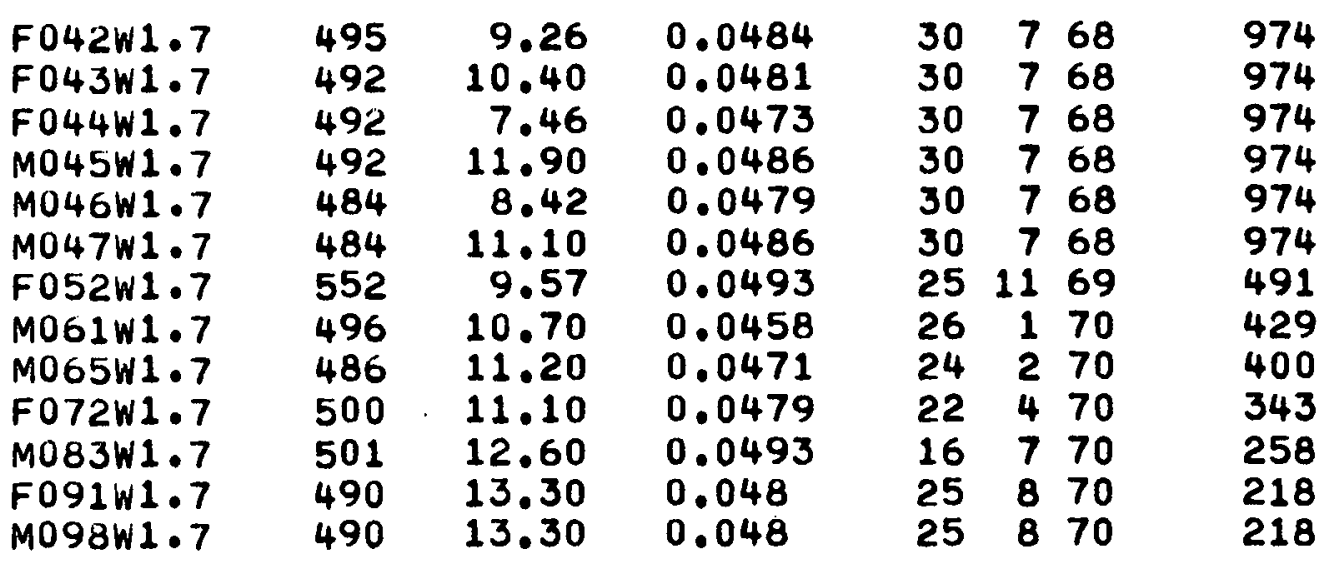

F007W2.0

F008W2.0

M019W2.0

$M 027 W 2.0$

M038W2.0

F039W2.0

M053W2.0

F066W2.0

M073W2.0

F084W2.0

M085W2.0

F092W2.0

$\begin{array}{rr}561 & 12.60 \\ 561 & 11.70 \\ 513 & 13.40 \\ 473 & 12.70 \\ 477 & 9.88 \\ 468 & 9.21 \\ 498 & 9.24 \\ 486 & 9.12 \\ 552 & 14.30 \\ 493 & 10.60 \\ 493 & 10.80 \\ 490 & 10.60\end{array}$

0.0952

0.0957

0.097

0.0961

0.0945

0.0948

0.096

0.0935

0.0965

0.0984

0.0987

0.0962

$\begin{array}{rrrr}15 & 9 & 66 & 1658 \\ 15 & 9 & 66 & 1658 \\ 21 & 3 & 68 & 1105 \\ 8 & 5 & 68 & 1057 \\ 2 & 7 & 68 & 1002 \\ 2 & 7 & 68 & 1002 \\ 25 & 11 & 69 & 491 \\ 24 & 2 & 70 & 400 \\ 17 & 6 & 70 & 287 \\ 16 & 7 & 70 & 258 \\ 16 & 7 & 70 & 258 \\ 25 & 8 & 70 & 218\end{array}$

M005W3.0

F006W3.0

F018W3.0

M026W3.0
561

561

523

473
15.00

11.90

8.60

12.40
0.305

0.31

0.307

0.31
15966

15966

21368

8568
1658

1105

1510

547 
DOG

NUMBER

M004W1.0 F071W1.0 M082W1.0 F090W1.0 M097W1.0

F042W1.7 F $043 \mathrm{~W} 1.7$ F044W1.7 $M 045 W 1.7$ M046W1.7 $M 047 W 1.7$ FOS2W1.7 MOO1W1.7 M065W 1.7 F072W1.7 M083W1.7 F091W1.7 MO98W1.7

F007W2.0 FUUSW2.U MO19W2.0 $M 027 W 2.0$ MO38W2.0 FOS9W2.L MUS3W2. F006W2.0 M073W2.0 FO84W2.0 MOUSW2.U F0S2W2.0 


\section{DOG \\ NUMBER}

M036W3.0

F037W3.0

M054W3.0

M067W3.0

F074W3.0

F075W3.0

M086W3.0

F093W3.0

M100W3.0
AT INJECTION AGE WEIGHT (DAYS) (KG)

$477 \quad 11.00$

$468 \quad 8.44$

$498 \quad 10.50$

$485 \quad 11.80$

54210.00

555

493

490

542

9.42

11.30

11.20

11.00

INJECTED

( $\mu \mathrm{C} i / K G$ )

\begin{tabular}{|c|c|c|c|}
\hline $\begin{array}{l}\text { DA } \\
\text { NJE } \\
D M\end{array}$ & $\begin{array}{l}\text { ATE } \\
\text { ECT } \\
\text { MO }\end{array}$ & $\begin{array}{l}\text { TED } \\
\text { YR }\end{array}$ & $\begin{array}{l}\text { DAYS } \\
\text { INJECT } \\
31 / 3 / 71\end{array}$ \\
\hline $\begin{array}{rr}2 \\
2 \\
25 & 1 \\
24 & \\
22 & \\
17 & \\
16 & \\
25 & \\
2 & 1\end{array}$ & $\begin{array}{l}7 \\
7 \\
1 \\
2 \\
4 \\
6 \\
7 \\
8 \\
2\end{array}$ & $\begin{array}{l}68 \\
68 \\
69 \\
70 \\
70 \\
70 \\
70 \\
70 \\
70\end{array}$ & $\begin{array}{r}1002 \\
1002 \\
491 \\
400 \\
343 \\
287 \\
258 \\
218 \\
119\end{array}$ \\
\hline
\end{tabular}

0.305

0.294

0.306

0.295

0.302

0.308

0.312

0.301

0.304

$517 \quad 12.60$

0.897

517

9.40

9.87

0.911

F004W4.0

523

0.924

F025W4.0

MO34W4.O

473

10.50

477

10.70

0.927

477

8.87

498

8.37

485

11.80

0.893

0.902

0.914

M068W4.0

F076W4.0

M077W4.0

M087W4.0

F094W4.0

485

9.37

0.89

500

0.899

501

10.50

0.906

0.916

0.912

$\begin{array}{rrr}28 & 6 & 66 \\ 28 & 6 & 66 \\ 21 & 3 & 68 \\ 8 & 5 & 68 \\ 2 & 7 & 68 \\ 2 & 7 & 68 \\ 25 & 11 & 69 \\ 24 & 2 & 70 \\ 22 & 4 & 70 \\ 22 & 4 & 70 \\ 16 & 7 & 70 \\ 25 & 8 & 70\end{array}$

1737

1105

1533

1976

1057

1002

1002

491

400

343

343

258

218

$M 001 W 5.0$

M002W5.O
$517 \quad 10.40$

$517 \quad 12.70$
2.78
2.83 $\begin{array}{lll}28 & 6 & 66 \\ 28 & 6 & 66\end{array}$
401

448
DOSE TO

SKELETON

(RADS)
ION

DEATH 
DOG

NUMBER

MO36W 3.0

F037W3.0 M054W3.0

M067W3.0

F074W3.0

F075W3.O

MOo6W3.

F093W3.0

M100W3.0

MOU3W4.0 F0u.4W4.U $M O i 7 W 4.0$ F025W4.0 MOJ4W4.0 F035W4.0 FOS5W4.0 M068W4.0 F076W4.0 M077W4.O M087W4.U F094W4.U

MOO1W5.0 MUU2W5.O
COMMENTS ON DEAD DOGS

KIONEY, THYROID AND LIVER DEGENERATION 
G. CALIFORNIUM-252

\begin{tabular}{|c|c|c|c|c|c|c|c|}
\hline $\begin{array}{l}\text { DOG } \\
\text { NUMBER }\end{array}$ & $\begin{array}{l}\text { AT INJ } \\
\text { AGE W } \\
\text { (DAYS) }\end{array}$ & $\begin{aligned} E C T I O N \\
=I G H T \\
\\
=(K G)\end{aligned}$ & $\begin{array}{l}\text { INJECTED } \\
\left({ }_{\mu} C i / K G\right)\end{array}$ & $\begin{array}{c}\text { D } \\
\text { IN } \\
\text { D }\end{array}$ & $\begin{array}{l}\text { ATE } \\
\text { ECTED } \\
\text { MO YR }\end{array}$ & $\begin{array}{l}\text { DAYS SINCE } \\
\text { INJECTION } \\
31 / 3 / 71 \text { DEATH }\end{array}$ & $\begin{array}{l}\text { DOSE TO } \\
\text { SKELETON } \\
\text { (RADS) }\end{array}$ \\
\hline $\begin{array}{l}M 001 F 3.0 \\
F 002 F 3.0 \\
F 003 F 3.0 \\
F 004 F 3.0\end{array}$ & $\begin{array}{l}583 \\
583 \\
583 \\
583\end{array}$ & $\begin{array}{r}11.60 \\
10.60 \\
8.66 \\
9.69\end{array}$ & $\begin{array}{l}0.31 \\
0.31 \\
0.313 \\
0.316\end{array}$ & $\begin{array}{l}3 \\
3 \\
3 \\
3\end{array}$ & $\begin{array}{ll}3 & 71 \\
3 & 71 \\
3 & 71 \\
3 & 71\end{array}$ & $\begin{array}{l}28 \\
28 \\
28 \\
28\end{array}$ & \\
\hline
\end{tabular}


DOG

NUMBER

MOULF3.0

F002F3.0

FOU JF 3.0

F004F 3.0
COMMENTS ON DEAD DOGS 
H. CALIFORNIUM-249

\begin{tabular}{|c|c|c|c|c|c|c|c|}
\hline $\begin{array}{l}\text { DOG } \\
\text { NUMBER }\end{array}$ & $\begin{array}{l}\text { AT IN } \\
\text { AGE } \\
\text { (DAYS) }\end{array}$ & $\begin{array}{l}=\text { CTION } \\
\text { EIGHT } \\
(K G)\end{array}$ & $\begin{array}{l}\text { INJECTED } \\
(\mu C \vee K G)\end{array}$ & $\begin{array}{c}D / \\
\text { INJ } \\
D I\end{array}$ & $\begin{array}{l}\text { ATE } \\
\text { ECTED } \\
\text { MO YR }\end{array}$ & $\begin{array}{l}\text { DAYS SINCE } \\
\text { INJECTION } \\
31 / 3 / 71 \text { DEATH }\end{array}$ & $\begin{array}{l}\text { DOSE TO } \\
\text { SKELETON } \\
\text { (RADS) }\end{array}$ \\
\hline $\begin{array}{l}F 00163.0 \\
M 002 G 3.0 \\
M 003 G 3.0 \\
F 004 G 3.0\end{array}$ & $\begin{array}{l}584 \\
580 \\
580 \\
580\end{array}$ & $\begin{array}{r}11.60 \\
13.20 \\
13.70 \\
8.79\end{array}$ & $\begin{array}{l}0.29 \\
0.282 \\
0.284 \\
0.283\end{array}$ & $\begin{array}{l}24 \\
24 \\
24 \\
24\end{array}$ & $\begin{array}{ll}2 & 71 \\
2 & 71 \\
2 & 71 \\
2 & 71\end{array}$ & $\begin{array}{l}35 \\
35 \\
35 \\
35\end{array}$ & \\
\hline
\end{tabular}


$-63-$

DOG

NUMGER

COMMENTS ON DEAD DOGS

F00163.0

$M 00263.0$

MOOJG3.0

F004G3.0 
TABLE II.TEST ANIMALS (MAR, 31, 1971)

A. RADIUM-226*

DOG

NUMBER

TOO1R5.0

T002R5.0

TOO 3R5. 0

TOO 4R5.0

T005R5.0

TO06R5.0

TO07R5.0

TOU 8R5.0

TOO9R5.O

TO1OR5.0

TO11R5.0

T012R5.0

TO13R5. 0
AT INJECTION AGE WEIGHT (DAYS) (KG)
INJECTED

$(\mu \mathrm{Ci} / K G)$

$\begin{array}{rrc}996 & 11.10 & 10.3 \\ 920 & 8.40 & 4.39 \\ 1467 & 8.29 & 4.76 \\ 459 & 10.00 & 10.6 \\ 126 & 6.14 & 11.7 \\ 126 & 6.14 & 11.4 \\ 126 & 6.14 & 11.8 \\ 290 & 5.52 & 1.92 \\ 2275 & 10.40 & 1.94 \\ 43 & 1.02 & 1.98 \\ 43 & 1.58 & 1.91 \\ 397 & 12.30 & 9.72 \\ 397 & 7.59 & 9.76\end{array}$

996
920

1467

459

126

126

126

290

2275

43

397

397

7.59

9.76
8.123 .17

$\begin{array}{ll}T 014 R 4.0 & 674 \\ T 015 R 4.0 & 672\end{array}$
DATE INJECTED

D MO YR

11252

12153

12153

$\begin{array}{lll}6 & 7 & 53\end{array}$

61053

61053

$\begin{array}{lll}6 & 10 & 53\end{array}$

$10 \quad 555$

10555

10555

10555

9556

9556

$\begin{array}{lll}11 & 7 & 56 \\ 11 & 7 & 56\end{array}$

72
2127

12

1147

1226

1219

1340

386

587
DOSE TO

SKELETON

(RADS)

9469

4724

1316

24

25

24

25

488

585

293

363

2707

2319

$\begin{array}{llll}\text { TO17R5.OH } & 383 & 12.20 & 9.87 \\ \text { TO18R5.OH } & 383 & 11.10 & 10.8 \\ \text { TO19R5.OH } & 383 & 11.30 & 10.7 \\ \text { TO2OR5.OH } & 393 & 11.40 & 10.6 \\ \text { TO21R5.OH } & 381 & 11.80 & 10.1 \\ \text { TO22R5.OH } & 381 & 11.90 & 10.1\end{array}$

$\mathrm{T} 023 \mathrm{R} 4 \cdot \mathrm{OH}$

TO24R4.OH

$$
384
$$

9.50

$$
\begin{aligned}
& 4.05 \\
& 3.24 \\
& 3.42 \\
& 3.48
\end{aligned}
$$

T026R4.0H

379

11.30

11. 00

$\begin{array}{lllll}372 & 11.50 & 3.34 & 25 & 11\end{array}$

$\begin{array}{lll}25 & 11 & 58\end{array}$

1471

1505

1309

1780

1414

183

13655

12628

11580

13981

3710

5911

251158

$\begin{array}{lll}25 & 11 & 58\end{array}$

$\begin{array}{lllll}372 & 11.50 & 3.34 & 25 & 11\end{array}$

251158

387

357

T028R3.0H

372

$11.70 \quad 1.11$

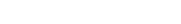


DOG

NUMGER

COMMENTS ON DEAD DOGS

TOU1R5.0

TOOZR5.0

TOOSR5.0

TOU4R5.U

TOU SR5.O

TOU6R5.O

TOO TR5.0

TOO 8R5.0

TOO9R5.0

TOLOR5.0

TO11R5.U

T012R5.0

T013R5.0

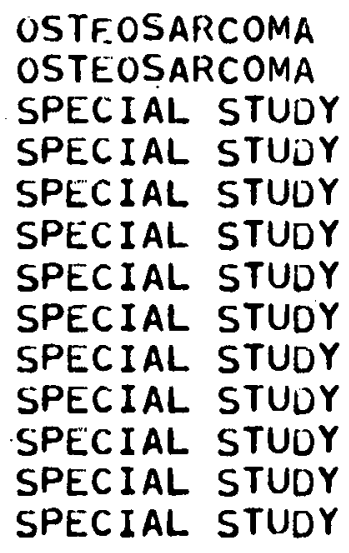

$T 014 R 4.0$

SPECIAL STUDY

T015R4.0 OSTEOSARCOMA

T016R5.O

TO17R5.UH

TO18R5.OH

T019R5.0H

TO20R5.0H

TOC1R5.OH

TO22R5.OH

T023R4.UH

TUट4R4.OH

TOC5R4.UH

TO26R4.OH

TO¿2R4.OH

TULOR3.OH SPECIAL STUDY

OSTEOSARCOMA

OSTEOSARCOMA

OSTEOSARCOMA

OSTEOSARCOMA

OSTEOSARCOMA

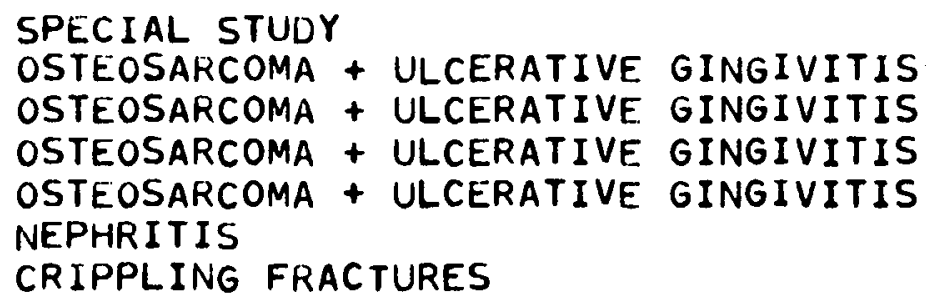


DOO

NURIBER

TOL9R5.U

TO3OR5.O

TOS1R5.0
AT INJECTION AGE WEIGHT (DAYS) (KG)
INJECTED

$(\mu C i / K G)$

474

474

471
13.50

10.4

10.4

10.4
DATE INJECTED

D MO YR

3359

3359

$3 \quad 359$
DAYS SINCE INJECTION 31/3/71 DEATH
DOSE TO

SKELETON

(RADS)

$216 \quad 3404$

$178 \quad 2851$

$303 \quad 4758$
T032R3.U

TOJSR3.0

TO34R3.0

TUSSR3.UJ

$\begin{array}{rrl}471 & 11.40 & 1.13 \\ 471 & 10.60 & 1.15 \\ 470 & 15.70 & 1.12 \\ 670 & 9.44 & 0.951\end{array}$

695

695

TO37R4.0

TO38R4.0
695

$\begin{array}{cl}10.20 & 2.99 \\ 9.53 & 3.0 \\ 10.10 & 3.02\end{array}$

89913.00

$899 \quad 12.70$

0.0483

0.0487

T041R1.0

T042R1.7

T043R1.7 963
14.00

13.20

0.146

0.145

0.937

0.941

0.928
$2212 \quad 60$

$\begin{array}{lll}22 & 12 & 60\end{array}$

$\begin{array}{lll}22 & 12 & 60\end{array}$

3462

3462

4462

4462
2249

1822

1737

8

1154

1627

1503
1864

1921

1603

14
T044R3.0

T045R3.U

TO46R3.0
$938 \quad 11.10$

93913.60

$810 \quad 12.50$ $\begin{array}{lll}4 & 4 & 62 \\ 5 & 4 & 62 \\ 5 & 4 & 62\end{array}$

68

7

69

7
64

64

2
11
71

12

103
3647

3234

3657
T047R6.0

TO4BR6.0

$\begin{array}{rrr}99 & 5.27 & 29.4 \\ 2842 & 11.20 & 25.1\end{array}$

$11 \quad 6 \quad 62$

$27 \quad 1262$
352

4

49
T049R5.0

TOSOR5.O

TOS1R5.C

$$
\begin{array}{lll}
485 & 10.60 & 7.54 \\
485 & 13.70 & 7.46 \\
418 & 13.30 & 8.48
\end{array}
$$

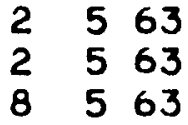

$\begin{array}{rr}5 & 111 \\ 15 & 274 \\ 92 & 1689\end{array}$


DOG

NUMBER

COMMENTS ON DEAD DOGS

T029R5.0

TO3OR5.0

TO31R5.0

TU32R3.0 T033R3.0

TO34R3.0

T035R3.0J

TO36R4.0

TUS7R4.0

TOSBR4.0.

T040R1.0

T041R1.0.

T042R1.7 T043R1.7

T044R3.0

TO45R3.0

TO46R3.0

T047R6.0

T048R6.U

T049R5.0

TOSOR5.0

TOSIR5.0
NEPHRITIS

NEPHRITIS

NEPHRITIS
OSTEOSARCOMA
OSTEOSARCOMA
OSTEOSARCOMA

SPECIAL STUDY SPECIAL STUDY

SPECIAL STUDY SPECIAL STUDY

SPECIAL STUUY SPECIAL STUDY SPECIAL STUDY

SPECIAL STUUY LEUKOPENIA. PNFUMONIA + SPECIAL MELANOMA STUDY

SPECIAL STUOY

SPECIAL STUDY

SPECIAL STUOY 
DOG

NUMBER

TOS2R5.0

T053R5.0

TOS4R5.U

TOS5R5.O

T056R5.0

TO57R4.0

TOSBR4.O

TU59R4.U

TUEOR4.0

TOO1R4.U

T062R4.U

T063R3.0

T064R3.0

T065R3.0

TO66R3.0

T0OTR3.U

T068R3. 0

TOG9R3.0

TOTOR3.0
AT INJECTION AGE WEIGHT

(DAYS) (KG)

$\begin{array}{lll}418 & 10.70 & 8.57 \\ 418 & 12.00 & 8.5 \\ 417 & 11.40 & 8.76 \\ 417 & 11.60 & 8.61 \\ 417 & 11.60 & 8.61\end{array}$

501

496

496

490

490

490
INJECTED

$(\mu \mathrm{Ci} / K(G)$
DATE

INJECTED

D MO YR $31 / 3 / 71$ DEATH
DOSE TO

SKELETON

(RADS)

$\begin{array}{rrr}8 & 5 & 63 \\ 8 & 5 & 63 \\ 22 & 5 & 63 \\ 22 & 5 & 63 \\ 22 & 5 & 63\end{array}$

15

33

5

33

90
258

611

88

534

1461
15863

15863

15863

15863

15863

15863

\section{4}

61

63

117

371

460
54

286

272

415

1567

1586

$\begin{array}{lllllll}\text { TOTIR5.0 } & 4025 & 13.80 & 9.23 & 28 & 169\end{array}$

42

698

* The multiple injection dogs were male beagles born in Davis, California but injected in our laboratory. Each was injected 6 times over a 280 day period with 56 days between each injection. Each ${ }^{226}$ Ra injection was $20.0 \mu \mathrm{C}$ i for the dogs TI7R5H - T22R5H; $6.41 \mu \mathrm{Ci}$ for T23R4H -

$T 27 R 4 H$; and $2.16 \mu \mathrm{Ci}$ for T28R3H. Tabulated for each dog are his age at lst injection, his average weight during the injection period, total $\mu \mathrm{C}$ /average weight, the date of lst injection, the time from lst injection to death, and sum of the skeletal doses computed from each injection to death.

T35R3J also received $99 \mu \mathrm{Ci}{ }^{85} \mathrm{Sr}$.

T39RO. 0 has been reassigned and is now MI2MO.O 
DOG

NUMBER

COMMENTS ON DEAD DOGS

TOS2R5.U

SPECIAL STUDY

TOS3R5.O

SPECIAL STUDY

TO54R5. O

SPECIAL STUDY

T055R5.U

SPECIAL STUDY

T056R5.0

SPECIAL STUDY

TOS7R4.C

SPECIAL STUDY

TOS8R4.0

SPECIAL STUDY

TO59R4.0

SPECIAL STUDY

TOGOR4.U

SPECIAL STUDY

T061R4.0

SPECIAL STUDY

TOG2R4.U

SPECIAL STUOY

T063R3.0

T004R3.0

TU65R3.U

T066R3.0

T067R3.0

T068R3.0

TO69R3.0

TO70R3.0

SPECIAL STUDY

SPECIAL STUDY

SPECIAL STUDY

SPECIAL STUDY

SPECIAL STUDY

OSTEOSARCOMA

SPECIAL STUDY

OSTEOSARCOMA

TU71R5.0 MELANOMA ORAL CAVITY 
B. PLUTONIUM-239*

DUG
NUMEER

T0UUP5.U

TOU1P5.0

T002P5.0

T0U3P5.U

T004P5.U

T005P5.0

T006P5.0

TOU7P5.U

T008P5.U

TOU9P5.0

TO10P5.0

T011P5. 0

T012P5.0

T013P5.U

TO14P5.U

T015P5.U

T016P5.U

T017P5.U

TO18P5.U

T019P5.U

TO20P5.U

T021P5.O

T023P1.0

TO $\angle 4 P 1.0$

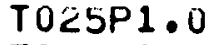

T026P1.0
AT INUJECTION AGE WEIGHT (DAYS) (KG)

$\begin{array}{rrr}647 & 11.40 & 3.05 \\ 1581 & 12.70 & 3.04 \\ 914 & 11.90 & 6.85 \\ 942 & 9.65 & 3.22 \\ 1016 & 8.78 & 3.02 \\ 474 & 10.40 & 2.69 \\ 527 & 6.16 & 2.73 \\ 475 & 7.40 & 2.68 \\ 527 & 8.32 & 2.67 \\ 551 & 10.30 & 2.8 \\ 534 & 11.90 & 2.74 \\ 516 & 12.10 & 2.76 \\ 487 & 9.23 & 2.74 \\ 587 & 8.27 & 3.16 \\ 587 & 9.38 & 2.43 \\ 737 & 8.32 & 2.79 \\ 673 & 10.70 & 2.85 \\ 739 & 11.10 & 3.01 \\ 739 & 8.16 & 2.83 \\ 688 & 8.86 & 2.91 \\ 688 & 13.00 & 2.68 \\ 688 & 10.30 & 2.72\end{array}$

$647 \quad 11.40$

$1581 \quad 12.70$

$914 \quad 11.90$

9429.65

$1016 \quad 8.78$

474

527

475

551

534

516

487

587

587

737

673

739

739

688

688
INJECTED

$(\mu C \mathrm{i} / K G)$

3.05

3.04

6.85

2.69

2.73

2.68

2.67

2.74

2.76

2.74

3.16

2.43

2.79

2.85

3.01

2.83

2.91

2.72
DATE

INJECTED

D MO YR

$24 \quad 652$

$13 \quad 10 \quad 52$

15952

$13 \quad 10 \quad 52$

131052

141254

$14 \quad 1254$

$14 \quad 1254$

141254

221155

$23 \quad 1155$

$22 \quad 1155$

231155

$24 \quad 456$

$24 \quad 456$

$15 \quad 10 \quad 56$

101056

$12 \quad 257$

$12 \quad 257$

151260

$\begin{array}{lll}15 & 12 & 60\end{array}$

151260
DAYS SINCE INJECTION

31/3/71 DEATH
DOSE TO

SKELETON

(RADS)

$\begin{array}{rr}1 & 10 \\ 29 & 160 \\ 44 & 520 \\ 610 & 3040 \\ 365 & 1750 \\ 400 & 1720 \\ 406 & 1750 \\ 777 & 3230 \\ 863 & 3540 \\ 15 & 80 \\ 15 & 70 \\ 28 & 140 \\ 28 & 140 \\ 3 & 20 \\ 7 & 30 \\ 1 & 10 \\ 92 & 440 \\ 210 & 990 \\ 217 & 960 \\ 1400 & 6129 \\ 474 & 1970 \\ 939 & 3940\end{array}$

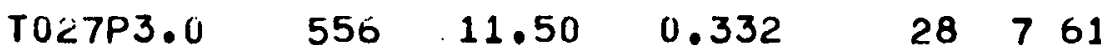

755

390

T028P1.0 $552 \cdot 10.50 \quad 0.015$

9861

559

10

$\begin{array}{llll}\text { T029P3.0 } & 552 & 12.10 & 0.296\end{array}$

9861

560

260 
DOG

NUMBER

COMMENTS ON DEAD DOGS

TUUOP5.U

TOOLPS.U

TOU2P5.U

TOU 3P5.U

TOU 4P5.0

T005P5.0

T0U6P5.O

TOU7P5.0

T008P5.0

TUO9P5.0

TOLOPS.O

T011P5.0

TO12P5.0

TO13P5.U

T014P5.0

TO15P5.0

T016P5.0

T017P5.0

T018P5.0

T019P5.0

TOZOP5.0

TUE1P5.O

T023P1.0

TU24P1.U

TO25P1.0

T026P1.0

TU27P3.0

TU¿̇8P1.0

SPECIAL STUUY

T0<9P3.0

SPECIAL STUDY

SPECIAL STUUY

SPECIAL STUDY

SPECIAL STUDY

SPECIAL STUDY

SPECIAL STUDY

SPECIAL STUDY

SPECIAL STUDY

SPECIAL STUDY

SPECIAL STUDY

SPECIAL STUDY

SPECIAL STUUY

SPECIAL STUDY

SPECIAL STUDY

SPECIAL STUOY

SPECIAL STUDY

SPECIAL STUDY

SPECIAL STUDY

SPECIAL STUDY

SPECIAL STUDY

SPECIAL STUDY

SPECIAL STUDY

SPECIAL STUDY

SPECIAL STUDY

SPECIAL STUDY
OSTEOSAFICOMA,BLOOD DYSCRASIA.LIVER DEGENERATION LIVER DEGENERATION. ASCITES + THROMBOCYTOPENIA

TOXIC NEPHRITIS + LIVER DEGENERATION 


\begin{tabular}{|c|c|c|c|c|c|c|c|c|c|}
\hline $\begin{array}{l}\text { DOG } \\
\text { NUMGER }\end{array}$ & $\begin{array}{l}\text { AT INJ } \\
\text { AGE W } \\
\text { (DAYS) }\end{array}$ & $\begin{aligned} E C T I O N \\
E I G H T \\
\\
(K G)\end{aligned}$ & $\begin{array}{l}\text { INJECTED } \\
(\mu C i / K G)\end{array}$ & $\begin{array}{c}0 \\
\text { IN } \\
D\end{array}$ & $\begin{array}{l}\text { DATE } \\
\text { JEC } \\
\text { MO }\end{array}$ & $\begin{array}{l}\text { TED } \\
\text { YR }\end{array}$ & $\begin{array}{r}\text { DAYS } \\
\text { INJEC } \\
31 / 3 / 71\end{array}$ & $\begin{array}{l}\text { SINCE } \\
\text { TION } \\
\text { DEATH }\end{array}$ & $\begin{array}{l}\text { DOSE TO } \\
\text { SKELETON } \\
\text { (RADS) }\end{array}$ \\
\hline TOSOP1.0 & 548 & 12.40 & 0.0148 & 9 & 8 & 61 & & 35 & 1 \\
\hline TOJ1P3.0 & 520 & 13.00 & 0.305 & 9 & 8 & 61 & & 40 & 20 \\
\hline $\begin{array}{l}\text { T032P1.0 } \\
\text { T033P1.L } \\
\text { T034P1.0 }\end{array}$ & $\begin{array}{l}520 \\
550 \\
550\end{array}$ & $\begin{array}{r}8.47 \\
10.70 \\
9.68\end{array}$ & $\begin{array}{l}0.0162 \\
0.0153 \\
0.0154\end{array}$ & $\begin{array}{r}9 \\
15 \\
15\end{array}$ & $\begin{array}{l}8 \\
9 \\
9\end{array}$ & $\begin{array}{l}61 \\
61 \\
61\end{array}$ & & $\begin{array}{l}274 \\
375 \\
746\end{array}$ & $\begin{array}{l}10 \\
10 \\
20\end{array}$ \\
\hline T035P3.0 & 550 & 11.90 & 0.303 & 15 & 9 & 61 & & 362 & 180 \\
\hline $\begin{array}{l}\text { T036P1.0 } \\
\text { T037P1.0 }\end{array}$ & $\begin{array}{l}544 \\
542\end{array}$ & $\begin{array}{r}10.40 \\
8.59\end{array}$ & $\begin{array}{l}0.0158 \\
0.0148\end{array}$ & $\begin{array}{l}15 \\
15\end{array}$ & $\begin{array}{l}9 \\
9\end{array}$ & $\begin{array}{l}61 \\
61\end{array}$ & & $\begin{array}{r}5 \\
186\end{array}$ & 4 \\
\hline T038P3.0 & 489 & 7.96 & 0.304 & 15 & 9 & 61 & . & 187 & 90 \\
\hline $\begin{array}{l}\text { T039P1.U } \\
\text { T040P1.0 }\end{array}$ & $\begin{array}{l}1534 \\
1534\end{array}$ & $\begin{array}{r}10.70 \\
9.92\end{array}$ & $\begin{array}{l}0.0151 \\
0.0177\end{array}$ & $\begin{array}{l}15 \\
15\end{array}$ & $\begin{array}{l}9 \\
9\end{array}$ & $\begin{array}{l}61 \\
61\end{array}$ & & $\begin{array}{l}376 \\
769\end{array}$ & $\begin{array}{l}10 \\
20\end{array}$ \\
\hline $\begin{array}{l}\text { TO41P5.O } \\
\text { TO42P5. U } \\
\text { TO43P5.OH } \\
\text { TO44P5.OH } \\
\text { TO4SP5.OH } \\
\text { TO46P5.O } \\
\text { TO47P5.0 } \\
\text { TO48P5.0 }\end{array}$ & $\begin{array}{l}543 \\
510 \\
600 \\
517 \\
420 \\
420 \\
806 \\
554\end{array}$ & $\begin{array}{r}8.50 \\
11.40 \\
14.00 \\
12.00 \\
12.30 \\
11.90 \\
12.40 \\
8.50\end{array}$ & $\begin{array}{l}3.01 \\
2.4 \\
2.86 \\
2.72 \\
2.98 \\
3.01 \\
3.02 \\
2.61\end{array}$ & $\begin{array}{l}30 \\
10 \\
15 \\
21 \\
28 \\
28 \\
30 \\
11\end{array}$ & $\begin{array}{r}11 \\
2 \\
7 \\
9 \\
10 \\
10 \\
11 \\
3\end{array}$ & $\begin{array}{l}64 \\
65 \\
65 \\
65 \\
65 \\
65 \\
65 \\
66\end{array}$ & . & $\begin{array}{r}1227 \\
13 \\
40 \\
35 \\
5 / 24 \\
732 \\
69 \\
1327\end{array}$ & $\begin{array}{r}5586 \\
57 \\
200 \\
168 \\
1 \\
3402 \\
353 \\
5222\end{array}$ \\
\hline
\end{tabular}


DOG

NUMBER

COMMENTS ON DEAD DOGS

TUJOP1.0. SPECIAL STUDY

TO3IP3.U SPECIAL STUOY

T032P1.0

SPECIAL STUDY

T033P1.0 SPECIAL STUOY

T034P1.O SPECIAL STUDY

TU35P3.U SPECIAL STUOY

TU36P1.0 SPECIAL STUUY

TOJ7P1.U ' SPECIAL STUDY

TO38P3.0 . SPECIAL STUDY

TOJ9P1.0 SPECIAL STUDY T040P1.0 SPECIAL STUOY

T041P5.U T042P5.O

T043P5.0H

TO44P5. UH

T045P5.CH

TU4ÖP5.U

TO47P5.U

TO48P5:U
PURPURA HEMORRHAGICA: AUTOHEMAGGLUTINATION LIVER DEGENERATN SPECIAL STUDY SPECIAL STUDY SPECIAL STUDY SPECIAL STUDY

LIVER DEGENERATION

SPECIAL STUDY

UNUIFFERETIATEO SARCOMA (BONE) 


\begin{tabular}{|c|c|c|c|c|c|c|c|c|c|}
\hline $\begin{array}{l}\text { DOG } \\
\text { NUMBER }\end{array}$ & $\begin{array}{l}A T \text { INJI } \\
\text { AGE WI } \\
\text { (DAYS) }\end{array}$ & $\begin{array}{l}\text { ECTION } \\
\text { EIGHT } \\
\text { (KG) }\end{array}$ & $\begin{array}{l}\text { INJECTED } \\
\left({ }_{\mu \mathrm{C} / K G)} / K G\right.\end{array}$ & & $\begin{array}{l}\text { ATE } \\
\text { ECT } \\
\text { MO }\end{array}$ & $\begin{array}{l}E \\
\text { TED } \\
Y R\end{array}$ & $\begin{array}{r}\text { DAYS } \\
\text { INJEC } \\
31 / 3 / 71\end{array}$ & $\begin{array}{l}\text { SINCE } \\
\text { IION } \\
\text { DEATH }\end{array}$ & $\begin{array}{l}\text { DOSE TO } \\
\text { SKELETON } \\
\text { (RADS) }\end{array}$ \\
\hline T049P1.0 & 103 & 5.00 & 0.0162 & 5 & 7 & 66 & 1730 & & \\
\hline T050P3.0 & 103 & 5.30 & 0.296 & 5 & 7 & 66 & 1730 & & \\
\hline TOS1P5.0 & 104 & 4.80 & 2.73 & 6 & 7 & 66 & & 1055 & 4382 \\
\hline TOS2P4.O & 437 & 11.80 & 0.949 & 7 & 7 & 67 & & 14 & 24 \\
\hline $\begin{array}{l}\text { T053P5. } \\
\text { T0S4P5.0 }\end{array}$ & $\begin{array}{r}1517 \\
906\end{array}$ & $\begin{array}{l}13.90 \\
11.30\end{array}$ & $\begin{array}{l}2.82 \\
2.77\end{array}$ & $\begin{array}{l}11 \\
11\end{array}$ & $\begin{array}{l}3 \\
3\end{array}$ & $\begin{array}{l}69 \\
69\end{array}$ & 750 & 404 & 1769 \\
\hline T055P4.U & 445 & 10.60 & 0.785 & 3 & 6 & 69 & & 14 & 20 \\
\hline T056P5.5 & 501 & 11.20 & 3.73 & 29 & 7 & 69 & & 7 & 48 \\
\hline TOSTP2. OE & 618 & 49.40 & 0.0961 & 10 & 9 & 69 & 567 & & \\
\hline $\begin{array}{l}\text { TUS\&P3. UE } \\
\text { TOS9P3. UE } \\
\text { TUOOP3. OE }\end{array}$ & $\begin{array}{l}573 \\
591 \\
567\end{array}$ & $\begin{array}{l}52.30 \\
44.50 \\
45.20\end{array}$ & $\begin{array}{l}0.291 \\
0.29 \\
0.314\end{array}$ & $\begin{array}{r}10 \\
5 \\
6\end{array}$ & $\begin{array}{r}9 \\
11 \\
1\end{array}$ & $\begin{array}{l}69 \\
69 \\
70\end{array}$ & $\begin{array}{l}567 \\
511 \\
449\end{array}$ & & \\
\hline
\end{tabular}

$\begin{array}{llllrlll}\text { TUE1P2.OE } & 581 & 47.20 & 0.0983 & 6 & 170 & 449 \\ \text { TOOLP2. OE } & 583 & 52.50 & 0.156 & 22 & 170 & 433\end{array}$


DOG

NUMBEER

T049P1.0

T050P3.0

TOS1P5.0O ÖTEOSARCOMA

TUSZP4.U SPECIAL STUDY

T0S3P5.0

TO54P5.0: SPECIAL STUDY

T055P4.0. SPECIAL STUDY

TOSGP5.5 SPECIAL STUUY

TOS7F2. UE

TOSOP3.UE TOS9P3.UE T060P3.0E

TOO1P2.UE T062P2.OE
COMMENTS ON DEAD DOGS 


\begin{tabular}{|c|c|c|c|c|c|}
\hline $\begin{array}{l}\text { DOG } \\
\text { NUMBER }\end{array}$ & $\begin{array}{l}\text { AT INJECTION } \\
\text { AGE WEIGHT } \\
\text { (DAYS) (KG) }\end{array}$ & $\begin{array}{l}\text { INJECTED } \\
(\mu C \vee K G)\end{array}$ & $\begin{array}{l}\text { UATE } \\
\text { INJECTED } \\
\text { D MO YR }\end{array}$ & $\begin{array}{l}\text { DAYS SINCE } \\
\text { INJECTION } \\
31 / 3 / 71 \text { DEATH }\end{array}$ & $\begin{array}{l}\text { DOSE TO } \\
\text { SKELETON } \\
\text { (RADS) }\end{array}$ \\
\hline T063P5.0 & 9.13 & 2.77 & $14 \quad 1270$ & 107 & \\
\hline
\end{tabular}

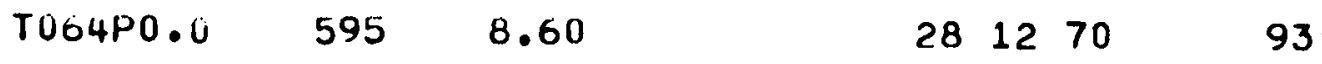

* T22P0.0 has been reassigned and is now F06TO.0A.

T043P5. OH was also given $1.01 \mu \mathrm{Ci}{ }^{239} \mathrm{Pu} / \mathrm{kg}$ one day prior to sacrifice.

T044P5. OH was given $0.833 \mu \mathrm{Ci} 23 y \mathrm{Pu} / \mathrm{kg}$ and about $9.17 \mu \mathrm{Ci} 59 \mathrm{Fe} / \mathrm{kg}$

one day prior to sacrifice.

Dogs T57 through T62 are St. Bernards. 
$-77-$

DOG

NUMBER

T0O3P5.0

T064P0.0

\section{COMMENTS ON DEAD DOGS}


C. RADIUM-228 (MESOTHORIUM) *

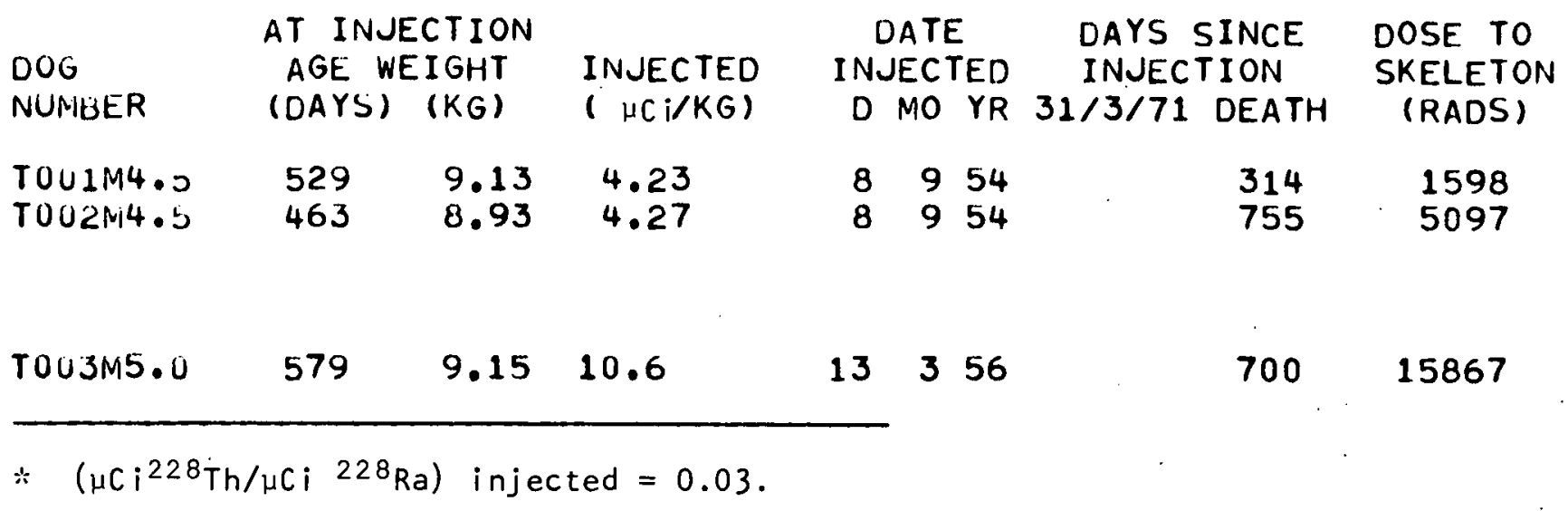


$-79-$

DOG

NUMBER

T001M4.5

TOU2M4.5
COMMENTS ON DEAD DOGS

CANINE DISTEMPER

SPECIAL STUDY

TUO3M5.0 ULCERATIVE GINGIVITIS, SEVERE ANEMIA + CRIPPLING FRACTURE 
D. THORIUM-228 (RADIOTHORIUM)*

DUG

NUMBER

TOU1T5.0

TOU2T5.0
AT INJECTION AGE WEIGHT (DAYS) (KG)

$$
\begin{aligned}
& 607 \\
& 501
\end{aligned}
$$

$$
9.30
$$$$
8.48
$$

INUECTED

$(\mu \mathrm{Ci} / K G)$

$$
\begin{array}{crc}
\multicolumn{4}{c}{\text { DATE }} \\
\multicolumn{2}{c}{\text { DATECTED }} \\
\text { INUEC } \\
\text { D } & \text { MO } & \text { YR } \\
1 & 12 & 53 \\
8 & 2 & 54
\end{array}
$$

DAYS SINCE

23
77

TOU3T4.0

429

$$
10.40
$$

0.87

8254

820

4878

T004T5.6

TOOST5.O

455
455

8.92

10.10

2.59
2.32

$\begin{array}{lll}28 & 9 & 54\end{array}$

28954

113

65

2883

1524

T006T4.0

591

7.01

0.884

$18 \quad 10 \quad 55$

651

4273

TOUTT3.0

TOU 813.0

TOU9T3.0

T010T3.O

T011T3.0

T012T3.0

T013T3.O

0.298
0.293
0.285
0.289
0.335
0.302
0.298

$\begin{array}{rrr}18 & 10 & 55 \\ 14 & 10 & 58 \\ 4 & 2 & 59 \\ 4 & 2 & 59 \\ 16 & 6 & 59 \\ 7 & 7 & 59 \\ 28 & 7 & 59\end{array}$

910

1043

1

22

22

22
1161
1979

DOSE TO

(RADSI

(RADS)

* TIl, 12, 13T3 received 40,4, and $0.4 \mathrm{mg}^{232} \mathrm{Th}$, respectively. 
DUÖ

NUIMBER

TOO1T5:0

TOU2T5.0

TOU $3 T 4.0^{\circ}$

$7004 T 5.0$

T005T5.0

T006T4.0

TOU $7 T 3.0$

T008T3.0

TOU9T3.0

TO10T3.0

TU11T3.U

TO12T3.0

TU13T3.U
COMMENTS ON DËAD DOGS

DIED. SPECIAL STUDY

SPECIAL STUUY

CRIPPLING FRACTURES + NEPHRITIS

THROMBOCYTOPENIA + PURPURA

NEPHRITIS. THROMBOCYTOPENIA + PURPURA

CRIPPLING FRACTURES

SPECIAL STUDY

OSTEOSARCOMA

SPECIAL STUDY

SPECIAL STUDY

SPECIAL STUDY

SPECIAL STUDY

SPECIAL STUDY 
E. STRONTIUM-90*

DOG

NUPIBER

TUO150.0

TOU2S5.U

TOO355.

TOU4S5.U

TOUं5\$5.0

TOUOS5.0

TOU755.U
AT INJECTION AGE WEIGHT (DAYS) (KG)
DATE

INJEC TED

( $H(\mathrm{i} / K G$ )

\section{INJECTED}

D MO YR

5354

$151 \quad 7.71$

5

$\begin{array}{rrr}5 & 3 & 54 \\ 5 & 3 & 54 \\ 5 & 3 & 54 \\ 5 & 3 & 54 \\ 16 & 3 & 54 \\ 16 & 3 & 54\end{array}$

18

28

41

116

$1 / 24$

2

112

$$
\begin{array}{rr}
6.85 & 148.0 \\
6.19 & 148.0 \\
7.05 & 148.0 \\
5.25 & 148.0 \\
7.01 & 87.0 \\
6.74 & 87.0
\end{array}
$$

155
155

$$
243 \quad 7.00
$$

T00850.0 $243 \quad 7.00$

T008S2. UH

TOU9S2.0H

TO1OS2.UH

TO11S2.UH
$67 \quad 3.69$

$67 \quad 2.79$

$67 \quad 3.11$

$67 \quad 3.85$

2.74

3.62

3.25

2.62
27. 955

27955

27955

$27 \quad 955$

$\begin{array}{lll}11 & 9 & 57\end{array}$

T01354.0

$324 \quad 10.50 \quad 19.1$

$\begin{array}{lll}542 & 10.00 \quad 96.1\end{array}$

$\begin{array}{lll}595 & 9.43 \quad 98.4\end{array}$

TO14S5.0
T015S5.0

T01652.0

604

$9.71 \quad 3.27$

81161
8760

8

50

$\begin{array}{rr}66 & 31 \\ 66 & 40 \\ 132 & 93 \\ 132 & 75\end{array}$

5

15

$\begin{array}{lll}7 & 11 & 61\end{array}$

9
30

175

\section{1 \\ 40 \\ 75}

50

$7 \begin{array}{lll}11 & 61\end{array}$
626

957

1945

4863

84

T017S6.0

670

$7.18 \quad 295.0$

670

5.94302 .0

$\begin{array}{lll}19 & 1 & 62 \\ 19 & 1 & 62\end{array}$ 
DOG

NUMBER

COMMENTS ON DEAD DOGS

T00150.0 SPECIAL STUDY

T00255.0

$T 00355.0$

T00455.U

T000555.0

T00655.0

700755.0

SPECIAL STUDY

SPECIAL STUDY

SPECIAL STUDY

SPECIAL STUOY

SPECIAL STUDY

SPECIAL STUDY

TOU8S0.0 SPECIAL STUDY

T008S2.0H

TOOGS2.0H

T010S2.0H

SPECIAL STUDY

SPECIAL STUDY

SPECIAL STUOY

TO11S2.OH

SPECIAL STUDY

$T 01253.0$

BREMSSTRAHLUNG PHANTOM

$T 01354.0$

BREMSSTRAHLUNG PHANTOM SAM MCGEE

T01455.0

SPECIAL STUDY

T015S5.0

SPECIAL STUDY

T016S2.0

SPECIAL STUUY

TU1756.0

TU1856.0 


\begin{tabular}{|c|c|c|c|c|c|c|c|c|c|}
\hline \multirow{2}{*}{$\begin{array}{l}\text { DOG } \\
\text { NUNBEER }\end{array}$} & \multicolumn{2}{|c|}{$\begin{array}{l}\text { AT INJECTION } \\
\text { AGE WEIGHT }\end{array}$} & \multirow{2}{*}{$\begin{array}{l}\text { INJECTED } \\
(\mu C i / K G)\end{array}$} & \multicolumn{3}{|c|}{$\begin{array}{c}\text { DATE } \\
\text { INJECTED }\end{array}$} & \multicolumn{2}{|c|}{$\begin{array}{l}\text { DAYS SINCE } \\
\text { INUECTION }\end{array}$} & \multirow{2}{*}{$\begin{array}{l}\text { DOSE TO } \\
\text { SKELETON } \\
\text { (RADS) }\end{array}$} \\
\hline & & $(K G)$ & & $D$ & MO & YR & $31 / 3 / 71$ & DEATH & \\
\hline TO19S6.0 & 670 & 5.43 & 284.0 & 19 & 1 & 62 & & 23 & 637 \\
\hline T020S4.0J & 440 & 8.54 & 28.9 & 2 & 10 & 63 & & 13 & 78 \\
\hline T021S2.5 & 363 & 7.20 & 8.3 & 2 & 10 & 63 & & 13 & 143 \\
\hline $\begin{array}{l}\text { T022S5.0 } \\
T 02355.0\end{array}$ & $\begin{array}{l}545 \\
545\end{array}$ & $\begin{array}{r}9.01 \\
11.60\end{array}$ & $\begin{array}{r}99.0 \\
100.0\end{array}$ & $\begin{array}{l}1 \\
1\end{array}$ & $\begin{array}{l}4 \\
4\end{array}$ & $\begin{array}{l}69 \\
69\end{array}$ & $\begin{array}{l}729 \\
729\end{array}$ & & \\
\hline $\begin{array}{l}\text { T08. } \\
\text { Age at } \mathrm{f} \\
\mu \mathrm{Ci} / \mathrm{kg} \text { is } \\
\text { from firs } \\
\text { to death. } \\
\text { T20S4.0J } \\
\text { T21S2.5J }\end{array}$ & $\begin{array}{l}\text { IIS2.0H } \\
\text { rst inje } \\
\text { total } 9 \\
\text { inject } \\
\text { received } \\
\text { received }\end{array}$ & $\begin{array}{l}\text { were gi } \\
\text { tion, w } \\
\text { Srlaver } \\
\text { on to d }\end{array}$ & $\begin{array}{l}\text { ven } 10 \text { inject } \\
\mathrm{t.} \text { is average } \\
\text { age weight, } \\
\text { eath, and dos } \\
{ }^{85} \mathrm{Sr} \text {. } \\
{ }^{85} \mathrm{Sr} \text { and } 600\end{array}$ & $\begin{array}{l}\text { nes } \\
\text { duri } \\
\text { is }\end{array}$ & $\begin{array}{ll}1 & \mu \\
n g & t \\
s & \text { at } \\
\text { comp }\end{array}$ & & $\begin{array}{l}\text { each at we } \\
\text { injection } \\
\text { rst inject } \\
\text { d from mid. }\end{array}$ & $\begin{array}{l}\text { ekly int } \\
\text { period, } \\
\text { ion, day } \\
\text {-injecti }\end{array}$ & $\begin{array}{l}\text { ervals. } \\
\text { s are } \\
\text { on }\end{array}$ \\
\hline
\end{tabular}


DOG

NUMBER

$T 01956.0$

TU200S4.UJ

SPECIAL STUDY

T021S2.5J SPECIAL STUDY
COMMENTS ON DEAD DOGS

LEUKOPENIA, THROMBOCYTOPENIA + PURPURA

T02255.0

102355.0 
F. RADIUM-224*

\begin{tabular}{|c|c|c|c|c|c|c|c|c|c|}
\hline $\begin{array}{l}\text { DOG } \\
\text { NUMBER }\end{array}$ & $\begin{array}{l}\text { AT IN } \\
\text { AGE h } \\
\text { (DAYS) }\end{array}$ & $\begin{array}{l}\text { ECTION } \\
\text { EIGHT } \\
\text { (KG) }\end{array}$ & $\begin{array}{l}\text { INJECTED } \\
\left({ }_{\mu C \mathrm{i} / K G)}\right.\end{array}$ & $\begin{array}{c}D \\
\text { INJ } \\
D\end{array}$ & $\begin{array}{l}\text { ATE } \\
\text { ECT } \\
\text { MO }\end{array}$ & $\begin{array}{l}E_{\text {TED }} \\
\text { YR }\end{array}$ & $\begin{array}{c}\text { DAYS } \\
\text { INJEC } \\
31 / 3 / 71\end{array}$ & $\begin{array}{l}\text { SINCE } \\
\text { TION } \\
\text { DEATH }\end{array}$ & $\begin{array}{l}\text { DOSE TO } \\
\text { SKELETON } \\
\text { (RADS) }\end{array}$ \\
\hline Tou103.0J & 460 & 9.55 & 0.875 & 26 & 3 & 63 & & $4 / 24$ & \\
\hline $\begin{array}{l}T 002 Q 4.0 \\
T 00384.0\end{array}$ & $\begin{array}{l}466 \\
466\end{array}$ & $\begin{array}{l}12.00 \\
13.10\end{array}$ & $\begin{array}{l}2.91 \\
2.91\end{array}$ & $\begin{array}{l}27 \\
27\end{array}$ & $\begin{array}{l}3 \\
3\end{array}$ & $\begin{array}{l}63 \\
63\end{array}$ & & $\begin{array}{l}2317 \\
2708\end{array}$ & $\begin{array}{l}100 \\
100\end{array}$ \\
\hline $\begin{array}{l}\text { TOU 4Q5.U } \\
\text { T00565.0 }\end{array}$ & $\begin{array}{l}480 \\
455\end{array}$ & $\begin{array}{l}9.55 \\
9.67\end{array}$ & $\begin{array}{l}9.71 \\
9.59\end{array}$ & $\begin{array}{l}24 \\
24\end{array}$ & $\begin{array}{l}4 \\
4\end{array}$ & $\begin{array}{l}63 \\
63\end{array}$ & & $\begin{array}{l}1462 \\
1638\end{array}$ & $\begin{array}{l}400 \\
400\end{array}$ \\
\hline TOUGQ6.U & 455 & 8.29 & 21.4 & 17 & 10 & 63 & & 13 & 800 \\
\hline $\begin{array}{l}\text { T0u7Q5.0 } \\
\text { T0u8Q5.u }\end{array}$ & $\begin{array}{l}465 \\
475\end{array}$ & $\begin{array}{r}11.80 \\
9.77\end{array}$ & $\begin{array}{l}8.56 \\
8.62\end{array}$ & $\begin{array}{l}6 \\
6\end{array}$ & $\begin{array}{l}11 \\
11\end{array}$ & $\begin{array}{l}63 \\
63\end{array}$ & & $\begin{array}{r}2053 \\
16\end{array}$ & $\begin{array}{l}400 \\
300\end{array}$ \\
\hline $\begin{array}{l}\text { TOU9Q4.0 } \\
\text { TO10Q4.U }\end{array}$ & $\begin{array}{l}503 \\
503\end{array}$ & $\begin{array}{r}9.80 \\
10.30\end{array}$ & $\begin{array}{l}2.57 \\
2.57\end{array}$ & $\begin{array}{l}4 \\
4\end{array}$ & $\begin{array}{l}12 \\
12\end{array}$ & $\begin{array}{l}63 \\
63\end{array}$ & & $\begin{array}{r}1451 \\
262\end{array}$ & $\begin{array}{l}100 \\
100\end{array}$ \\
\hline $\begin{array}{l}T 011 Q 3.0 \\
T 012 Q 3.0 \\
T 013 Q 3.0 \\
T 014 Q 3.0\end{array}$ & $\begin{array}{l}495 \\
495 \\
495 \\
438\end{array}$ & $\begin{array}{r}9.10 \\
13.50 \\
11.30 \\
10.30\end{array}$ & $\begin{array}{l}0.885 \\
0.889 \\
0.912 \\
0.87\end{array}$ & $\begin{array}{l}4 \\
4 \\
4 \\
4\end{array}$ & $\begin{array}{l}12 \\
12 \\
12 \\
12\end{array}$ & $\begin{array}{l}63 \\
63 \\
63 \\
63\end{array}$ & $\begin{array}{l}2674 \\
2674 \\
2674 \\
2674\end{array}$ & & \\
\hline T015Q4.0 & 515 & 12.70 & 2.73 & 1 & 2 & 68 & 1154 & & \\
\hline $\begin{array}{l}\text { T016Q2.0 } \\
\text { T01702.0 } \\
\text { T018Q2.0 }\end{array}$ & $\begin{array}{l}515 \\
515 \\
502\end{array}$ & $\begin{array}{r}9.36 \\
10.20 \\
9.68\end{array}$ & $\begin{array}{l}0.31 \\
0.311 \\
0.306\end{array}$ & $\begin{array}{l}1 \\
1 \\
1\end{array}$ & $\begin{array}{l}2 \\
2 \\
2\end{array}$ & $\begin{array}{l}68 \\
68 \\
68\end{array}$ & $\begin{array}{l}1154 \\
1154 \\
1154\end{array}$ & & \\
\hline
\end{tabular}


DOG

NUMBER

COMMENTS ON DEAD DOGS

TOU1Q3.0J SPECIAL STUDY

T002Q4.000

TOO3Q4.0

TUO4Q5.U TOOSQ5.U

TOG6Q6.0

TOU 7.05.0 TOO 8Q5.0

T00964.0 TO10Q4.0

$T 011 Q 3.0$ $T 012 Q 3.0$ TO13Q3.O T014Q3. U
OSTEOSARCOMA HEMANG IOSARCOMA

OSTEOSARCOMA. EPIDERMOID CARCINOMA (FRONTAL SINUS) OSTEOSARCOMA

PURPURA HEMORRHAGICA

OSTEOSARCOMA

PURPURA HEMORRHAGICA

STRANGULATION ON VOMITUS AND GRAND MAL STATUS EPILEPTICUS

T015G4. U

T01602.U

TU1702.U

TU18Q2.U 


\begin{tabular}{|c|c|c|c|c|c|c|c|c|}
\hline $\begin{array}{l}\text { DOG } \\
\text { NUNiEEER }\end{array}$ & $\begin{array}{l}\text { AT IN } \\
\text { AGE } \\
\text { (DAYS) }\end{array}$ & $\begin{array}{l}\text { CTION } \\
\text { IGHT } \\
\text { (KG) }\end{array}$ & $\begin{array}{l}\text { INJECTED } \\
(\mu C i / K G)\end{array}$ & $\begin{array}{c}D \\
\text { INU } \\
D\end{array}$ & $\begin{array}{l}\text { ATE } \\
\text { EC } \\
\text { MO }\end{array}$ & $\begin{array}{l}\text { TED } \\
\text { YR }\end{array}$ & $\begin{array}{l}\text { DAYS SINCE } \\
\text { INUECTION } \\
31 / 3 / 71 \text { DEATH }\end{array}$ & $\begin{array}{l}\text { DOSE TO } \\
\text { SKELETON } \\
\text { (RADS) }\end{array}$ \\
\hline $\begin{array}{l}T 01901 \cdot 0 \\
T 020 Q 1 \cdot 0 \\
T 02101 \cdot 0\end{array}$ & $\begin{array}{l}515 \\
515 \\
502\end{array}$ & $\begin{array}{r}11.80 \\
10.40 \\
9.08\end{array}$ & $\begin{array}{l}0.0475 \\
0.0472 \\
0.0447\end{array}$ & $\begin{array}{l}1 \\
1 \\
1\end{array}$ & $\begin{array}{l}2 \\
2 \\
2\end{array}$ & $\begin{array}{l}68 \\
68 \\
68\end{array}$ & $\begin{array}{l}1154 \\
1154 \\
1154\end{array}$ & \\
\hline
\end{tabular}

* The skeletal doses in rads are only from ${ }^{224} \mathrm{Ra}$ and its daughters. In at least some of these dogs, appreciable $210 \mathrm{~Pb}$ and $228 \mathrm{Th}$ contamination was injected. The dose from the $210 \mathrm{~Pb}$ and ${ }^{228} \mathrm{Th}$ has not been included. (see the article ${ }^{210} \mathrm{~Pb}$ Contamination of ${ }^{228} \mathrm{Th}$ : I ts Contribution to Dose in Beagles in Our ${ }^{228} \mathrm{Th}$ Toxicity Studies in $(00-119-237)$. T00IQ3.0J also received $18.0 \mu \mathrm{Ci}{ }^{85} \mathrm{Sr}$. 
DOG

NUMIBER

T019G1.U

T020Q1.0

$T 0 \angle 1 Q 1.0$

\section{COMMENTS ON DEAD DOGS}

$?$ 
G. AMERICIIJM-241*

\begin{tabular}{|c|c|c|c|c|c|c|c|c|c|}
\hline DOG & \multicolumn{2}{|c|}{$\begin{array}{l}\text { AT INJECTIION } \\
\text { AGE WEIGHT }\end{array}$} & \multirow{2}{*}{$\begin{array}{l}\text { INJECTED } \\
(\mu C \mathrm{i} / K G)\end{array}$} & \multicolumn{3}{|c|}{$\begin{array}{l}\text { DATE } \\
\text { INJFCTFO }\end{array}$} & \multicolumn{2}{|c|}{$\begin{array}{l}\text { DAYS SINCE } \\
\text { INJECTION }\end{array}$} & \multirow{2}{*}{$\begin{array}{l}\text { DOSE TO } \\
\text { SKELETON } \\
\text { (RADS) }\end{array}$} \\
\hline NUMBER & (DAYS) & $(K G)$ & & & MO & $Y R$ & $31 / 3 / 71$ & DEATH & \\
\hline TO15W5.5 & 858 & 11.50 & 4.53 & 23 & 10 & 67 & & 1 & 10 \\
\hline T016W5.0 & 461 & 10.70 & 2.78 & 29 & 1 & 68 & & 22 & 80 \\
\hline $\begin{array}{l}T 032 W 5.5 \\
T 033 W 5.5\end{array}$ & $\begin{array}{l}553 \\
393\end{array}$ & $\begin{array}{l}11.00 \\
10.50\end{array}$ & $\begin{array}{l}4.46 \\
4.47\end{array}$ & $\begin{array}{l}30 \\
30\end{array}$ & $\begin{array}{l}4 \\
4\end{array}$ & $\begin{array}{l}68 \\
68\end{array}$ & & $\begin{array}{l}7 \\
8\end{array}$ & $\begin{array}{l}40 \\
46\end{array}$ \\
\hline $\begin{array}{l}\text { T056W5.0 } \\
\text { T057W5.0 } \\
\text { T099w5.0 }\end{array}$ & $\begin{array}{l}552 \\
496 \\
547\end{array}$ & $\begin{array}{r}11.30 \\
7.01 \\
11.30\end{array}$ & $\begin{array}{l}2.9 \\
2.77 \\
2.67\end{array}$ & $\begin{array}{l}25 \\
26 \\
10\end{array}$ & $\begin{array}{r}11 \\
11\end{array}$ & $\begin{array}{l}69 \\
70 \\
70\end{array}$ & 141 & $\begin{array}{l}15 \\
15\end{array}$ & $\begin{array}{l}50 \\
47\end{array}$ \\
\hline
\end{tabular}

${ }^{241} \mathrm{Am}$ dogs missing from the sequence fro "test" animals have been redesignated as "Toxicity" animals and appear earlier in Table 1. 
$-91-$

DOG

NUMBER

TO 1.5W5.5 SPECIAL STUDY

T016W5.0 SPECIAL STUDY

TOS2W5.5 SPECIAL STUDY

TO 3 $3 W 5.5$ SPECIAL STUDY

TOS6W5.0 SPECIAL STUDY

TOS.7W5.0

T099W5.0

SPECIAL STUDY
COMMENTS ON DEAD DOGS 
H. LEAD-210*

\begin{tabular}{|c|c|c|c|c|c|c|c|c|}
\hline \multirow{2}{*}{$\begin{array}{l}\text { DOG } \\
\text { NUMBER }\end{array}$} & \multicolumn{2}{|c|}{$\begin{array}{l}\text { AT INJECTION } \\
\text { AGE WEIGHT }\end{array}$} & \multirow{2}{*}{$\begin{array}{l}\text { INJECTED } \\
(\mu C i / K G)\end{array}$} & \multicolumn{2}{|c|}{$\begin{array}{l}\text { DATE } \\
\text { INJECTED }\end{array}$} & \multicolumn{2}{|c|}{$\begin{array}{l}\text { DAYS SINCE } \\
\text { INJECTION }\end{array}$} & \multirow{2}{*}{$\begin{array}{l}\text { DOSE TO } \\
\text { SKELETON } \\
\text { (RADS) }\end{array}$} \\
\hline & (DAYS) & $(K G)$ & & 0 & MO YR & $31 / 3 / 71$ & DEATH & \\
\hline $\begin{array}{l}T 001 L 5.0 \\
T 002 L 5.0 \\
T 003 L 5.0\end{array}$ & $\begin{array}{l}522 \\
522 \\
522\end{array}$ & $\begin{array}{l}9.78 \\
9.16 \\
9.78\end{array}$ & $\begin{array}{l}10.7 \\
10.7 \\
10.7\end{array}$ & $\begin{array}{l}24 \\
24 \\
24\end{array}$ & $\begin{array}{ll}6 & 69 \\
6 & 69 \\
6 & 69\end{array}$ & $\begin{array}{l}645 \\
645\end{array}$ & 2 & 180 \\
\hline
\end{tabular}




$$
-93-
$$

DOG

NUMBER

COMMENTS ON DEAD DOGS

T0O1L5.O

TOUZL5.O

TOO 3LS.O

SPECIAL STUUY 
I. CALIFORNIUM-249

\begin{tabular}{|c|c|c|c|c|c|c|c|c|}
\hline $\begin{array}{l}\text { DOG } \\
\text { NUMBER }\end{array}$ & $\begin{array}{l}\text { AT INJ } \\
\text { AGE W } \\
\text { (DAYS) }\end{array}$ & $\begin{array}{l}\text { CTION } \\
\text { I GHT } \\
(K G)\end{array}$ & $\begin{array}{l}\text { INJECTED } \\
\left({ }_{\mu} \mathrm{Ci} / K G\right)\end{array}$ & $\begin{array}{c}D \\
\text { INJ } \\
D\end{array}$ & $\begin{array}{l}\text { ATE } \\
\text { ECTED } \\
\text { MO YR }\end{array}$ & $\begin{array}{l}\text { DAYS } \\
\text { INJECT } \\
31 / 3 / 71\end{array}$ & $\begin{array}{l}\text { SINCE } \\
\text { TION } \\
\text { DEATH }\end{array}$ & $\begin{array}{l}\text { DOSE TO } \\
\text { SKELETON } \\
\text { (RADS) }\end{array}$ \\
\hline $\begin{array}{l}00165.0 \\
00265.0 \\
00365.0\end{array}$ & $\begin{array}{l}597 \\
584 \\
584\end{array}$ & $\begin{array}{r}12.20 \\
10.70 \\
9.89\end{array}$ & $\begin{array}{l}2.84 \\
2.77 \\
2.8\end{array}$ & $\begin{array}{l}24 \\
24 \\
24\end{array}$ & $\begin{array}{ll}2 & 71 \\
2 & 71 \\
2 & 71\end{array}$ & 35 & $\begin{array}{r}7 \\
21\end{array}$ & \\
\hline
\end{tabular}




$$
-95-
$$

DOG

NUMÜER

COMMENTS ON DEAD DOGS

TOU1G5.U

T002G5.0

SPECIAL STUDY

T003G5.0

SPECIAL STUDY 
DOG

NUMBER

F001A

F002A

MOO3A

MOU 4A

M005A

M006A

MOU7A

M008A

F009A

F010A

F011A

F012A

F013A

F014A

F015A

F016A

F017A

F018A

F019A

F020A

F021A

F022A

M023A

M024A

F025A

M026A

M027A

MO2BA

MO $29 A$

F031A

F032A

F033A

F034A

M035A

M036A

M037A

F038A

M039A

M040A

F041A

M042A

F043A

F044A
DAYS AGE

AS OF

$31 / 3 / 71$ DEATH
DOSE TO

SKELETON

(RADS)

1383

2492

1451

3346

3747

5266

3896

3746

3719

2605

4198

4219

4527

3777

4874

4415

2145

5921

4166

2464

5508

4350

1741

3074

5646

4133

2130

3114

5017

5266

1990

3282

2584

529

1.971

4091

3802

4406

4666

4704

1265

3883

5016 
DOU

NUMBER

COMMENTS ON DEAD DOGS

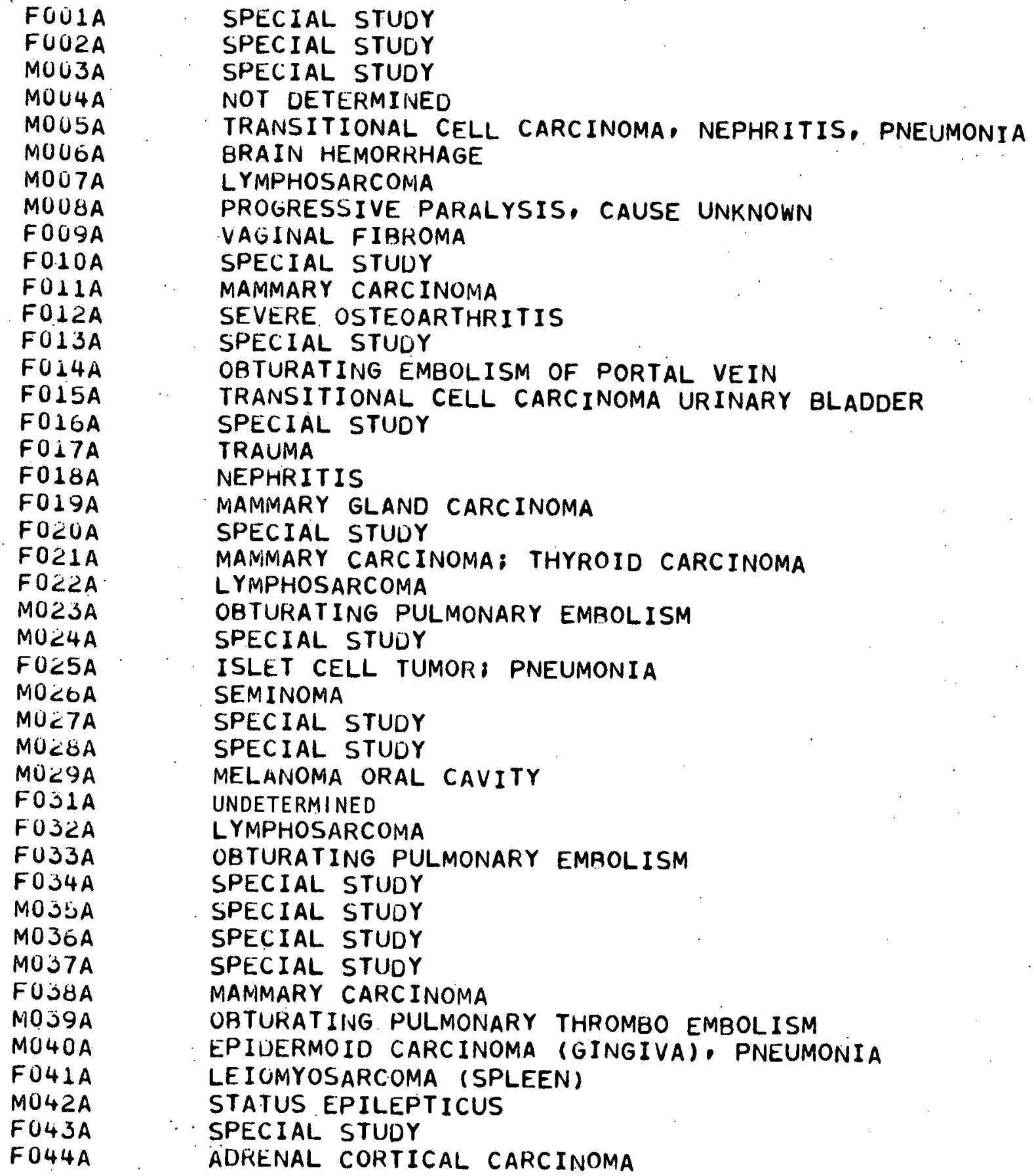


DOG

NUMBER

F045A

F047A

F048A

F049A

MOSOA

F051A

F052A

F0S3A

F054A

F055A

M056A

F057A

M058A

M059A

M060A

M061A

F062A

F063A

F068A

F070A

M071A

M073A

F074A

M075A

F076A

F077A

F078A

F079A

F080A

F081A

M082A

F083A

M084A

M085A

M086A

F087A

F088A

F089A

F090A

F091A

F092A

M093A

F094A

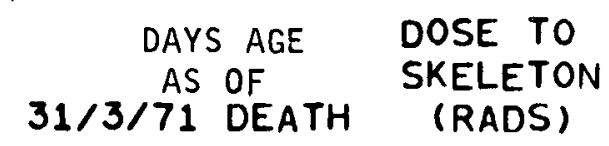

5858

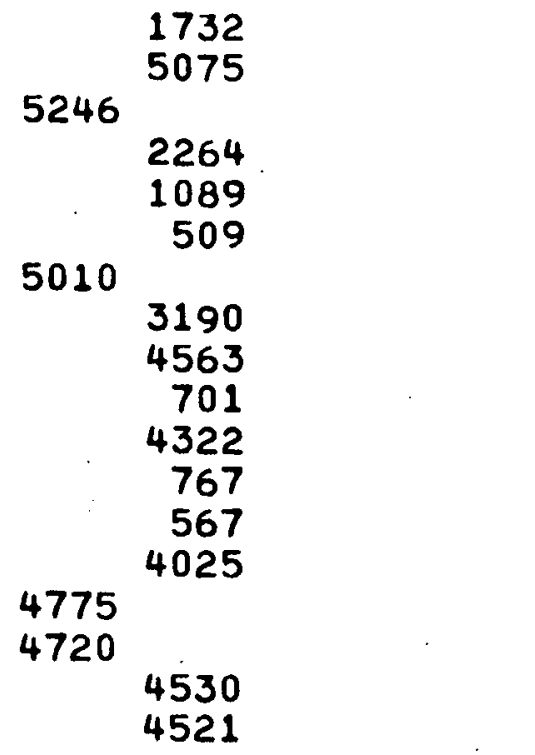

4131

1472

5695

5553

5284

4041

4026

3760

3671

3615

3615

3378

3302

3302

3572

2810

499 
DOO

NUIMISER

COMMENTS ON DEAD DOGS

F045A

FO47A

FU4४A

F049A

MO50A

FUS1A

F052A

FOS3A

F054A

FOS5A

M056A

FU57A

MO58A

MOS9A

M060A

M061A

F002A

F0O3A

F0ல8A

F070A

MO71A

MO73A

F074A

MO75A

F076A

F077A

F078A

F079A

FOEOA

FOBIA

MOB2A

F0B3A

MOB4A

MO\&5A

MUSGA

F067A

FUOBA

FOOYA

FU9OA

F091A

F092A

MO9JA

FOY4A

SPECIAL STUOY

CHRONIC PANCREATITIS

SPECIAL STUUY

SPECIAL STUDY

SPECIAL STUDY

SPECIAL STUUY

NEPHRITIS: METASTATIC CALCIFICATION

VOLVULUS + PERITONITIS

UNDIFFERENTIATED MALIGNANCY

SPECIAL STUDY

SPECIAL STUDY

TRANSFERRED TO EXPERIMENTAL GROUP (SEE TO71R50).

MAMMARY CARCINOMA. TRANSITIONAL CELL CARCINOMA UNDIFFERENTIATED CARCINOMA

SPECIAL STUDY

DEGENERATION OF ADRENAL GLAND + DIABETES MELLITUS

LYMPHO SARCOMA

AORTIC THROMBUS

SPECIAL STUOY 
DOG

NUMUER

F095A

F096A

F097A

F098A

F099A

M10OA

MIUIA

F10\%A

M103A

M104A

F105A

F1UGA

F107A

F108A

FIO9A

F110A

FIIIA

F112A

F113A

F114A

$\begin{array}{ccc}\text { DAYS AGE } & \text { DOSE TO } \\ \text { AS OF } & \text { D } & \text { SKELETON } \\ 31 / 3 / 71 & \text { DEATH } & \text { (RADS) } \\ & & \\ 2670 & & \\ 2653 & & \\ 2653 & & \\ 2559 & & \\ & 479 & \\ & 407 & \\ & 290 & \\ & 243 & \\ & 217 & \\ & 188 & \\ & 157 & \\ 2254 & & \\ 2163 & & \\ & 1969 & \\ 1990 & & \\ 1760 & & \\ 1748 & & \\ 1479 & & \\ 615 & & \\ 619 & \end{array}$


$-101-$

DOG

NUMBER

F095A

F096A

F097A

FU96A

F099A

M1UOA

MIUIA

FIU2A

M103A

M104A

F1U5A

F106A

F107A

F1 U.8A

F109A

FIIUA

FIIIA

F112A

F113A

F114A.
COMMENTS ON DEAD DOGS

SPECIAL STUOY

SPECIAL STUDY

SPECIAL STUOY

SPECIAL STUDY

SPECIAL STUDY

SPECIAL STUDY

SPECIAL STUDY

- ENCEPHALOMALACIA (BACTERIAL) 


\section{CALIFORNIUM RETENTION, EXCRETION AND DISTRIBUTION IN BEAGLES SOON AFTER INJECTION}

Ray D. Lloyd, Charles W. Mays, David R. Atherton, Glenn N. Taylor, and Jerry L. Williams

Abstract: The metabolism of californium has been studied in 11 beagles from 0 to 82 days after intravenous injection with Cf-249 or Cf-252 as Cf(ПT) in citrate buffer. Total excretion during the first 21 days after injection was mainly urinary. of the Cf eliminated in this 3 week period, about $3 / 5$ appeared in the first day's collection. Nearly twice as much californium was excreted in 3 weeks after injection as has been observed with beagles given Am-241 or Pu-239. A combination of totalbody and partial-body gamma-ray counting of the living dogs indicated that at. I week about $20 \%$ of the injected Cf was deposited in the liver and that nearly $60 \%$ remained in non-liver tissue (mainly skeleton). This retention pattern persisted until at least 82 days after injection. In contrast, the retention of Am-24l during a corresponding period averaged about $50 \%$ of the injected activity in liver and $40 \%$ in skeleton, while values for Pu-239 averaged about $30 \%$ in 1 iver and $60 \%$ in skeleton. Two dogs were sacrificed for distribution studies 7 and 21 days after the injection of Cf-249. Tissues exhibiting relatively high Cf concentrations were liver, skeleton, kidney, dura, connective tissue, and, in the 7 day dog, the thyroid. Although liver concentration of Cf was lower relative to that of Pu-239 or especially Am-241, kidney concentration of $C f$ was significantly higher. Skeletal Cf concentration was similar to that for Pu-239 but was about double that for Am-24l at corresponding burden times. Average thyroid concentrations of these 3 elements were highest for americium and californium but lowest for plutonium. Tissues at risk from incorporated californium appear to be liver, skeleton, kidney, and thyroid.

\section{INTRODUCTION}

Californium-252 decays by spontaneous fission in about $3 \%$ of its radioactive disintegrations. (1) Because of the accompanying emission of fission neutrons, Cf-252 has been proposed as a portable neutron source of very small size with virtually unlimited applications. (2) The U.S. Atomic Energy Commission has made $\mathrm{Cf}-252$ available in microgram and milligram quantities for research and development in such varied applications 
as cancer therapy, neutron radiography, clinical laboratory tests;

pollution control; prospecting for minerals or underground water; nondestructive testing or quality control in manufacturing; short-lived radionuclide production; studies of neutron effects, neutron shielding, or neutron scattering; fissile materials detection; soil moisture determination; chemical or metallurgical studies; in the manufacture of electronic components; civil defense planning; startup of nuclear reactors or sustaining operation of subcritical facilities, and reactor design studies. $(2,3)$ Estimates have been made of $\mathrm{Cf}-252$ production requirements by 1980 of up to several hundred grams per year. $(2,3)$ As the use of cf-252 increases, an accurate assessment of its biological hazard when accidentally incorporated into humans becomes imperative.

The purpose of our present studies is to compare metabolism and effects of Cf-252 in beagles with those of previously studied emitters so that an evaluation of the $\mathrm{Cf}-252$ hazards to man can be made.

Cf -249 was also included in the experiment. Because its radioactive decay is virtually all by alpha emission, comparison of the biological effects of Cf-249 with those of Cf-252 can provide a method of identifying the separate effects of alpha and fission fragment emission by $\mathrm{cf}-252$. In addition, the discrete 333 and $388 \mathrm{keV}$ gamma-rays of $\mathrm{Cf}-249^{(1)}$ make this isotope much more convenient to use in tracer and metabolic experiments than does the continuous spectrum of fission gamma-rays from $\mathrm{C} f-252$.

\section{CAL IFORNIUM DECAY ENERGIES}

Cf-249 releases $5.83 \mathrm{MeV}$ of alpha ${ }^{(1)}$ plus $0.10 \mathrm{MeV}$ of recoil energy per disintegration (5.93 MeV total).

Each radioactive disintegration of $\mathrm{C} f-252$ by fission (3.1\%) releases 
$185 \mathrm{MeV},{ }^{(4)}$ and each disintegration by alpha emission (96.9\%) releases $6.11 \mathrm{MeV}$ alpha ${ }^{(1)}$ plus $0.10 \mathrm{MeV}$ recoil energy (6.21 MeV total). Approximately half of the total alpha-plus-fission dose-rate is accounted for by each of these two modes of Cf-252 decay:

$$
\begin{aligned}
& \text { fission }=185 \mathrm{MeV} \times 3.1 \%=5.74 \mathrm{MeV} \\
& \text { alpha }=6.21 \mathrm{MeV} \times 96.9 \%=6.02 \mathrm{MeV} \\
& \text { total energy } / \mathrm{Cf}-252 \text { decay }=11.76 \mathrm{MeV}
\end{aligned}
$$

The dose-rate per retained $\mu \mathrm{C} i$ of $\mathrm{Cf}-252$ is therefore nearly twice that of $C F-249$.

\section{METHODS}

The $C f-252$ and $C f-249$ used in these studies were both obtained from the Isotopes Sales Division, Oak Ridge National Laboratory. Injection solutions were subsequently prepared by putting $C f(I I I)$ into a sodium citrate-citric acid buffer solution of $\mathrm{pH} 3.5$. Eleven young adult beagles were injected intravenously with either Cf-249 or Cf-252 (Table 1). Animals were housed in separate stainless steel metabolism cages for the first 21 days after injection. All excreta produced during this period were collected and assayed for Cf content by comparing the gamma-ray counting rate of each sample with that of a standard in an identical container.

Two of the dogs which had been given Cf-249 were sacrificed for distribution studies, T2G5 at 7 days and T3G5 at 21 days after injection. Individual bones, organs or tissues were assayed for their Cf-249 content by gamma-ray counting. Californium retention in the total-body and in the liver was determined in the living animal by a combination of total-body counting and partial-body counting. Details of this procedure can be found in Refer- 
Table 1. Beagles injected with Cf -249 or Cf -252

\begin{tabular}{|c|c|c|c|c|c|c|}
\hline I sotope & Dog & Sex & $\begin{array}{c}\text { Age } \\
\text { (days) }\end{array}$ & $\begin{array}{l}\text { We ight } \\
(\mathrm{kg})\end{array}$ & $\begin{array}{c}\text { Injected } \\
\mu \mathrm{Ci}\end{array}$ & $\mu \mathrm{Ci} / \mathrm{kg}$ \\
\hline \multicolumn{7}{|l|}{$c f-249 \%$} \\
\hline 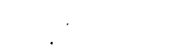 & TIG5 & $M$ & 597 & 12.2 & 34.6 & 2.84 \\
\hline & $\mathrm{T} 2 \mathrm{G} 5$ & M & 584 & 10.7 & 29.6 & 2.77 \\
\hline & T3G5 & $F$ & 584 & 9.89 & 27.7 & 2.80 \\
\hline \multirow[t]{3}{*}{$\therefore$} & $F \mid G 3$ & $\mathrm{~F}$ & 584 & 11.6 & 3.37 & 0.29 \\
\hline & $M 2 G 3$ & M & 580 & 13.2 & 3.72 & 0.28 \\
\hline & M3G3 & $M$ & 580 & 13.7 & 3.89 & 0.28 \\
\hline & $F 4 G 3$ & $F$ & 580 & 8.79 & 2.49 & 0.28 \\
\hline \multicolumn{7}{|l|}{ Cf $-252 *$} \\
\hline & MIF3 & $M$ & 583 & 11.6 & 3.5 & 0.3 \\
\hline : & $\mathrm{F} 2 \mathrm{~F} 3$ & $F$ & 583 & 10.6 & 3.2 & 0.3 \\
\hline$\therefore$ & $\mathrm{F} 3 \mathrm{~F} 3$ & $\mathrm{~F}$ & 583 & 8.66 & 2.6 & 0.3 \\
\hline & $\mathrm{F} 4 \mathrm{F3}$ & $F$ & 583 & 9.69 & 2.9 & 0.3 \\
\hline
\end{tabular}

*The "G" in each dog's experimental number designates Gammaemitting californium-249.

$*$ The "F" in each dog's experimental number designates. Fissioning californium-252. 
ence 5 and a description of the counting system is given in Reference 6 . The anesthetized animal was placed for total-body.counting in a curved lucite box which bent his midline into an arc having a $33-\mathrm{cm}$ radius. The box was positioned such that the dog's midline was $33 \mathrm{~cm}$ from the face of an $8 \times 4$ inch Nal (TI) crystal. This counting arrangement was designed so that detector response would be relatively independent of the location of an emitter along the length of a dog. The lucite container molded the animals to a constant $15 \mathrm{~cm}$ thickness to provide similar photon absorption from dog to dog, regardless of size, within the size limits of our adult beagles. Both the animal and the detector were housed during the counting period in a low-background iron room constructed of 12 inch thick battleship steel.

A lead $(\mathrm{Pb})$ shield $20 \mathrm{~cm}$ high, $18 \mathrm{~cm}$ wide, and $2.54 \mathrm{~cm}$ thick was interposed between the crystal and the dog's liver during partial-body counting. A shield of this size is large enough to adequately cover the liver. Its $2.54 \mathrm{~cm}$ thickness attenuated the 333 and $388 \mathrm{keV}$ gamma-rays of $\mathrm{cf}-249$ to less than $0.3 \%$. (7) Calculation of the Cf-249 activity in the liver of the intact dog was based on (a) the calibration of total-body counting using the cal ifornium burden computed as injected activity minus the activity which had been excreted for the first 5 days after injection; and (b) the cal ibration provided by two Cf -249 dogs which were counted with and without the $\mathrm{Pb}$ shield immediately following sacrifice and liver excision. Livers were placed in polyethylene bottles, and their gamma-ray count ing rates were compared with that of a known activity of Cf-249 in an identical bottle. The radioactivity in this standard was diluted with distilled 
water to the approximate volume of the livers so that effects of geometry and self absorption in the standard and in the livers would be similar. In these 2 dogs, the fraction of non-liver californium covered by the $\mathrm{Pb}$ shield during partial-body counting averaged about 0.38 . Each dog's counting rate with the $\mathrm{Pb}$ shield in place was therefore divided by $(1-0.38)=$ 0.62 to estimate the counting rate of the total non-liver californium. The counting rate of the activity in the liver was found by subtracting the calculated counting rate of the non-liver activity from the counting rate of the unshielded dog. Percent retained $C f$ values were then obtained by comparing the counting rates of (a) non-liver $C f,(b) l i v e r ~ C f$, and (c) total dog Cf with that of a duplicate of the dog's Cf injection inside of a suitable phantom. (6)

Although the total-body counting of dogs injected with Cf-252 was calibrated adequately by use of the excreta subtraction technique described for the cf-249 dogs, determination of the liver vs. non-liver partitioning for Cf-252 by total-body and partial-body counting results was not as satisfactory. It was found that the fission gamma-ray spectrum of $\mathrm{Cf}-252$ was attenuated to only $33.6 \%$ by $2.54 \mathrm{~cm}$ of $\mathrm{Pb}$, to $23.8 \%$ by $5.08 \mathrm{~cm}$ of $\mathrm{Pb}$, and to $18.6 \%$ by $7.62 \mathrm{~cm}$ of $\mathrm{Pb}$. This is at least partly because of the high average energy of the fission gamma-rays and their continuous energy distribution in the spectrum. Since the liver retention values for $\mathrm{Cf}-252$ obtained by counting the living dog are so much more uncertain than those for Cf-249, only the total-body retention values for Cf-252 are reported here. As dogs injected with $\mathrm{Cf}-252$ are sacrificed and excised livers become available, the calibration for $\mathrm{Cf}-252$ liver retention can be completed. 
Until then, it will be assumed that partitioning of $\mathrm{Cf}-252$ between liver and non-liver tissue is identical to that for Cf-249.

\section{RESULTS AND DISCUSSION}

Excretion. Table 2 summarizes the average'measured californium excretion during the first 3 weeks after injection for all 11 dogs.

Table 2. Average excretion of Cf -249 or $\mathrm{Cf}-252$ by 11 Beagles during the first 3 weeks after injection.

\begin{tabular}{|c|c|c|c|c|}
\hline \multirow{2}{*}{$\begin{array}{c}\text { Collection } \\
\text { Interval } \\
\text { (days) }\end{array}$} & \multicolumn{3}{|c|}{ Percent of Injected Californium } & \multirow{2}{*}{$\begin{array}{r}\text { Excreted } \\
\text { Total }\end{array}$} \\
\hline & Urine & $\begin{array}{c}\text { Cage } \\
\text { Washings }\end{array}$ & Feces & \\
\hline $0-1$ & $10.297 \%$ & $0.958 \%$ & $3.223 \%$ & $14.478 \%$ \\
\hline $1-2$ & 0.905 & 0.326 & 1.415 & 2.646 \\
\hline $2-3$ & 1.267 & 0.231 & 1.148 & 2.646 \\
\hline $3-7$ & 0.683 & 0.457 & 1.071 & 2.211 \\
\hline $7-14$ & 0.393 & 0.364 & 0.408 & 1.165 \\
\hline $14-21$ & 0.248 & 0.232 & 0.222 & 0.702 \\
\hline $0-21$ & $13.793 \%$ & $2.568 \%$ & $7.487 \%$ & $23.848 \%$ \\
\hline
\end{tabular}

The excretion of Cf-249 did not differ significantly from that of cf -252 . of the total excretion during this 3 week period, about $43 \%$ appeared. in the first day's urine collection, and nearly $14 \%$ in the first day's fecal collection. After the first week, urine collections contained about as much of the injected californium as the fecal collections during the same time period. In contrast to other radionuclide studies we have made in beagles, cage washings contained significant amounts of activity. The 
cages were washed periodically with an acid solution that might have picked up californium which had plated from the urine onto the stainless steel cage floor. Nearly all the californium in cage washings was therefore tentatively assigned to the urine. Further studies are planned to determine what fraction of the activity in cage washings originates from urine and from feces.

A comparison of $\mathrm{Cf}$ excretion with that of $\mathrm{Pu}$ and $\mathrm{Am}$ (Table 3) reveals that about twice as much of the injected $\mathrm{Cf}$ as $\mathrm{Pu}$ or Am was el iminated during this initial 3 week period. Both Am and Cf were excreted mainly in the urine while Pu excretion was predominantly fecal.

Table 3. Excretion of Pu, Am, and Cf by Beagles during the first 3 weeks after intravenous injection

\begin{tabular}{cccccc}
\hline $\begin{array}{l}\text { Number } \\
\text { of dogs }\end{array}$ & Element & Reference $\%$ in Urine & $\%$ in Feces & $\begin{array}{c}\text { Total } \% \\
\text { Excreted }\end{array}$ \\
\hline $\begin{array}{r}19 \\
4\end{array}$ & Pu & $(8)$ & 3.9 & 8.2 & 12.1 \\
11 & Am & $(5)$ & 9.7 & 1.4 & 11.1 \\
\hline
\end{tabular}

Retention. The measured total-body retention and partitioning of retained californium activity between liver and non-liver tissue is shown in Table 4. For comparison, the total-body retention calculated by excreta subtraction at corresponding times is also given. At 1 week following injection, nearly $60 \%$ of the injected californium was found in non-1iver tissue (mainly skeleton) and about $20 \%$ remained in the liver. Total-body retention of $\mathrm{Cf}-249$ and $\mathrm{Cf}-252$ at corresponding times soon after injection appeared to be similar. 
Table 4. Biological retention of injected californium in beagles.

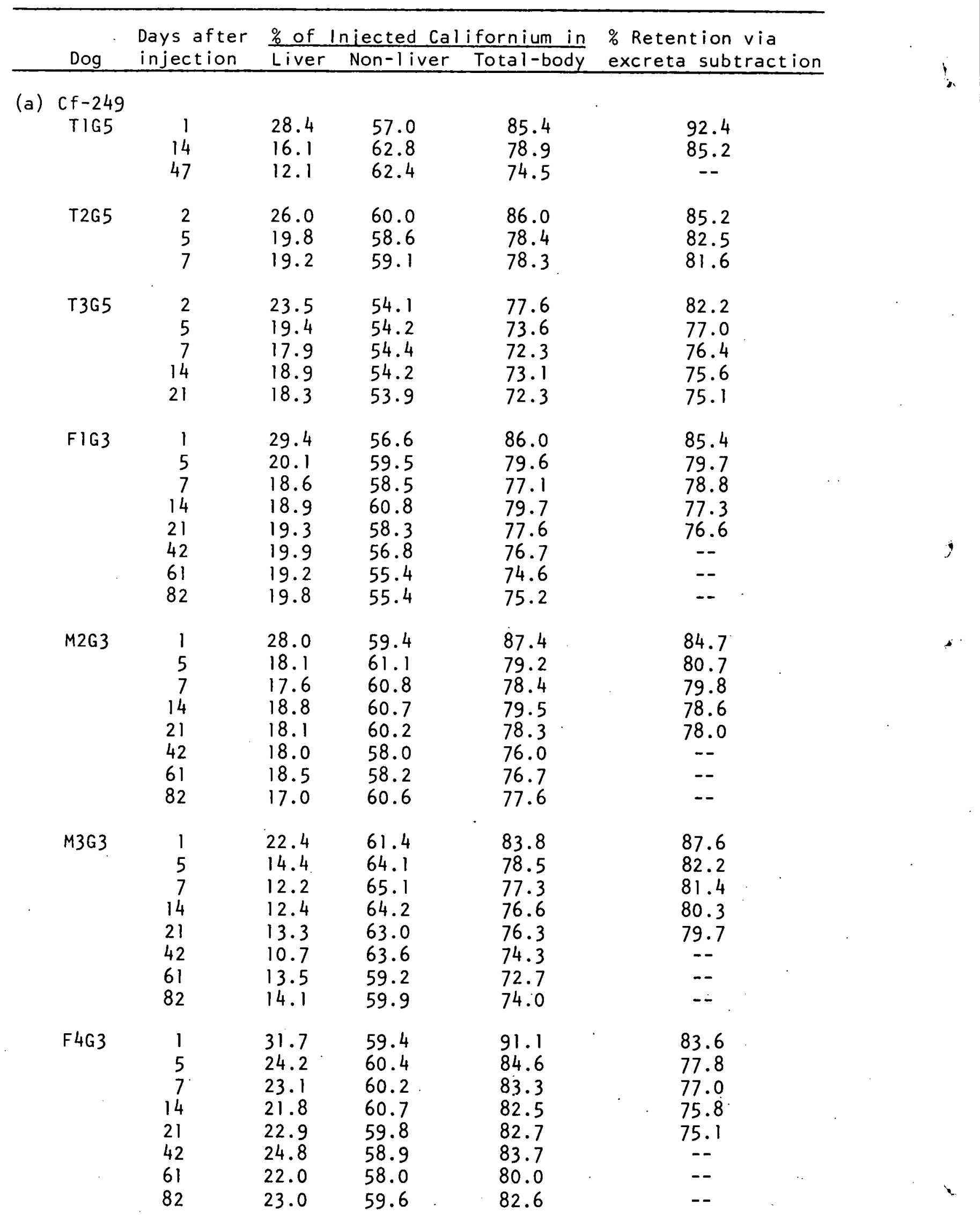


Table 4 (continued)

\begin{tabular}{|c|c|c|c|c|c|c|c|}
\hline & Dog & $\begin{array}{l}\text { Days after } \\
\text { injection. }\end{array}$ & $\%$ of & $\begin{array}{l}\text { Injected Cal ifornium } \\
\text { in Total-body }\end{array}$ & $\%$ & $\begin{array}{l}\text { Retention via } \\
\text { excreta subtra }\end{array}$ & action \\
\hline (b) & $\begin{array}{c}\text { Cf }-252 \\
\text { MIF } 3 \\
\vdots\end{array}$ & $\begin{array}{l}7 \\
36 \\
54 \\
75\end{array}$ & & $\begin{array}{l}79.4 \\
76.2 \\
75.1 \\
73.9\end{array}$ & & $\begin{array}{c}78.5 \\
-- \\
-- \\
--\end{array}$ & \\
\hline & $F 2 F 3$ & $\begin{array}{r}7 \\
36 \\
54 \\
75\end{array}$ & - & $\begin{array}{l}77.2 \\
73.4 \\
73.0 \\
69.8\end{array}$ & & $\begin{array}{c}77.3 \\
-- \\
-- \\
--\end{array}$ & \\
\hline & $\mathrm{F} 3 \mathrm{~F} 3$ & $\begin{array}{r}7 \\
36 \\
54 \\
75\end{array}$ & & $\begin{array}{l}75.0 \\
69.7 \\
68.8 \\
66.2\end{array}$ & & $\begin{array}{l}73.4 \\
-- \\
-- \\
--\end{array}$ & \\
\hline & F4F3 & $\begin{array}{r}7 \\
36 \\
54 \\
.75\end{array}$ & & $\begin{array}{l}76.5 \\
72.1 \\
72.8 \\
69.6\end{array}$ & & $\begin{array}{c}79.0 \\
-- \\
-- \\
--\end{array}$ & \\
\hline
\end{tabular}

One week following the injection of Am-241, in beagles, about $50 \%$ of the injected activity was deposited in liver and about $40 \%$ in non-liver tissue (mainly skeleton). (5) Injected Pu-239 deposits about $60 \%$ in the skeleton and $30 \%$ in the liver. ${ }^{(8)}$ Retention values for americium and plutonium are compared with those for californium in Table 5.

Table 5. Retention of Pu, Am and $\mathrm{Cf}$ by beagles one week after intravenous injection in citrate solution

\begin{tabular}{|c|c|c|c|c|}
\hline \multirow[b]{2}{*}{ Reference } & \multirow[b]{2}{*}{ Element } & \multirow{2}{*}{$\begin{array}{l}\text { Percent of } \\
\text { Liver }\end{array}$} & \multicolumn{2}{|c|}{ Injected Radioactivity } \\
\hline & & & Non-liver & Total \\
\hline$(8)$ & Plutonium & 30 & 60 & 90 \\
\hline (5) & Americium & 50 & 40 & 90 \\
\hline (Table 4) & Californium & 20 & 60 & 80 \\
\hline
\end{tabular}


Distribution. Cf-249 was found in every tissue which was counted (Table 6). At 1 and 3 weeks after injection, about $50 \%$ of the injected cal ifornium was in the skeleton, about $20 \%$ was in the liver and about $10 \%$ was in other tissues. Some organs and tissues exhibiting a relatively high concentration of Cf-249 were the liver, skeleton, kidney, connective tissue, dura, and, in one dog, the thyroid. Californium compares with Am-241 in tissue distribution, ${ }^{(5)}$ except that the average concentration of $C f$ was greater in the skeleton and relatively less in the liver and thyroid. Also, Cf seems to exhibit a more ubiquitous distribution. For example, while the brain and thymus of these two dogs definitely contained $C f$, these two organs were below the 1 imit of detection in the four Am-241 dogs sacrificed 1 to 22 days after injection. (5) The concentration (\% injected activity per $\mathrm{kg}$ ) in the skeleton was about 0.64 of that in the liver in T2G5 and 0.69 in T3G5, while it averaged only 0.15 in four dogs given Am-24l and sacrificed 1 to 22 days after injection. (5) This compares with an average of about 0.70 in two dogs reported in Reference 8 which were injected with Pu-239 and sacrificed 29 to 44 days later. Relative concentrations of californium in skeleton and liver are more like plutonium than americium (Table 7).

The kidney concentration of $\mathrm{Cf}$ was higher than for either Am or Pu at early times. Table 7 shows that the average kidney concentration of Cf-249 in two dogs sacrificed at 7 and 21 days was $22.8 \%$, while the average of four dogs given Am-241 and sacrificed 1 to 22 days later was 15.6*. (5) The average kidney concentration in four dogs sacrificed $7,14,35$, and 40 days after the injection of Pu-239 was $14.6 \%$.

* Percent of total injected activity retained within organ divided by organ weight in kilograms. 
Table 6. Distribution of injected $\mathrm{Cf}-249$ in the tissues of two beagles.

\begin{tabular}{|c|c|c|c|c|c|c|}
\hline \multirow[b]{2}{*}{ Tissue } & \multicolumn{3}{|c|}{$\begin{array}{c}\text { Male Dog T2G5 } \\
7 \text { days after injection } \\
\end{array}$} & \multicolumn{3}{|c|}{$\begin{array}{l}\text { Female Dog T3G5 } \\
21 \text { days after injection }\end{array}$} \\
\hline & $\begin{array}{l}\text { Wet we ight } \\
(g)\end{array}$ & $\begin{array}{c}\% \text { of } \\
\text { Injected } \\
\text { Cf }-249\end{array}$ & $\frac{\%}{\mathrm{~kg}}$ & $\begin{array}{c}\text { Wet weight } \\
(g)\end{array}$ & $\begin{array}{c}\% \text { of } \\
\text { Injected } \\
\text { Cf }-249\end{array}$ & $\frac{\%}{\mathrm{~kg}}$ \\
\hline $\begin{array}{l}\text { Liver } \\
\text { Skeleton } \\
\text { Thyroid } \\
\text { Kidneys } \\
\text { Dura } \\
\text { Connective Tissue* } \\
\text { Lymphatic Tissue* } \\
\text { Lungs and Trachea } \\
\text { Spleen } \\
\text { Aorta } \\
\text { Salivary Glands } \\
\text { Adrenals } \\
\text { Prostate } \\
\text { Pituitary } \\
\text { Ovaries } \\
\text { GI Tract } \\
\text { Pelt.. } \\
\text { Heart } \\
\text { Eyes } \\
\text { Thymus } \\
\text { Pancreas } \\
\text { Testes } \\
\text { Muscle* } \\
\text { Brain } \\
\text { Omentum }\end{array}$ & $\begin{array}{c}301.6 \\
1070 . \\
0.853 \\
42.5 \\
1.021 \\
9.81 * \\
8.87 * \\
83.39 \\
24.01 \\
3.82 \\
-1.31 \\
7.11 \\
0.070 \\
-1--- \\
440.5 \\
1600 . \\
102.88 \\
12.9 \\
5.611 \\
18.59 \\
23.9 \\
4500 . * \\
82.86 \\
---1\end{array}$ & $\begin{array}{l}19.2 \\
44.13 \\
0.0491 \\
0.927 \\
0.020 \\
0.185 \\
0.123 \\
1.21 \\
0.224 \\
0.037 \\
-. .- \\
0.008 \\
0.030 \\
0.00027 \\
-.-1-. \\
1.685 \\
4.132 \\
0.207 \\
0.026 \\
0.0095 \\
0.044 \\
0.033 \\
3.400 \\
0.013 \\
--.-1-\end{array}$ & $\begin{array}{r}63.7 \\
41.2 \\
57.6 \\
21.8 \\
19.6 \\
18.9 \\
13.9 \\
14.5 \\
9.3 \\
9.7 \\
-1 . \\
6.1 \\
4.2 \\
3.9 \\
--- \\
3.8 \\
2.6 \\
2.0 \\
2.0 \\
1.7 \\
2.3 \\
1.4 \\
0.8 \\
0.2 \\
----\end{array}$ & $\begin{array}{c}235.5 \\
989 . \\
0.561 \\
37.32 \\
0.802 \\
--.- \\
6.35 * \\
67.71 \\
18.37 \\
4.90 \\
11.75 \\
0.992 \\
--0.060 \\
0.060 \\
0.595 \\
375.0 \\
1650 . \\
80.62 \\
11.25 \\
19.19 \\
16.87 \\
--.-- \\
5000 . * \\
76.9 \\
139.5\end{array}$ & $\begin{array}{l}18.3 \\
53.13 \\
0.00908 \\
0.886 \\
0.016 \\
.0 .-16 \\
0.075 \\
0.559 \\
0.117 \\
0.025 \\
0.074 \\
0.006 \\
-.-1-.- \\
0.00023 \\
0.002 \\
0.525 \\
2.095 \\
0.118 \\
0.017 \\
0.030 \\
0.015 \\
-.-1 \\
2.657 \\
0.017 \\
0.027\end{array}$ & $\begin{array}{r}77.7 \\
53.7 \\
16.2 \\
23.7 \\
20.0 \\
--.- \\
11.8 \\
8.3 \\
6.4 \\
5.1 \\
6.3 \\
6.0 \\
--.- \\
3.8 \\
3.4 \\
1.4 \\
1.3 \\
1.5 \\
1.5 \\
1.6 \\
0.9 \\
---. \\
0.5 \\
0.2 \\
0.2\end{array}$ \\
\hline Total Cf-249 & & 75.693 & & & 78.700 & \\
\hline Ret. by body count $i$ & & 78.3 & & & 72.2 & \\
\hline Ret. by excreta $s$ & . & 81.6 & & & $75: 1$ & \\
\hline
\end{tabular}

* Incomplete sample

-- Not measured 
Table 7. Concentration of $\mathrm{Cf}, \mathrm{Am}$, and $\mathrm{Pu}$ in skeleton, liver, kidney, and thyroid of beagles soon after injection.

\begin{tabular}{|c|c|c|c|c|c|}
\hline \multirow{2}{*}{$\begin{array}{l}\text { Days after } \\
\text { Injection }\end{array}$} & \multirow[b]{2}{*}{ Dog } & \multicolumn{4}{|c|}{$\%$ of Injected Activity per $\mathrm{kg}$} \\
\hline & & Skeleton & Liver & Kidney & Thyroid \\
\hline 7 & $\mathrm{~T} 2 \mathrm{G} 5$ & 41.2 & 63.7 & 21.8 & 57.6 \\
\hline \multirow[t]{2}{*}{21} & T3G5 & $\underline{53.7}$ & 77.7 & 23.7 & 16.2 \\
\hline & Average $\mathrm{Cf}$ & 47.4 & 70.7 & 22.8 & 36.9 \\
\hline 1 & $\mathrm{~T} 15 \mathrm{~W} 5.5$ & 24.6 & 175.2 & 24.7 & 114.6 \\
\hline 7 & T32W5. 5 & $27 \cdot 5$ & 191.5 & 13.5 & 43.2 \\
\hline 8 & T33W5. 5 & 28.6 & 153.2 & 11.8 & 42.0 \\
\hline \multirow[t]{2}{*}{22} & T16W5 & 27.5 & 194.2 & 9.7 & 20.4 \\
\hline & Average Am & 27.0 & 178.5 & 15.6 & 55.1 \\
\hline 29 & TIP5 & 49.2 & 73.0 & & \\
\hline 44 & $\mathrm{~T} 2 \mathrm{PS}$ & 55.8 & 76.6 & & \\
\hline 7 & T56P5 & & 106.1 & & \\
\hline 7 & T14P5 & & 68.7 & 18.8 & \\
\hline 14 & T55P5 & & 110.6 & 13.4 & \\
\hline 35 & $\mathrm{~T} 30 \mathrm{PI}$ & & 159.7 & 18.7 & \\
\hline 40 & T31P3 & & 102.9 & 7.4 & \\
\hline 13 & $T 42 P 5$ & & & & 5.3 \\
\hline 35 & T44P5 & & & & 6.8 \\
\hline \multirow[t]{2}{*}{$(404) *$} & $(T 54 P 5) *$ & & & & $(6.6) \div$ \\
\hline & Average $\mathrm{Pu}$ & 52.5 & 99.7 & 14.6 & 6.1 \\
\hline
\end{tabular}

*Although the thyroid concentration for this 404 day dog was not included in the average for short-term animals, it is shown for comparative purposes. 
Thyroid concentrations of $\mathrm{CF}$, Am, and $\mathrm{Pu}$ at comparable times a.fter injection are also shown in Table 7 . It was much less for Pu-239 than Am or Cf. Although the average for the two Cf-249 dogs was somewhat lower than that for the four Am-24l dogs, one of the Cf dogs (T2G5) exhibited a thyroid concentration (57.6\% per $\mathrm{kg}$ ) as high as the Am average of 55.1 . It is hoped that the sacrifice of additional animals after Cf injection will help explain the wide variation in thyroid concentration between the two dogs already studied (Table 6). Based on the tissue distribution of $\dot{C} f$ and the observed effects in beagles of injected Pu-239 $(9,10)$ and Am-241, (11) we expect the skeleton, kidney, liver and thyroid to be among the organs at risk after californium injection.

\section{ACKNOWLEDGEMENTS}

We are grateful for the assistance of Niels Little, Stan Gwiazdowski, and Terry McClellan who made the excreta collections; Susan Gaufin, Darcie Smith, and Gary Goates who did much of the work connected with gamma-ray analyses; Chall McRoberts and Ned Nebeker for their help with dog totalbody counting.

\section{REFERENCES}

1. C.M. Lederer, J.M. Hollander and I. Perlman; Table of Isotopes, Sixth Edition (John Wiley and Sons, Inc., New York); pp 149, 442, 443 (1967).

2. Glenn T. Seaborg; Californium-252: radioisotope with a future; in CONF681032 (U.S.A.E.C. Div. of Tech. Info.) 1-9 (1968).

3. J.L. Crandall; Survey of applications for Cf-252; Ibid.; 225-256 (1968).

4. A. Prince; Nuclear and physical properties of $\mathrm{Cf}-252$; Ibid; p. 37 (1968). 
5. R. D. Lloyd, C. W. Mays, G. N. Taylor, and D. R. Atherton; Americium241 studies in beagles; Health Physics 18: 149-156 (1970).

6. R. D. Lloyd, D. H. Taysum, and C. W. Mays; Design and calibration of a total-body counting system for measuring radioactivity in beagles; in Retention and Dosimetry of. Some Injected Radionuclides in Beagles (Univ. of Utah Report C00-119-241);2-24 (1970).

7. Robley D. Evans; The Atomic Nucleus; McGraw-Hill Book Co., New York; p. $716(1962)$.

8. Betsy J. Stover, D. R. Atherton, F. W. Bruenger, and Dawn S. Buster; 239 PulV: its distribution in the beagle; in Delayed Effects of BoneSeeking Radionuclides, C. W. Mays et al., editors; University of Utah Press, Salt Lake City; 109-123 (1969).

9. C. W. Mays et al.; Radiation-induced bone cancer in beagles; lbid; $387-408$ (1969).

10. G. N. Taylor, T. F. Dougherty, L. Shabestari, and J. H. Dougherty; Soft tissue tumors in internally-irradiated beagles; lbid., 323336.

11. Ray D. Lloyd, Webster S. S. Jee, David R. Atherton, Glenn N. Taylor, and Charles W. Mays; Am-24l in beagles: biological effects and skeletal distribution; in The Radiobiology of Plutonium, (Betsy J. Stover and W. S. S. Jee, editors); in press. 


\title{
EARLY HEMATOLOGIC EFFECTS OF CALIFORNIUM IN THE BEAGLE
}

\author{
Jean H. Dougherty
}

\begin{abstract}
The hematologic changes following intravenous injection $\overline{\text { of } 249 \mathrm{Cf}}$ or ${ }^{252 \mathrm{Cf}}$ into 11 young adult beagles are reported for the first 8 weeks post-injection. Three dogs which received $\approx 2.8 \mu \mathrm{Ci} / \mathrm{kg}$ of $2{ }^{49} \mathrm{Cf}$ developed a severe depression of granular leukocytes and platelets which was maximal 2 to 3 weeks following injection with little recovery by 8 weeks. The lymphocytes were decreased below normal by 2 weeks and continued to fall thereafter to one-third of pre-injection values. Changes in granular leukocyte values on 4 dogs injected with $\sim 0.28 \mu \mathrm{Ci} / \mathrm{kg}$ of $24{ }^{9} \mathrm{Cf}$ were compared to those of 4 dogs injected with $\sim 0.28 \mu \mathrm{Ci} / \mathrm{kg}$ of ${ }^{252} \mathrm{Cf}$. There was a greater and more prolonged depression in the ${ }^{252} \mathrm{Cf}$ injected dogs probably due to the added bone dose rate from fission fragments on bone surfaces which would cause a greater irradiation of bone marrow. There have been no changes thus far in red cells, platelets or lymphocytes in dogs receiving $0.28 \mu \mathrm{Ci} / \mathrm{kg}$ of either ${ }^{249} \mathrm{Cf}$ or ${ }^{252} \mathrm{Cf}$.
\end{abstract}

\section{INTRODUCTION}

Study of the effects of ${ }^{249} \mathrm{Cf}$ and ${ }^{252} \mathrm{Cf}$ in beagles has been underway in the Radiobiology Division for several months. The following report gives the hematologic changes in these initial animals over the first 8 weeks post-injection. Since the retention, excretion and distribution of californium in beagles differs from $241 \mathrm{Am}$ and $239 \mathrm{Pu},(1)$ it is of interest to compare the early hematologic changes of these transuranic elements at similar injection levels. Also, since ${ }^{249} \mathrm{Cf}$ decays mainly by alpha emission and ${ }^{252} \mathrm{Cf}$ by fission fragment and alpha emission, a comparison of the hematologic changes at similar injected activities will give an indication of the relative toxicity to the hematopoietic system of alpha particles vs. fission fragments.

\section{METHODS}

The injection levels and related data on the 11 dogs injected with 
${ }^{249} \mathrm{Cf}$ or ${ }^{252} \mathrm{Cf}$ are given in Table $\mathrm{l}$ of the previous reference. (1) Hematologic methods are the same as performed on the other radionuclides in our study and have been reported previously. (2) since no californium dogs have been injected at the 0 -level as yet, the hematologic changes noted on each dog at each dose level with time will be related back to the dog's own pre-injection control counts.

The effect on red cells is evaluated by determining volume of packed red cells (VPRC), hemoglobin (Hgb) and reticulocytes. White cell values obtained are total leukocyte count (WBC) and absolute numbers of polymorphonuclear leukocytes (pmns), lymphocytes, monocytes, and eosinophils. Blood platelets and sedimentation rates are also determined.

Blood counts on $3-$ level dogs injected with ${ }^{249} \mathrm{Cf}$ (G3) or ${ }^{252} \mathrm{Cf}$ (F3) have been made at 5 days post-injection and then at weekly intervals for the 8 week period that has elapsed since the time of injection. Only one 5-level dog (TIG5) has been on the experiment this period of time. Dog T2G5 was sacrificed 1 week and T3G5 at 3 weeks after injection for distribution studies.

\section{RESULTS AND DISCUSSION}

5-level $249 \mathrm{Cf}$ Dogs. Blood cell changes on the 3 dogs at the highest level of ${ }^{249} \mathrm{Cf}$ (dogs TIG5, T2G5 and T3G5) are given in Figures 1 and 2. The leukocytes (Fig. 1) are decreased in numbers as early as 5 days after injection due mainly to a pronounced fall in pmns. The pmns reach their lowest levels by 2 to 3 weeks (mean of $450 \mathrm{cells}$ per cu mm) and by 8 weeks in the one surviving dog there may be a beginning recovery. The lymphocytes fall more slowly and in TIG5 are one-third of pre-injection values at 8 weeks. The platelets are maximally depressed by 3 to 4 weeks 


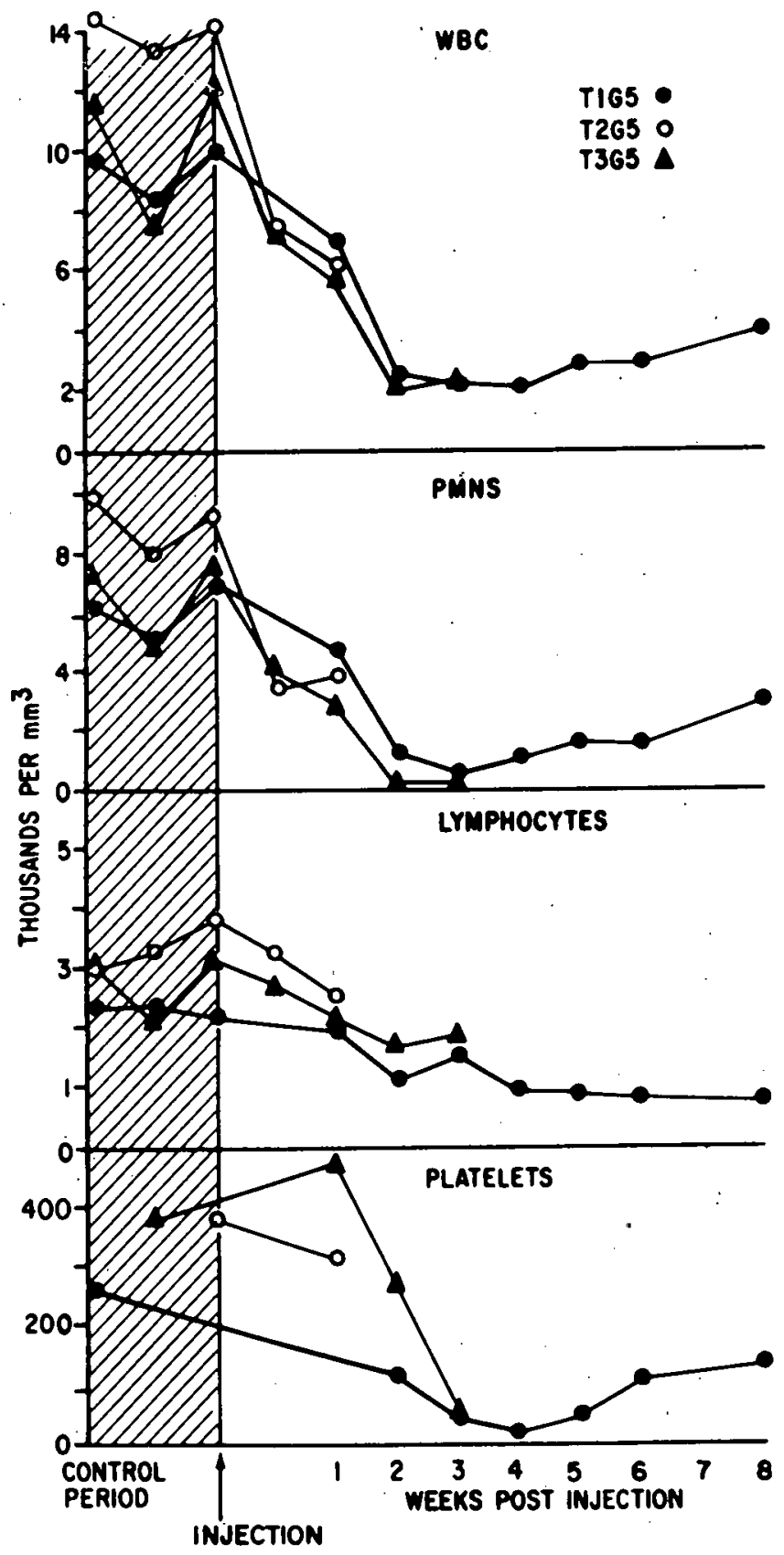

Fig. 1. Leukocyte and platelet responses following injection of approximately $2.8 \mu \mathrm{Ci} / \mathrm{kg}$ of ${ }^{2149} \mathrm{Cf}(5-$ level $)$ for 8 weeks post-injection. 
$-120-$

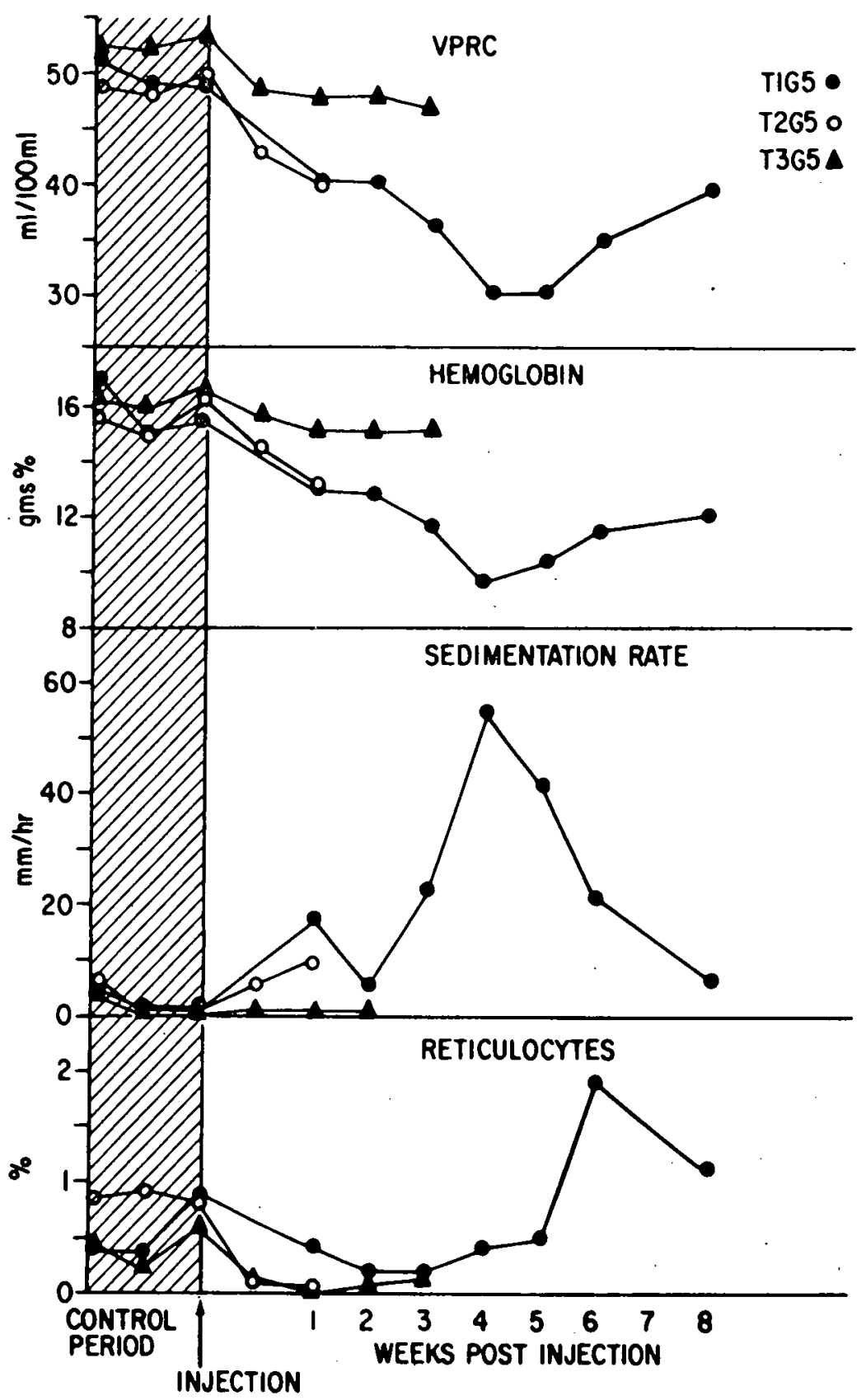

Fig. 2. Red cell values (VPRC, Hgb, reticulocytes) and sedimentation rate of same dogs as Fig. 1. 
and thereafter show a slight rise (TIG5). Monocytes and eosinophils respond similarly to pmns.

The red cell picture as shown by VPRC, Hgb, reticulocytes and sedimentation rates is given in Fig. 2. There is a disparity in the effects among these 3 dogs. The more severe changes in TIG5 may possibly be due to repeated liver biopsies which were performed after injection. The dog sacrificed at 1 week (T2G5) had a slight fall in VPRC, Hgb and sedimentation rate and a drop in reticulocytes from a pre-injection mean of $0.8 \%$ to $0.1 \%$. Dog T $3 G 5$ sacrificed at 3 weeks showed essentially no changes in any of the above values at any time interval studied with the exception of a decrease in reticulocytes. Dog TIG5, on the other hand, had a fall in red cell values beginning at 5 days and becoming maximal between 4 and 5 weeks post-injection at which time the VPRC was $30 \mathrm{ml} / 100 \mathrm{ml}$, Hgb 9.8 $\mathrm{gm} \%$ and the sedimentation rate was $56 \mathrm{~mm} / \mathrm{hr}$. The reticulocytes fell to $0.2 \%$ at 2 weeks and rose to a high of $1.7 \%$ at 6 weeks. At 8 weeks, VPRC and Hgb were not back to pre-injection levels.

The above early changes in leukocytes and platelet levels following injection of $\sim 2.8 \mu \mathrm{Ci} / \mathrm{kg}$ of ${ }^{249} \mathrm{Cf}$ are similar to those seen after injection of $\sim 2.8 \mu \mathrm{C} \mathrm{i} / \mathrm{kg}$ of $241 \mathrm{Am}\left(5-\right.$ level) into 4 adult beagles, ${ }^{(3)}$ and in dogs injected with $2.8 \mu \mathrm{Ci} / \mathrm{kg}$ of $239 \mathrm{pu} .{ }^{(4)}$ The leukocyte recovery rate seems to be a little slower in the 5-level californium dogs but this is based on only one dog at 8 weeks post-injection. It is obviously not possible to make comparisons of the red cell response with any other radionuclides at this time.

3-Level ${ }^{249} \mathrm{Cf}$ and ${ }^{252} \mathrm{Cf}$ Dogs. The leukocyte and platelet values of the 4 dogs injected with ${ }^{249} \mathrm{Cf}$ are given in Fig. 3 and those of the 4 dogs 
$-122-$

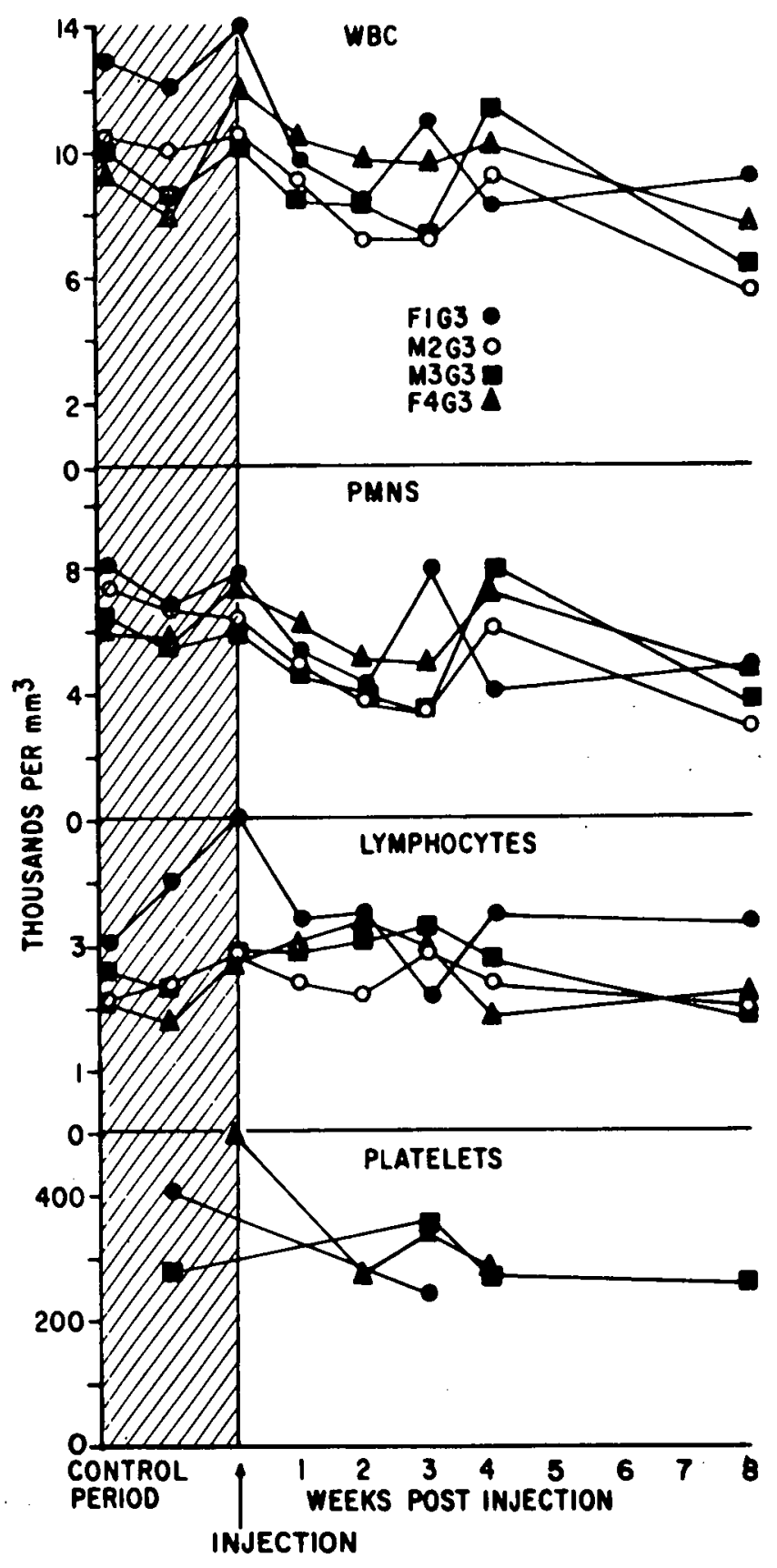

Fig. 3. Leukocyte responses following injection of approximately 0.28 $\mu \mathrm{Ci} / \mathrm{kg}$ of ${ }^{249} \mathrm{Cf}(3-$ level $)$ for 8 weeks post-injection. 
$-123-$

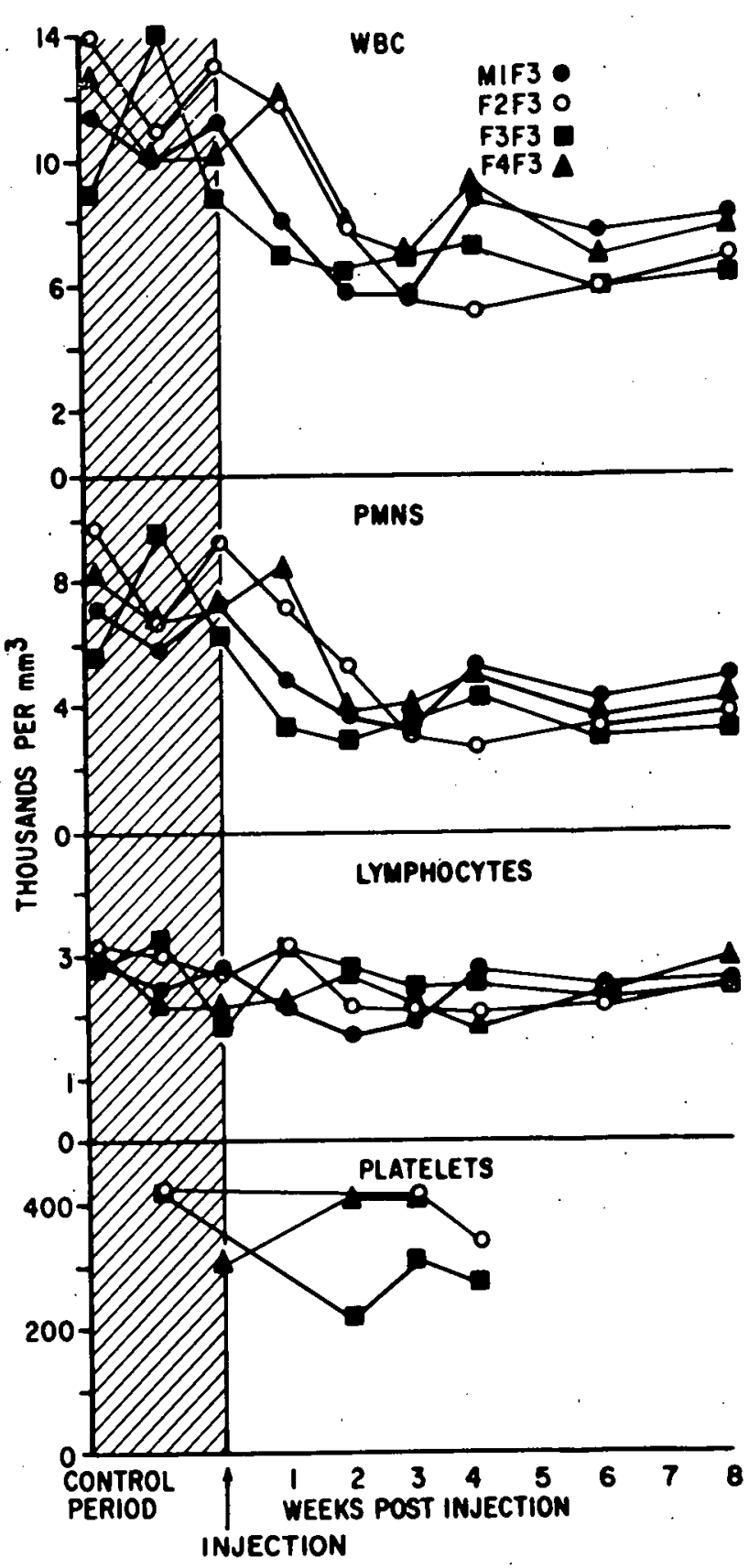

Fig. 4. Leukocyte responses following injection of approximately 0.28 $\mu \mathrm{Ci} / \mathrm{kg}$ of ${ }^{252} \mathrm{Cf}(3-\mathrm{level})$ for 8 weeks post-injection. 
injected with ${ }^{252} \mathrm{Cf}$ in Fig. 4. There were no significant changes in red cell values in any of the 3-level dogs so these values were not graphed. The leukocytes of dogs at the 3-level of $24{ }^{9} \mathrm{Cf}$ (Fig. 3) did not show the sharp decrease seen in the 65 dogs (dose dependency). There was a slight decline in pmns at 2 to 3 weeks with recovery to normal values thereafter, but no deçrease in lymphocytes. There was very little if any effect on platelets at this level as all post-injection counts were within normal limits.

The leukocyte depression was a little greater in the dogs injected with ${ }^{252} \mathrm{Cf}$. In this group the pmns reached values below $4,000 \mathrm{cells} / \mathrm{mm}^{3}$ whereas the ${ }^{249} \mathrm{Cf}$ injected dogs remained with two exceptions (dogs M3G3 and F $4 G 3$ at 3 weeks) above 4,000 cells. There was also less recovery of pmns in the ${ }^{252} \mathrm{Cf}$ dogs. Again, as with $24{ }^{9} \mathrm{Cf}$, there were no significant changes in lymphocytes or platelets from control values.

The more pronounced depressive effect on the pmns of the dogs injected with ${ }^{252} \mathrm{Cf}$ is probably due to the added bone dose rate from fission fragments on the bone surfaces which would cause a greater irradiation of the hematopoietic bone marrow tissue.

\section{ACKNOWLEDGMENTS}

The author wishes to thank Lois Russell and Peggy Soren for their help in this study.

\section{REFERENCES}

I. R. D. Lloyd, C. W. Mays, D. R. Atherton, G. N. Taylor and J. L. Williams; Californium retention, excretion and distribution in beagles soon after injection. (This report.) 
2. Jean H. Dougherty and L. S. Rosenblatt; Changes in the hemogram of the beagle with age. J. Gerontol., 20: 131-138 (1965).

3. Jean H. Dougherty; Preliminary report on hematological effects of ${ }^{241} \mathrm{Am}$ in the beagle. C00-119-242, pp. 354-362 (1970).

4. Jean H. Dougherty; Hematologic changes induced by ${ }^{239} \mathrm{Pu}$ in beagles. In: The Radiobiology of Plutonium, ed. by W. S. S. Jee and Betsy J. Stover (in Press, 1971). ? 
DISTRIBUTION OF CALIFORNIUM-249 AND BERKELIUM-249 IN THE SOFT TISSUES OF BEAGLES

G. N. Taylor, W. S. S. Jee, R. B. Dell, C. W. Mays, J. L. Williams and L. Shabistari

Abstract: The microscopic distribution pattern of $24{ }^{9} \mathrm{Cf}$ and $24{ }_{B k}$ in the soft tissues of beagles, at one to three weeks following a single intravenous injection of a citrate solution, was very similar to ${ }^{241} \mathrm{Am}$. Relatively high concentrations occurred in the hepatic cells of the liver, the glomeruli of the kidney, the interfollicular region of the thyroid, the cartilaginous tissues of the lung, and media of the smaller arterioles of most organs. Very intense, but sparsely scattered "hot spots" were also present in the renal papillae and in the submucosa of the bronchioles. Lesser sites of localization were the endocardium of the AV heart valves, the glassy membranes of the larger hairs of the coat, the zona pellucida of the Graafian follicles and the zona arcuata of the adrenal cortex. With the exception of the liver, where the radionuclide was principally within the hepatic cells, most of the deposition sites were extracellular, within or adjacent to connective tissue which gave a positive periodic acid-schiff reaction.

\section{INTRODUCTION}

Two well known similarities in the biological behavior of elements in the lanthanide and actinide series is their tendency to localize in the skeleton and liver $(1-13)$. In the rat the skeletal concentration has been observed to vary inversely with that initially in the liver and the degree of localization to be somewhat related to the ionic radius (9) As would be expected, the similarities in tissue retention extend beyond these two organs, at least with respect to some of the transuranics.

It is the purpose of this study to summarize some of the more obvious soft tissue sites of early ${ }^{249} \mathrm{Cf}$ and ${ }^{249} \mathrm{Bk}$ localization in the dog。 
inbred beagle colony which received the radionuclide via a single intravenous injection of a citrate solution at $\sim 19$ months of age ${ }^{(14)}$. The two dogs were sacrificed at 7 and 21 days post-injection. In addition to the ${ }^{249} \mathrm{Cf}$, tracer amounts of $24{ }^{9} \mathrm{Bk}$ were also present in the injection solution. However, this relatively small amount of $249 \mathrm{Bk}$ on an atom basis resulted in an appreciable number of beta tracks because of its relatively short half-life (314 days). Because of the low energy (0.125 MeV maximum) of the B-particles from ${ }^{249} \mathrm{Bk}$, its dose in rads is insignificant compared to the $\alpha$-particle dose from $24{ }^{9} \mathrm{Cf}(5.83 \mathrm{MeV}$, average).

The autoradiograms were from acetone fixed tissues, processed according to the methods of Arnold and Jee (15).

\section{RESULTS}

The early deposition of ${ }^{249} \mathrm{Cf}$ in the soft tissues occurred in both intracellular and interstitial sites. The principal intracellular retention was in the hepatic cells of the liver with little if any activity in the reticuloendothelial (RE) cells or the portal structures, at these relatively short post-injection times (Fig. 1). Within the hepatic parenchyma the distribution was uniform without any apparent "hot spots".

Much lesser sites of intracellular deposition were the zona arcuata cells of the adrenal cortex and RE cells in the spleen and lymph nodes.

Most of the soft tissue extracellular deposition of californium was retained in or on connective $t$ issue which was generally PAS positive; however, retention did not occur in all PAS positive tissues.

The most widely distributed deposition site was the media of the small arterioles, principally those with only 1 - 2 layers of muscle. The nuclide appeared to be localized in the connective tissue and not 
the smooth muscle component (Fig. 2). Significant retention in this portion of the arterial system was found in all of the organs examined.

A second arterial site in which above aberage retention occurred was the aorta and the coronary arteries, with the concentration being significantly higher in the coronaries (Fig. 3). Relatively intense "hot spots" were present in the circumflex branch. As in the various other arterial sites, the ${ }^{249} \mathrm{Cf}$ appeared to be retained in the connective tissue component.

In addition to the coronary arteries, selective cardiac localization also occurred in the connective tissue of the endocardium on the ventricular aspect of the mitral valve. The most intense activity was at a point very near the valvular attachment to the cardiac skeleton. In the lungs most of the ${ }^{249} \mathrm{Cf}$ was in or immediately adjacent to the perichondrium of the cartilaginous plates. However, a lesser but preferential deposition also occurred in the lamina propria of the bronchioles (Figs. 4-5). Occasional, very intense, "hot spots" were present in the submucosa of the bronchioles, but these were relatively infrequent.

The most generalized interstitial deposition of ${ }^{249} \mathrm{Cf}$ within any organ occurred in the thyroid where retention was almost exclusively in the interfollicular connective tissue (Fig. 6). Although some activity was present in all of the intersitital areas, significant regional variations in concentration occurred, including the presence of some relatively focal "hot spots". Activity in the colloid or epithelial compenents was very low.

Another organ with a very significant ${ }^{249} \mathrm{Cf}$ connective tissue retention 
was the kidney. High concentrations were present in the glomeruli and the renal papililae (Fig. 7). Lesser amounts were retained in the intertubular tissue, principally in the cortical areas (Fig. 8). Occasional, very intense, "hot spots"' were present in the medulla, usually fairly close to the renal papillae (Fig. 9). The precise location of californium in the glomerular tuft could not be unequivocally determined by autoradiography; however, the high activity of the capsular basement membrane was very suggestive that its homologue, the glomerular basement membrane, was the principal site of deposition in the region of the glomerular capillaries.

A rather unique site of relatively high extracellular localization was in the glassy membrane of the hair follicles (Figs. 10-11). Deposition was restricted to a short segment peripheral to the neck of the papilla and deep to the point of attachment of the erector pili muscle. Such deposition was found only in the primary hairs. Retention in the secondary follicles and the various other adnexa was not observed.

Another extracellular site of focal $249 \mathrm{Cf}$ retention was the region of the zona pellucida of some of the larger and more mature Graafian follicles (Figs, 12-13). The activity was not high but could have significant consequences because of its proximity to the ovum. Selective localization in the smaller follicles did not occur.

The general distribution of $249 \mathrm{Bk}$, which was injected concurrently with $249 \mathrm{Cf}$, in the amount of perhaps $1 \%$ on an atom basis was almost identical to that of Cf. However, we have not determined, as yet, the relative tissue concentration factors and quantitative differences that may exist. Autoradiographic distinction between the two radionuclides was readily achieved because of the differences in the types of energy 
released, beta for the $249 \mathrm{Bk}$ and alpha for ${ }^{249} \mathrm{Cf}$. There were no sites found in which either one of these radionuclides was deposited unilaterally.

\section{DISCUSSION}

Our clinical experience with ${ }^{249} \mathrm{Cf}$ presently covers only about 4 months; however, its qualitative resemblence to ${ }^{241} \mathrm{Am}$ in the local soft tissue deposition pattern indicates that the toxicity syndromes of the two radionuclides should have some similarities ${ }^{(1-12)}$. Any major variation will probably be related to differences in the degree of localization and retention and not to differences in sites.

Evaluation of the ultimate consequences of the soft tissue ${ }^{249} \mathrm{Cf}$ burden will require relatively long latent periods, especially at the lower dose levels. However, at the highest level, $2.8 \mu \mathrm{Ci} 249 \mathrm{Cf} / \mathrm{kg}$, it is reasonably safe at this time to predict that renal failure will be a major end-point and probably the primary cause of death because of the relatively marked localization in the glomeruli. Our experience with 241 Am suggests that such deaths from renal failure should occur beginning at $\sim 400$ days post-injection. ${ }^{249} \mathrm{Cf}$ induced thyroid lesions, similar to those observed in ${ }^{241}$ Am toxicity are also expected.

Thus far, ${ }^{241} \mathrm{Am}$ soft $t$ issue neoplasms have not been observed, such that we do not have a good basis for predicting the carcinoginicity of ${ }^{249} \mathrm{Cf}$. However, the liver, thyroid, kidney and possibly the hair follicles are certainly potential sites. Nevertheless, these possible tumor sites are in competition with the skeleton as neoplastic end-points and may never undergo neoplasia because of earlier death from bone cancer. We know this competitive factor is at least partly responsible for the 
relatively low incidence of liver tumors in $239 \mathrm{pu}$ toxicity in the dog.

The potential hazard of the moderate localization of ${ }^{249} \mathrm{Cf}$ adjacent to the ovum, in the Graafian follicle, is as yet undetermined. However, with the deposition occurring principally in the relatively mature follicles, the radiation would be delivered during its more radioresistant stage of development, at least in comparison to the oogonia, but this would not be the case in the adjacent granulosa cells which are actively dividing at this time. (16-19)

\section{ACKNOWLEDGEMENTS}

The authors wish especially to thank Laura DeKorver for her assistance in this study.

\section{REFERENCES}

1. J. Carritt, R. Fryxell, J. Kleinschmidt, R. Kleinschmidt, W. Langham, A. San Pietro, R. Schaffer, and B. Schnap; The distribution and excretion of plutonium administered intravenously to the rat; J. Biol. Chem. 171: 273-283 (1947).

2. K. G. Scott, D. J. Axelrod, H. Fisher, J. F. Crowley, and J: G. Hamilton; The metabolism of plutonium in rats following intramuscular injection; J. Biol. Chem. 176: 283-293 (1948).

3. J. Schubert, M. P. Finkel, M. R: White, and G. M. Hirsch; Plutonium and yttrium content of the blood, liver, and the skeleton of the rat at different times after intravenous administration; J. Biol. Chem. 182: $635-642(1950)$.

4. H. G. Parker, A. G. Low-Beer, and E. L. I saac; Comparison of retention and organ distribution of ${ }^{241} \mathrm{Am}$ and ${ }^{252} \mathrm{Cf}$ in mice; Health Physics 8: $679-684$ (1962). 
5. B. J. Stover, D. R. Atherton, and H. Keller; Metabolism of $239 \mathrm{Pu}$ in adult beagle dogs; Rad. Res. 10: 2, 130-47 (1959).

6. W. H. Langham; Physiology and toxicology of plutonium-239 and its industrial medical control; Health Phys. 2: 172-185 (1959).

7. D. M. Taylor, F. D. Lowby, and M. F. Kember; The metabolism of americium and plutonium in the rat; Phys. Med. Biol. 6: 73-86 (1961).

8. W. J. Bair, D. H. Willard, J. P. Herring, and L. A. George II; Retention, translocation, and excretion of inhaled $239 \mathrm{pu}$; Health Phys. 8: $6,639-649(1962)$.

9. P. W. Durbin; Distribution of the transuranic elements in mammals; Health Phys. 8: 665-671 (1962).

10. J. E. Ballou, W. J. Bair, A. C. Case, and R. C. Thompson; Studies of neptunium in the rat; Health Phys. $\underline{8}: 685-688$ (1962).

11. G. N. Taylor, W. S. S. Jee, J. L. Williams, B. Burggraff, and W. Angus; Microscopic distribution of $241 \mathrm{Am}$ in the beagle; Research in Radiobiology, c00-119-240, 97-118 (1969).

12. G. N. Taylor, W. S. S. Jee, N. Dockum, and E. Hromyk; Microscopic distribution of $241 \mathrm{Am}$ in the beagle thyroid gland; Health Physics 17: $5,723-725$ (1969)

13. P. J. Magno, P. E. Kauffman and P. R. Groulx; Plutonium-239 in human tissues and bone; Rad. Health Data 10: 4, 47-50 (1969).

14. T. F. Dougherty, B. J. Stover, J. H. Dougherty, W. S. S. Jee, C. W. Mays, C. E. Rehfeld, W. R. Christensen, and H. C. Goldthrope; Studies of the biological effects of ${ }^{226} \mathrm{Ra},{ }^{239} \mathrm{Pu},{ }^{228} \mathrm{Ra}$ (MsTh), ${ }^{228} \mathrm{Th}$ (RdTh), and $90 \mathrm{Sr}$ in adult beagles; Radiat. Res。17: 625-681 (1962).

15. J. S. Arnold and W. S. S. Jee; Embedding and sectioning of undecalcified bone and its application to radioautography; Stain Techn. 29: 
225-239 (1954).

16. P. Rubin and G. W. Casarett; Clinical Radiat. Pathology; W. B. Saunders Co., Philadelphia, 401-402 (1968).

17. A. M. Mand1; The radiosensitivity of germ cells; Biol. Rev. 39: 288-371 (1964).

18. B. H. Erickson; Radioresponse of the prepuberal porcine ovary; Int. J. Radiat. Biol. 13: 1, 57-67 (1967).

19. H. Peters; Radiation sensitivity of oocytes at different stages of development in the immature mouse; Rad. Res. 15: 582-593 (1961). 


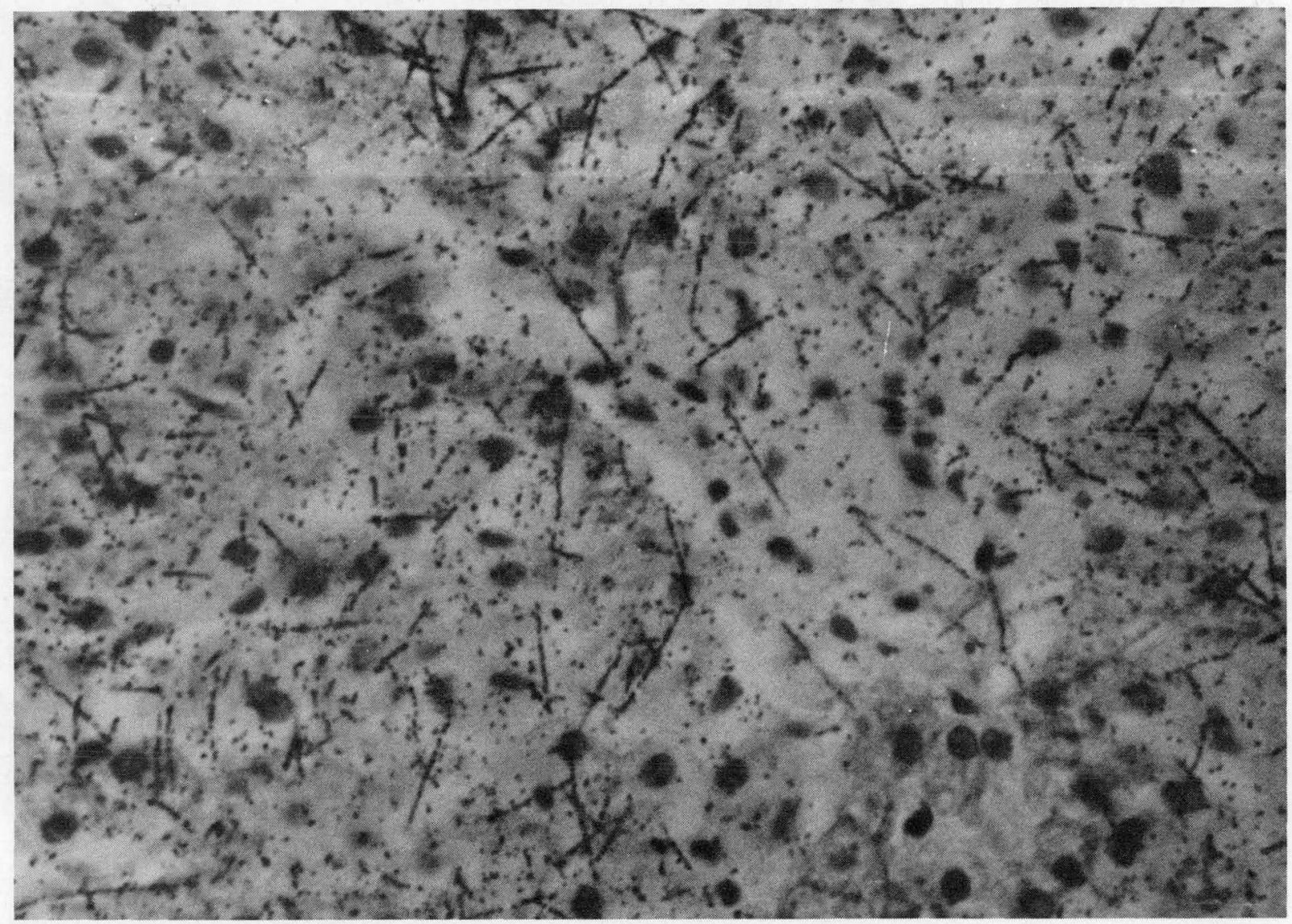

Fig. 1. Autoradiogram of liver 7 days following injection of $\sim 2.8 \mu \mathrm{Ci} / \mathrm{kg}$ of $\alpha$-emitting ${ }^{249} \mathrm{Cf}$ plus tracer amounts of $\beta$-emitting ${ }^{249} \mathrm{Bk}$ showing focal deposition of both ${ }^{249} \mathrm{Bk}$ and ${ }^{249} \mathrm{Cf}$ in the hepatic parenchyma of beagle T2G5. 21 day exposure. The $\alpha$ particles from ${ }^{249} \mathrm{Cf}$ show as line tracks, whereas the $\beta$-particles from ${ }^{249} \mathrm{Bk}$ show as point dots. 


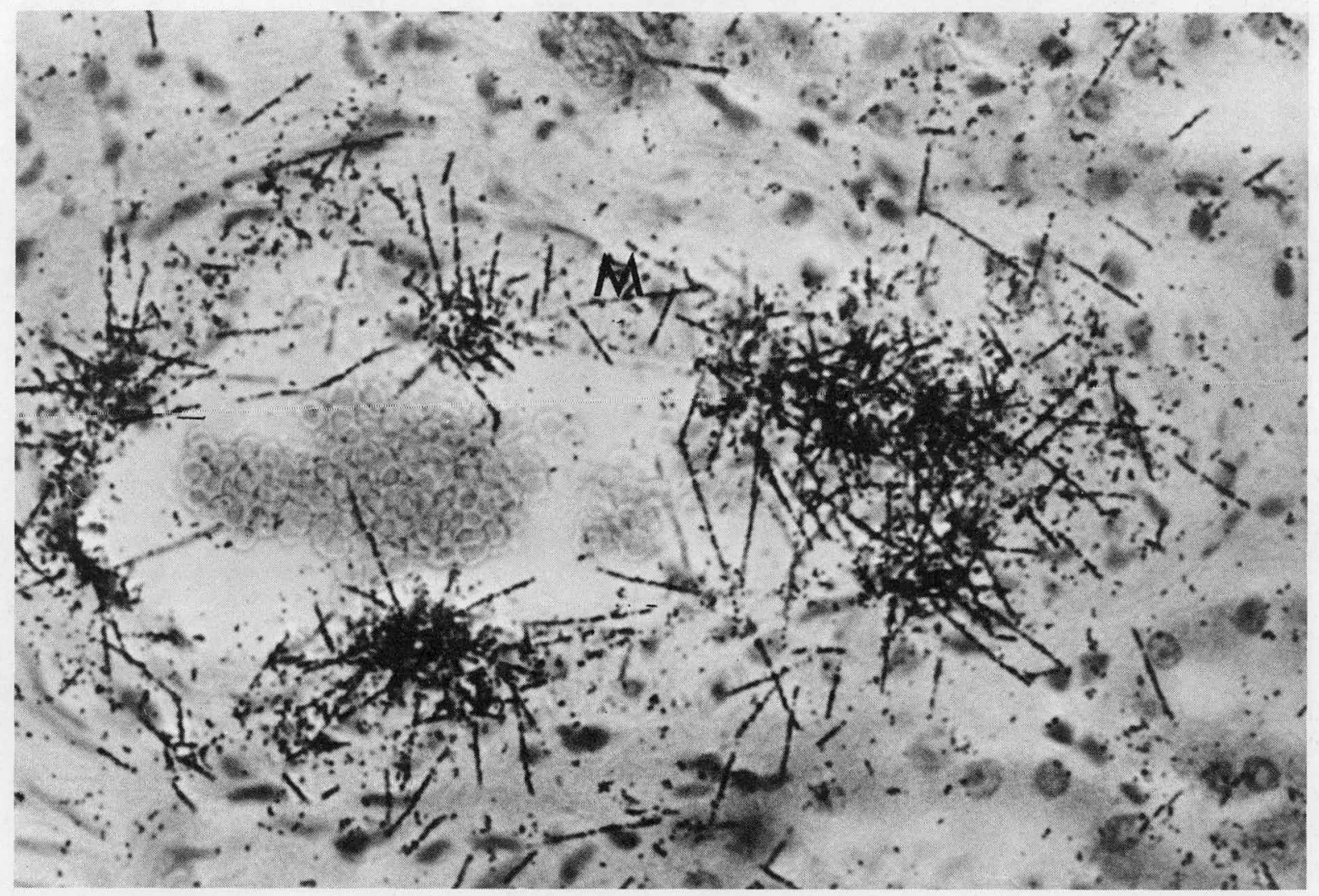

Fig. 2. Autoradiogram of arteriole in beagle kidney 7 days following injection showing focal deposition of $249 \mathrm{Cf}$ and ${ }^{249} \mathrm{Bk}$ in the media (M) of the vessel wall. Same dog as Fig. 1. 35 day exposure. $\times 550$. 


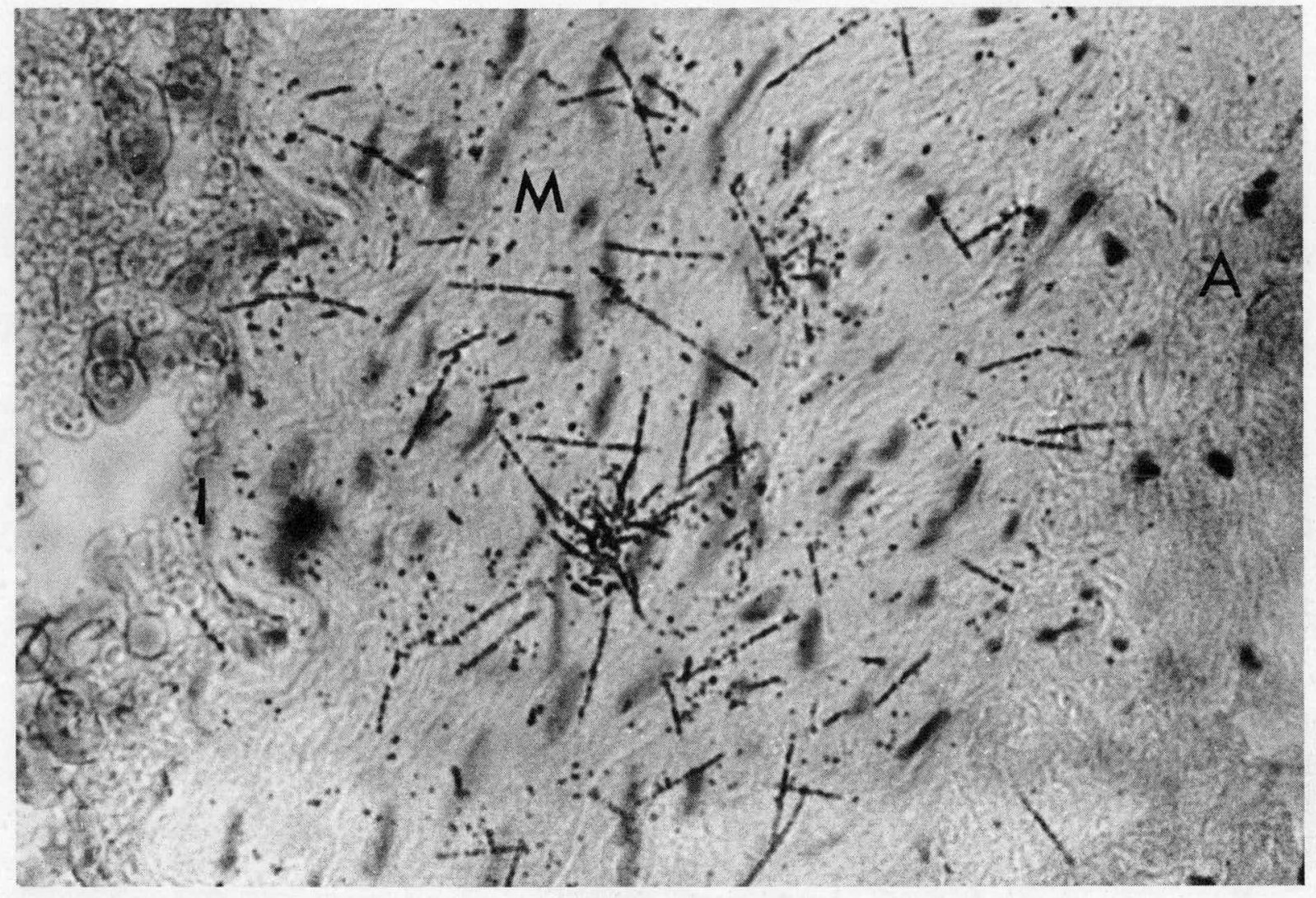

Fig. 3. Autoradiogram of coronary artery 7 days post-injection showing localization of ${ }^{249} \mathrm{Cf}$ and ${ }^{249} \mathrm{Bk}$ in the media (M). No preferential deposition occurred in the intima ( 1 ) or the adventitia (A). Same dog as Fig. 1. 21 days exposure. $\times 550$. 


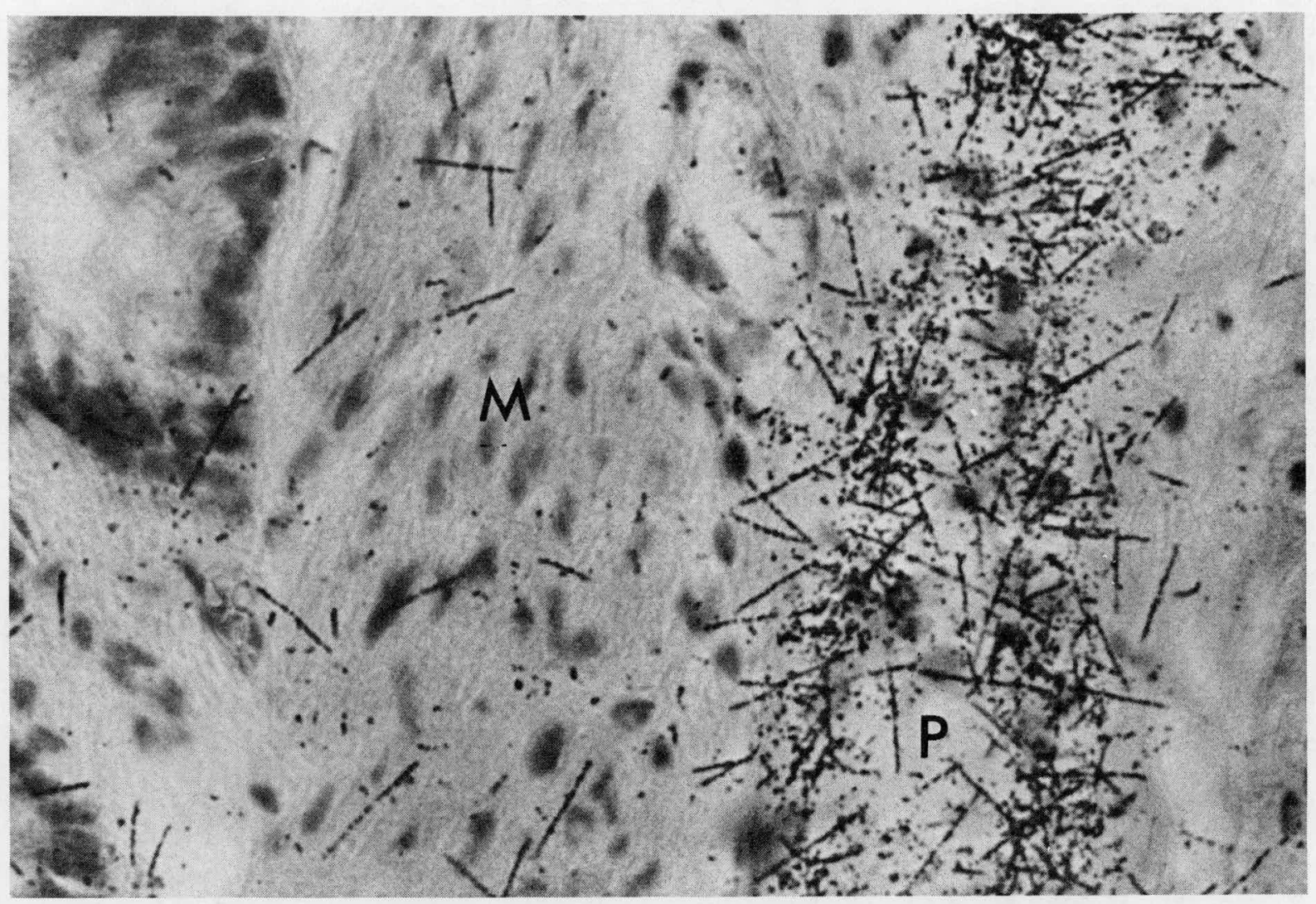

Fig. 4. Autoradiogram of the wall of small bronchiole 21 days following injection of $\sim 2.8 \mu \mathrm{Ci}{ }^{249} \mathrm{Cf} / \mathrm{kg}$ in beagle $\mathrm{T} 3 \mathrm{G} 5$ showing relatively heavy localization of ${ }^{249} \mathrm{Cf}$ and ${ }^{249} \mathrm{Bk}$ in the perichondrium and/or periphery of a cartilaginous plate $(P)$. A moderate increase in activity is also apparent in the lamina propria and muscle layer (M). 14 day exposure. $\times 550$. 


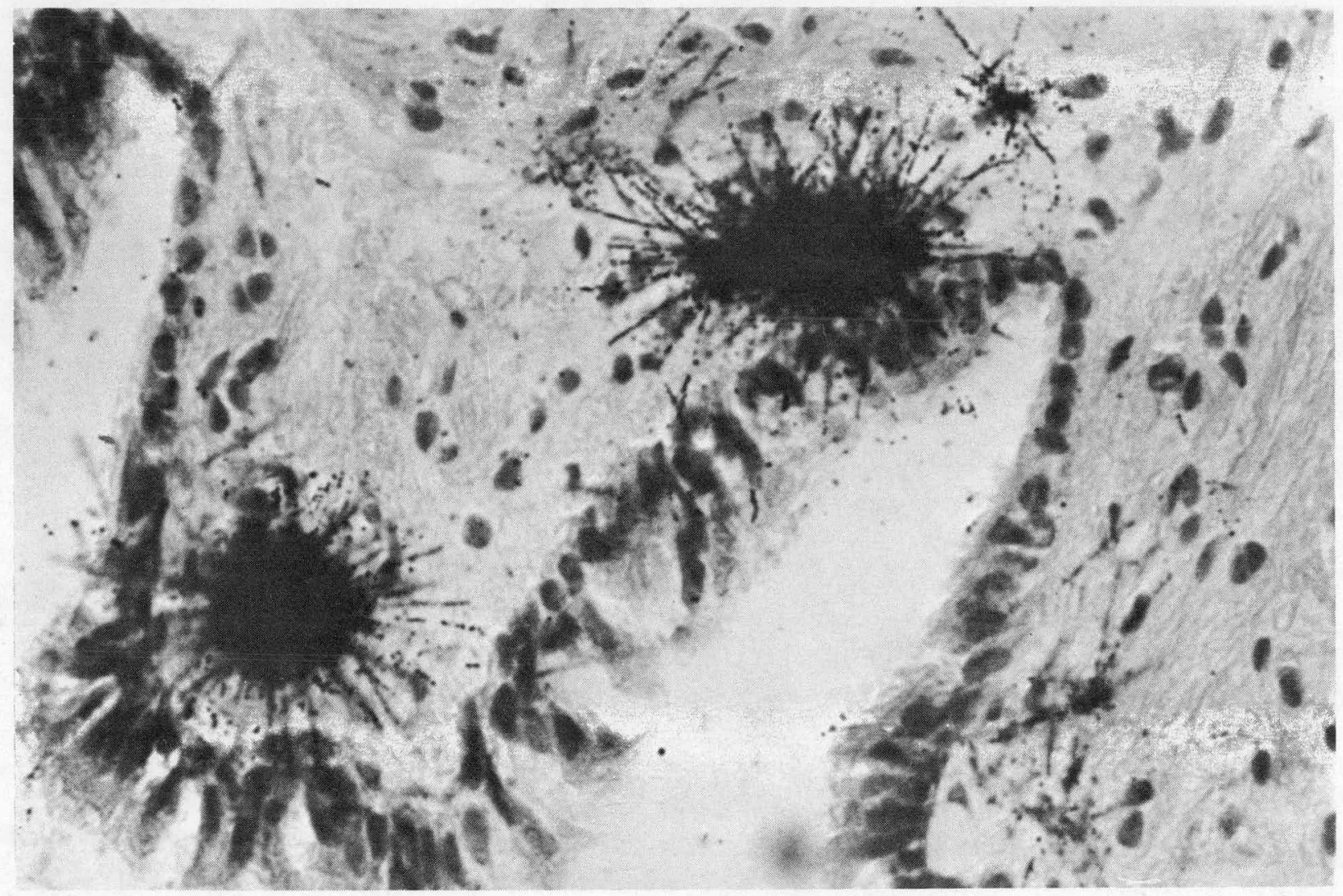

Fig. 5. Autoradiogram of wall of bronchiole 21 days following injection of ${ }^{249} \mathrm{Cf}$ and ${ }^{249} \mathrm{Bk}$ showing the intense "hot spots" occasionally seen in the lamina propria. Same dog as Fig. 4. 14 day exposure. $\times 550$. 


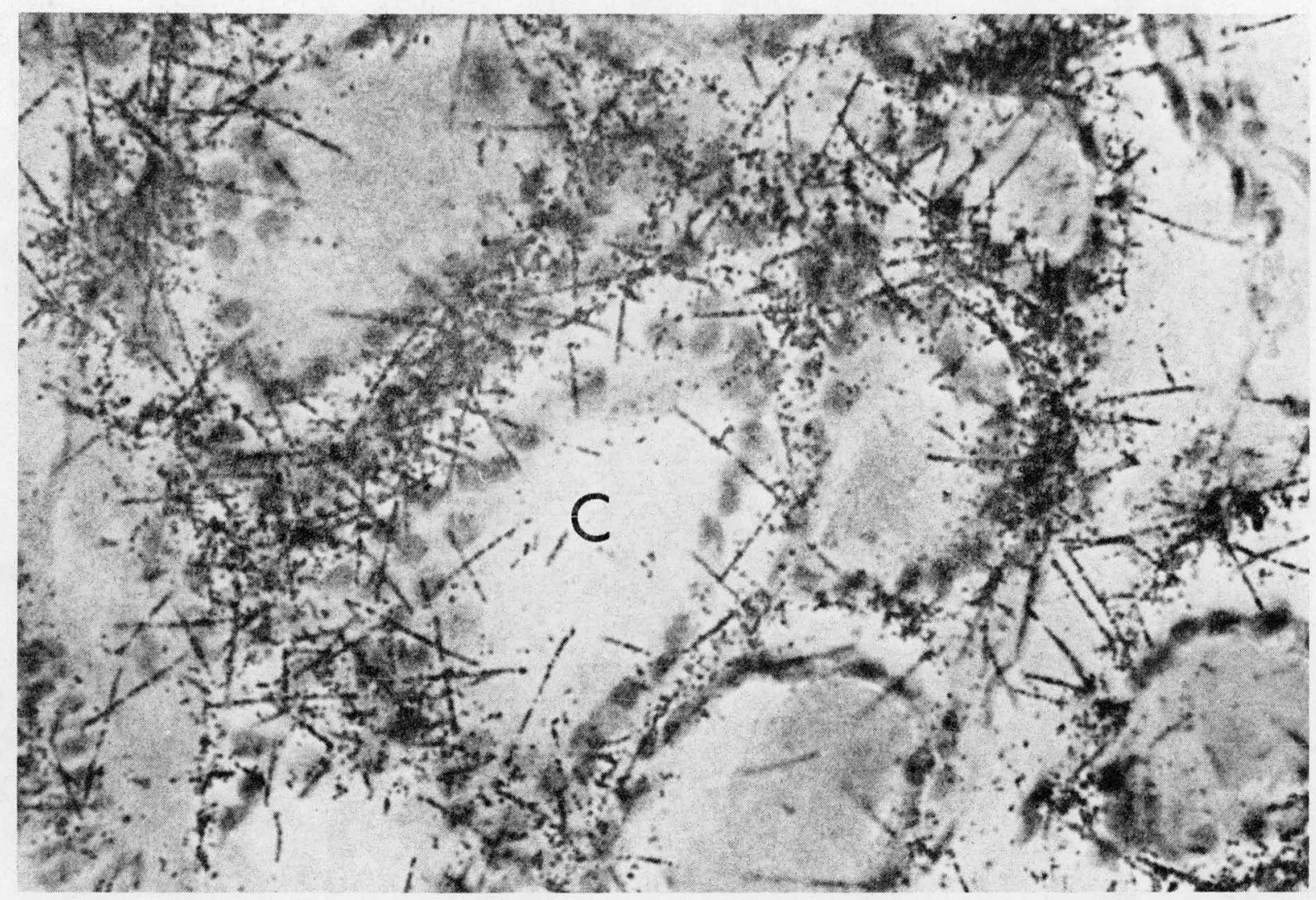

Fig. 6. Autoradiogram of thyroid 7 days following injection, showing the relatively high focal depositions of ${ }^{249} \mathrm{Cf}$ and ${ }^{249} \mathrm{Bk}$ in the interfollicular region. Retention in the colloid (c) was low or absent. Same dog as Fig. 1. 35 day exposure. $\times 550$. 


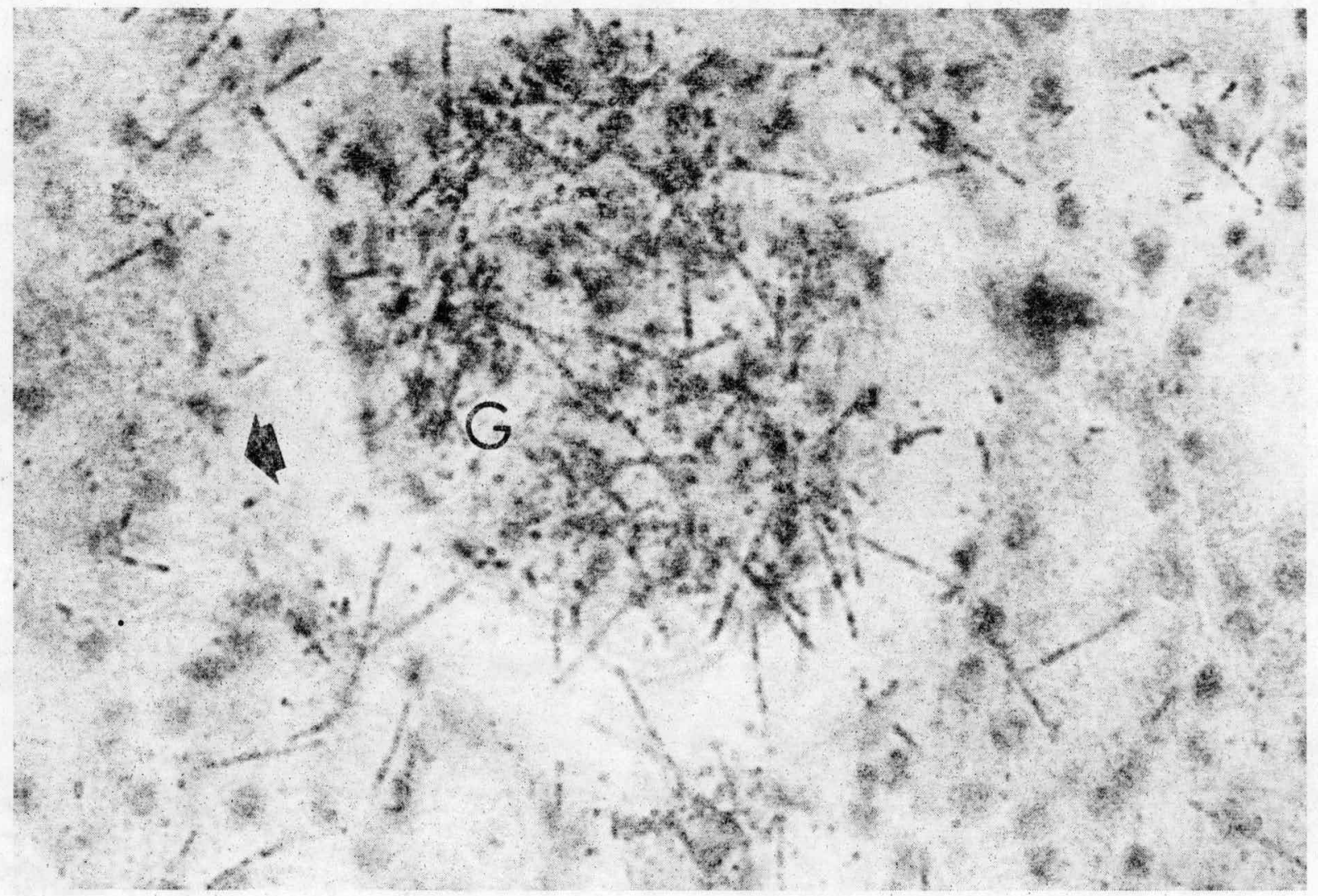

Fig. 7. Autoradiogram of kidney 7 days following injection showing selective deposition of ${ }^{249} \mathrm{Cf}$ and ${ }^{249} \mathrm{Bk}$ in the glomerular tuft $(\mathrm{G})$, the capsular basement membrane (arrow) and the intertubular region. Same dog as Fig. 1. 21 days exposure $\times 550$. 


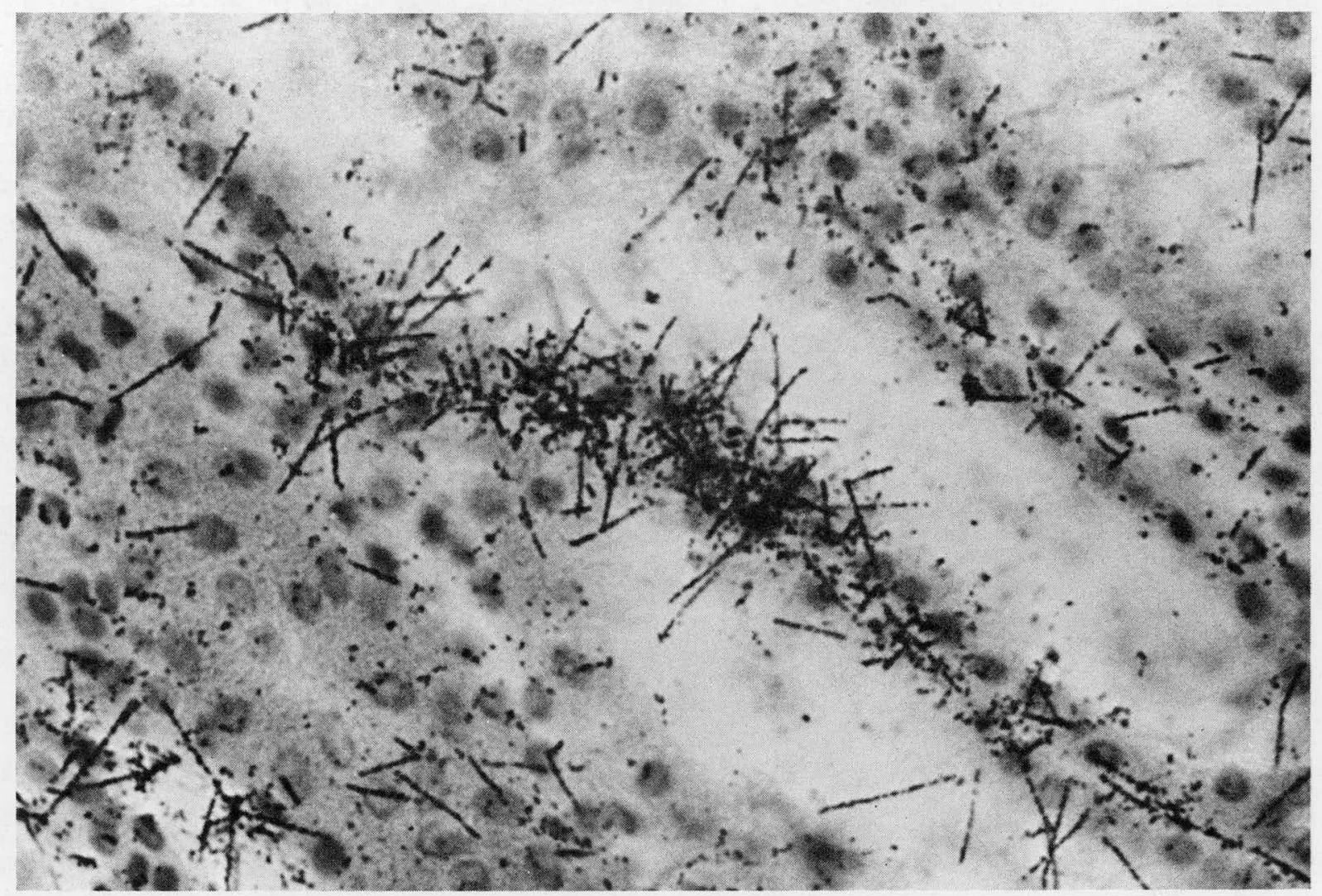

Fig. 8. Autoradiogram of kidney cortex 7 days following injection showing focal deposition of ${ }^{249} \mathrm{Cf}$ and ${ }^{249} \mathrm{Bk}$ in the intertubular region. Same dog as Fig. 1. 5 week exposure. $\times 550$. 


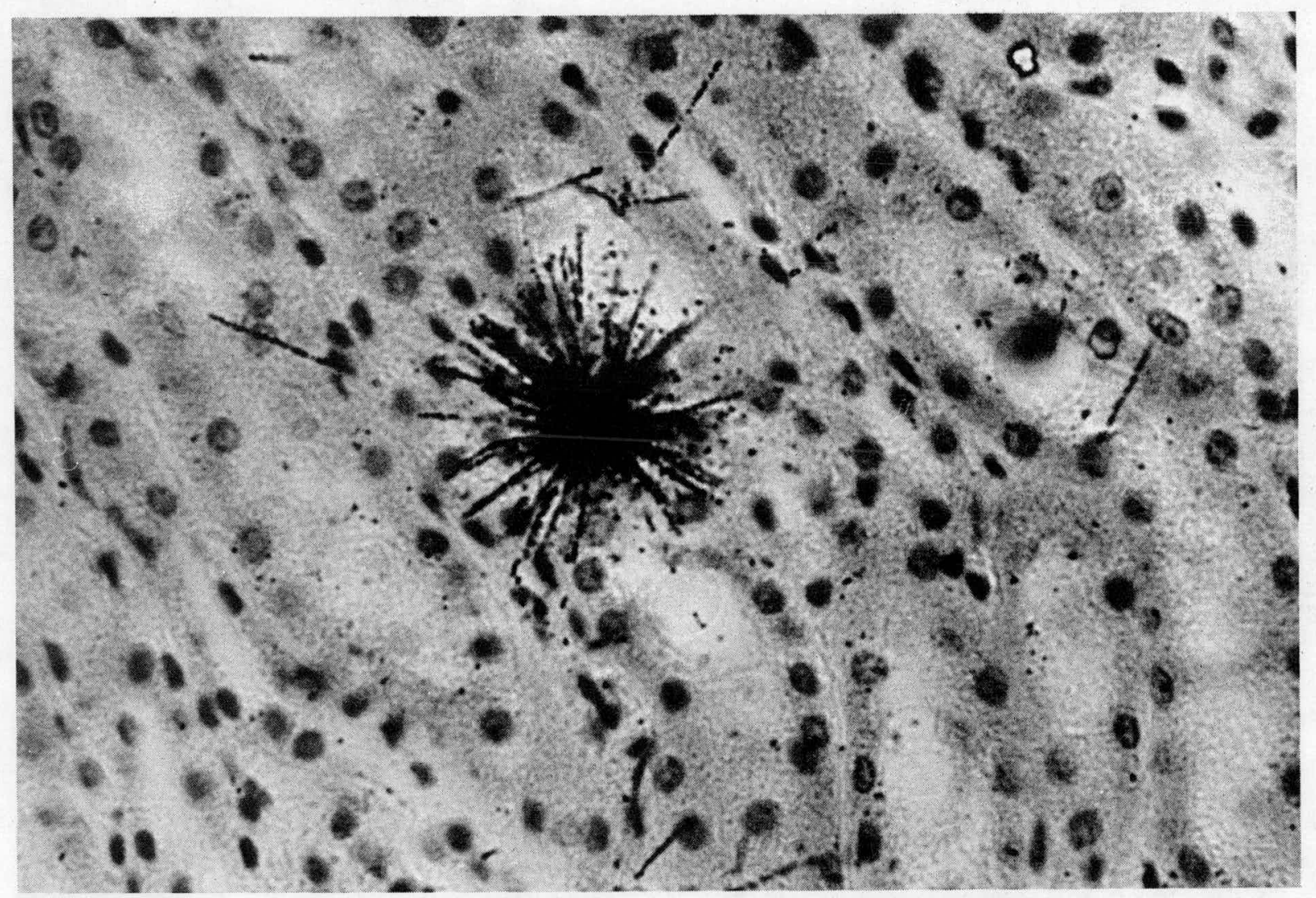

Fig. 9. Autoradiogram of medullary region in kidney 7 days following injection showing the "hot spots" of ${ }^{249} \mathrm{Cf}$ and $249 \mathrm{Bk}$ which occurred in moderate numbers near the pelvis. These tentatively appeared to be in the interstitial areas, but this could not be unequivocally established. Same dog as Fig. 1. 21 day exposure. $\times 550$. 


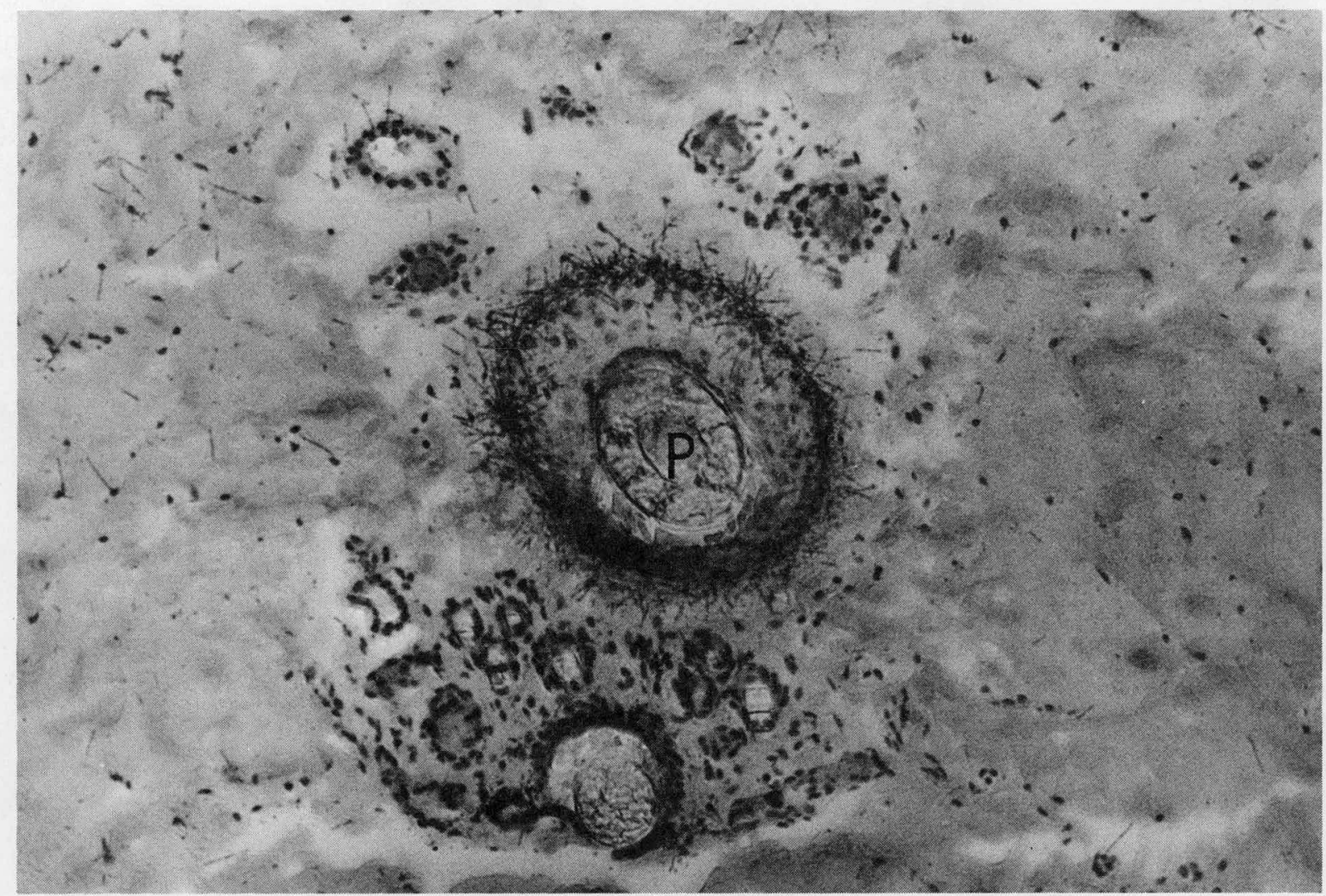

Fig. 10. Autoradiogram of skin 7 days following injection showing selective deposition of ${ }^{249} \mathrm{Cf}$ and ${ }^{249} \mathrm{Bk}$ in the region of the glassy membrane of a primary hair follicle $(P)$. There is no significant activity in the secondary follicles or the adnexa. Same dog as Fig. 1. 35 day exposure. $\times 200$. 


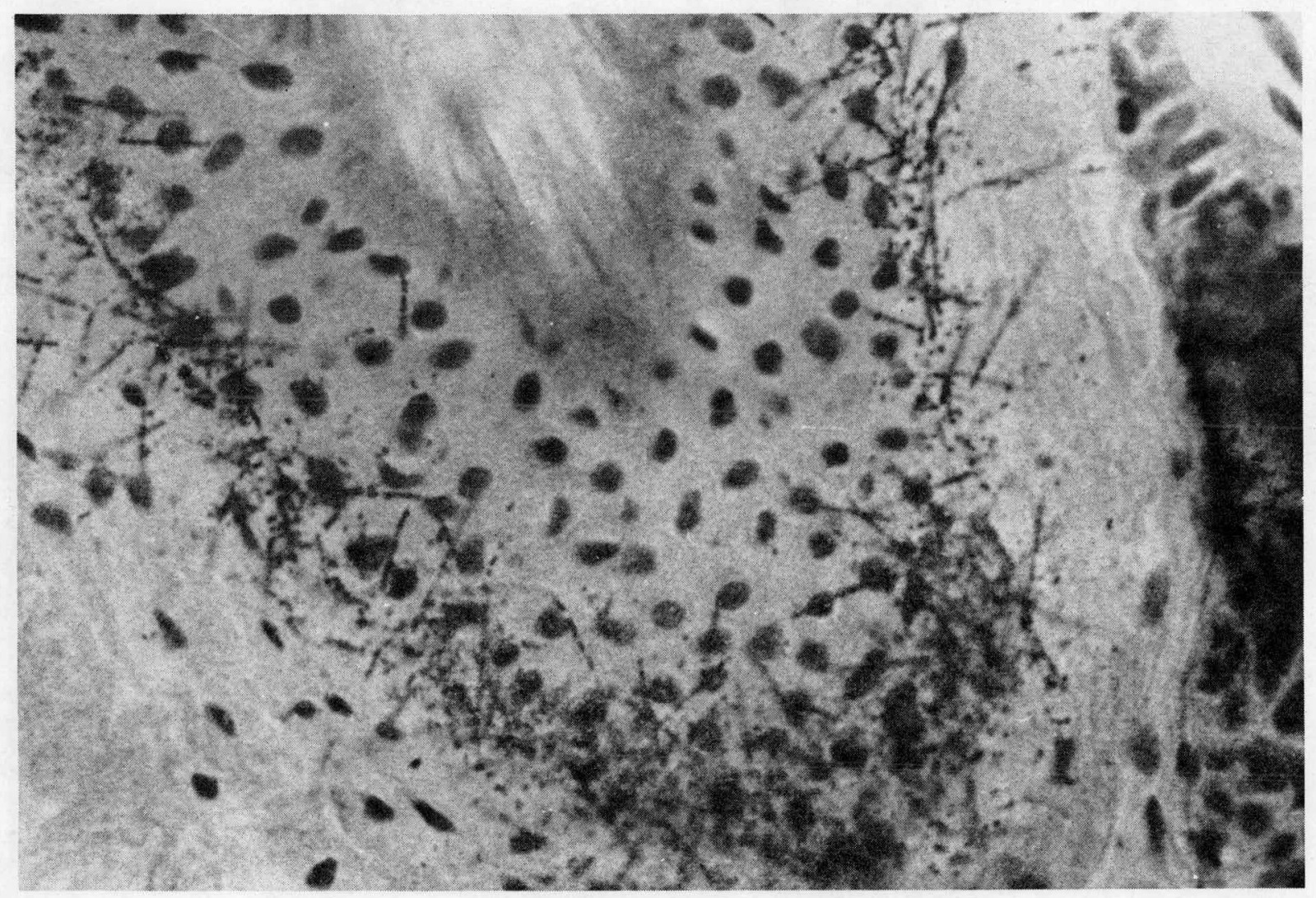

Fig. 11. Autoradiogram of primary hair follicle 21 days following injection showing focal deposition of ${ }^{249} \mathrm{Cf}$ and ${ }^{249} \mathrm{BK}$ in the region of the glassy membrane. There is no significant activity in the other regions of the follicle. Same dog as Fig. 4. 14 day exposure. $\times 550$. 


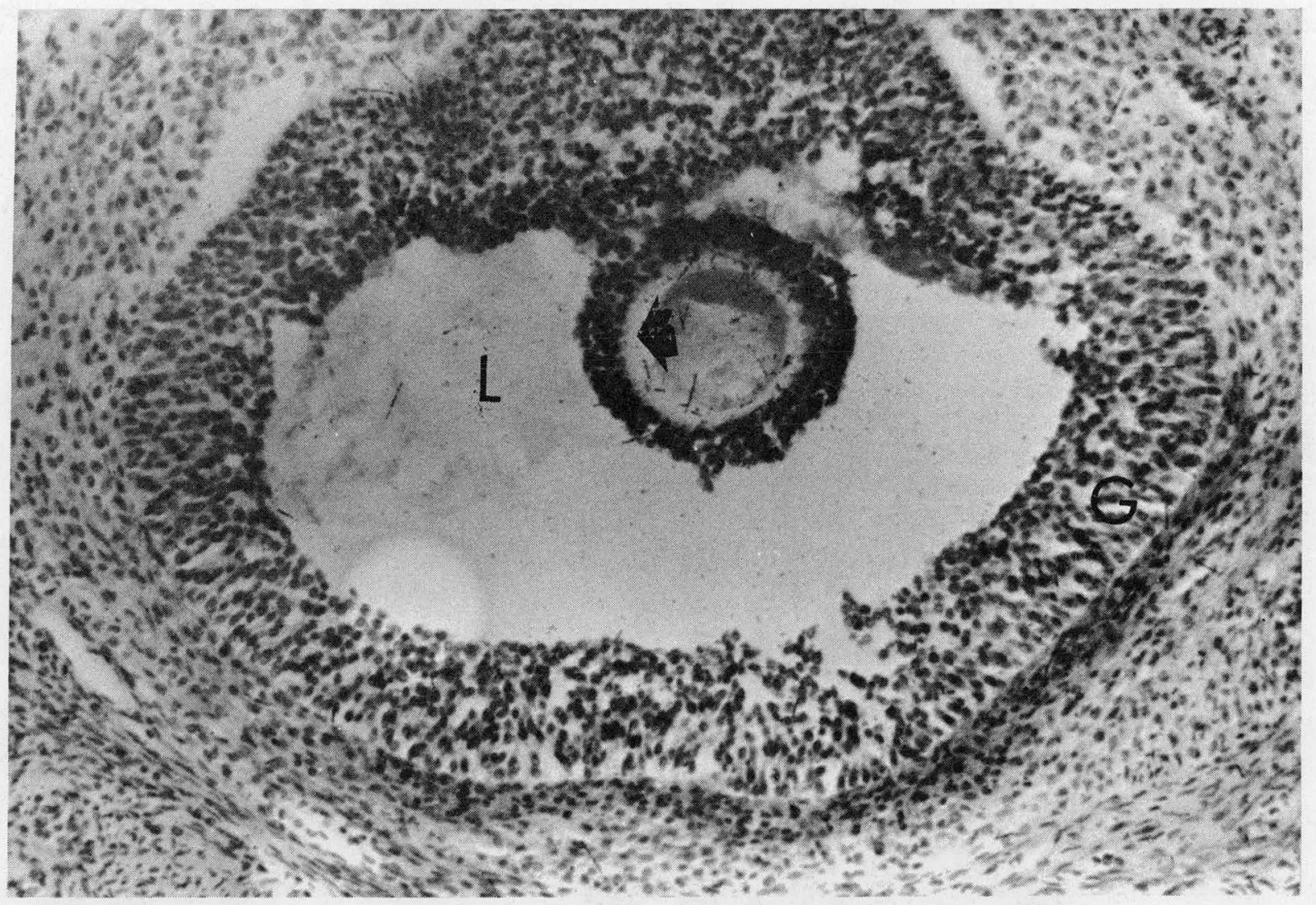

Fig. 12. Autoradiogram of Graafian follicle 7 days following injection showing moderate focal deposition of ${ }^{249} \mathrm{Cf}$ and ${ }^{249} \mathrm{Bk}$ in the region of zona pellucidum (arrow). There is no significant localization in the granulosa cells $(G)$ or the region of follicular liquid (L). Same dog as Fig. I. 56 day exposure. $\times 200$. 


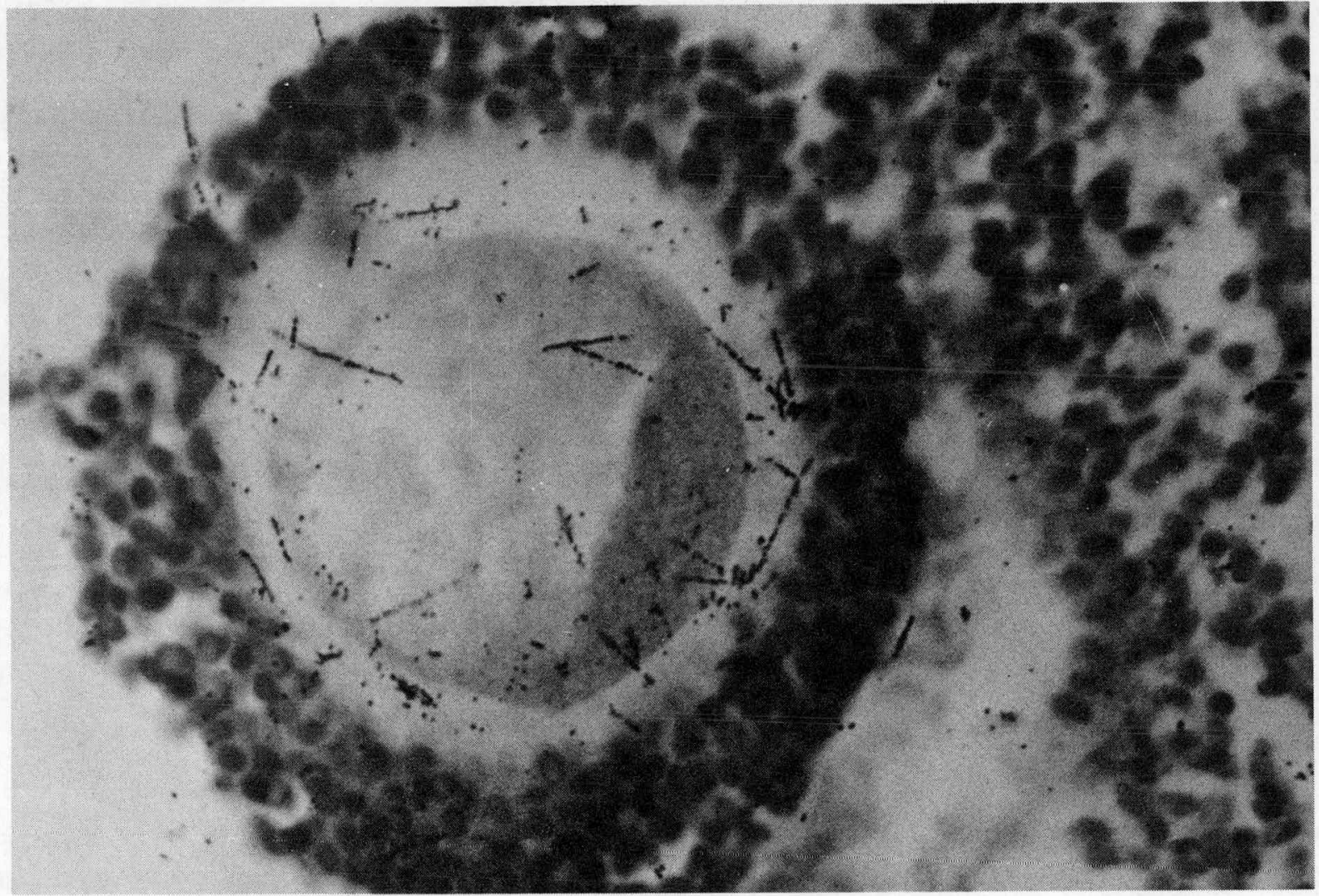

Fig. 13. Higher magnification of same autoradiogram shown in Fig. 12 . $\times 550$. 
THE DISAPPEARANCE OF CALIFORNIUM-249 AND CALIFORNIUM-252

FROM THE BLOOD OF BEAGLES*

Walter Stevens and F. W. Bruenger

Beagles were injected with ${ }^{249} \mathrm{Cf}$ and $252 \mathrm{Cf}$ in citrate buffer,

$\mathrm{pH}$ 3.5. The concentration of the nuclide in the plasma and whole blood was measured at increasing time intervals from 5 minutes to 48 hours post-injection. Small quantities of californium were found with the cellular component. The concentration in plasma decreased very rapidly during the first few hours after injection. At $24 \mathrm{hr}$, less than $1 \%$ of the injected dose was still circulating. These data are similar to the disappearance of americium from the blood of dogs. $249 \mathrm{Cf}$ and ${ }^{252} \mathrm{Cf}$ disappeared from the circulation at the same rate. Plasma constituents were separated by gel filtration and ion exchange chromatography. Because of the rapid removal of the nuclide from the blood, meaningful data were obtained only at short times after injection. Californium was found to be associated with high molecular weight proteins and those of a molecular weight of approximately 70,000 . Ion exchange chromatography on DEAE Sephadex of this fraction showed that transferrin was involved in this association. Data obtained in vivo from canines were extended by in vitro experiments with human blood. ${ }^{249} \mathrm{Cf}$ was incubated in vitro at $37^{\circ} 0$ with human blood for 20 minutes. At the end of this time, cells were separated from the plasma and the plasma was subjected to gel chromatography on double columns of Sephadex G-100-G-200. This chromatography showed that californium-protein distribution pattern was nearly identical

* Abstract Submitted to the Eleventh Hanford Biology Symposium: The Biological Implications of The Transuranium Elements 
to that seen in dogs. Re-chromatography of the G-100-G-200 fractions on DEAE-Sephadex columns indicated that the peaks of transferrin and californium did not coincide exactly which provides evidence for the presence of another yet unidentified protein component capable of associating with or binding californium. Appreciable quantities of the nuclide appeared in the low molecular weight region indicating that protein does not bind californium tenaciously and that complexes with inorganic or other molecules of low molecular weight found in plasma were formed. The low stability of the californium-protein complex is probably responsible for the high rate of its disappearance from the blood stream. 
INTRACELLULAR DISTRIBUTION OF $24{ }^{\circ} \mathrm{CF}$ IN CANINE LIVER:

F. W. Bruenger, D. R. Atherton, and W. Stevens

Three beagles were injected intravenously with $249^{9} \mathrm{Cf}$ in citrate buffer. Two of these dogs were sacrificed at 7 days and 21 days respectively. Liver biopsies were performed on the third dog starting at one day after injection. Liver specimens from all dogs were homogenized in sucrose $-\mathrm{Ca}^{++}$and subjected to differential centrifugation. The concentrations of $249 \mathrm{Cf}$ and protein were determined in each fraction. A redistribution of the nuclide in the various fractions as a function of time was observed. Most of the ${ }^{249} \mathrm{Cf}$ was initially bound by soluble proteins, probably ferritin. At later times increasing quantities were associated with intracellular organelles. In addition, homogenate fractions free of nuclei and debris (homogenate after $6000 \mathrm{~g}-\mathrm{min}$ ) were subjected to centrifugation for $220,000 \mathrm{~g}-\mathrm{min}$ in a continuous linear sucrose gradient of 10-50\%. All fractions were collected and analyzed for: ${ }^{249} \mathrm{Cf}$, protein, acid phosphatase (lysosomal marker) and cytochrome coxidase (mitochondrial marker). At one day after injection more than $50 \%$ of the nuclide was found in the three lightest fractions and approximately $10 \%$ in the three heaviest fractions. Their relation was reversed with time and at 21 days $10 \%$ was found in the lightest fractions and $43 \%$ in the heaviest fractions. At this time more than $50 \%$ of the nuclide in the liver was associated with the fraction collected at $60,000 \mathrm{~g}-\mathrm{min}$, designated as mitochondria. This fraction showed high cytochrome oxidase

\footnotetext{
* Abstract Submitted to the Eleventh Hanford Biology Symposium: The
} Biological Implications of The Transuranium Elements 
activity and also acid phosphatase activity. It is presently assumed that redistribution occurs from soluble proteins into mitochondria and then into lysosomes. Similar data have been obtained from kidney and spleen homogenates. 


\section{DISTRIBUT ION OF INJECTED ${ }^{241} \mathrm{Am}$ IN THE BEAGLE SKELETON}

R. D. Lloyd, D. R. Atherton, Susan S. Gauf in and C. W. Mays

Abstract: The distribution of ${ }^{241} \mathrm{Am}$ in the skeletons of 10 beagles injected with 0.31 to $4.53 \mu \mathrm{Ci} / \mathrm{kg}$ at $\mathrm{l}$ to 1533 days prior to sacrifice. was determined by gammaray counting. Comparison of percent retained skeletal ${ }^{341} \mathrm{Am}$ values with percent skeletal ash values for each bone or bone group showed that bones containing much trabecular bone had a higher ratio of skeletal Am to skeletal ash than the average for the total skeleton, while bones containing much cortical bone had a lower ratio than the skeletal average.

\section{INTRODUCTION}

Studies of the metabolism and radiotoxicity of ${ }^{241} \mathrm{Am}$ in beagles have been in progress at this laboratory since 1966. Preliminary results of the investigation and the experimental design have been reported previously. $(1-15)$

\section{METHODS}

Individual bones or bone groups were obtained at autopsy from ten of the ${ }^{241} \mathrm{Am}$-burdened beagles. Virtually the entire skeleton of each animal was made available for this study. Each bone was placed midway between the opposed faces of two $8 \times 4$ inch NaI(TI) crystals ${ }^{(16)}$ so that its ${ }^{241} \mathrm{Am}$ content could be determined via the $60 \mathrm{keV}$ gamma-ray. Summed data from the two crystals were recorded by a multi-channel pulse-height analyser. The counting rate of each whole bone or bone group at $60 \mathrm{keV}$ was compared with that of a duplicate of the $\operatorname{dog}{ }^{\prime}{ }^{241} A m$ injection solution. These injection standards were counted in such a configuration as to duplicate 
the photon self-absorption and geometry of the bone.

\section{RESULTS AND DISCUSSION}

The percent of retained skeletal ${ }^{241} \mathrm{Am}$ in each bone or bone group is shown for all ten dogs in Table 1 . There was striking uniformity in relative skeletal distribution among all dogs but T6W3. No obvious reason for the difference in fractional retention between T6W3 and the other animals is clearly obvious at the present time. Two other dogs (T57W5 and T4W4) were females, and one other dog (T4W4) lived at least as long after injection. Examination of post-mortem skeletal radiographs revealed no important difference in bone size or cortical thickness between T6W3 and other dogs in Table 1. A similar variation in relative distribution was observed by Stover et al., among beagles injected with $239 \mathrm{Pu}$. They reported that in one of three dogs studied in detail, there was a greater proportion of retained plutonium in the extremities and less in the ribs and vertebrae.(17)

It is of interest to compare the distribution of ${ }^{241} \mathrm{Am}$ with the distribution of mineral in the beagle skeleton. The first column in Table 2 lists the average percent skeleta $1^{241} \mathrm{Am}$ values for individual bones or bone groups from Table 1 . In the second column is an estimate of the percent skeletal ash contained in each of the corresponding bones or bone groups. These data represent an average of 22 dogs from our colony for which skeletal ash weights have been reported. $(18,19)$ The third column in Table 2 is a ratio of percent skeletal ${ }^{241} \mathrm{Am}$ and percent skeletal ash for each bone. 
Since injected ${ }^{241} \mathrm{Am}$ deposits on bone surfaces,(15) it is not surprising that the bones for which this ratio is significantly higher than the average of 1.0 for the total skeleton (such as the sternum, thoracic vertebrae, lumbar vertebrae, and caudal vertebrae) are those which contain a significantly higher fraction of trabecular bone than the average for the total skeleton. This is probably due to the greater area of bone surfaces per gram in trabecular as opposed to cortical bone. Moreover, the ratios shown in Table 2 for bones containing much cortical bone (lower leg bones, paws, skuli, and mandible) are significantly lower than the average for the total skeleton of 1.0 , while the ratio is close to the skeletal average for bones such as the cervical vertebrae, humerus, femur, pelvis, and scapula, which contain a more representative mixture of trabecular and cortical bone.

\section{REFERENCES}

1. R. D. Lloyd, C. W. Mays, G. N. Taylor, D. R. Atherton, and L. R. Shabestari; Retention of injected ${ }^{241} \mathrm{Am}$ in beagles; Health Physics 13: 938 (1967).

2. R. D. Lloyd, C. W. Mays, G. N. Taylor, D. R. Atherton, and L. R. Shabestari; Americium metabolism in beagles; Research in Radiobiology, Univ. of Utah Report C00-119-236, 197-206 (1967) .

3. R. D. Lloyd, D. R. Atherton, G. N. Taylor, and C. W. Mays; Soft-tissue deposition of injected ${ }^{241} \mathrm{Am}$; Health Physics 15: 175 (1968). 
4. D. R. Atherton, R. D. Lloyd, G. N. Taylor, B. J. Stover, and C. W. Mays; Distribution of ${ }^{241} \mathrm{Am}$ in the beagle; Radiation Research 33: 506 (1968).

5. F. W. Bruenger, W. Stevens, and B. J. Stover; ${ }^{241} \mathrm{Am}$ in the blood; in vivo and in vitro observations; Radiation Research 37: 349-360 (1969); and Research in Radiobiology, Univ. of Utah Report C00-119-237, 135-152 (1968) .

6. W. Stevens, Betsy J. Stover, F. W. Bruenger, and G. N. Taylor; Some observations on the deposition of Americium-241 in the thyroid gland of the beagle; Radiation Research 39: 201-206 (1969); and Research in Radiobiology, Univ. of Utah Report C00-119-237, 133-134 (1968) .

7. R. D. Lloyd, C. W. Mays, and G. N. Taylor; Strontium, radium, and americium metabolism in beagles; Health Physics 17: 384 (1969) .

8. D. R. Atherton, R. D. Lloyd, G. N. Taylor, B. J. Stover, and C. W. Mays; Distribution of ${ }^{241} \mathrm{Am}$ in the beagle; Research in Radiobiology, Univ. of Utah Report C00-119-237, 117-123 (1968).

9. David R. Atherton, Betsy J. Stover, R. D. Lloyd, and F. W. Bruenger; A comparison of the macro-distribution of ${ }^{241} \mathrm{Am}$ and ${ }^{59} \mathrm{Fe}$ in the young adult beagle; Radiation Research 39 : 478 (1969); and Research in Radiobiology, Univ. of Utah Report C00-119-240, 129-138 (1969) .

10. R. D. Lloyd, C. W. Mays, D. R. Atherton, and G. N. Taylor; Am-241 studies in beagles; Health Physics 18: 149-156 (1970).

11. R. D. Lloyd, C. W. Mays, D. R. Atherton, and G. N. Taylor; 
Am-241 retention in beagles; Retention and Dosimetry of Some Injected Radionuclides in Beagles, Univ. of Utah Report C00$119-241,123-143 .(1970)$

12. G. N. Taylor, W. S. S. Jee, N. Dockum, and E. Hromyk; Microscopic distribution of Am-24l in the beagle thyroid gland; Health Physics 17: 723-725 (1969); and Research in Radiobiology, Univ. of Utah Report C00-119-237, 124-132 (1968) .

13. Betsy J. Stover, F. W. Bruenger, and W. Stevens; The subcellular distribution of ${ }^{239} \mathrm{Pu}$ and ${ }^{241} \mathrm{Am}$ in the canine liver; Research in Radiobiology, Univ, of Utah Report C00-119-242, $202(1970)$

14. Jean H. Dougherty; Preliminary report on the hematological effects of ${ }^{241} \mathrm{Am}$ in the beagle; Research in Radiobiology, Univ. of Utah Report C00-119-242, 354-362 (1970) .

15. Ray D. Lloyd, Webster S. S. Jee, David R. Atherton, Glenn N. Taylor, and Charles W. Mays; Am-24l in beagles; biological effects and skeletal distribution; in The Radiobiology of Plutonium (W. S. S. Jee and Betsy J. Stover, editors). In press.

16. R. D. Lloyd, R. L. Aamodt, W. W. Wagner, and R. C. Pendleton; Calibration of a gamma-ray spectrometer for soils counting; International Journal of Applied Radiation and Isotopes $\underline{19}$ : $773-775$ (1968)

17. Betsy J. Stover, D. R. Atherton, F. W. Bruenger and Dawn S. Buster; ${ }^{3{ }^{9}} \mathrm{Pu}(\mathrm{IV})$ : its distribution in the beagle; in Delayed Effects of Bone-Seeking Radionuclides (C. W. Mays et al., editors) University of Utah Press, Salt Lake City, 109-123 
(1969) 。

18. D. R. Atherton, C. W. Mays, and Betsy J. Stover; Radionuclide distribution in adult beagle bones; Radiobiology Laboratory Semi-Annual Progress Report C00-217, 118-125 (1958).

19. David R. Atherton, Betsy J. Stover, and F. W. Bruenger; Fractional weight of the beagle skeleton; Research in Radiobiology, University of Utah Report C00-119-240, 162-171 (1969). 
Table 1. Distribution of Injected ${ }^{241} \mathrm{Am}$ in the. Beagle Skeleton

\begin{tabular}{|c|c|c|c|c|c|c|c|c|c|c|c|c|}
\hline $\begin{array}{l}\text { Days } \\
\text { after } \\
\text { injection }\end{array}$ & 1 & 7 & 8 & 15 & 15 & 22 & 401 & 448 & 1510 & 1533 & & \\
\hline Inj $\mu \mathrm{Ci} / \mathrm{kg}$ & 4.53 & 4.46 & 4.47 & 2.90 & 2.77 & 2.78 & 2.78 & 2.83 & 0.31 & 0.91 & & . \\
\hline Sex & $M$ & $M$ & M & $M$ & $F$ & $M$ & $M$ & $M$ & $\mathbf{F}$ & $\mathbf{F}$ & & . \\
\hline \multirow[t]{2}{*}{ Dog } & T15W5.5 & T32W5. 5 & T33W5. 5 & T56W5 & T57WS & Tl6W5 & TlW5 & T2W5 & T6W3 & T4W4 & Mean & S.D. \\
\hline & & & PER & CENT OF & RETA INED & SKELETA & $\mathrm{AL}{ }^{241} \mathrm{Am}$ & & $\therefore$ & & & \\
\hline Ca lva rium & $2.61 \%$ & $1.63 \%$ & $1.25 \%$ & $1.80 \%$ & $3.13 \%$ & $2.12 \%$ & $2.31 \%$ & $3.24 \%$ & $2.54 \%$ & $3.93 \%$ & $2.46^{\circ}$ & \pm 0.81 \\
\hline Maxillae & 4.53 & 5.35 & 6.83 & 5.72 & 5.40 & 6.24 & 5.92 & 6.64 & 8.10 & 5.10 & 5.98 & \pm 1.02 \\
\hline Mandibles & 2.00 & 2.51 & 3.33 & 2.81 & 2.27 & 2.66 & 2.65 & 2.60 & 4.14 & 2.22 & 2.72 & \pm 0.62 \\
\hline Cerv. Vert & 8.44 & 8.01 & 5.69 & 8.54 & 8.23 & 8.54 & 9.11 & 7.91 & 6.18 & 8.71 & 7.94 & \pm 1.11 \\
\hline Thor. Vert & 18.29 & 18.19 & 17.56 & 17.88 & 18.41 & 18.51 & 16.96 & 16.47 & 9.03 & 18.20 & 16.95 & \pm 2.86 \\
\hline Lumb. Vert* & 20.41 & 19.03 & 17.56 & 18.74 & 19.35 & 18.89 & 16.61 & 17.65 & 8.76 & 18.26 & 17.53 & \pm 3.26 \\
\hline Caud. Vert & 1.55 & 1.98 & 1.91 & 1.85 & 1.68 & 1.87 & 1.80 & 1.75 & 1.63 & 1.72 & 1.77 & \pm 0.13 \\
\hline Paws & 1.63 & 2.09 & 2.41 & 1.83 & 1.92 & 2.21 & 2.32 & 2.42 & 8.35 & 2.55 & 2.77 & \pm 1.98 \\
\hline Radii & 0.91 & 1.05 & 1.36 & 1.15 & 1.01 & 1.16 & 1.14 & 1.28 & 1.85 & 0.99 & 1.19 & \pm 0.27 \\
\hline Ulnae & 1.07 & 1.30 & 1.54 & 1.48 & 1.30 & 1.35 & 1.38 & 1.42 & 2.31 & 1.32 & 1.45 & \pm 0.33 \\
\hline Humeri & 6.29 & 6.56 & 6.40 & 6.05 & 6.16 & 5.69 & 6.80 & 6.10 & 7.37 & 5.94 & 6.34 & \pm 0.48 \\
\hline $\mathrm{Tib}+\mathrm{Fib}{ }^{+}$ & 2.81 & 3.74 & 3.74 & 3.22 & 3.21 & 3.32 & 3.94 & 3.70 & 5.76 & 3.04 & 3.65 & \pm 0.82 \\
\hline Femora & 5.31 & 6.53 & 5.86 & 6.04 & 5.83 & 5.31 & 5.97 & 5.90 & 7.93 & 5.87 & 6.06 & \pm 0.75 \\
\hline Pelves & 5.10 & 4.84 & 5.38 & 4.61 & 4.82 & 4.54 & 5.85 & 5.13 & 7.26 & 5.06 & 5.26 & \pm 0.80 \\
\hline Scapulae & 2.86 & 3.00 & 3.99 & 3.50 & 4.02 & 3.61 & 3.93 & 3.62 & 4.79 & 3.77 & 3.71 & \pm 0.55 \\
\hline Ribs: & 8.61 & 8.11 & 9.03 & 8.68 & 8.02 & 8.69 & 8.74 & 8.44 & 10.45 & 7.18 & 8.60 & \pm 0.83 \\
\hline Sternum & 7.21 & 5.88 & 5.96 & 6.10 & 5.24 & 5.29 & 4.57 & 5.33 & 3.55 & 6.14 & 5.53 & \pm 0.99 \\
\hline Os Penis ${ }^{\ddagger}$ & 0.37 & 0.20 & 0.20 & -- & & -- & -- & 0.40 & & & 0.29 & \pm 0.11 \\
\hline $\begin{array}{l}\text { TOTAL } \\
\% \text { of Inj } \\
241 \mathrm{Am} \mathrm{in}\end{array}$ & $100.0 \%$ & $100.0 \%$ & $100.0 \%$ & $100.0 \%$ & $100.0 \%$ & $100.0 \%$ & $100.0 \%$ & $100.0 \%$ & $100.0 \%$ & $100.0 \%$ & & \\
\hline Skeleton & $19.6 \%$ & $19.0 \%$ & $18.8 \%$ & $24.3 \%$ & $23.6 \%$ & $18.6 \%$ & $29.2 \%$ & $33.3 \%$ & $33.4 \%$ & $31.5 \%$ & & \\
\hline
\end{tabular}


Table 2. ${ }^{241} \mathrm{Am}$ in the Beagle Skeleton

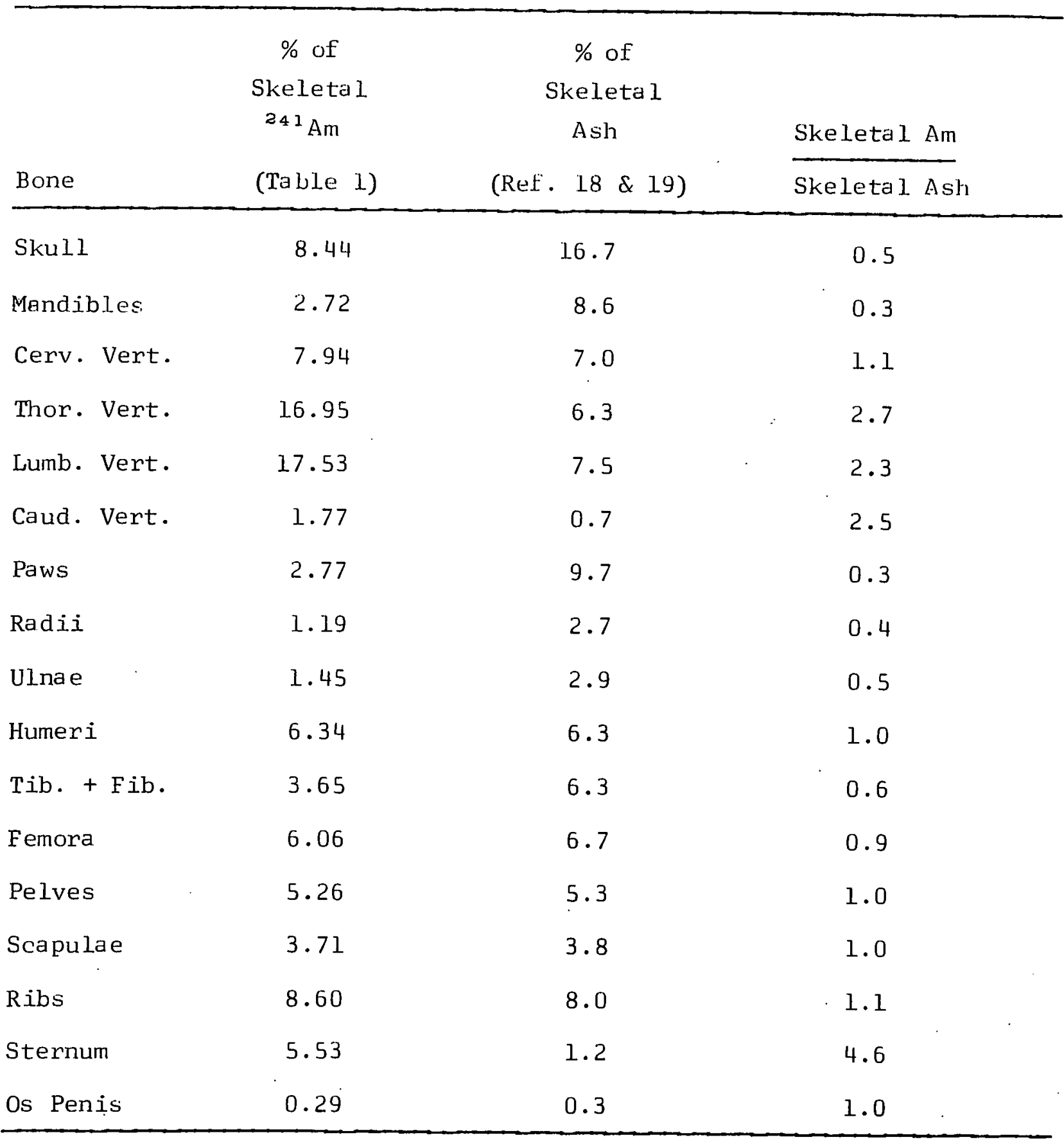




\author{
SUBCELLULAR DISTRIBUTION OF ${ }^{241}$ Am(III) AND 239 PU(IV) \\ IN LIVERS STUDIED SERIALLY \\ W. Stevens, F.W. Bruenger, D.R. Atherton, \\ and Betsy J. Stover
}

\begin{abstract}
Two beagles were injected with $2.67 \mu \mathrm{Ci}$ of $241 \mathrm{AmII}$. and $2.77 \mu \mathrm{Ci}$ of $239 \mathrm{PuIV} / \mathrm{kg}$ respectively. Liver specimens were obtained by serial surgical biopsies. Samples were homogenized, subjected to differential and sucrose density gradient centrifugation. Specific enzyme markers were used for locating mi tochondria and lysosomes. The density distribution of these organelles in the dog did not allow a clear separation of these particles. At short times after injection, both nuclides were associated mostly with soluble liver proteins (ferritin). Later, increasing quantities migrated into the mitochondriallysosomal fraction. The rate of redistribution was faster for plutonium than for americium. In the dog injected with plutonium the percent dose in the cytosol changed from $44 \%$ to $3 \%$ and the percent dose in the mitochondrial-lysosomal fraction from $28 \%$ to $62 \%$ during a period of 70 days. Gradient separation of 6,000 g-min supernatants showed a shift in the americium content of heavy fractions from $3 \%$ to $50 \%$ and a concomittant shift from $76 \%$ to $29 \%$ in the light fractions during the same period. The respective values for plutonium are $8 \%$ to $32 \%$ in the heavy fraction and $66 \%$ to $21 \%$ in the light fraction during a period of 30 days with a second redistribution at time $\geq 30$ days. On the basis of protein concentration, the highest concentration of both nuclides was associated with fractions of high acid phosphatase activity, but no linear relationship between acid phosphatase and total radioactivity was observed.
\end{abstract}

\title{
INTRODUCTION
}

Liver is one of the principal target organs for ${ }^{241} \mathrm{Am}$ and ${ }^{239} \mathrm{Pu}$ when monomeric forms of these nuclides are injected into canines. The uptake, distribution, retention and chemical association of these nuclides in the liver have long been of interest in this laboratory. Previous reports from other laboratories have described the localization of plutonium in lysosomal fractions (Rahman and Lindenbaum, Boocock, et al. $(1,2)$ ) in rodent livers. Some preliminary data on the relative concentration of $239 \mathrm{pu}$ and ${ }^{241} \mathrm{Am}$ and $\mathrm{its}$ association with ferritin in the cytosol were presented earlier. $(3,4,5)$ 
In liver fractionated by differential centrifugation, the largest percentage of plutonium was in the fraction designated as the mitochondrial-lysosmal fraction $(10,000 \times \mathrm{g}$ and $25,000 \times \mathrm{g})$ followed by the nuclei-cell debris fraction $(1,000 \times \mathrm{g}$ pellet). The cytosol contained $1 / 2$ to $1 / 3$ of that seen in the other two fractions. In the cytosol the majority of either nuclide was bound to ferritin. These and other data $(6,7)$ indicated also that a redistribution of nuclide in the liver takes place between short times (0-2 weeks) and long times ( 5 years) after injection. In this communication the redistribution of the nuclides at the molecular and subcellular level is described for times between 0 and 70 days post-injection.

\section{MATERIALS AND METHODS}

A male beagle weighing $11.3 \mathrm{~kg}$ received an intravenous injection of $2.67 \mu \mathrm{Ci}$ of $241 \mathrm{Am} / \mathrm{kg}$ in citrate buffer of $\mathrm{pH} \mathrm{3.5.} \mathrm{At} \mathrm{one} \mathrm{hour} \mathrm{after} \mathrm{in-}$ jection less than $10 \%$ of the injected dose was circulating and a section of liver was removed by surgical biopsy. Successive biopsies were performed at 7,29 , and 69 days post-injection. Similarly, a female beagle weighing $9.13 \mathrm{~kg}$ received an intravenous injection of $2.77 \mu \mathrm{Ci}$ of $239 \mathrm{Pu} / \mathrm{kg}$ in the medium described above. Since plutonium is cleared from the circulation at a much slower rate, the first biopsy was not performed until 1 day after injection when about $24 \%$ of the nuclide was still circulating. Further biopsies were performed at 4,8,30, and 71 days post-injection.

Liver specimens were immmediately cooled in ice, weighed, minced, and homogenized 2 times in two volumes of 0.25 molar sucrose which was also three millimolar in calcium ion and 0.1 molar in sodium chloride. The homogenate was then separated by differential centrifugation and by density gradient centrifugation. Fractions were analyzed for protein content, 
acid phosphatase, cytochrome $C$ oxidase, and radioactivity. A flow sheet outlining the differential centrifugation procedure is presented in Fig. 1 . for comparison the schema of previous differential centrifugation procedures is included and appears in the upper right hand corner of Fig. 1. Changes in the procedure were made to bring this technique of analyzing canine livers in line with that of others in order to facilitate comparisons with work done on animals other than the beagle.

Gradient centrifugation was carried out with the $600 \times \mathrm{g}$ supernatant and the resuspended $3,000 \times \mathrm{g}$, and $40,000 \times \mathrm{g}$ pellets. Gradients were prepared in an automatic gradient maker (Beckman). One $m l$ of $82 \%$ sucrose was placed in the bottom of each tube to avoid the formation of a pellet. The gradients covered the range of sucrose concentration from 52 to $12 \%$. An aliquot of the $600 \times \mathrm{g}$ supernatant was layered on the top of the gradient. This was then centrifuged for 120 minutes at $1,850 \times \mathrm{g}$ after which the bottoms of the tubes were punctured and fractions were collected. On each of these fractions protein was determined according to the method of Lowry ( 8 ) Total acid phosphatase was done according to technical bulletin 104 of Sigma Chemical Company and cytochrome oxidase was determined according to the method of Cooperstein and Lazarow. (9) Americium was quantitated by counting its $60 \mathrm{keV}$ gamma radiation. $239 \mathrm{pu}$ alpha particles were counted by a scintillation counting technique.

\section{RESULTS}

The distribution of $239 \mathrm{pu}$ in canine livers, 7 days post-injection, is shown in Table 1. These data were obtained and reported in last year's Progress Report.

fugation as shown in the upper right hand corner of Fig. 1. The largest 
percentage of plutonium in the liver was found in the fraction designated as mitochondrial-lysosomal followed by the nuclei and debris fraction. The majority of the ${ }^{239} \mathrm{pu}$ found in the cytosol was bound to ferritin. The large concentration of plutonium found in the nuclei and debris fraction may be due to the presence of whole cells that would also sediment at $6,000 \mathrm{~g}-\mathrm{min}$.

The relative distribution of acid phosphatase, cytochrome $C$ oxidase, americium expressed as counts per minute per $\mathrm{mg}$ of protein and the percent of the total americium in each fraction are shown in Fig. 2. These data vere obtained by sucrose gradient centrifugation of $600 \times \mathrm{g}$ supernatants from a dog injected with americium. The acid phosphatase activity is a marker for lysosomes, and the cytochrome C oxidase represents mitochondria. No change in distribution of acid phosphatase was observed. Beginning at 7 days post-injection, the peaks of acid phosphatase activity (Sigma units/mg. of protein) and the concentration of americium (CPM/mg of protein) coincided. However, the amount of nuclide, that is the percent of total americium in these fractions, was small. At short times after injection, americium was found mostly in the light fractions; later it became associated with the heavier fractions. The heavy portion represents mostly mitochondria; the lighter one (top) light particles and soluble material.

Similar data were obtained from the animal injected with $239 \mathrm{Pu}$ and subjected to serial liver biopsies as shown in Fig. 3. The data obtained are similar to those observed in the dog injected with americium. Beginning at 1 day after injection the concentration of plutonium (counts per minute/ $\mathrm{mg}$ of protein) showed a peak occurring at intermediate densities, representing lysosomes. This was maintained throughout the length of the experiment. The distribution (percent of the total activity in each fraction), 
however, shifted from. light fractions at one day to mostly heavy fractions at 30 days, and by 71 days this distribution had changed once again so that the plutonium was now equally distributed throughout the entire density range studied. This is in contrast to the americium where at this time the largest portion of the material was found in the heavy fraction. The two areas of cytochrome $C$ oxidase activity represent a heavy fraction. containing intact mitochondria and a light fraction representing cytochrome C oxidase that has been solubilized due to the rupture and destruction of mi tochondria.

Table 2 summarizes the density distributions of plutonium and americium in specimens obtained by liver biopsy at various times after injection. The heavy fraction represents the large mitochondria and some of the larger microsomes (first 3 tubes of sucrose gradient were pooled). The light fraction represents the last 3 tubes of sucrose gradient fractionation and contains the very small cellular organelles and soluble material. The data are presented as the percent of the total nuclide placed on the gradient. As the percent of the total radioactivity in the light fraction decreased a concomittant increase was seen in the heavy fractions in both animals.

The percent of the injected plutonium in the whole liver found in the mitochondrial fraction $(3,000 \times \mathrm{g}$ pellet) and the ratio of the mitochondrial fraction to that of the whole liver are shown in Table 3 . The amount of plutonium in the whole liver remained constant throughout the experiment with the exception of the values seen at 4 days which probably represents a sampling artifact. The relative concentration of the plutonium in the mi tochondrial pellet increased gradual ly from 1 day to 70 days and mitochondria and other heavy organelles contained $62 \%$ of the total plutonium 
found in the whole liver. Sucrose density fractionation of this mitochondrial pellet indicated that the vast majority was associated with the heaviest particles. Similar treatment of the $40,000 \times \mathrm{g}$ pellet (1ysosomes) showed a distribution of radioactivity which was more nearly uniform throughout the gradient.

In livers from animals injected with americium, the mitochondria showed a similar pattern, and at the end of the experimental period (69 days) the mitochondrial fraction contained $50 \%$ of the americium found in the liver, representing more than $30 \%$ of the total nuclide retained by the animal. Thus, the total amount of nuclide found in the mitochondrial fraction of the liver was greater for the dog injected with americium than for that injected with plutonium. Similar data for liver cytosols obtained from both the plutonium and the americium dog are given in Table 4 and the ratio of the respective amounts in cytosol and whole liver is given. In dogs injected with americium the percent of the injected dose in the cytosol decreased from $20 \%$ to $5 \%$ and the ratio of concentration from 0.37 to 0.11 , thus, both the amount and the concentration in the cytosol changed at approximately the same rate. Similar trends were observed in cytosols from dogs injected with plutonium although the decrease was more marked, going from $\sim 7 \%$ to $0.6 \%$ in the total amount and from 0.44 to 0.3 in the ratio of concentration. This is a rather distinct change in plutonium distribution and correlates with the increases seen in the mitochondrial fractions.

\section{DISCUSSION}

Monomeric americium and plutonium when injected as the citrate were. bound to ferritin in canine livers. At short times after injection, a 
redistribution occurred and the nuclides became associated with subcellular organelles. A similar redistribution was observed earlier in rodents injected with Pu. (2) In this case, evidence was obtained that the nuclide was associated with lysosomes. In canines the highest concentration of both nuclides (on the basis of radioactivity/mg of protein) also coincided with the highest concentration of acid phosphatase (measured as enzymeactivity/mg of protein) but in terms of total radioactivity present, the amount of nuclide in the regions of acid phosphatase activity was very small and no linear relationship between phosphatase activity. and radioactivity existed at any time during the period of observation. From this we conclude that in the canine (whose metabolism of the two nuclides differs from that in the rodent) there is little or no direct transfer of americium and plutonium from the soluble form into the lysosomes.

Figure 4 illustrates what we propose happens to monomeric $239 \mathrm{pu}$ when injected intravenously into dogs. First the nuclide is picked up by transferrin and transported both to the liver and the bone marrow. In each of these organs it is released from the transferrin at the cell membrane (erythroblasts in bone marrow, parenchymal cell in liver) and is bound by the glycoprotein matrix of bone and by ferritin in the liver cell. In the liver cell the plutonium ferritin can be found free in the cytosol or within mitochondria. Plutonium ferritin in mitochondria is probably in equilibrium with the soluble plutonium in the cytosol and/or membrane bound plutonium. Evidence for the binding of plutonium to subcellular membranes was obtained by rupture of these membranes with sonic shock or treatment of the mitochondrial pellet with sodium deoxycholate. Neither of these treatments caused the release of more than $30 \%$ of plutonium or americium from this fraction, the membrane fraction contained more than 
$70 \%$ of the initial radioactivity. Finally, upon death of mitochondria from irradiation or other causes, plutonium is released and is subsequently picked up by the lysosomes where the dead mitochondria are broken down and metabolized into component parts. Death of cells, which contain large amounts of plutonium, result in the release of this nuclide into the blood stream as large particles which are then taken up by macrophages and concentrated in the periportal areas. A similar mechanism may exist for americium but it is too early to describe its details. This schema would exist only for plutonium or americium in the completely monomeric form. Polymeric plutonium would be handled in a different fashion and would initially be phagocytized by the reticuloendothelial cells of the liver. In the reticuloendothelial cells then the plutonium polymer may be broken down and transported in a soluble form to the hepatocytes.

\section{REFERENCES}

1. Y. E. Rahman and A. Lindenbaum; Lysosome particles and subcellular distributions of polymeric tetravalent plutonium-239; Radiat. Res. 21: $575(1964)$.

2. G. Boocock, C. J. Danpure, D. S. Popplewell, and D. M. Taylor; The subcellular distribution of plutonium in rat liver; Radiat. Res. 42: 381 (1970).

3. F. W. Bruenger, Betsy J. Stover, W. Stevens, and D. R. Atherton; Exchange of $23{ }^{9} \mathrm{Pu} I \mathrm{~V}$ between transferrin and ferritin in vitro; Health Phys. 16: 339 (1969).

4. Betsy J. Stover, F. W. Bruenger, and W. Stevens; Association of americium with ferritin in the canine lịver; Radiat. Res. 43: 173 (1970).

5. F。 W. Bruenger, Betsy JoStover, and W. Stevens; ${ }^{39}{ }^{9} \mathrm{Pu}($ IV) : Its 
subcellular distribution and association with ferritin in canine livers; Health Phys. (in Press).

6. G. N. Taylor, W. S. S. Jee, N. L. Dockum, and E. Hromyk; Translocation of. Pu and Am in beagle livers; (Abstract) Rad. Res. Soc. Annual Meeting (1967).

7. G. N. Taylor, T. F. Dougherty, and W. R. Christensen; Some toxicity aspects of internally deposited plutonium-239; Pathology of Irradiation, Edited by Charles C. Perdjis, Williams and Wilkins (1971).

8. O. H. Lowry, N. J. Rosebrough, A. L. Farr, and R. J. Randall; Protein measurement with the Fol in phenol reagent; J. Biol. Chem. 193: 265 (1951).

9. S. J. Cooperstein and A. Lazarow; A microspectrophotometric method for the determination of cytochrome oxidase; J. Biol. Chem., 189: 665 (1951).

10. Betsy J. Stover, F. W. Bruenger, and W. Stevens; The subcellular distribution of plutonium in the liver and its association with ferritin; Res. in Radiobiology, Univ. of Utah Report C00-119-242, 131 (1970). 
TABLE I

DISTRIBUTION OF $239 \mathrm{PU}$ IN LIVER FRACTIONS

$\%$ of Total
Retained

$\%$ of Total

in the Liver

\begin{tabular}{lll}
\hline Nuclei and debris & 6.5 & 24.0 \\
Mitochondria & 8.5 & 31.5 \\
Cytosol & 2.8 & 10.5
\end{tabular}

Liver retention was $27 \%$ of total body retention.

TABLE 2

DISTRIBUTION OF ${ }^{241}$ Am AND $239 \mathrm{PU}$ IN HEAVY

AND LIGHT FRACTIONS AFTER SUCROSE

GRADIENT SEPARATION OF $600 \mathrm{~g}$ SUPERNATANTS $\uparrow$

\begin{tabular}{lllll}
$\begin{array}{l}\text { Time after } \\
\text { injection }\end{array}$ & \multicolumn{2}{l}{ Heavy* } & \multicolumn{2}{l}{ Light*\% } \\
\hline I hour & Am & Pu & Am & Pu \\
1 day & 3.4 & & 76.2 & \\
4 days & & 8.1 & & 66.0 \\
$7 / 8$ days & 12.1 & 22.6 & 45.0 & 34.8 \\
$29 / 30$ days & 16.9 & 31.9 & 49.3 & 13.2 \\
$69 / 70$ days & 50.4 & 17.6 & 29.4 & 20.8 \\
\hline
\end{tabular}

$+\%$ of total activity in gradient.

* Sum of first three fractions.

$* *$ Sum of last three tubes. 
TABLE 3

PERCENT DOSE OF $239^{\circ} \mathrm{PU}$ IN WHOLE LIVER AND LIVER MITOCHONDRIAL FRACTION $(3000 \times \mathrm{g})$

Sample

Time after injection

\begin{tabular}{|c|c|c|c|}
\hline Sample & \multicolumn{3}{|c|}{ Time after injection } \\
\hline & 1 day & 4 days & 8 days \\
\hline$\%$ D in whole liver & 15.1 & 25.2 & 16.8 \\
\hline$\%$ D in mi tochondria* & 4.2 & 9.1 & 6.5 \\
\hline$[\% D$ in mitochondria $]$ & \multirow{2}{*}{0.278} & \multirow{2}{*}{0.361} & \multirow{2}{*}{0.387} \\
\hline$\% D$ in whole liver $j$ & & & \\
\hline
\end{tabular}

30 days

70 days

17.0

18.8

11.0

11.6

0.647

0.617 
TABLE 4

PERCENT DOSE OF NUCLIDE IN LIVER CYTOSOL*

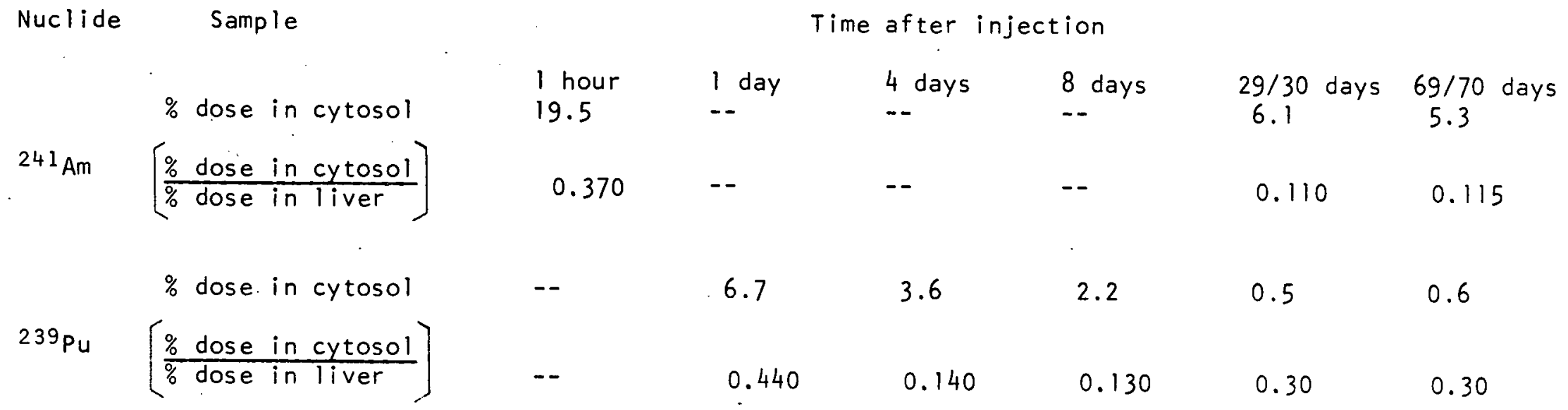

* Assume cytosol comprises $40 \%$ of total liver protein. 


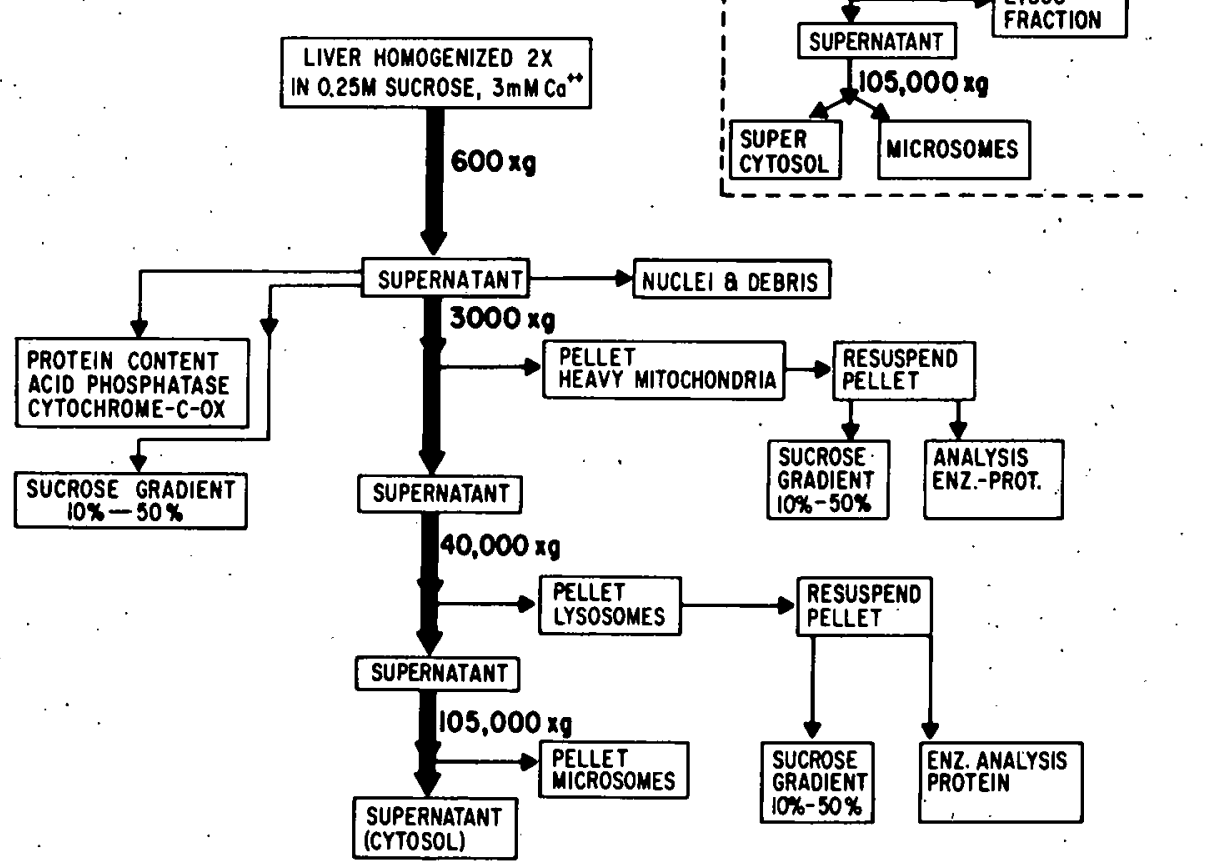

Fig. 1. Schema outlining the present procedure used in the separation of liver tissue. The insert shows the separation procedure used previously. 


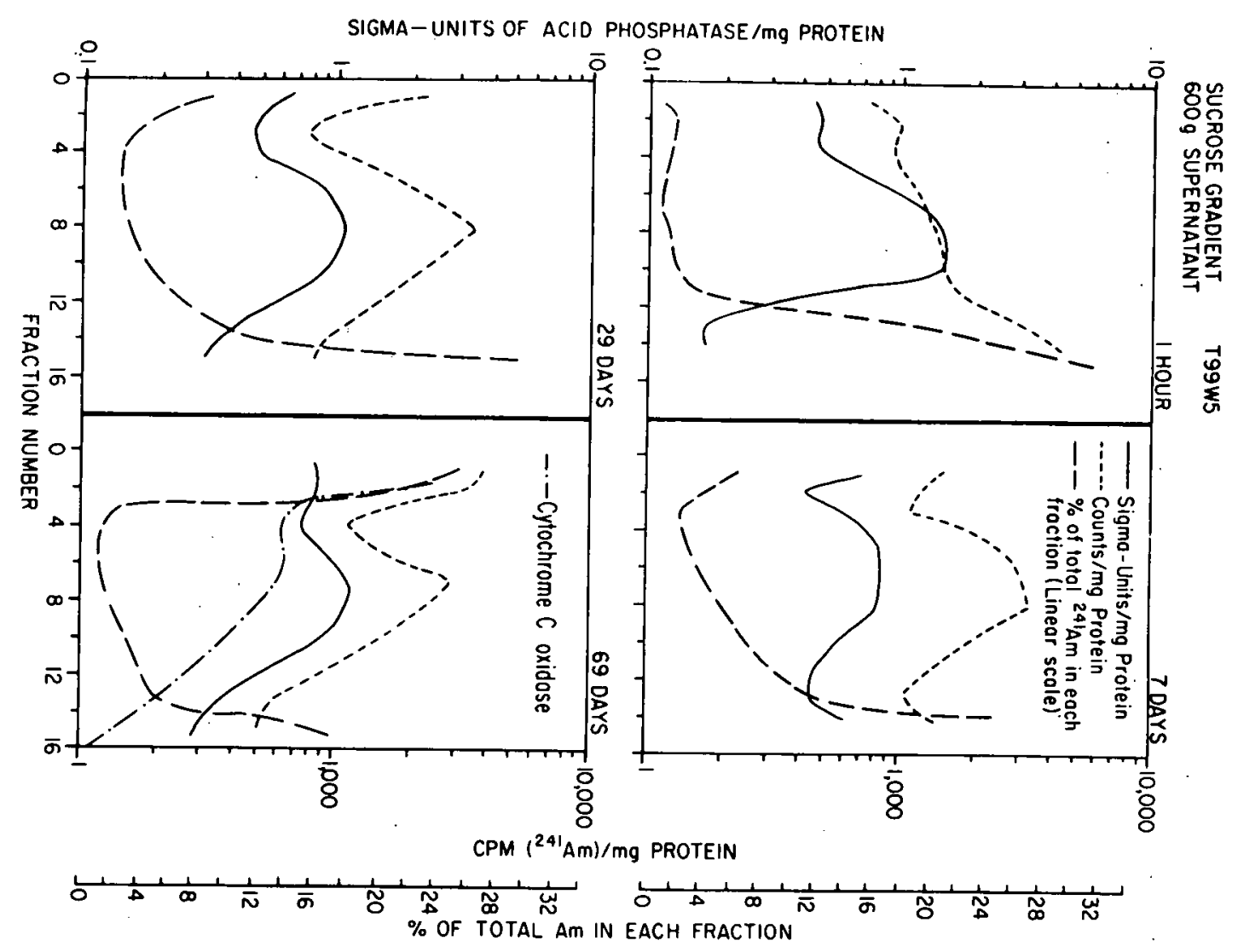

Fig. 2. Density distribution of acid phosphatase, cytochrome $C$ oxidase and americium found in $600 \times \mathrm{g}$ supernatant of liver biopsies following centrifugation in 12 to $52 \%$ sucrose gradients. 


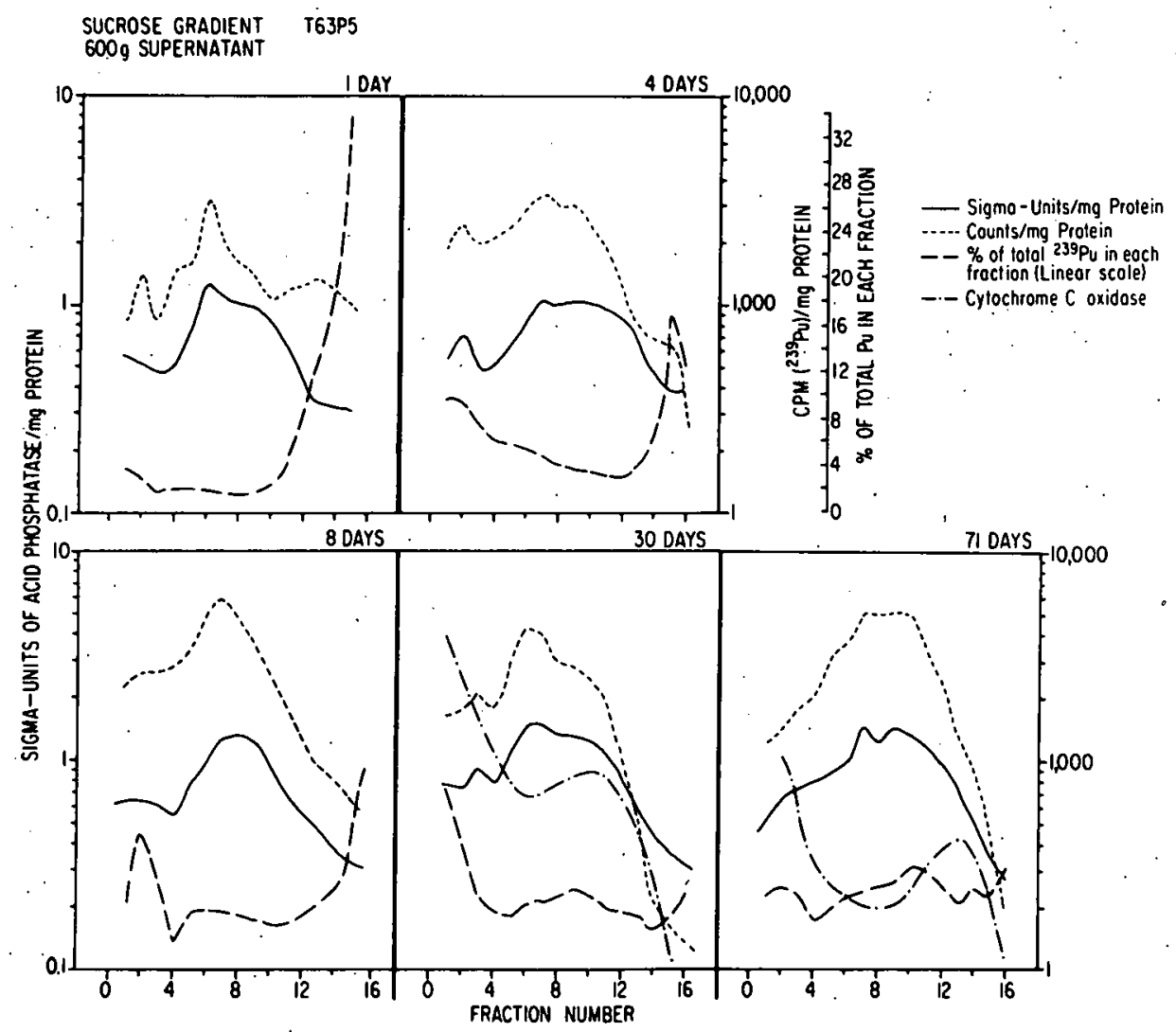

Fig. 3. Density distribution of acid phosphatase, cytochrome $C$ oxidase and Pu found in $600 \times 9$ supernatant of liver biopsies following centrifugation in 12 to $52 \%$ sucrose gradients. 


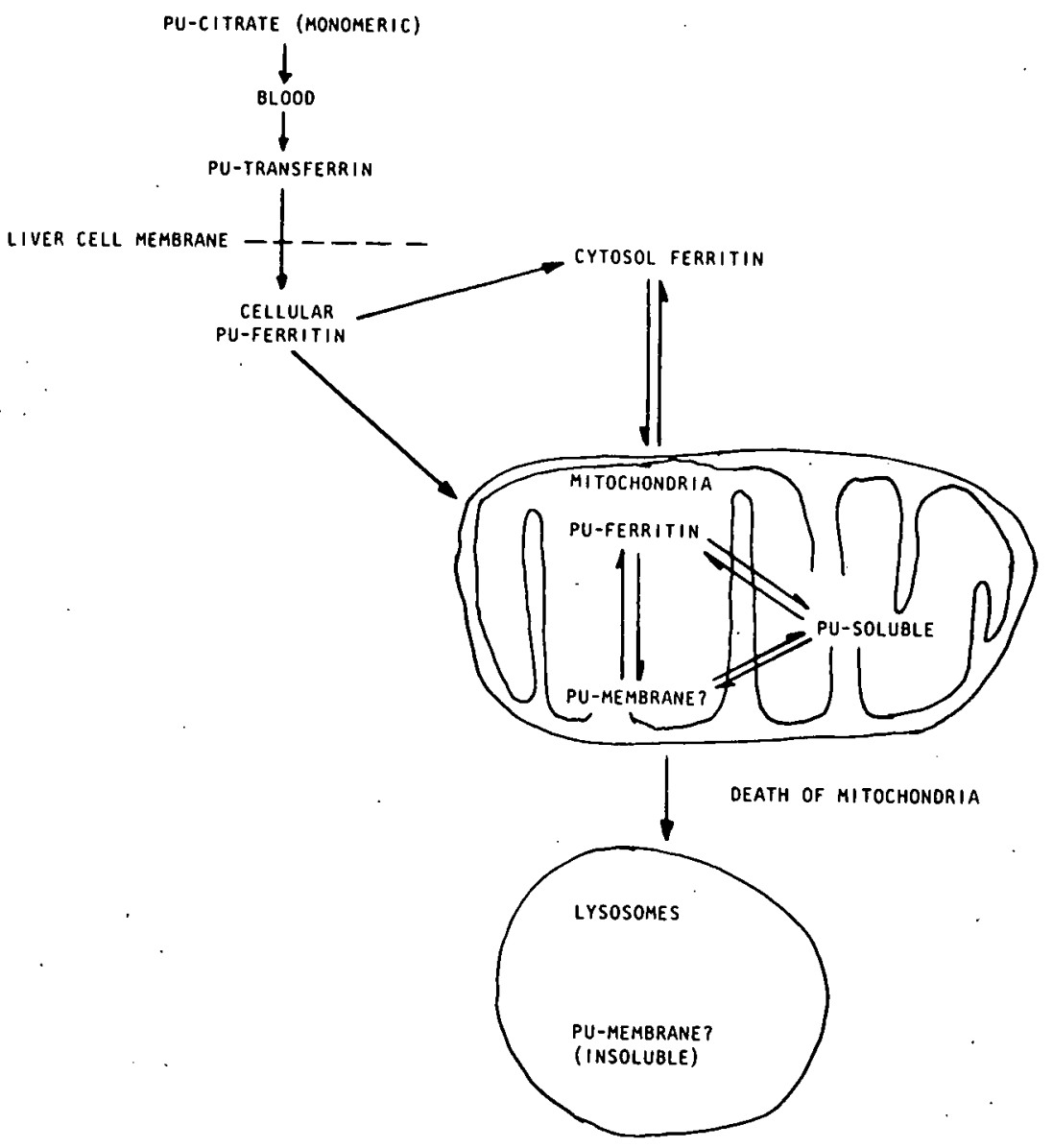

Fig. 4. A hypothetical schema of the fate of monomeric plutonium in liver following i.v. injection. 


\section{RETENTION OF $239 \mathrm{Pu}$ (IV) BY THE YOUNG ADULT BEAGLE* \\ Betsy J. Stover, D. R. Atherton, D. S. Buster, and $F$. W. Bruenger}

When $239 \mathrm{Pu}(\mathrm{IV})$ is given intravenously in $0.08 \mathrm{M}$ citrate buffer, $\mathrm{pH}$ 3.5, the important deposition sites are liver and skeleton. Metabolism of plutonium over six dose levels, $(0.016$ to $2.8 \mu \mathrm{Ci} 239 \mathrm{Pu} / \mathrm{kg}$ injected), is characterized by very slow rates of decrease, and by considerable variation between dogs which may mask effects of time and dose level. No effect of dose level on excretion rate nor of time on skeletal retention at the $2.8 \mu \mathrm{Ci} / \mathrm{kg}$ level was observed. In contrast plutonium is lost from liver at a rate that increases with increasing dose level. Skeletal retention at lower dose levels during the first two years has been determined from measurements of 16 skeletons, from four dogs at 0.30 $\mu \mathrm{Ci} / \mathrm{kg}$ and 12 at $0.016 \mu \mathrm{Ci} / \mathrm{kg}$, and is given by

$$
B=48.3 e^{-0.000458 t}
$$

in which $B$ is percent injected plutonium in the skeleton and time is expressed in days. Retention in the humerus and third lumbar vertebra at subsequent times covering the normal life-span of the beagle is higher than predicted by this equation. These results are consistent with a higher rate of bone remodelling, which leads to removal from and burial of plutonium initially on bone surfaces, during early adult years, followed by a decrease in bone remodelling during which the skeletal retention of plutonium decreases more slowly.

\footnotetext{
* Abstract of presentation at the Radiation Research Society Meeting, Boston, May 1971.
} 
EARLY SKELETAL DISTRIBUTION AND RETENTION OF 239 Pu(IV) AT AN INTERMEDIATE AND LOW DOSE LEVEL IN THE BEAGLE

Betsy J. Stover, David R. Atherton, and Dawn S. Buster

Abstract: Four dogs were injected intravenously with $0.30 \mu \mathrm{C} i$ $239 \mathrm{Pu} / \mathrm{kg}$ and twelve with $0.016 \mu \mathrm{Ci} 239 \mathrm{Pu} / \mathrm{kg}$ and sacrificed at times ranging from 5 to 769 days after injection. Tetravalent, non-colloidal plutonium in about $9 \mathrm{ml} 0.08 \mathrm{M}$ citrate buffer solution of $\mathrm{pH} 3.5$ was given in each case. Representative portions of all parts of the skeleton (except the sacrum) were analyzed for $239 \mathrm{pu}$. Both the amount and the concentration in wet bone were measured so that total skeletal retention and average radiation dose rate for a particular bone could be estimated. The calculated skeletal retention is given by

$$
B=48.9 e^{-0.00050 t} \text { for } t<1000 d s \text {. }
$$

which is not valid beyond about 1000 days. To illustrate the variation in skeletal deposition and retention from dog to dog and also bone to bone, data for each of the 16 are presented in this report.

\section{NTRODUCT ION}

Our initial measurements of the distribution and retention of plutonium in the beagle were limited to high dose levels and the first four years after injection (1). A skeletal retention equation was de$r$ ived from measurements of excretion and hepatic retention which was consistent with the limited skeletal measurements. However, since it was obtained mainly by difference, it was, in a sense, an upper limit for retention in the skeleton.

Extension of the measurements of excretion rate through eight years gave mostly values consistent with extrapolation of the equation for four years for urinary excretion and somewhat higher values for urinary plus fecal excretion (2). A few samples from dogs at the P2-level $(0.095 \mu \mathrm{Ci} / \mathrm{kg})$ were somewhat higher than anticipated. There was also evidence that retention in the liver at the $5-$ level $(2.9 \mu \mathrm{Ci} / \mathrm{kg})$ decreased more rapidly. 
Investigation of the dose level (i.e., radiation damage) effect on hepatic retention was extended over six dose levels $(0.016 \mu \mathrm{Ci} / \mathrm{kg}$ to $2.9 \mu(\mathrm{i} / \mathrm{kg})$, and the data on excretion were reanalyzed for effect of dose level $(3,4,5)$. A set of four equations for hepatic retention of $239 \mathrm{pu}$ was developed from the experimental results. Dose levels $\mathrm{Pl}$, $P 1.7$, and $P 2$ did not show a significant dose level effect and one equation suffices. Separate equations were calculated for the P3,P4, and P5 dose levels: Initial depositions did not differ significantly but the rate of loss of plutonium from the liver increased with increasing dose level. Interim excretion measurements from six months tó four years exhibited no dose level effect for dose levels P2, P3, P4, and P5. However, this was not conclusive since the fluctuations in the excretion could mask a small dose level effect.

Measurement of the retention of $239 \mathrm{pu}$ in the humerus and third lumbar vertebra of 22 dogs at the highest dose level over 3 to 2059 days showed no significant decrease with time. However, the mean of the long term vertebral retention at a mean time of 1338 days exceeded that for the $\mathrm{P} 4$ dose level at 1320 days $(0.01<p<0.02)$, and the long term retentions in both bones from the P.5 dose level at 1338 days exceeded those of the $P 3$ dose level at a mean time of 1650 days $(p<0.01)$.

These results suggested that, in the absence of a gross effect of dose level on excretion rate, the effect of dose level on skeletal retention was opposite to that on hepatic retention. If so, then determination of this effect was necessary in order to calculate skeletal dose rates at the all important low dose levels. It was 
clear that the original skeletal retention equation yielded an overestimation of the long term dose rate at low dose levels, and that additional data must be obtained.

\section{MATERIALS AND METHODS}

Young adult beagles were given intravenous injections of $239 \mathrm{Pu}$ (IV) in $0.08 \mathrm{M}$ citrate buffer solution of $\mathrm{pH} \mathrm{3.5.} \mathrm{Four} \mathrm{received} 0.30$ $\mu \mathrm{Ci} / \mathrm{kg}(\mathrm{P3}-\mathrm{level})$ and twelve received $0.016 \mu \mathrm{Ci} / \mathrm{kg}(\mathrm{Pl}-\mathrm{level})$. The dogs were sacrificed at times ranging from 5 to 769 days after injection. Death for each animal was by exsanguination following sodium pentothal anesthesia.

Skeletal parts of each animal available for distributional analysis amounted to about $40 \%$ of the entire skeleton, the actual fraction varying from dog to dog. Each bone was carefully defleshed and, whenever possible, an attempt was made to obtain wet as well as ashed weights of all parts. Some of the skeletons had been inadvertently stored in acetone, $;$ and could not be rehydrated satisfactorily, however, these wet weights are included in the results section. Ashed weights were obtained on all skeletal parts and, of course, are the more accurate of the two weights.

Teeth were not separated from bone in which they were set, thus upper teeth are included in skull specimens and lower teeth in mandibular samples.

The analysis of these specimens for their $239 \mathrm{pu}$ content was done by extracting the plutonium from an appropriate aliquot into

$*$ Skeletons of T35P3, T24,30,39PI were stored in acetone. 
scintillator solution. with EHPA (di-2-ethyl-hexyl phosphoric acid) according to the method reported previously. (6).

Samples were done in duplicate and a pair of samples from a bone solution containing a known concentration of $239 \mathrm{pu}$ were run with each extraction set (up to 20 samples). Counting gear was monitored by counting a known quantity of $239 \mathrm{pu}$ (contained in a solution of the same constitution as the bone and control samples) several times during the counting of each set of samples.

The yield of the extraction system, as determined on 96 control samples, averaged $89.4 \%$ with a fractional standard deviation of 0.063 . These control samples contained from about 500 to $1500 \mathrm{pCi}$ of $239 \mathrm{pu}$ each.

The agreement between pairs of samples was appraised by relating the range between the members of a sample pair to their mean value $(r / \bar{R})$. The average such value for 415 pairs of samples was $0.044 \pm$ 0.014. The amounts of plutonium in these samples ranged from a few tens to a few thousand $\mathrm{pCi}$. Yield did not appear to be affected by the amount of plutonium in the sample.

The counting equipment was nicely consistent, giving $1.02 \pm 0.011$ counts/disintegration in a series of 553 observations of the ${ }^{239} \mathrm{Pu}-$ EHPA-scintillator standard (4077 PCi).

\section{RESULTS}

The results of the skeletal analyses are presented in Tables 1 through 16. The animals at the P3-level are listed first in order of increasing time after injection and those at the $\mathrm{Pl-level}$ follow in 
the same order. The distribution and estimated total retention: are given for each dog. Since only portions of the skeletons were analyzed, some assumptions had to be made in order to estimate the total retention. The fraction of a specific skeletal part that was actually analyzed is given in the second column of each of the Tables 1-16. In the case of the symmetrical skeleton, deposition was assumed to be symmetrical and one member of the pair was analyzed and the result was multiplied by two to give the $\%$ dose/part shown in the third column. The results obtained on portions of the asymmetric skeleton were treated similarly but required a more drastic assumption. For example, if the sample consisted of four of the seven cervical vertebrae, the total was obtained by multiplying the measured amount of plutonium in the sample of four by $7 / 4$ to obtain an estimate of the total amount in the cervical vertebrae. This has the serious limitation that the implicit assumptions that the concentration of plutonium in, and the size of the three missing vertebrae are equal to the average values of these quantities for the four that were measured. A further short-coming is that the fraction analyzed was not the same throughout the series. For example, samples of thoracic vertebrae contained $5,6,7,8,9,10$, or 11 vertebrae.

The sacrum was missing from each skeleton, and cervical vertebrae humeri, and sternum, were missing in one, two, and three, skeletons. respectively. "Paper sacra", etc. were "constructed" as follows: In a prior report the sacrum was shown from measurements on eleven dogs to comprise $1.14 \%$ of the skeleton on an ashed weight basis (7). Using this value and the measured skeletal ash, a corrected value for total skeletal ash is obtained. Then from the observed average ashed weight/ :Retention is in \% of injected dose. 
wet weight for each dog a wet weight is calculated for the sacrum and a corrected value for total wet skeletal weight is obtained. Similarly the average fraction of total skeletal plutonium in the sacrum is used to estimate the plutonium in the sacrum (or other missing bone). From this fraction and the measured total a corrected value for total skeletal retention is obtained.

The paws were not completely defleshed in this series of measurements and thus the wet weight was not obtained. It was assumed to be equal to the average value of the ashed weight/wet weight ratio of the samples that were actually measured for the particular dog.

The final column in Tables 1-16 gives the relative concentration in each skeletal part. If $10 \%$ of the ${ }^{239} \mathrm{Pu}$ in the skeleton is in a set of bones which has a weight equal to $10 \%$ of the total skeleton then the ratio is unity. The advantage of this quantity is that if only one skeletal part is available for analysis, but the relative concentration and the fraction of the skeleton comprised by this part are known, then a rough estimate of total ${ }^{239} \mathrm{Pu}$ in the skeleton can be made.

The means and standard deviations of the percent dose per skeletal part, percent dose per gram of wet bone, the ratio of ashed weight to wet weight of the skeletal part: and the relative concentration are given in Tables 17,18 and 19 for four dogs at the P3 dose level, eleven at the $\mathrm{PI}$ level, and for the combined fifteen animals respectively. One dog at the $P I$ dose level was sacrificed at just 5 days after injection and was not included. The values of percent dose per

*The average ratio of total skeletal ash to its wet weight for the 16 dogs in this study is $0.422 \pm 0.025$. 
gram of wet bone show that the average skeletal dose rates for these skeletal parts vary considerably from the average for the entire skeleton. (Note that the value for the tail is most likely too low since complete defleshing was difficult.) The relative concentration is lower than average in the bones of the head, neck, tail, and distal halves of the extremities, and higher than average in the bones of the chest, pelvis, and proximal halves of the extremities.

Another aspect of the variability of skeletal retention is shown in Tables 20, 21, 22 for the four $P 3$, eleven $P 1$, and fifteen $P 3+P I$ dogs, respectively. (The dog sacrificed at 5 days has been omitted again.) A single exponential has been fit to each set of data for retention in a given skeletal part. The calculated values of the intercept, $a$, and the coefficient of $t$ (days), $b$, in a $e^{b t}$ are given as well as the probability, $p$, that /b/ differs significantly from zero. The apparent increases with time are not significant but a number of the decreases are, including the estimated total skeletal retention.

\section{DISCUSSION}

The distribution of $239 \mathrm{pu}$ in the skeleton during the first two years after injection has been determined for beagles at the Pl level $(0.016 \mu \mathrm{Ci} / \mathrm{kg})$. At this dose level in the beagle there is no significant life-shortening but incidence of osteosarcoma is about $36 \%$. Supporting data were also obtained from dogs at the P3 level $(0.30$ $\mu \mathrm{Ci} / \mathrm{kg})$. There is considerable variation in the macroscopic distribution in the various skeletal parts. In some parts the retention appeared constant, which probably means that the rate of decrease was 
masked by the variation between dogs. In other skeletal parts, retention decreased during the two years as did the estimated total retention. The latter is given by

$$
B=(48.9 \pm 3.4) \mathrm{e}^{-(5.01 \pm 1.45) 10^{-4} t}
$$

for $t<1000$ days.

Hepatic retention was also measured in the two groups of dogs. The results have been reported in conjunction with long term data at the six dose levels ranging from 0.016 to $2.9 \mu \mathrm{Ci} / \mathrm{kg}(2,3,4,5)$. Single exponentials for retention in the liver were calculated for each dose level, and for groups of dose levels. In all cases the value of the intercept (at $t=0$ ) fell between 30 and $35 \%$ of the injected dose, and the rate of decrease of hepatic retention decreased with decreasing dose level, i.e., the coefficients of $t$ became smaller. However, when the values for the $P I$ dogs which were sacrificed during the first two years are analyzed in the absence of the long term data, there is no significant decrease with time, and the mean is $32.5 \%$ of the injected dose.

In Table 23 we combine this result, and Eq. (1), for bone with results on excretion and distribution in other soft tissues (4) to obtain a "balance sheet" for the early disposition of $239 \mathrm{pu}$ at the time when the amount of circulating plutonium has become quite low, i.e., several weeks after injection. Most of the injected plutonium is accounted for, and, if the same fractional loss is assigned to each of the four categories, the corrected values are obtained. As noted above, values for "initial" deposition in the liver are 30 to $35 \%$. Values for skeletal retention at 22 days, which were obtained by 
difference, and therefore are probably a little too high, are, for the P5 level $B=57 \pm 10$, and for the $P 3$ level $B=55 \pm 9$ (4). Thus, when the young adult beagle is given an intravenous injection of $239 \mathrm{Pu}$ (IV) in $0.08 \mathrm{M} \mathrm{citrate}$ buffer of $\mathrm{pH} 3.5$ over the injected dose level range 0.016 to $2.9 \mu \mathrm{Ci} / \mathrm{kg}$, about $1 / 2$ goes to the skeleton, $1 / 3$ goes to the liver, and $1 / 6$ is either excreted or is deposited in other soft tissue. In Figure 1 are shown the data for hepatic and skeletal retention in the $P 1$ dogs during the first two years after injection. During these two years, skeletal retention decreases so that at 2 years and at low dose levels, approximately $1 / 3$ of the injected $239 \mathrm{pu}$ is in the skeleton, $1 / 3$ in the 1 iver, and $1 / 3$ has been excreted. (The previous report gave $30 \pm 4 \%$ excreted at four years for dose levels P2 $(0.095$ $\mu \mathrm{Ci} / \mathrm{kg})$ to $\mathrm{P5}(4)$.

At higher dose levels, decrease in skeletal retention is slower than at the PI level (4). At longer times at the Pl level the decrease is slower than that given by Eq (1). (8). Both are consistent with the observation that the normal rate of bone remodeling in the dog is still rapid at 1.5 years of age and decreases to a low value at three years, and that at the higher dose levels radiation damage impedes the remodeling processes (9). 


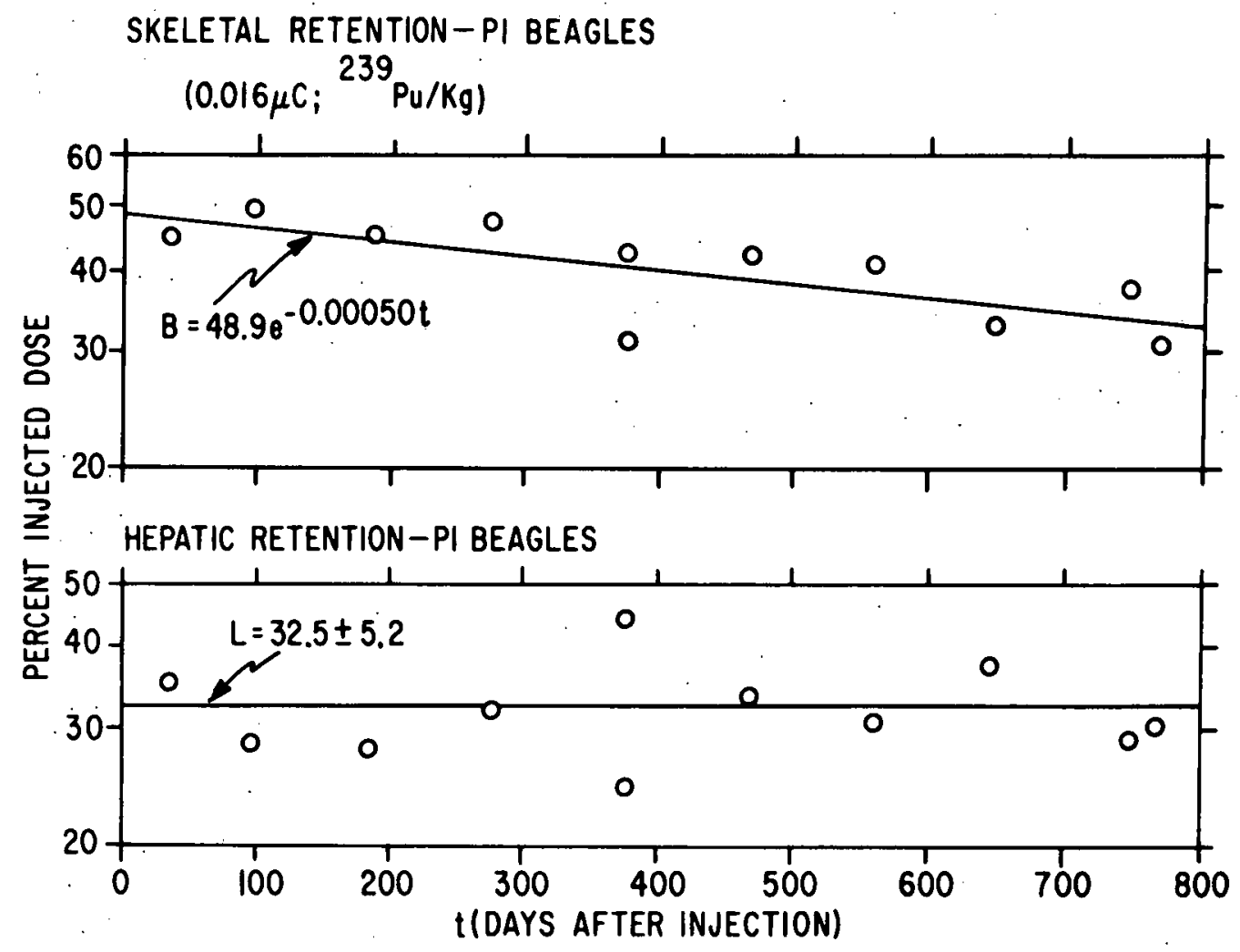

Fig. I. Skeletal and hepatic retention by the beagle for 2 years following intravenous injection of $0.016 \mu \mathrm{Ci} / \mathrm{kg}$ of $239 \mathrm{Pu}$. 
Table 1

T31P3

Wt. at Injection: $13000(\mathrm{~g})$

Inj. to Doath: $\quad 40($ diays)
Wt. of Wet Skeleton: 853

Wt. of" Ashed Skoleton: 355 (g)

(s)

\begin{tabular}{|c|c|c|c|c|c|}
\hline \multirow[t]{2}{*}{ Skeletal Part } & \multirow{2}{*}{$\begin{array}{l}\text { Fraction } \\
\text { Analyzed }\end{array}$} & \multirow{2}{*}{$\frac{\% \text { Dose }}{\text { Part }}$} & $\%$ Dose & \multirow{2}{*}{$\frac{\text { A. hed } W t}{\text { Wet } W t}$} & \multirow{2}{*}{$\begin{array}{l}\text { Rolativex: } \\
\text { Conc. }\end{array}$} \\
\hline & & & g Wet Bone & & \\
\hline SkulI & $1 / 2$ & 3.08 & 0.0245 & 0.463 & 0.45 \\
\hline Mandibles & $1 / 2$ & 0.99 & 0.0176 & 0.552 & 0.32 \\
\hline Cervical & & & & & \\
\hline Vertebrae & $4 / 7$ & 2.26 & 0.0390 & 0.468 & 0.72 \\
\hline Thoracic & & & & & \\
\hline Vertebrae & $6 / 13$ & 6.67 & 0.110 & 0.380 & 2.02 \\
\hline Lumbar & & & & & \\
\hline Vertebrae & $2 / 7$ & 6.80 & 0.117 & 0.367 & 2.14 \\
\hline Caudal & & & & & \\
\hline Vertebrae & $12 / 15$ & 0.32 & 0.0118 & 0.139 & 0.22 \\
\hline Paws* & $2 / 4$ & 1.21 & 0.0147 & 0.436 & 0.27 \\
\hline Radii & $1 / 2$ & 0.48 & 0.0236 & 0.451 & 0.44 \\
\hline Ulnae & $1 / 2$ & 0.47 & 0.02 .14 & 0.481 & 0.39 \\
\hline Humer $i$ & $1 / 2$ & 4.16 & 0.0662 & 0.357 & 1.21 \\
\hline Tibiáe-Fibulae & $1 / 2$ & 2.18 & 0.0455 & 0.483 & 0.83 \\
\hline Femora & $1 / 2$ & 4.06 & 0.0750 & 0.448 & 1.37 \\
\hline Pelvis & $1 / 2$ & 3.64 & 0.0829 & 0.439 & 1.52 \\
\hline Scapulae & $1 / 2$ & 2.56 & 0.0818 & 0.418 & 1.50 \\
\hline Ribs & $13 / 26$ & 5.32 & 0.0653 & 0.347 & 1.20 \\
\hline Sternum & $4 / 7$ & 1.16 & 0.101 & 0.179 & 1.86 \\
\hline Sa crum & 0 & 1.24 & 0.127 & 0.416 & 2.34 \\
\hline Total & & 46.5 & 0.0545 & 0.416 & 1.00 \\
\hline
\end{tabular}

* Wet bone not weighed - Estimated using average ashed wt/wet wt for this dog.

** Fraction of ${ }^{239} \mathrm{Pu}$ retained by skeletal part Fraction of skeletal wet weight in part 
Table 2

T38P3

Wt. at Injection: $7960(\mathrm{~g})$

Wt. of Wet Skeleton: 608 (g)

Inj. to Death: 187 (days)

Wt. of Ashed Skeleton: 249 (g)

\begin{tabular}{lccccc} 
Skeletal Part & $\begin{array}{c}\text { Fraction } \\
\text { Analyzed }\end{array}$ & $\frac{\% \text { Dose }}{\text { Part }}$ & $\frac{\% \text { Dose }}{\text { g.Wet Bone }}$ & $\frac{\text { Ashed Wt. }}{\text { Wet Wt. }}$ & $\begin{array}{c}\text { Relative } \\
\text { Conc. }\end{array}$ \\
\hline Skull & $1 / 2$ & 3.60 & 0.0419 & 0.482 & 0.58 \\
$\begin{array}{l}\text { Mandibles } \\
\text { Cervical } \\
\text { Vertebrae }\end{array}$ & $1 / 2$ & 1.23 & 0.0329 & 0.535 & 0.45 \\
& $4 / 7$ & 2.33 & 0.0514 & 0.458 & 0.70
\end{tabular}

Thoracic

Vertebrae

$6 / 13 \quad 6.50$

0.157

0.384

2.16

Lumbar

Vertebrae

$3 / 7 \quad 4.85$

0.114

0.360

1.56

Caudal

Vertebrae

Paws*

Radii

Ulnae

Humeri

Tibiae-Fibulae

Femora

$12 / 15 \quad 0.24$

0.0129

0.152

0.18

$2 / 4 \quad 1.42$

0.0298

0.410

0.33

$1 / 2$

0.40

0.0306

0.480

0.42

$1 / 2$

0.38

0.0271

0.492

0.37

$1 / 2 \quad 3.47$

0.0806

0.356

1.10

$1 / 2 \quad 1.56$

0.0434

0.423

0.60

$1 / 2 \cdot 3.68$

0.0902

0.395

1.24

$1 / 2 \quad 3.18$

0.113

0.452

1.55

Scapulàe

Ribs

$1 / 2$

2.84

0.135

0.451

1.85

$12 / 26$

6.35

0.101

0.345

1.38

Sternum

Sacrum .

$1 / 1$

1.16

0.100

0.159

1.37

1.18

0.170

0.410

2.33

Total

44.4

0.0730

0.410

1.00

* Wet bone not weighed - Estimated using average ashed wt/wet wt for this dog.

* * Fraction of ${ }^{239} \mathrm{Pu}$ retained by skeletal part Fraction of skeletal wet weight in part 
Table 3

T35P3

Wt. at Injection: $11900(\mathrm{~g})$

Wt. of Wet Skeleton: 947

Wt. of Ashed Skeleton: 442

(g)

(g)

\begin{tabular}{|c|c|c|c|c|c|}
\hline \multirow[t]{2}{*}{ Skeletal Part } & \multirow{2}{*}{$\begin{array}{l}\text { Fraction } \\
\text { Analyzed }\end{array}$} & \multirow{2}{*}{$\frac{\% \text { Dose }}{\text { Part }}$} & $\%$ Dose & \multirow{2}{*}{$\frac{\text { Ashed Wt. }}{\text { Wet Wt : }}$} & \multirow{2}{*}{$\begin{array}{l}\text { Relative*** } \\
\text { Conc. }\end{array}$} \\
\hline & & & $g$ Wet Bone & & \\
\hline Skull & $1 / 2$ & 3.28 & $0.023,5$ & 0.499 & 0.50 \\
\hline Mandibles & $1 / 2$ & 1.17 & 0.0183 & 0.564 & 0.39 \\
\hline Cervical & & & & & $\because$ \\
\hline Vertebrae & $4 / 7$ & 2.22 & 0.0304 & 0.540 & 0.65 \\
\hline Thoracic & & & & & \\
\hline Vertebrae & $6 / 13$ & 8.06 & 0.120 & 0.467 & 2.57 \\
\hline $\begin{array}{l}\text { Lumbar } \\
\text { Vertebrae }\end{array}$ & & & & & \\
\hline Caudal & $3 / 7$ & 4.24 & 0.0731 & 0.443 & 1.57 \\
\hline Vertebrae & $12 / 15$ & 0.31 & 0.0111 & 0.162 & 0.24 \\
\hline Paws* & $2 / 4$ & 1.73 & 0.0230 & 0.466 & 0.49 \\
\hline Radii & $1 / 2$ & 0.42 & 0.0180 & 0.527 & 0.39 \\
\hline Ulnae & $1 / 2$ & 0.41 & 0.0154 & 0.514 & 0.33 \\
\hline Humer $i$ & $1 / 2$ & 3.15 & 0.0536 & 0.396 & 1.15 \\
\hline Tibiae-Fibulae & $1 / 2$ & 1.65 & 0.0284 & 0.499 & 0.61 \\
\hline Femora & $1 / 2$ & 4.18 & 0.0629 & 0.484 & 1.35 \\
\hline Pelvis & $1 / 2$ & 3.50 & 0.0663 & 0.510 & 1.42 \\
\hline Scapulae & $1 / 2$ & 2.24 & 0.0590 & 0.475 & 1.27 \\
\hline Ribs & $13 / 26$ & 4.56 & 0.0522 & 0.408 & 1.12 \\
\hline Sternum & $1 / 1$ & 1.84 & 0.0911 & 0.199 & 1.96 \\
\hline Sacrum & 0 & 1.17 & 0.1 .08 & 0.466 & 2.34 \\
\hline Total & & 44.1 & 0.0466 & 0.466 & 1.00 \\
\hline
\end{tabular}

* Wet bone not weighed - Estimated using average ashed wt/wet wt for this dog.

* Fraction of ${ }^{239}$ Pu retained by skeletal part Fraction of skeletal wet weight in part 
Table 4

T29P3

Wt. at Injection: $12100(\mathrm{~g})$

Wt. of Wet Skeleton: 832 (g)

Inj. to Death: 560 (days)

Wt. of Ashed Skeleton: 363 (g)

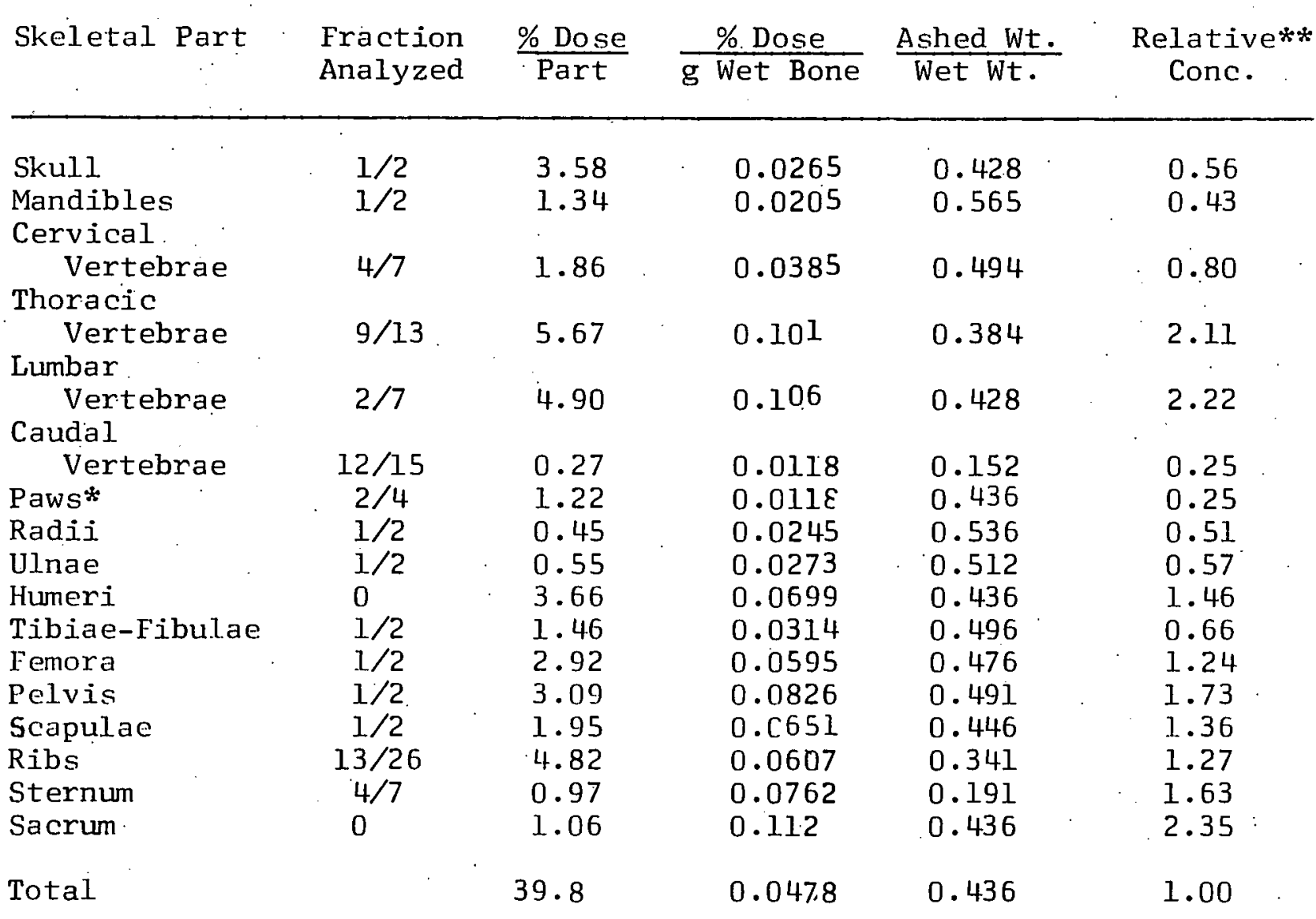

* Wet bone not weighed - Estimated using average ashed wt/wet w.t for this dog.

* Fraction of ${ }^{239} \mathrm{Pu}$ retained by skeletal part

Fraction of skeletal wet weight in part 
Table 5

T36Pl

Wt. at Injection: $10400(\mathrm{~g})$

Inj. to Death: 5 (days)

Wt. of Wet Skeleton: 773

Wt. of Ashed Skeleton: 322 (g)

(g)

\begin{tabular}{|c|c|c|c|c|c|}
\hline Skeletal Part & $\begin{array}{l}\text { Fraction } \\
\text { Analyzed }\end{array}$ & $\frac{\% \text { Dose }}{\text { Part }}$ & $\frac{\% \text { Dose }}{\mathrm{g} \text { Wet Bone }}$ & $\frac{\text { Ashed Wt. }}{\text { Wet } W t .}$ & $\begin{array}{c}\text { Relative*** } \\
\text { Conc. }\end{array}$ \\
\hline Skull & $1 / 2$ & 2.44 & 0.020 & 0.473 & 0.34 \\
\hline $\begin{array}{l}\text { Mandibles } \\
\text { Cervical }\end{array}$ & $1 / 2$ & 1.16 & 0.0196 & 0.551 & 0.33 \\
\hline $\begin{array}{l}\text { Vertebrae } \\
\text { Thoracic }\end{array}$ & $4 / 7$ & 2.25 & 0.0458 & 0.479 & 0.76 \\
\hline $\begin{array}{l}\text { Vertebrae } \\
\text { Lumbar }\end{array}$ & $6 / 13$ & 7.73 & 0.157 & 0.378 & 2.61 \\
\hline $\begin{array}{l}\text { Vertebrae } \\
\text { Caudal }\end{array}$ & $2 / 7$ & 6.32 & 0.130 & 0.370 & 2.16 \\
\hline Vertebrae & $15 / 15$ & 0.16 & 0.0070 & 0.124 & 0.12 \\
\hline Paws* & $2 / 4$ & 1.11 & 0.0144 & 0.417 & 0.24 \\
\hline Radii & $1 / 2$ & 0.33 & 0.0156 & 0.453 & 0.26 \\
\hline Ulnae & $1 / 2$ & 0.30 & 0.0140 & 0.452 & 0.23 \\
\hline Humeri & $1 / 2$ & 4.94 & 0.0978 & 0.426 & 1.62 \\
\hline Tibiae-Fibulae & $1 / 2$ & 1.59 & 0.0344 & 0.445 & 0.57 \\
\hline Femora & $1 / 2$ & 4.36 & 0.0868 & 0.436 & 1.44 \\
\hline Pelvis & $1 / 2$ & 3.47 & 0.0909 & 0.452 & 1.51 \\
\hline Scapulae & $1 / 2$ & 2.93 & 0.0977 & 0.437 & 1.67 \\
\hline Ribs & $13 / 26$ & 5.44 & 0.0728 & 0.345 & 1.21 \\
\hline Sternum & $1 / 1$ & 0.86 & 0.137 & 0.184 & 2.26 \\
\hline Sacrum & 0 & 1.18 & 0.134 & 0.417 & 2.22 \\
\hline Total & & 46.6 & 0.0603 & 0.417 & 1.00 \\
\hline
\end{tabular}

* Wet bone not weighed - Estimated using average ashed wt/wet wt for this dog.

** Fraction of ${ }^{239}$ Pu retained by skeletal part Fraction of skeletal wet weight in part 
Table 6

T30P1

Wt. at Injection: $12400(\mathrm{~g})$

Wt. of Wet Skeleton: 722 (g)

Inj. to Death: 35 (days)

Wt. of Ashed Skeleton: 328 (g)

Skeletal Part

Fraction \% Dose Analyzed

\section{Skull}

Mandibles

Cervical

Vertebrae

Thoracic

Vertebrae

Lumbar

Vertebrae

Caudal

Paws*

Radii

UInae

Humeri

Tibiae-Fibulae

Femora

Pelvis

Scapulae

Ribs

Sternum

Sacrum

Total

$\begin{array}{ll}1 / 2 & 2.54 \\ 1 / 2 & 0.80\end{array}$

0.80

$4 / 7$

$11 / 13$

$3 / 7$

$15 / 15$

$2 / 4$

$1 / 2$

$1 / 2$

$1 / 2$

$1 / 2$

$1 / 2$

$1 / 2$

$1 / 2$

$13 / 26$

0

0

0.64

1.14

2.35

7.98

5.69

0.18

1.53

0.35

0.40

5.17

1.81

3.30

3.41

2.32

5.26

44.9
$\%$ Dose g Wet Bone

0.0228

0.0164

0.469

0.561

0.0448

0.495

0.161

0.425

0.440

0.123

0.0187

0.0215

0.0194

0.0209

0.111

0.0406

0.0670

0.0874

0.0789

0.0671

0.0729

0.136

0.255

0.449

0.480

0.506

0.466

0.486

0.442

0.449

0.436

0.354

0.171

0.449

0.0621

0.449

* Wet bone not weighed - Estimated using average ashed wt/wet wt for this dog.

$* *$ Fraction of ${ }^{239} \mathrm{Pu}$ retained by skeletal part

$$
\text { Fraction of skeletal wet weight in part }
$$


$\mathrm{T} 24 \mathrm{P} 1$.

Wt. at Injection: $1.3100(\mathrm{~g})$

Inj. to Death: 97 (days)

Wt. of Wet Skeleton: 793

wt. ol: Ashed Skeleton: 357

(g)

(g)

Sholetal Part Fraction

\% Dose \% Dose

Ashod Wt. Reliative** Analyzed

Part g Wot Bone Wet Wt.

Conc.

\begin{tabular}{|c|c|c|c|c|c|}
\hline Skull & $1 / 2$ & 3.83 & 0.0313 & 0.496 & 0.50 \\
\hline Mandibles & $.1 . / 2$ & 1. .23 & 0.0248 & 0.565 & 0.40 \\
\hline Cervical. & & & & & \\
\hline $\begin{array}{l}\text { Vertebrae } \\
\text { Thoracic }\end{array}$ & $4 / 7$ & 2.39 & 0.0424 & 0.503 & 0.68 \\
\hline $\begin{array}{l}\text { Thoracic } \\
\text { Vertebrae }\end{array}$ & $8 / 13$ & 5.70 & 0.134 & 0.425 & 2.14 \\
\hline Lumbar & & & & & \\
\hline $\begin{array}{l}\text { Vertebrae } \\
\text { Caudal }\end{array}$ & $2 / 7$ & 5.48 & 0.103 & 0.445 & 1.74 \\
\hline Vertebrae & $15 / 15$ & 0.30 & 0.0220 & 0.231 & 0.34 \\
\hline Paws* & $2 / 4$ & 2.09 & 0.0248 & 0.450 & 0.40 \\
\hline Radii & $1 / 2$ & 0.39 & 0.0197 & 0.477 & 0.31 \\
\hline Ulnae & $1 / 2$ & 0.49 & 0.0220 & 0.490 & 0.35 \\
\hline Humeri & $1 / 2$ & 5.34 & 0.108 & 0.460 & 1.73 \\
\hline Tibiae-fibulae & $1 / 2$ & 2.28 & 0.0437 & 0.482 & 0.70 \\
\hline Femora & $1 / 2$ & 4.72 & 0.0821 & 0.437 & 1.31 \\
\hline Pelvis & $1 / 2$ & 3.49 & 0.0861 & 0.487 & 1.38 \\
\hline Scapulae & $1 / 2$ & 3.09 & 0.100 & 0.432 & 1.60 \\
\hline Ribs & $13 / 26$ & 6.48 & 0.0771 & 0.359 & 1.23 \\
\hline Sternum & $1 / 1$ & 1.03 & 0.146 & 0.210 & 2.33 \\
\hline Sacrum & 0 & 1. .26 & 0.139 & 0.450 & 2.22 \\
\hline Total & & 49.6 & 0.0626 & 0.450 & 1.00 \\
\hline
\end{tabular}

* Wet bone not weighed - Estimated using average așhed wt/wet wt for this dog.

** Fraction of ${ }^{239} \mathrm{Pu}$.retained by skeletal part Fraction of skeletal wet weight in part 
Table 8

T37P1

$\begin{array}{lcll}\text { Wt. at Injection: } & 8590(\mathrm{~g}) & \text { Wt. of Wet Skeleton: } & 695 \\ \text { Inj. to Death: } & 186 \text { (days) } & \text { Wt. of Ashed Skeleton: } & 294 .:(\mathrm{g})\end{array}$

Skeletal Part $\begin{aligned} & \text { Fraction } \\ & \text { Analyzed }\end{aligned} \frac{\% \text { Dose }}{\text { Part }} \quad \frac{\% \text { Dose }}{\mathrm{g} \text { Wet Bone }} \frac{\text { Ashed Wt. }}{\text { Wet Wt. }} \quad \begin{gathered}\text { Relative** } \\ \text { Conc. }\end{gathered}$

\begin{tabular}{|c|c|c|c|c|c|}
\hline Skull & $1 / 2$ & 3.52 & 0.0318 & 0.441 & 0.49 \\
\hline Mandibles & $1 / 2$ & 1.02 & 0.0230 & 0.534 & 0.35 \\
\hline Cervical & & & & & \\
\hline Vertebrae & $4 / 7$ & 1.96 & 0.0430 & 0.488 & 0.66 \\
\hline Thoracic & & & & & \\
\hline Vertebrae & $10 / 13$ & 6.41 & 0.137 & 0.395 & 2.12 \\
\hline Lumbar & & & & & \\
\hline Vertebrae & $4 / 7$ & 5.41 & 0.127 & 0.454 & I. 96 \\
\hline $\begin{array}{l}\text { Caudal } \\
\text { Vertebrae }\end{array}$ & $15 / 15$ & 0.24 & 0.0175 & 0.186 & 07 \\
\hline Paws* & $2 / 4$ & 1.94 & 0.0266 & 0.424 & 0.41 \\
\hline Radii & $1 / 2$ & 0.50 & 0.0296 & 0.484 & 0.46 \\
\hline Ulnae & $1 / 2$ & 0.47 & 0.0262 & 0.465 & 0.40 \\
\hline Humer $i$ & $1 / 2$ & 4.53 & 0.101 & 0.406 & 1.56 \\
\hline Tibiae-Fibulae & $1 / 2$ & 2.14 & 0.0496 & 0.471 & 0.77 \\
\hline Femora & $1 / 2$ & 3.80 & 0.0867 & 0.467 & 1.34 \\
\hline Pelvis & $1 / 2$ & 3.24 & 0.0856 & 0.440 & 1.32 \\
\hline Scapulae & $1 / 2$ & 2.19 & 0.0852 & 0.423 & 1.32 \\
\hline Ribs & $13 / 26$ & 5.87 & 0.0795 & 0.33 .9 & 1.20 \\
\hline Sternum & $1 / 1$ & 0.65 & 0.136 & 0.178 & 2.12 \\
\hline Sacrum & 0 & 1.14 & 0.144 & 0.424 & 2.22 \\
\hline Total & & 45.0 & 0.0648 & 0.424 & 1.00 \\
\hline
\end{tabular}

* Wet bone not weighed - Estimated using average ashed wt/wet wt for this dog.

* Fraction of ${ }^{239}$ Pu retained by skeletal part Fraction of skeletal wet weight in part 
Table 9

T32P1.

Wt. at Injection: $8470(\mathrm{~g})$

Inj. to Death: 274 (days)

Wt. of: Wet Skeleton: 569

Wt. of Ashed Skel.eton: 212

(g)

(g)

\begin{tabular}{|c|c|c|c|c|c|}
\hline Skeletal Part & $\begin{array}{l}\text { Fraction } \\
\text { Analyzed }\end{array}$ & $\frac{\% \text { Dose }}{\text { Part }}$ & $\frac{\% \text { Dose }}{\mathrm{g} \text { Wet Bone }}$ & $\frac{\text { Ashed Wt. }}{\text { Wet Wt. }}$ & $\begin{array}{c}\text { Relative } \\
\text { Conc. }\end{array}$ \\
\hline Skull & $1 / 2$ & 5.62 & 0.0505 & 0.412 & 0.61 \\
\hline $\begin{array}{l}\text { Mandibles } \\
\text { Cervical }\end{array}$ & $1 / 2$ & 2.50 & 0.0546 & 0.528 & 0.66 \\
\hline $\begin{array}{l}\text { Vertebrae } \\
\text { Thoracic }\end{array}$ & 0 & 2.10 & 0.0505 & 0.373 & 0.71 \\
\hline $\begin{array}{l}\text { Vertebrae } \\
\text { Lumbar }\end{array}$ & $7 / 13$ & 5.61 & 0.131 & 0.310 & 1.58 \\
\hline $\begin{array}{l}\text { Vertebrae } \\
\text { Caudal }\end{array}$ & $2 / 7$ & 5.48 & 0.170 & 0.312 & 2.05 \\
\hline Vertebrae & $15 / 15$ & 0.24 & 0.0178 & 0.125 & 0.21 \\
\hline Paws* & $2 / 4$ & 1.81 & 0.0363 . & 0.373 & 0.44 \\
\hline Radii & $1 / 2$ & 0.49 & 0.0408 & 0.445 & 0.49 \\
\hline Ulnae & $1 / 2$ & 0.54 & 0.0467 & 0.399 & 0.56 \\
\hline Humeri & $1 / 2$ & 7.4 .5 & 0.247 & 0.431 & 2.98 \\
\hline Tibiae-Fibulae & $1 / 2$ & 1.40 & 0.0537 & 0.411 & 0.65 \\
\hline Femora & $1 / 2$ & 3.42 & 0.110 & 0.418 & 1.33 \\
\hline Pelvis & $1 / 2$ & ]. .88 & 0.0824 & 0.401 & 1.00 \\
\hline Scapulae & $1 / 2$ & 1.98 & 0.0767 & 0.316 & 0.93 \\
\hline Ribs & $\cdot 12 / 26$ & 4.96 & 0.0811 & 0.306 & 1.07 \\
\hline Sternum & $1 / 1$ & 0.39 & 0.113 & 0.194 & 1.37 \\
\hline Sacrum & 0 & 1.19 & 0.184 & 0.373 & 2.22 \\
\hline Total & & $47 \cdot 1$ & 0.0827 & 0.373 & 1.00 \\
\hline
\end{tabular}

* Wet bone not weighed - Estimated using average ashed wt/wet wt for this dog.

** Fraction of ${ }^{239}$ Pu retained by skeletal part Fraction of skeletal wet weight in part 
Table 10

T33P1

Wt. at.Injection: $10700(\mathrm{~g})$

Inj. to Death: 375 (days)

Wt. of Wet Skeleton: 969 (g)

Wt. of Ashed Skeleton: 374 (g)

\begin{tabular}{|c|c|c|c|c|c|}
\hline Skeletal Part & Fraction & \% Dose & $\%$ Dose & Ashed Wt. & Relati \\
\hline & Analyzed & Part & g Wet Bone & Wet Wt. & Conc \\
\hline Skull & $1 / 2$ & 4.25 & 0.0248 & 0.407 & 0.57 \\
\hline Mandibles & $1 / 2$ & 1.25 & 0.017 .6 & 0.540 & 0.41 \\
\hline Cervical & & & & & \\
\hline Vertebrae & $4 / 7$ & 2.02 & 0.0316 & 0.428 & 0.73 \\
\hline Thoracic & & & & & \\
\hline Vertebrae & $6 / 13$ & 6.00 & 0.0902 & 0.332 & 2.07 \\
\hline Lumbar & & & & & \\
\hline Vertebrae & $3 / 7$ & 4.82 & 0.0822 & 0.375 & 1.89 \\
\hline $\begin{array}{l}\text { Caudal } \\
\text { Vertebrae }\end{array}$ & & & & & \\
\hline $\begin{array}{l}\text { vertebrae } \\
\text { Paws* }\end{array}$ & $15 / 15$ & 0.22 & 0.0080 & 0.121 & 0.18 \\
\hline Radii & $\begin{array}{l}2 / 4 \\
1 / 2\end{array}$ & 1.44 & 0.0136 & 0.386 & 0.31 \\
\hline Ulnae & $1 / 2$ & 0.39 & 0.0193 & 0.485 & 0.45 \\
\hline Humer $i$ & $\begin{array}{l}1 / 2 \\
1 / 2\end{array}$ & 0.41 & 0.0184 & 0.483 & 0.43 \\
\hline Tibiae-Fibulae & $1 / 2$ & 3.00 & 0.0950 & 0.435 & 2.15 \\
\hline Femora & $\begin{array}{l}1 / 2 \\
1 / 2\end{array}$ & $1 \cdot 21$ & $0.0<3.0$ & 0.452 & 0.54 \\
\hline Pelvis & $\begin{array}{l}1 / 2 \\
1 / 2\end{array}$ & 3.30 & 0.0004 & 0.425 & 1.39 \\
\hline Scapulae & $1 / 2$ & 2.93 & 0.0601 & $0.4<0$ & 1.5 \\
\hline Ribs & $\begin{array}{l}1 / 2 \\
13 / 26\end{array}$ & 2.01 & 0.0540 & 0.406 & 1.24 \\
\hline Sternum & $\begin{array}{l}13 / 26 \\
1 / 1\end{array}$ & 5.14 & 0.0525 & 0.301 & 1.2 \\
\hline Sacrum & $\begin{array}{l}1 / 1 \\
0\end{array}$ & $\begin{array}{l}1.01 \\
0.01\end{array}$ & 0.05306 & $\begin{array}{l}0.1<0 \\
0.186\end{array}$ & $\begin{array}{l}1.27 \\
2.22\end{array}$ \\
\hline & & & & & \\
\hline Total. & & $42 \cdot 1$ & 0.043 .5 & 0.386 & 1.00 \\
\hline
\end{tabular}

* Wet bone not weighed - Estimated using average ashed wt/wet wt for this dog.

** Fraction of ${ }^{239} \mathrm{Pu}$ retained by skeletal part Fraction of skeletal wet weight in part 
Table 11

T39Pl.

Wt. at Injection: $10700(\mathrm{~g})$

Inj. to Death: $\quad 376$ (days)

Wt. of Wet Skeleton: 822

Wt. of Ashod Skeleton: 371

(g)

(g)

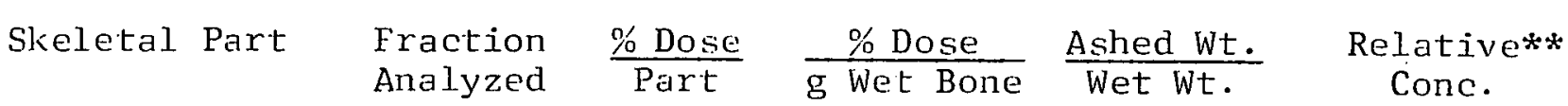

\begin{tabular}{lccccc}
\hline $\begin{array}{l}\text { Skull } \\
\text { Mandibles }\end{array}$ & $1 / 2$ & 2.83 & 0.0210 & 0.462 & 0.55 \\
$\begin{array}{l}\text { Cervical } \\
\quad \text { Vertebrae }\end{array}$ & $1 / 2$ & 0.67 & 0.0128 & 0.544 & 0.33 \\
$\begin{array}{l}\text { Thoracic } \\
\quad \text { Vertebrae }\end{array}$ & $4 / 7$ & 2.81 & 0.0625 & 0.638 & 1.64 \\
$\begin{array}{l}\text { Lumbar } \\
\quad \text { Vertebrae }\end{array}$ & $3 / 13$ & 5.49 & 0.0764 & 0.320 & 2.00 \\
$\begin{array}{l}\text { Caudal } \\
\quad \text { Vertebrae }\end{array}$ & $15 / 15$ & 0.36 & 0.0124 & 0.188 & 2.11 \\
$\begin{array}{l}\text { Paws* } \\
\text { Radii }\end{array}$ & $2 / 4$ & 1.22 & 0.0156 & 0.45 .1 & 0.32 \\
Ulnae & $1 / 2$ & 0.21 & 0.0116 & 0.506 & 0.31 \\
Humeri & $1 / 2$ & 0.27 & 0.0132 & 0.526 & 0.35 \\
Tibiae-Fibulae & $1 / 2$ & 3.42 & 0.0705 & 0.463 & 1.85 \\
Femora & $1 / 2$ & 0.91 & 0.0185 & 0.491 & 0.48 \\
$\begin{array}{l}\text { Pelvis } \\
\text { Scapulae }\end{array}$ & $1 / 2$ & 3.04 & 0.0594 & 0.463 & 1.56 \\
Ribs & $1 / 2$ & 2.52 & 0.0632 & 0.486 & 1.65 \\
Sternum & $1 / 2$ & 1.56 & 0.0510 & 0.445 & 1.34 \\
Sacrum & $13 / 26$ & 4.01 & 0.0485 & 0.366 & 1.27 \\
Total & 0 & 0.64 & 0.0836 & 0.172 & 2.20 \\
& 0 & 0.80 & 0.0850 & 0.451 & 2.22 \\
\hline
\end{tabular}

* Wet bone not weighed - Estimated using average ashed wt/wet wt for this dog.

** Fraction of ${ }^{239} \mathrm{Pu}$ retained by skeletal part

Fraction of skeletal wet weight in part 
Table 12

T25P1

Wt. at Injection: $13800(\mathrm{~g})$

Wt. of Wet Skeleton: 95.3 (g)

Inj. to Death: . 467 (days)

Wt. of Ashed Skeleton: 398 (g)

Skeletal Part $\begin{aligned} & \text { Fraction } \\ & \text { Analyzed }\end{aligned} \frac{\% \text { Dose }}{\text { Part }} \frac{\% \text { Dose }}{\mathrm{g} \text { Wet Bone }} \frac{\text { Ashed Wt. }}{\text { Wet Wt. }} \quad \begin{gathered}\text { Relative** } \\ \text { Conc. }\end{gathered}$

\begin{tabular}{|c|c|c|c|c|c|}
\hline SkuLl & $1 / 2$ & 3.90 & 0.0244 & 0.442 & 0.55 \\
\hline $\begin{array}{l}\text { Mandibles } \\
\text { Cervical }\end{array}$ & $i / 2$ & 1.19 & 0.0193 & 0.538 & 0.44 \\
\hline Vertebrae & $4 / 7$ & 1.94 & 0.0305 & 0.493 & 0.69 \\
\hline $\begin{array}{l}\text { Thoracic } \\
\quad \text { Vertebrae }\end{array}$ & $7 / 13$ & 5.91 & 0.0816 & 0.371 & 1.85 \\
\hline $\begin{array}{l}\text { Lumbar } \\
\text { Vertebrae } \\
\text { Caudal }\end{array}$ & $3 / 7$ & 4.41 & 0.0721 & 0.433 & 1.63 \\
\hline Vertebrae & $15 / 15$ & 0.61 & 0.0717 & 0.165 & 1.63 \\
\hline $\begin{array}{l}\text { Paws } \\
\text { Radii }\end{array}$ & $\begin{array}{l}2 / 4 \\
1 / 2\end{array}$ & $\begin{array}{l}2.50 \\
0.86\end{array}$ & $\begin{array}{l}0.0246 \\
0.0372\end{array}$ & $\begin{array}{l}0.418 \\
0.476\end{array}$ & $\begin{array}{l}0.56 \\
0.84\end{array}$ \\
\hline Ulnae & $1 / 2$ & $0.54^{\circ}$ & 0.0211 & 0.477 & 0.48 \\
\hline Humeri ${ }^{2}$ & $1 / 2$ & 3.84 & 0.0713 & 0.473 & 1.62 \\
\hline Tibiae-Fibulae & $1 / 2$ & 1.64 & 0.0291. & 0.462 & 0.66 \\
\hline Femora & $1 / 2$ & 3.30 & 0.0564 & 0.439 & 1.28 \\
\hline Pelvis & $1 / 2$ & 2.82 & 0.0561 & 0.442 & 1.27 \\
\hline Scapulae & $1 / 2$ & 1.77 & 0.0465 & 0.416 & 1.06 \\
\hline Ribs & $13 / 26$ & 5.10 & 0.0527 & 0.338 & 1.20 \\
\hline Sternum & 0 & 0.64 & 0.0648 & 0.172 & 1.47 \\
\hline Sacrum & 0 & 1.05 & 0.0962 & 0.418 & 2.19 \\
\hline Total & & 42.0 & 0.0441 & 0.418 & 1.00 \\
\hline
\end{tabular}

- Wet weights obtained on only these two parts. Other wet weights are estimated from ashed wt/wet weight average of the other animals in this series.

* Fraction of ${ }^{39} \mathrm{Pu}$ retained by skeletal part Fraction of skeletal wet weight in part 
Tuble L3

T28PI.

Wt. at Injection: $10500(\mathrm{~g})$

Inj. to Death: 559 (d.ays)

Wt. of Wet Skeleton: 799 (g)

Wt. of: Ashed Skeleton: 31.8 (g)

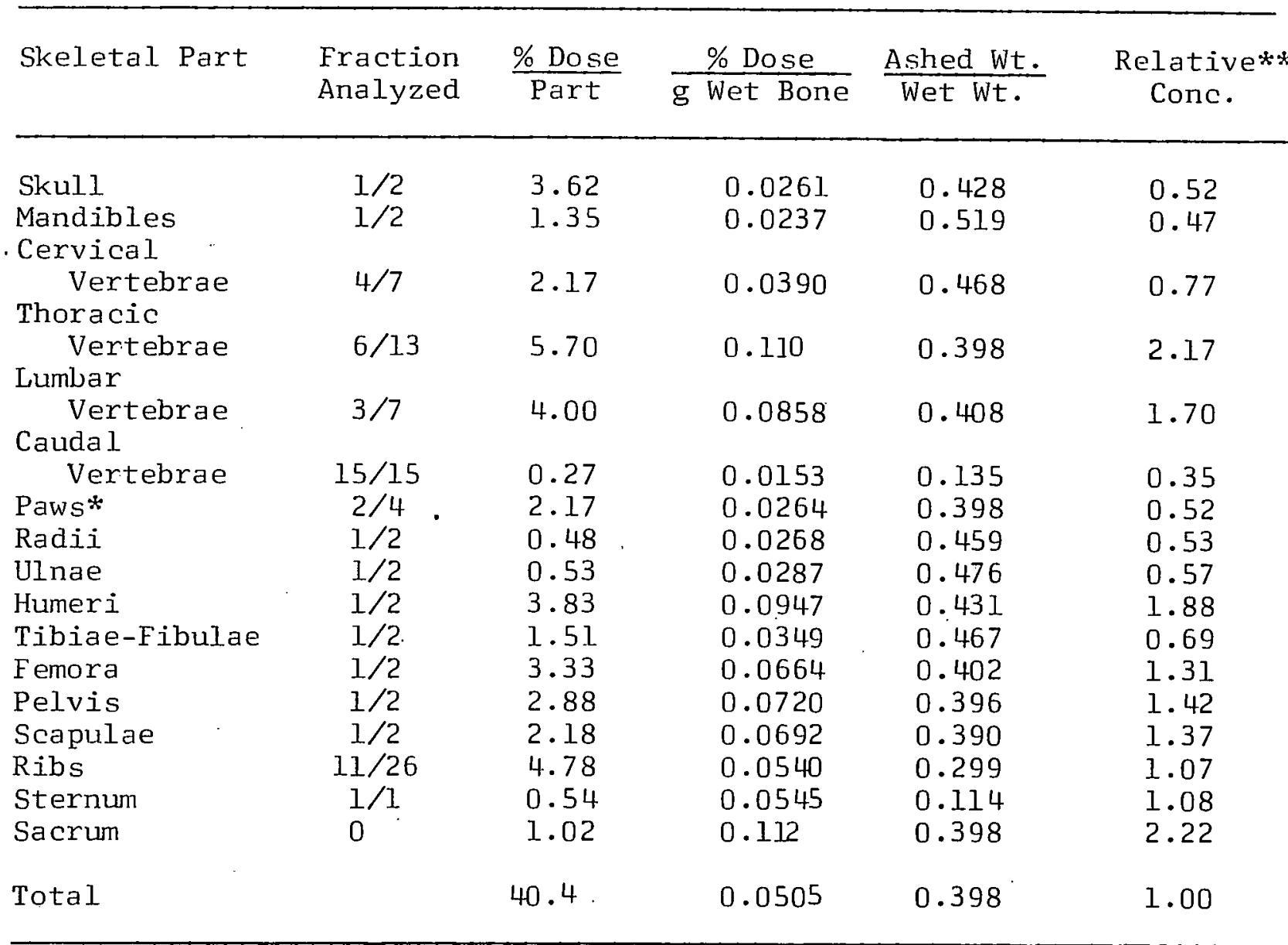

* Wet bone not weighed - Estimated using average ashed wt/wet wt for this dog.

** Fraction of 239 Pu retained by skeletal part

Fraction of skeletal wet weight in part 
Table 14

$\mathrm{T} 26 \mathrm{P} 1$

Wt. at Injection: $12000(\mathrm{~g})$

Inj. to Death: 647 (days)

Wt. of Wet Skeleton: $\quad 793$ (g)

Wt. of Ashed Skeleton: 325 (g)

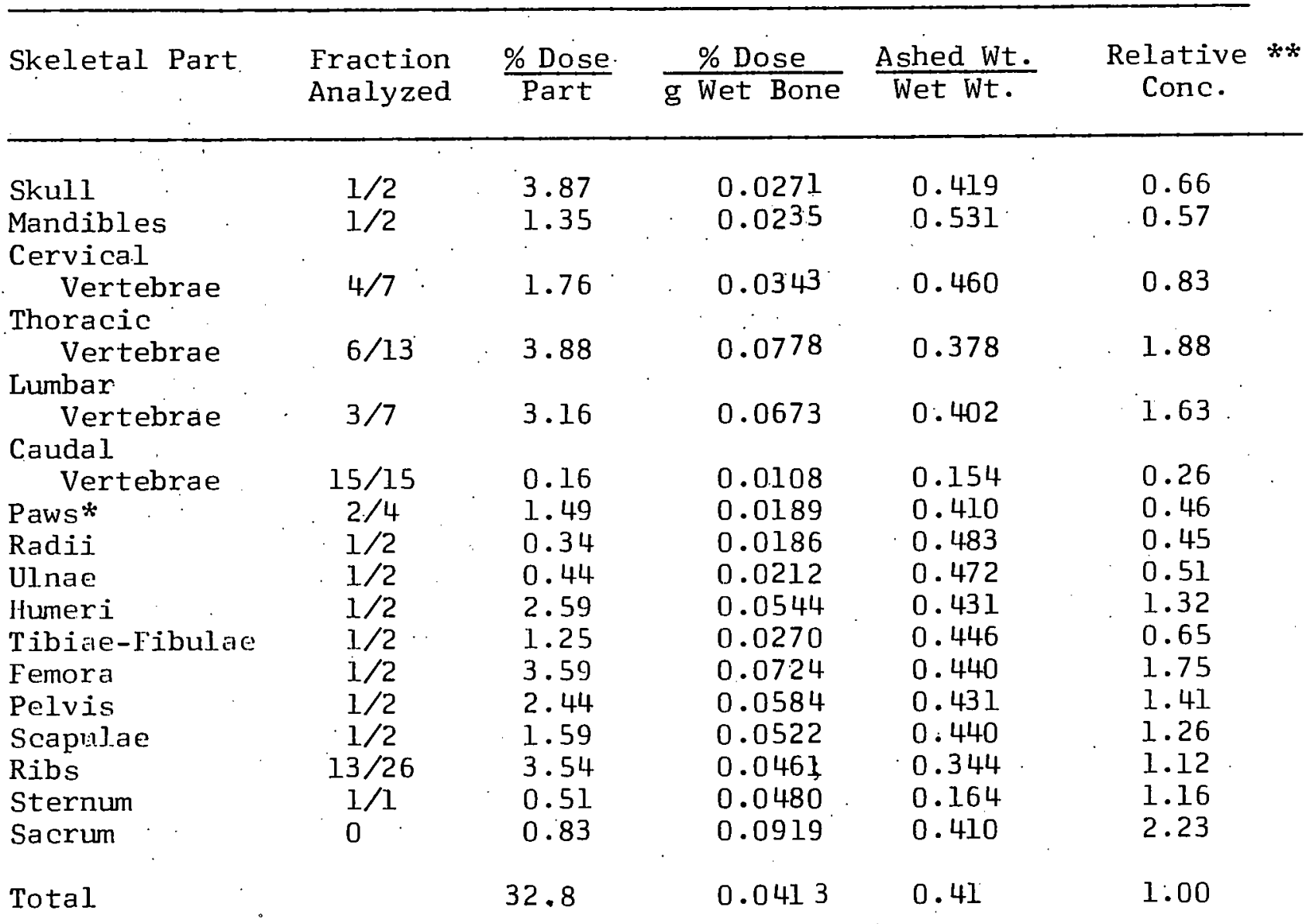

* Wet bone not weighed - Estimated using average ashed wt/wet wt for this dog.

* Fraction of 239 pu retained by skeletal part Fraction of skeletal wet weight in part 
Table 15

T3 4.P?

Wt. at Injection:

Inj. to Death: $9680(\mathrm{~g})$

746 (days)
Wt. of: Wet Skeleton: $\quad 707$

Wt. of Ashed Skeleton: 296 (g)

(g)

\begin{tabular}{|c|c|c|c|c|c|}
\hline \multirow[t]{2}{*}{ Skeletal Part } & \multirow{2}{*}{$\begin{array}{l}\text { Fraction } \\
\text { Analyzed }\end{array}$} & \multirow{2}{*}{$\frac{\% \text { Dose }}{\text { Part }}$} & $\%$ Dose & \multirow{2}{*}{$\frac{\text { Ashed Wt. }}{\text { Wet Wt. }}$} & \multirow{2}{*}{$\begin{array}{l}\text { Relative** } \\
\text { Conc. }\end{array}$} \\
\hline & & & $g$ Wet Bone & & \\
\hline Skull. & $1 / 2$ & 4.13 & 0.0327 & 0.428 & 0.56 \\
\hline Mandibles & $1 / 2$ & 1.43 & 0.0270 & 0.530 & 0.52 \\
\hline Cervical & & & & & \\
\hline Vertebrae & $3 / 7$ & 1.84 & 0.0393 & 0.496 & 0.75 \\
\hline Thoracic & & & & & \\
\hline Vertebrae & $5 / 13$ & 4.48 & 0.102 & 0.419 & 1.96 \\
\hline Lumbar & & & & & \\
\hline $\begin{array}{l}\text { Vertebrae } \\
\text { Caudal }\end{array}$ & $1 . / 7$ & 3.26 & 0.0869 & 0.426 & 1.60 \\
\hline Vertebrae & $15 / 15$ & 0.26 & 0.0154 & 0.131 & 0.30 \\
\hline Paws* & $2 / 4$ & 1.90 & 0.0266 & 0.419 & 0.51 \\
\hline Radii & $1 / 2$ & 0.52 & 0.0305 & 0.485 & 0.58 \\
\hline Ulnae & $1 / 2$ & 0.60 & 0.0317 & 0.484 & 0.61 \\
\hline Humeri & 0 & 4.37 & 0.104 & 0.419 & 2.00 \\
\hline Tibiae-Fibulae & $1 / 2$ & 1.59 & 0.0379 & 0.476 & 0.72 \\
\hline Femora & $1 / 2$ & 2.70 & 0.061 .9 & 0.448 & 0.77 \\
\hline Pelvis & $1 / 2$ & 2.45 & 0.0704 & 0.444 & 1.35 \\
\hline Scapulae & $1 / 2$ & 1.92 & 0.0716 & 0.428 & 1.37 \\
\hline Ribs & $13 \not 26$ & 4.10 & 0.0574 & 0.352 & 1.10 \\
\hline Sternum & $1 / 1$ & 0.38 & 0.0680 & 0.185 & 1.30 \\
\hline Sacrum & 0 & 0.94 & 0.116 & 0.419 & 2.23 \\
\hline Total. & & 36.9 & 0.0522 & 0.4 .19 & 1.00 \\
\hline
\end{tabular}

* Wet bone not weighed - Estimated using average ashed wt/wet wt for this dog.

* * Fraction of 239 Pu retained by skeletal part

Fraction of skeletal wet weight in part 
Table 16

$\mathrm{T} 40 \mathrm{Pl}$

Wt. at Injection: $\quad 9920(\mathrm{~g})$

Wt. of Wet Skeleton: 848 (g)

Inj. to Death: 769 (days)

Wt. of Ashed Skeleton: 357 (g)

Skeletal Part $\begin{aligned} & \text { Fraction } \\ & \text { Analyzed }\end{aligned} \frac{\% \text { Dose }}{\text { Part }} \frac{\% \text { Dose }}{\mathrm{g} \text { Wet Bone }} \frac{\text { Ashed Wt. }}{\text { Wet Wt. }} \begin{gathered}\text { Relative** } \\ \text { Conc. }\end{gathered}$

\begin{tabular}{|c|c|c|c|c|c|}
\hline $\begin{array}{l}\text { Skull } \\
\text { Mandibles }\end{array}$ & $\begin{array}{l}1 / 2 \\
1 / 2\end{array}$ & $\begin{array}{l}2.90 \\
0.99\end{array}$ & $\begin{array}{l}0.0224 \\
0.0180\end{array}$ & $\begin{array}{l}0.430 \\
0.520\end{array}$ & $\begin{array}{l}0.62 \\
0.50\end{array}$ \\
\hline \multicolumn{6}{|l|}{ Cervical } \\
\hline Vertebrae & $4 / 7$ & 1.62 & 0.0272 & 0.477 & 0.75 \\
\hline \multicolumn{6}{|l|}{ Thoracic } \\
\hline Vertebrae & $6 / 13$ & 5.33 & 0.0818 & 0.373 & 2.25 \\
\hline \multicolumn{6}{|l|}{ Lumbar } \\
\hline Vertebrae & $3 / 7$ & 3.96 & 0.0705 & 0.420 & 1.94 \\
\hline \multicolumn{6}{|l|}{ Caudal } \\
\hline Vertebrae & $15 / 15$ & 0.20 & 0.0130 & 0.166 & 0.37 \\
\hline Paws* & $2 / 4$ & 1.44 & 0.0175 & 0.421 & 0.48 \\
\hline Radii & $1 / 2$ & 0.38 & 0.0190. & 0.484 & 0.52 \\
\hline Ulnae & $1 / 2$ & 0.35 & 0.0159 & 0.492 & 0.44 \\
\hline Humeri & $1 / 2$ & 2.81 & 0.0550 & 0.451 & 1.51 \\
\hline Tibiae-Fibulae & $1 / 2$ & 1.05 & 0.0200 & 0.451 & 0.55 \\
\hline Femora & $1 / 2$ & 1.80 & 0.0324 & 0.448 & 0.89 \\
\hline Pelvis & $1 / 2$ & 2.60 & 0.0571 & 0.460 & 1.57 \\
\hline Scapulae & $1 / 2$ & 1.73 & 0.0511 & 0.426 & 1.40 \\
\hline Ribs & $13 / 26$ & 2.19 & 0.0255 & 0.357 & 0.70 \\
\hline Sternum & $1 / 1$ & 0.75 & 0.0882 . & 0.196 & 2.42 \\
\hline Sacrum & 0 & 0.78 & 0.0810 & 0.421 & 2.22 \\
\hline Total & & 30.9 & 0.0364 & 0.421 & 1.00 \\
\hline
\end{tabular}

* Wet bone not weighed - Estimated using average ashed wt/wet wt for this dog.

* Fraction of ${ }^{239} \mathrm{Pu}$ retained by skeletal part Fraction of skeletal wet weight in part 
Table 17

Average Skeletal Retention and Distribution for Four 3-Level

Plutonium Beagles 40 to 560 Days after Injection

\begin{tabular}{|c|c|c|c|c|c|c|c|c|}
\hline \multirow[t]{2}{*}{ Skeletal Part } & \multicolumn{2}{|c|}{$\frac{\% \text { Dose }}{\text { Part }}$} & \multicolumn{2}{|c|}{$\%$ Dose } & \multicolumn{2}{|c|}{$\frac{\text { Ashed Wt. }}{\text { Wet Wt. }}$} & \multicolumn{2}{|c|}{$\begin{array}{c}\text { Relative } \\
\text { Concentration }\end{array}$} \\
\hline & Av. & FSD* & $A v$. & FSD * & $A v$. & $\mathrm{FSD} *$ & Av. & $\mathrm{FSD} *$ \\
\hline Skull & 3.38 & 0.074 & 0.0291 & 0.30 & 0.468 & 0.065 & 0.52 & 0.11 \\
\hline $\begin{array}{l}\text { Mandibles } \\
\text { Cervical }\end{array}$ & 1.18 & 0.12 & 0.0223 & 0.32 & 0.554 & 0.025 & 0.40 & 0.14 \\
\hline $\begin{array}{l}\text { Vertebrae } \\
\text { Thoracic }\end{array}$ & 2.17 & 0.098 & 0.0398 & 0.22 & 0.490 & 0.075 & 0.72 & 0.088 \\
\hline $\begin{array}{l}\text { Vertebrae } \\
\text { Lurnbar }\end{array}$ & 6.72 & 0.15 & 0.122 & 0.20 & 0.404 & 0.10 & 2.22 & 0.11 \\
\hline $\begin{array}{l}\text { Vertebrae } \\
\text { Caudal }\end{array}$ & 5.20 & 0.21 & 0.114 & 0.20 & 0.400 & 0.11 & 1.87 & 0.19 \\
\hline $\begin{array}{l}\quad \text { Vertebrae } \\
\text { Paws } \\
\text { Radii } \\
\text { Ulnae } \\
\text { Humeri } \\
\text { Tibiae- }\end{array}$ & $\begin{array}{l}0.28 \\
1.40 \\
0.44 \\
0.45 \\
3.61\end{array}$ & $\begin{array}{l}0.14 \\
0.17 \\
0.083 \\
0.17 \\
0.12\end{array}$ & $\begin{array}{l}0.0119 \\
0.0183 \\
0.0242 \\
0.0228 \\
0.0676\end{array}$ & $\begin{array}{l}0.062 \\
0.33 \\
0.21 \\
0.25 \\
0.16\end{array}$ & $\begin{array}{l}0.151 \\
0.429 \\
0.498 \\
0.470 \\
0.386\end{array}$ & $\begin{array}{l}0.062 \\
0.059 \\
0.081 \\
0.11 \\
0.099\end{array}$ & $\begin{array}{l}0.22 \\
0.33 \\
0.44 \\
0.42 \\
1.23\end{array}$ & $\begin{array}{l}0.14 \\
0.33 \\
0.12 \\
0.26 \\
0.13\end{array}$ \\
\hline $\begin{array}{l}\quad \text { Fibulae } \\
\text { Femora } \\
\text { Pelvis } \\
\text { Scapulae } \\
\text { Ribs } \\
\text { Sternum }\end{array}$ & $\begin{array}{l}1.71 \\
3.71 \\
3.35 \\
2.40 \\
5.26 \\
1.28\end{array}$ & $\begin{array}{l}0.19 \\
0.15 \\
0.077 \\
0.16 \\
0.15 \\
0.30\end{array}$ & $\begin{array}{l}0.0372 \\
0.0719 \\
0.0862 \\
0.0762 \\
0.0698 \\
0.0921\end{array}$ & $\begin{array}{l}0.23 \\
0.19 \\
0.23 \\
0.59 \\
0.31 \\
0.12\end{array}$ & $\begin{array}{l}0.475 \\
0.451 \\
0.473 \\
0.448 \\
0.360 \\
0.182\end{array}$ & $\begin{array}{l}0.075 \\
0.089 \\
0.070 \\
0.052 \\
0.089 \\
0.095\end{array}$ & $\begin{array}{l}0.68 \\
1.30 \\
1.56 \\
1.49 \\
1.24 \\
1.70\end{array}$ & $\begin{array}{l}0.16 \\
0.055 \\
0.082 \\
0.17 \\
0.089 \\
0.16\end{array}$ \\
\hline
\end{tabular}

* Fractional Standard Deviation 
Table 18

Average Skeletal Retention and Distribution for Eleven 1-Level Plutonium Beagles 35 to 769 Days after Injection.

\begin{tabular}{|c|c|c|c|c|c|c|c|c|}
\hline \multirow[t]{2}{*}{ Skeletal Part } & \multicolumn{2}{|c|}{$\frac{\% \text { Dose }}{\text { Part }}$} & \multicolumn{2}{|c|}{$\%$ Dose } & \multicolumn{2}{|c|}{$\frac{\text { Ashed Wt. }}{\text { Wet Wt. }}$} & \multicolumn{2}{|c|}{$\begin{array}{c}\text { Relative } \\
\text { Concentration }\end{array}$} \\
\hline & $A v$ & FSD* & Av. & $\mathrm{FSD} *$ & Av. & FSD* & Av. & $\mathrm{FSD} *$ \\
\hline Skull & 3.73 & 0.22 & 0.0286 & 0.29 & 0.440 & 0.061 & 0.55 & 0.14 \\
\hline $\begin{array}{l}\text { Mandibles } \\
\text { Cervical }\end{array}$ & 1.25 & 0.38 . & 0.0237 & 0.47 & 0.537 & 0.027 & 0.45 & 0.25 \\
\hline $\begin{array}{l}\text { Vertebrae } \\
\text { Thoracic }\end{array}$ & 2.09 & 0.16 & 0.0405 & 0.25 & 0.484 & 0.132 & 0.81 & 0.34 \\
\hline $\begin{array}{l}\text { Vertebrae } \\
\text { Lumbar }\end{array}$ & 5.68 & 0.18 & 0.108 & 0.27 & 0.377 & 0.109 & 2.06 & 0.12 \\
\hline $\begin{array}{l}\text { Vertebrae } \\
\text { Caudal }\end{array}$ & 4.67 & 0.20 & 0.0971 & 0.32 & 0.416 & 0.102 & 1.84 & 0.096 \\
\hline Vertebrae & 0.28 & 0.44 & 0.0202 & 0.87 & 0.169 & 0.259 & 0.41 & 0.99 \\
\hline Paws & 1.78 & 0.22 & 0.0229 & 0.28 & 0.418 & 0.062 & 0.44 & 0.17 \\
\hline Radii & 0.45 & 0.36 & 0.0248 & 0.36 & 0.472 & 0.073 & 0.48 & 0.32 \\
\hline Ulnae & 0.46 & 0.21 & 0.0242 & 0.38 & 0.479 & 0.066 & 0.46 & 0.21 \\
\hline $\begin{array}{l}\text { Humeri } \\
\text { Tibiae- }\end{array}$ & 4.40 & 0.31 & 0.101 & 0.52 & 0.442 & 0.049 & 1.85 & 0.24 \\
\hline Fibulae & 1.53 & 0.28 & 0.0348 & 0.34 & 0.463 & 0.049 & 0.67 & 0.20 \\
\hline Femora : & 3.30 & 0.22 & 0.0686 & 0.29 & 0.439 & 0.043 & 1.33 & 0.17 \\
\hline Pelvis & 2.79 & 0.17 & 0.0713 & 0.17 & 0.442 & 0.067 & 1.39 & 0.12 \\
\hline Scapulae & 2.03 & 0.21 & 0.0669 & 0.26 & 0.414 & 0.087 & 1.29 & 0.14 \\
\hline Ribs & 4.68 & 0.25 & 0.0581 & 0.28 & 0.338 & 0.072 & 1.12 & 0.14 \\
\hline Sternum & 0.61 & 0.29 & 0.0846 & 0.40 & 0.171 & 0.168 & 1.61 & 0.31 \\
\hline
\end{tabular}

* Fractional Standard Deviation 
Table 19

Average Skeletal Retention and Distribution for Fifteen One and Three Level Plutonium Beagles 35 to 769 Days after Injection

\begin{tabular}{|c|c|c|c|c|c|c|c|c|}
\hline \multirow[t]{2}{*}{ Skeletal Part } & \multicolumn{2}{|c|}{$\frac{\% \text { Dose }}{\text { Part }}$} & \multicolumn{2}{|c|}{$\frac{\% \text { Dose }}{g \text { Wet Bone }}$} & \multicolumn{2}{|c|}{$\frac{\text { Ashed Wt. }}{\text { Wet Wt. }}$} & \multicolumn{2}{|c|}{$\begin{array}{l}\text { Relative } \\
\text { Concentration }\end{array}$} \\
\hline & Av & FSD* & Av. & $\mathrm{FSD} *$ & Av. & $\mathrm{FSD} *$ & Av. & $F S D *$ \\
\hline $\begin{array}{l}\text { Skull } \\
\text { Mandibles } \\
\text { Cervical }\end{array}$ & $\begin{array}{l}3.64 \\
1.23\end{array}$ & $\begin{array}{l}0.20 \\
0.33\end{array}$ & $\begin{array}{l}0.0286 \\
0.0233\end{array}$ & $\begin{array}{l}0.29 \\
0.43\end{array}$ & $\begin{array}{l}0.447 \\
0.542\end{array}$ & $\begin{array}{l}0.067 \\
0.029\end{array}$ & $\begin{array}{l}0.54 \\
0.43\end{array}$ & $\begin{array}{l}0.13 \\
0.23\end{array}$ \\
\hline $\begin{array}{l}\text { Vertebrae } \\
\text { Thoracic }\end{array}$ & 2.11 & 0.14 & 0.403 & 0.23 & 0.485 & 0.12 & 0.79 & 0.30 \\
\hline $\begin{array}{l}\text { Vertebrae } \\
\text { Lumbar }\end{array}$ & 5.96 & 0.18 & 0.111 & 0.26 & 0.384 & 0.11 & 2.10 & 0.12 \\
\hline $\begin{array}{l}\text { Vertebrae } \\
\text { Caudal }\end{array}$ & 4.72 & 0.20 & 0.0986 & 0.29 & 0.412 & 0.10 & 1.85 & 0.12 \\
\hline Vertebrae & 0.28 & 0.38 & 0.0180 & 0.85 & 0.164 & 0.38 & 0.36 & 0.99 \\
\hline Paws & 1.67 & 0.23 & 0.0217 & 0.30 & 0.421 & 0.060 & 0.41 & 0.23 \\
\hline Radii & 0.44 & 0.31 & 0.0246 & 0.32 & 0.479 & $0: 076$ & 0.47 & 0.29 \\
\hline Ulnae & 0.46 & 0.20 & 0.0238 & 0.34 & 0.485 & 0.060 & 0.45 & 0.22 \\
\hline $\begin{array}{l}\text { Humeri } \\
\text { Tibiae- }\end{array}$ & 4.19 & 0.29 & 0.0920 & 0.51 & 0.428 & 0.085 & 1.69 & 0.28 \\
\hline $\begin{array}{l}\quad \text { Fibulae } \\
\text { Femora } \\
\text { Pelvis } \\
\text { Scapulae } \\
\text { Ribs } \\
\text { Sternum }\end{array}$ & $\begin{array}{l}1.58 \\
3.41 \\
2.94 \\
2.13 \\
4.83 \\
0.79\end{array}$ & $\begin{array}{l}0.25 \\
0.20 \\
0.17 \\
0.21 \\
0.23 \\
0.48\end{array}$ & $\begin{array}{l}0.0351 \\
0.0695 \\
0.0753 \\
0.0694 \\
0.0612 \\
0.0866\end{array}$ & $\begin{array}{l}0.31 \\
0.26 \\
0.20 \\
0.37 \\
0.29 \\
0.33\end{array}$ & $\begin{array}{l}0.466 \\
0.442 \\
0.450 \\
0.423 \\
0.344 \\
0.174\end{array}$ & $\begin{array}{l}0.056 \\
0.056 \\
0.073 \\
0.084 \\
0.080 \\
0.15\end{array}$ & $\begin{array}{l}0.67 \\
1.32 \\
1.44 \\
1.34 \\
1.15 \\
1.64\end{array}$ & $\begin{array}{l}0.19 \\
0.14 \\
0.12 \\
0.16 \\
0.13 \\
0.27\end{array}$ \\
\hline
\end{tabular}

Fractional Standard Deviation 
Table 20

Early Retention and Distribution of ${ }^{239} \mathrm{Pu}$ by

Four 3-Level Beagles ${ }^{a}$ Described by $R=a \cdot e^{b t}$

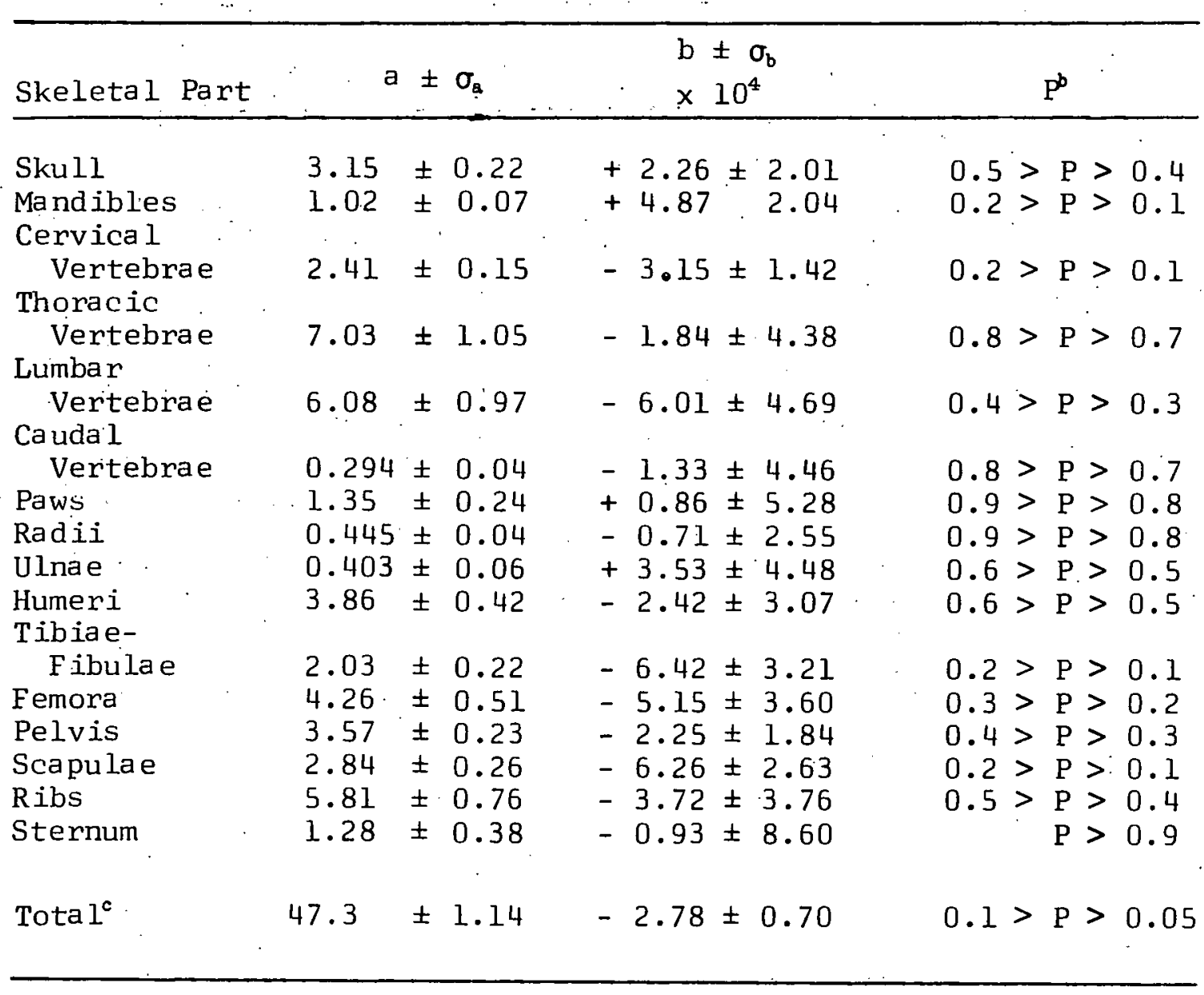

a Interval from injection to death ranged from 40 to 560 days.

brobability that calculated slope, b, does not differ from zero.

c An estimate of the retention by the sacrum is included in this value. 
Táble 21

Early Retention and Distribution of ${ }^{339} \mathrm{Pu}$ by Eleven 1-Level Beagles ${ }^{*}$ Described by $R=a e^{b t}$

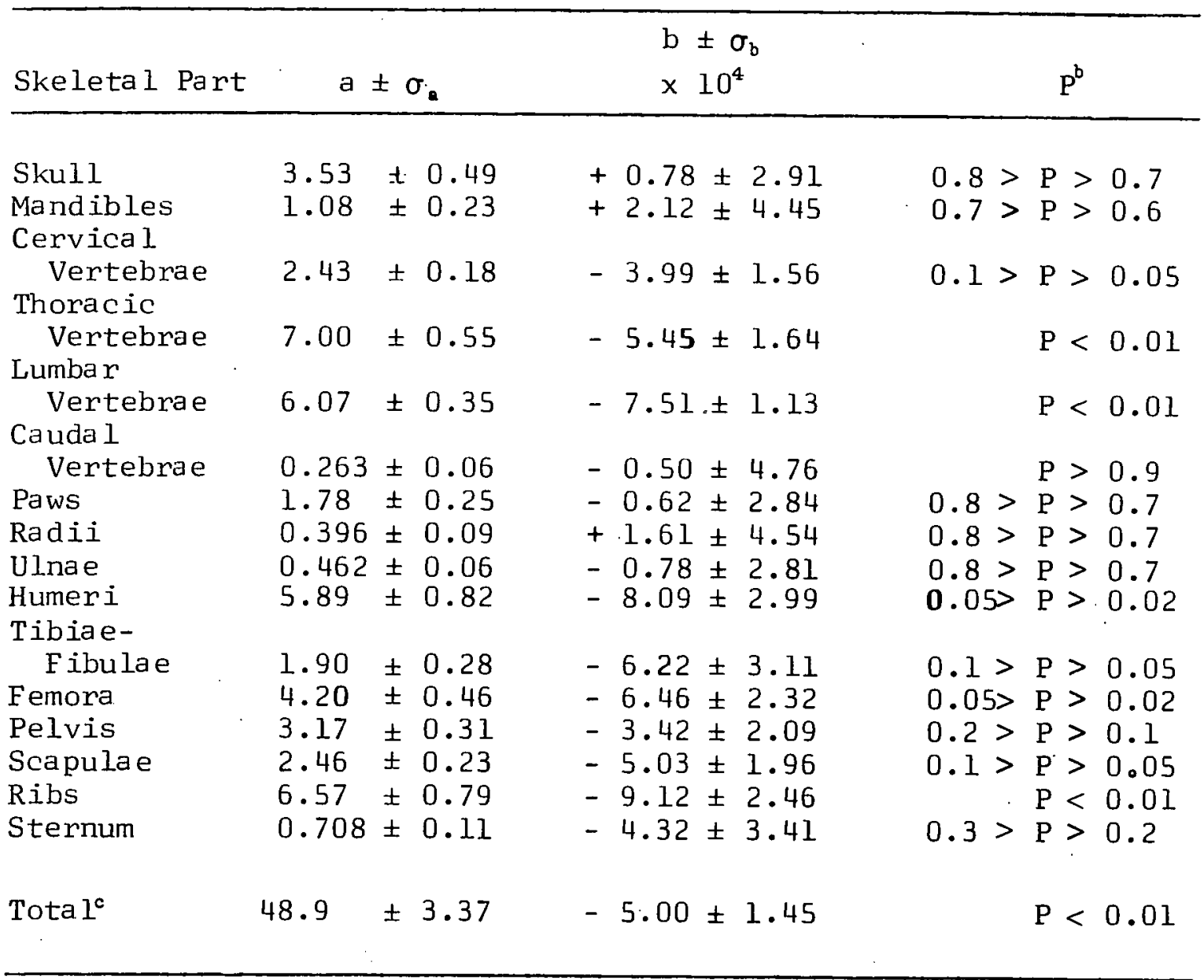

a Interval from injection to death ranged from 35 to 790 days.

b Probability that calculated slope, b, does not differ from zero.

${ }^{c}$ An estimate of the retention by the sacrum is included in this value. 
Table 22

Early Retention and Distribution of $23^{9} \mathrm{Pu}$ by Four 3-Level and Eleven 1-Level Beagles ${ }^{a}$ Described by $R=a e^{b}$

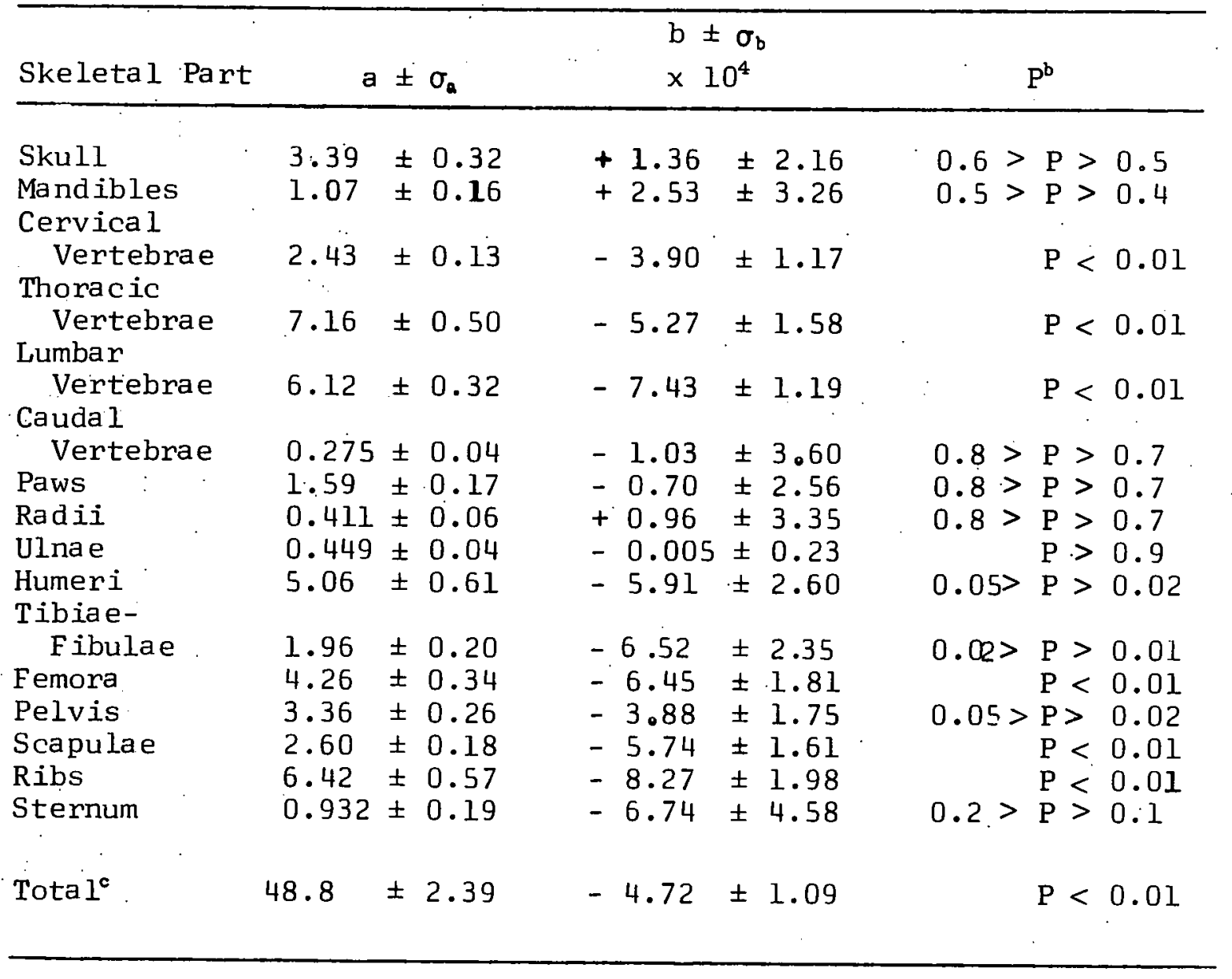

Interval from injection to death ranged from 35 to 769 days.

' Probability that calculated slope, b, does not differ from zero.

cAn estimate of the retention by the sacrum is included in this value. 
Table 23

Distribution of ${ }^{239} \mathrm{Pu}$ at $\mathrm{t} \approx 22$ days

Observed (\% dose) Corrected (\% dose)

Skeleton

Liver

Excreta

Other

Total
$48.9 \pm 3.4$

$32.5 \pm 5.2$

$12.1 \pm 2.1$

2.0

95.6
51

34

13

2

100 


\section{REFERENCES}

1. Betsy J. Stover, D.R. Atherton, and N. Keller: Metabolism of $239 \mathrm{Pu}$ in adult beagle dogs. Radiat. Res. 10:2, 130-147 (1959).

2. Betsy J. Stover, D.R. Atherton, F.W. Bruenger, and D.S. Buster: Further studies of the metabolism of ${ }^{239} \mathrm{Pu}$ in adult beagles. Health Physics 8:6, 589-597 (1962).

3. Betsy J. Stover, David R. Atherton, Friedrich W. Bruenger, and Dawn S. Buster: $239 \mathrm{pu}$ in liver, spleen, and kidneys of the beagle. Health Phys. 14:2, 193-197 (1968).

4. Betsy J. Stover, D.R. Atherton, F.W. Bruenger, and Dawn S. Buster: ${ }^{239} \mathrm{Pu}(\mathrm{IV})$ : Its distribution in the beagle. In Delayed Effects of Bone-Seeking Radionuclides. C.W. Mays et al. Eds., University of Utah Press, Salt Lake City, pp 109-123 (1969).

5. Betsy J. Stover, David R. Atherton, and Dawn S. Buster: Protracted hepatic splenic, and renal retention of $239 \mathrm{pu}$ in the beagle. Health Phys. 20:369-374 (1971):

6. David R. Atherton. EHPA-Scintillator method for the analysis of biological material for small quantities of ${ }^{90} \mathrm{Sr},{ }^{228} \mathrm{Th}$, and ${ }^{239} \mathrm{Pu}$. Research in Radiobiology, University of Utah, C00-119-240, March 1969, pp. 181-187.

7. D.R. Atherton, C.W. Mays, and Betsy J. Stover: Radionuclide distribution in adult beagle bones. Radiobiology Laboratory SemiAnnual Progress Report, C00-217, Sept. 1958, pp. 118-125.

8. Betsy J. Stover, D.R. Atherton, D.S. Buster, and F.W. Bruenger: Retention of $239 \mathrm{Pu}$ (IV) by the young adult beagle. Abstracts of papers for the 19th Annual Meeting of the Radiation Research Society, 1971, p. 97. 
9. W.S.S. Jee, H.Z. Park, and R. Burggraaf: Estimates of residence time of $239 \mathrm{Pu}$ in trabecular bones of beagles. Research in Radiobiology, University of Utah, C00-119-240, March 1969, pp. 188-198. 
THE INTERACTION OF SOME ACTINIDE ELEMENTS WITH BLOOD CONSTITUENTS: D.R. Atherton, F.W. Bruenger and.Betsy J. Stover

The distribution of a number of actinide elements in canine and human blood were studied and compared to extensive, al ready existing data on ${ }^{239} \mathrm{PuIV}$ and ${ }^{241} \mathrm{AmIII}$ in dogs. ${ }^{227} \mathrm{AC},{ }^{228} \mathrm{Th},{ }^{233} \mathrm{~Pa}, 233 \mathrm{UIV}, 233 \mathrm{UVI}$, $137 \mathrm{NpIV},{ }^{237} \mathrm{NpIV}$, and $239 \mathrm{Pulll}$ were used in these studies. Each nuclide in $0.08 \mathrm{M}$ citrate, $\mathrm{pH} 3.5$, was incubated in vitro with canine and/or human whole blood. Cells were removed and evaluated for nuclide retention. Except for $239 \mathrm{puill}$, the concentration of the nuclide in the plasma was at least lox that found with cells. This factor was about 5 for 239 pulli. Following gel-chromatography on G-25, varying percentages of the nuclides were associated with the peak eluting at the void volume. These are ${ }^{227} \mathrm{AC}-42 \%,{ }^{228} \mathrm{Th}-78 \%,{ }^{233} \mathrm{~Pa}-69 \%, 233 \mathrm{UIV}-7 \%, 233 \mathrm{UVI}-9 \%, 237 \mathrm{NpIV}-$ $20 \%, \quad{ }^{237} \mathrm{NpVI}-21 \%$ and $239 \mathrm{Pull}-65 \%$. Nuclides forming strong complexes with inorganic entities $\left(\mathrm{HCO}_{3}{ }^{-}\right)$show limited binding to protein constiuents. Further separation of protein-bound nuclides was achieved by gel-chromatography on gels of lower cross linkage and by anion-exchange procedures. Regions of protein-complex stability were determined in some cases by difference-spectrophotometry. *Abstract of presentation at the Radiation Research Society Meeting,
Boston, May 1971 . 
INTERACTION BETWEEN BLOOD CONSTITUENTS AND SOME ACTINIDES

F. W. Bruenger, D. R. Atherton, W. Stevens and Betsy J. Stover

Abstract: The interaction of a number of actinide elements with constituents of canine and human blood was studied and compared to extensive, already existing data on $239 \mathrm{PuIV}$ and ${ }^{241} \mathrm{Amlll}$ in beagles. ${ }^{228} \mathrm{Th}, 233 \mathrm{~Pa}, 233 \mathrm{U}, 237 \mathrm{~Np}$ and ${ }^{249} \mathrm{Cf}$ were used for these experiments. Each of these nuclides in $0.08 \mathrm{M}$ citrate buffer was incubated in vitro with canine and/or human blood. None of the nuclides had a marked affinity for blood cells. High and low molecular weight components of plasma were separated by gel chromatography on Sephadex G-25 and amounts of nuclide associated with each fraction were evaluated. Binding to plasma proteins was further evaluated by gel chromatography on resins of low cross linkage and by anion exchange chromatography. Nuclides forming strong complexes with inorganic constituents of plasma showed only limited binding to protein constituents. The pH-ranges of protein complex stabllities were determined in some cases by difference spectrophotometry.

\section{INTRODUCT ION}

Considerable differences are observed in the distribution of the actinide elements when these are injected intravenously in citrate buffer of low $\mathrm{pH}$. The reaction at the site of deposition not only depends on the reactivity of certain specific biochemical entities which form stable bonds with the nuclides, but, also, the chemical form of the nuclide when it reaches the deposition site. Nuclides may bind to plasma proteins and form metalloproteins and also may be complexed by the various inorganic constituents of plasma or may simply hydrolize and form polymers. The type of product formed in plasma, its stability, and the molecular size will have a strong influence on the subsequent reaction at the site of deposition. Extensive data on the reaction of plutonium and americium with plasma constituents are available $(1-5)$. Some data are also available for curium(6). 
No at tempt has been made to study and to correlate the interaction of a larger number of these important actinide nuclides with blood constituents. This preliminary communication will provide some comparative information on this subject.

\section{METHODS}

The following nuclides were available for the experiment: $227 \mathrm{Ac}$, ${ }^{228} \mathrm{Th}, 233 \mathrm{~Pa},{ }^{233} \mathrm{U},{ }^{237} \mathrm{~Np},{ }^{239} \mathrm{Pu}, 241 \mathrm{Am}$, and ${ }^{249} \mathrm{Cf}$. Purification (when necessary) and attainment of specific oxidation states were done by s.tandard techniques. Blood was obtained from healthy adult beagles or a healthy male human. The element under study was dissolved in $0.08 \mathrm{M}$ citrate of $\mathrm{pH}-3.5$, and added to the blood sample immediately after drawing. The mixture was then incubated for $30 \mathrm{~min}$. at $40^{\circ} \mathrm{C}$. After incubation, the blood was centrifuged and plasma and cells were separated. Distribution of the nuclides in the blood was determined by the following procedures: separation and purification of cells, gel filtration of plasma on Sephadex G-25 and G-100 - G-200, ion exchange chromatography, and difference spectrophotometry of isolated proteins.

Gel chromatography on Sephadex G-25 was performed on a $1 \mathrm{~cm} \times 35 \mathrm{~cm}$ column. A known quantity of tagged plasma was applied and eluted with a buffer containing $0.1 \mathrm{M}$ TRIS (Tris (hydroxymethyl)aminomethane) and $1 \%$ $\mathrm{NaCl}$. Fractions were collected for protein determination and counting of radioactivity. Gel chromatography on Sephadex G-100 - G-200 was carried out as described earlier(1). Plasma was separated on G-100-G-200 into three protein peaks designated 1, 11 , and 111 in order of descending molecular weight. Fractions comprising the third protein peak were pooled, dialyzed against 0.1 M TRIS, pervaporated to a small volume, and 
rechromatographed on DEAE-anion exchange resin. Anion exchange chromatography was carried out with Sephadex DEAE A-50, equilibrated with $0.05 \mathrm{M}$ TRIS buffer of $\mathrm{pH} 8$. Columns were eluted with a linear salt gradient consisting of $0.1 \mathrm{MTRIS} \rightarrow 0.1 \mathrm{MTRIS}+0.5 \mathrm{M} \mathrm{NaCl}$.

Difference spectra were taken on samples prepared by the following method: An appropriate quantity of purified apo-conalbumin was dissolved in saline for spectrophotometry. Each sample was then divided into two and a sufficient quantity of nuclide was added to one with the other serving as a reference. Both tubes were then adjusted to equal pH-values and readings were taken over an appropriate range on either side of physiological pH. The difference in adsorption seen was due to the interaction of the metal and conalbumin.

\section{RESULTS}

The associations of nuclides with the cellular component of blood were expressed as the ratio of concentration of nuclide in cells to the concentration of nuclide in plasma, $\left(\frac{c \text { cells }}{c_{\text {plasma }}}=\frac{c_{c}}{c_{p}}\right)$. These data are listed in Table 1. The affinity of these elements for blood cells was low. In the case of Pulll the reaction exceeded $10 \%$ but the cause for the relatively strong association is unknown.

The separation of plasma on Sephadex G-25 served two purposes.

1) To separate protein bound nuclides and other high molecular weight material from low molecular weight and largely ionic material. Should a nuclide in this system undergo hydrolysis, its products would also appear in the high $M$. W. region of the chroma togram. 
2) To show the relative affinity of the element for protein as compared to the gel surface measured by resin sectioning. Non-protein bound, ionic nuclide might be lost by surface adsorption on the resin and the estimate of the protein bound material might be too high.

In all but ${ }^{227} \mathrm{Ac},{ }^{228} \mathrm{Th}$, and ${ }^{233} \mathrm{~Pa}$, the peak of protein and high molecular weight material was followed by a peak of high radioactivity about five or six fractions later and this material was not associated with protein. Uranium IV showed the greatest association with material of low molecular weight. The data are given in Table 2. (239pu and $249 \mathrm{Cf}$ are not included in this listing.)

A more detailed study of the distribution of the nuclides in plasma was made by chromatography on gels of low cross linkage, i.e. G-100- G-200. Reproducibility was generally good in this system and as long as plasma was obtained from the same source, little variation between individual. samples was seen. A typical result of this method of separation is seen in Fig. 1. The upper part shows the elution spectrum of beagle plasma tagged with ${ }^{59} \mathrm{Fe}$ and ${ }^{239} \mathrm{PuIV}$ and subjected to gel chromatography on Sephadex G-100-G-200. Both nuclides in this case were administered intravenously in $0.08 \mathrm{M}$ citrate buffer. The solid line shows the familiar three major protein peaks. The small peak to the right represents low molecular weight U. V. light absorbing material, and the dashed and dotted lines represent the plutonium and iron respectively. The peak of ${ }^{59} \mathrm{Fe}$ and $239 \mathrm{Pu}$ are not precisely coincident with protein peak 111 , but are slightly displaced to the left, indicating that the protein-nuclide complex is associated with a minor, slower moving component of peak 111 . 
Material from peak 111 was pooled and rechromatographed on the ion exchange resin DEAE-Sephadex and the results are seen, in the insert. During this operation, the protein of the pooled material was resolved into 2 peaks, transferrin and albumin; Iron appears only with the transferrin peak and, while plutonium is mostly associated with transferrin, a small fraction does appear with the albumin peak. Earlier papers have shown that the most important protein in the transport of PuIV is transferrin, the iron transport protein $(2,3,4)$. The amount of plutonium found associated with the transferrin peak can be altered by changing the degree to which transferrin is saturated with iron: Plutonium can be displaced from the protein by the addition of iron to an already equilibrated system of Pu-transferrin. This indicates the relative strength of the two metallo-protein complexes.

In the lower portion of Fig. I the distribution of the ${ }^{239} \mathrm{Pu}$ in canine blood after in vivo administration is compared with the chromatogram obtained following the in vitro tagging of human blood with plutonium. Both elution spectra are very similar and in each case plutonium is associated with, but appears slightly to the left of protein peak 111 . The in vitro procedure using human blood from a single source was used in most cases for subsequent experiments with the other nuclides.

Table 3 is an appraisal of the spectra of the activities of the 8 nuclides tested as these activities relate to the three major protein peaks: high molecular weight, intermediate molecular weight, and that of low molecular weight. Actinium, protactinium, neptunium, and californium show a moderate tendency to associate with the first protein peak, while thorium, plutonium, and americium have a lesser tendency to do so. 
Uranium is the only one in this group which shows even a slight tendency to associate with protein peak 11 . All chromatograms show a peak of activity associated with the third protein peak; actinium, thorium, and plutonium having the greatest affinity, followed by uranium, neptunium, and californium. Protactinium and americium have only a moderate tendency to associate with proteins of peak ill. The peaks of radioactivity seen in protein peak 111 are all displaced slightly to the left of the protein peak (Fig: 1). This indicates different degrees of association of these elements with transferrin. Neptunium and americium had only slight affinity to bind to material of medium molecular weight $(15,000-17,000)$, the others have a somewhat greater tendency to do so. All show a moderate association with low molecular weight components. Plutonium and americium have the lowest affinity for constituents found in this weight range. Carbonate, bicarbonate and phosphate complexes are necessary for the associations described obove to occur.

The results of rechromatography of the pooled fractions of protein peak 111 on DEAE-Sephadex are tabulated in Table 4 . As before, the protein was resolved into a transferrin and an albumin peak. Actinium, thorium, protactinium, plutonium, and californium exhibit a strong association with transferrin, while uranium, neptunium, and americium do so only to a moderate degree. All elements are found to some degree with the albumin peak. Only uranium is equally divided between albumin and transferrin and there is more americium in the albumin peak than in the transferrin peak.

The existence of metalloprotein complexes was verified spectrophotometrically. With all other conditions equal except for the presence 
of the metal, the spectra show only the effect of the nuclide on the $U$. $V$. light absorption properties of the protein. Spectra as a function of the $\mathrm{pH}$ were obtained with nuclides that had a sufficiently long half-life to be used in quantities so that saturation of the protein could be achieved without excessive radiation hazard. Spectra of uranium, neptunium, plutonium, and iron (the naturally associated metal) are presented in Figs. 2, 3, and 4. Attempts to obtain a spectrum of the thorium-conalbumin complex failed in spite of the fact that its existence was demonstrated from chromatographic data. All complexes show two major peaks of U. V: light absorption at approximately 243 and $294 \mathrm{~nm}$. The highest absorption is observed between $\mathrm{pH} 7$ and $\mathrm{pH} 8$. At a $\mathrm{pH}<5$ the peaks vanish, indicating that the complex dissociates. At $\mathrm{pH}>9$ the absorption peak at $243 \mathrm{~nm}$ diminishes and shifts towards higher wave length. In the case of iron and $U V I$ this gives $r$ ise to the appearance of a new peak at $\sim 270 \mathrm{~nm}$.

\section{DISCUSSION}

The data presented here are used in an attempt to correlate the binding properties of the actinide elements with constituents of blood. They are still incomplete since curium, berkelium, and, of course, all other actinides of atomic number $>98$ are still missing. It is not justified to make a direct extrapolation of these qualitative data which describe the binding of the various nuclides by plasma constituents to the distribution in the body. A few conclusions do, however, seen obvious. A rapid rate of removal from the body would appear to reflect a low stability of the metalloprotein complex, possibly with subsequent formation of polymeric species because of hydrolysis as in the case of americium. A relatively strong, specific complex may be partially 
responsible for low excretion rates and greater interaction with constituents of bone rather than the liver as in californium and plutonium (i.e. transferrin). Formation of strong complexes with low molecular weight inorganic constituents of blood will probably favor a high excretion rate as seen in uranium $V I$. The fact that bone-seeking $U V I$ is first bound on bone surfaces but soon migrates through the whole volume of bone, may well. be due to a competitive reaction between the binding species of bone (glycoprotein) and the complex formed with carbonate and bicarbonate ions $(8)$.

A more complex study of this subject may pave the way for a better understanding of the differences seen in the final tissue distribution of these elements. Stability constants of the metalloprotein complexes are needed to make better predictions of the initial fate of the nuclide after injection. Difference spectra may be helpful in obtaining these when sufficient quantities of pure and undenatured transferrin become available. The present spectra have only qualitative value since they are based on the assumption that conalbumin protein has properties identical with transferrin, including molecular structure. If, in addition, it becomes possible to make a reasonable estimate of the concentration of the ionic species of the nuclides in this system, then stability constants can be calculated very easily.

\section{REFERENCES}

1. Stevens, W., Bruenger, F. W., Stover, Betsy J.; In vitro studies of the interactions of PuIV with blood proteins. Radiation Res. 26, $114(1965)$. 
2. Boocock, G., Popplewell, D. S.; Distribution of plutonium in serum proteins following intravenous injection into rats. Nature 208 , 282 (1965).

3. Stevens, W., Bruenger, F. W., Stover, Betsy J.; In vivo studies on the interactions of PuIV with blood constituents. Radiation Res. 33, $490(1968)$.

4. Stover, Betsy J., Bruenger, F. W., Stevens, W.; The reaction of PuIV with the iron transport system in human blood serum. Radiation $\operatorname{Res} \underline{33}, 381$ (1968).

5. Bruenger, F. W., Stevens, W., Stover; Betsy J.; Americium-241 in blood: In vivo and in vitro observations. Radiation Res. 37, 349 (1969).

6. Boocock, G., Popplewell, D. S.; In vitro distribution of americium in human blood serum proteins. Nature 210, 1283 (1966).

7. Stover, Betsy J., Atherton, D. R., Bruenger, F. W., Mays, C. W.; Distribution of ${ }^{226}$ Ra between blood cells and plasma. Health Phys. $11,617(1965)$.

8. Rowland, R. E., Farnham, J. E.; The deposition of uranium in bone. Argonne Natl. Laboratory Radiological Physics Division, Report ANL-7489, pp. 33-36 (July 1967-June 1968). 
Table 1. Association of Nuclides with Blood Cells 
Table 2. G-25 Sephadex Separation*

\begin{tabular}{|c|c|c|c|c|c|c|c|c|c|c|c|}
\hline Element & $\begin{array}{c}\% \text { of } \\
\text { Applied } \\
\text { Recovered }\end{array}$ & $\begin{array}{l}3 \text { Peak } \\
\text { Protein } \\
\text { Tubes }\end{array}$ & $\begin{array}{l}5 \text { th } \\
\text { Tube } \\
\text { Post } \\
\text { Peak }\end{array}$ & $\begin{array}{l}\text { loth } \\
\text { Tube } \\
\text { Post } \\
\text { Peak }\end{array}$ & $\begin{array}{l}15 \text { th } \\
\text { Tube } \\
\text { Post } \\
\text { Peak }\end{array}$ & $\begin{array}{l}20 \text { th } \\
\text { Tube } \\
\text { Post } \\
\text { Peak }\end{array}$ & $\begin{array}{c}\text { Resin } \\
\text { Section } \\
1\end{array}$ & $\begin{array}{l}\text { Resin } \\
\text { Section } \\
\quad \text { II }\end{array}$ & $\begin{array}{l}\text { Resin } \\
\text { Section } \\
\quad \text { lll }\end{array}$ & $\begin{array}{l}\text { Resin } \\
\text { Section } \\
\text { IV }\end{array}$ & $\begin{array}{c}\text { Resin } \\
\text { Section } \\
V\end{array}$ \\
\hline${ }^{227} A C$ & 95.4 & 42.1 & 0.6 & 0.3 & 0.4 & 0.1 & 19.0 & 8.4 & 7.2 & 3.4 & 5.7 \\
\hline${ }^{228} \mathrm{Th}$ & 96.6 & 78.5 & 0.4 & 0.03 & 0.01 & 0.01 & 0.5 & 0.1 & 0.03 & 0.06 & 0.04 \\
\hline $233 \mathrm{~Pa}$ & 100 & 68.8 & 1.1 & 0.01 & 0 & 0 & 5.6 & 4.5 & 2.1 & 2. & 1.6 \\
\hline 233 UIV & 92. & 6.8 & 22.0 & 3.1 & 0.16 & 0.07 & 0.2 & 0.05 & 0.07 & 0.08 & 0.16 \\
\hline $233 \mathrm{UVI}$ & 95.4 & 9.0 & 8.8 & 0.02 & 0.02 & 0 & 9.4 & 34.9 & 5.6 & 0.02 & 0.02 \\
\hline $237 \mathrm{~Np}$ IV & 80. & 19.8 & 12.7 & 0.3 & 0.3 & 0.05 & 4.2 & 5.3 & 2.8 & 0.5 & 0.05 \\
\hline $237 \mathrm{NpVI}$ & 99.2 & 20.8 & 7.8 & 0.5 & 0.4 & 0.1 & 0.1 & 0.7 & 32.7 & 0.6 & 0.07 \\
\hline $239 \mathrm{Pu} \mid 11$ & 100 & 64.7 & 4. & 0.1 & 0 & 0 & 3. & 0.5 & 0.4 & 0.4 & 1.5 \\
\hline${ }^{241} \mathrm{Am}$ & 83. & 13.2 & 12.8 & 0.2 & 0.04 & 0.01 & 2.6 & 2.7 & 3.1 & 2.5 & 9.8 \\
\hline
\end{tabular}

* Figures in \% of recovered activity. 
Table 3. Gel Chromatography of Tagged Human Plasma on Sephadex G100-G200

\begin{tabular}{|c|c|c|c|c|c|c|c|c|}
\hline $\begin{array}{l}\text { Atomic } \\
\text { Number }\end{array}$ & $\begin{array}{l}\text { Mass } \\
\text { Number }\end{array}$ & El ement & Valence & ${ }^{\mathrm{F}}$ & $\begin{array}{l}\text { tein } \\
\text { II }\end{array}$ & $\begin{array}{l}\text { Peak } \\
\quad \text { III }\end{array}$ & $\begin{array}{c}\text { Intermediate } \\
M W\end{array}$ & $\begin{array}{l}\text { Low } \\
\text { MW }\end{array}$ \\
\hline 89 & 227 & $A C$ & 111 & ++ & - & ++++ & + & +++ \\
\hline 90 & 228 & Th & IV & + & - & +++ & + & ++++ \\
\hline 91 & 233 & $\mathrm{~Pa}$ & v & + & - & ++ & + & $++t$ \\
\hline 92 & 233 & $u$ & VI & - & + & +++ & + & ++++ \\
\hline 93 & 237 & $\mathrm{~Np}$ & v & ++ & - & +++ & - & ++++ \\
\hline 94 & 239 & $\mathrm{Pu}$ & IV & + & - & +++ & + & ++ \\
\hline 95 & 241 & $\mathrm{Am}$ & 111 & + & - & ++ & - & ++ \\
\hline 98 & 249 & $C f$ & 111 & ++ & - & +++ & + & ++++ \\
\hline
\end{tabular}

Table 4. Ion-Exchange Chromatography of Tagged Human Plasma on DEAE Sephadex

\begin{tabular}{cccccc}
$\begin{array}{c}\text { Atomic } \\
\text { Number }\end{array}$ & $\begin{array}{c}\text { Mass } \\
\text { Number }\end{array}$ & Element & Valence & Transferrin & $\begin{array}{c}\text { Albumin } \\
\text { Ac }\end{array}$ \\
\hline 89 & 227 & III & ++++ & + \\
90 & 228 & Th & IV & ++++ & + \\
91 & 233 & Pa & V & ++++ & ++ \\
92 & 233 & U & VI & ++ \\
93 & 237 & Np & V & ++ \\
94 & 239 & Pu & IV & ++++ & + \\
95 & 241 & Am & III & ++ \\
98 & 249 & Cf & III & ++++
\end{tabular}




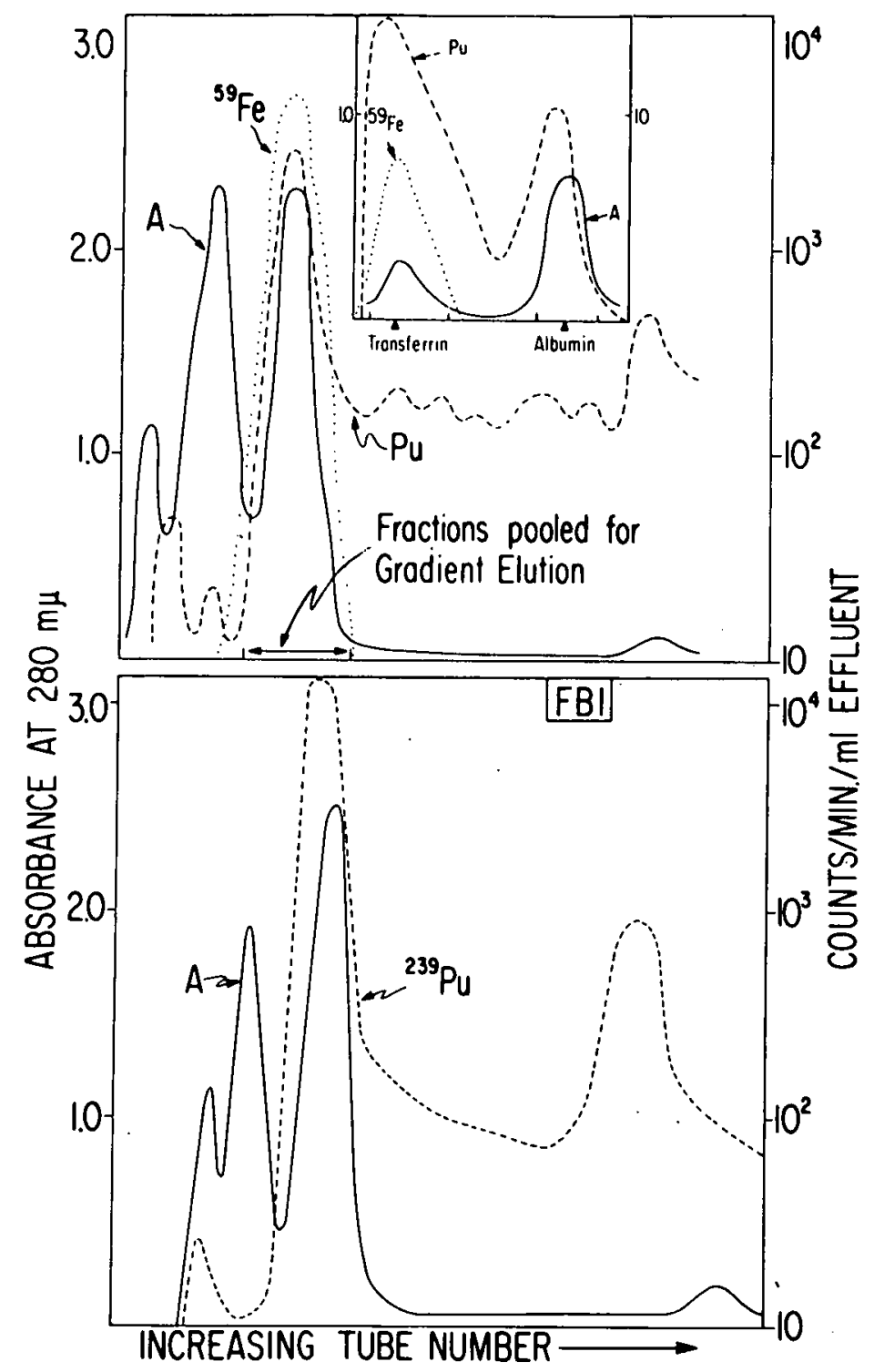

Fig. I Elution spectra of tagged plasma on G-100-G-200. Top: elution spectrum of a canine plasma tagged with ${ }^{59} \mathrm{Fe}$ and $239 \mathrm{Pu}$. Most of the radioactivity was associated with protein peak 111 ( $A=$ absorbance). Radioactivity peaks are slightly displaced to the left shoulder. Insert shows the result of rechromatography of pooled peak III material on DEAE ion exchange resin. Lower graph: elution spectrum of plutonium tagged human plasma after gel chromatography on G-100 - G-200. 


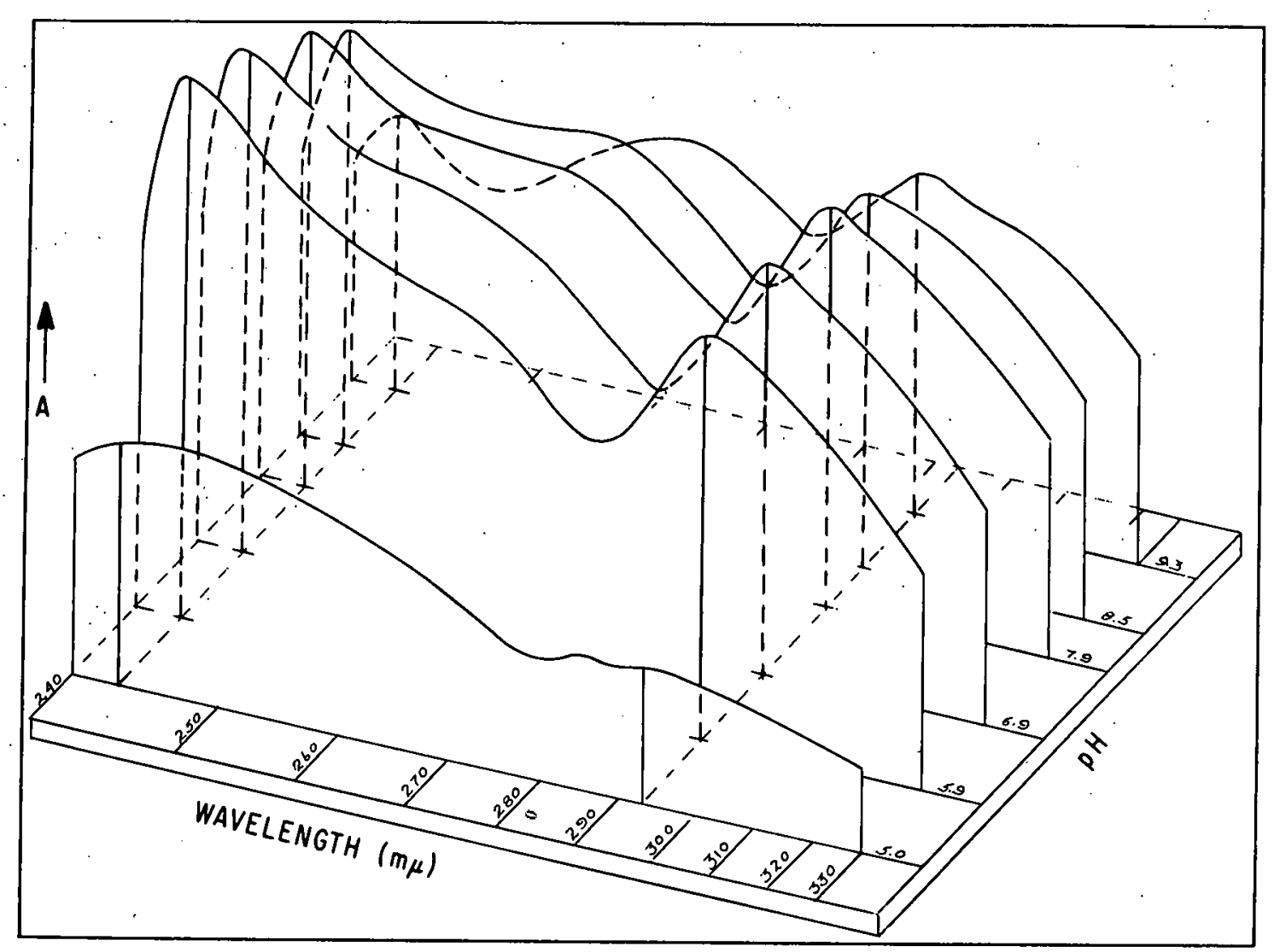

Fig. 2 Difference spectrum of Fe-conalbumin as a function of $\mathrm{pH}$. 

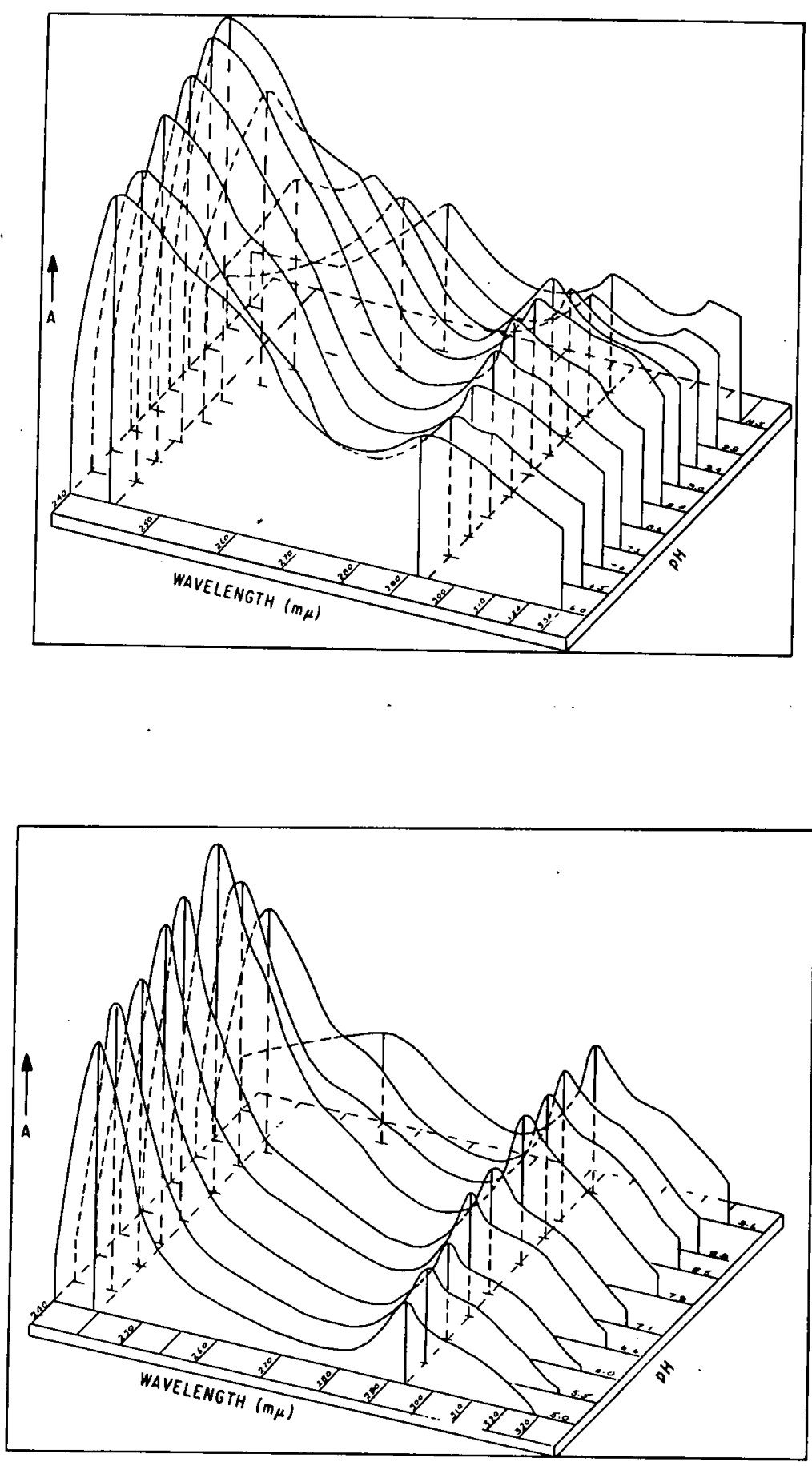

Fig. 3 Difference spectra of UVI-(top) and NpVI-(bottom) conalbumin as a function of $\mathrm{pH}$. 

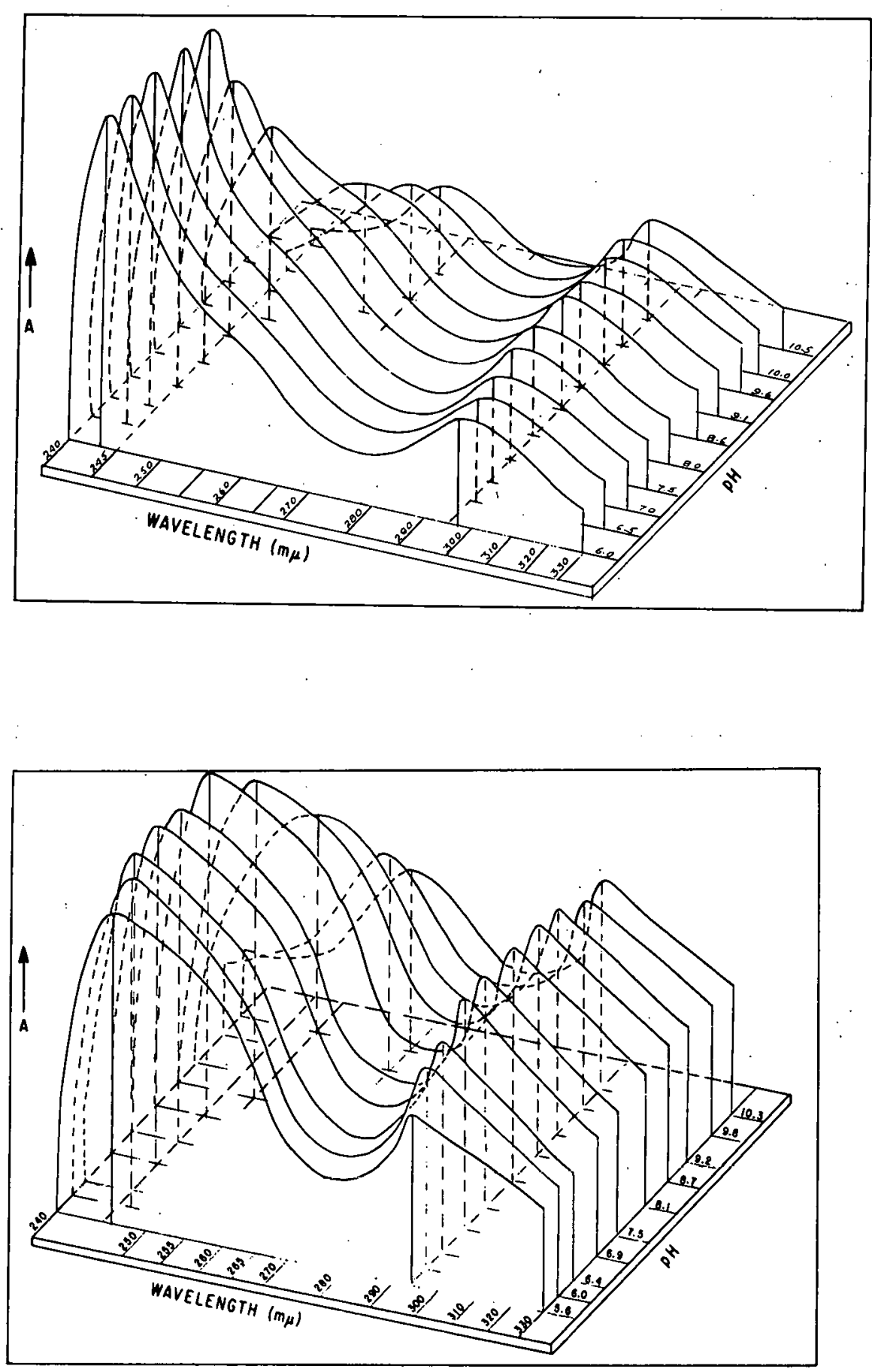

Fig. 4 Difference spectra of PuIV-(top) and PuVI-(bottom) conalbumin as a function of $\mathrm{pH}$. 
ACCUMULATION OF MACROPHAGES LABELLED WITH PLUTONIUM-239

IN MARROW SPACES OF LUMBAR VERTEBRAL BODIES

Webster S. S. Jee

Abstract: Labeled macrophages are generated when osteoclasts progressively concentrate plutonium after resorption of bone surfaces labeled with plutonium, and when subsequently the macrophages engulf the dead osteoclasts which contain the plutonium or bind the plutonium freed by the disintegrating osteoclast. The efflux of labeled macrophages occur when live, dead or fragmented macrophages laden with plutonium are swept out of the marrow into the circulation. The accumulation of labeled macrophages is an indicator of altered kinetics of both macrophages and bone cells. Labeled macrophages are observed in beagles injected with $2.7,0.9,0.3$, 0.09 and $0.05 \mu \mathrm{Ci} 239 \mathrm{Pu} / \mathrm{kg}$, but not in $0.015 \mu \mathrm{Ci} 239 \mathrm{Pu} / \mathrm{kg}$ dogs at death ( 4 to 6 years post-injection). Optimal accumulation of labeled macrophages appears in the $0.05 \mu \mathrm{Ci}{ }^{239} \mathrm{Pu} / \mathrm{kg}$ injected dogs. At the lowest dose level $(0.015 \mu \mathrm{C} / \mathrm{kg}$ injected), there is peak labeling at $1 / 4$ to 2 years postinjection and no evidence of labeled cells at post-injection times greater than 4 years.

Despite the accumulation of labeled macrophages, there is a paucity of death due to hematopoietic changes and hematopoietic neoplasms in the dogs. These dogs died mostly of osteosarcoma death.

\section{INTRODUCTION}

It was not until 1957 that the definitive report describing the autoradiographic distribution of plutonium-239 in rats by Arnold and Jee was published in the American Journal of Anatomy. (1) Until then, perfecting techniques to produce suitable detailed autoradiographs had proved a tough 
nut to crack. There had been three brief communications from Hamilton's laboratory $(2-4)$ and numerous short communications from our laboratory. (5-10) The autoradiographic findings we described proved not only to be most artistic, but have survived the test of time. Briefly, we observed: (1) plutonium was found to localize in high concentration at endosteal surfaces and to a lesser degree at periosteal surfaces and vascular channels of cortical bone, (2) the strata of initially-deposited plutonium was overlayed by new bone formed after injection, (3) all post-injection bone was, readily identified by its diffuse labeling, (4) osteoclasts resorbing bone labeled with plutonium were progressively concentrating plutonium, (5) plutonium in the osteoclast was later transferred to macrophages, (6) the labeled macrophages were also loaded with hemosiderin, (7) formative and destructive phases of bone reconstruction were uniquely demonstrated by tracing the fate of plutonium, and (8) plutonium concentration in osteoclast was interpreted as evidence of the active role of that cell in bone resorption.

\section{DISTRIBUTION IN ADULT DOG BONES}

Next came our autoradiographic studies on the distribution of plutonium-239 (+4) citrate (monomeric Pu) in young adult beagles' bones. (II-28) One such effort was the description of the percentage of total plutonium associated with the key histological structures in the lumbar vertebral bodies of dogs injected with approximately $2.7 \mu \mathrm{Ci}$ of $239 \mathrm{pu} / \mathrm{kg}$ in $18 \mathrm{dogs}$ serial sacrificed up to 2059 days post-injection by Twente and co-workers. (29) Briefly, these findings include (Table I): (1) Initially the largest. percentage of plutonium is concentrated on the endosteal surface of trabeculae. (as high as 97\%). This concentration on the surface decreased 
with increasing burden times, (2) the concentration associated with cortical bone and periosteal surfaces does not constitute more than $5 \%$ of the total plutonium, (3) the percentage of plutonium found in osteoclast was found to be on the order of $10 \%$, was first detected at about two weeks after injection, and showed spurts of activity, (4) macrophages laden with plutonium appeared in the marrow at approximately the same time as osteoclasts laden with plutonium. The Pu percentage in macrophages generally ranged between 6 and $10 \%$ and did not increase with burden time, indicating that these macrophages do not accumulate in the marrow, and (5) new bone (diffusely labeled post-injection bone) began to form three months after injection and eventually amounted to at least $10 \%$ of the total plutonium in dogs surviving three years after injection.

\section{ACCUMULATION IN MACROPHAGES}

of particular interest was the accumulation of $239 \mathrm{Pu}$ labeled macrophages in the marrow as a function of increasing burden time and dose levels. At one time we thought the accumulation was an important concentration of alpha irradiation for osteosarcomas induction. Despite the accumulation of labeled macrophages, there is a paucity of death due to hematopoietic changes and hematopoietic neoplasms in our dogs. Nevertheless, there is a slim chance that these aggregates may contribute to the induction of osteosarcomas.

The accumulation of labeled macrophages in marrow spaces is dependent upon the biologic factors which control the rate of influx (production) and efflux (attrition) of labeled macrophages. Labeled macrophages were generated when osteoclasts progressively concentrated plutonium after 
TABLE I - Percentage of 239 Pu Associated with Sites Within Lumbar Vertebral Bodies, as Studied Autoradiographically in Beagles Injected with $2.7 \mu \mathrm{Ci} / \mathrm{kg}$ (Mean \pm S.D.)

\begin{tabular}{|c|c|c|c|c|c|c|}
\hline $\begin{array}{c}\text { Days } \\
\text { post } \\
\text { injection } \\
\end{array}$ & $\begin{array}{l}\text { Trabecular } \\
\text { surfaces } \\
\end{array}$ & Osteoclasts & Macrophages & $\begin{array}{l}\text { Post } \\
\text { inj. } \\
\text { bone }\end{array}$ & $\begin{array}{l}\text { Haversian } \\
\text { systems } \\
\end{array}$ & $\begin{array}{l}\text { Periosteal } \\
\text { surface } \\
\end{array}$ \\
\hline 1 & $96.2 \pm 1.8$ & 0 & 0 & 0 & $1.0 \pm 0.4$ & $2.8 \pm 1.4$ \\
\hline 3 & $94.5 \pm 2.3$ & 0 & 0 & 0 & $2.7 \pm 1.5$ & $2.8 \pm 0.8$ \\
\hline 7 & $97.1 \pm 1.7$ & 0 & 0 & 0 & $1.1 \pm 0.7$ & $1.8 \pm 1.1$ \\
\hline 15 & $02.5 \pm 5.2$ & $3.9 \pm 5.1$ & $2.8 \pm 2.2$ & 0 & $1.5 \pm 0.8$ & $2.7 \pm 1.1$ \\
\hline 15 & $87.5 \pm 10.7$ & $6.0 \pm 7.4$ & $3.0 \pm 3.1$ & 0 & $1.5 \pm 0.6$ & $2.0 \pm 0.7$ \\
\hline 28 & $71 \cdot 3 \pm 10.8$ & $16.5 \pm 6.0$ & $9.5 \pm 5.3$. & 0 & $1.2 \pm 0.4$ & $1.5 \pm 0.7$ \\
\hline 28 & $79.5 \pm 5.3$ & $8.1 \pm 4.7$ & $7 \cdot 7 \pm 3.3$ & 0 & $1.6 \pm 0.3$ & $3.2 \pm 1.4$ \\
\hline 92 & $76.2 \pm 14.0$ & $7.9 \pm 8.0$ & $8.2 \pm 7.5$ & $4.1 \pm 3.8$ & $1.4 \pm 0.6$ & $2.3 \pm 0.9$ \\
\hline 210 & $72.2 \pm 4.1$ & $10.4 \pm 2.4$ & $11.2 \pm 0.9$ & $3.1 \pm 1.5$ & $1.0 \pm 0.4$ & $2.2 \pm 0.7$ \\
\hline 217 & $61.3 \pm 9.8$ & $6.7 \pm 0.4$ & $28.0 \pm 8.8$ & $1.8 \pm 1.4$ & $0.7 \pm 0.4$ & $1.6 \pm 0.8$ \\
\hline 400 & $74.3 \pm 6.9$ & $9.9 \pm 4.5$ & $5.7 \pm 1.7$ & $6.5 \pm 2.2$ & $1.2 \pm 0.4$ & $2.7 \pm 1.2$ \\
\hline 777 & $71.8 \pm 10.3$ & $11.2 \pm 12.5$ & $7.2 \pm 5.3$ & $6.0 \pm 6.3$ & $1.7 \pm 1.3$ & $2.2 \pm 0.5$ \\
\hline 1192 & $72.6 \pm 2.3$ & $8.1 \pm 3.4$ & $6.5 \pm 0.9$ & $8.6 \pm 0.4$ & $1.7 \pm 0.3$ & $2.5 \pm 1.4$ \\
\hline 1194 & $68.3 \pm 2.0$ & $6.9 \pm 0.6$ & $2.2 \pm 0.6$ & $18.5 \pm 2.7$ & $1.8 \pm 1.5$ & $2.2 \pm 0.2$ \\
\hline 1491 & $76.8 \pm 0.9$ & $7.0 \pm 0.9$ & $5.0 \pm 0.1$ & $8.2 \pm 0.3$ & $1.5 \pm 0.4$ & $2.1 \pm 0.4$ \\
\hline 1562 & $63.4 \pm 5.5$ & $9.5 \pm 3.9$ & $4.0 \pm 0.9$ & $19.2 \pm 3.6$ & $1.5 \pm 0.2$ & $2.2 \pm 0.6$ \\
\hline 1576 & $67.5 \pm 4.9$ & $13.4 \pm 5.7$ & $7.2 \pm 0.8$ & $8.2 \pm 1.3$ & $1.3 \pm 0.2$ & $2.4 \pm 0.3$ \\
\hline 2059 & $73.7 \pm 5.1$ & $10.1 \pm 1.0$ & $1.7 \pm 1.6$ & $10.4 \pm 2.1$ & $2.0 \pm 0.7$ & $2.3 \pm 0.3$ \\
\hline
\end{tabular}


resorbing bone surfaces labeled with plutonium and when subsequently the macrophages engulfed the dead osteoclasts with the plutonium and concentrated the plutonium or bound the plutonium freed by the disintegrating osteoclast. The efflux of labeled macrophages occurred when live, dead or fragmented macrophages laden with plutonium were swept out of the marrow into the circulation. Thus, the influx of labeled macrophages is related to osteoclastic resorption of bone surface labeled with $\mathrm{Pu}$, and the production of non-labeled macrophages. At high dose levels $(2.7$ and $0.9(\mathrm{i} / \mathrm{kg})$, bone resorption was depressed and the bone marrow was depleted; therefore, few labeled macrophages were observed (Table $I I)$.

TABLE II - Relationship of numbers of macrophages with star-producing aggregates in a longitudinal section of lumbar vertebral bodies marrow to injected doses of $239 \mathrm{pu}$ in young adult Beagles as studied by autoradiography. (Mean \pm S.D.)

\begin{tabular}{|c|c|c|c|c|}
\hline $\begin{array}{c}\text { Injected dose } \\
(\mu \mathrm{Ci} / \mathrm{kg})\end{array}$ & No. dogs & $\begin{array}{l}\text { Age at injection } \\
\text { (days) } \\
\end{array}$ & $\begin{array}{c}\text { Burden time: } \\
\text { (days) } \\
\end{array}$ & $\begin{array}{l}\text { No. of Macrophages } \\
\text { with } 239 \mathrm{Pu} \\
\end{array}$ \\
\hline 2.7 & 6 & $632 \pm 248$ & $1518 \pm 303$ & $77 \pm 34$ \\
\hline 0.9 & 9 & $522 \pm 68$ & $1316 \pm 197$ & $135 \pm 98$ \\
\hline 0.3 & 3 & $503 \pm 80$ & $1724 \pm 160$ & $1388 \pm 293$ \\
\hline 0.09 & 3 & $538 \pm 114$ & $2109 \pm 730$ & $9929 \pm 5007$ \\
\hline 0.015 & 2 & $588 \pm 45$ & $1899 \pm 509$ & 0 \\
\hline
\end{tabular}

* Time between injection and death

A direct relationship of numbers of labeled macrophages to burial of plutonium was observed in $0.3 \mu \mathrm{C} i$ dose level dogs (Table III). Thus, incidence of plutonium burial (bone formation) was used as an index of bone remodeling assuming bone formation equals bone resorption. 
TABLE III - Relationship of numbers of macrophages with star-producing aggregates to index of bone remodelling as measured by burial of bone surface plutonium in young adult Beagles injected with $\sim 0.3 \mu \mathrm{Ci}$ of $239 \mathrm{pu} / \mathrm{kg}$ as studied by autoradiography.

Time after Age at inj. Remodelling index: Number of macrophages injection (days) Buried/Surface

$\begin{array}{rrrr}40 \text { days } & 519 & 1.62 & 1955 \\ 187 \text { days } & 489 & 2.57 & 2888 \\ 362 \text { days } & 550 & 2.24 & 2300 \\ 1476 \text { days } & 417 & 5.61 & 5780 \\ 1771 \text { days } & 406 & 5.51 & 4910\end{array}$

* Assumes bone formation is coupled (equal) to bone resorption. Therefore burial (bone formation) represents bone resorption.

Increasing numbers of labeled macrophages occurred in dead dogs which had been injected with decreasing dose-levels to $0.05 \mu \mathrm{Ci}$ of $239 \mathrm{Pu} / \mathrm{kg}$ (Table TI.). Optimal accumulation of labeled macrophages appeared in dead dogs injected with $0.05 \mu \mathrm{Ci}$ of ${ }^{239} \mathrm{Pu} / \mathrm{kg}$. The actual number of macrophages in lumbar vertebral bodies of these dogs could not be counted because of the marked clumping of labeled macrophages into aggregates, which made counting impossible. Surprisingly, the two $0.015 \mu \mathrm{Ci}$ injected dogs sacrificed at 1539 and 2257 days did not contain labeled cells.

The studies of numbers of labeled cells with increasing burden times showed peak labeling varied with dose-levels. Peak labeling occurred at 217 days in $2.7 \mu \mathrm{C} i$ injected dogs, at 1771 days (death) in $0.3 \mu \mathrm{Ci}$ injected dogs and 560 days in $0.015 \mu \mathrm{Ci}$ injected dogs (Tables I, III, LV). At high dose-levels there. was an early and transient spurt of bone resorption at 7 months post injection (Table I), but in general the level of osteoclastic resorption, as shown in the small numbers of labeled macrophages 
per section, was depressed because of the intense irradiation. At the intermediate dose, peak labeling was observed at post mortem, indicating that there was a continual influx of labeled macrophages into the marrow throughout the life span of these dogs. This in turn means there was a depressed rate of resorption (remodeling) of labeled bone surfaces and labeled post-injection bone. On the contrary, at the lowest dose-levels $(0.015 \mu \mathrm{C}$ injected), there was peak labeling at 2 years post-injection and no evidence of labeled cells at post-injection times greater than 1500 days. This indicates that at low doses all labeled bone can be resorbed by osteoclasts well within 2 years post-injection; thus, wiping out the source of $239 \mathrm{pu}$ on which macrophages concentrate. Furthermore, the post-injection bones were so lightly labeled that labeled osteoclasts and macrophages did not accumulate sufficient $\mathrm{Pu}$ to register star-producing aggregates by autoradiography.

One possible method by which macrophages accumulate plutonium is the binding of plutonium freed from osteoclasts with the hemosiderin residing in macrophages. Hemosiderin is an iron-containing substance (hydrated ferrous oxide in combination with protein), resulting from the splitting up of hematin during the phagocytic digestion of effete erythrocytes. Further electron microscopic autoradiography of labeled macrophages should clarify whether hemosiderin is essential for the binding of $239 \mathrm{pu}$ in macrophages.

Until now, we have neglected to study the impact of moderate doses of alpha irradiation upon the population of macrophages. We know from our histological studies that high dose-levels obviously depressed this population. It is not known what moderate and low doses will do. If 
TABLE IK - Incidence of macrophages with.star-producing aggregates in lumbar vertebral bodies from young adult Beagles given 0.015 $\mu \mathrm{Ci}$ of $239 \mathrm{Pu} / \mathrm{kg}$ as studied by autoradiography.

Time after injection

5 days

35 days

96 days

97 days

186 days

375 days

376 days

559 days

647

1539 days

2257
Age at injection (days)

554

548

1485

559

542

550

1534

647

556

620

556
Number of macrophages with $239 \mathrm{pu}$

2173

1913

1246

1807

1980

0

0

Exposure time was 2519 days

the source of alpha irradiation from labeled macrophages is important in radiation carcinogenesis, it is imperative that we do further study of the effect of graded doses of $239 \mathrm{pu}$ upon cells.

The efflux of labeled macrophages from marrow spaces was depressed in all but the $0.015 \mu \mathrm{C}$ injected dogs. The time necessary to clear these cells from the marrow of $0.015 \mu \mathrm{C}$ injected dogs was, at most, 2 years. No evidence of labeled macrophages was seen at about 4 years post-injection, when at 2 years post-injection the lumbar vertebral bodies contained half the peak load of these cells (Table TV). Previously, we reported that 
in the $2.7 \mu \mathrm{C} i$ injected dogs, labeled macrophages did not increase with burden times and concluded that this was evidence that the macrophages were cleared from the marrow. Subsequent studies at lower dose-levels $(0.09$ and $0.05 \mu \mathrm{Ci}$ injected) showed that in these dogs there was ample time for the macrophages to translocate to other sites. There is no doubt that the clearance of labeled macrophages has been slowed, and that the piling up of labeled cells is the consequence of depressed rate of removal of plutonium labeled bone and labeled macrophages from the marrow.

It must be emphasized that in acute cases of humans contaminated with $239 \mathrm{Pu}$, the accumulation of labeled macrophages will be similar to the $0.015 \mu \mathrm{Ci}$ injected dogs. Obviously, bones from individuals with extremely long burden times will not show many labeled macrophages.

\section{REFERENCES}

1. J. S. Arnold and W. S. S. Jee: Bone growth and osteoclastic as indicated by radioautographic distribution of $\mathrm{Pu}^{239}$ : Am. J. Anat.: 101: $367-417$ (1957).

2. J. G. Hamilton: The metabolism of the fission products and the heaviest elements: Radiology, 49: 325-343 (1947).

3. J.G. Hamilton: The metabolic properties of the fission products and actinide elements: Rev. Modern Phys. 20: 718-728 (1948).

4. D. H. Copp, D. J. Axelrod and J. G. Hamilton: The deposition of radioactive metals in bone as a potential health hazard: Amer. J. Roent. Rad. Ther. 58: 10-16 (1947).

5. J. S. Arnold: Metabolism of bone as studied by radioautographic distribution of calcium, plutonium and radium: Am. J. Physiol. 167: 765 (1951): 
6. J. S. Arnold: General features of bone deposition: Second Annual Conference on Plutonium, Radium and Mesothorium: Ed. by C. N. Stover, Jr., Radiobiology Laboratory, U. of Utah Report, TID-7639, 4-18 (1954).

7. J. S. Arnold: Some observations on plutonium and radium in bone: Therapy of Radioelements Poisoning, Ed. by M. W. Rosenthal, Argonne National Laboratory, ANL-5584, 131-i43.(1955).

8. J. S. Arnold: Skeletal changes correlated with irradiation in radium and plutonium intoxicated dogs: Anat. Rec. 124: 451 (1956).

9. J.S. Arnold and W. S. S. Jee: Radioautographic and pathologic changes in bone of dogs receiving ${ }^{239} \mathrm{Pu}$ and ${ }^{226} \mathrm{Ra}$ : Rad. Res. 5: 466 (1956).

10. W. S. S. Jee: Osteoclastic activity in beagles and rats as shown by detailed radioautography distribution of plutonium-239: Anat. Rec. 124: $313(1956)$.

11. W. S. S. Jee, J.S. Arnold and C. R. Mott: Distribution of plutonium-239 in skeleton of normal, rachitic and healing rachitic rats: Anat. Rec. 130: 420 (1958).

12. W. S. S. Jee, J. S. Arnold and T. H. Cochran: Skeletal changes induced by chronic doses of plutonium, radium, mesothorium, and radiothorium: Anat. Rec. 130: 421 (1958).

13. J. A. Twente, J. S. Arnold, C. W. Mays, D. H. Taysum and W. S. S. Jee: Localized dosimetry in bone. 1. Instrumentation; Radiobiology Laboratory, U. of Utah Report C00-215, 98-101 (1958).

14. J. A. Twente and W. S. S. Jee: Localized dosimetry in bone: Radiobiology Laboratory, U. of Utah Report C00-217, 147-160 (1958).

15. J. A. Twente, E. G. Butler, 0. Freudenberger and W. S. S. Jee: Localized plutonium dosimetry in bone: Radiobiology Lab., U. of 
Utah Report C00-218, 190-206 (1959).

16. J. A. Twente and D. R. Atherton: Determination of $\mathrm{Pu}^{239}$ content of bone tissue: A comparison of radiochemical and photoelectric density techniques: Radiobiology Lab., U. of Utah Report C00-218, 207209 (1959).

17. J. S. Arnold and W. S. S. Jee: Autoradiography in the localization of radiation dosage of $\mathrm{Ra}^{226}$ and $\mathrm{Pu}^{239}$ in bones of dog: Lab. Invest. 8: $194-204$ (1959).

18. W. S. S. Jee: Microradiographic and autoradiographic studies of bones containing radioisotopes: Anat. Rec. 133: 395-396 (1959).

19. W. S. S. Jee and J. S. Arnold: The effect of internally deposited irradiation upon the vascular supply of cortical bone: Anat. Rec. 133: 293 (1959).

20. W. S. S. Jee and J. S. Arnold: Structural changes in dog skeleton containing plutonium: J. Bone and Joint Surg. 4lA: 771 (1959).

21. W. S. S. Jee and J.S. Arnold: Structural changes in teeth and their supporting structures containing bone-seeking radioisotopes: J. Dent. Res. 38: 692 (1959).

22. W. S. S. Jee and J. S. Arnold: The indirect effect of internally deposited radioisotopes on bone: Rad. Res. 11: 447 (1959).

23. J. A. Twente, W. S. S. Jee and J. S. Arnold: A new technique for measuring localized tissue content of alpha emitting isotopes: Rad. Res. 11: 474 (1959).

24. W. S. S. Jee and J.S. Arnold: Remodelling of bones as visualized by autoradiography: Anat. Rec. 136: 217 (1960).

25. W. S. S. Jee and J. S. Arnold: Internally deposited radioisotopes in dog teeth: Rad. Res. 12: 445-446 (1960). 
26. W. S. S. Jee, J.A. Twente and J. S. Arnold: The toxicity of plutonium deposited in skeletal tissues of beagles: in Radiation Damage in Bone - Conference on the Relation of Radiation Damage to Radiation Dose in Bone, International Atomic Energy Agency, Karntnerring, Vienna, 30-31 (1960).

27. W. S. S. Jee and J. S. Arnold: Radioisotopes in the teeth of dogs. 1 - The distribution of plutonium, radium, radiothorium, mesothorium and strontium and the sequence of histopathologic changes in teeth containing plutionium: Arch. Oral Biol. 2: 215-238 (1960).

28. W. S. S. Jee and J. S. Arnold: Effects of internally deposited radioisotopes upon blood vessels of cortical bones: Proc. Soc. Biol. and Med. 105: $351-3.56$ (1960).

29. J. A. Twente, E. G. Butler and W. S. S. Jee: The localized distribution of $\mathrm{Pu}^{239}$ in the lumbar vertebral centra of 5-level dogs: Radiobiology Laboratory, U. of Utah Report C00-220, 168-196 (1960). 


\section{HIGH RESOLUTION NEUTRON-INDUCED AUTORADIOGRAPHY OF BONE CONTAINING PLUTONIUM-239}

W. S. S. Jee, L. G. Miller* and R. B. Dell

Abstract: " The detailed neutron-induced autoradiographic process for bones containing plutonium-239 produced autoradiographs with both fission fragment tracks and a corresponding bone image. Seven microns thick undecalcified bone sections were apposed on 300 microns thick Lexan (polycarbonate) film and exposed to neutrons in the thermal column of the Material Testing Reactor (MTR) at the National Reactor Testing Station in Idaho. The specimens were immersed in $28 \% \mathrm{KOH}$ at $50^{\circ} \mathrm{C}$ for one hour to etch pinholes at the location of each fission track and pitting of the film at the location of the bone. The film, when inspected microscopically, exhibited both fission fragment tracks and a corresponding bone image. When the films were etched immediately after irradiation, no bone image was produced. When the bone sections were allowed to remain on the film for several weeks after irradiation, the bone caused a pitting of the film surface. Betas from phosphorus -32 seemed to be the main charged particles available to produce the pitting. This detailed neutron-induced autoradiographic process has advantages over the nuclear emulsion autoradiography of bones because it eliminated long exposure times and fading of latent image.

\section{INTRODUCTION}

Previous to 1967, conventional nuclear emulsion photographic autoradiography was used to determine the distribution of $239 \mathrm{pu}$ in bone. $(1-3)$

* Reactor Development Branch, Idaho Nuclear Corp., Idaho Falls, Idaho, 83401 . 
More recently, the technique of reutron-induced fission track autoradiography has been used to characterize the temporal and quantitative distribution of plutonium in bone..$^{(4-7)}$ Thin bone sections are attached to thin polycarbonate films and irradiated in a high neutron flux. The neutron-irradiation of the very small quantities of plutonium produce fission tracks in the polycarbonate film. Using track etching techniques, the fission tracks become visible in the film. This neutron-induced autoradiography has advantages over the conventional nuclear emulsion because it eliminates long exposure times for bone containing only a small quantity of plutonium (in the order of pico pico curies per $\mathrm{cm}^{2}$ ). It also eliminates the fading of latent image (loss of the photographic image) which plagues nuclear emulsion autoradiography.

In the studies of Bleaney, ${ }^{(4)}$ bone sections were sandwiched between polycarbonate films and exposed to thermal neutrons. The films were detached following irradiation and then etched to reveal the fission fragment tracks. The fission fragment tracks recorded by the "sandwich" technique are technically contact autoradiographs. This technique made it difficult to know, by superposition of foil and section, whether fission fragment tracks arose from the bone surface, bone or marrow cells. The work described in this paper demonstrates the feasibility of producing high resolution detailed neutron-induced autoradiographs that give superb resolution, equal to that of liquid emulsion coating of thin bone sections. (1) The detailed neutron-induced autoradiographic process produces autoradiographs with both fission fragment tracks and a corresponding bone image. A description of the process and an attempt to explain what causes the bone image is presented in the following sections. 


\section{PROCESS DESCRIPTION}

Thin undecalcified bone sections are a prerequisite to high resolution autoradiography, whether the conventional nuclear or neutron-induced, autoradiographic techniques are employed. Blocks of undecalcified dog bones are fixed in absolute acetone, defatted in ether, embedded in a combination of ethyl/butyl methacrylate and sectioned on a mechanized heavyduty Jung microtome. ${ }^{(8)}$ The $7 \mu$ bone sections are floated of $f$ the knives with the aid of $80 \%$ alcohol, a brush and spatula, and apposed on a 300 microns thick Lexan (polycarbonate) film (Westlake Plastics, Lenni Mills, Pa.) which has been previously coated with $0.5 \%$ calf skin gelatin. The specimens (bone section apposed to Lexan foil) are allowed to air dry. They are then exposed to neutrons in the thermal column of the Material Testing Reactor (MTR) at the National Reactor Testing Station in Idaho. Neutron fluence in the range of $10^{13}$ to $10^{14} \mathrm{n} / \mathrm{cm}^{2}$ is used. During the irradiation the temperature must be kept below $32^{\circ} \mathrm{C}$. Higher temperatures will anneal the tracks. Neutron irradiations were made in the MTR thermal column because of 'its high thermal neutron flux and low gamma heating. Subsequent to neutron irradiation, the specimens are allowed to age for a period greater than several weeks before immersing in $28 \% \mathrm{KOH}$ at $60^{\circ} \mathrm{C}$ for one hour to etch pinholes several microns in diameter at the location of each fission track. The bone section separates from the film during the etching process. The etched film is rinsed in tap water, air dried and inspected microscopically. The film exhibits both the fission fragment tracks and a corresponding bone image.

In a contact neutron-induced autoradiograph of a bone section with plutonium localized in both the bone and bone marrow, the exact position 


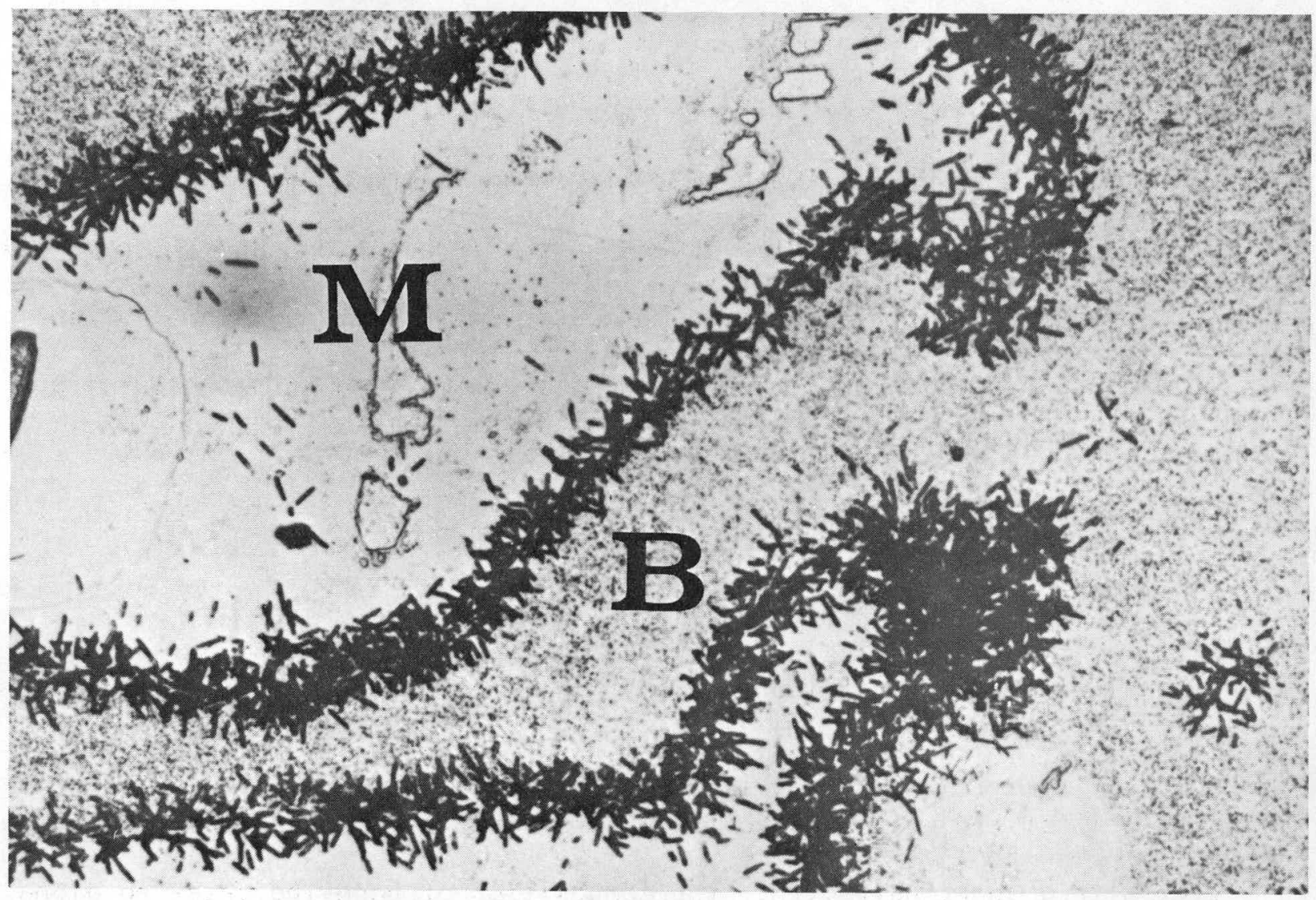

Fig. 1. Detailed neutron-induced autoradiograph of portions of two bone spicules, showing fission fragment tracks distributed mostly upon bone surfaces in the lumbar vertebral body from a dog given $2.7 \mu \mathrm{C}$ of ${ }^{239} \mathrm{Pu} / \mathrm{kg}$ and killed 28 days later. Few isolated tracks are found in the bone marrow. B denotes bone, M denotes marrow $(x \quad 210)$

of the fission tracks with respect to bone surface or bone marrow is uncertain because a bone image is not present to give the investigator the necessary orientation. $(4-7)$ If the polycarbonate film is etched immediately 
after thermal neutron irradiation, we obtain the same result as with a contact neutron-induced autoradiograph. If the bone sections are allowed to remain on the polycarbonate film for several weeks after irradiation, the decay radiation from the bone causes a pitting of the film surface with results shown in Figures 1-3. In these figures, the bone was left on the polycarbonate film for 4 weeks after irradiation. As is quite evident, the radiation from the bone produced small pitting in the surface, which show as grey areas. The etched film exhibiting both fission fragment and bone images permits a more accurate characterization of the plutonium distribution.

\section{ATTEMPTS TO EXPLAIN BONE IMAGE}

Since the film pitting occurs after irradiation, reactions such as $(n, n),(n, p),(n, d)$ or $(n, n)$ by fast neutrons are ruled out. Radiation must be from the activation of bone constituents, i.e. calcium, phosphorus, etc. with a short half-life. The composition of bone indicates no alpha emitter would be produced and no alpha activity was found on control (plutonium-free) dog bone sections after irradiation.

Only beta activity was found in the sample. Absorption curves with aluminum absorbers indicated that most of the activity was from phosphorus32, a $1.71 \mathrm{MeV}$ beta emitter with a 14-day half-life. Some calcium activation should have occurred, but little activity other than phosphorus-32 was observed.

Human bone marrow produce greater amounts of film pitting than dog bone marrow. This clue so far has not helped. to identify the decay radiation causing this pitting. Betas from phosphorus-32 seem to be the main charged particles available to produce the pitting. Pitting by betas has 


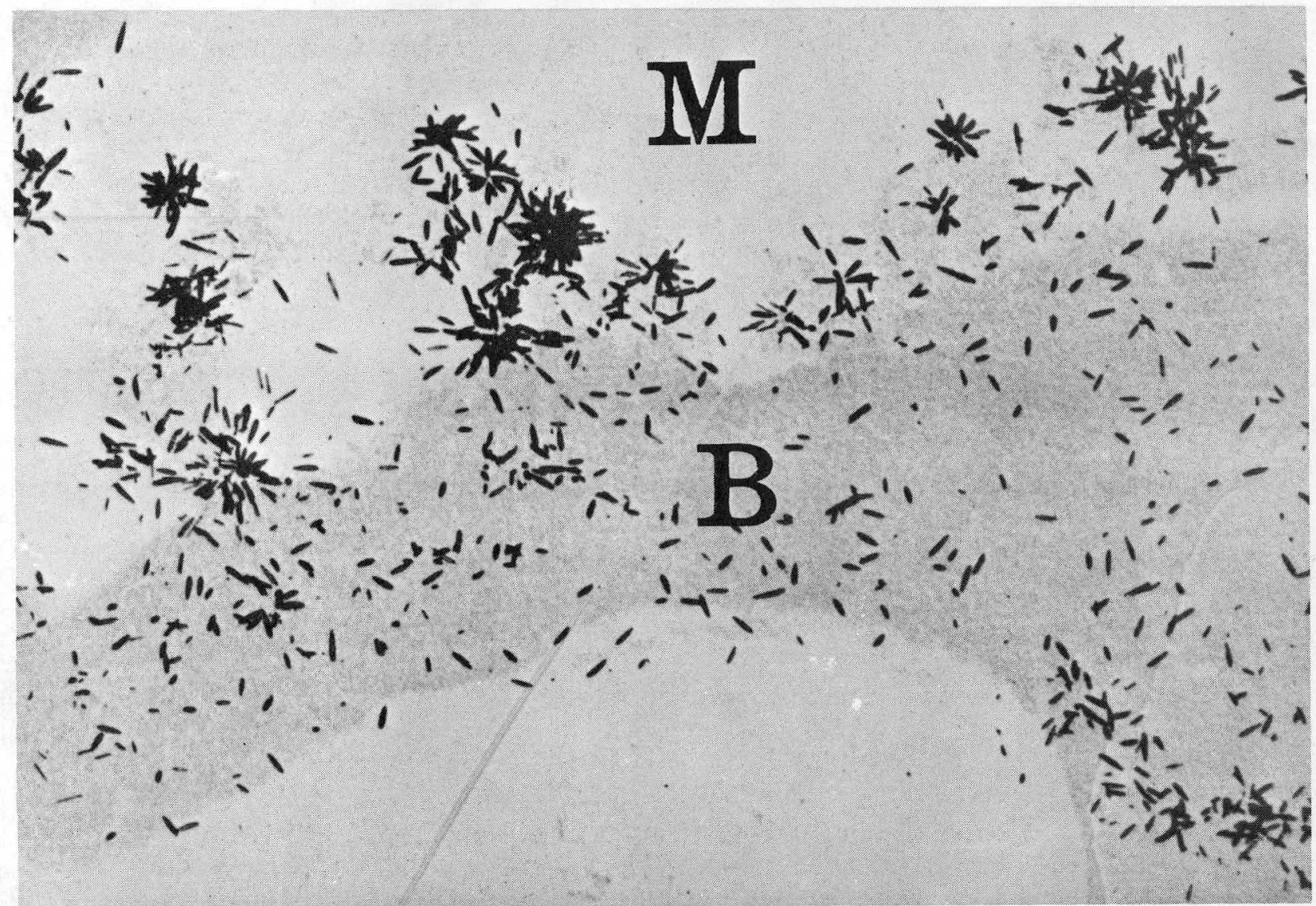

Fig. 2. Detailed neutron-induced autoradiograph showing a portion of a bone spicule diffusely labeled with tracks (B) and star-producing aggregates of fission fragment tracks in the bone marrow in the lumbar vertebral body from a dog given $0.96 \mu \mathrm{Ci}$ of $239 \mathrm{Pu} /$ $\mathrm{kg}$ and killed 1617 days later (X 210).

never been reported in the literature. More work is needed before the source of pitting is known.

Previously, Kleeman and Lovering ${ }^{(9)}$ obtained prints of their ore sample with thick Lexan foils that were exposed to neutrons in contact with certain minerals. They too have observed a fine pitting of the foil surface 
in contact with certain types of minerals. Although this is not caused. by decay radiation from activation of the sample as we have observed, it is caused by small charged particles lighter than alphas. Nevertheless, the prints of the bone image allowed us to study the distribution of plutonium-239 in bone, with considerable saving in time and without fear of having the latent image fade.

\section{APPLICATION OF TECHNIQUE}

In order to express properly the radiation dose delivered to the bone lining cells in radiation carcinogenesis of bone seeking radionuclides, the residence time (reciprocal of "turnover rate") of the plutonium must be known. We are in the process of determining the resident time of plutonium on lumbar vertebral body bone surfaces in young adult beagles (15 months old) given a single intravenous injection of $0.015 \mu \mathrm{C} i$ of $239 \mathrm{Pu}$ citrate/kg using detailed neutron-induced autoradiography (Table I). The percent bone surface with plutonium (fission fragment tracks) and percent of bone with buried plutonium was determined by microscopic sampling. Details of the methods have been reported in a study using detailed autoradiographic methods. (10) The ongoing neutron-induced autoradiographic study showed that $69.6 \%$ of the bone surface contains plutonium, $30.4 \%$ of the bone surface is free of plutonium and $13.2 \%$ of the bone surface contains buried plutonium at 5 days post injection. In other words, $43.4 \%$ of the bare bone surfaces exhibit buried plutonium. The buried plutonium was formerly located on bone surfaces at day 1. The bone surface deposits drop to $21.4 \%$ and $3.4 \%$ at 97 and 186 days post injection respectively. Our current program calls for the use of neutron-induced autoradiography to determine the quantity of plutonium in both the marrow and bone, 


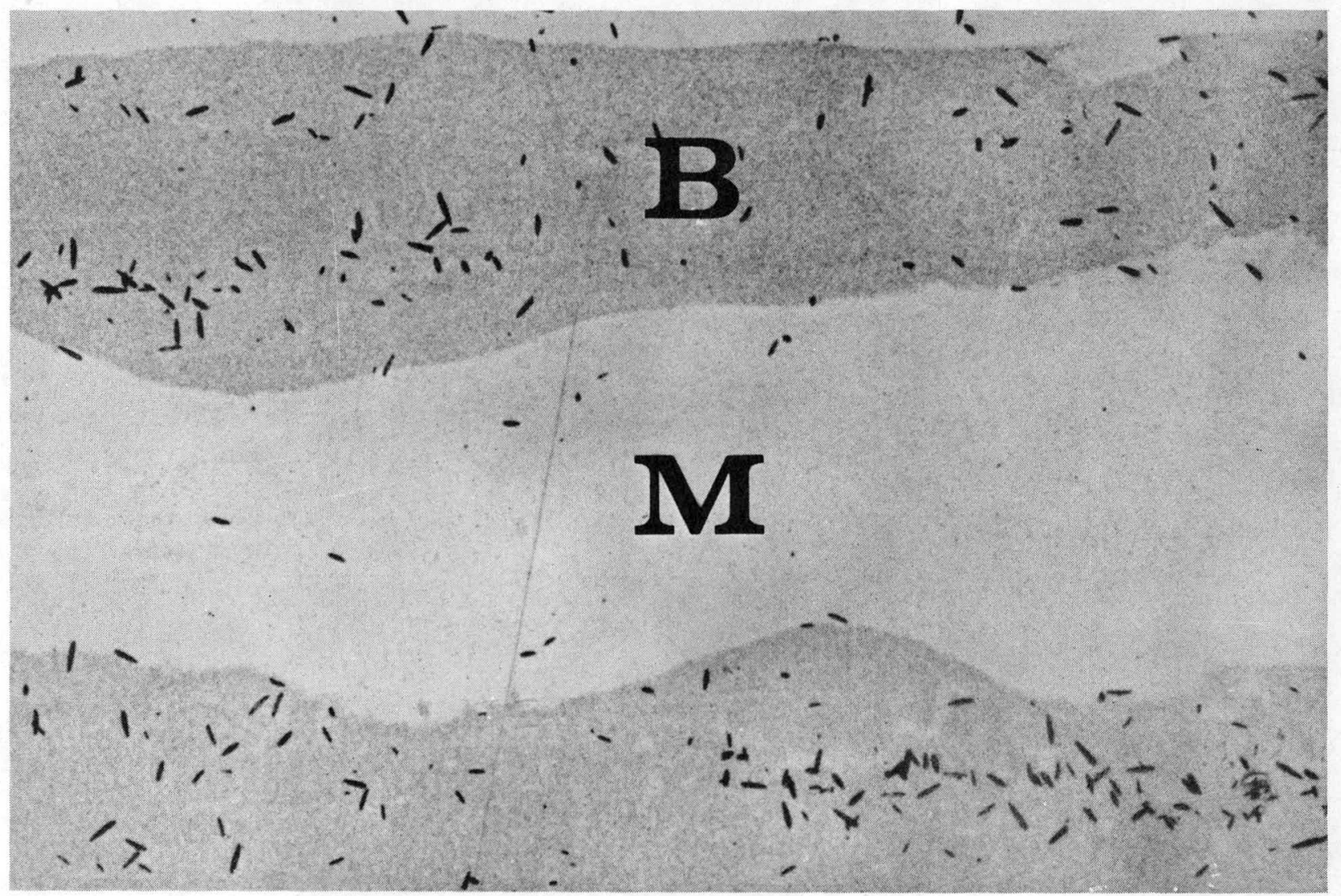

Fig. 3. Detailed neutron-induced autoradiograph of a portion of two bone spicules showing diffusely labeled bone in upper spicules, and a band of tracks in the lower spicules in a lumbar vertebral body from a dog injected with $0.0142 \mu \mathrm{C}$ of ${ }^{239} \mathrm{Pu} / \mathrm{kg}$ and sacrificed 1539 days later. Very few tracks are located in the marrow. $B$ denotes bone and $M$ denotes marrow ( $x$ 210).

using automatic track counting techniques. Previously, visual track counting proved to be time consuming and demoralizing. We will subject these bones to neutron irradiation and immediately etch them. Total plutonium value in the bone sections can be determined by spark countingll or by 
track counting with the Quantitative Television Microscope (QTM ${ }^{12}$ ). Using the detailed neutron-induced autoradiography on the next serial section, the plutonium-in-bone value can be obtained by counting fission fragment tracks localized within bone with the QTM. Thus, the marrow Pu content can be derived by subtracting the bone count from the total Pu count.

\section{TABLE I}

$\begin{aligned} & \text { Distribution of Plutonium-239 in Lumbar Vertebral } \\
& \text { Trabeculae of Beagles Injected with } 0.015 \mu \mathrm{Ci} / \mathrm{kg}\end{aligned}$
\begin{tabular}{lcc}
$\begin{array}{l}\text { Time after } \\
\text { injection }\end{array}$ & $\frac{\% \text { Surface }}{2 \text { Buried }}$ \\
\hline 5 days & 69.6 & 13.2 \\
97 days & 21.4 & 53.1 \\
186 days & 3.4 & 43.5
\end{tabular}

\section{REFERENCES}

1. J. S. Arnold. "An Improved Technique for Liquid Emulsion Autoradiography." Proc. Soc. Expt 1. Biol. and Med. 85: 113 (1954).

2. J. S. Arnold and W. S. S. Jee. "Bone Growth and Osteoclastic Activity as Indicated by Radioautographic Distribution of Fu239." Am. J. Anat. 101: 367 (1957).

3. J. S. Arnold and W. S. S. Jee: "The Toxicity of Plutonium Deposited in Skeletal Tissues of Beagles. 1. The Relation of Distribution of Plutonium to the Sequence of Histopathologic Bone Changes." Lab. Invest. 7: $797(1961)$.

4. B. Bleaney. "Radiation Dose Rates Near Bone Surfaces in Rabbits After an Injection of Plutonium." Phys. Med. Biol. 12: 145 (1967). 
5. B. Bleaney. "The Radiation Dose-rates Near Bone Surface in Rabbits after I.V. or I.M. Injection of Plutonium-239." Brit. J. Radiol. 42: 51 (1969).

6. B. Bleaney. "Plutonium Deposition on Bone Surface and in Bone Marrow Following Intravenous and Intramuscular Injections." In Delayed Effects of Bone-Seeking Radionuclides, Ed. By C. W. Mays, R. D. Lloyd and W. S. S. Jee, P. 125, U. of Utah Press, Salt Lake City (1969).

7. K. Becker and D. R. Johnson. 'Non-photographic Alpha Autoradiography and Neutron-Induced Autoradiography." Science, 167: 1370 (1970).

8. R. Dell, R. S. Mical and W. S. S. Jee. "Modified Techniques in Successful Thin Sectioning and Detailed Autoradiography of Undecalcified Bone"' (in preparation).

9. J. D. Kleeman and J. F. Lovering. "Uranium Distribution Studies by Fission Track Registration in Lexan Plastic Prints." In Proceedings of the International Conference on Nuclear Track Registration in Solids, Sect. VI, p. 41, Univ. of Clermount-Ferrand, France (1969).

10. W. S. S. Jee, H. Z. Park and R. Burggraff. "Estimates of Residence Time of ${ }^{239} \mathrm{Pu}$ in Trabecular Bone of Beagles." Research in Radiobiology, U. of Utah Report C00-119-246, p. 188 (1969).

11. D. R. Johnson, R. H. Boyett and K. Becker. "Sensitive Automatic Counting of Alpha Particle Tracks in Polymers and Its Applications in Dosimetry." Health Physics, 18: 424 (1970).

12. M. H. Bartley, S. Targonski, S. Seamans and W. S. S. Jee. "Comparison of Some Quantitative Studies of Trabecular Bone." In Stereology, Ed. by H. Elias, p. 68, Springer-Verlag, New York (1967). 


\section{ELECTRON MICROSCOPY OF RADIATION DAMAGE IN BONE}

William S. Whitson and Webster S. S. Jee

Abstract: Some morphological effects of radionuclides on bone are described with the use of the electron microscope. Haversian canal and osteocytic lacunar fibrosis, perivascular cell reduction and osteolys is and subsequent osteostasis are present. Endothelial vacuolization increases with dosage level. Kidney failure leads to an increase in the number of osteoclasts and fusion between osteoclasts and adjacent cells are found.

\section{INTRODUCT I ON}

The purpose of this study with the electron microscope is to confirm and possibly add to observations made with the light microscope on changes in the bone morphology induced by alpha irradiation.

The numbers of radionuclides used and the variety of dosage levels given, together with the natural morphological changes in bone which occur with age, make comparison between the effects of different radionuclides difficult. However, some general findings on the effects of radiation on bone as a whole are possible and will be described briefly.

\section{MATERIALS AND METHODS}

At autopsy one metatarsal is removed from the dog and small pieces of spongy bone, cortical bone, and articular cartilage are fixed for electron microscopy in $2 \%$ cacodylate buffered glutaraldehyde ( $f$ inal buffer $=.025 \mathrm{M})$. Sucrose is added to the fixative $(.045 \mathrm{~g} / \mathrm{ml})$ to minimize inherent osmotic problems in bone. Part of the bones are decalcified in 4\% EDTA and part remain undecalcified. All bone and cartilage is postfixed in cacodylate buffered osmium tetroxide, dehydrated with graded ethyl alcohols and embedded in Epon 812. Sections for light and electron microscopy are obtained on a MT-1 Porter-Blum ultramicrotome. One micron 
sections are stained with paragon stain for light microscopy and thin sections, stained with uranyl acetate and lead citrate for electron microscopy. Electron micrographs are taken on an RCA electron microscope at $50 \mathrm{KV}$.

\section{RESULTS}

A summary of our preliminary findings follows:

A. Perivascular Observations:

1. There is a decrease in the number of perivascular cells in the Haversian canals of both ageing controls and irradiated dogs (Figs. $1,2,3$ ).

2. At low injection levels of radionuclide normal bone formation can occur and tight junctions are prevalent between ósteoblasts and periosteoblasts (1) (Figs. 5,6,7).

3. Perivascular cells in irradiated animals have more lysosomallike inclusions in their cytoplasm than controls (Figs. 7,8).

4. In perivascular fibrosis, which occurs subsequent to radiation damage, the collagen fibril present is of smaller caliber than the normal bone collagen fibril (Fig. 9).

B. Vascular Observations:

1. With increasing dosage levels the small pinocytotic vesicles normally present are replaced to varying degrees with larger vacuoles (Figs. 7,8).

2. The basement membrane appears to become somewhat thicker and more ragged in appearance (Fig. 8).

3. The endothelial cell acquires an increased number of inclusion particles (lysosomes) (Figs. 7,8 ). 
4. Blistering of the endothelial cytoplasm can occur also (Fig. 4).

C. Osteocytic Changes:

1. The lacunar borders of some osteocytes show evidence of lacunar repair after apparent initial osteolysis (Figs. 10,11,12).

2. Empty lacunae can be found which are filled to various degrees with fine fibrillar material (Figs. 3,13 ).

D. Osteoclast Formation:

1. Several dogs have become terminal because of kidney failure. In each case of kidney failure there is an increase in the number of osteoclasts observed in compact bone, even though some of these dogs are quite old (Fig. 14,15,16).

2. Some osteoclasts have been found which appear to be fusing with another cell (Figs. 15, 16).

\section{DISCUSSION}

The overall vascular findings in the bone vascular system of internally irradiated dogs are in general agreement with those described by Berdjis $^{(2)}$ for externally irradiated animals. It is interesting to note that examples of each stage of vascular deterioration can be found in the bone vasculature of dogs injected with radionuclides many months before. The question naturally arises whether the vascular injury resulted from the latent effects of initial irradiation or whether, since much of the residual radioactivity resides in bone, the visible effects are the result of recent radiation damage.

The extent of initial osteolysis can be seen by the reversal lines around the perimeter of the osteocytic lacuna. Some osteocytes have 
more than one line which suggests several periods of recovery and variable osteocytic activity. The osteocytes pictured (Figs. 10, 11, 12) all have new osteoid on the inside of the lacunar border indicating that the osteocytes have entered a synthesizing phase (osteostasis). Correlations between the current osteocytic activity and the appearance of vascular supply may be an important factor in evaluating this "life history." Kidney failure in the dog brings about predictable morphological changes in bone of control or irradiated dogs. Osteoclast formation is increased and, depending on the time course of the disease, can be of value in studying osteoclast formation and osteoclasis. Fusion of osteoclasts is found and is less confusing to study because the numbers of perivascular cells are decreased.

\section{REFERENCES}

1. S. W. Whitson; Tight junction formation in the osteon; Accepted for publication, Clinical Orthopaedics (1971).

2. C. C. Berdjis; The cardiovascular system; In Pathology of Irradiation; Ed. by C. C. Berdjis, Williams and Wilkins, Baltimore, 377-407 (1970). 


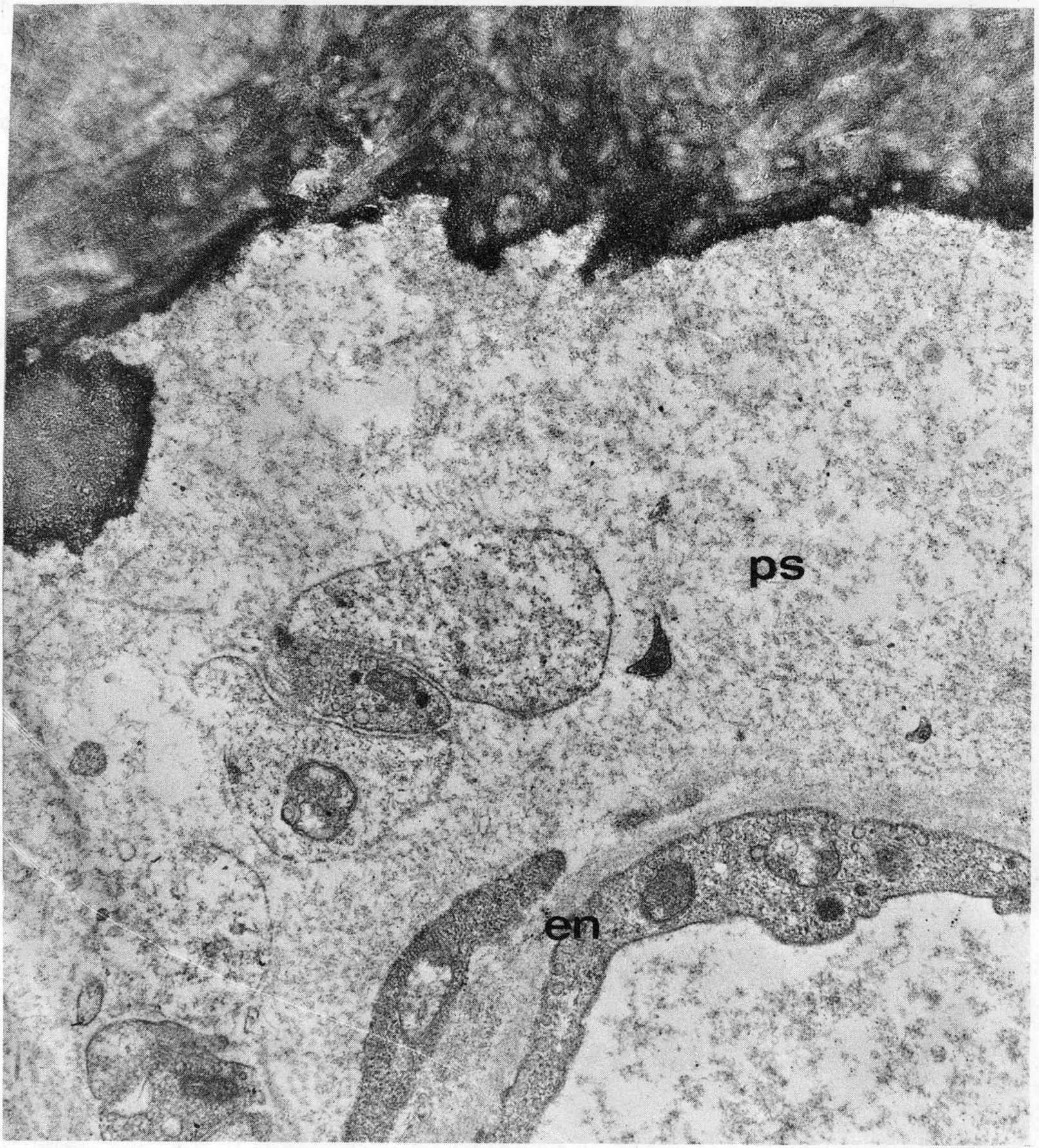

Fig. 1. Area of haversian canal of metatarsal shaft from a 5426 days old control beagle (M6MO). The endothelium (en) has many small pinocytotic vesicles and there are few cells in the perivascular space (ps). $\times 21,000$ 


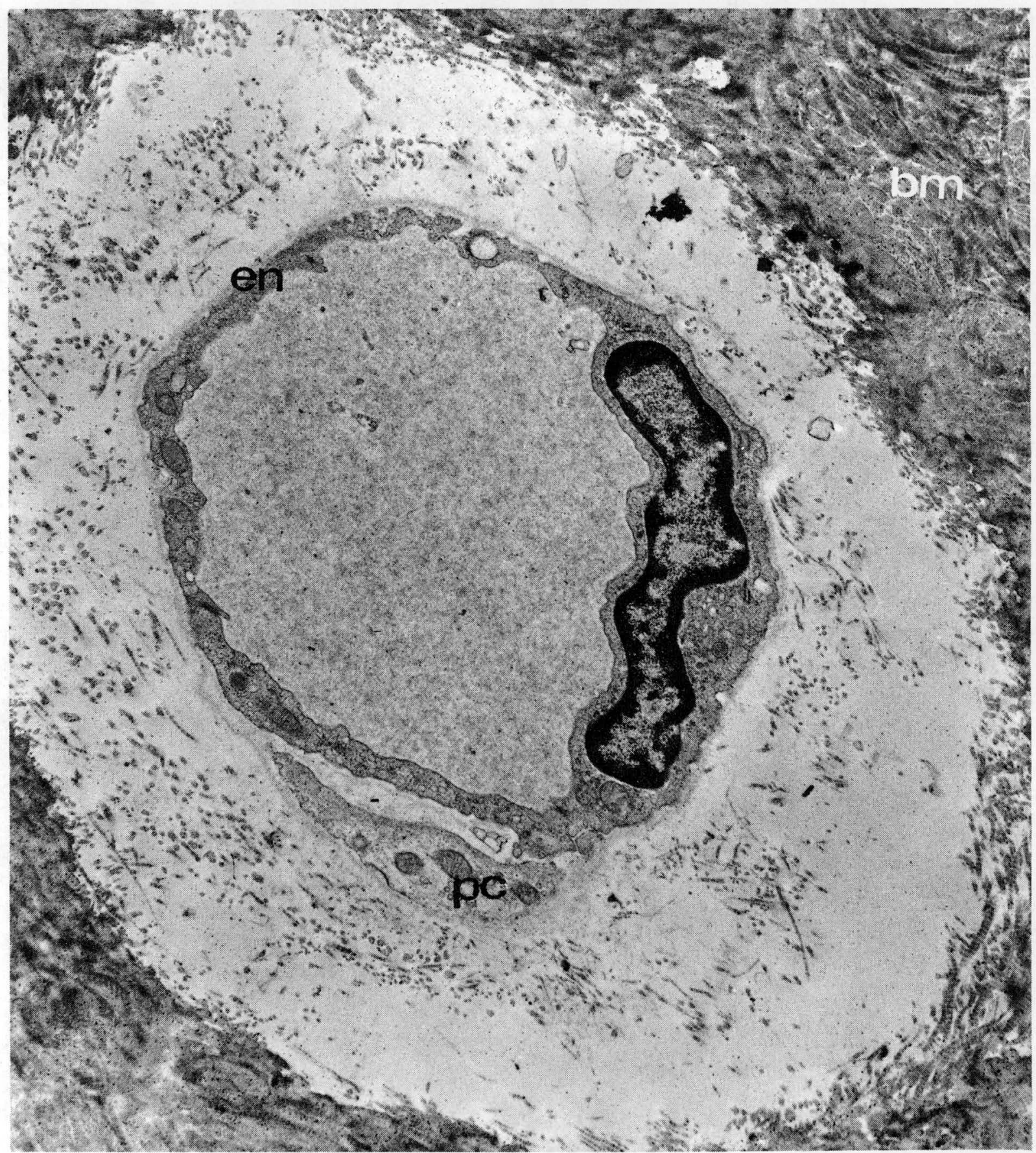

Fig. 2. Haversian canal showing absence of perivascular cells, with the exception of a small pericytic process ( $p c)$, in the metatarsal shaft of a dog (M4RI.7) given an i.v. injection of $0.163 \mu \mathrm{C} i$ of $226 \mathrm{Ra} / \mathrm{kg}$ at 514 days and sacrificed 5495 days later. Endothelium (en), bone matrix (bm) $\times 15,300$ 


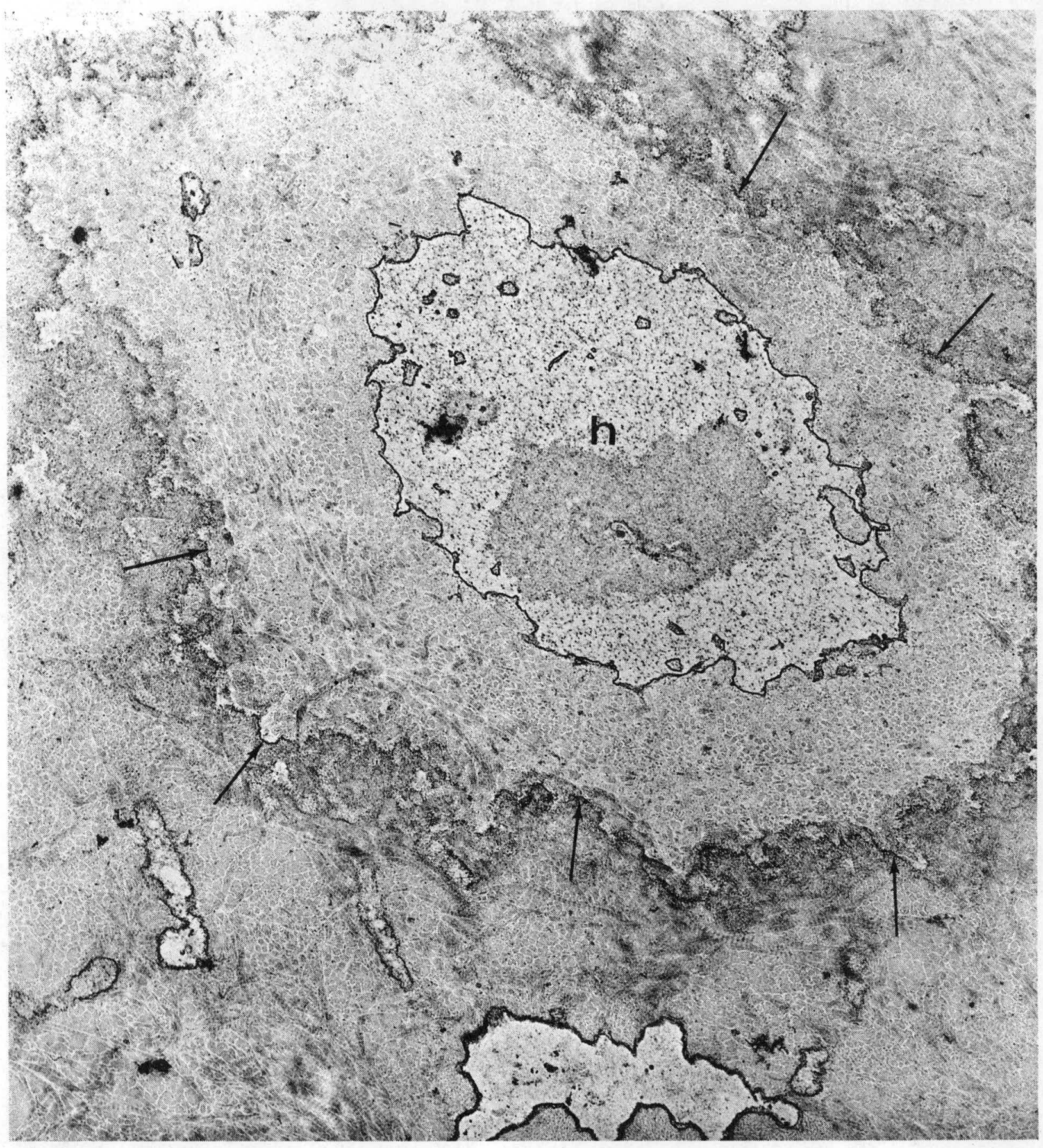

Fig. 3. Haversian Canal (h) from the same dog as figure 2 (M4R1.7). No blood capillary is present. If the limit of the original canal border is traced (arrows), it is evident that a new concentric layer of dense matrix (osteoid)has reduced its size. The resulting canal is filled with debris as is the empty osteocytic lacunae perpherally. $\times 12,800$ 


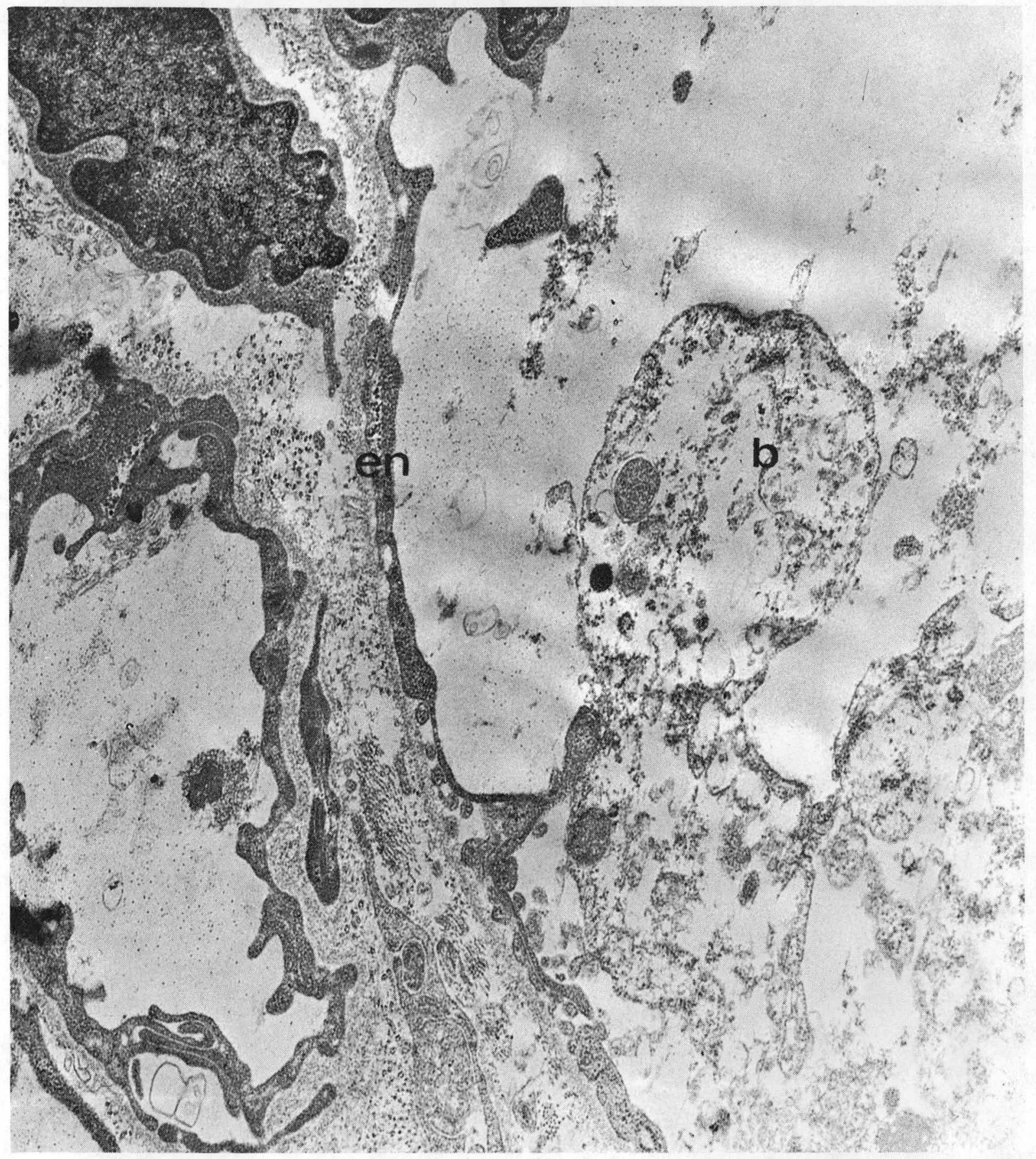

Fig. 4. Capillary endothelium (en) exhibiting a blister (b) which protrudes into the capillary lumen in a haversian canal of the metatarsal shaft of an adult dog (T6W3) given an i.v. injection of $0.31 \mu \mathrm{C}$ of ${ }^{241} \mathrm{Am}$ and sacrificed 1510 days post injection at 2027 days of age. $\times 25,200$ 


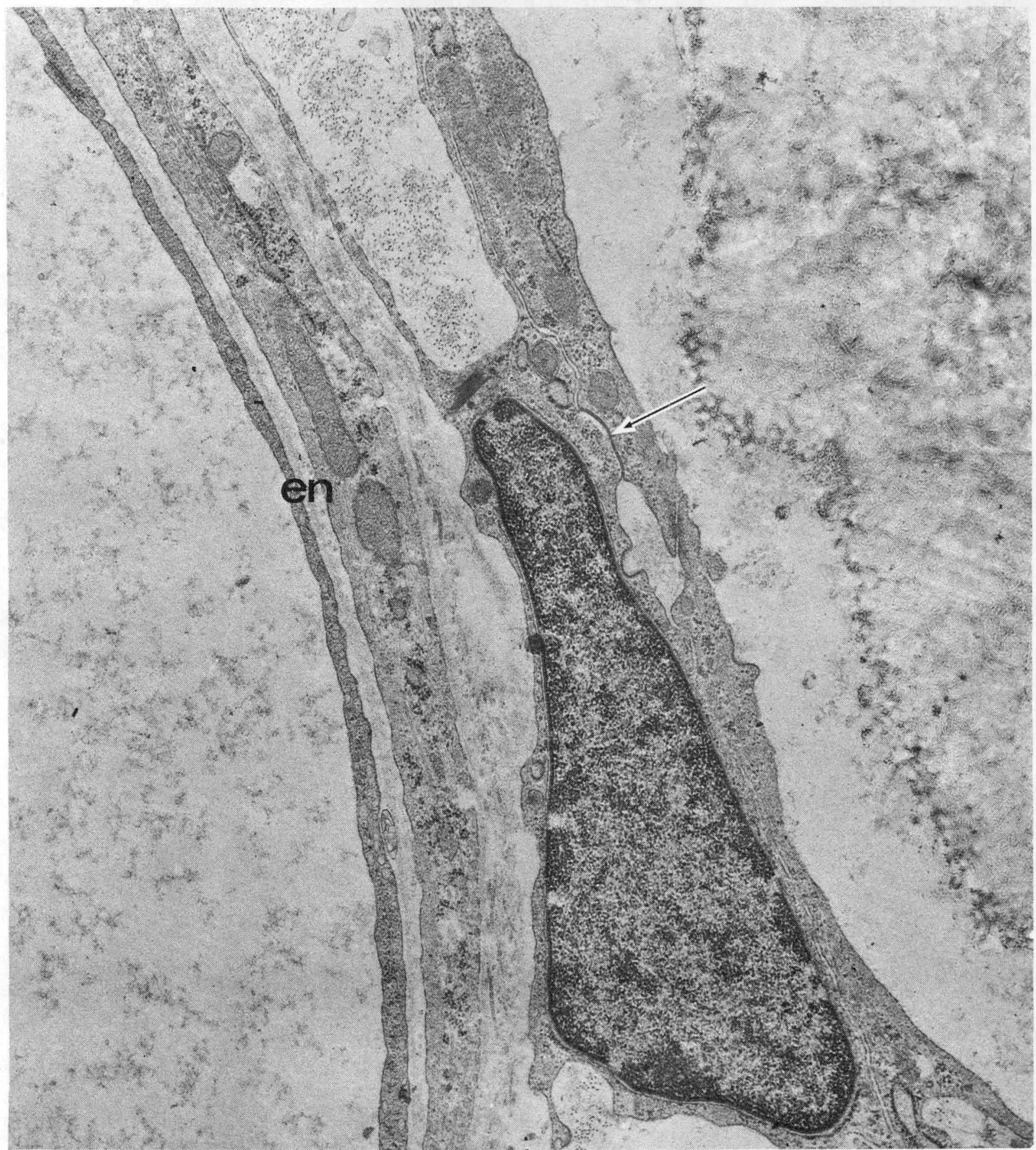

Fig. 5. Tight-junction formation (arrow) between osteoblasts in a haversian canal from the metatarsal of the same dog as in figure 2 (M4R1.7). Endothelium (en) $\times 21,000$ 


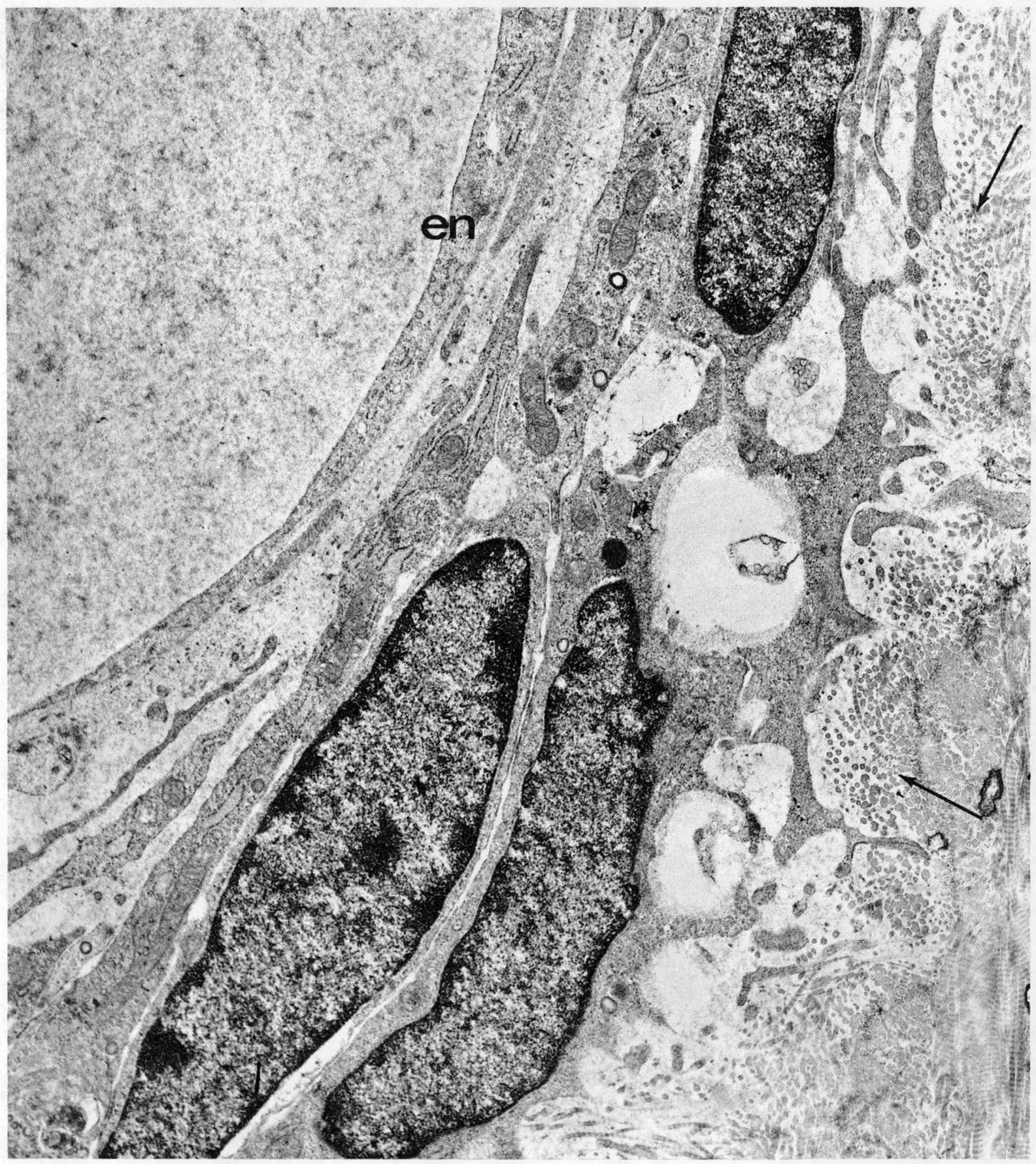

Fig. 6. New osteoid (arrows) is being formed by the overlapped osteoblasts on the perimeter of the haversian canal in the metatarsal shaft of a dog (FIOTl) given an i.v. injection of $0.015 \mu \mathrm{C} i$ of ${ }^{228}$ Th at 508 days old and killed 3420 days later. Endothelium (en) $\times 13,400$ 


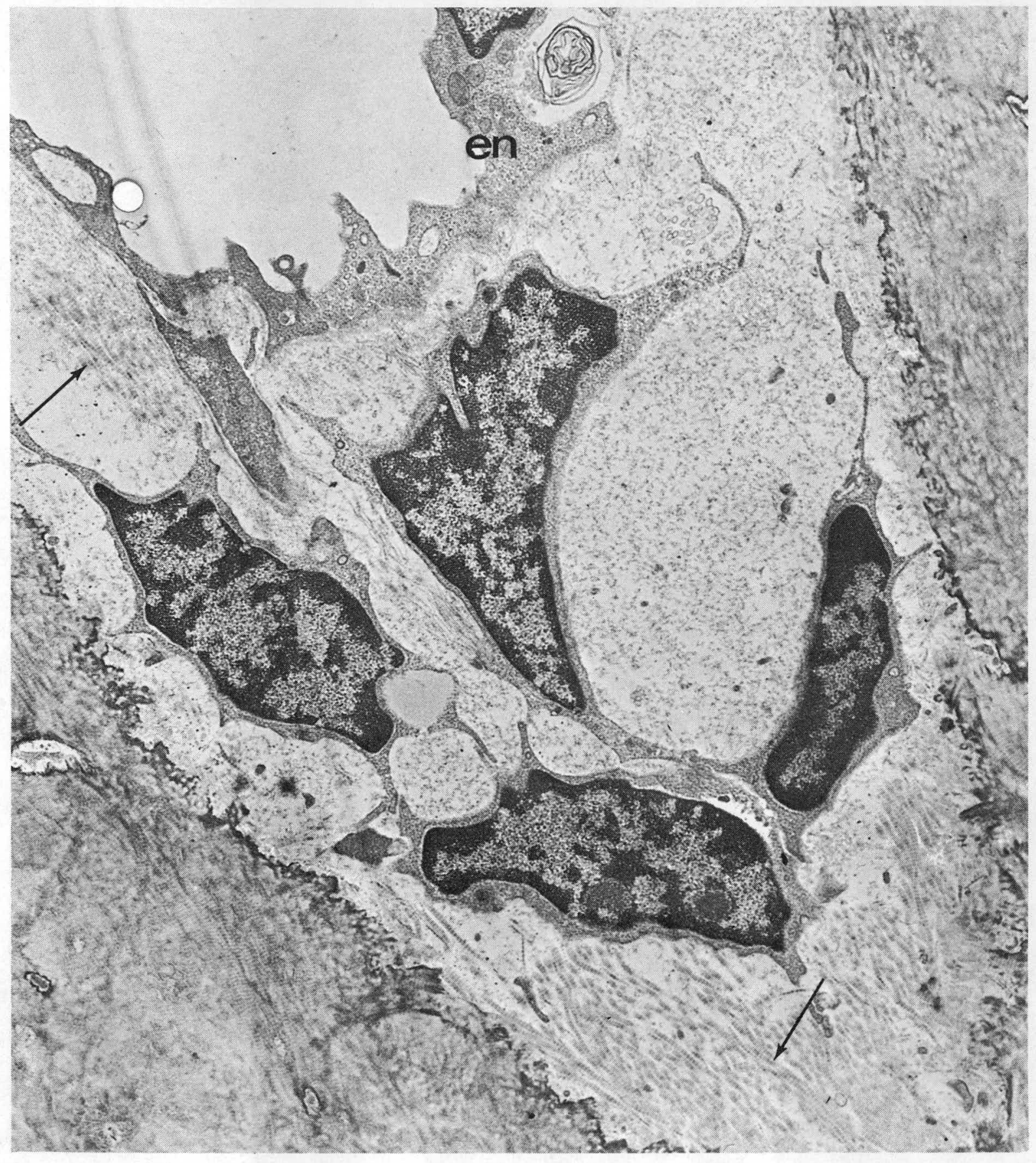

Fig. 7. Haversian canal from a 5297 days old dog (F4S2) injected with $3.41 \mu \mathrm{Ci}$ of $90 \mathrm{Sr} / \mathrm{kg}$ and sacrificed at 4775 days post injection (tangentially cut). Bone formation is occurring (arrows) and a large myelin figure is present partially surrounded by endothelial cytoplasm (en). $\times 10,300$ 


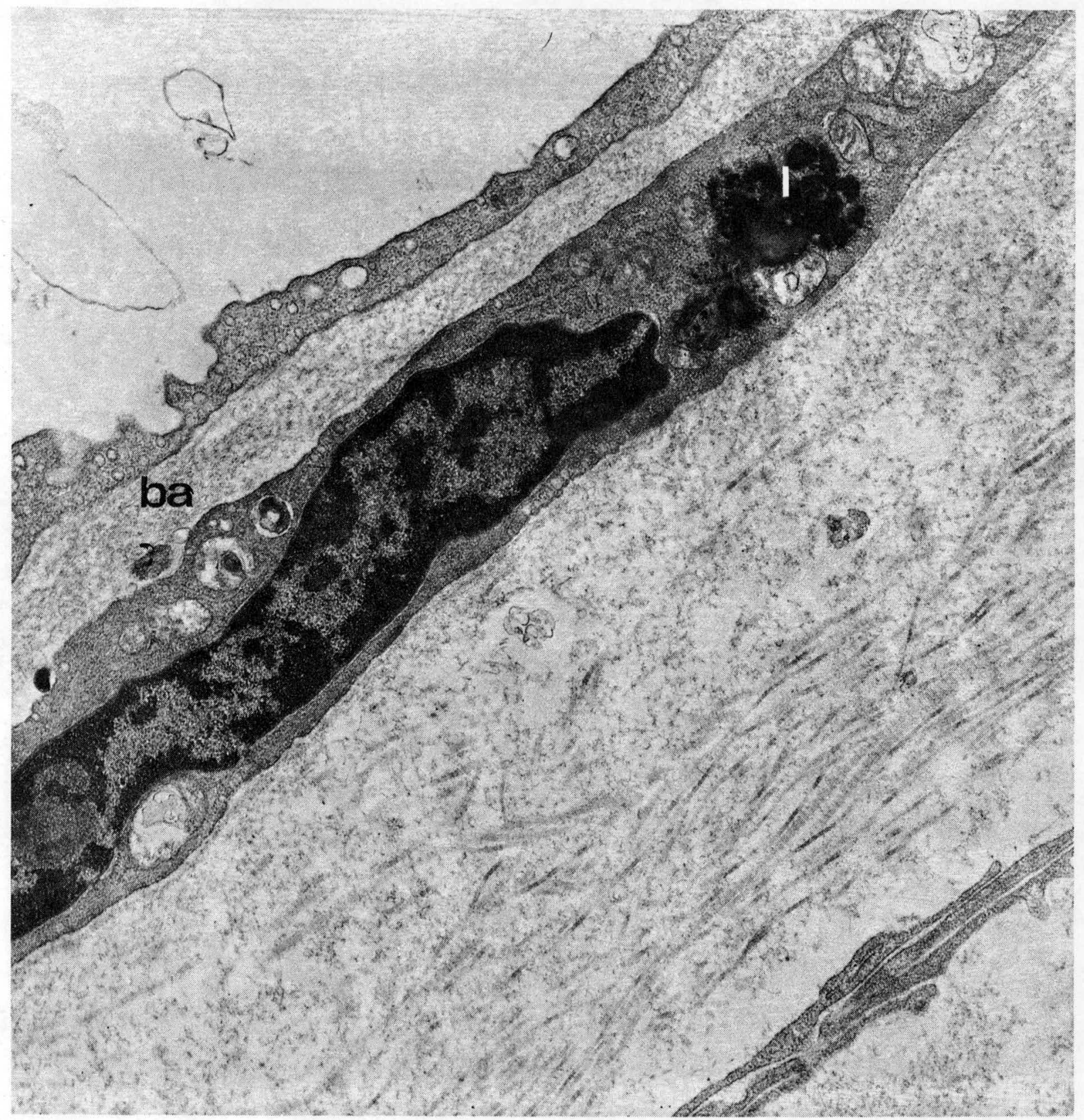

Fig. 8. An area of haversian canal (longitudinal section) from the metatarsal shaft of the same dog as figure 7 (F4s2). The basement membrane (ba) appears thickened and the preosteoblasts have large lysosomes (1). A loose network of collagen fibrils lie between the preosteoblast and the thin osteoblastic processes nearer the bone matrix. $\times 15,600$ 


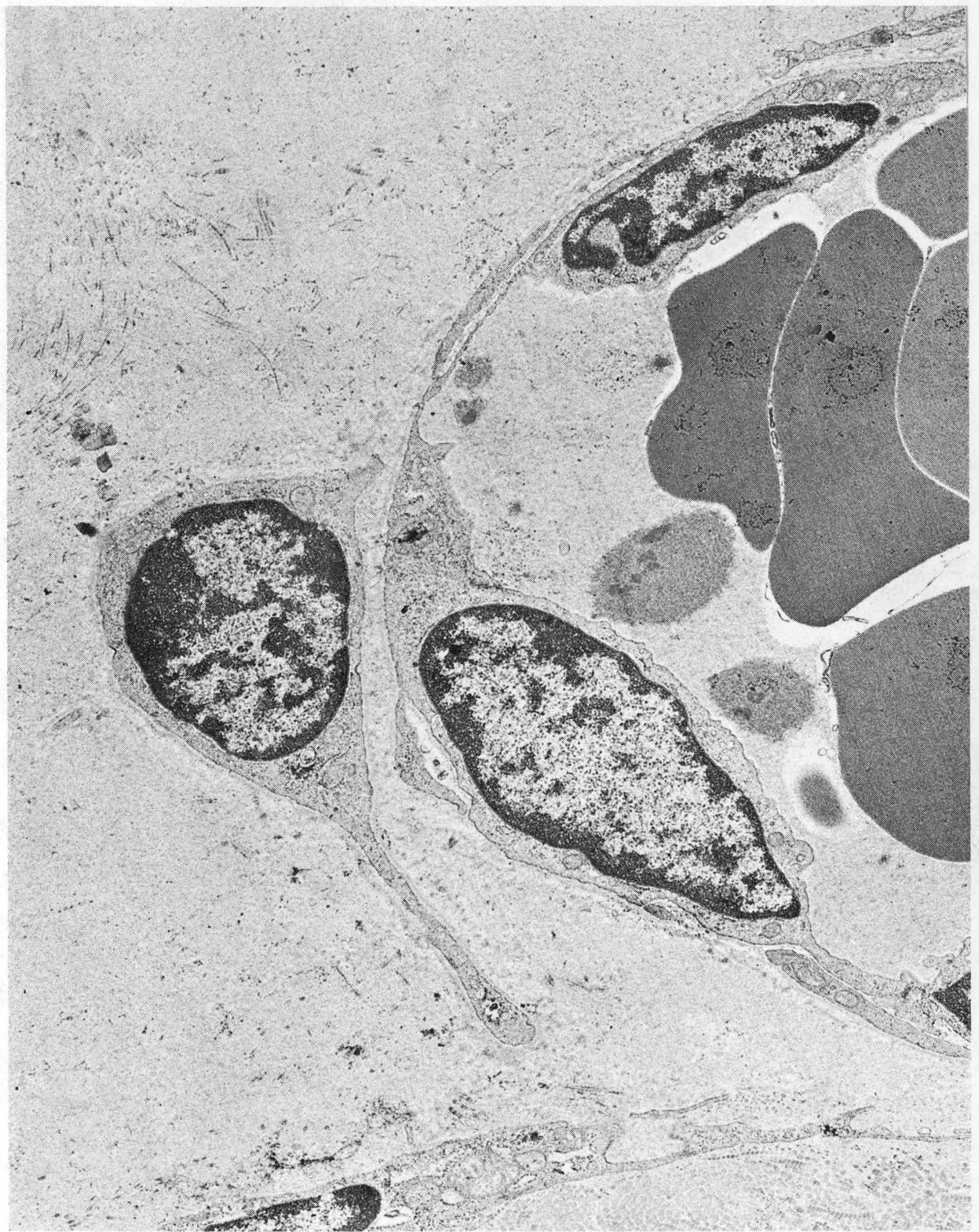

Fig. 9. Area of haversian canal from the metatarsal shaft of the same dog as in figure 6 (FIOTI). The entire perivascular space surrounding endothelium (en) and the pericyte ( $p c$ ) is completely surrounded by a dense, but small-fibered (arrow) matrix. x 11,400 


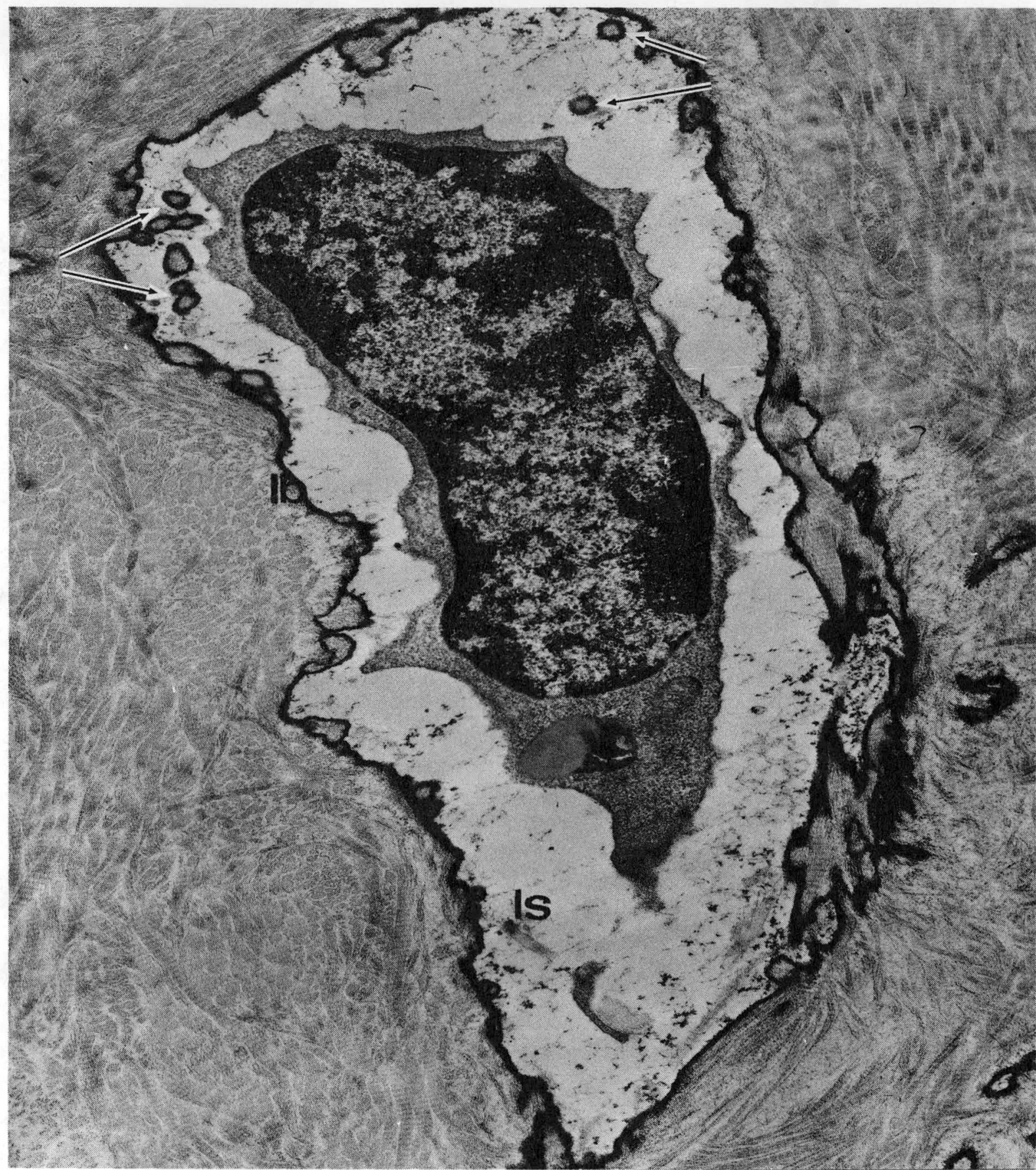

Fig. 10. Osteocyte from the metatarsal shaft of the same dog as figure 7 (F4S2). The lacunar border presents a very irregular bor$\operatorname{der}(1 \mathrm{~b})$ and together with the small islands of collagen ( $1 \mathrm{~s}$, arrows) located in the lacunar space typically result from osteolytic activity. Fibrillar material is minimal. $\times 18,200$ 


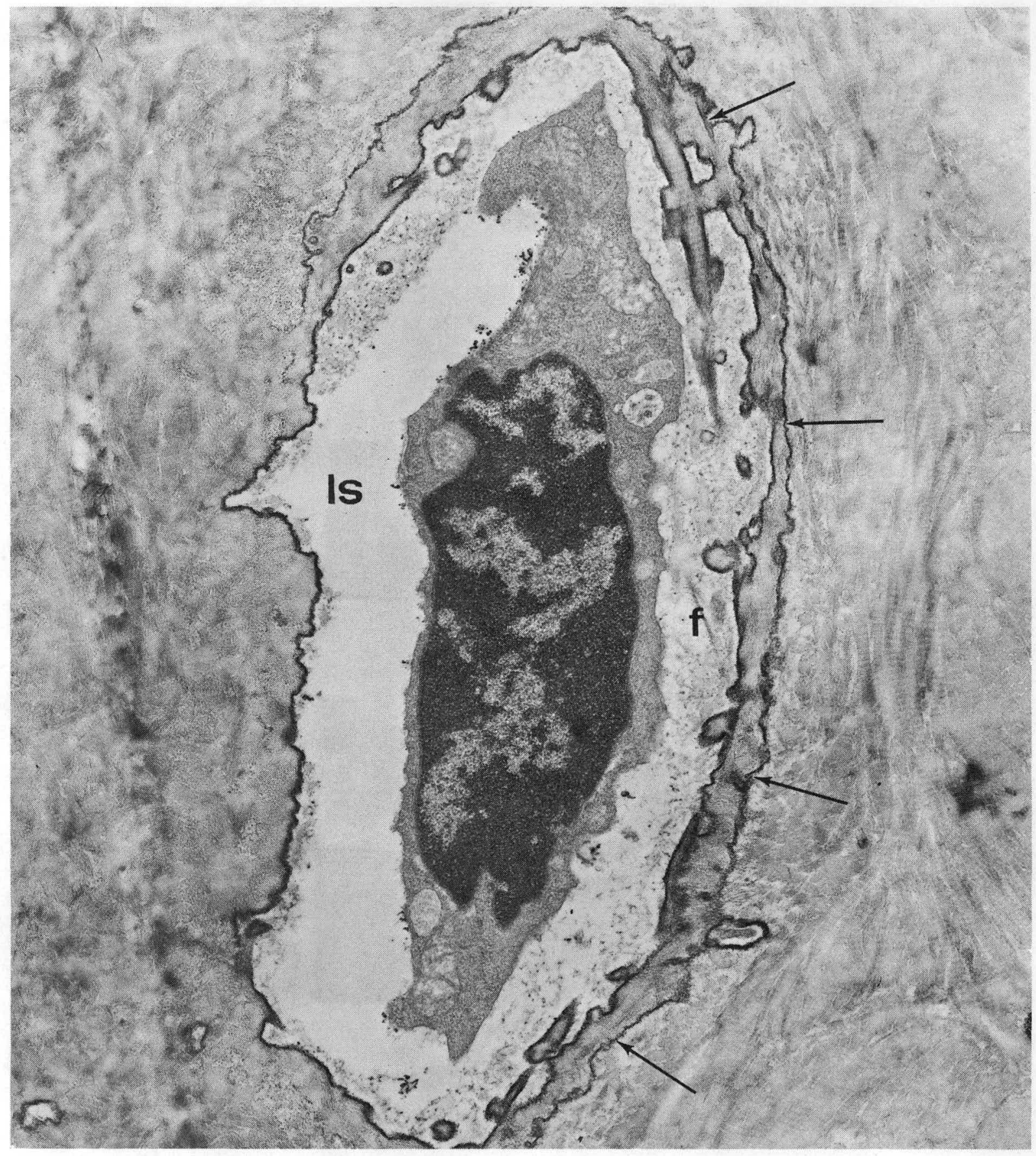

Fig. 11. Osteocyte, same treatment as animal in figure 7 (F4S2). The osteolysis evident along the lacunar border appears to be secondary to an attempt at lacunar repair as represented by the "reversal" line (arrows) of an earlier border limit. Some new collagen fibrils (f) are present. $\times 18,200$ 


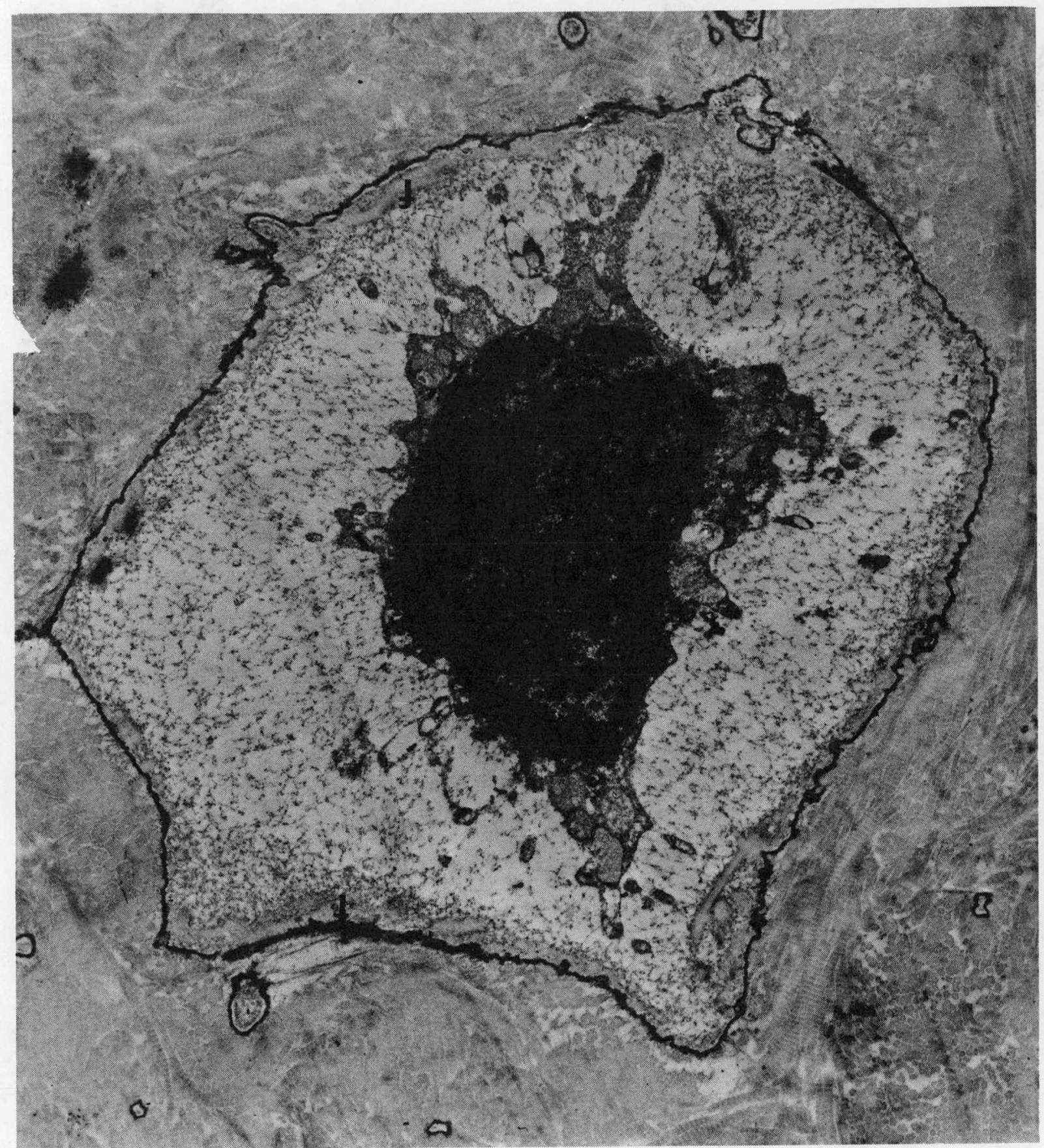

Fig. 12. Osteocyte, same animal as figure 7 (F4S2). The lacunar border is smooth in appearance but exhibits a new thin layer of collagen fibrils (f) along the entire extent of the lacunar border. 


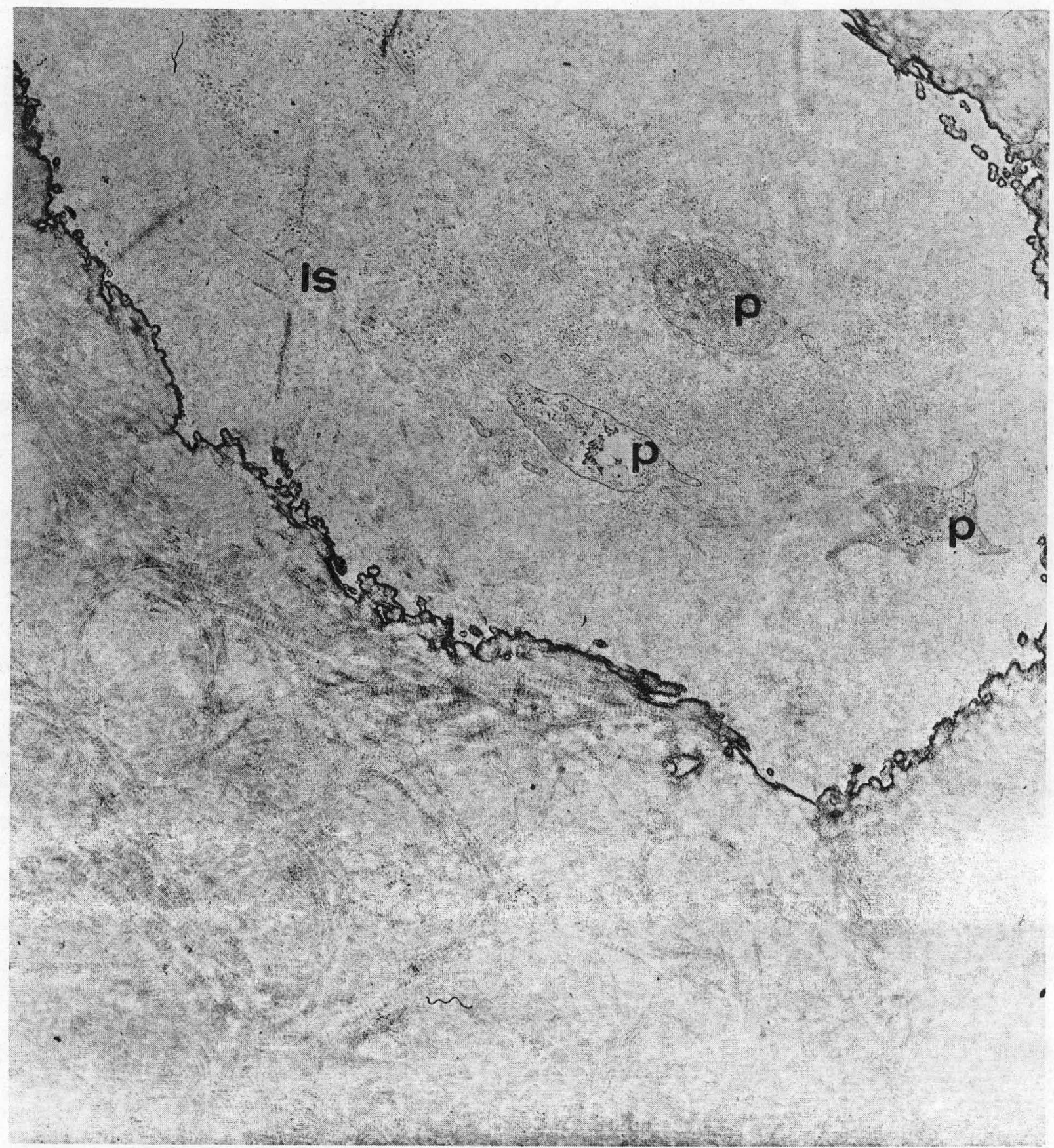

Fig. 13. Osteocytic lacunae from metatarsal midshät of a dog (F1154.5) injected i.v. with $63.8 \mu \mathrm{Ci}$ of $90 \mathrm{~s} / \mathrm{kg}$ at age 496 days and sacrificed 1758 days later. Three cytoplasmic processes ( $p$ ) are evident but the rest of the lacunar space (1s) is filled with fine fibrillar material. $\times 15,400$ 


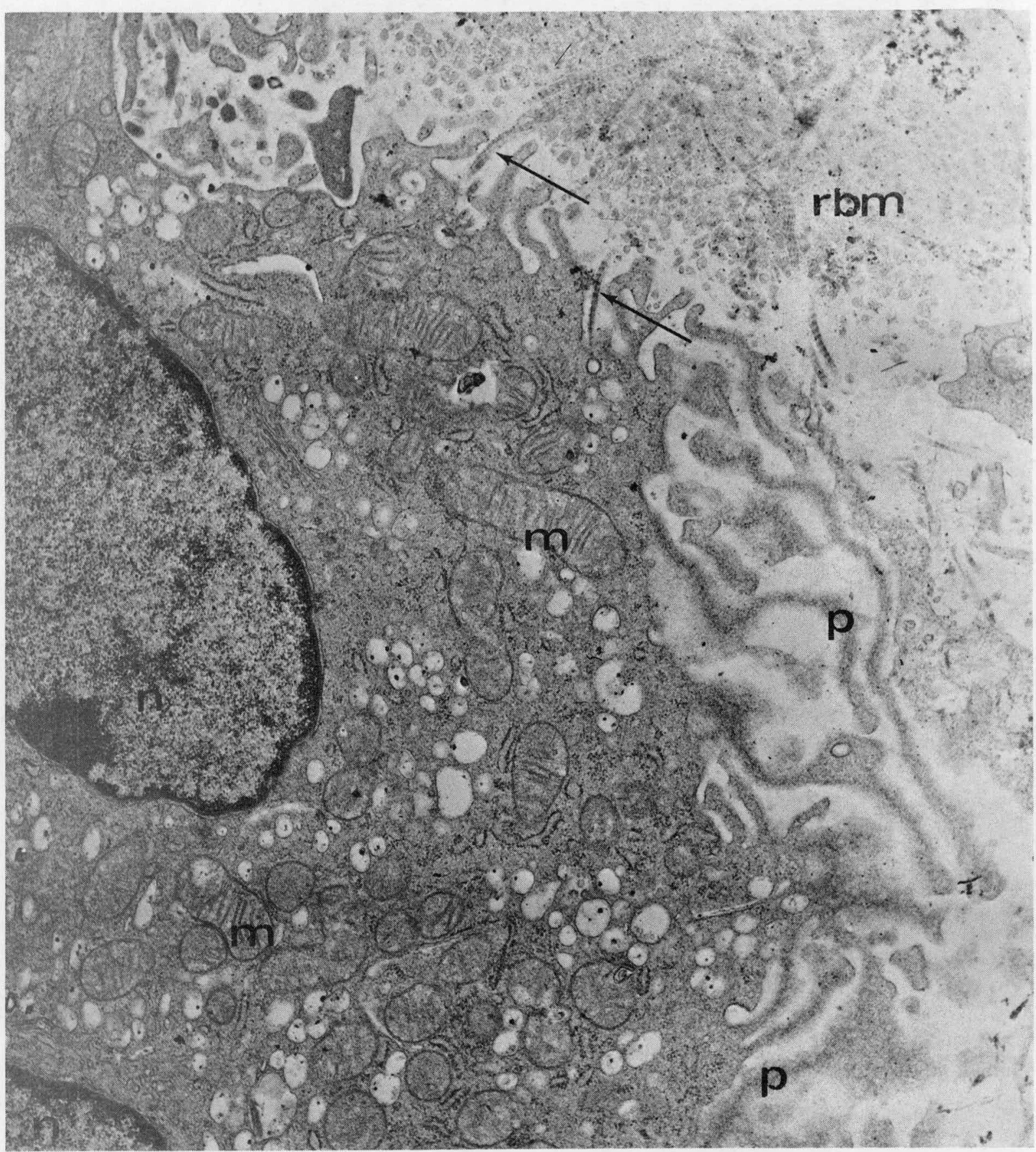

Fig. 14. Osteoclast from the metatarsal midshaft of the same dog as figure $2(M 4 R 1.7)$. Note the parts of two nuclei $(n)$, the numerous mitochondria $(\mathrm{m})$, and the modification of the plasma membrane into many irregular processes $(p)$, some with collagen fibrils between them (arrows). Resorbing bone matrix (rbm) $\times 18,000$ 


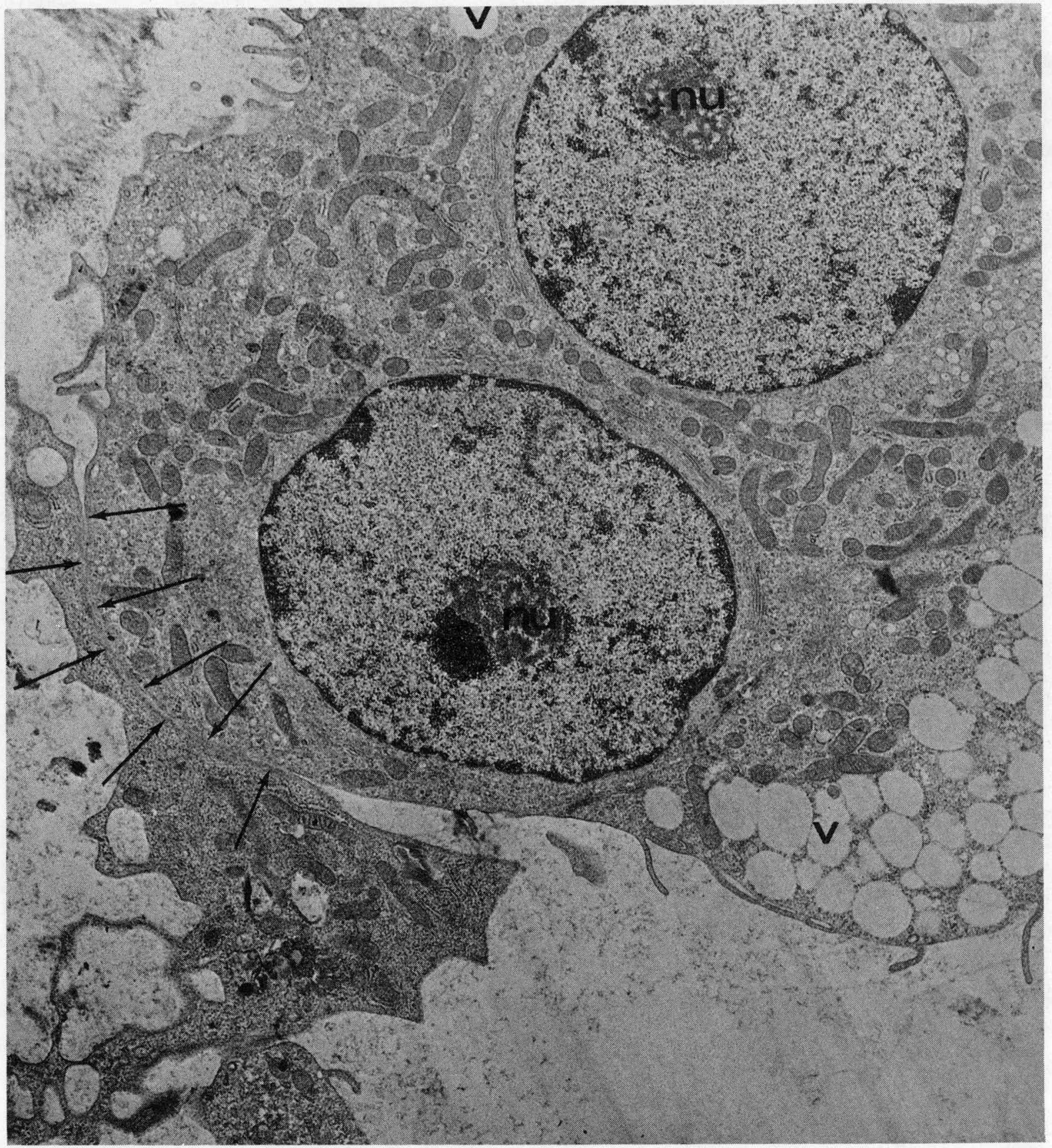

Fig. 15. Osteoclast from the epiphysial bone of the metatarsal of the same control as figure $1(M 6 M 0)$. In addition to the organelles previously mentioned note the prominent nucleoli (nu), within the nuclei, the occurrence of large $v a c$ uolated areas of cytoplasm (v), and the apparent fusion of a neighboring cell to the osteoclast (between arrows). $\times 10,400$ 


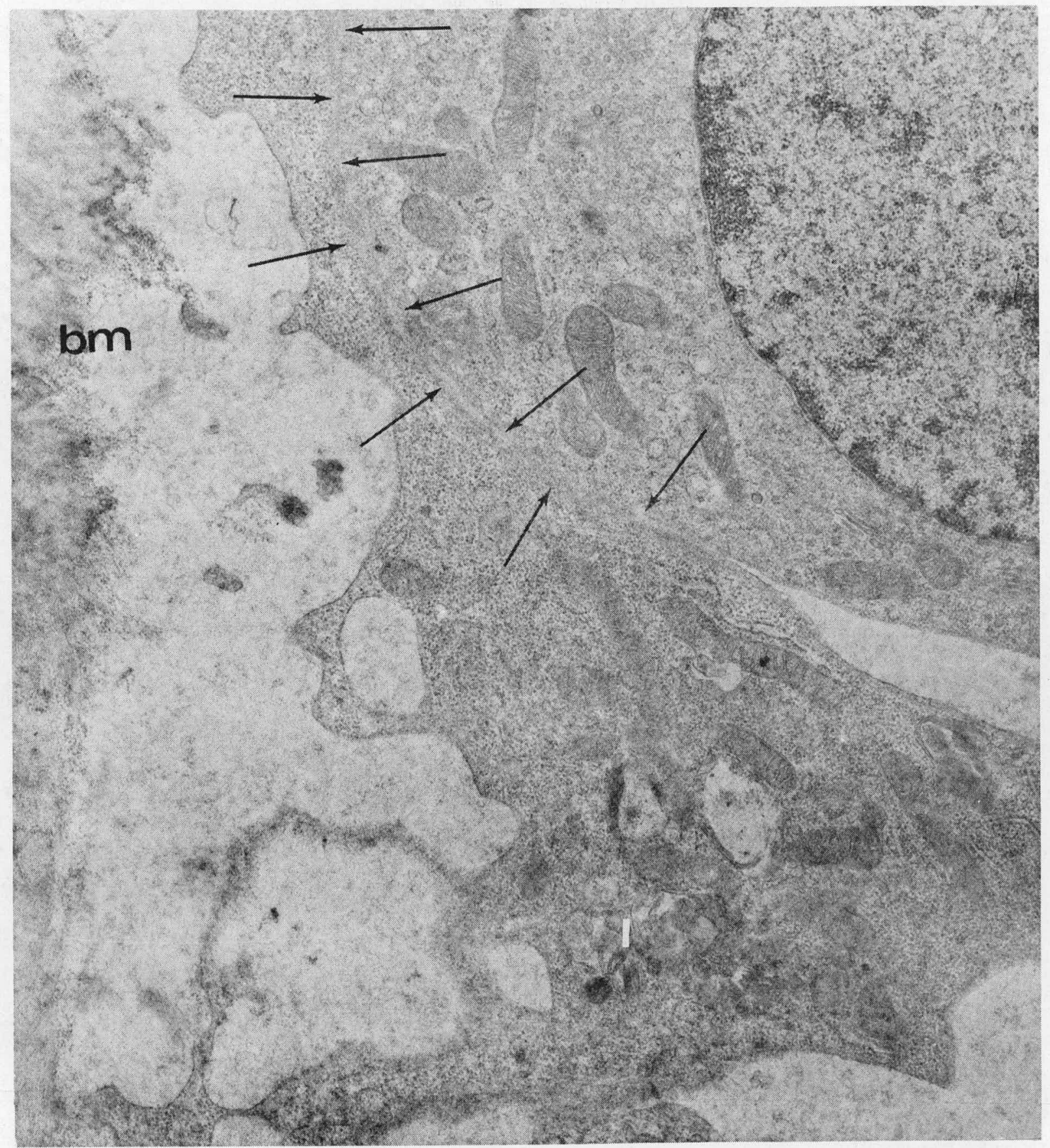

Fig. 16. High magnification of figure 15 (M6MO) in the area of fusion (between arrows). Besides the fusion the ragged appearance of the bone matrix (bm) and lysosomal formation (1) is seen to better advantage. $\times 20,600$ 


\section{AUTORADIOGRAPHIC STUDY OF THE EARLY DISTRIBUTION OF ${ }^{45} \mathrm{Ca}$ IN ALVEOLAR BONE OF DOGS}

W. W. S. Jee, Rebecca B. Dell and M. A. Davis*

Abstract: An autoradiographic study designed to yield information about the prompt uptake of $45 \mathrm{Ca}$ in alveolar bones of adult mongrels at 2 and 30 hours after injection of $45 \mathrm{Ca}$ found the greatest darkening at alveolar bone surfaces located at or near the alveolar crest and at forming bone surfaces of trabeculae and forming osteons. The next greatest darkening is seen at cemental and the remaining alveolar bone surfaces. Haversian canals of formed osteons of intermediate mineralization are poorly labeled with

${ }^{45} \mathrm{Ca}$. Our findings suggest that the greatest exchange of calcium between bone and blood takes place at the bone surfaces with the richest blood supply (i.e. alveolar crest and areas of bone formation).

\section{INTRODUCTION}

The bone group in cooperation with Drs. M. A. Davis and J. James

Adelstein of the Division of Nuclear Medicine, Peter Bent Brigham Hospital, Harvard Medical School, Dr. D. Garcia, Department of Radiology, Harvard Dental School and Dr. L. Blau of the Hospital for Special Surgery, New York City, are developing methods needed to apply radionuclide scanning techniques to the mineral metabolism of the jaws and alveolar bone of the beagles with and without periodontal diseases. The above individuals will develop the scanning methods and our group will carry out histological studies to correlate external nuclide counts with autoradiographic evidence of calcium-45 incorporation.

Scanning of the skeleton following administration of bone-seeking radionuclide has found an important role in many diagnostic procedures in the practice of orthopaedics. Detectable differences in the avidity for

* Dr. M. A. Davis, Division of Nuclear Medicine, Department of Radiology, Harvard Medical School, Peter Bent Brigham Hospital, Boston, Mass. 
radioactivity have been found in bone surrounding tumors, fractures and infections. Early changes in bone pathology were detected by bone scanning weeks and months prior to detectable density differences in conventional radiographs. These scans were performed using ${ }^{85} \mathrm{Sr}$. It is our plan to use strontium- $87 \mathrm{~m}$. The clinical use of ${ }^{87 \mathrm{~m}} \mathrm{Sr}$ will permit repetitive use and still be within acceptable radiation dose limits for humans. The calculated total bone dose of 0.14 rads for ${ }^{87 \mathrm{~m}} \mathrm{Sr}$ (half-life: $2.8 \mathrm{hrs}$ ) per $\mathrm{mC} i$ injected in a $70 \mathrm{~kg}$. man is less than $10 \%$ that received with 0.1 $\mathrm{mC} i$ of longer 1 ived bone-seeking radionuclides (calcium- 47 and strontium85).

The research plan for this study will initially involve mongrel dogs given a dose ranging from 1 to $4 \mathrm{mC}$ of $87 \mathrm{~m}_{\mathrm{Sr}}$ per scan. With a physical half life of 2.8 hours, the radioactivity should disappear in 24 to 28 hours. Thus, it is imperative to determine whether there is a differential uptake of calcium-like radionuclides in areas of bone remodeling during this short time interval.

In 1935, Chiewitz and Hevesy ${ }^{(1)}$ indicated that the rate of uptake of ${ }^{32} \mathrm{p}$ by bone was too rapid to be due to growth alone and there exists an exchange reaction between the bone mineral and the bone-seeking radioisotopes in the circulating fluids. More recently, Rowland ${ }^{(2)}$ identified the locations in compact bone of the femur which took up calcium- 45 between 12 minutes to several days after intravenous administration of the boneseeking radionuclide. He demonstrated that those bone structures with the most intimate contact with the circulating fluids were the primary sites of rapid exchange between blood and bone and that lowly mineralized structures are not the major sites of exchange between bone and blood.

The pilot study reported here was designed to yield qualitative 
autoradiographic information about the prompt uptake of calcium- 45 in alveolar bones of adult mongrels at 2 and 30 hours after intravenous injection of calcium-45.

\section{METHODS AND MATERIALS}

Two adult mongrel dogs $(75 \%$ beagle) were sacrificed at 2 and 30 hours after intravenous injection of $2 \mathrm{mC}$ of ${ }^{45} \mathrm{Ca}$ by $\mathrm{Dr}$. M. A. Davis. Immediately after sacrifice, the mandibles and tibiae were rapidly removed and fixed in 3 changes of absolute acetone and shipped to Utah. At Utah, the segments of the mandible with the first and second premolars and third and fourth premolars and one of the proximal tibiae were sawed, defatted in several changes of ether, embedded in bioplastic and ground into 100 micronthick sections. These sections were microradiographed and then contact autoradiographed on Eastman No-Screen film and Eastman NTB 10 micron-thick plates. Subsequently, these same sections were dipped in Eastman NTB liquid emulsion.

\section{RESULTS}

Shown in Figures 1 through 3 are microradiographs, contact autoradiographs and detailed autoradiographs of the interradicular alveolar bone of the second premolar tooth section from a dog sacrificed 2 hours post ${ }^{45} \mathrm{Ca}$ administration. At this early time period, all the ${ }^{45} \mathrm{Ca}$ is deposited upon bone surfaces. In the autoradiographs, there is high uptake of ${ }^{45} \mathrm{Ca}$ at the cementum and alveolar bone surfaces. The deposit at the cemental surface was of uniform intensity, while the deposition on the alveolar bone surface was more irregular. Higher deposits of ${ }^{45} \mathrm{Ca}$ were located in a scalloped area (lower left) and on the coronal border (left portion of micrographs) of the alveolar bone. Two other hotspots are seen within the alveolar 
bone. One corresponds to a forming Haversian system possessing a concenteric layer of poorly mineralized bone (recently formed bone), while the other possesses very little lowly mineralized bone.

Figures 4 to 6 are microradiograph, contact autoradiograph and detailed autoradiograph of the interdental alveolar bone between the first and second premolars from a dog sacrificed 2 hours post injection. Again, there is a high uptake of ${ }^{45} \mathrm{Ca}$ at the cemental and alveolar bone surfaces. The heavier deposition areas occur at the alveolar crest (left) of and neighboring alveolar bone surfaces. Active bone resorption is restricted to the crest. Another region of the alveolar bone surface which has been resorbed (top right corner) shows a portion of its surface with a heavy 45 ca deposition. It corresponds to an area of scalloped alveolar bone sur. face with a lowly mineralized osteon situated near the surface. The only other hotspot is located within the bone and near the crest. The hotspot corresponds to a forming osteon possessing poorly and highly mineralized bone surfaces.

Figures 7 through 10 are examples of active or recent bone resorption of alveolar bone surfaces, a consequence of periodonta? diseases. Figure 7 shows the marked destruction of the interdental alveolar crest leaving behind srabeculae with poorly and highly mineralized bone surfaces. There is a high uptake of ${ }^{45} \mathrm{Ca}$ on these bone surfaces regardless of their state of mineralization (Fig. 8). The resulting trabeculation at this site made more surfaces available for ${ }^{45} \mathrm{Ca}$ deposition. In Figure 9 , the coronal tip of the interradicular alveolar bone is well-scalloped by Howship's lacunae. The corresponding autoradiograph shows that the heavy deposition 
on this surface is quite irregular (Fig. 10). Moreover, the hotspot corresponds to areas of lowly mineralized bone (newly formed or forming bone).

\section{DISCUSSION}

The autoradiographs from these two dogs clearly indicated that at 2 and 30 hours, the greatest darkening was seen over the alveolar bone surfaces located at or near the alveolar crest and bone surfaces of forming bone in trabeculae and osteons located within the alveolar bone. The next greatest darkening was seen at cemental and alveolar bone surfaces. Our observations partially agree with Rowland's ${ }^{(2)}$ hypothes is "that the greatest exchange between bone and blood takes place at those bone surfaces with the most intimate contact with the circulating fluids, regardless of their degree of mineralization." Our tentative findings suggest at very short time intervals that the greatest exchange of calcium between bone and blood take place at those bone surfaces with the richest blood supply (i.e. the alveolar bone at the alveolar crest is probably better vascularized than alveolar bone surface adjacent to the periodontal 1 igament).

Heavy deposits of ${ }^{45} \mathrm{Ca}$ were located on bone surfaces of forming new bone at both 2 and 30 hours post-injection regardless of their location. Haversian canals of osteons of intermediate mineralization were poorly labeled. Most of the heavily labeled osteon possessed bits of poorly mineralized bone or smooth, highly mineralized bone surface. Even the cavities with highly mineralized bone surfaces may be actually laying down osteoid which microradiography could not detect. This is why we need a detailed autoradiographic method which will allow us to stain the undecalcified bone section to demonstrate vascularity, active bone formation and resorption. 
In this study we were able to produce unstained, undecalcified liquid emulsion coated autoradiographs. We have not tried staining these specimens, but we expect some difficulty in finding a suitable stain to penetrate through the bioplastic, and stain the undecalcified bone with a low affinity for the liquid emulsion.

We were very fortunate that $\mathrm{Dr}$. Davis chose to use two dogs with low grade periodontal disease. The destruction of the alveolar crest bone by periodontal disease increased the bone surfaces avallable to take up the heavy alveolar crest deposits of ${ }^{45} \mathrm{Ca}$ (Fig. 9 and 10). Whether these deposits are of sufficient quantity to allow detection by in vivo scanning of jaws must await development of suitable bone scanning instruments to view small tissue volumes.

\section{REFERENCES}

1. 0. Chiewitz and G. Hevesy; Radioactive indicators in the study of phosphorus metabollism in rats; Nature, 136: 754 (1935).

2. R. E. Rowland, Exchangeable bone calcium; Clinical Or thopaedics, 49: $233-248(1966)$ 
Fig. 1. Microradiograph of the interradicular alveolar bone of the second premolar from a dog injected with $2 \mathrm{mC} i$ of ${ }^{45} \mathrm{Ca}$ and sacrificed 2 hours later. (1) denotes cemental surface, (2) denotes alveolar bone surface (coronal portion), (3) denotes scalloped alveolar bone surface, (4) denotes forming osteon with lowly mineralized bone, (5) denotes cavity in alveolar bone with portion of bone surface lined with poorly mineralized bone, (6) denotes formed osteon with lowly mineralized bone and partial highly mineralized bone border and (7) denotes osteon with intermediate mineralized border to Haversian canal, $\times 56$.

Fig. 2. Corresponding NTB contact autoradiograph to Fig. 1. Note the heavy darkening at structures (1) through (5). The much lower uptake of ${ }^{45} \mathrm{Ca}$ at structure (6) and (7).

Fig. 3. Detailed autoradiograph of same specimen as Fig. 1. Liquid emulsion coated 100 micron-thick section mounted in water. 

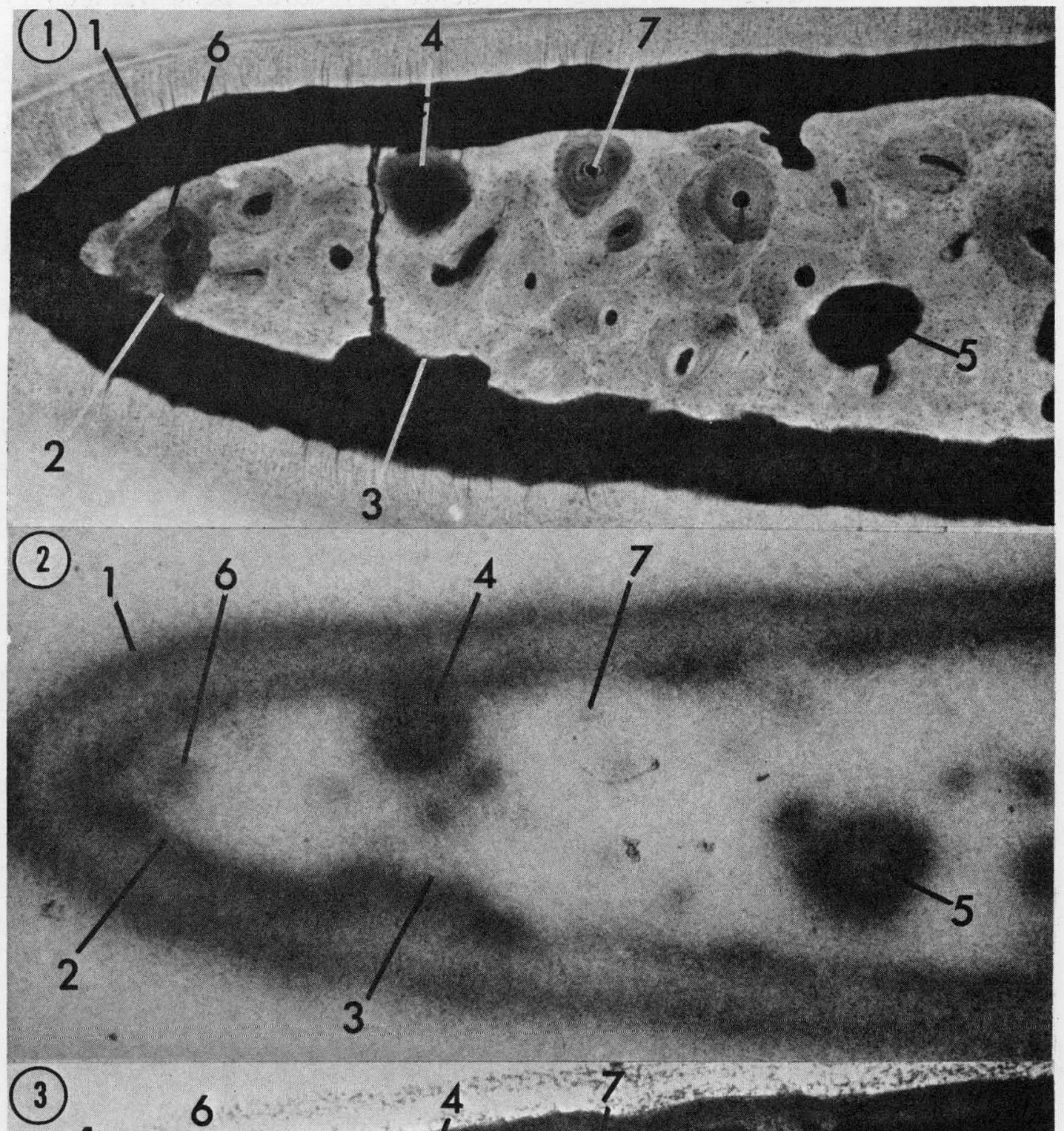

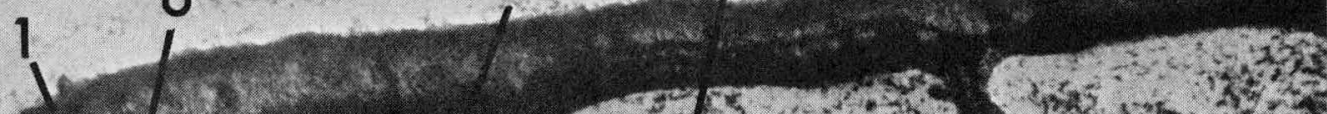

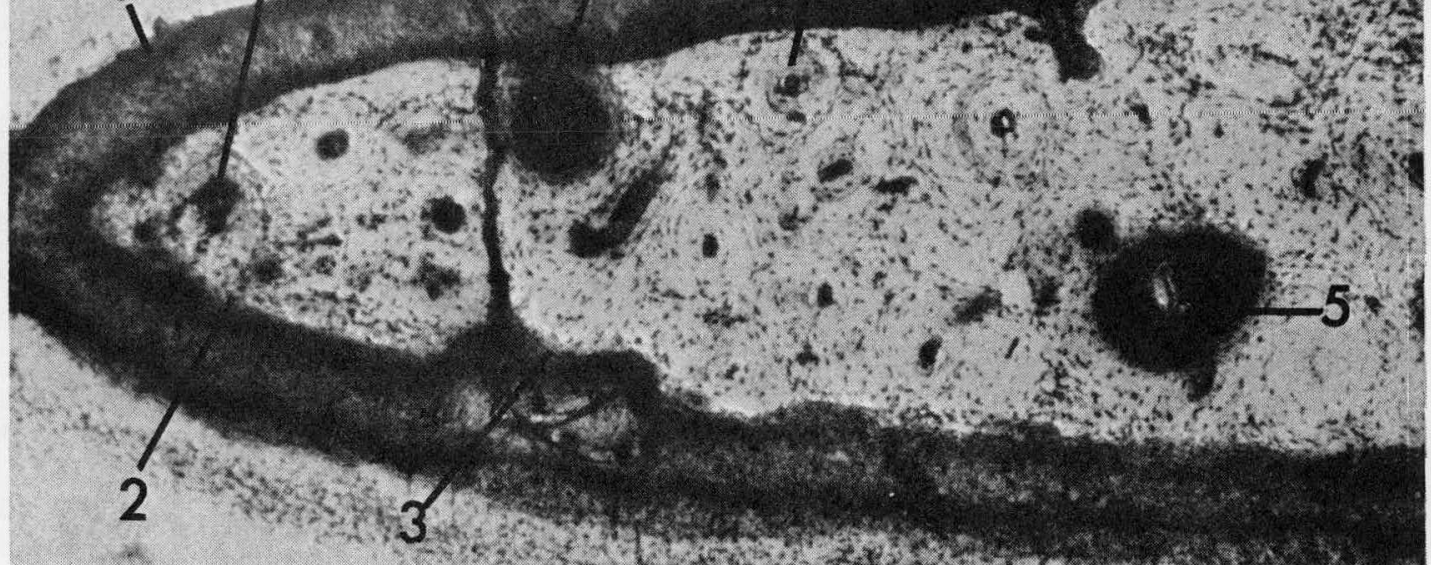


Fig. 4. Microradiograph of the interdental alveolar bone between first and second premolars from a dog injected with $2 \mathrm{mC} i$ of ${ }^{45} \mathrm{Ca}$ and sacrificed 2 hours later. (1) denotes cemental surfaces, (2) denotes alveolar bone surface (coronal portion), (3) denotes partially forming osteon and (4) a lowly mineralized osteon near a scalloped border of alveolar bone, $\times 56$.

Fig. 5. Corresponding NTB contact autoradiograph to Fig. 4. Note the heavy deposits of ${ }^{45} \mathrm{Ca}$ at structures (2), (3) and (4). The cemental surface (1) possesses intermediate darkening.

Fig. 6. Detailed autoradiograph of same specimen as Fig. 4. Liquid emulsion coated 100 micron-thick section mounted in water. 

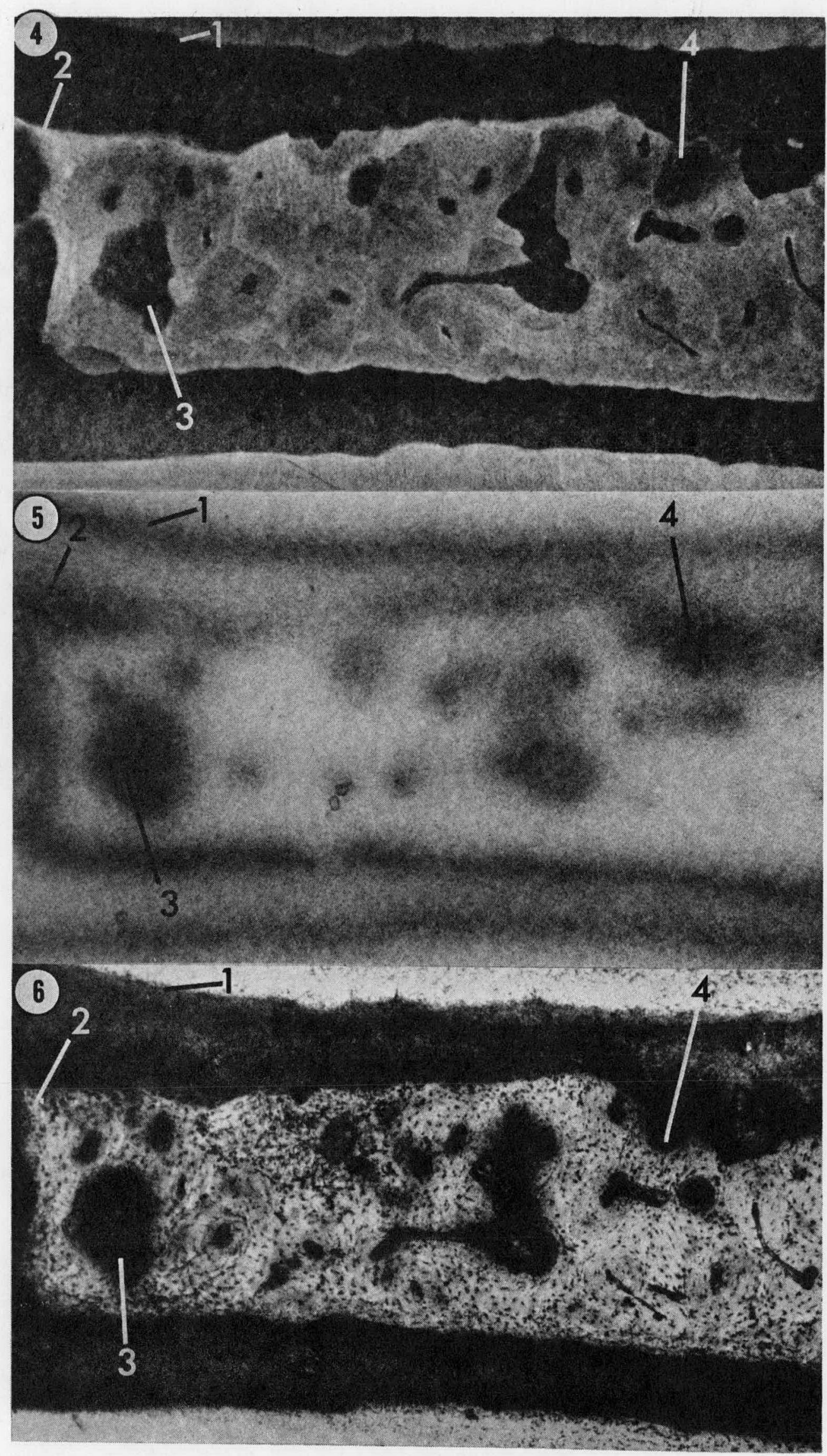
Fig. 7. Microradiograph of the interdental alveolar bone of the third and fourth premolar from a dog injected with $2 \mathrm{mC} i$ of ${ }^{45} \mathrm{Ca}$ and sacrificed 30 hours later. Note the spicules with lowly (grey) and highly (white) mineralized bone surfaces. (1) and (2) denote lowly mineralized bone surfaces, (3) a partially filled osteon and (4) a resorption cavity beginning to fill in, $\mathrm{x} 85$.

Fig. 8. Corresponding NTB contact autoradiograph to Fig. 7. Note the heavy deposits upon the bone surfaces of the spicule in the area which was formerly the alveolar crest. Note the darker blackening at sites (1) and (2) which corresponds to lowly mineralized bone surfaces. A much lighter darkening is seen in filling osteon (3) as compared to forming bone at osteon (4). 


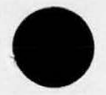

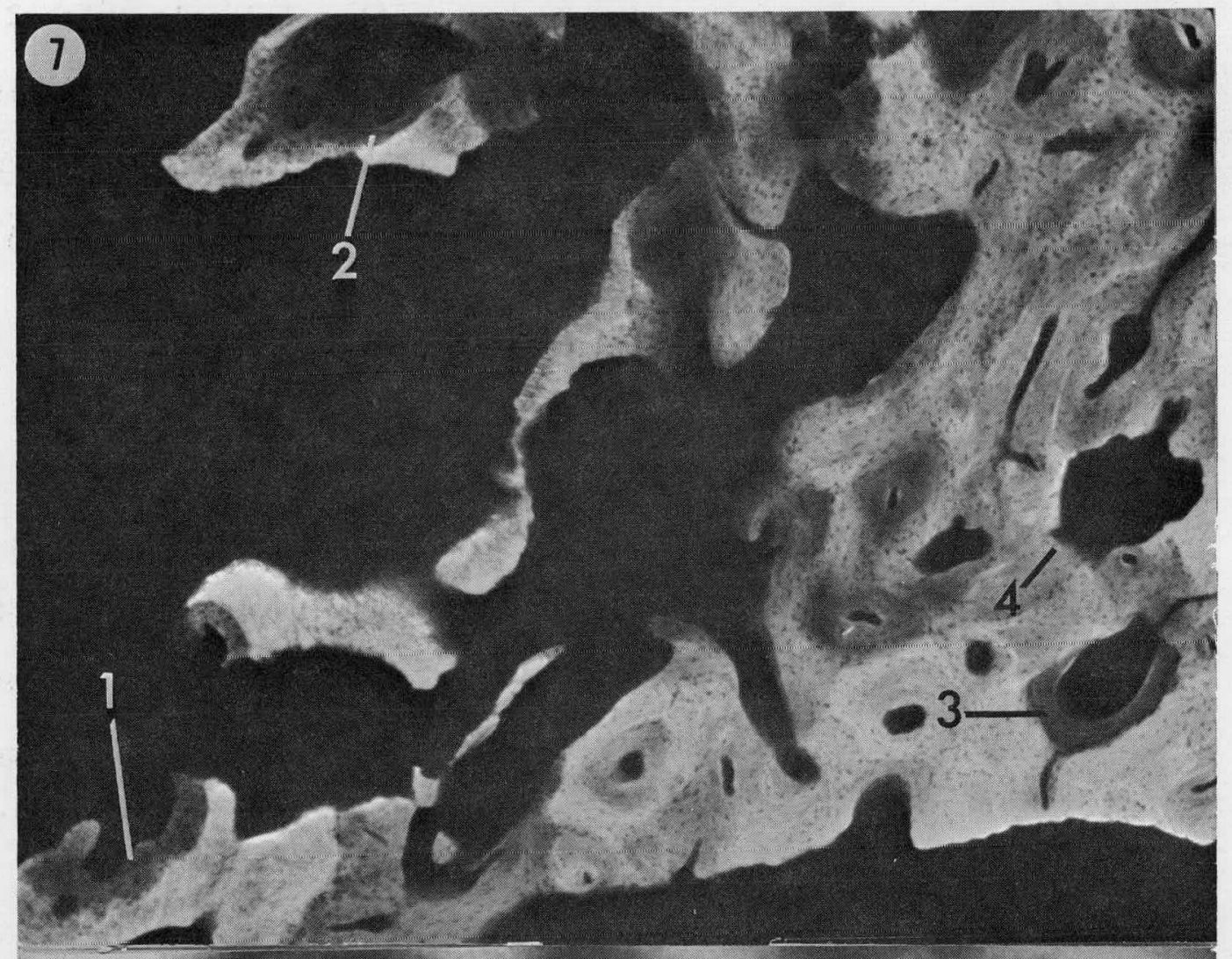

(8)
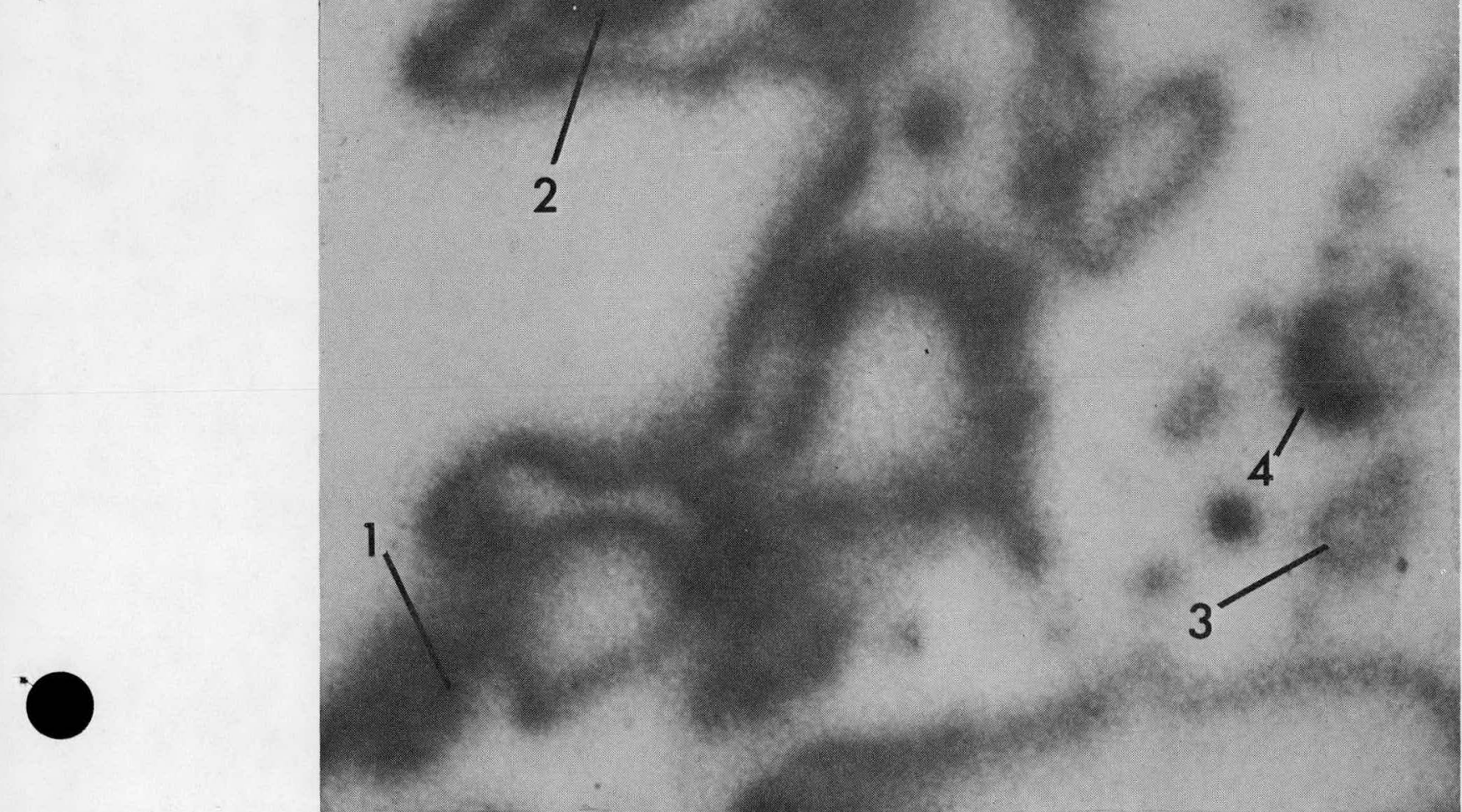
Fig. 9. Microradiograph of the interradicular alveolar bone of the fourth premolar from a dog 30 hours after injection with 2 $\mathrm{mC} \mathrm{i}$ of ${ }^{45} \mathrm{Ca}$. Note the ragged alveolar bone surface. It is difficult to determine whether it is actively resorbing from a microradiograph. (1) denotes cemental surfaces, (2), (3) and (4) denote scalloped alveolar bone surfaces and (5) a partially forming osteon, $\times 85$.

Fig. 10. Corresponding NTB contact autoradiograph to Fig. 9. Note the hotspots irregularly located at the alveolar bone surface. It is difficult to determine whether these hotspots correspond to resorbing or forming bone surfaces at sites (2), (3), and (4). Note right border of osteon (5) attracts a high concentration of ${ }^{45} \mathrm{Ca}$. 
$-283-$

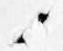

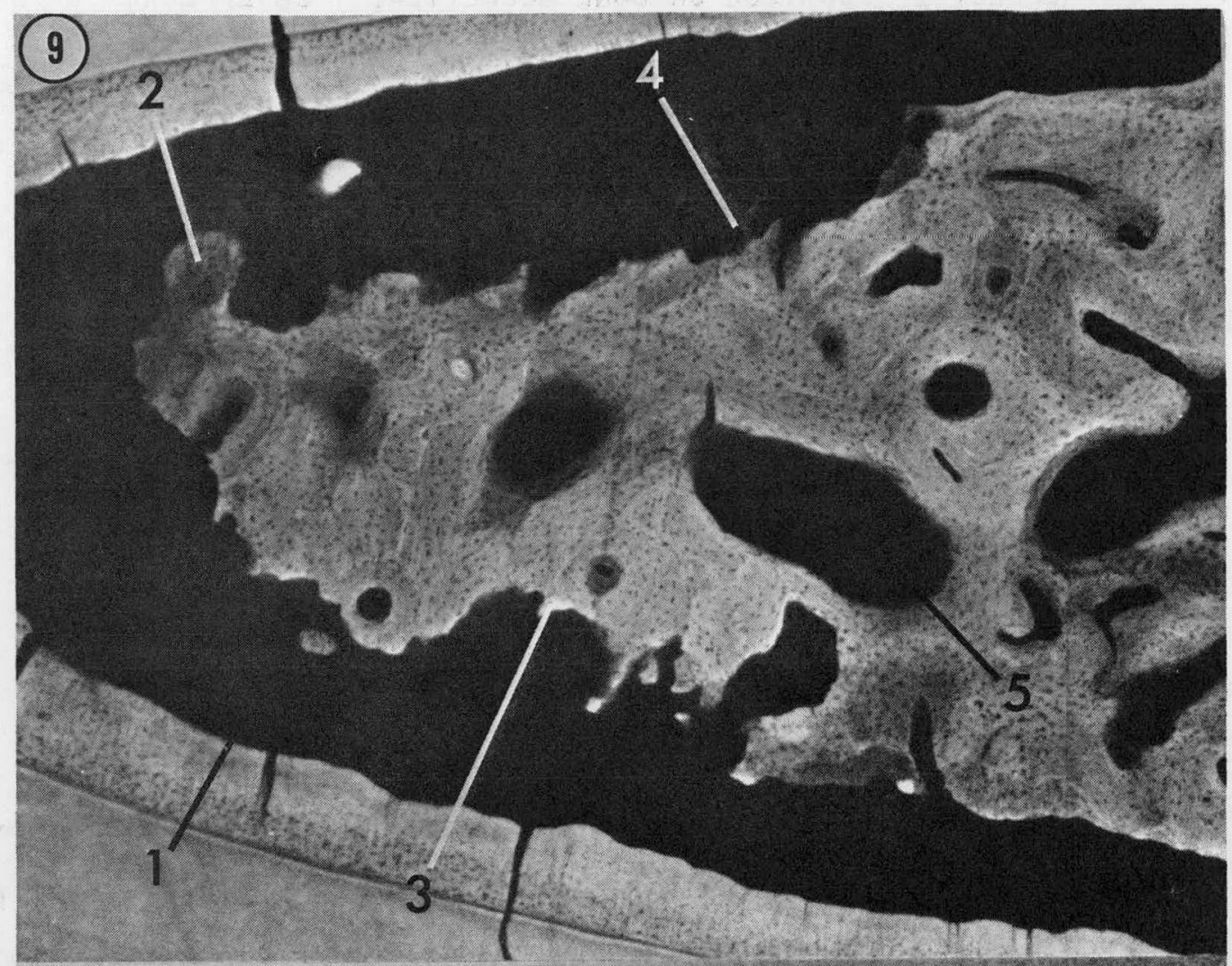

(10) 2 1
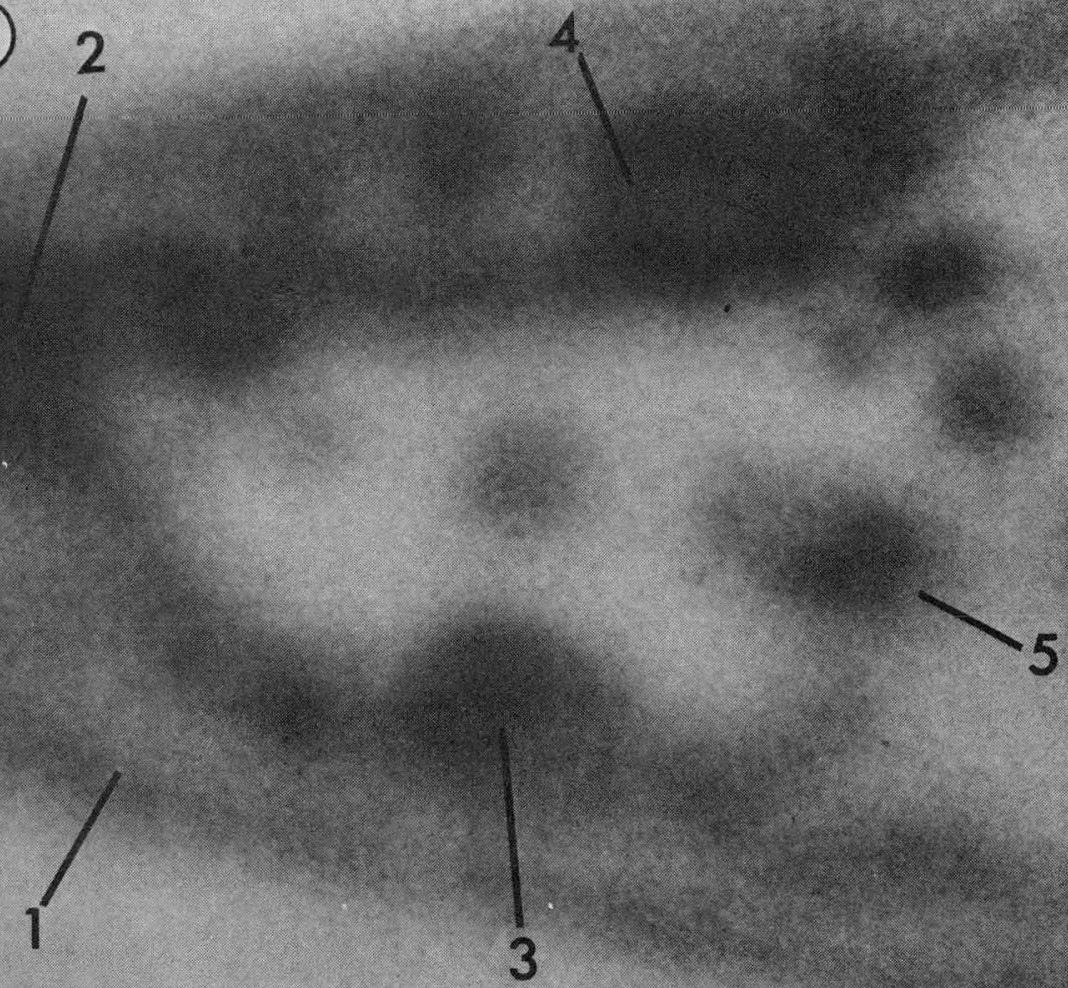


\section{EFFECT OF CORTISOL ON BONE ACCRETION, ${ }^{45} \mathrm{Ca}$ EFFLUX, AND TRABECULAR BONE RESORPTION \\ H. Z. Park, K. W. Jee, and W. S. S. Jee}

Abstract: In dose response studies using $0,0.5,1,5,20$ and $75 \mathrm{mg}$ of cortisol/ kg/day for 7 days in $100 \mathrm{~g}$ rats, a significant reduction in tibial metaphyseal bone volume was measured in male rats injected with 1 and $5 \mathrm{mg}$ of cortisol/ $\mathrm{kg} /$ day. Female rats did not show such change. Endochondral growth of male rats measured by tetracycline labeling (25 mg/ $\mathrm{kg}$ body weight) showed that there was significant inhibition of bone growth at dose levels of 20 and $75 \mathrm{mg}$ of cortisol $\mathrm{kg} /$ day. Decreased efflux of "deep store ${ }^{11}{ }^{45} \mathrm{Ca}$ was observed at day 3 of treatment with doses of $0.5,5$, and $20 \mathrm{mg}$ of cortisol kg/day. At day 6 , the differences of efflux among these three dose levels became insignificant.

\section{INTRODUCT ION}

Excessive dose of glucocorticoid is known to inhibit bone growth,

cause the loss of bone volume, ${ }^{(2)}$ and suppress the efflux of ${ }^{45} \mathrm{Ca}$ from the deep store pool of bone. (3) In this study, the effects of various dose levels of cortisol on bone resorption, suppression of bone growth, and ${ }^{45} \mathrm{Ca}$ efflux were examined to determine the possible mechanism of osteoporosis induced by cortisol.

\section{METHODS}

Young male and female Sprague-Dawley rats weighing 100 to $200 \mathrm{~g}$ were used. Rats were injected with $0,0.5,1,5,20$ and $75 \mathrm{mg}$ of cortisol per kilogram body weight per day. At autopsy, the right tibia was fixed in acetone, defatted, dehydrated and embedded in Bioplastic and sawed. The sections were ground to 100 microns thickness for microradiographs and then reground to 50 microns and examined under a Leitz-Wetzlar U.V. microscope to determine the rate of endochondral bone formation. The microradiographs were examined with the Quantitative Television 
Microscope (Metals Research, Ltd., Cambridge, England), which measures the percent bone volume in metaphysis of tibial bone.

The calcium-45 was allowed to enter the deep bone stores for two weeks after injection of 40 microcuries of ${ }^{45} \mathrm{Ca}$ (International Chemical and Nuclear Corporation, Irvine, California). One hundred lambda of blood serum samples were obtained from the tail vein and counted in a Packard refrigerated scintillation counter. Tetracycline (25 mg Achromycin/kg) was injected to label newly deposited bone 3 days prior to sacrifice of animal.

\section{RESULTS}

Effect of cortisol on bone volume in tibial spongiosa.

As shown in Fig. 1, control male rats show about $44 \%$ bone in the metaphyseal area of the proximal tibia. After 7 days of treatment with cortisol, low dose levels ( 1 and $5 \mathrm{mg}$ ) showed a decrease of bone to $33 \%$ and high doses (above $20 \mathrm{mg}$ ) increased slightly, but insignificantly, at day 7. Later studies show that this trend was definite and an in-

crease of bone was observed. (4) In females, a similar trend was observed, but it was insignificant statistically.

Effect of endochondral bone formation.

At dose levels of 1 and $5 \mathrm{mg}$, there were insignificant differences of endochondral bone growth rate. However, at 20 and $75 \mathrm{mg} \mathrm{level,} \mathrm{bone}$ formation was completely suppressed (Fig. 2).

Efflux of deep store ${ }^{45} \mathrm{Ca}$ from bone to systemic fluid.

Mean value of ${ }^{45} \mathrm{Ca}$ in 100 lambda of serum was 2420 disintegrations per minute. Control rats responded to tail bleeding with fluctuation 
between $94.7 \%$ to $97.9 \%$ of the day 0 value for ${ }^{45} \mathrm{Ca}$ concentration in serum. At a dose level of $0.5 \mathrm{mg} / \mathrm{kg}$ per day, calcium-45 efflux decreased to 90.6 (day 1), 76.9 (day 3) and 55.3 (day 6) percent of day 0 values. After day 6, the values leveled off. A dose response was observed at day 1 and 3 of treatment after $0.5,5$ and $20 \mathrm{mg} / \mathrm{kg} /$ day. At day 6 , the differences in ${ }^{45} \mathrm{Ca}$ efflux among these three dose levels were insignificant.

\section{DISCUSSION}

The suppressed bone formation rate at higher doses of cortisol administration and the increase in metaphyseal bone volume could be accounted if there was less resorption at high doses as well, and less trabecular bone volume with low dose must be the consequence of stimulated bone resorption. Therefore, the bone change by cortisol administration can be attributed to super normal bone resorption with normal or subnormal bone formation at low dose, and super subnormal bone resorption with subnormal bone formation at high dose.

The efflux of calcium-45 pool, which is affected by various endocrine factors, ${ }^{(3)}$ shows the time-dose relationship in the effect of cortisol on mineral transport. This may account for the biphasic response observed in rat treated with low dose. (4)

\section{REFERENCES}

1. R. H. Follis, Jr.; Effect of cortisone on growing bone of the rat; Proc. Soc. Exp. Biol. Med., 76: 722 (1951).

2. F. Albright; Cushing's Syndrome: Its pathological physiology, its relationship to adreno-genital syndrome, and its connection with problems of reaction of body to injurious agents ("alarm reaction" of Selye); Harvey Lect., 1942-1943, 38, 123 (1943). 
3. R. V. Talmage, H. Z. Park, and W. S. S. Jee; Parathyroid hormone and calcitonin function in cortisol treated rats; Endocrinology, 86: 1080 (1970).

4. G. H. Kenner, W. S. S. Jee and H. Z. Park; Cortisol and mineral transport -- effect of time and graded doses upon strontium-85 retention in young and adult rats; Research in Radiobiology U.S.A.E.C. Report c00-119-242, $282(1970)$. 


\section{EFFECT OF CORTISOL ON \% TRABECULAR BONE OF INTACT MALE AND FEMALE RATS \\ * significant at 0.05 level}

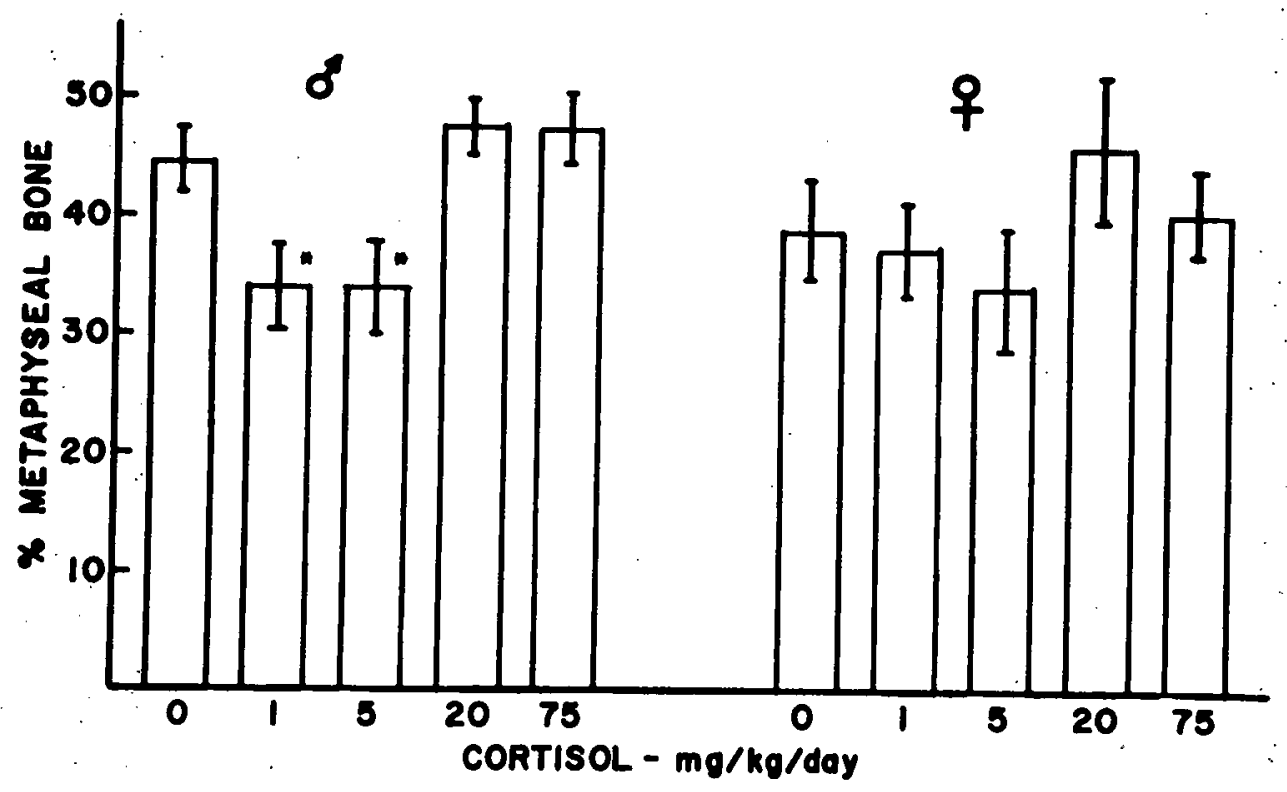

Fig. 1. Bar graphs illustrating changes in quantity of proximal tibial metaphyseal bone after 7 days of cortisol treatment. 
EFFECT OF CORTISOL ON ENDOCHONDRAL GROWTH OF INTACT MALE RATS MEASURED BY TE TRACYCLINE LABELING

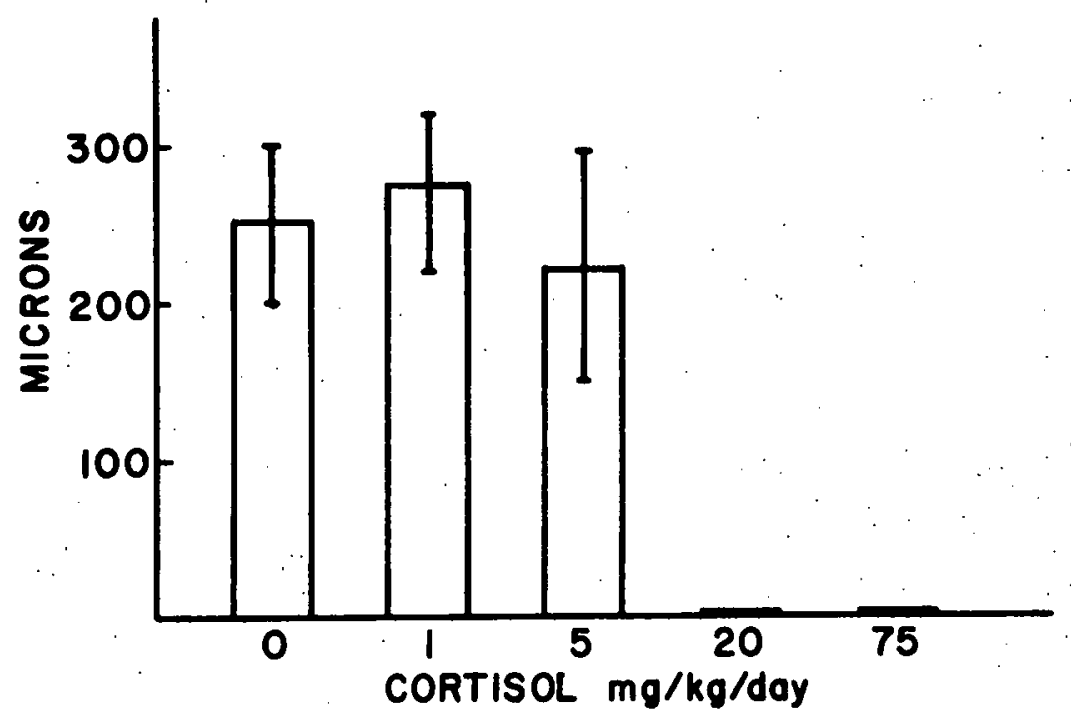

Fig. 2. Bar graphs showing change in endochrondral bone formation rate measured by tetracycline labeling 3 days before sacrifice. 


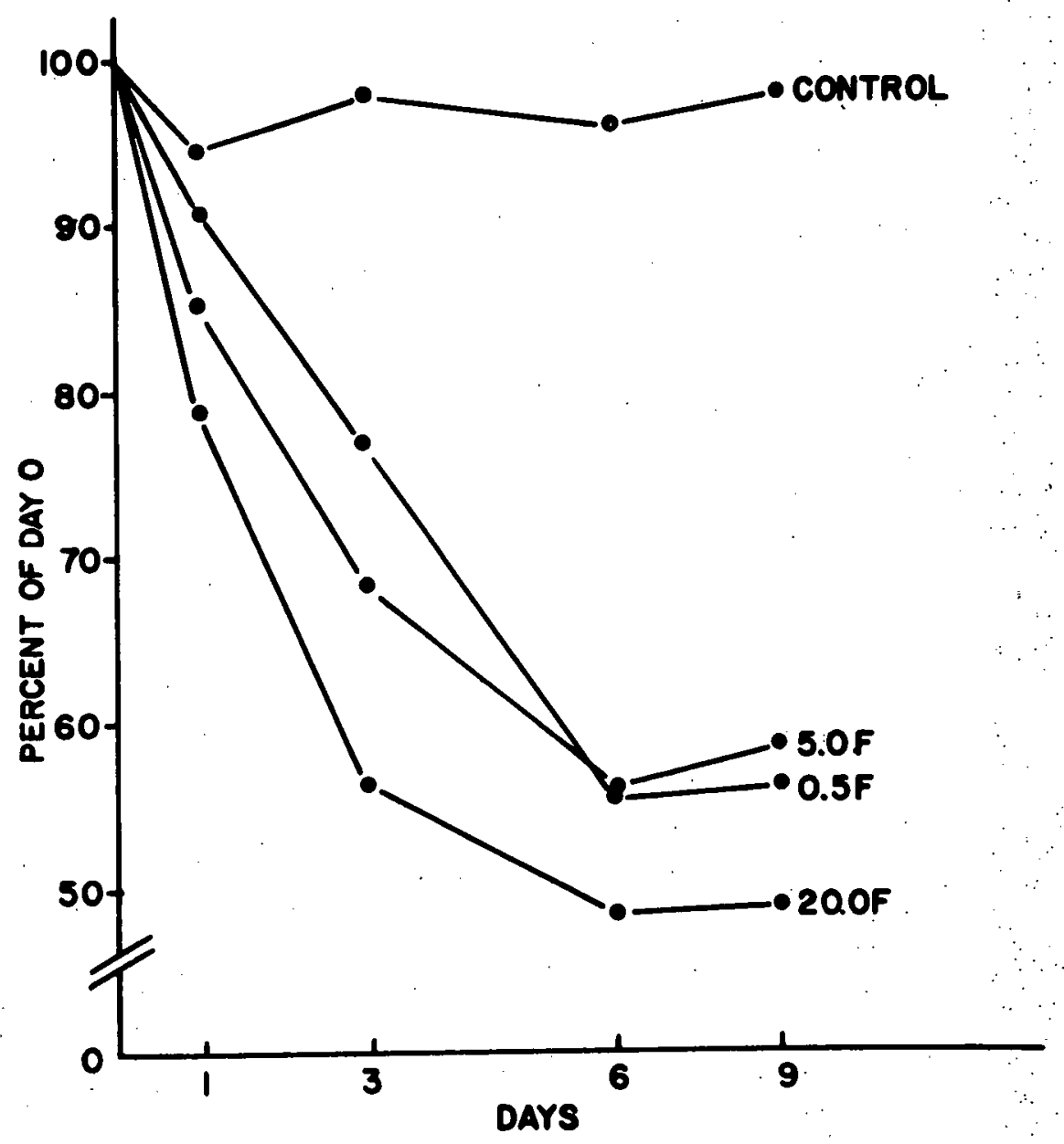

Fig. 3. Graph showing the efflux of calcium-45 given 14 days before the start of cortisol treatment. Serum concentration at the start of cortisol treatment (day 0 ) is expressed as $100 \%$. 


\section{INTERRELATED EFFECTS OF GLUCOCORTICOID AND PARATHYROID HORMONE UPON BONE REMODELLING \\ W.S.S. Jee, W.E. Roberts, G. Julian, H.Z. Park and M. Kramer}

Abstract: A review of the animal and human data in the literature as well as the studies in the rat and rabbit in our laboratory shows that the possible mechanisms by which glucocorticoid acts in promoting bone resorption involves complex responses at the histological level as follows: (1). the effect of cortisol upon bone is dose dependent; (2) high doses suppress bone resorption; (3) cortisol acts upon bone cells by directly inhibiting precursor cell proliferation and by indirectly stimulating parathyroid hormone secretion; (4) inhibition of precursor cell proliferation is the overriding effect after high doses; and (5) the parathyroid hormone-mediated effect is the overriding effect after low doses.

\section{INTRODUCTION}

Excessive glucocorticoid is known to inhibit bone growth, ${ }^{(14)}$ suppress the synthesis of bone matrix proteins, $(1,2)$ and cause the loss of bone volume (osteoporosis) (3). The cause of bone volume loss has been studied experimentally in animals and man, but there is disagreement about how the steroid effects bone remodeling to cause the osteoporosis. The osteo-. porosis has been attributed to (1) normal bone resorption with subnormal bone formation, (2) subnormal bone resorption with an even greater subnormal bone formation, and (3) supernormal bone resorption with subnormal bone formation.

The first purpose of this report is to develop a unified hypothes is of glucocorticoid action on bone remodeling by examining the recent pub- 
lications and our studies on glucocorticosteroid actions on humans and experimental animals.

The second purpose is to examine whether or not this osteoporotic action is the direct effect of glucocorticoids, or is mediated through the parathyroid glands.

For clarity, this report will use a dose of $5.0 \mathrm{mg}$ of cortisol. (hydrocortisone) $\mathrm{kg} /$ day or less as low dose levels, and anything above as high dose levels. Most of the previous research has used cortisone and prednisone. It is not known on the organ level for bone whether a given amount of cortisone or prednisone is equivalent to cortisol. Unfortunately, we have not studied the potency relationships of cortisone and prednisone to cortisol like we have for other anti-inflammatory steroids (corticosterone, prednisolone, dexamethasone, etc. ${ }^{(4,5)}$ ) The closest relative to cortisone and prednisone is corticosterone and prednisolone, possessing an $11 \beta-h y-$ droxal instead of an 11-keto group. Corticosterone is one fourth as potent, while prednisolone is 2 times more potent than cortisol; therefore, tentatively at least, we assume that cortisone is one fourth and prednisone is twice as potent as cortisol.

From a review of the most recent literature (Table 1), we can conclude that there is a consistent suppression in precursor cell division, bone formation, numbers of osteoblasts, bone mass and numbers of osteoclasts at higher dose levels. Moderated to massive dose levels were employed in the rat experiments while doses in the neighborhood of $2.5 \mathrm{mg}$ cortisol/ $\mathrm{kg} /$ day were used for rabbits. These investigators $(4,10)$ found dose levels exceeding $5 \mathrm{mg} / \mathrm{kg} /$ day for over 30 days were lethal.

Four reports in Table 1 showed a reduction in osteoclasts. Simmons 
(\% OF CONTROL VALUE)

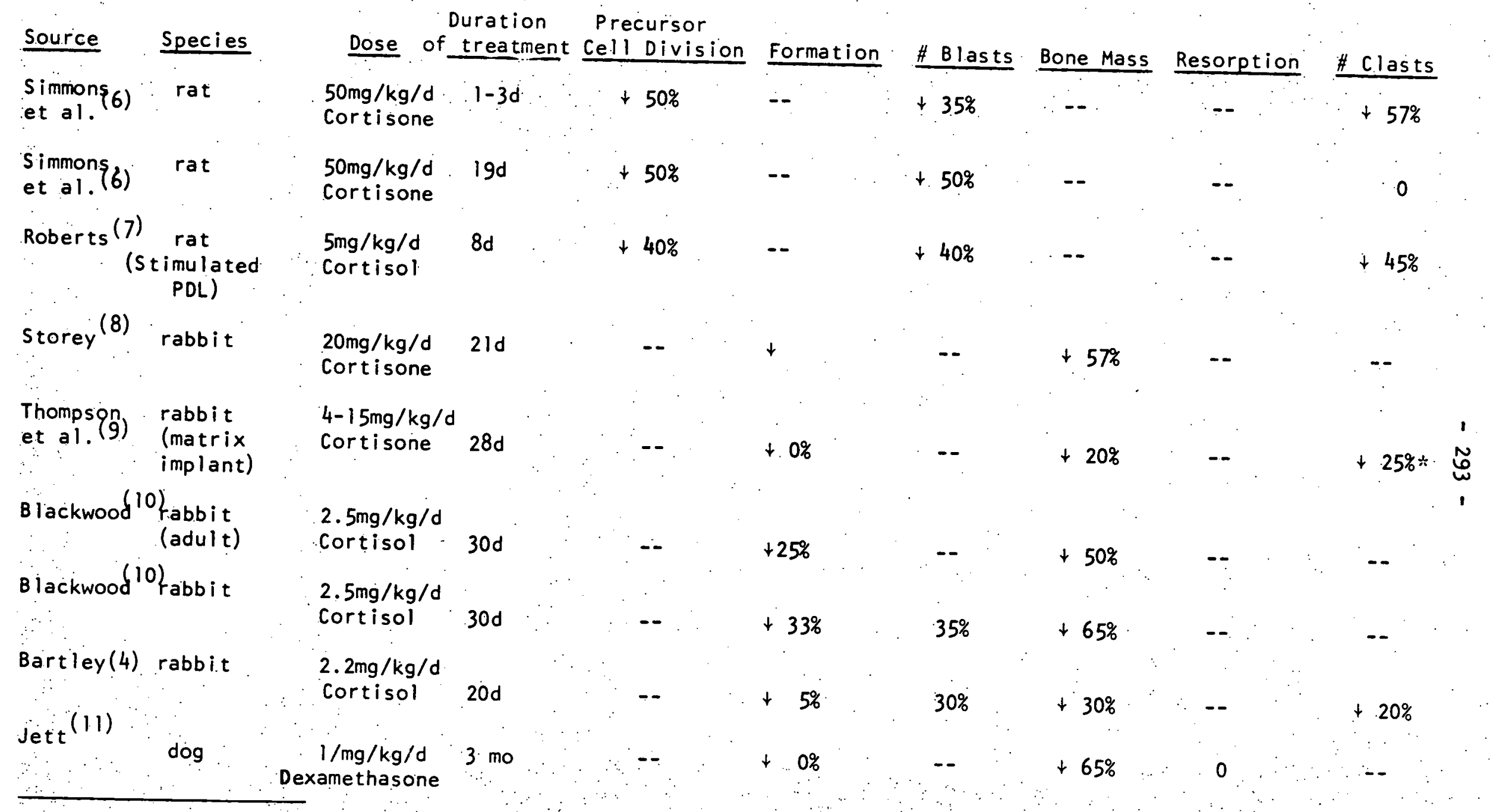


and Kunin ${ }^{(6)}$ reported a transient reduction in osteoclasts, and two other studies $(4,9)$ of slightly longer duration also showed reduction in numbers of osteoclasts.

At this relatively high dose, ( $5 \mathrm{mg} / \mathrm{kg} / \mathrm{day}$ or more) loss of bone mass (osteoporosis) results from a subnormal bone resorption with an even greater subnormal bone formation. These high doses also depress the division of precursor cells, which may be an important reason why bone formation was more depressed than bone resorption. This will be discussed later in the report.

Reports dealing with experimental animals treated with low dose levels of cortisol are sparse. It is puzzling that investigators have avoided experimenting with doses below $2 \mathrm{mg}$ of cortisol/kg/day when almost all of the clinical reports are below this dose level. Extensive dose response studies on the relationship of cortisol and bone remodeling have been and are being carried out in our laboratory. The most informative one is the study by Roberts ${ }^{(7)}$ using the unstimulated periodontal ligament (PDL) model in rats given $0.5,2.5,5.25$. and $50 \mathrm{mg}$ of cortisol/kg/day for 8 days. He quantified the numbers of tritiated thymidine labeled PDL fibroblasts (precursor cells), the number of osteoblasts and osteoclasts, and the los of aveolar bone. His studies showed that 0.5 and $2.5 \mathrm{mg} / \mathrm{kg} / \mathrm{day}$ for 8 days stimulated PDL fibroblast labeling, decreased the number of osteoblasts, reduced bone mass, and dramatically increased the number of osteoclasts. Furthermore, despite the finding that osteoblasts were not made, there was an increase in the number of PDL fibroblasts. This is the best evidence of 'decoupling' or 'block differentiation' of precursor cells to osteoblasts. Moreoever, the stimulated labeling of PDL fibroblast is not a transient 
event. Elevated labeling index of PDL fibroblasts was observed in rats treated. with $0.6 \mathrm{mg}$ of cortisol/ $\mathrm{kg} /$ day for 150 days.

In summary, low doses of cortisol cause osteoporosis by supernormal bone resorption with subnormal bone formation. These events are accompanied by an increase in precursor cell proliferation.

Roberts' (7) dose response study needs to be discussed further. It is best to begin by characterizing the model, and follow with a description of the events occurring at all dose levels.

The unstimulated PDL of the mesial root of the first maxillary molar in $200 \mathrm{~g}$ rats is remodeling the alveolar bone of the tooth socket at a very low rate. Both bone formation and resorption are occurring. (The typical characteristics of the PDL for those cells involved with the remodeling of alveolar bone are $143.5 \pm 1.2$ (S.D.) fibroblasts, $0.83 \pm 0.13$ osteoblasts and $0.14 \pm 0.08$ osteoclasts per field $\left(4 \times 10^{4} \mu^{2}\right)$. Dose levels of 0.5 and $2.5 \mathrm{mg}$ of cortisol/ $\mathrm{kg} /$ day increase fibroblast proliferation, decrease number of osteoblasts, decrease bone mass, and increase the number of osteoblasts (Table 11 ). At $5 \mathrm{mg}$ of cortisol/kg/day, osteoblast numbers and bone mass were decreased, but osteoclast numbers were still dramatically elevated. Massive doses of 25 and $50 \mathrm{mg}$ of cortisol/kg/day suppressed fibroblast proliferation and the number of osteoblasts, while bone mass and number of osteoclasts were unchanged.

We interpreted this action of cortisol to be (1) an increased morphogenesis of bone precursor cells to osteoclasts, (2) a decrease of morphogenesis of bone precursor cell to osteoblasts or 'decoupling' of bone formation, (3) decreased proliferation of precursor cell division by high doses, and (4) iñcreased proliferation of precursor cell division at low doses. $(7,12)$ 
TABLE I I

DOSE RESPONSE OF MORPHOLOGICAL FEATURES OF UNSTIMULATED PERIODONTAL

LIGAMENT (PDL) OF RATS TO CORTISOL (\% OF CONTROL VALUE)

Adapted from Roberts $(7)$

\begin{tabular}{|c|c|c|c|c|c|}
\hline Dose & Duration & $\begin{array}{c}\text { Precursor } \\
\text { Cell Division } \\
\end{array}$ & Blasts & $\begin{array}{l}\text { Bone } \\
\text { Mass*t }\end{array}$ & Clasts \\
\hline$\therefore .5 \mathrm{mg} / \mathrm{kg} / \mathrm{d}$ & $8 d$ & $+150 \%$ & $+0 \%$ & $+91 \%$ & $\uparrow 1200 \%$ \\
\hline $2.5 \mathrm{mg} / \mathrm{kg} / \mathrm{d}$ & $8 d$ & $\uparrow 130 \%$ & $+0 \%$ & $+90 \%$ & ^. $1400 \%$ \\
\hline $5.0 \mathrm{mg} / \mathrm{kg} / \mathrm{d}$ & $8 d$ & $100 \%$ & $+0 \%$ & $+89 \%$ & $\uparrow 1400 \%$ \\
\hline $25 \mathrm{mg} / \mathrm{kg} / \mathrm{d}$ & $8 d$ & $+25 \%$ & $+0 \%$ & 0 & $\uparrow \quad 190 \%$ \\
\hline $50 \mathrm{mg} / \mathrm{kg} / \mathrm{d}$ & $8 d$ & $+5 \%$ & $+0 \%$ & 0 & \\
\hline
\end{tabular}

$* \forall$ in width of $P D L=$ loss of alveolar bone; $t$-increase, $t$-decrease; 0 -no change.

There is no way to escape the conclusion that cortisol favors morphogenes is of precursor cells to osteoclast. At $25 \mathrm{mg}$ of cortisol/ $\mathrm{kg} /$ day when the labeled PDL Fibroblast was $25 \%$ of normal, the number of osteoclasts was still elevated 200\% and the number of osteoblasts was zero. No reduction of bone mass was observed, probably because the measured width of PDL is an insensitive index of alveolar bone resorption. Furthermore, at $50 \mathrm{mg}$ of cortisol/ $\mathrm{kg} /$ day, we found the labeling index of PDL fibroblasts to be $5 \%$ of normal, which apparently produces sufficient precursor cells for morphogenes is to osteoolasts only to achieve an osteoclast population comparable to control value. (Table 11 )

Besides the above experiment, which produced alveolar bone loss in rats given $0.5,2.5$, and $5 \mathrm{mg} / \mathrm{kg} /$ day for 8 days, we have been able to produce significant reduction in tibial metaphseal bone mass in rats and rabbits with 'relative' low doses of cortisol.

Heretofore rats have been shown to resist developing osteoporosis 
when glucocorticoids were administered.

Unfortunately, these studies involve large doses of cortisone. In one of our dose response studies using $0,1,5,20$ and $75 \mathrm{mg}$ of cortisol $/ \mathrm{kg} /$ day for 8 days in $100 \mathrm{~g}$ rats, a significant reduction in tibial metaphyseal bone mass was measured in the 1 and $5 \mathrm{mg}$ of cortisol/kg/day injected male rats ${ }^{(15)}$. Female rats did not show. such changes.

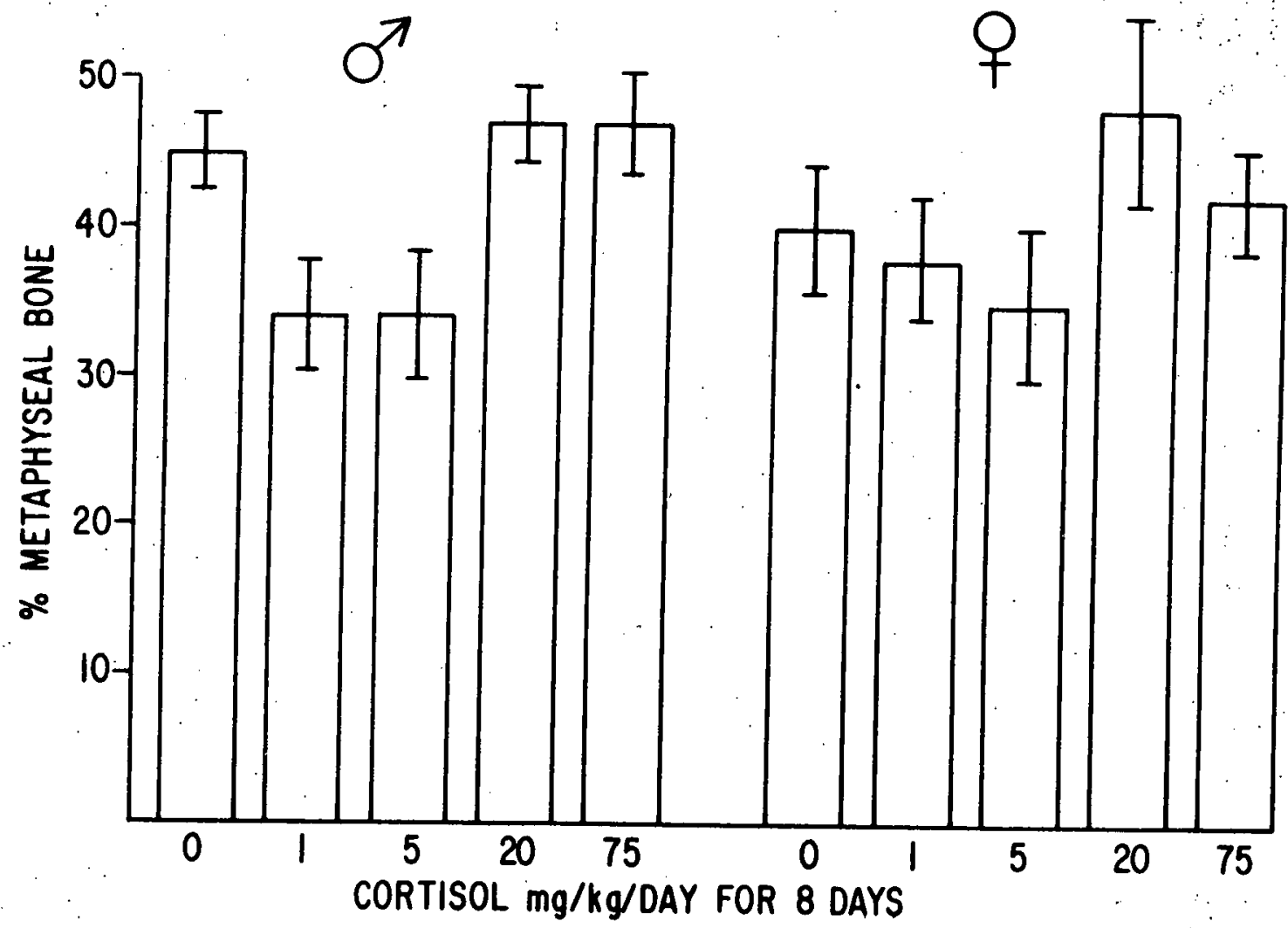

Figure 1. Bar graphs illustrating significant reduction in quantity of proximal tibial metaphyseal bone in intact male rats given 1 or $5 \mathrm{mg}$ of cortisol/kg/day for 8 days. The female rats did not show this change.

Suprisingly enough, we were able to produce a reduction in tibial 
day. (Fig. $2,{ }^{(4)}$ ) These dose levels are considerably lower than what has been reported thus far. Previously, doses of $10 \mathrm{mg}$ of cortisone/kg/day or more, in combination with a calcium deficient diet and mechanical stress, have been used to demonstrate the osteoporotic effect of cortisone:

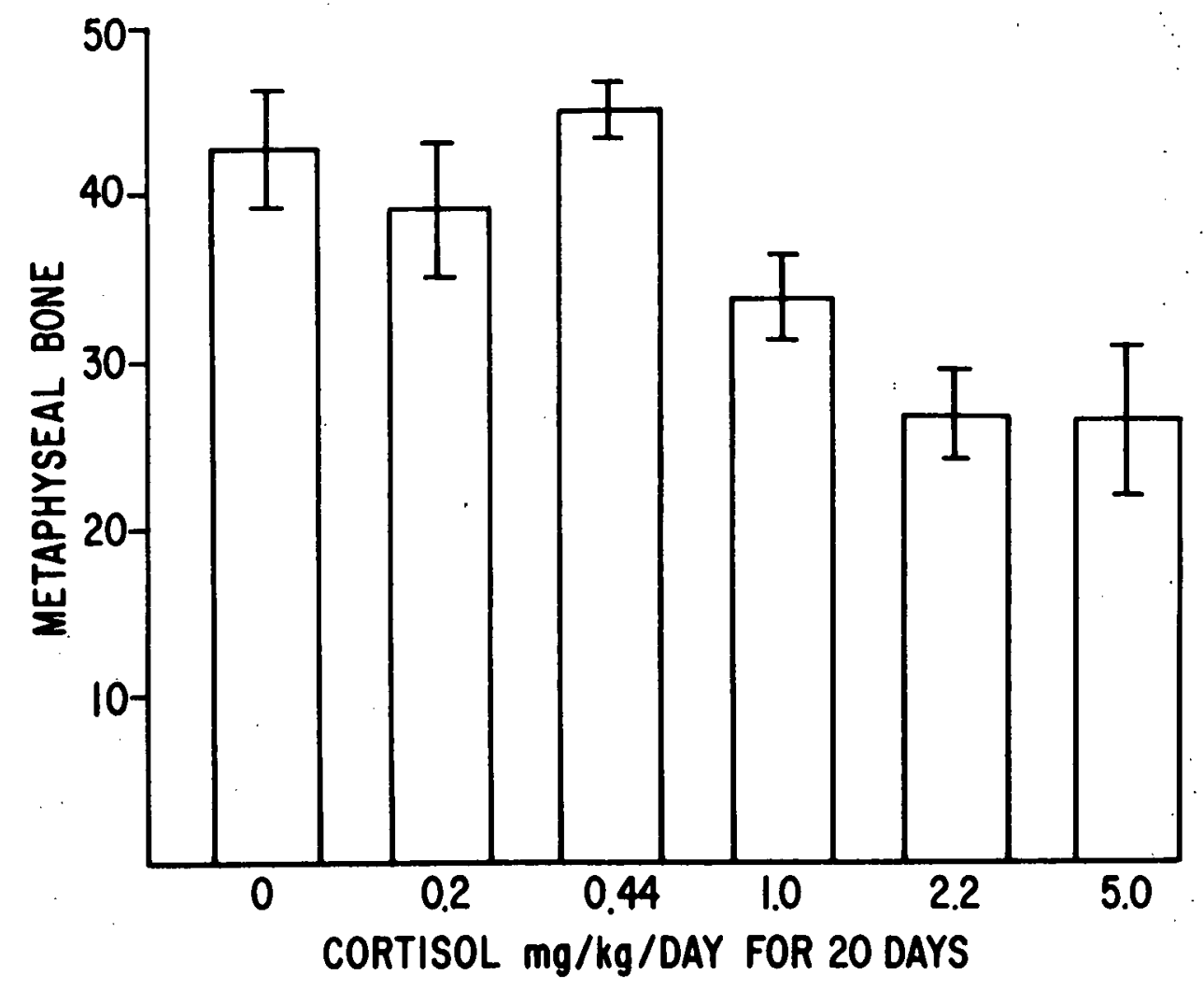

Figure 2. Bar graphs showing significant reduction in quantity of proximal tibial metaphyseal bone in New Zealand female rabbits given $1.0,2.2$, or $5.0 \mathrm{mg}$ of cortisol/ $\mathrm{kg} /$ day for 20 days.

The cause of bone loss with excessive glucocorticoid has been the subject of both experimental studies in man and investigations of patients afflicted with Cushing's syndrome (Table $\mid 11$ ). All available information indicated a decrease in bone formation $(11,16,18)$. However, norma $(11,14)$ 


$$
\text { increased }(16,18) \text {, and decreased }(11) \text { bone resorption have been reported. }
$$

\section{TABLE 111.}

MORPHOLOGICAL FEATURES OF BONES IN PATIENTS WITH EXCESSIVE GLUCOCORTICOID (\% OF CONTROL VALUE)

\begin{tabular}{|c|c|c|c|c|c|c|}
\hline Source & $\#$ & Dose & $\begin{array}{l}\text { Duration of } \\
\text { Burden } \\
\end{array}$ & Formation & $\begin{array}{l}\text { Bone } \\
\text { Mass } \\
\end{array}$ & Resorption \\
\hline Jett, et al. (11) & 1 & Cushing & Chronic & $+0 \%$ & $+65 \%$ & $0 \div *$ \\
\hline Jowsey, et al $(16)$ & $4 \div$ & Cushing & Chronic & $+0 \%$ & -- & $\uparrow 200 \% \div \div \%$ \\
\hline Riggs, et. al (17) & $\begin{array}{r}11 \\
1\end{array}$ & $\begin{array}{l}\text { Cushing } \\
\text { Exogenous }\end{array}$ & Chronic & $+4 \%$ & -- & $\uparrow 240 \% * * *$ \\
\hline Jowsey, et al. & $\begin{array}{l}2 \\
3\end{array}$ & $\begin{array}{l}\text { Cushing } \\
\text { Exogenous }\end{array}$ & Chronic & $\downarrow 5 \%$ & -- & $\uparrow 400 \%$ \\
\hline
\end{tabular}

$* 1$ case with normal resorption; $*: 0-$ no change; ***average of all cases reported; $\uparrow$-increase; $\downarrow$-decrease.

It is best to restrict most of our discussion on humans to experimentally treated man. Jowsey and co-workers $(17,18)$ have reported studies on one adrenalectomized pațients given $30 \mathrm{mg}$ of cortisone acetate and 3 patients given 10 to $60 \mathrm{mg}$ of prednisone daily. These dose levels are within the range we have previously designated as low doses for experimental. animals: If we assume that the potency for osteoporosis of cortisone and prednisone is about $1 / 4$ and 2 times cortisol, then these patients would be receiving 15 to $120 \mathrm{mg}$ or 0.2 to $1.7 \mathrm{mg} / \mathrm{kg} /$ day of cortisol for a $70 \mathrm{mg}$ person. These 4 patients responded with subnormal bone formation and supernormal bone resorption (identical to the behavior of animals injected with low doses of cortisol).

All but two of the persons afflicted with Cushing's syndrome have increased bone resorption. In both cases, bone resorption was normal! $(11,17)$ It is conceivable that these individuals possessed extremely high blood glucocorticosteroid level, and can be classified under our category of 
high dose level effects.

For the sake of simplicity, let us start with a four compartment model for bone remodeling (Fig. 3). These compartments are as follows: the proliferating precursors 1 (pool 1), proliferating precursor daughters II (pool 2), the fully differentiated osteoblasts (pool 3), and osteoclasts (pool 4). in order to transit out of pool 1 (proliferating precursors), there must be cell division. Transit out of pool 2 (proliferating precursor daughters II) involves differentiation. Furthermore, the model assumes that the proliferating precursor daughter cells differentiate first into osteoclasts (pool 3) and later into osteoblasts (pool 4). Thus, the normal sequence in bone remodeling involves 3 transits which sequentially connect 4 cellular pools. This is Frost's A R F ${ }^{(20)}$. A remodeling unit is activated $(A)$ by some stimulus to produce new, proliferating precursor daughter cells. These daughter cells are initially osteoclasts which resorb $(R)$. The osteoclasts then disappear and new osteoblasts appear to lay down bone ( $F$ ). We have experimental proof of such a sequence in the Roberts' stimulated PDL model. (7) Briefly, it is a model in which after 5 days of cortisol injections, an orthodontic elastic band is placed between the first and second maxillary molars to initiate a sequence of 40 hours of bone resorption followed by 68 hours of bone formation in the tooth socket.

Low doses of cortisol favor transit from pool 1 (proliferating precursors 1) to pool 2 (proliferating precursor daughters II) and to pool 3 (osteoclasts) by increasing precursor cell division and differentiation to osteoclasts, but block the transit into pool 4 (osteoblasts; Fig. 3).

High doses of cortisol depress transit from pool l (proliferating 

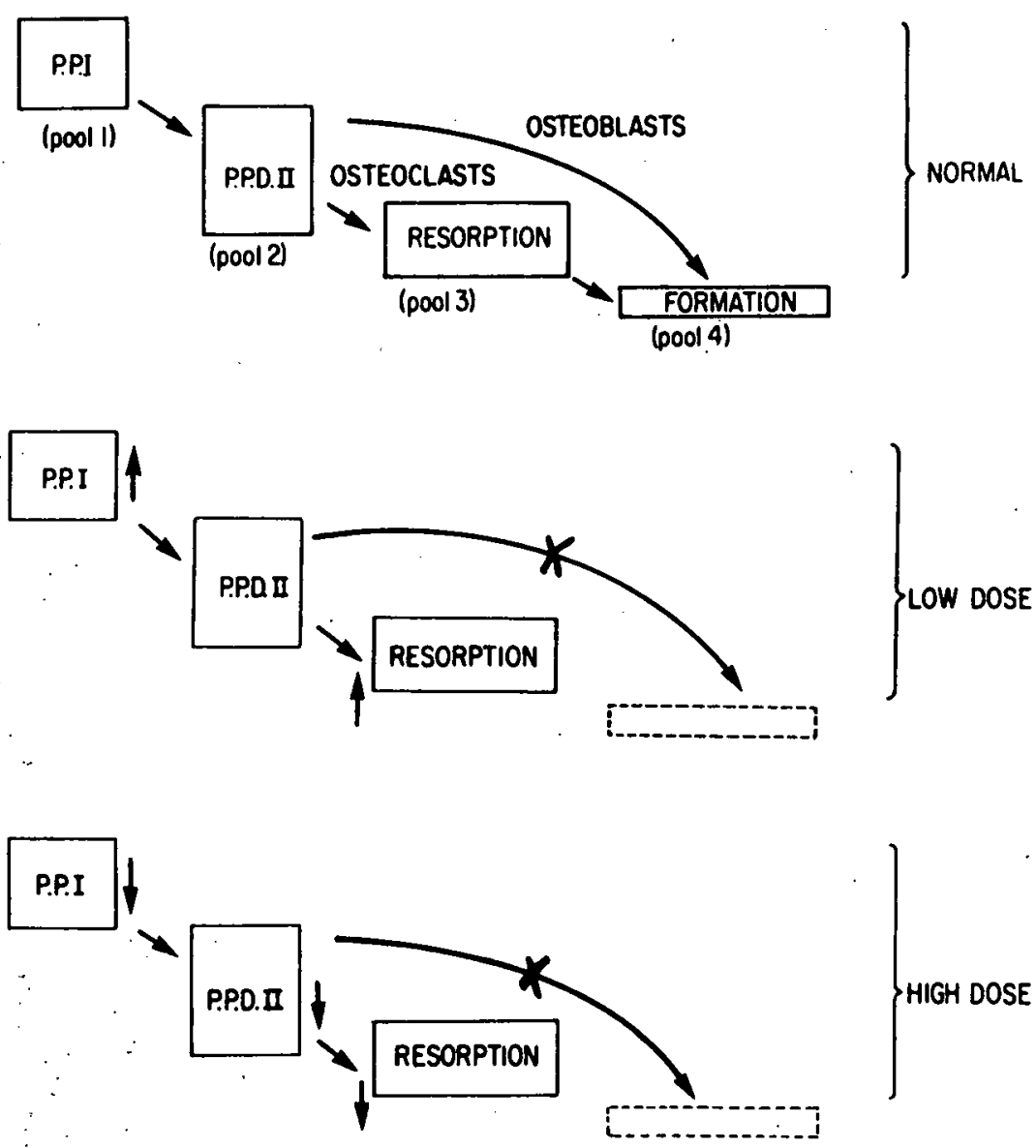

Figure 3. A four compartment model for bone remodeling. The normal sequence in bone remodeling involves transits from the proliferating precursors (pool 1) to proliferating precursor daughters (pool 2) to osteoclasts (pool 3), and proliferating precursor daughters (pool 2) to osteoblasts (pool 4). Low dose levels of cortisol stimulated precursor cell division, stimulated differentiation to osteoclasts and blocked morphogenesis of osteoblasts. High dose levels of cortisol depressed precursor cell division, depressed differentiation to osteoclasts and blocked morphogenes is to osteoblasts. 
precursors 1) to pools 2 (proliferating precursor daughters 11) and 3 (osteoclasts) by suppressing precursor cell proliferation, and block the transit into pool 4 (osteoblasts; Fig. 3.).

Our knowledge of the mechanism by which glucocorticoids effect changes in bone remodeling is not yet clear. It has been postulated that the cellular effect of cortisol on bone is the result of (1) direct inhibition of protein synthesis; (2) direct inhibition of precursor cell proliferation and/or (3) parathyroid hormone mobilization of skeletal calcium.

The glucocorticoids have been shown directly to depress protein synthesis. $(1,2)$ Most investigators also agree that these corticoids directly inhibit bone formation. Glucocorticoids are known to possess anti-proliferative ptential.. $(21,22)$ However, we reported a significant increase in thymidine incorporation into unstimulated PDL fibroblasts with 0.5 and 2.5 $\mathrm{mg}$ of cortisol/kg/day. Since this observation conflicted with the proven antiproliferative action of glucocorticoids, we attempted to explain it by (1) the possible conversion of cortisol to cortisone by the 118-hydroxydehydrogenase system in fibroblasts; ${ }^{(22)}$ cortisone is a compound shown to stimulate fibroblastic proliferation in tissue culture; and (2) secondary hyperparathyroidism subsequent to cortisol administration. $(8,24-26)$

There are many reports which support the hypothesis that the cellular effect of glucocorticoid actions is mediated through the parathyroids. Numerous investigators believe that the calcium-lowering effect of the corticosteroid stimulated the parathyroid glands to maintain serum calcium levels. $(27,28)$

Cortisol is believed to lower serum calcium by depressing intestinal calcium absorption, $(24,30)$ promoting hypercalciuria, ${ }^{(31)}$ and depressing efflux of ${ }^{45} \mathrm{Ca}$ in previously labeled bone. $(12,32-35)^{\circ}$ Nevertheless, it is most 
difficult to demonstrate depression of serum calcium level unless you deprive the animal of its parathyroid. $(28,36)$ stoerk et al. (28) reported that parathyroidectomized (PTX) rats injected with $3 \mathrm{mg}$ of cortisol/kg/day exhibited more pronounced hypocalcemia than PTX controls. The serum calcium in nonPTX rats was not lowered after injection of the steroid. Apparently the parathyroids compensate so rapidly that the effect of cortisol upon serum calcium level escapes detection unless the parathyroids are eliminated.

Our tritiated thymidine labeling of precursor cells of alveolar bone in PTX and endogenous parathyroid stimulated rats and rats given Lilly's parathyroid extract PTE, further support the hypothesis that the parathyroid hormone is involved in stimulating precursor cell division in rats injected with low doses of cortisol. We found that the addition of PTE or the stimulation of endogenous parathyroid hormone secretion increased precursor cell proliferation, and the removal of the parathyroids or the addition of low doses of cortisol to PTX rats diminished precursor cell division. These findings can be summarized as follows:

Table IV

RESPONSE OF RAT PDL FIBROBLASTS

(\% OF CONTROL VALUE)

Treatments

Intact +125 u. PTE

Intact +250 u. PTE

Intact + Ca free diet

PTX

PTX + 125 U. PTE

PTX + 250 u. PTE

PTX $+0.5 \mathrm{mg} / \mathrm{kg} / \mathrm{d}$
Unstimulated

PDL Fibroblasts

$\uparrow 185 \%$

$+360 \%$

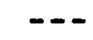

$+75 \%$
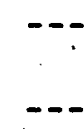

Stimulated

PDL Fibroblasts

$\uparrow 150 \%$

$\uparrow 200 \%$

$\uparrow 150 \%$

$+75 \%$

$+75 \%$

$\uparrow 125 \%$

$+50 \%$
Reference 
(1) In intact rats the injection of 125 or 250 units of PTE/rat/12 hour period, tritiated thymidine labeled stimulated PDL fibroblasts were increased to 150 and $200 \%$ of control value respectively. The labeled unstimulated PDL fibroblasts were increased to 185 and $360 \%$ of control value. (37) (2) In intact rats fed a calcium-free diet supplemented with $5 \mathrm{mg} \%$ of $\mathrm{CaCl}_{2}$ in their drinking water to stimulate endogenous parathyroid hormone secretion, labeled stimulated PDL fibroblasts were increased to $150 \%$ of control values.

(3) In PTX rats without any supplemental treatment, the labeled stimulated and unstimulated PDL fibroblasts were devreased to $75 \%$ or less of control values.

(4) In PTX rats given 125 or 250 units of PTE/rat/12 hour intervals, the labeled stimulated PDL fibroblasts were diminished to $75 \%$ and increased to $125 \%$ of control values respectively. (39)

(5) In PTX rats given $0.5 \mathrm{mg}$ of cortisol/ $\mathrm{kg} /$ day for 7 days, the labeled. stimulated. PDL fibroblasts were only $50 \%$ of control values. (39)

These findings best support the hypothesis that the cellular effects of cortisol upon bone tissue are a complex interaction of two antagonistic mechanisms: (a) direct inhibition of precursor cell proliferation by cortisol; and (b) indirect stimulation of parathyroid hormone secretion by cortisol. $(17,13)$ Low dose levels of cortisol stimulated precursor cells proliferation, decreased bone formation, increased the number of osteoclasts and increased bone resorption. At low dose levels, the importance of the parathyroid's mediating effect is most apparent. Indeed, the cellular effect. of low doses of cortisol on bone remodeling are identical to those for parathyroid hormone. Therefore, we believe that at low doses the parathyroid's 
mediating effect overrides the anti-proliferative effect of the cortisol: (Fig. 4)

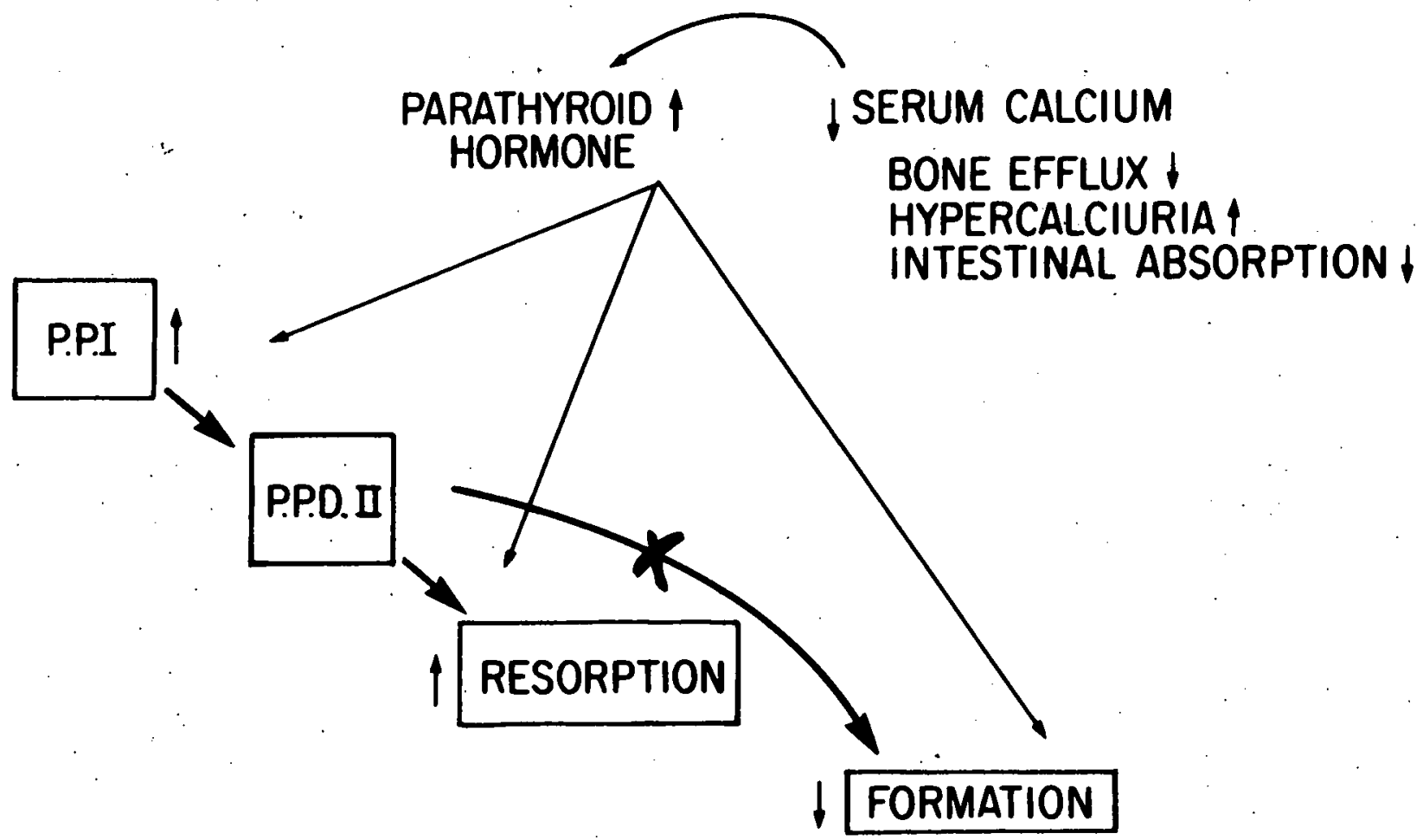

Figure 4. Schema for cellular hypothes is of low dose level glucocorticoid induced osteoporosis. Cortisol acts by inhibiting precursor cell proliferation directly and stimulating parathyroid hormone secretion indirectly (via bone, kidney and intestine). At low dose levels, the parathyroid's mediating effect overrides the antiproliferative effect, while at high dose levels, the anti-proliferative action of cortisol prevails.

High dose levels of cortisol depressed precursor cell proliferation and decreased bone formation without any evidence of bone resorption. At 
higher dose levels, the importance of the anti-proliferative action of cortisol is most apparent. Furthermore, cortisol can block the parathyroid's mediating effect by inhibiting parathyroid secretion directly and opposing the hormone action at its target sites in bone and kidney. (40) Depression of precurosi cells by cortisol would not allow the secondary hyperparathyroidism to express itself because of insufficient precursor cells. Moreover, severe depression of precursor cells would result in subnormal osteoclastic activity. 


\section{REFERENCES}

1. Clark, I.; The effect of cortisone upon protein synthesis. Journal of Biological Chemistry, 200: 69-76, (.1953).

2. Peck, W.A., Brandt, J. and Miller, 1.; Hydrocortisone-induced inhibitors of protein synthesis and uridine incorporation in isolated bone cells in vitro. Proceedings of National Academy of Science, U.S.A., 57, 1599-1606, (1967).

3. Albright, F.; Cushing's syndrome: its pathological physiology, its relationship to adreno-genital syndrome, and its connection with problem of reaction of body to injurious agents ("alarm reaction". of Selye). Harvey Lect. (1942-1943) 38: 123-186, (1943).

4. Bartley, M.H., Jr.; Structural Activities of the Anti-inflammatory Steroids and their Relationship to Osseous Tissue. Ph.D. Thes is, Department of Anatomy, University of Utah Salt Lake City, Utah, (1968).

5. Berliner, D.L., Bartley, M.H., Kenner, G.H. and Jee, W.S.S.; Activity of anti-inflammatory steroids upon fibroblasts and bones. British Journal of Dermatology, 82:Suppl. 6: 53-61, (1970).

6. Simmons, D.J. and Kunin, A.S.; Autoradiographic and biochemical investigations of the effect of cortisone on. the bones of the rat. Clinical Orthopaedics, 55: 201-215, (1967).

7. Roberts, W.E.; The Effects of Cortisol on the Cellular Kinetcs and Cell Population Dynamics of Periodontal Ligament Bone Cells. Ph.D. Thes is Department of Anatomy, University of Utah, Salt Lake City, Utah, (1969).

8. Storey, E.; The influence of adrenal cortical hormones on bone formation and resorption, Clinical Orthopaedics, 30: 197-217 (1963).

9. Thompson, J. and Urist, M.R.; Influence of cortisone and calcitonin on bone morphogenesis. Clinical Orthopaedics, 71: 253-270, (1970).

10. Blackwood, E.L.; The Effects of Cortisol on the Bones and Teeth of Young and Adult Rabbits. Ph.D. Thesis, Department of Anatomy, University of Utah, Salt Lake City, Utah, (1969).

11. Jett, S., Wh, K. Duncan, H., and Frost, H.M.; Adrenal-corticosteroid and salicylate actions on human and canine haversian bone formation and resorption. Clinical Orthopaedics, 68: 301-315, (1970).

12. Kenner, G.H.; Adrenal Cortical Hormone and Minerial Kinetics in Young and Adult Rats. Ph.D. Thesis, Department of Anatomy, University of Utah, Salt Lake City, Utah, (1970). 
13. Jee, W.S.S., Park, H.Z., Roberts, W.E. and Kenner, G.H.; Corticosteroid and bone. American Journal of Anatomy, 129: 477-480, (i970).

14. Follis, R.H., Jr.; Effect of cortisone on growing bones of the rat. Proceedings of the Society of Experimental Biology and Medicine, 76: 722-724, (1951).

15. Park, H.Z., Jee, K.W., Burggraaf, R., and Jee, W.S.S.; Dichotomy of effects of cortisol upon metaphyseal bone. Journal of Dental Research, 49, abstract number 113, page $77,(1970)$.

16. Jowsey, J., Kelly, P.J., Riggs, L.B., Bianco, A.J., Scholz, D.A. and Gershon, Cohen, J.; Quantitative microradiograptic studies of normal and osteoporotic bone. Journal of Bone and joint Surgery, 47A: 785806 , (1965).

17. Riggs, B.L., Jowsey, J. and Kelly, P.; Quantitative microradiographic studies of bone remodeling in Cushings's syndrome. Metabolism, 15: 733-780, (1966).

18. Jowsey, J. and Riggs, B.L.; Bone formation in hypercortisonism. Acta Endocrinologica, 63: 21-28, (1970).

19. Sissons, H.A.; The osteoporos is of Cashing's syndrome: Journal of Bone and Joint Surgery, 38B: 418-433, (1956).

20. Frost, H.M.; Mathematical Elements of Lamellar Bone Remodeling. Charles C. Thomas, Springfield, (1964).

21. Dougherty, T.F. and White, A.; Functional alterations in lymphoid tissue induced by adrenal cortical secretion. American Journal of Anatomy, 77 : 81-116, (1945).

22. Dougherty, T.F., Berliner, D. L. and Berliner, M.L.; Corticosteroid-: Tissue Interactions, Metabolism, 10: 966-989, (1961).

23. Berliner, D.L., and Ruhmann, A.G.; Comparison of the growth of fibroblasts under the influence of 11 -hydroxy and 11 -keto corticosteoids. Endocrinology, 78: 373-382, (1966).

24. Collins, E.J., Garett, E.R and Johnston, R.L.; Effect of adrenal steroids on radio-calcium metabolism in dogs. Metabolism 11: 716-726, (1962).

25. Gordan, G.W., Hansen, J. and Lubick, W.; Effects of hormonal steroids on osteolysis. In: Proceedings of Second International Congress of Hormonal Steroids. Excerpta Medica International Congress Series No. 132: 786-793, (1967).

26. Rasmussen, H.; The parathyroids. In: Textbook of Endocrinology, R.H. Williams, editor, p. 895, W.B. Saunders Co., Philadelphia, (1968). 
27. Pincus, J.B., Natelson, S. and Lugovoy, J.K.; V. Effect of epinephrine, ACTH and cortisone on citrate, calcium, glucose and phosphate levels in rabbits. Proceedings of Society for Experimental Biology and Medicine, 78: 25-27, (1951).

28. Stoerk, H.C., Peterson, A.C. and Jelinck, V.C.; The blood calcium lowering effect of hydrocortisone in parathyroidectomized rats. Proceedings of Society for Experimental Biology and Medicine, 114: 690-695, (1963).

29. Talmage, R.V.; Morphological and physiological considerations in a new concept of calcium transport in bone. American Journal of Anatomy, 129: 467-476, (1970).

30. Harrison, H.E. and Harrison, H.C.; Transfer of $\mathrm{Ca}^{47}$ across the intestinal wall in vitro in relation to action of vitamin D. and cortisol. American Journal of Physiology, 199: 265-271, (1960).

31. Laake, H.; The action of corticosteroids on the renal reabsorption of calcium. Acta Endocrinologica, 34: 60-64, (1960).

32. Raisz, L.G.; Bone resorption in tissue culture: Factors influencing the response to parathyroid hormone. Journal of Clinical Investigation, 44: 103-116, (1965).

33. Schafer, S.A., Stevens, W., Jr: and Jee, W.S.S.; Calcium transport in bone organ culture by cortisol. Journal of Dental Research, 48 , abstract number 679, p. 210, (1969).

34. Stern, P.H.; Inhibition by steroids of parathyroid hormone-induced Ca45 release from embryonic rat bone in vitro. The Journal of Pharmacology and Experimental Therapeutics, 168: 211-217, (1969).

35. Talmage, R.V., Park, H.Z. and Jee, W.S.S.; Parathyroid hormone and thyrocalcitonin function. in cortisol-treated rats. Endocrinology, 86: 1080-1084, (1970).

36. Canas, F.M., Bergstrom, W.H. and Churgin, S.J.; Effects of the adrenal on calcium homeostatsis in the rat. Metabolism, 16:670-675, (1967).

37. Chase, D.C., Roberts, W.E. and Jee, W.S.S.; ${ }^{3} \mathrm{H}$-thymidine evaluation of the effect of parathyroid extract on the cell kinetics of orthodontic tooth movements in the rat. Journal of Dental Research, 48, abstract number 524 , page 171, (1969).

38. Kramer, M., Roberts, W.E., Park, H.A. and Jee, W.S.S.; Endogenous parathyroid hormone and the proliferation of peridontal ligament fibroblasts. Journal of Dental Research, 50, abstract number 827, p. 259, (1971).

39. Julian, G., Park, H.Z., Roberts, W.E. and Jee, W.S.S.; Parathyroid-cortisol relationships measured by periodontal ligament labeling indices. Journal of Dental Research, 50, abstract number 825, p. 259, (1971). 
40. Eliel, L.P., Thomsen, C. and Chanes, R.; Antagonism between parathroid extract and adrenal cortical steroids in man. Journal of Clinical Endocrinology, 25: 457-464, (1965). 


\section{EFFECT OF CORTISOL ON INCORPORATION OF TRITIATED-TETRACYCLINE INTO BONE}

S. A. Schafer and W. S. S. Jee

Abstract: Young-adult male mice were treated daily for eleven days with 25 micrograms cortisol per gram body weight. Three days before sacrifice, all mice were given a single injection of tritiated-tetracycline. Data indicate the following: 1) While control animals gained in total body weight throughout the experimental period, cortisol caused a rapid loss of weight, with a trend toward recovery after the first four days. The tritiated-tetracycline itself caused weight-loss in both groups of animals: 2) Blood radioactivity was the same in treated and control animals at five minutes after injection. The cortisol-treated animals showed less circulating tetracycline thereafter. 3) Bone weights at the time of sacrifice were less in cortisol-treated mice than in controls. 4) At sacrifice, total bone radioactivity was less in cortisol-treated mice than in controls. 5) Extraction of the tibiae with hydrochloric acid caused the release of the same percentage of tetracycline (diffuse component) in both groups.

\section{INTRODUCTION}

Previous studies in this laboratory have indicated that quantitative measurements of radioactive tetracycline could be used as an index of new bone formation if the diffuse component were first eluted from the bone (1). This experiment was designed to study the effect of cortisol on bone formation in young-adult mice, as determined by tritiatedtetracycline incorporation into the tibiae.

\section{MATERIALS AND METHODS}

Eight CBA male mice, 65 days of age with an average weight of 21.4 grams, were divided into two groups. The treated animals were given subcutaneous injections of cortisol ( 25 micrograms per gram body weight) at the same hour every morning for eleven days. The steroid was dissolved in an injection solution of saline with $16 \%$ propylene glycol and $8 \%$ ethyl alcohol. The control group received the carrier solution alone 
at the same time periods. Three days before sacrifice (day 8 of the experiment) all mice were given 2 microcuries tritiated-tetracycline (specific activity $1.2 \mathrm{mCi} / \mathrm{mg}$ ) per gram body weight intraperitoneally. Blood samples were taken by orbital sinus puncture at 5 minutes and 1,2 , and 3 days after injection of the radioactivity. On day 11 , the animals were sacrificed and the tibiae were cleaned of connective tissue and muscle, and weighed. One tibia from each animal was extracted for one hour at room temperature with $3 \times 10^{-3} \mathrm{~N} \mathrm{HCl}$. The bones were then pulverized, dissolved overnight in Soluene (Packard Sample Solubilizer), and prepared for liquid scintillation counting. The second tibia from half of the animals in each group was extracted and fixed in acetone. The remaining tibiae were fixed in acetone immediately after sacrifice. Blood samples, $\mathrm{HCl}$ eluants and dissolved bones were counted in a Packard Tricarb Liquid Scintillation Counter with an efficiency for tritium of $20 \%$. The tibiae prepared for autoradiography were embedded undecalcified in ethyl-butyl-methacrylate, cut at 5 microns on a Jung Model $\mathrm{K}$ microtome, and dipped in Kodak NTB photographic emulsion. The autoradiographic results will not be discussed in this paper.

\section{RESULTS}

Figure 1 shows the average change in weight in the cortisol-treated and control mice for the eleven days of the experiment. Control animals showed a $2 \%$ increase in their original weights until the time of tetracycline injection (indicated by arrows). The radioactive antibiotic resulted in a $4 \%$ total loss in body weight, which appeared to have stabilized by the third day after the injection. The cortisol-treated animals showed a rapid loss of weight which reached a maximum loss of $14 \%$ of the 
original weight by the fourth day of treatment. Thereafter the animals recovered $9 \%$ of their original weight by the sixth day. After the sixth day, the loss in weight began to occur again, compounded by the injection of tetracycline on the eighth day.

Figure 2 shows the distribution of the tetracycline in the blood for a period of three days after injection. The five minute values of the cortisol-treated and control animals are equivalent. The cortisoltreated animals show a faster than control loss of radioactivity from the blood. The radioactivity found in the tibiae upon sacrifice is indicated on the graph by $X^{\prime}$ 's on the eleventh day of the experiment. The cortisol-treated animals showed a decrease in total tetracycline associated with the bone. The bone in both groups however, has a higher tetracycline concentration than the corresponding blood.

Tables 1 and $\mid 1$ show the results of the extraction of the tibiae with hydrochloric acid. Although the tibiae of the control animals contained 1.75 times more tetracycline than those of the treated animals, the partial demineralization released $77 \%$ of the tetracycline in both cases (Table 1). Because the tibiae of the cortisol-treated animais weighed less than those of controls, the radioactivity values are also expressed as a function of unit weight (Table II).

\section{DISCUSSION}

Loss of total body weight by the cortisol-treated mice in this experiment is an indication of the anti-anabolic and/or catabolic effectiveness of this steroid in this species. Pharmacologic concentrations of cortisone have previously been reported to have no effect on mice (2). Reports of the general protein-inhibitory side effect of 
Table I

${ }^{3} \mathrm{H}-\mathrm{Tet}$ racycline Incorporation Into Tibiae

\begin{tabular}{|c|c|c|c|c|c|}
\hline \multirow[b]{2}{*}{ Trea tment } & \multicolumn{4}{|c|}{ Activity $\left(D P M \times 10^{3}\right)$} & Hot-Spots \\
\hline & Total & $\mathrm{HCl}$ Wash & \multicolumn{2}{|c|}{ Bone } & Left In Bone \\
\hline Cortisol & $21.3 \pm 3.2$ & $16.4 \pm 2.4$ & \multicolumn{2}{|c|}{$4.8 \pm 1.1$} & $22.6 \pm 3.1$ \\
\hline Control & $37.3 \pm 5.9$ & $28.6 \pm 4.1$ & \multicolumn{2}{|c|}{$8.6 \pm 2.8$} & $22.9 \pm 5.8$ \\
\hline \multicolumn{6}{|c|}{ Table II } \\
\hline . & ${ }^{3} \mathrm{H}-\mathrm{Tetracycline}$ & \multicolumn{4}{|c|}{ Incorporation Into Tibiae } \\
\hline & \multirow{2}{*}{$\begin{array}{l}\text { Tibial } \\
\text { Weights }\end{array}$} & \multicolumn{4}{|c|}{$\mathrm{DPM} / \mathrm{GM} \times 10^{5}$} \\
\hline Trea tment & & \multicolumn{2}{|c|}{ Total } & HCl Wash & Bone \\
\hline Cortisol & $39.1 \pm 3.7$ & \multicolumn{2}{|c|}{$5.47 \pm 0.88$} & $4.23 \pm 0.74$ & $1.23 \pm 0.23$ \\
\hline Control & $44.0 \pm 6.3$ & \multicolumn{2}{|c|}{$8.52 \pm 1.13$} & $6.58 \pm 1.12$ & $1.93 \pm 0.46$ \\
\hline
\end{tabular}

tetracycline are also substantiated by the loss in total body weights of both groups of mice after injection of the tetracycline (3). The recovery of some weight between days 4 and 6 in the cortisol-treated animals is an indication of compensatory homeostatic mechanisms. Among these would certainly be that of secondary hyperparathyroidism. However, the animals never regain their original weight and, in fact, appear to be failing again after the sixth day. This failure might indicate an exhaustion of the homeostatic mechanisms just mentioned.

Eight days of high-level cortisol treatment had no effect on the uptake of tetracycline from the peritoneal cavity. It did however cause an increased removal of the tetracycline from the blood. This could be accounted for in two ways: 1) increased pooling and/or binding of the 
tetracycline in body tissues, particularly the skeleton and 2). increased excretion of tetracycline via the feces and urine (4). The values of bone radioactivity three days after injection show there is in fact decreased quantities of tetracycline associated with the calcified tissues. The second explanation of increased excretion seems to be the correct one.

The data obtained from the extraction of the bone with hydrochloric acid indicate that both components of tetracycline in the bone are decreased: that associated diffusely throughout all bone matrix and that actively incorporated into areas of newly-mineralizing osteoid (hot- : spot). In addition, the decrease in diffuse tetracycline is equivalent to the decrease in hot-spot tetracycline. It seems likely that not only. is bone formation depressed by cortisol, but the very transport or diffusion of tetracycline through the bone is also depressed. The anti-anabolic effect of the steroid may in fact be the result of a failure of metabolites in general to reach the bone cells.

\section{REFERENCES}

1. S. A. Schafer, D. Higgenbottom, H. Z. Park, and W. S. S. Jee; The distribution of tritiated-tetracycline in young-adult mouse bone A rapid method for the quantitation of new bone formation. This publication.

2. R. H. Follis, Jr.; Non-effect of cortisone on growing bones of mice, guinia pigs, and rabbits. Proc. Soc. Exp. Biol. Med. 78: 723-724 (1951).

3. P. Demers, D. Fraser, R. B. Goldbloom, J. C. Haworth, J. LaRochelle, R. MacLean, and T. K. Murray; Effects of tetracyclines on skeletal 
growth and dentition. Canad. Med. Ass. J. 99: 849-854 (1968).

4. R. G. Kelly, and D. A. Buyske; Metabollism of tetracycline in the rat and the dog; J. Pharmacol. Exp. Ther. 130: 144-149 (1960). 


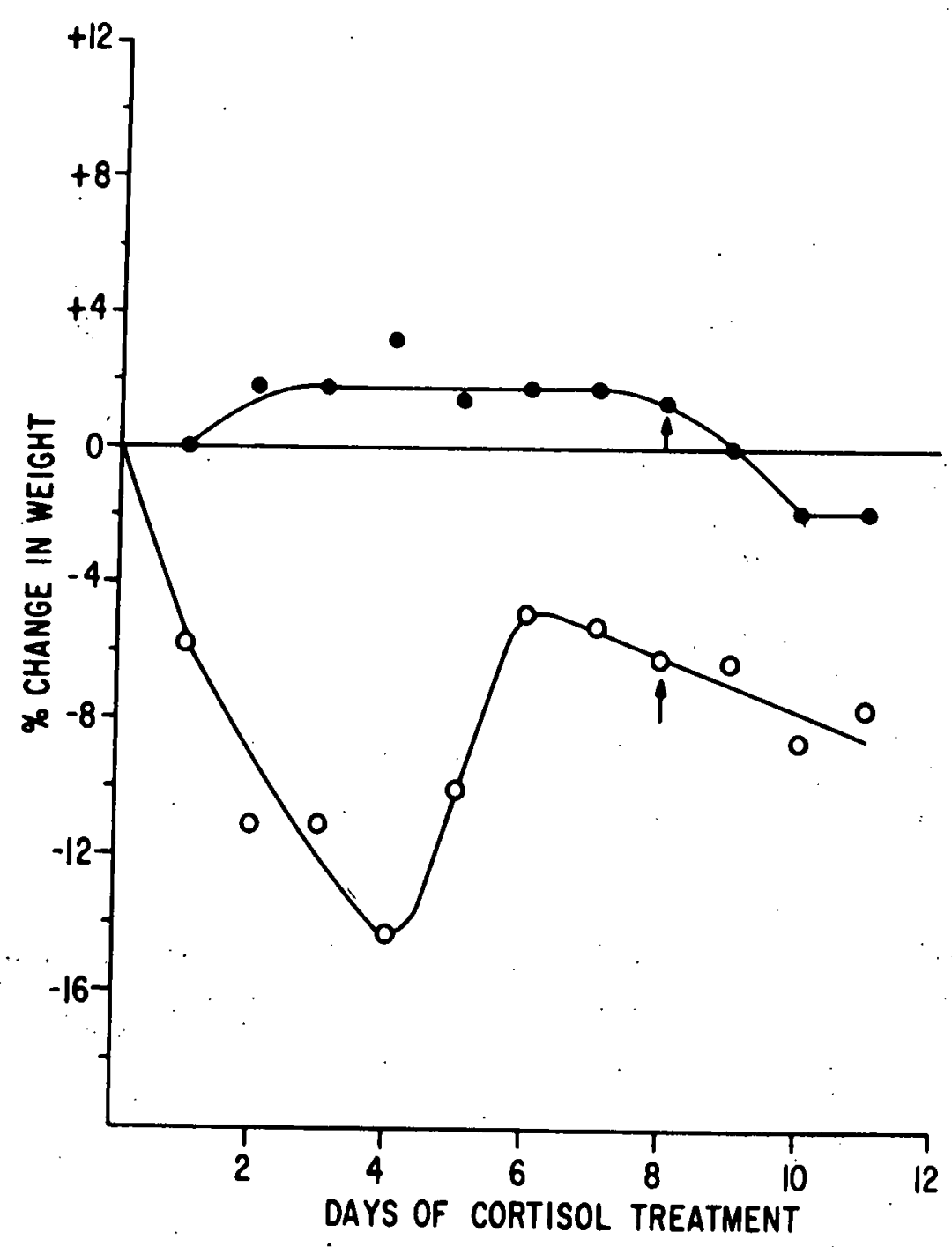

Fig: 1. The effect of cortisol on percent change in total body weights. Solid circles represent the arithmetic means of control animals; open circles, of cortisol-treated animals. Arrows indicate the times of tetracycline injection. 


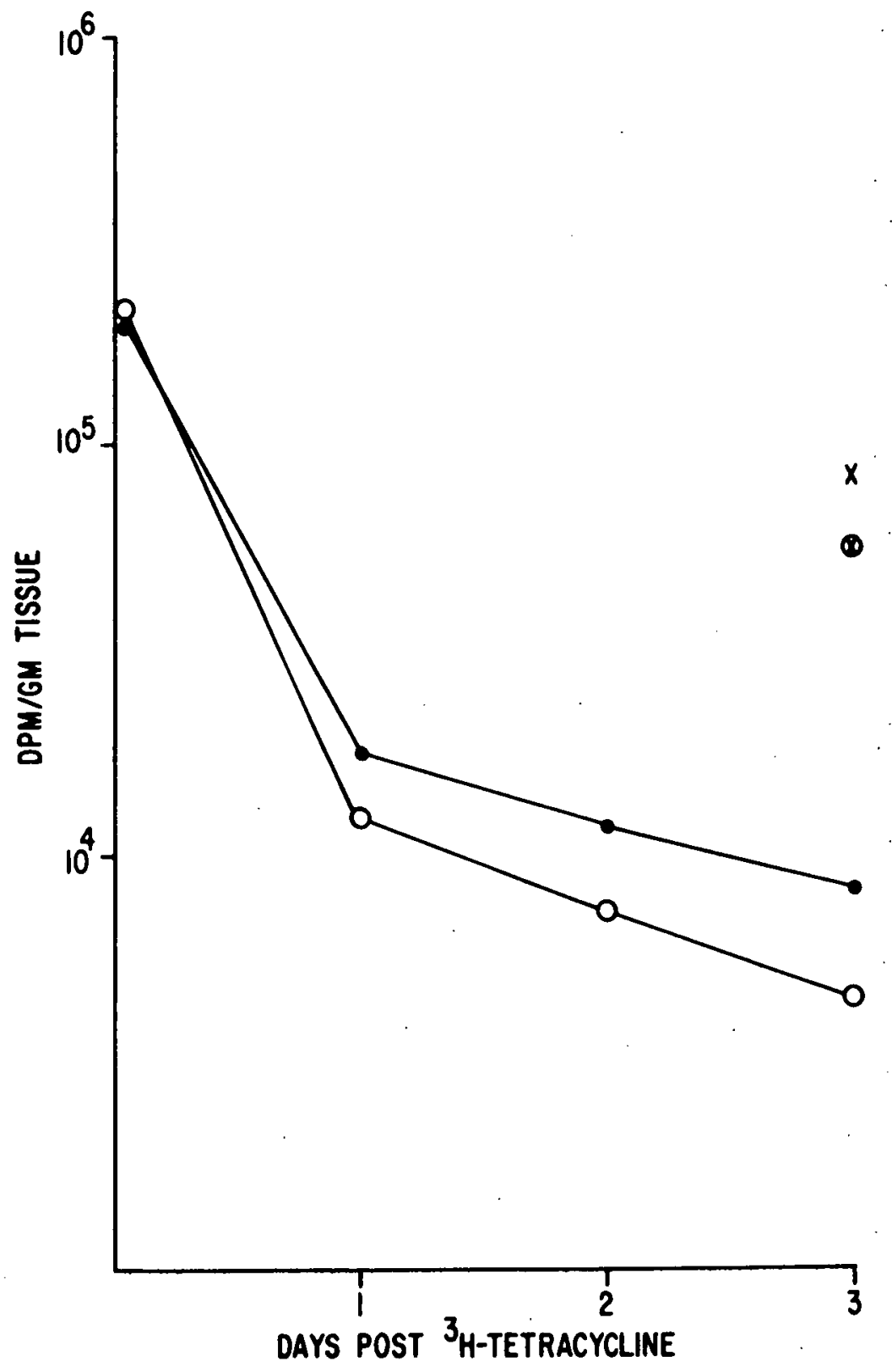

Fig. 2. The effect of cortisol on tritiated-tetracycline incorporation into blood and bone. Solid circles represent the arithmetic mean of blood radioactivity in control animals; open circles, of cortisol-treated animals. The $X$ indicates the radioactivity in control tibiae, the circled $x$, in cortisol-treated tibiae, three days after tetracycline injection. 
THE DISTRIBUTION OF ${ }^{3}$ H-TETRACYCLINE IN YOUNG-ADULT MOUSE BONE A RAPID METHOD FOR THE QUANTITATION OF NEW BONE FORMATION

\author{
S. A. Schafer, D. Higgenbottom, H. Z. Park, \\ and W. S. S. Jee
}

\begin{abstract}
Three-month-old female mice were injected with 2 microcuries tritiated-tetracycline per gram body weight. Blood samples were taken by orbital sinus puncture at 0,5 minutes, $1,2,3,4$, and 5 days. Bone samples were taken at 1,3 , and 5 days. The association of the tetracycline with the lipid and mineral phases of the bone was then investigated by sequential extraction with chloroform, chloroform/ methanol, and chloroform/methanol/HCl. The data indicate the following: 1) The bone loses radioactivity as rapidly as the blood, with a biological half-life of 3.65 days. 2) Neither diffuse nor hot-spot tetracycline shows any correlation with the neutral lipid compartment of the bone. 3) The diffuse tetracycline comprises the majority of the compound deposited in bone, possibly amounting to $70 \%$. This fact makes it meaningless to use total radioactive tetracycline measurements as an index of new bone formation, at least in short time periods up to five days after injection. Since the only relevant fraction is that bound in newly-mineralizing areas, so called hot-spots, the two components must be dissociated. 4) We would like to suggest that bone formation can be quantitated by measurements of tetracycline radioactivity remain-. ing in bone after partial, controlled dissolution of the hydroxyapatite. Since the diffuse tetracycline is loosely associated with the bone, possibly by electrostatic bonds, there is a point during demineralization where the diffuse component is virtually eliminated leaving a preparation of hot-spot tetracycline. We therefore have a technique which replaces the time-consuming classical techniques now employed to study bone formation.
\end{abstract}

\title{
INTRODUCTION
}

Since the initial isolation of chlortetracycline in $1948,(1)$ tetracycline has become the third major antibiotic after penicillin and streptomycin. (2) Two decades of usage have brought to light certain important skeletal and dental side effects caused by its administration. One of these side effects is a specific yellowish fluorescence in the bones and in enamel and dentine of the teeth. Studies by Milch, (3) by Frost, (4) and by Harris ${ }^{(5)}$ all showed that the affinity of tetracycline for calcified 
tissues was of two varieties. The major component was said to be actively deposited in all sites of newly-mineralizing bone and to be relatively permanently fixed in bone until resorption occurred. A so-called lesser component was said to be diffuse and not as tightly bound. Tetracycline bone labeling, followed by ultraviolet microscopic measurements of the width, area, or volume of hot-spot fluorescent zones is now commonly used as an index of skeletal metabolic activity. (6) Such activity is expressed as appositional growth rate, radial rate of osteon closure, and osteon maturation rate.

This paper concerns our attempts to separate by chemical extraction the diffuse and hot-spot components of the tetracycline deposited in bone. The purpose of this research was two-fold. In the first place, we wanted to be able to make direct measurements of the total quantity of tetracycline bound to bone-forming sites, i.e. the hot-spot component. This would be a new tool for measuring bone formation, eliminating the tedious sectioning and microscopy currently employed. Secondarily, the chemical nature of any substance which would bring about a successful separation of the two components would give us clues to the nature of the tetracycline affinities to the different skeletal areas.

\section{MATERIALS AND METHODS}

Ten C3Hf female mice, prior to closure of their growth plates, were used in this study: They were three months of age, with an average weight of 23 grams. At time 0 , the mice were injected intraperitoneally with 2 microcuries tritiated-tetracycline (specific activity $1: 2 \mathrm{mC} / / \mathrm{mg}$ ) per gram body weight. Blood samples were taken by orbital sinus puncture at 0,5 minutes, 12 hours, and each day for 5 days after injection. 
Groups of animals were sacrificed and bone samples were taken at 1,3 , and 5 days after injection. After the connective tissue and muscle had been removed, the tibiae were sequentially extracted for one hour at room temperature in $1 \mathrm{ml}$ of each of the following solvents:

chloroform

chloroform/methanol, 2/1

chloroform/methanol/HCl, 200/100/1.

Samples of bone at each step of the extraction were prepared for autoradiography. They were fixed in acetone, embedded undecalcified in ethy!-butyl-methacrylate and cut at 5 microns on a Jung Model $\mathrm{K}$ microtome. They were dipped in Kodak NTB emulsion and exposed for 28 to 56 days. After development and fixation, the sections were stained with Mayer's hematoxylin and eosin $Y$.

\section{RESULTS}

The results of this experiment are tabulated to show:

1) the distribution of radioactivity in the blood and bone at the time periods mentioned,

2) the amount of radioactivity eluted with the three solvents and. that remaining in the bone after each extraction,

3) autoradiographic representations of the location of the tetracycline remaining in the bone after each extraction.

As seen in Figure 1 , the bone of these animals had reached its maximum radioactivity within the first day. Thereafter blood and bone lost radioactivity at the same rate; the biological half-time of the tetracycline computed to be 3.65 days. 
The results of the sequential extraction of the tibiae are shown in Figure 2. By statistical analysis of parallelism, the rates of loss of tetracycline from the bone as a whole and from the hydroxyapatitelipid compartment in particular, i.e. the diffuse component, are not significantly different from each other. The biological half-time, as mentioned, is 3.65 days. Only that tetracycline eluting with the chloroform-neutral lipid fraction is lost at a different, faster rate, with a biological half-time of 1.86 days.

Expressing the value for radioactivity of each extraction as percentages of total radioactivity (Figure 3) makes evident the fact that most of the tetracycline, more than $90 \%$, remains in the bone after the lipids have been removed. Seventy percent is eluted out with the partial dissolution of the hydroxyaptite. After one hour of extraction, an average of $23 \%$ of the original tetracycline remains tightly bound to the bone.

Autoradiographs of the bone before extraction and after passage through chloroform and chloroform/methanol are virtually identical. These show the diffuse component to be more outstanding than as seen under the ultraviolet microscope. The diffuse component completely overshadows the hot-spots (Figure 4 ).

In contrast, elution with acidic chloroform/methanol shows a loss of the majority of the label. Under high power; that tetracycline remaining is shown to be in areas deep to osteoid, i.e. those areas which were the calcifying front of newly-mineralizing bone at the time of injection (Figure 5). 


\section{DISCUSSION}

Tetracycline is sequestered by bone almost immediately. After the first day, the bone loses radioactivity as rapidly as the blood. of interest to this finding is the fact that the fluorescent picture of bone changes within five days after injection, hot-spots becoming more brilliant. Because it has been shown that tetracycline fluoresces in vitro only after chelation with calcium, the increase in fluorescence with time in vivo has been assumed to be due to an increase in the amount of the compound activly bound to hydroxyapatite and not to an increase in the total amount present. This assumption is supported by the fact that the total bone radioactivity in itself is not increasing after the first day.

The rationale for the bone extractions centered around two assumed properties of tetracycline:

1) Its solubility in or actual binding to lipids. This was assumed from reports that tetracycline fluorescence was used to identify lipids on chromatograms. (7) This information appears to have been false as there is' no reference to such a technique in the literature and further there is in fact no correlation between the lipid compartment and tetracycline.

2) The second property is well-substantiated, namely its chelation with divalent cations, specifically magnesium, manganese and calcium. $(8,9)$ This property could account for both components of tetracycline labeling. In any event, that tetracycline entering with calcium into newlymineralizing bone might be more tightly bound or as frost has suggested "fixed". (6) 
Urist indicated that there were two types of hydroxyapatite. (10) That first laid down on osteoid is loose, composed of larger lattices and less packed with collagen than the second variety. This structure leaves more positions in the crystal open for exchange with tetracycline. As the crystal ages (as rapidly as 24 hours) some positions in the crystal are buried by polysaccharides, by collagen and by packing. If these newlyburied positions were occupied by tetracycline, the antibiotic would indeed now be cemented in.

Shapiro (Table 1) showed that the majority of lipids in anorganic bone is eluted out with chloroform and chloroform/methanol. (11). Less than $5 \%$ of the mean total eluted phosphatides are associated with the bone after treatment with acidified chloroform/methanol. The effect of the acidic chloroform/methanol solvent system is also to cause almost complete solubilization of the hydroxyapatite.

\section{Table 1}

The Percentage Distribution of Phospholipids Removed By Solvent Elution From Anorganic Bone (11)

\begin{tabular}{|c|c|c|c|}
\hline \multirow[t]{2}{*}{ Expt. No. } & o of Lipid & moved at Eacl & Extraction Stage \\
\hline & Chloroform & $\begin{array}{l}\text { Chloroform/ } \\
\text { Methanol }\end{array}$ & $\begin{array}{l}\text { Acidified } \\
\text { Chloroform/ } \\
\text { Methanol }\end{array}$ \\
\hline 1 & 82.4 & 11.7 & 5.9 \\
\hline 2 & 79.6 & 16.5 & 3.9 \\
\hline
\end{tabular}

The radioactivity eluted out with the lipid solvents shows that neither the diffuse nor the hot-spot tetracycline correlates with the neutral lipid compartment of the bone. The diffuse tetracycline comprises the majority of the compound deposited in bone, possibly amounting to 
$70 \%$. This fact makes it meaningless to use total radioactive tetracycline measurements as an index of new bone formation, at least in short time periods up to five days after injection. Since the only relevant fraction is that bound-in newly-mineralizing areas, so called hot-spots, the two components must be dissociated. We would like to suggest that bone formation can be quantitated by measurements of tetracycline radioactivity remaining in bone after partial, controlled dissolution of the hydroxapatite. Since the diffuse tetracycline is loosely associated with the bone, possibly by electrostatic bonds, there is a point during demineralization where the diffuse component is virtually eliminated leaving a preparation of only hot-spot tetracycline. We therefore have a technique which replaces the time-consuming classical techniques now employed to study bone formation.

\section{ACKNOWLEGEMENT}

The authors wish to thank Dr. Lowell Woodbury for his suggestions. and statistical analysis of the data.

\section{REFERENCES}

1. B. M. Duggar; Aureomycin; A product of the continuing search for new antibiotics; Ann. N. Y. Acad. Sci. 51: 177-181 (1948).

2. E. M. Ory; The tetracyclines; Med. Clinics of No. Am. 54: 1173-1186 (1970) 。

3. R. A. Milch, D. P. Rall, and J.E. Tobie; Bone localization of the tetracyclines; J. Nat. Cancer Inst. 19: 87-93 (1957).

4. H. M. Frost, A. R. Villanueva, and H. Roth; Tetracycline s.taining of newly forming bone and mineralizing cartilage in vivo; Stain Technol. 35: $135-138(1960)$ 
5. W. H. Harris, R. H. Jackson, and J. Jowsey; The in vivo distribution of tetracyclines in canine bone; J. Bone Jt. Surg. 44A: 1308-1320 (1962).

6. H. M. Frost, A. R. Villanueva, H. Roth, and S. Stanisavljevic; Tetracycline bone labeling; J. New Drugs 1 : 206-216 (196i).

7. H. Z. Park; personal communication.

8. K. W. Kohn; Mediation of divalent metal ions in the binding of tetracycline to macromolecules; Nature 191: 1156 (1961).

9. K. H. Ibsen, and M. R. Urist; Complexes of calcium and magnesium with oxytetracycline; Proc. Soc. Exp. Biol. Med. 109: 797-801 (1962).

10. M. R. Urist, and K. H. Ibsen; Chemical reactivity of mineralized tissue with oxytetracycline; Arch. Path. 76: 28-40 (1963).

11. 1. M. Shapiro; The association of phospholipids with anorganic bone; Calc. Tiss. Res. 5: 13-20 (1970). 


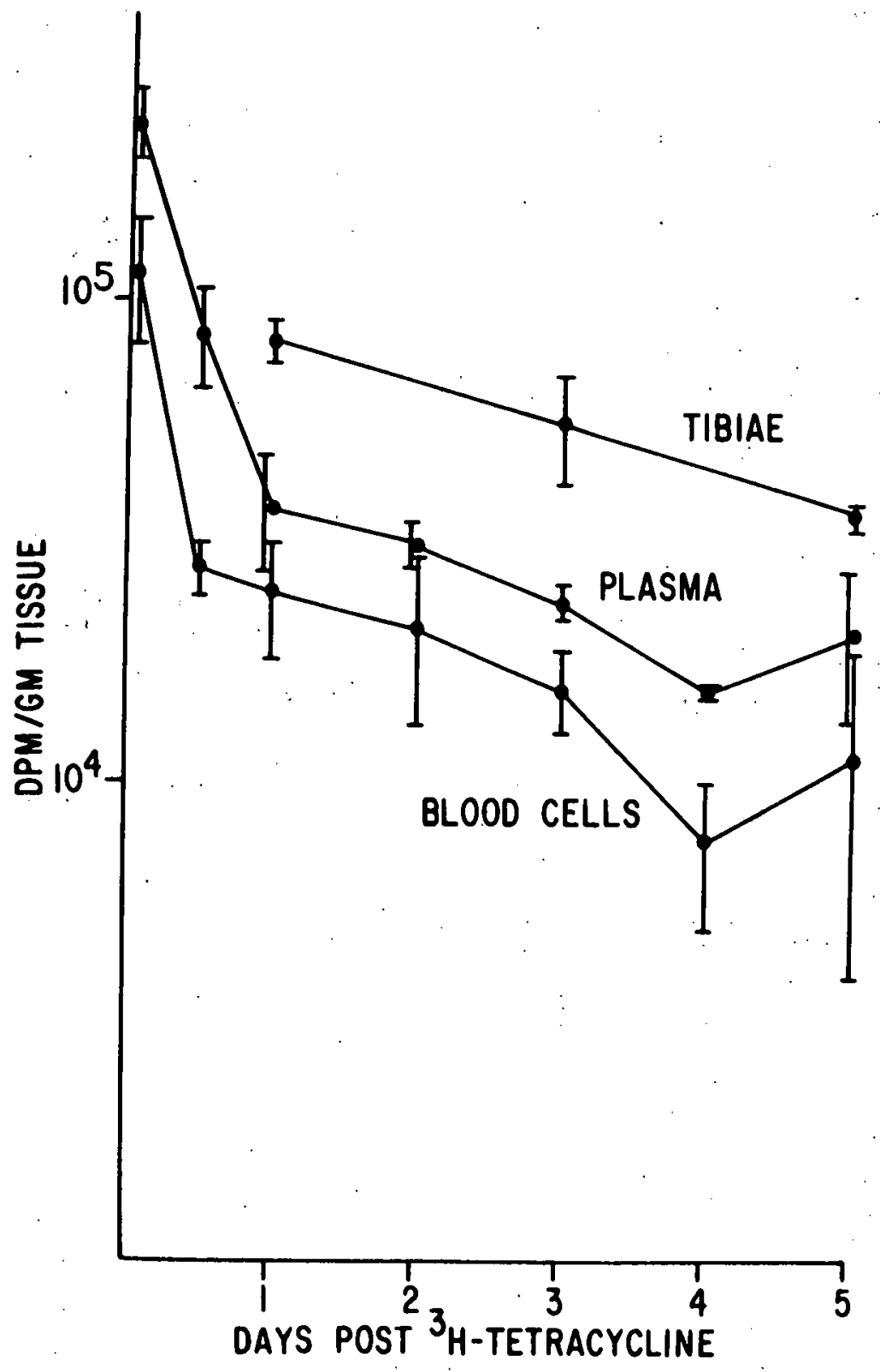

Fig. 1. Distribution of tritiated-tetracycline in blood cells, plasma and bone. Each point represents the arithmet ic mean \pm standard deviation. 


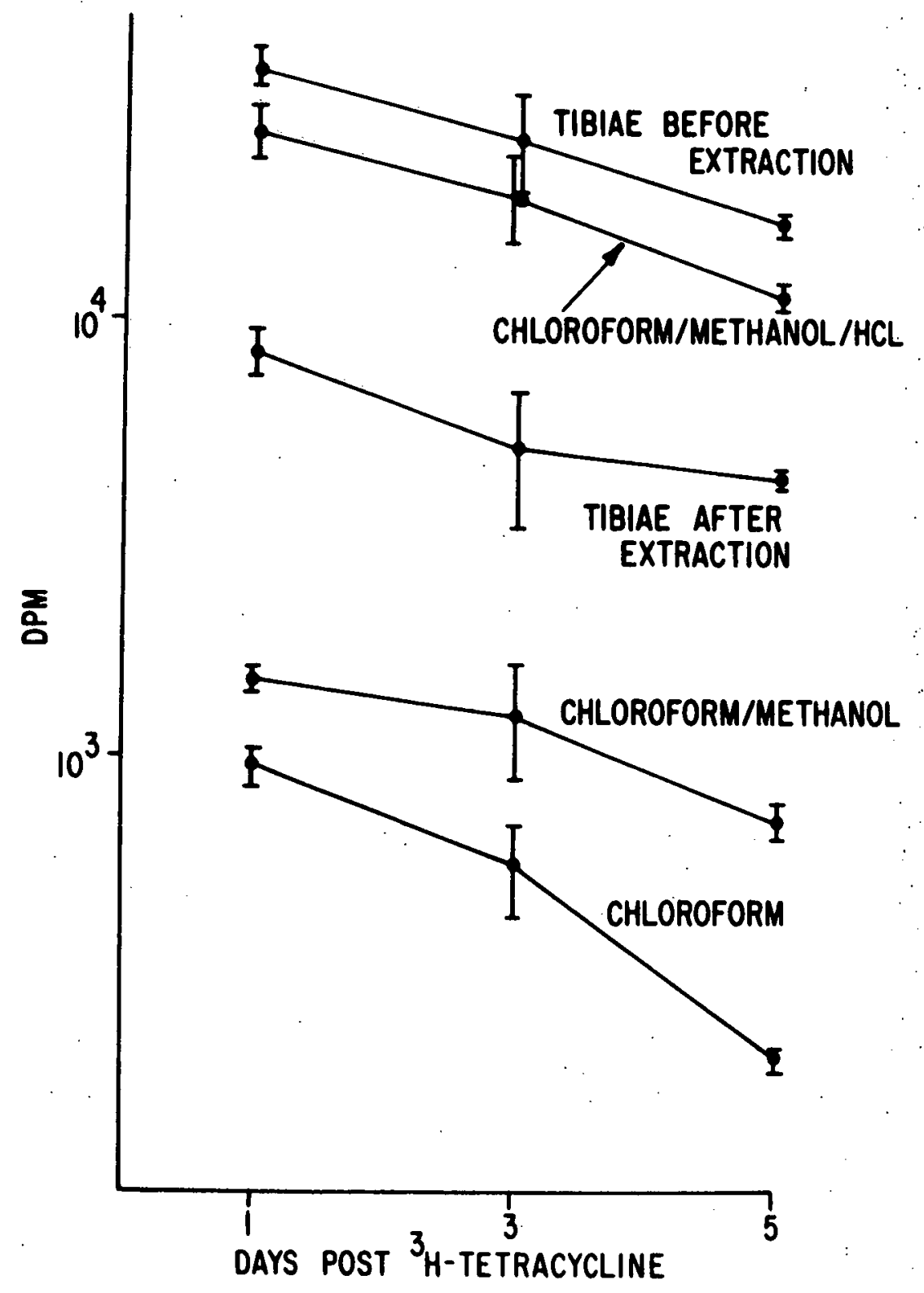

Fig. 2. Tritiated-tetracycline removed by three solvents from tibiae. Each point represents the arithmetic mean \pm standard deviation. 
-

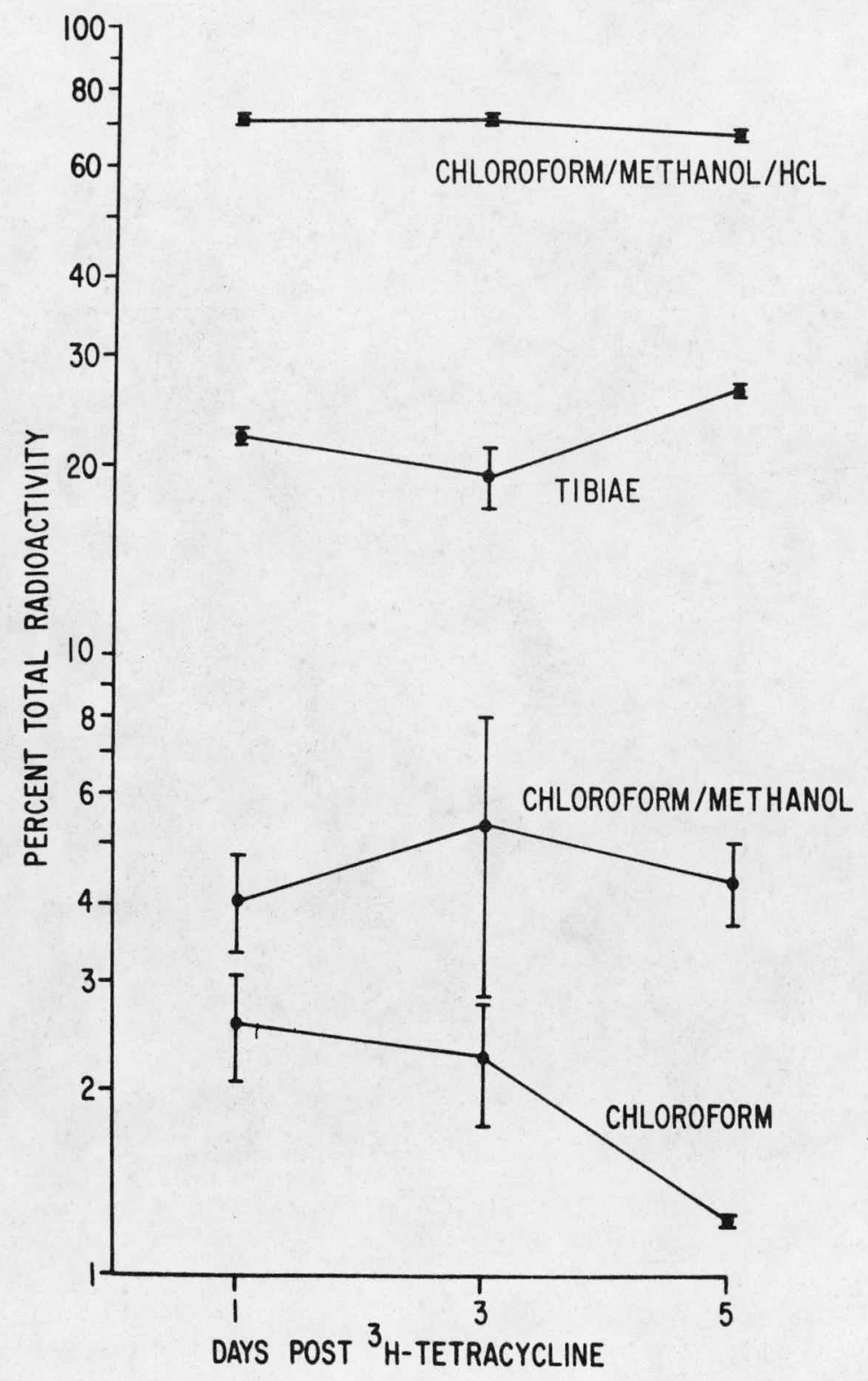

Fig. 3. Percentage distribution tritiated-tetracycline in three elutions of tibiae. Each point represents the arithmetic mean \pm standard deviation. 


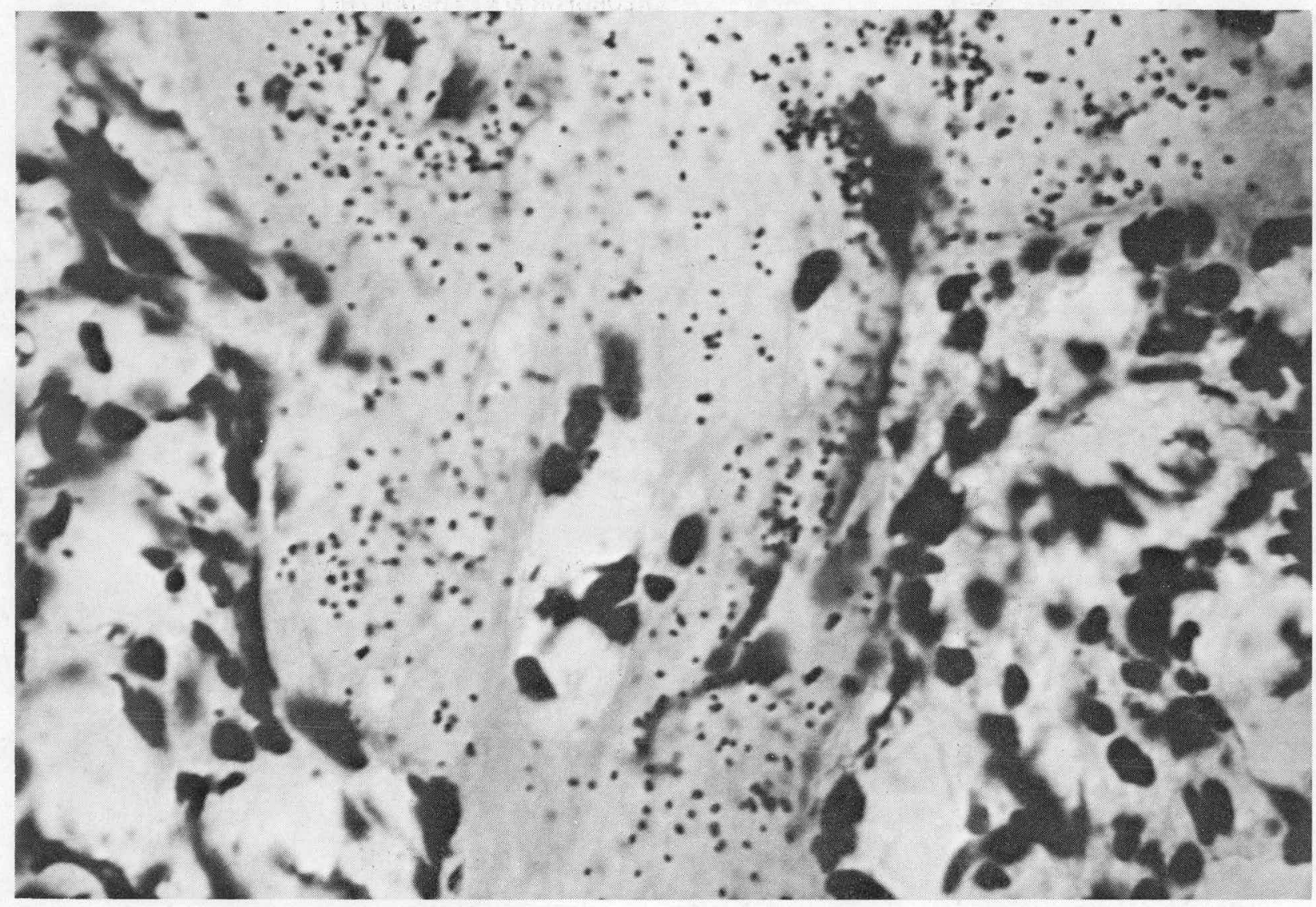

Fig. 4. Mouse tibia labeled with tritiated-tetracycline. Autoradiograph made before extraction procedure. Note size of diffuse component. 


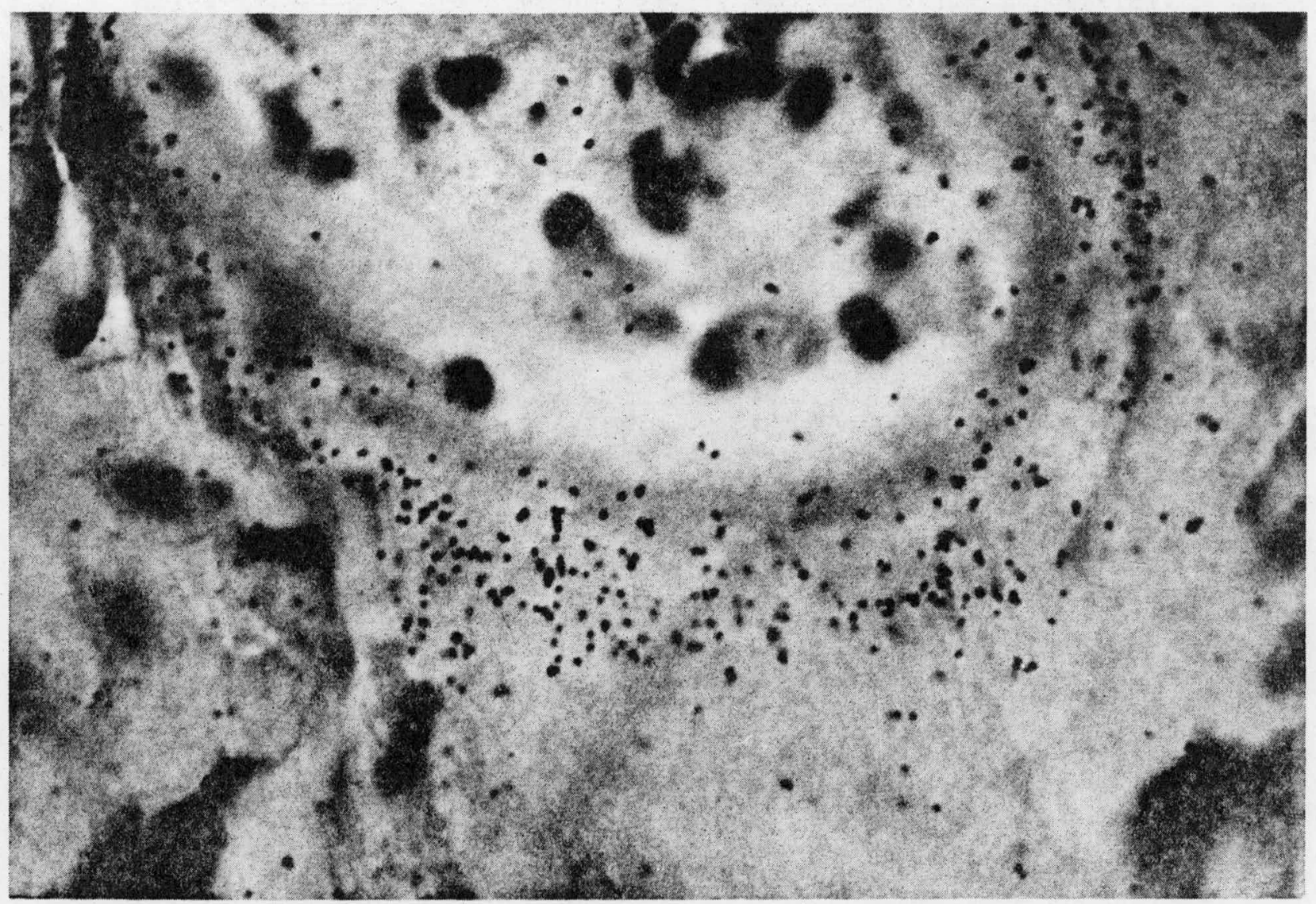

Fig. 5. Autoradiograph of labeled tibia after extraction with chloroform/methanol/HCl. Seventy percent of tetracycline has been eluted out; that remaining is predominantly in hot-spots. 


\title{
STRUCTURAL ACTIVITY RELATIONSHIP OF CORTICOSTEROIDS TO GROWING BONES: COMPARISON OF ACTIVITIES OF CORTISOL, PREDNISOLONE, BETAMETHASONE AND DEXAMETHASONE
}

\author{
J. A. Yee, G. H. Kenner, and W. S. S. Jee
}

Abstract: The relative potencies of betamethasone $(9 \alpha-f l u o r o-$ $11 \beta, 17 \alpha, 21-t r i o l-16 \beta$-methyl-pregnan-1, 4-diene-3, 20-dione)

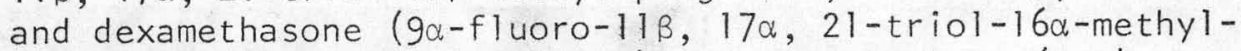
pregnan-1, 4-diene-3, 20-dione) and prednisolone (1, 4-pregnan-

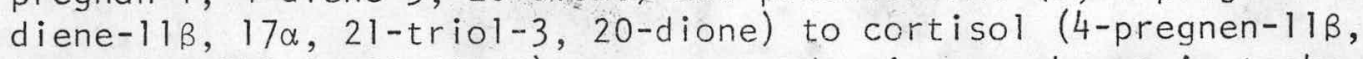
$17 \alpha, 21$-triol-3, 20-dione) were assayed using morphometric techniques. The suppression of endochondral ossification (longitudinal growth), periosteal accretion and endosteal accretion were obtained by measuring tetracycline labels using fluorescence microscopy and morphometric techniques. Reduction in metaphyseal bone and cell counts were determined using the point-hit and the Quantimet Television Microscopic method. Prednisolone was found to be 2 to 3 times, betamethasone was 10 to 26 times and dexamethasone 9 to 44 times more potent than cortisol. Dexamethasone was consistently more effective in suppressing bone accretion and endochondral ossification than betamethasone. The addition of the fluorine atom at the $c-9$ position conferred an increased degree of bone growth suppression activity to the steroid molecule.

\section{INTRODUCTION}

The clinical use of anti-inflammatory hormones has been greatly inhibited by side effects produced by these corticosteroids (i.e., reduction in bone volume or osteoporosis). Since pharmaceutical companies have been synthesizing many corticosteroids in an attempt to find one which exhibits maximal anti-inflammatory activity with minimal osteoporotic side effects, it is important that the relative potencies of these hormones be determined. As a continuation of many experiments done in our laboratory on both naturally occurring and synthetically produced corticosteroids, this experiment was designed to determine structural activity relationships between betamethasone, dexamethasone, prednisolone and cortisol. The relative potencies, indices of precision and fiducial limits for these four corticosteroids were determined by analysis of dose response curves plotted for a number of bone 
growth measurements.

\section{MATERIALS AND METHODS}

Eighty, 8 week old, male New Zealand White Rabbits were given daily subcutaneous injections of the corticosteroids for twenty days. The dose levels of the corticosteroids are listed in Table 1 while the molecular configuations of each corticosteroid are shown in figure 1. Estimated potency ratios were derived from fibroblastic assays $(1)$ and then multiplied by the dose levels of cortisol being used. Control animals were given daily injections of vehicle only. Intramuscular injections of tetracycline (Achromycin, Lederle) were given on days 2 and 16 of the experiment to label new sites of bone formation. Animals were sacrificed and the bones were defleshed. The right side of the skeleton was fixed in acetone and the left side in 10\% formalin. The left proximal tibia were embedded in plexiglass and 6 micron sections were cut on the Jung microtome. These were stained with $H$. and $E$. for bone cell counts. The number of os teoblasts and osteoclasts per unit area were counted in 10 random fields in a standardized area in the metaphysis. The right proximal tibia were embedded in bioplastic, sectioned on a bone saw and the sections ground between glass plates. The longitudinal frontal sections of the proximal tibia were first ground to $100 \mathrm{microns}$ for microradiography and measurement of per cent trabecular metaphyseal bone. The sections were then reground to 50 microns for measurement of endochondral growth using ultraviolet microscopy. Fifty micron sections of the tibial midshaft were used for periosteal accretion measurements on the ultraviolet microscope. Table II summarizes the processing, method of analysis and data obtained from 
various skeletal sites. The relative potencies, indices of precision, and fiducial limits for these four corticosteroids were determined by analysis of dose response curves plotted for endochondral bone growth, periosteal accretion, numbers of metaphyseal osteoblasts and per cent metaphyseal bone (Figs, 2-5). The methods used to analyze these values have been reported previously. (2)

Table 1

Injected dose levels (mg/kg/day)

Cortisol

Prednisolone

Betame thasone

Dexame thasone
$2.2,1.0,0.44,0.25$

$2.2,1.0,0.3,0.1,0.03$

$0.25,0.09,0.014,0.006$

$0.25,0.09,0.014,0.006$

\section{RESULTS AND DISCUSSION}

Dose response curves were used to determine the relative potencies, indices of precision and fiducial limits of prednisolone, betamethasone and dexamethasone as compared to cortisol, the standard which was assigned a potency of 1 .

The minimal dose at which significant changes from the control group were noted is found in Table 111 . Betamethasone and dexamethasone were similar in their effectiveness in causing significant changes in the parameters measured in both the proximal tibia and tibial midshaft. Prednisolone was shown to be just slightly more effective in causing significant differences than cortisol which was the least effective.

The potency ratios, fiducial limits, and indices of precision ( $\lambda$ values) are found in Table IV. Dexamethasone ( $9 \alpha$-fluoro, $16 \beta$-methyl), was shown to be the most potent with potency ratios ranging from 9-44 times that of 
Table II

Summary of Processings and Analyses

\begin{tabular}{|c|c|c|c|c|}
\hline Skeletal Site & Tissue Plane & $\begin{array}{l}\text { Product for } \\
\text { Analys is }\end{array}$ & $\begin{array}{l}\text { Me thod of } \\
\text { Analys is }\end{array}$ & Data determined \\
\hline tibia, diaphysis & $x$-section & $\begin{array}{l}50 \mu \text { undecal. } \\
(\text { tet.) }\end{array}$ & $\begin{array}{l}\text { u.v. microscopy } \\
\text { linear-reticule }\end{array}$ & $\begin{array}{l}\text { periosteal accretion } \\
\text { (transverse growth) }\end{array}$ \\
\hline $\begin{array}{l}\text { tibia, proximal } \\
\text { (reground section) }\end{array}$ & frontal & $\begin{array}{l}100 \mu \text { undecal } \\
\text { microradiograph }\end{array}$ & $\begin{array}{l}\text { projection upon } \\
\text { screen/pt.-hit }\end{array}$ & \%metaphyseal bone \\
\hline tibia, proximal & frontal & $6 \mu$ decal. & light microscopy & \# of osteoblasts \\
\hline
\end{tabular}


cortisol. Betamethasone ( $9 \alpha$-fluoro, 16 -methyl) was slightly less potent than dexamethasone, its potency being 10-26 times cortisol. Prednisolone was only 2-3 times more potent than the standard.

Table |||

Minimal Dose of Steroids Producing Skeletal Changes

\begin{tabular}{lllcc}
$\begin{array}{l}\text { Anti-inflammatory } \\
\text { steroids }\end{array}$ & $\begin{array}{l}\text { Endochondral } \\
\text { bone growth }\end{array}$ & $\begin{array}{l}\text { Parameters } \\
\text { periosteal } \\
\text { accretion }\end{array}$ & \% bone & $\begin{array}{l}\text { 0steoblast } \\
\text { depression }\end{array}$ \\
\hline Cortisol & 0.44 & 0.44 & 2.0 & 0.44 \\
Prednisolone & 0.10 & 0.10 & $*$ & $*$ \\
Betamethasone & 0.006 & 0.006 & 0.09 & 0.006 \\
Dexamethasone & 0.006 & 0.006 & 0.09 & 0.006 \\
\hline
\end{tabular}

$\because$ data not compiled for these parameters as of yet

The best indices of precision were found for the endochondral bone growth data, ranging from 0.08 to 0.19 , implying that the data for this parameter are consistently precise. These anti-inflammatory corticosteroids may be ranked as to their potency in the following order (from most to least potent): Dexamethasone, betamethasone, prednisolone and cortisol. The differences in potency of these steroids in causing changes in. the bone growth parameters measured may be said to arise from the substitutions made to the steroid molecule. Prednisolone which is only slightly more potent than cortisol, differs from the standard only by the addition of a double bond between $\mathrm{C}-1$ and $\mathrm{C}-2$. Dexamethasone and betame thasone which are 9-44 and 10-26 times more potent than cortisol respectively, differ quite markedly in that in addition to the $\Delta^{2}$ double bond as in prednisolone, both molecules are halogenated at $\mathrm{C}-9$ with fluorine in the alpha position, and both are methylated at $\mathrm{c}-16$. The difference in potency existing between dexamethasone and betamethasone is probably due to the fact that the methyl 
Table

Summary of Relative Potencies, Fiducial Limits and Indices of Precision Values for Various. Bone Bioassays

Parameter- Steroid

Potency Ratio

Fiducial Limits

Index of Precision

-Vàlues

periosteal accretion - tibial shaft cortisol

prednisolone

1

be tame thasone

2.10

13.49

dexame thasone

16.92

$3.93-0.05$
$36.07-4.62$
$44.88-6.14$

0.21

0.30

0.52

$\%$ metaphyseal bone - prox. tibia cortisol

1

16.92

22.07

dexame thasone

endochondral bone growth - prox. tibia cortisol

prednisolone

betame thasone

1

dexame thasone

3.03

21.62

44.09

osteoblast depression - prox. tibia cortisol

betame thasone

dexarie thas one
1

12.53

10.16
0.56

0.27

0.41

0.38

49.01-4.77

55.69-9.33

0.08

3.96-0.37

$29.28-15.87$

60.55-32.08

0.15

0.19

0.15

$19.23-8.05$

$19.23-8.05$
$15.70-6.50$

0.23

0.23

0.22 
group is in the alpha position in dexamethasone and the beta position in betamethasone. The $16 \alpha$-methyl imparts slightly more potency to the molecule than the 16 B-methyl.

\section{RE FERENCES}

I. A.G. Ruhmann and D.L. Berliner; Influence of steroids on fibroblasts: 11. The fibroblast as an assay system for topical anti-inflammatory potency of corticosteroids; J. Invest. Derm. 49: 123-130 (1967).

2. M.H. Bartley and W.S.S. Jee; Structural Activity Relationships of Anti-inflammatory Steroid Hormones to Growing Bone. 1. Growth Parameters and Resorption of Proximal Tibia; Research in Radiobiology; Radiobiology Division, Department of Anatomy, University of Utah, College of Medicine, U.S.A.E.C. Report C00-119-240, 199-213 (1969). 

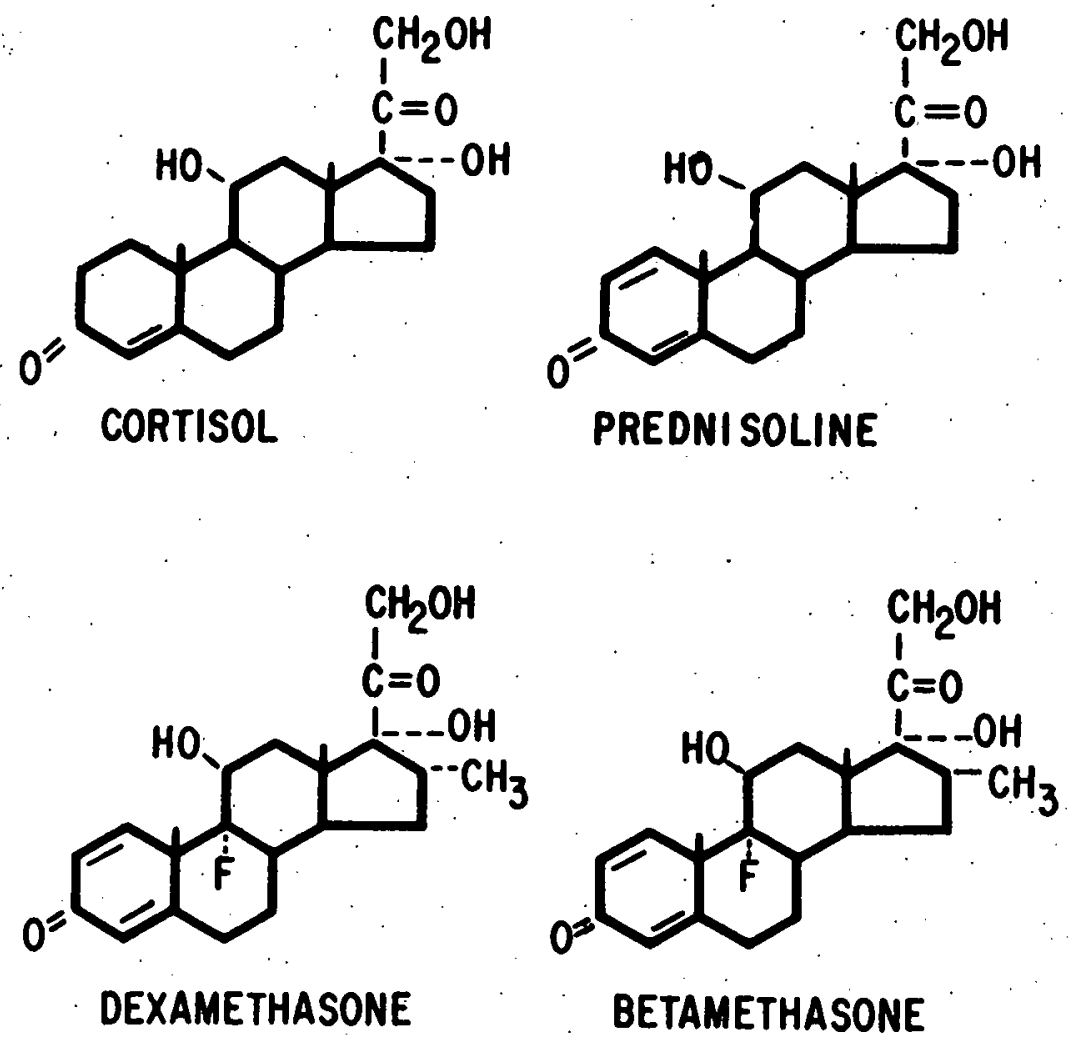

Fig. 1. Molecular configuration of corticosteroids. 


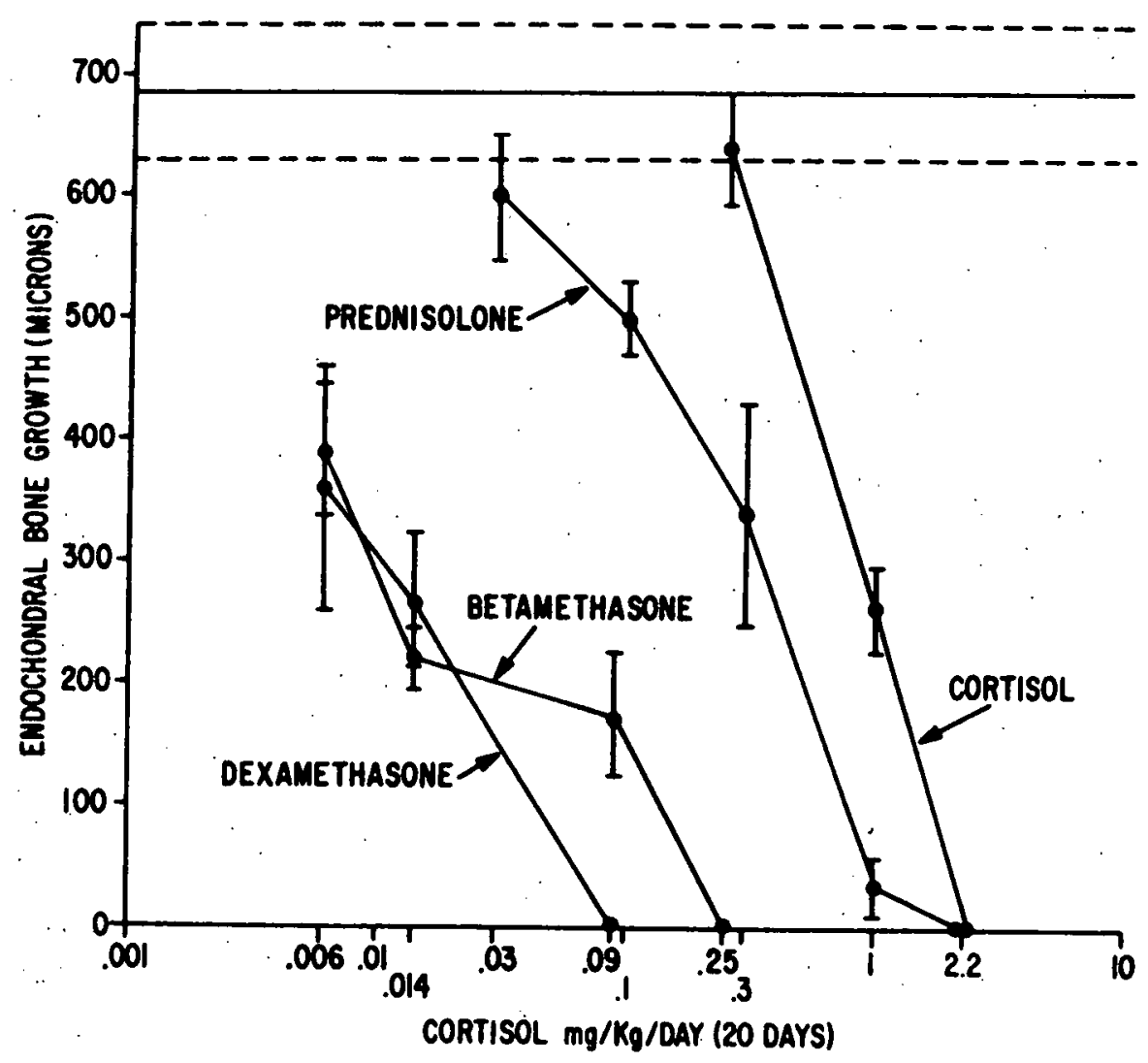

Fig. 2. Dose response curves for effects upon endochondral growth by 4 different corticosteroids. 


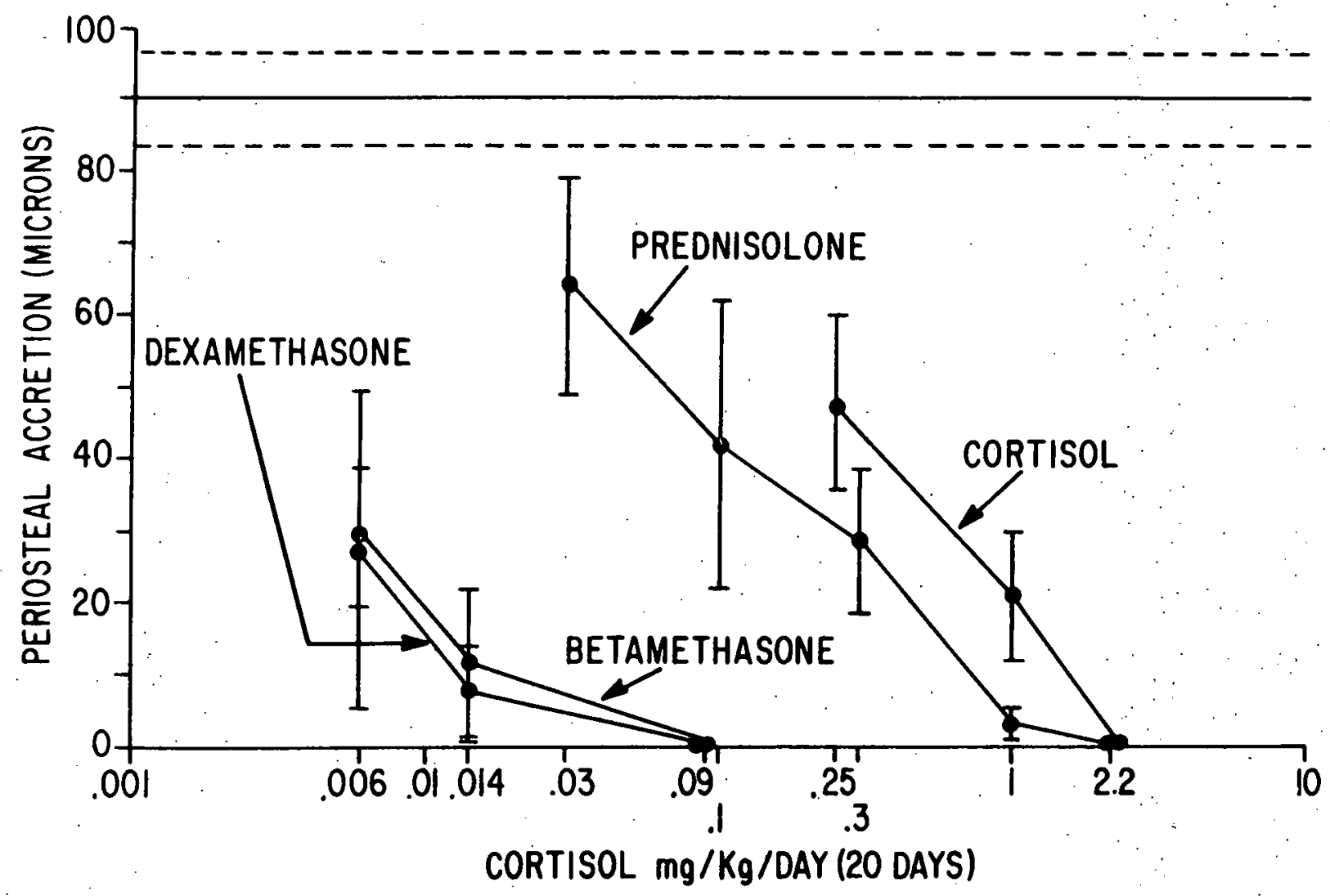

Fig. 3. Dose response curves for effects upon periosteal accretion by 4 different corticosteroids. 


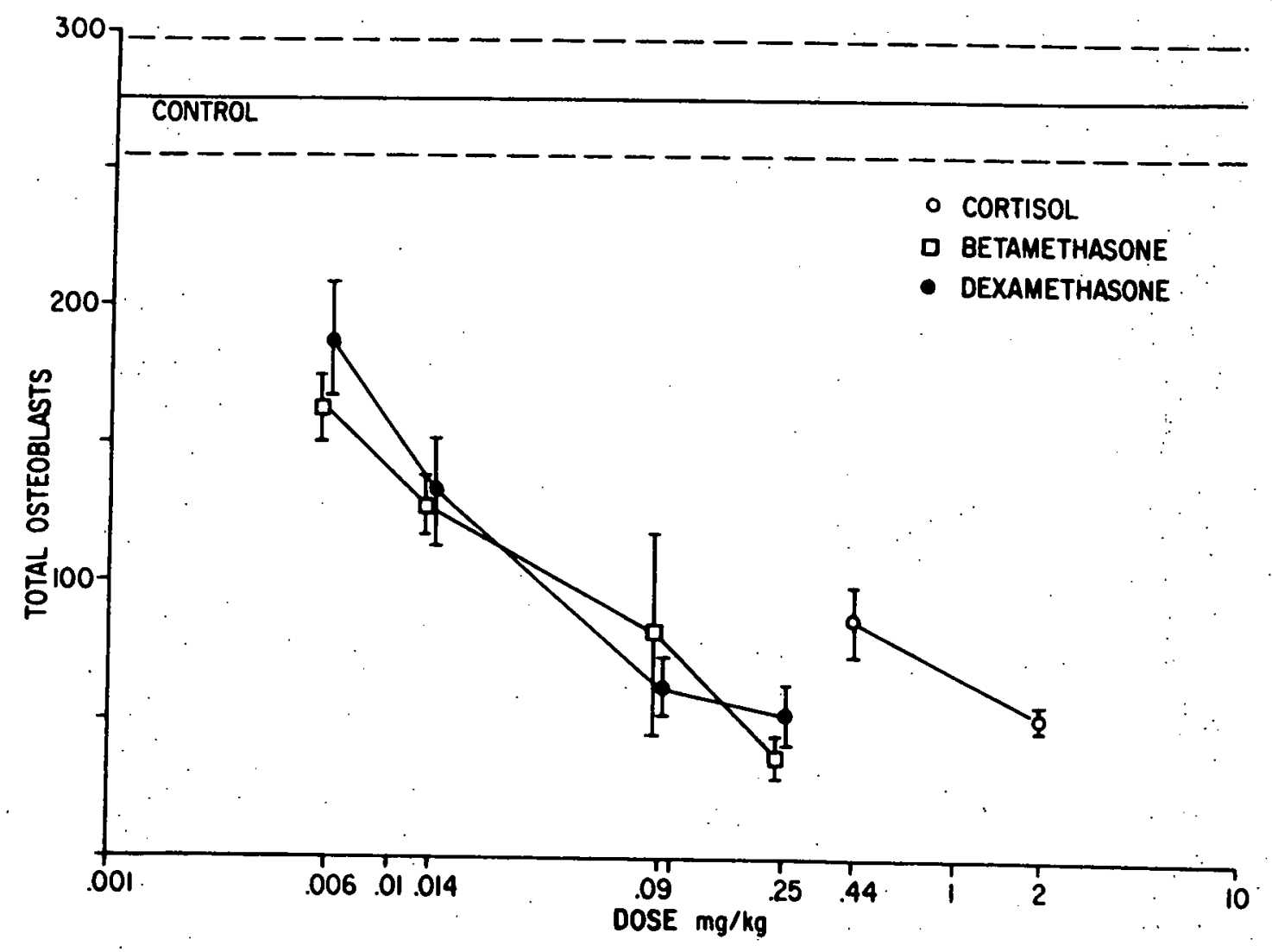

Fig. 4. Dose response curves for effects upon total osteoblast numbers by 4 different corticosteroids. 


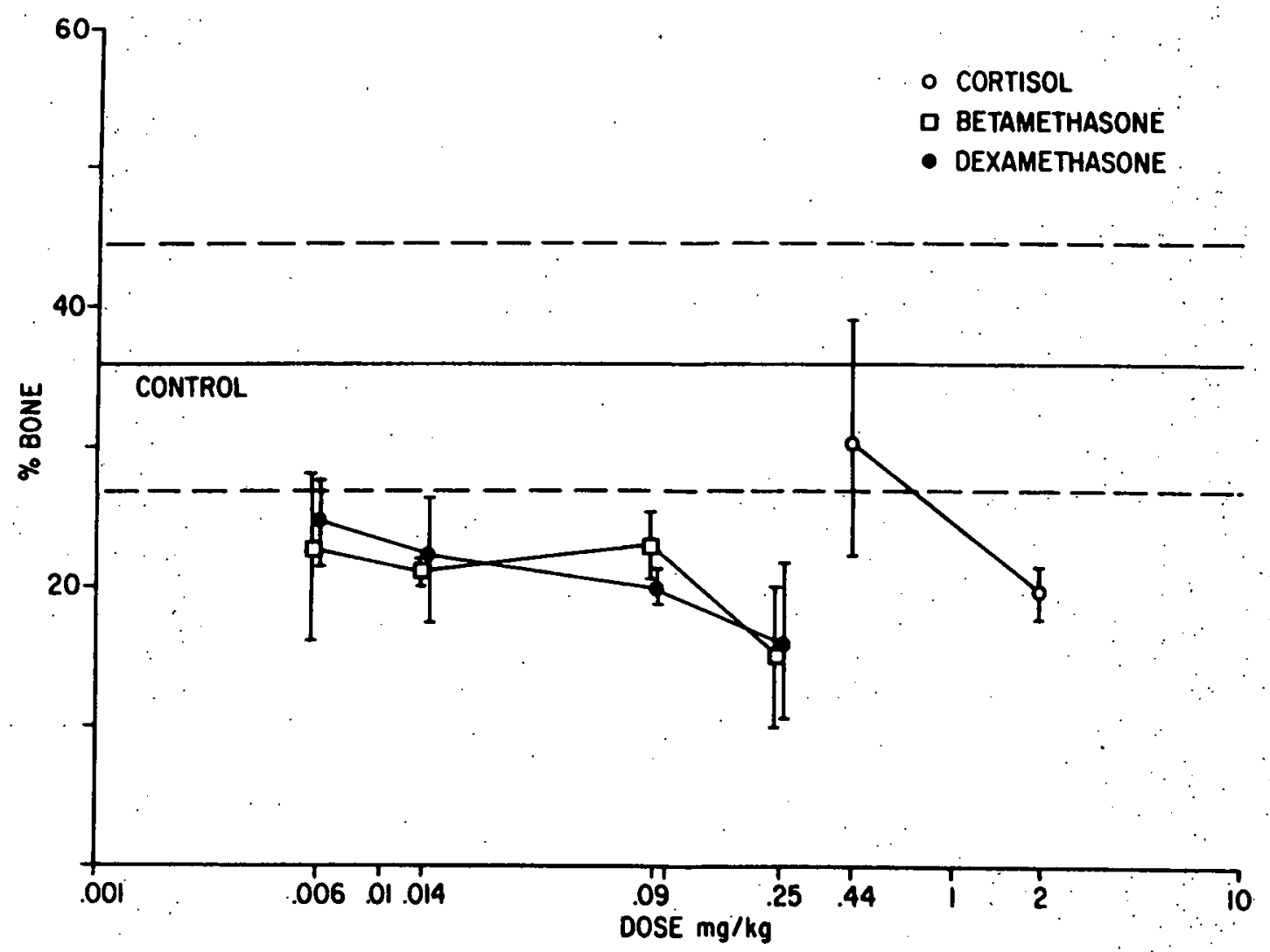

Fig. 5. Dose response curves for effects upon per cent metaphyseal bone by 4 different corticosteroids. 


\title{
KIDNEY FUNCTION IN AGING CONTROL BEAGLE DOGS
}

\author{
Charles J. Nabors, Jr. and Walter Stevens
}

Abstract: Normal blood levels of blood urea nitrogen and creatinine were determined in a group of control beagles for a period of 1 year. The age of the animals ranged from 1-203 months. No changes with age were noted and male dogs had slightly higher serum levels than females.

\section{INTRODUCT ION}

In our last progress report ${ }^{(1)}$ preliminary values for serumblood urea nitrogen (BUN) and creatinine determinations in aging control animals were reported. We now have collected data on this group of animals for a 12-month period. The animals range in age from 1 to 203 months. The purpose of this study is to establish normal values for BUN and creatinine of aging control animals in our colony. It has been shown that ${ }^{241} \mathrm{Am}$ and 239 pu deposit in the kidneys of beagles. (2) Both of these radionuclides are also deposited in significant concentrations in other soft tissues. These blood biochemical measurements may be used to evaluate kidney function in irradiated dogs. This report constitutes the final normal serum levels for male and female Beagles.

\section{METHODS}

The animals were purebred beagles raised in our laboratory. All of the animals were either zero level animals or aging control dogs that showed no pathology, and were judged to be in good health. The. determinations were made using routine clinical laboratory procedures. $(3,4)$ Blood urea nitrogen was measured using urease. (3) Creatinine was determined by the method of Fol in and. Wu. (4) Means and standard deviations for the various ages of animals were calculated by the use of the Wang 
Series 700 computer.

\section{RESULTS}

Table I gives the means and standard deviations obtained in male and female dogs at 4 time intervals of measurement in this study. There. are no differences greater than 2 standard deviations from the mean between the sexes or among the various time periods that we have measured. Note that the total mean values for BUN for male animals is slightly higher (20.68) than those for female dogs (18.138). The same sex difference exists in the creatinine values.

Table II shows the blood urea nitrogen data obtained when animals were grouped by 2-year age periods. These are all of the values obtained for animals of a particular age measured over the same: time period reported in Table 1. There is a slight tendency for serum creatinine determinations in females to decrease with age. This tendency is less marked in male dogs. However, no statistically significant differences exist among the values in this table.

Data on serum creatinine values obtained from female and male control dogs are presented in Table 111 . As was the case with BUN, there is a tendency for creatinine values to decrease with age in female beagles. However, no differences could be found greater than two standard deviations from the mean. The male animals again demonstrate slightly higher values.

\section{DISCUSSION}

Measurements for BUN and creatinine reported here indicate slight decreases with increasing age. This is most clearly evident in female animals. No statistically significant differences could be discovered. 
The slight evelation of both values in males as compared to females may be due to greater muscle mass. These data will provide a baseline for future determinations on radionuclide bearing animals or on animals with suspected kidney pathology. The data reported here are done on the basis of age from birth. Elsewhere in this progress report, we are reporting differences measured in terms of radionuclide burden time. This is not possible with dogs that have not been injected, although it appears that radionuclide burden time is a very significant factor with actual age being of less significance in radionuclide bearing dogs in our colony.

\section{REFERENCES}

1. Nabors, Charles J., Jr. and W. Stevens; Preliminary study of kidney function in beagle dogs: Aging control dogs; Res. in Radiobiology; U. of Utah Research Report C00-119-242; pp. 205-208 (1970).

2. Atherton, D. R., R. D. Lloyd, G. N. Taylor, Betsy J. Stover, and C. W. Mays; Distribution of ${ }^{241} \mathrm{Am}$ in the beagle; Res. in Radiobiology; U. of Utah Research Report C00-119-237; pp. 117-123 (1968).

3. Technical bulletin \#14; Sigma Chemical Co., St. Louis, Mo.

4. Folin, 0. and H. Wu; A system of blood analysis; J. Biol. Chem. 38: $81-88$ (1919). 
BLOOD UREA NITROGEN AND CREATININE AVERAGES

Female Dogs

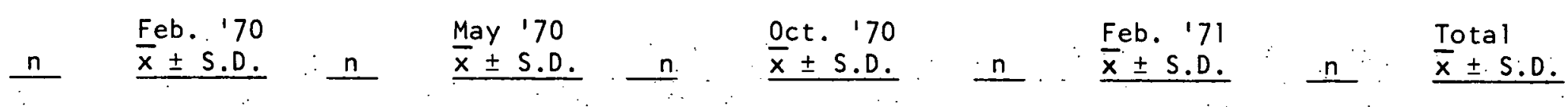

BUN $\quad 55 \quad 16.18 \pm 2.50 \quad: \quad 50 \quad 20.05 \pm 3.019 \quad 46 \quad 18.41 \pm 2.99 \quad 15118.14 \quad 5.06$

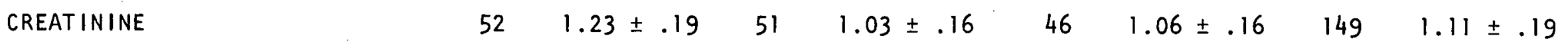

Male Dogs

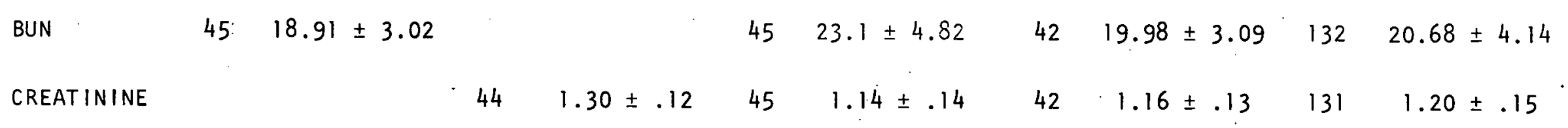

TABLE 1. Mean values and number of measurements for serum blood urea nitrogen and creatinine determinations in beagle dogs 1-203 months of age. 


\section{AGING SERUM CREATININE DATA}

FEMALE

MALE

$\begin{array}{ccccc}\begin{array}{c}\text { Age } \\ \text { (Months) }\end{array} & n & \underline{\mathrm{x}} \pm \mathrm{S.D} . & & \underline{\mathrm{x}} \pm \mathrm{S.D} . \\ 1-24 & 13 & 1.2 \pm .14 & 36 & 1.24 \pm .15 \\ 25-48 & 32 & 1.18 \pm .15 & 29 & 1.23 \pm .13 \\ 49-72 & 23 & 1.24 \pm .15 & 21 & 1.25 \pm .12 \\ 73-96 & 32 & 1.13 \pm .21 & 18 & 1.19 \pm .09 \\ 97-120 & 14 & 1.02 \pm .14 & 4 & 1.15 \pm .12 \\ 121-144 & 18 & .98 \pm .10 & 12 & 1.07 \pm .12 \\ 145-168 & 11 & .90 \pm .17 & 9 & 1.02 \pm .17 \\ 169-203 & 6 & .91 \pm .14 & 2 & 1.3 \pm .00\end{array}$

TABLE 111. Serum creatinine data for dogs grouped in two-year age periods. The number of measurements, mean and standard deviation are shown for each group. 


\section{AGING BLOOD UREA NITROGEN DATA}

\section{FEMALE}

Age

(Months)

$1-24$

$25-48$

49-72

$73-96$

$97-120$

$121-144$

$145-168$

169-203

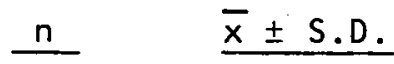

13

$19.26 \pm 2.42$

33

$18.43 \pm 3.41$

28

$18.85 \pm 2.67$

28

$18.38 \pm 3.61$

14

$17.75 \pm 3.26$

18

$17.29 \pm 2.90$

11

$16.15 \pm 3.93$

6

$16.76 \pm 3.29$

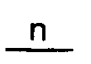

38

30

19

17

4

14

4

7

3
$20.94 \pm 5.50$

MALE

$\bar{x} \pm S . D$.

$20.09 \pm 2.50$

$22.08 \pm 5.41$

$19.39 \pm 2.50$

$20.67 \pm 2.29$

$22.17 \pm 2.38$

$19.25 \pm 4.13$

$26.63 \pm 12.20$

TABLE II. Blood urea nitrogen data for dogs grouped by age in two-year periods. The number of measurements, mean and standard deviation are given for each age grouping. 
GENETICS OF CANINE BLOOD GROUP "A" AND HYPOTHETICAL GROUPING OF THE BLOOD ANTIGENS ACCORDING TO THEIR SEROLOGICAL PROPERTIES

Stephen G. Jolley and Glenn N. Taylor

Abstract: The observed incidence of the canine blood group A in our Beagle colony and another study involving mixed breeds differed significantly. Deviations were possibly due to geographical selection or differences among various canine breeds as to the incidence of group A cells. Our pedigrees showed that the A factor could be explained in a system of multiple alleles or non-Mendelian, random traits. Canine blood group A could be a simple Mendelian dominant if blood group chimerism occurred in our Beagles, but our studies are presently insufficient to confirm this uncommon possibility. Certain serological characteristics of the canine A system, such as the ability to $f i x$ complement, were accepted as criteria for differentiating canine anti-A sera from canine anti-B, anti-C, anti-D, anti-E, anti-F, and anti-G sera. Antiglobulin reactions were proposed as a means of segregating anti-E and anti-F from ant $i-B$, ant $i-C$, ant $i-D$, and ant $i-G$. These serological properties of the various isohemagglutinins were used to theoretically group antigens $A_{1}$ and $A_{2}$ together; antigens $B, C, D$, and $G$ into one system; and antigens $E$ and $F$ as a separate system.

\section{INTRODUCTION}

For many years, scientists have paid little attention to compatability factors when transfusing dogs with blood from randomly chosen canine donors. These transfusions seldom produced visible reactions, since it was uncommon for a donor to be used more than once with the recipient. However, multiple transfusions with a common donor often produced violent hemolytic reactions in the recipient. $(14,15,16)$ ottenberg, et al. were one of the first groups to study this hemolytic phenomenon. Many of those who followed began to recognize several antigenic differences among canine red cells. $(1,4,9,10)$ Swisher, et al. (13) were the first to fully characterize eight antigenic differences on the canine erythrocyte distinct from those on human red cells. Seven $\left(A_{1}, B, C, D, E, F\right.$, and G) were believed to give rise to typical divalent isohemagglutinins. 
The reactivity of $A_{2}$, particularly in the Coombs' or anti-canine globulin (ACG) reaction; lent itself towards the formation of a possible "incomplete" or blocking isohemagglutinin; similar, in some respects, to the human Rho antibody.

The relationship of canine blood groups to the ABO system of man is not completely understood. Difficulties arose because of the apparent inconsistant genetic patterns of canine blood groups. Cohen, et al. (3) attempted to explain the canine A, B, C, and D systems in terms of autosomal dominant mechanisms. Swisher, et al. (13) also proposed a genetic pattern for canine $A$, but encountered problems in using data from random street dogs. Of the two, autosomal dominant mechanisms appeared to play the most important role in the aquisition of blood types.

\section{METHODS}

In 1964, our laboratory obtained some canine anti-A serum from Dr. S. N. Swisher, Department of Medicine, University of Rochester School of Medicine, for the purpose of typing our Beagle colony. We felt this colony would be excellent for studying the genetic distribution or incidence of any red cell antigens because of its well. kept pedigree records. The antiserum was initially used in selecting $A$ and non-A dogs for the further preparation of anti-A serum. Dog no. 613 (non-A) was immunized with type A erythrocytes from dog no. 035. Washed, packed 035 red cells were given daily in doses of $3.0 \mathrm{ml}$ intravenously and $3.0 \mathrm{ml}$ intraperitoneally. Aliquots of blood were collected at intervals throughout the immunization period, and titers determined, in an agglutination test with diluted sera. Anti-035 RBC serum was harvested when the titer reached a second plateau (Figure 1). 
The anti-A serum used in this study was collected from dog no. 613, inactivated at $56^{\circ} \mathrm{C}$ for thirty minutes, and the non-A isohemagglutinins adsorbed by a composite of red cells from eight non-A dogs. Adsorption was carried out by rotation of $1.0 \mathrm{ml}$ packed $\mathrm{RBC}$ and $4.0 \mathrm{ml}$ serum for an interval of fifteen minutes. Three to five adsorptions were carried out on each sample, depending on how much agglutination was still present. Red cells were removed from the suspension by centrifugation at $850 \mathrm{xg}$ for fifteen to twenty minutes. Desired antisera did not produce agglutination with non-A erythrocytes after adsorption. Isohemagglutinin $A$ in each case was characterized by complement ( $\left.C^{\prime}\right)$ fixation. $(2,7,13)$ Contrary to Stohlman, (12) we found that the hemolytic properties of canine blood group A could be enhanced by non-canine C', namely guinea pig C'. An important point with respect to anti-A's complement-fixing ability is also expressed in Tables 1 and 2. Our experience with C' fixation tests showed that canine anti-A doesn't perform well in the full-scale Kolmer ${ }^{(7)}$ test with sheep red blood cells (SRBC) and amboceptor. Limitations occurred in reading tubes when two hemolytic systems were involved, where hemolysis at high anti-A antibody concentration (test system) and at low anti-A antibody concentration (indicator system) resulted. One way of getting around this was to test the supernatant fluid from a mixture of anti-A serum, $A$ cells, and $C$ ' for unbound $C$ ' using the SRBC-amboceptor indicator system. But a more direct method, as used in this study, was a hemolysin titration technique; substituting canine anti-A for amboceptor and $2 \%$ group $A$ cells for SRBC. This allowed the observance of hemolysis only when $C^{\prime}$ was fixed in the test system. Antisera shown to possess specific anti-A properties were used to type our Beagle colony. The method employed here was a modification 
of the tube agglutination technique. (1) Fresh autologous serum from our Beagles was omitted as a red cell diluent because it produced nonspecific hemolysis on several occassions. We also avoided using detergents to wash glassware because of their hemolytic tendencies. (4) In lieu of autologous serum we mixed one drop ( $9^{\prime \prime}$. Pasteur pipette) of thrice-washed and packed red cells with $0.2 \mathrm{ml}$ antiserum in a $9 \times 75 \mathrm{~mm}$ Kahn tube. Such a system allowed us to detect both $A_{1}$ and $A_{2}$ cells as group $A$ without the use of $A C G$. Even though $A_{2}$ cellis react weakly with ant $i-A_{1}$ serum they react better with anti-A serum because of the possible $A_{2}$ isohemagglutinins in addition or in 1 ieu of $A_{1}$ antibodies. The absence of saline in these tests also enhanced the reactivity of $A$ cells. (1) Controls consisted of homologous serum from non-immunized dogs in place of antiserum. Incubation of the tubes was carried out in a $37^{\circ} \mathrm{C}$ water bath for fifteen minutes and at room temperature for an additional fifteen minutes. Each tube was read by pouring the contents onto a micro-slide and examining for gross agglutination. Anti-A titers determined by this method averaged from 128 to 256 .

\section{RESULTS AND DISCUSSION}

The incidence of group A dogs in our colony differed significantly from other studies shown in Table 3. Since the Rochester group utilized the largest number of animals it seemed reasonable to assume that it would be the most significant of the three. But, because the Rochester data includes only observed incidences of canine blood groups, it may. or may not represent the true blood group distribution in dogs. The validity of any such study cannot be checked due to the lack of a known genetic mechanism defining canine blood group inheritance. 
With this in mind we used chi-square $\left(\chi^{2}\right)$ to inter compare the Salt Lake data, the Jackson results, and the Rochester study. The $\chi^{2}$ value in Table 3 indicated that all group A incidences differed significantly from each other. The significant differences observed raised two important possibilities: (1) Do the large deviations from the Rochester group indicate a geographical localization of canine blood group A? (2) Is canine group A a genetic trait according to the Mendelian theory? of the three studies compared the Jackson study supported the first possibility. Here we saw an extremely high incidence of blood group $A$ in an in-bred colony of Basenjis and Cocker Spaniels. Such a high degree of in-breeding could ultimately result in the selection and high incidence of one or two blood groups. On the other hand, we expected that the Salt Lake colony would represent a true Beagle population, due to a moderate degree of in-breeding (C. E. Rehfeld, unpublished observations). The degree of in-breeding in the Salt Lake colony is somewhat less than a cross between two siblings. Therefore, the incidence of A should have been.similar to the Rochester group, however it was not. This might suggest that the group A incidence varies according to breed. This would certainly produce significant differences between the occurrence of canine group $A$ in pure-bred colonies and mongrels. At the present, though, there aren't any known breeds lacking type A completely.

Our second question deals with the inheritance properties of canine blood group A. Thus far; there hasn't been any correlations between canine blood groups and the human blood groups. Referring to Figure 2. we see a simple cross of two type A Beagles. Testing the application of simple Mendelian genetics we postulated that both animals were heterozygous $A$, or $A O \times A O$. As a result, such a cross was expected to give 
both type $A$ and non-A offspring. Thus, there appeared to be a non-detectable or recessive allele participating. Likewise, in Figure 3 , an AO $\times 00$ cross gave both types of offspring. Figure 4 , however, showed a high incidence of non-A offspring and one $A$ animal. Such was not expected in any of the crosses $A A \times 00, A 0 \times 00$, and $00 \times 00$. However, segregation of alleles in $A O \times 00$ crosses can produce this effect.

Referring to Figure 6 it appeared that a simple Mendelian theory" didn't fit. We had an $00 \times 00$ cross giving both type $A$ and non- $A$ offspring. Similarly, Figure 7 showed all A offspring from another $00 x$ 00 cross. Even if the 0 gene was dominant we would not expect to see all type $A$ offspring in a $A O \times A O$ cross, nor any non-A pups in an $A A x$ AA cross. Hence, the inheritance of type A did not follow a simple Mendelian pattern. The phenomenon of blood group chimerism ${ }^{(8)}$ might have been a factor in these crosses. We noted that both parents in each of the $00 \times 00$ crosses had siblings of blood type A (Figures 4 and 5 ). If blood group chimerism occurred then simple Mendelian genetics could have been operating and still have given the appearance of non-Mendelian incidences. However, homografts have not yet been done in each case to determine the possibility of chimerism. Figures 8 and 9 show more offspring distributions with various forms of blood type segregation.

Cohen, et al. (3) postulated that the A factor was an autosomal dominant. They felt that if an animal had the $A$ antigen it would have the $x^{a}$ gene. Similarly, those lacking the $A$ antigen would have an $x^{0}$ gene. Thus, the possible genotypes for a type $A \operatorname{dog}$ would be $x^{a} x^{a}$ and $x^{a} x^{0}$. A non-A dog would be $x^{0} x^{0}$. Again, using Figure 6 and the Jackson group's genotype for non-A animals, we see that this theory doesn't $f i t$, since it cannot allow for type $A$ offspring in non- $A \times$ non- $A$ 
pedigrees. With this in mind, we felt that the inheritance of type $A$ wasn't occurring as a simple autosomal dominant.

One explanation of this may be that the blood groups are non-Mendelian random traits selected during fertilization by some random process as determinants of the red cell antigens. Another possibility may lie in the presence of numerous alleles. The process of allelic pairing may involve so many combinations that the traits appear to be randomly distributed. One such theoretical situation is given in Figure 10. The hypothetical mechanism is outlined by tracing the distribution of alleles in two parents via meiotic division and gamete formation. Here there are five alleles with a dominance gradient of $z_{1}>a>z_{2}>z_{3}>z_{4}$. The randomness with which the alleles can pair and the random position of the three determinants on the genome result in 2,080 possible genotypes. Table 4 gives the genotypes for possible determinants. Such a system may also account for $A$ offspring in a non-A $x$ non-A cross. For this to occur the non-A parents would need a $\gamma$ determinant of genotype $z_{1} a$. Hence, the inheritance of A could involve a multiple allele or non-allele random mechanism.

The third possibility may involve the presence of secretory substances or abnormalities which alter the red cell surface. If this occured then a type A dog could be transformed from a non-A dog by the secretion of A-like substances (not related to man) which adsorb to the red cell walls. However, Kolmer ${ }^{(7)}$ C.' fixation tests done in our laboratory with anti-A serum and sera from type A dogs failed to give positive results (unpublished observations). Therefore, we concluded that secretory substances in the sera of group A dogs probably dọn't contribute significantly to the red cell agglutinogenicity. 
Another interesting aspect of canine blood groups which demands, some attention is the arrangement of blood antigens. The main question to be answered is whether the eight antigens mentioned by Swisher, et al. are components of one or many systems. For our purpose in this discussion we used serological data in an attempt to resolve this point. To begin with, we reviewed some of the factors influencing the formation of ant $i-$ bodies. It has been firmly established that the structure of antigens explicitly determines the chain conformation of the specific antibody, Hence, antibodies produced by stereochemically similar antigens usually have similar serological properties in the presence of their respective antigen. In some cases cross-reactions occur. Antigens do not have to cross-react in order to be in the same genetically-determined group, however. The best examples of this are the $A B O$ and Rh systems in man where antigens within a system do not cross-react. Here the reactivity of antibodies from each group in saline might be a means for segregating the two in genetic studies.

The serological characteristics we used to group the blood antigens are C' fixation and the ACG reaction. All canine blood groups have moderate to strong agglutinative power in vitro. (13) : of the eight, however, only four $\left(A_{1}, A_{2}, E\right.$, and $\left.F\right)$ have the ability to react with $A C G$. Two of these $\left(A_{1}\right.$ and $\left.A_{2}\right)$ can $f i x C^{\prime}$. From this one might be able to group $B, C, D$, and $G$ into one system because of their inability to fix $C^{\prime}$ or react with $A C G$.: Usually the structure of the crystallizable fragment ( $f c$ ) in an antibody, determines whether it can undergo $C$ ' fixation or reaction with ACG. Since it doesn't do either, one could theorize. that a bulky.fc sterically hinders attachment. E and F could be grouped together because of their reactivity with ACG and not C'。. In this case, 
the fc may not be as sterically hindered at the site of anti-canine antibody attachment as it is at the C'-binding portion. A third group may contain $A_{1}$ and $A_{2}$ because they possess both of the aforementioned

characteristics of $C^{\prime}$ fixation and $A C G$ reactivity. Johnson, et al. has shown that anti-A is predominately 75 globulin. The low molecular weight of anti-A may account for the loss of theoretical steric problems in the $\mathrm{fc}$.

Nevertheless, we feel that serological factors such as $C^{\prime}$ fixation and reaction of sensitized RBC's in the ACG reaction may be important criteria in the grouping of canine blood antigens into systems. If the blood group antigens could be grouped into systems it would simplify genetic studies.

\section{ACKNOWLEDGEMENTS}

The authors wish to thank Walter Angus, Stan Gwiazdowski, Danny Spikes, and Max Rothwell for their assistance in this study.

\section{REFERENCES}

1. R. M. Christian, D. M. Ervin, and L. E. Young; Observations on the in vitro behavior of dog isoantibodies; Jour. Immunol. 66: 37 (1951).

2. R. M. Christian, W. B. Stewart, C. L. Yuile, D. M. Ervin, and L. E. Young; Limitation of hemolysis in experimental transfusion reactions related to the depletion of complement and isoantibody in the recipient; Blood 6: $142(1951)$.

3. C. Cohen and J. L. Fuller; The inheritance of blood types in the dog; Jour. Heredity 44: $225 \cdot(1953)$.

4. A. S. Hamilton; Study of in vitro methods for the demonstration of isoagglutination with the bloods of normal and ill dogs; Am. Jour. 
Physiol. 154: 525 (1949).

5. F: Haurowitz; The formation of antibodies; Molecular Structure and Biological Specificity, Ed. by L. Pauling and H. A. Itano; Waverly Press, Baltimore, pp. 18-27. (1957).

6. J. S. Johnson, J.H. Vaughan, and S. N. Swisher; Canine immunoglobulins. 11. Antibody activities in six immunoglobulin classes; Jour. Immunol. 98: 935 (1967).

7. J. A. Kolmer, E. H. Spaulding, and H. W. Robinson, Approved Laboratory Technic, Appleton-Century-Crofts, Inc., 5th Ed., p.p. 797-939 (1951).

8. J. W. Nicholas, W. J. Jenkins, and W. L. Marsh; Human blood chimeras. A study of surviving twins; Brit. Med. Jour., 1: 1458 (1957).

9. W. A. O'Brien, S. N. Swisher, Jr., and L. E. Young; Observations on the wide spectrum of in vitro and in vivo behavior of immune isoantibodies in dogs; Clin. Res. Proc. 1: 67 (1953).

10. W. H. Olson; Natural isohemagglutination in dogs; Am. Jour. Physiol. 123: $203(1940)$

11. R. Ottenberg, D. J. Kaliski, and S. S. Friedman; Experimental agglutinative and hemolytic transfusions; Jour. Med. Res. 28: 141 (1913).

12. F. Stohlman; The nature of serum enhancement of the canine isohemagglutinin A: Role of conglutinin; Clin. Res. Proc, 1: 67 (1953).

13. S. N. Swisher and L. E. Young; The blood grouping systems of dogs; Physiol. Rev. 41: 495 (1961).

14. L. E. Young, D. M. Ervin, and C. L. Yuile; Hemolytic reactions produced in dogs by transfusion of incompatable dog blood and plasma. 1. Serologic and hematologic aspects; Blood, 4: 1218 (1949).

15. L. E. Young, R. M. Christian, D. M. Ervin, R. W. Davis, W. A. 
O'Brien, S. N. Swisher, and C. L. Yüile; Hemolytic disease in newborn dogs; Blood, 6: 291 (1951).

16. C. L. Yuile, T. F. Van Zandt, D. M. Ervin, and L. E. Young; Hemolytic reactions produced in dogs by transfusion of incompatable dog blood and plasma. Il. Renal aspects following whole blood transfusions; Blood, 4: 1232 (1949). 
Table 1. Kolmer Complement. Fixation Test with Canine Anti-A, 893 RBC (A-negative), 035 RBC (A-positive), SRBC, and Amboceptor (one-fifth method)

Serum Dilution Anti-A Serum and 035 RBC. Ant $i-A$ Serum and 893 RBC

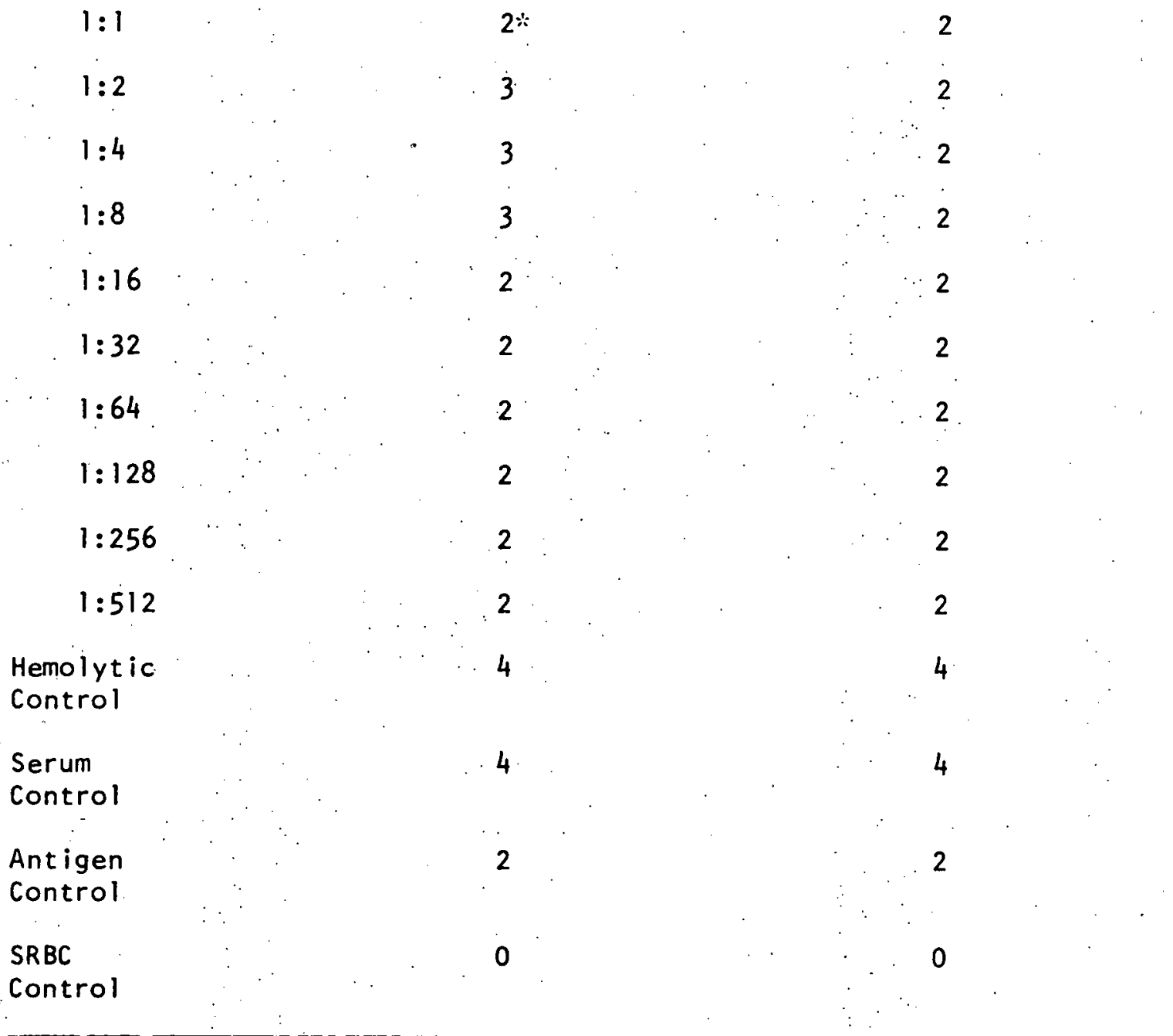

$* 0-4=$ Degree of Hemolys is. 
Table 2. Comparison of Anti-A Titers Obtained in a Complement Fixation Test without SRBC and Amboceptor to Those Obtained in Tube Agglutination (035 RBC source of cells).

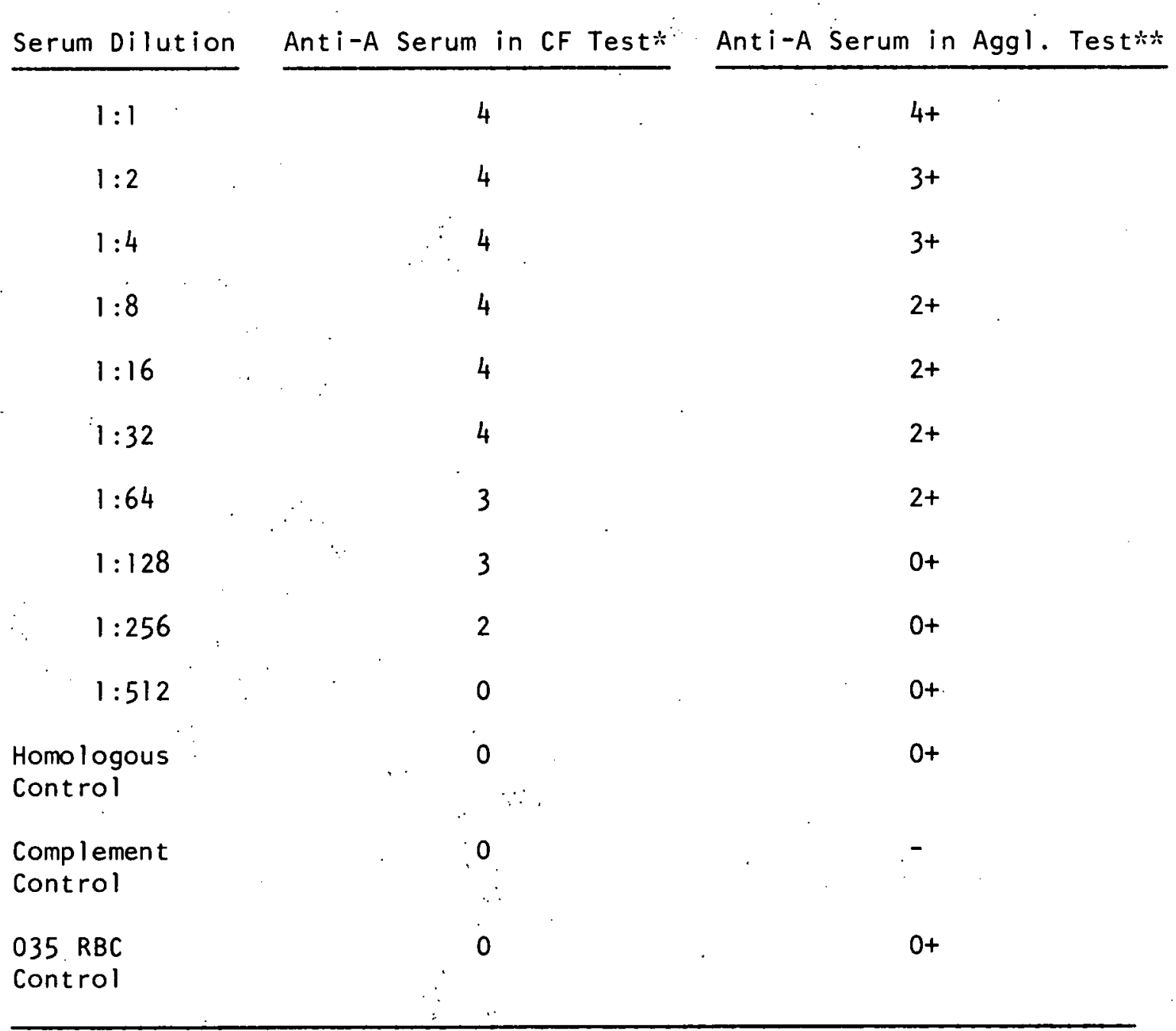

$$
\begin{aligned}
& * 0-4=\text { Degree of Hemolysis } \\
& * * 0+-4+=\text { Degree of Hemagglutination }
\end{aligned}
$$


Table 3. Comparison of Observed Incidences from Various Studies on Canine Blood Group A.

\begin{tabular}{lllll}
\hline Group & $\begin{array}{l}\text { Salt Lake } \\
\text { Beagles }\end{array}$ & $\begin{array}{l}\text { Jackson (3) } \\
\text { Basenjis and } \\
\text { Cocker Spaniels }\end{array}$ & $\begin{array}{c}\text { Rochester (13) } \\
\text { Mongrels }\end{array}$ & $\begin{array}{l}\text { Total } \\
\text { dogs }\end{array}$ \\
non A & 284 & 101 & 597 & 982 \\
\hline Total & 214 & 23 & 357 & 594 \\
& 498 & 124 & 954 & 1,576 \\
\hline
\end{tabular}

Table 4. Possible Genotypes of the Antigenic Determinanats using Five Alleles.

Determinant

$\gamma$
$A$
$\delta$
$\Sigma$
Genotypes

$$
\begin{gathered}
z_{1} z_{1}, z_{1} a, z_{1} z_{2}, z_{1} z_{3}, z_{1} z_{4} \\
a a, a z_{2}, a z_{3}, a z_{4} \\
z_{2} z_{2}, z_{2} z_{3}, z_{2} z_{4} \\
z_{3} z_{3}, z_{3} z_{4} \\
z_{4} z_{4}
\end{gathered}
$$




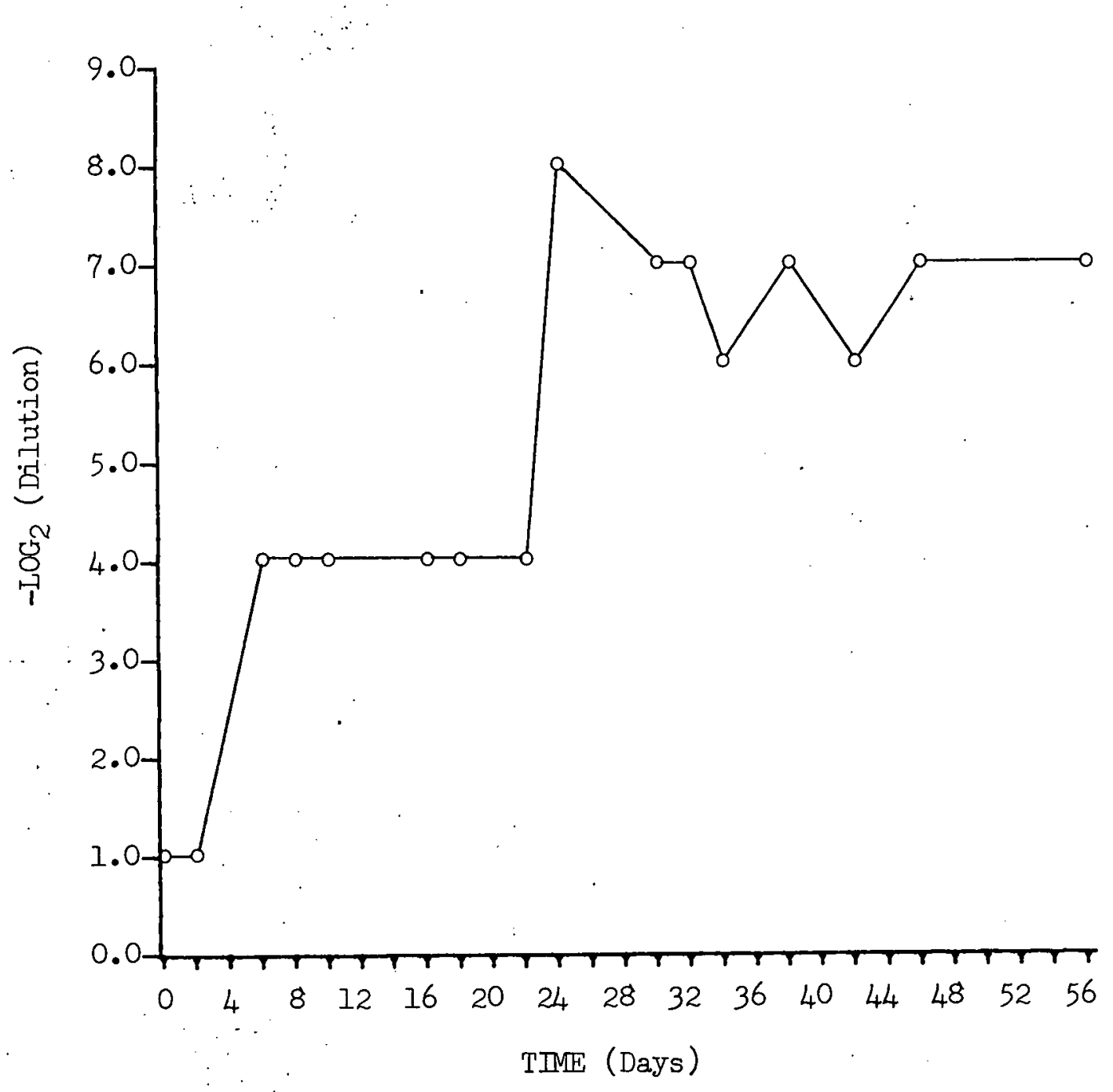

Fig. 1. Curve representing the titer of anti-035 RBC isohemagglutinin in dog no. 613's serum during repeated immunization with dog no. 035 erythrocytes (Sensitivity of test $= \pm$ one two-fold $\mathrm{di}$ lution). 


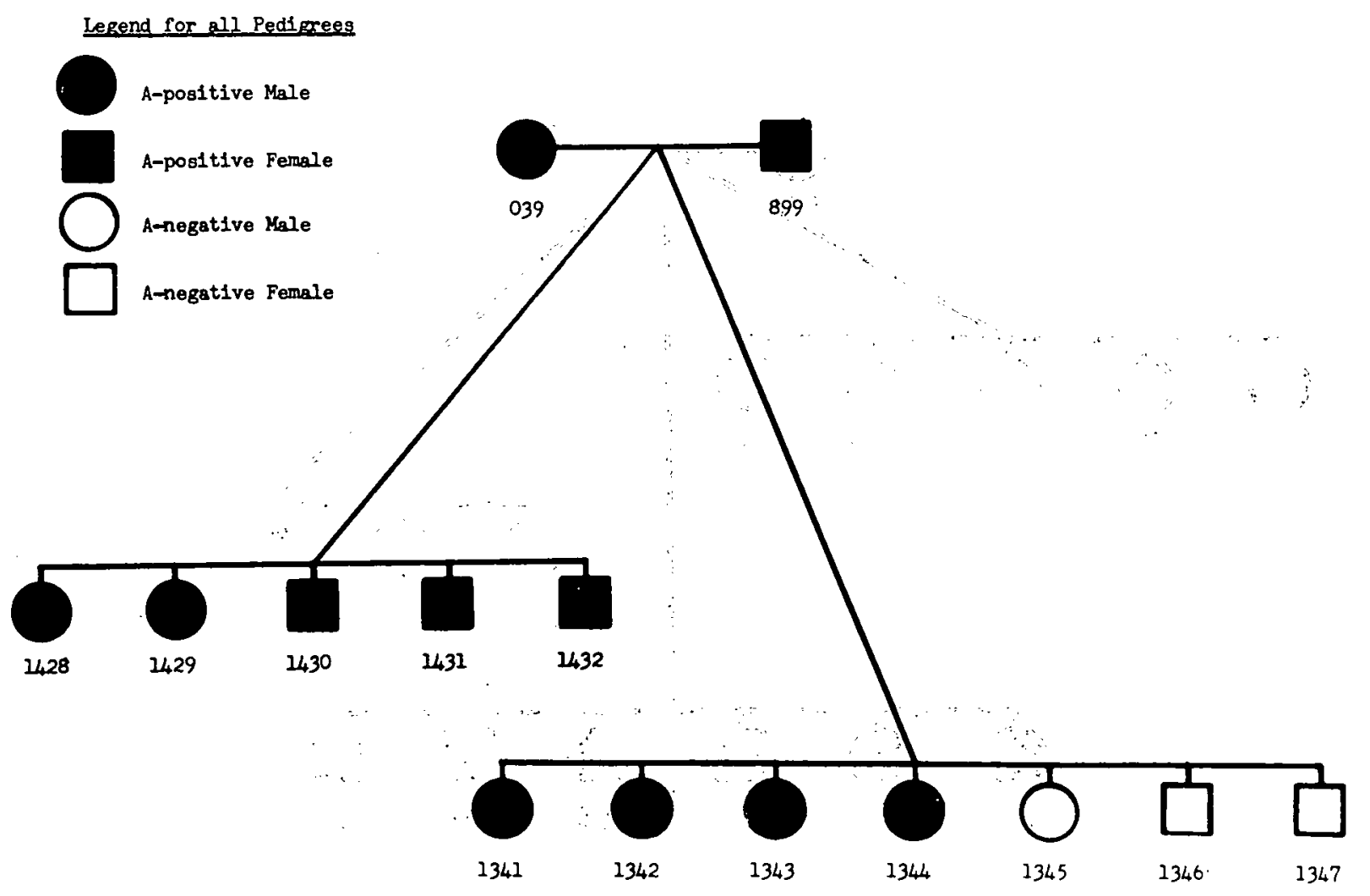

Fig. 2. Possible heterozygousity of two group A Beagles expressed by the ratios of group $A$ and non-A offspring in their litters. 


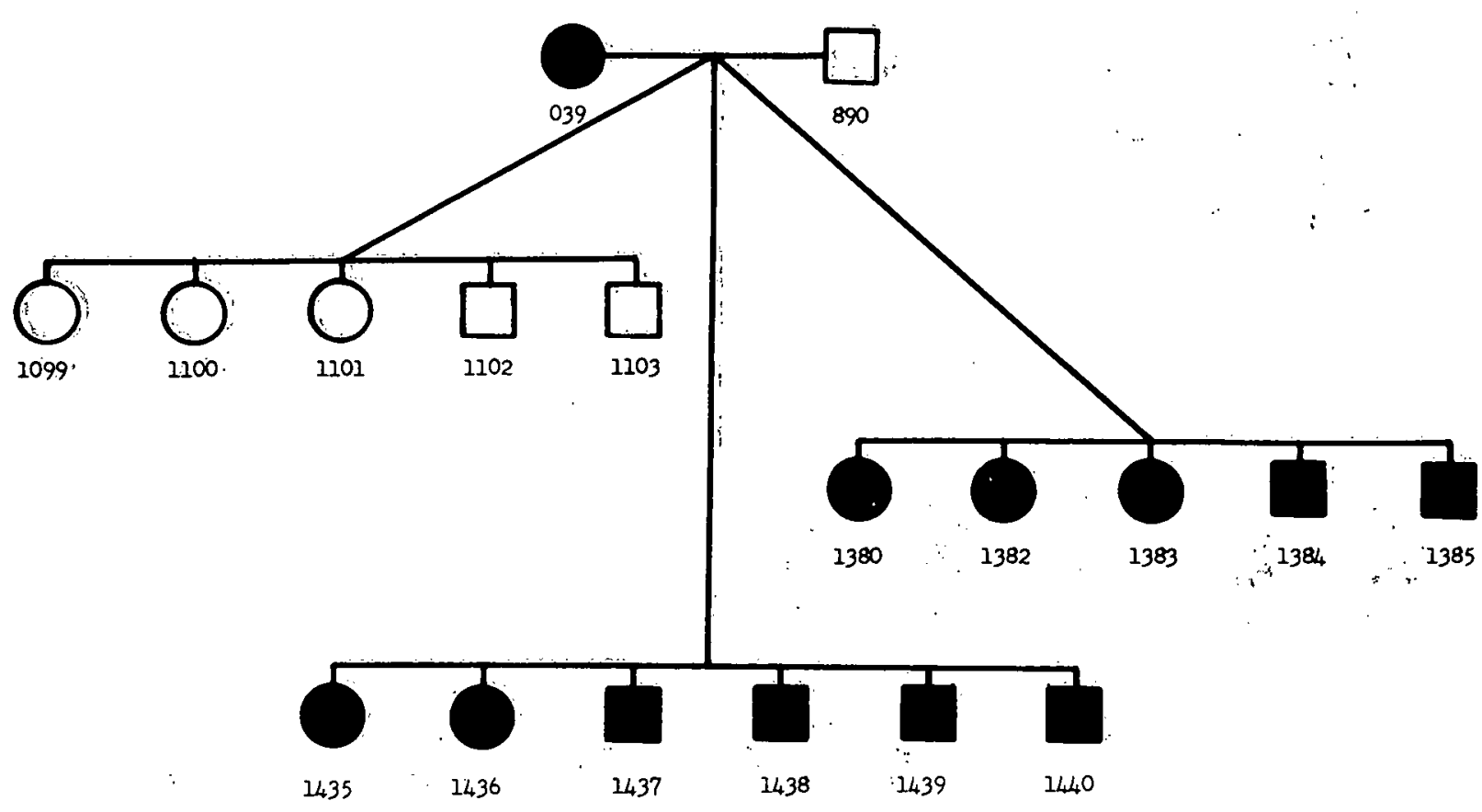

Fig. 3. Typical cross showing preference of a single blood type in eachilitter, but differences among the prevalent blood types of two litters. 


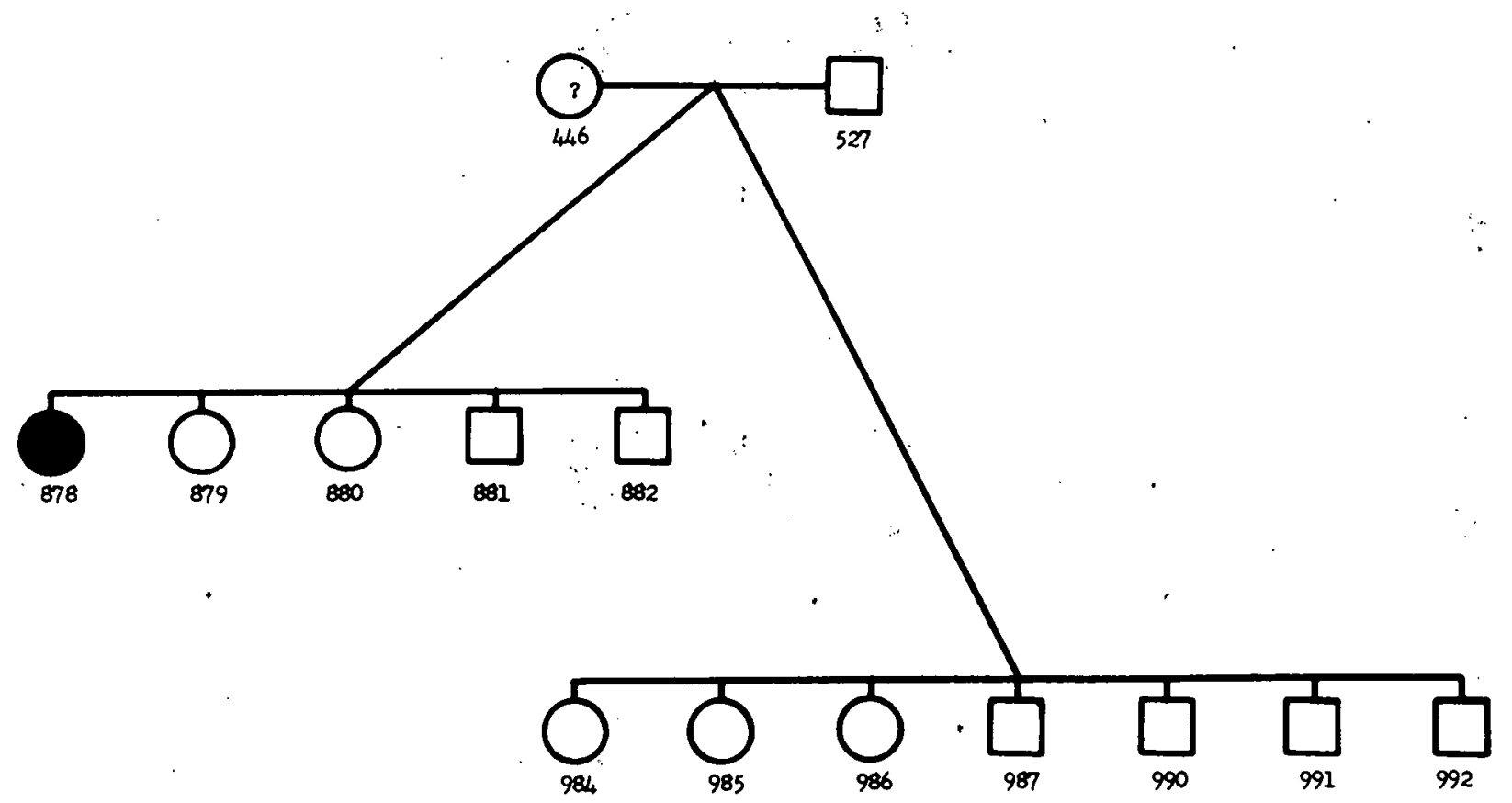

Fig. 4. Lineage of blood group $A$ in dog no. 879 showing a type A sibling (dog no. 878) "which could have participated iñ an in utero exchange of erythrocyte stem cells with dog no. 879 . 


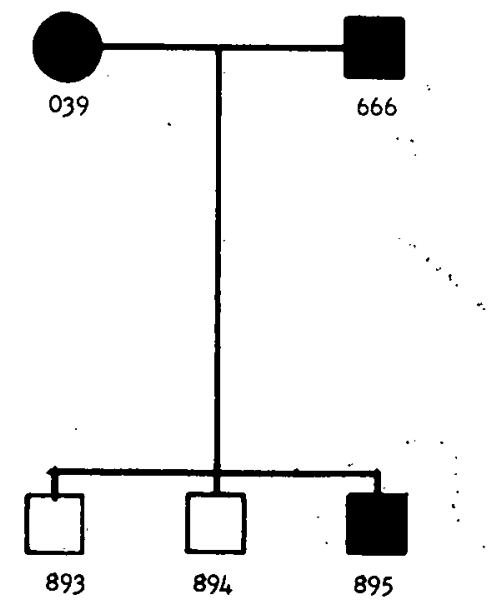

Fig. 5. History of group $A$ in dog nos. 893 and 894. Blood group chimerism may have occurred here with dog no. 895 acting as the donor of group A erythrocyte stem cells. 


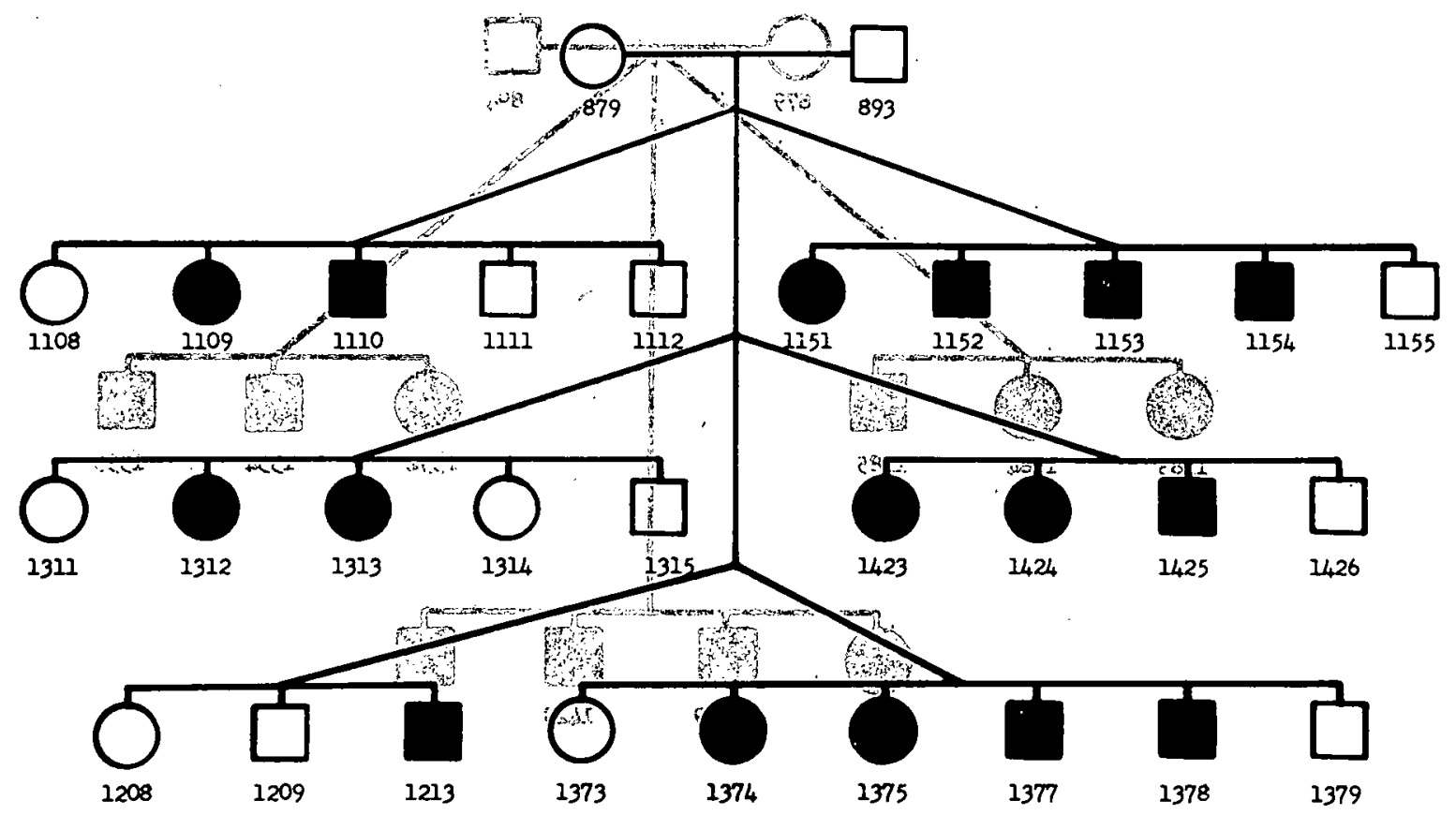

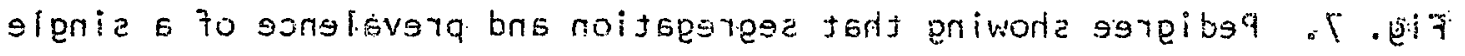

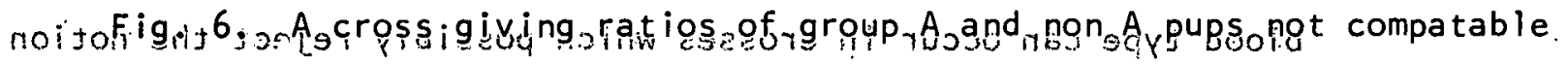

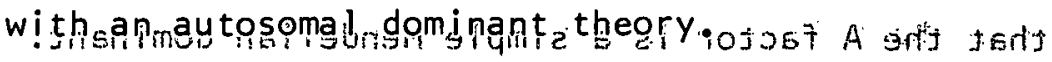




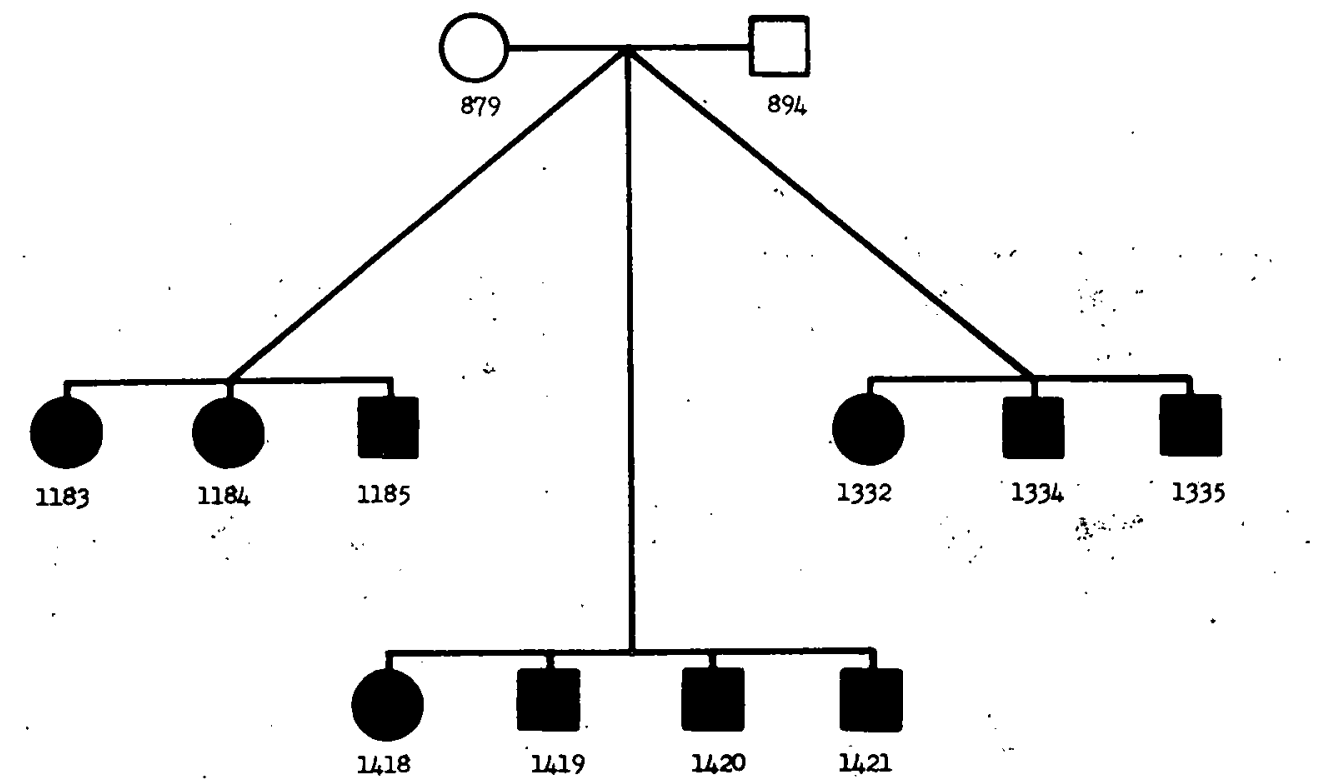

Fig. 7. Pedigree showing that segregation and prevalence of a single blood type can occur in crosses which possibly reject the notion that the A factor is a simple Mendelian dominant. 


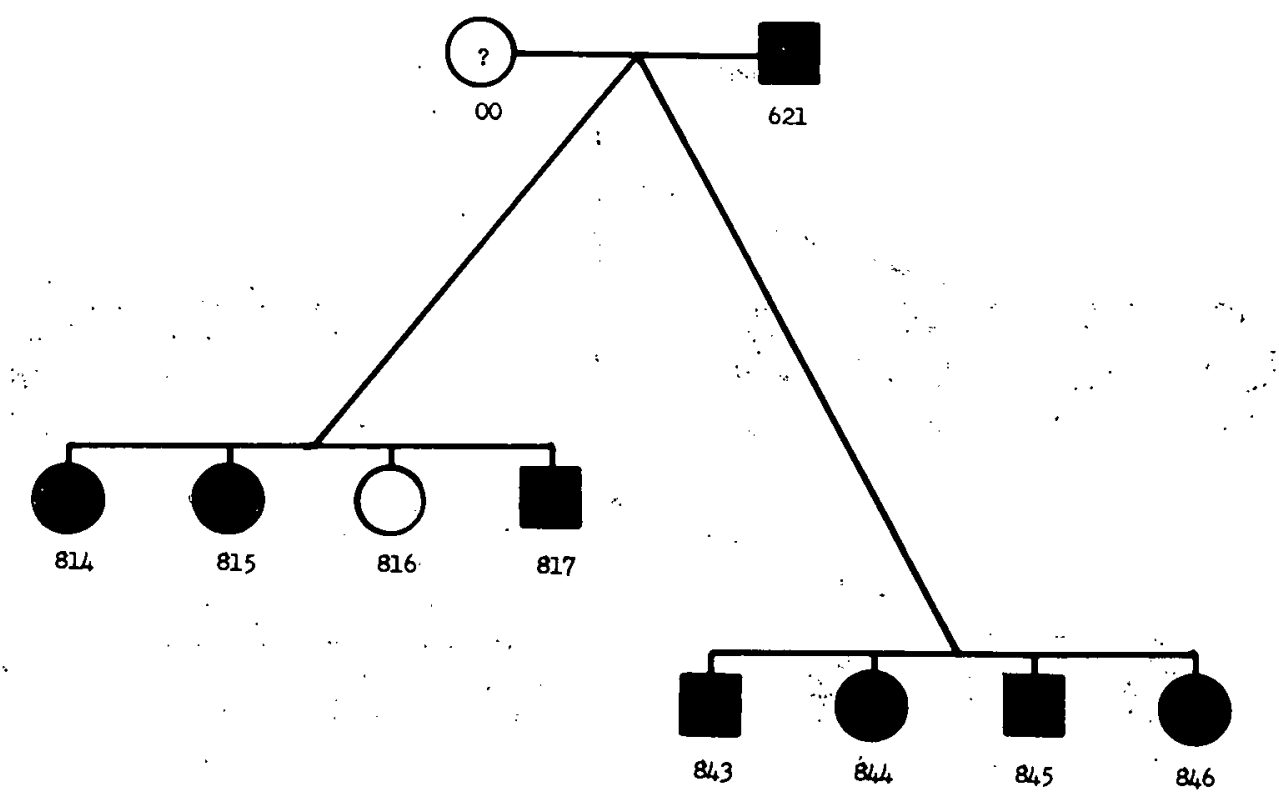

Fig. 8. A typical cross involving segregation of group A pups from non-A pups in contrast to the form of segregation in Fig. 4. 


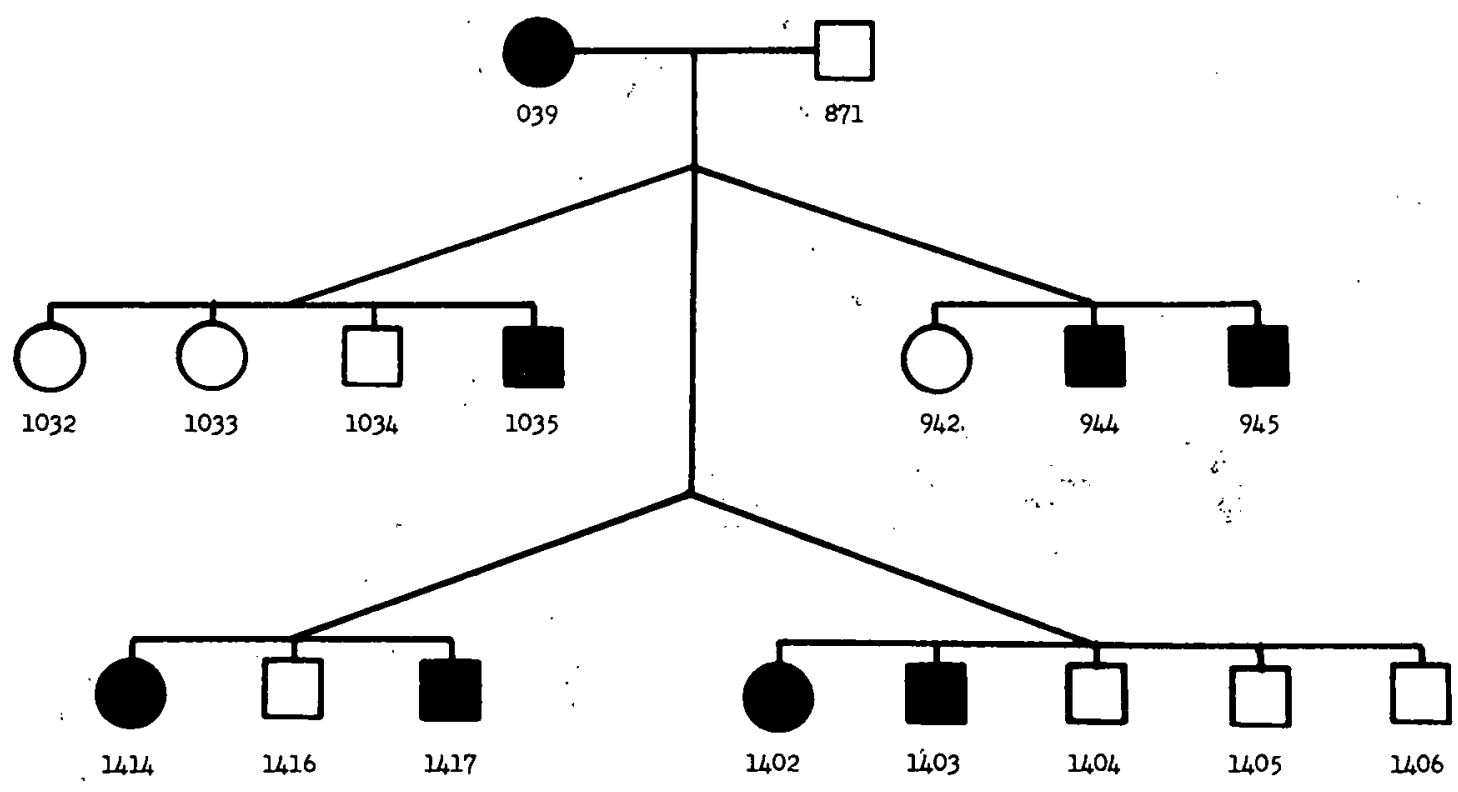

Fig.'9. An example of matings within. our colony that do not show any dominance nor preference of a single blood type within their litters. 


\section{Sire}

$$
\begin{gathered}
I * \\
a^{--z_{1}} \\
z_{2}--z_{3} \\
z_{1}--z_{4}
\end{gathered}
$$
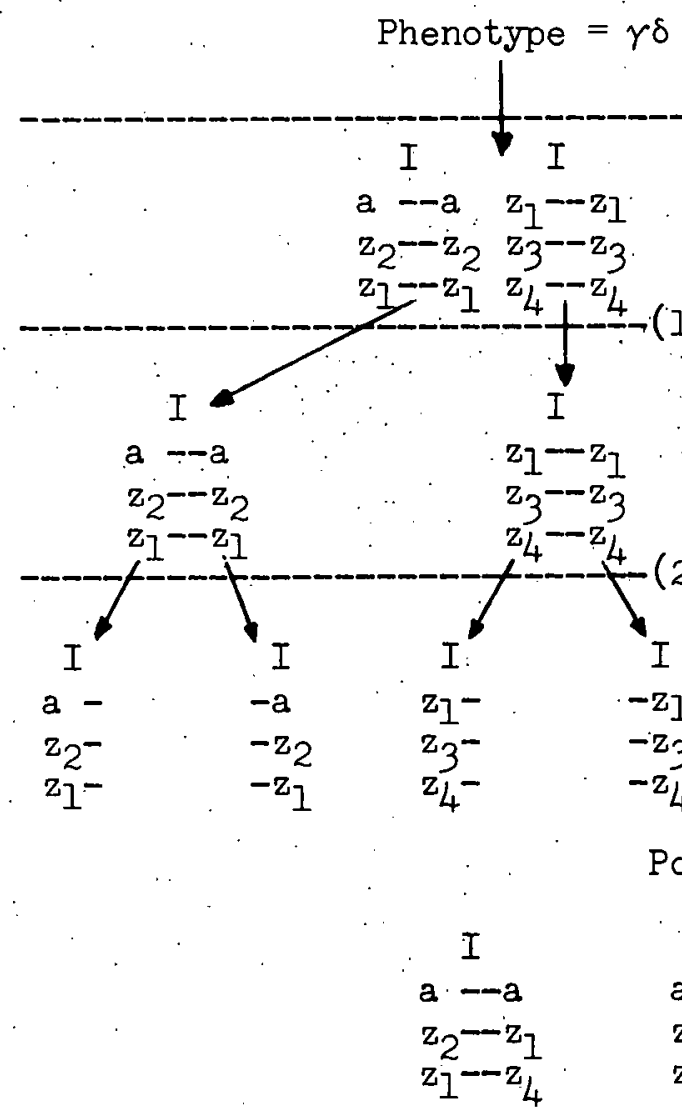

Phenotype $=$ AY

*Orientation of geriome
$I$
$a--a$
$z_{2}--z_{1}$
$z_{1}--z_{4}$ $-z_{1}$
Dam

$$
\begin{aligned}
& I \\
& \mathrm{a}--\mathrm{z}_{1} \\
& \mathrm{z}_{1}--\mathrm{a}^{2} \\
& \mathrm{z}_{4}--\mathrm{z}_{3}
\end{aligned}
$$

Phenotype $=\gamma \Sigma$

(Replication)

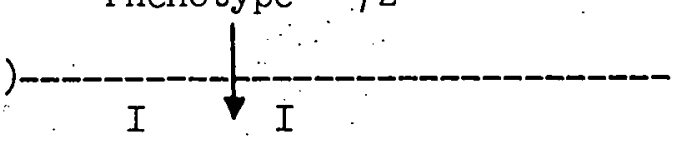

Daughter Cells.

a - -a $\quad z_{I}--z_{1}$

$z_{1}-z_{1} \quad a^{2}-a$

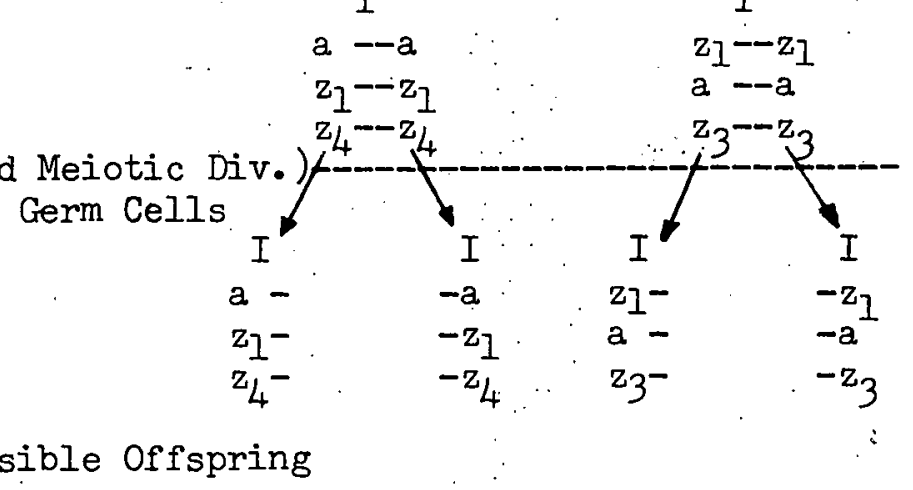

Possible Offspring

$z_{4}-z_{4} z_{3}-z_{3}$
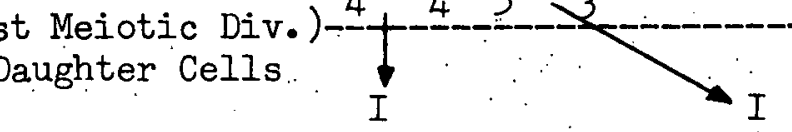

$\begin{array}{ccc}I & I & I \\ a^{--z_{1}} & z_{1}--a & z_{1}-z_{I} \\ z_{2}--a & z_{3}--z_{1} & z_{3}-a^{-a} \\ z_{1}--z_{3} & z_{4}--z_{4} & z_{4}--z_{3}\end{array}$

AY

$\gamma \Pi$

AY

Fig. 10. Hypothetical genetic mechanism for the inheritance of $A, \gamma$, $\delta, \Sigma$, and $\pi$ blood antigens. 


\section{GROWTH DYNAMICS OF OSTEOSARCOMAS INDUCED IN BEAGLES BY BONE-SEEKING RADIONUCLIDES*}

Gary B. Thurman, Charles W. Mays, Glenn N. Taylor, and Thomas F. Dougherty

Abstract: This study reports an analysis of the growth dynamics of 256 radiation-induced osteosarcomas in adult Beagles. The osteosarcomas were induced by intravenous injection of ${ }^{226} \mathrm{Ra}$ ( 80 tumors), 239pu (64 tumors), ${ }^{228} \mathrm{Ra}$ (43 tumors), ${ }^{228} \mathrm{Th}\left(56\right.$ tumors), ${ }^{90} \mathrm{Sr}\left(8\right.$ tumors) or ${ }^{224 R a}$ (5 tumors). Radiographs of each osteosarcoma were taken during the period of the tumor's growth. The growth dynamics of these osteosarcomas were estimated by measuring tumor dimensions on as many radiographs as possible. During the period of measurements, the tumor volumes appeared to enlarge exponentially with time. Exponential growth constants were calculated for 249 tumors, and the corresponding volume doubling times ranged from 4.7 to 60.3 days and averaged 12.4 days. The exponential growth constants (rates of tumor growth) were not significantly dependent upon sex, administered radionuclide, injected $\mu \mathrm{Ci} / \mathrm{kg}$, tumor location, tumor calcification, tumor volume at autopsy, or age of the animal at death. 


\section{RETENTION AND DISTRIBUTION OF INJECTED $210 \mathrm{~PB}$ IN :BEAGLES* \\ R. D. Lloyd, C. W. Mays, D. R. Atherton, F. W. Bruenger, and J. L. Williams}

Abstract: $210 \mathrm{~Pb}$ was administered to 10 young adult Beagles as a single intravenous injection in a citric acid-sodium citrate buffer solution at $\mathrm{pH}$ 3.5. Retention was determined by total-body counting of the 47 keV $\gamma$-ray. Total excreta collections from 3 dogs for the first 3 weeks after injection were assayed intact by $\gamma$-ray counting. About $3 / 4$ of the excreted $210 \mathrm{~Pb}$ appeared in the feces. The fraction of the injected activity still in the circulating blood was about 0.40 at 1 day, 0.14 at 1 week, and 0.03 at 1 month. After 1 hour following injection, red cells had more than $99 \%$ of the $210 \mathrm{~Pb}$ in the blood. Preliminary results indicate that, during the first 700 days, $36 \%$ of the injected $210 \mathrm{pb}$ is retained in the dog with a biological half-life of 4 days, $43 \%$ with 33 days, and $21 \%$ with 990 days. One dog sacrificed 28 days after injection had about $63 \%$ of the retained $210 \mathrm{~Pb}$ in the skeleton, $20 \%$ in the 1 iver, $8 \%$ in the blood and $9 \%$ in other soft tissues. Liver had the highest $210 \mathrm{~Pb}$ concentration of any tissue measured, 1.6 times that in the skeleton.

* Abstract Presented at the 15th Annual Meeting of the Health Physics Society at Chicago; Health Physics 19: 337 (1970). 
THE ASSOCIATION OF $210 \mathrm{~Pb}$ WITH CONSTITUENTS OF ERYTHROCYTES

F. W. Bruenger, W. Stevens, and Betsy J. Stover

Abstract: The interaction of trace amounts of lead with constituents of blood was investigated. In vivo experiments using $210 \mathrm{pb}$ were performed in beagles and in vitro studies were done with human and canine whole blood or isolated blood cells. At low concentrations of lead, about $90 \%$ of the nuclide found with red cells was associated with red cell cytoplasm and less than 10\% was bound to stroma. Transfer of $\mathrm{Pb}$ across the red cell membranes did not require binding of the nuclide to plasma proteins. Red cell cytoplasm analyzed by electrophoresis showed that most of the lead was found in the hemoglobin containing fractions. In the dog varying amounts were also found in fractions with an electrophoretic mobility greater than hemoglobin. The $\mathrm{HbA}_{2}\left(\alpha_{2} \delta_{2}\right)$ component of human erythrocytes had a much higher affinity for $210 \mathrm{~Pb}$ than the ma in $\mathrm{HbA}\left(\alpha_{2} \beta_{2}\right)$ fraction. Only after saturation of the $\mathrm{HbA}_{2}$ fraction were greater quantities of lead found in the main hemoglobin band. Lead also was bound to erythrocuprein.

\section{INTRODUCT ION}

Lead has received considerable attention lately as an environmental pollutant. Effects of long term exposure to small concentrations of lead may exist but have not been explored to any extent. Also exposure to consistently high levels of radioactive lead is a major occupational hazard among uranium miners. In blood, the majority of the lead is associated with erythrocytes and only a very small amount is found in plasma. It was accepted that the metal would bind mainly to the erythrocyte membrane. (1) In a preliminary report it was suggested that lead would bind to cytoplasmic components, i.e. hemoglobin $(2,3)$. Recently Barltrop and Smith ${ }^{(4)}$ described the binding of $203 \mathrm{~Pb}$ by "the cell contents rather than to stromal material". They concluded that lead in erythrocytes was bound primarily to hemoglobin. The reaction kinetics has been studied by Schubert and White, ${ }^{(5)}$ by Stover, ${ }^{(6)}$ and a number of other workers using stable lead, $210 \mathrm{pb}$ and $212 \mathrm{~Pb}$. In this paper the 
interaction of lead with constituents of canine and human blood in vivo and in vitro is described.

\section{METHODS}

For the in vivo experiments, $210 \mathrm{pb}$ in citrate buffer of $\mathrm{pH} 3.5$ was injected intravenously into beagles. In the in vitro studies $210 \mathrm{pb}$ in physiological sal ine solution was incubated with either whole blood or washed red cells.

Blood was obtained from healthy, young adult beagles or from humans free from any hematological disorders. Incubations were performed for 20 minutes at $40^{\circ} \mathrm{C}$ with quantities of $210 \mathrm{~Pb}$ from $0.1-0.3 \mu \mathrm{Ci} / \mathrm{ml}$ of blood $(0.014-0.042 \mu \mathrm{g} / \mathrm{ml})$. Blood cells were then separated by centrifugation, washed in physiological saline solution and after removal of the buffy coat they were laked and stroma and soluble material were separated by standard techniques. In some incubations $210 \mathrm{pb}$ was either replaced by other metals as $203 \mathrm{Hg},{ }^{65} \mathrm{Zn},{ }^{64} \mathrm{Cu}$, etc. or these metals were used in addition to lead.

The supernatant red cell cytoplasm (cytosol) was analyzed by gel filtration and/or disc electrophoresis. Gel filtration was done on Sephadex G-100 with an eluant containing $0.1 \mathrm{M} \mathrm{Tris-(hydroxymethyl)-}$ aminomethane (TRIS) and $0.68 \mathrm{M} \mathrm{NaCl}$. Analytical disc electrophoresis was carried out in duplicate for 70 minutes at $200 \mathrm{~V}$ using a separating gel with $7 \%$ acrylamide containing $0.25 \% \mathrm{~N}, \mathrm{~N}^{\prime}$-methylenebisacrylamide. One gel cylinder was stained for detection of protein bands, the other. was cut into slices of equal thickness $(\sim 1.3 \mathrm{~mm})$ and counted. High and" low molecular weight components of the cytosol were separated by dialysis through Visking. Nojax casing using a $0.05 \mathrm{M}$ TRIS-HCl buffer of $\mathrm{pH} 7.5$ at $4^{\circ} \mathrm{C}$. 
All counting was done with a $\mathrm{Nal}$ (TI) detector using the $47 \mathrm{keV} \gamma$ emission of $210 \mathrm{pb}$.

\section{RESULTS}

In tracer quantities, about $10 \%$ of $210 \mathrm{pb}$ was associated with the stroma and $90 \%$ with cytoplasmic components. Transfer across the membrane was time dependent (being complete in about 30 minutes) and did not require the presence of plasma constituents although lead can form complexes with plasma proteins. Raising the lead concentration to mg levels by addition of stable metal increased the fraction of lead associated with the red cell stroma as observed before. (5)

Lead in the ghost-free cytosol was not dialysable but it became ultrafiltrable in the presence of high concentrations of inorganic salts such as phosphate or $6 \mathrm{M}$ urea. After precipitation of the hemoglobin with 0.88 volumes of $\mathrm{EtOH}-\mathrm{CHCl}_{3}, 80-90 \%$ of the lead was found in the precipitate and $10-20 \%$ was rendered ultrafiltrable.

After gel chromatography of the cytosol on Sephadex G-100, a large fraction of the nuclide eluted with the hemoglobin peak (Fig. 1). An at tempt to separate the cytosol on DEAE-ion exchange resin under conditions which separate the various fractions of hemoglobin, was unsuccessful since practically all the lead remained on the column. Separation then was performed by gel disc-electrophoresis. The results of this procedure when applied to a human cytosol are presented in Fig. 2. Hemoglobin was resolved into two bands, a main band ( $\mathrm{HbA}\left(\alpha_{2} \beta_{2}\right)$ ) and a minor band $\left(\operatorname{HbA}_{2}\left(\alpha_{2} \hat{f}_{2}\right)\right)$. The $A_{2}$-band is typical for humans and was not found in cytosols derived from canine RBC. Since in RBC-cytosol approximately $95 \%$ of the protein is hemoglobin, it is quite difficult to 
separate nondestructively any minor protein components having the same range of mobility as $\mathrm{Hb}$. The position of some nonhemoglobin proteins, however, was determined as outlined by Haut et al. (?) These were catalase, carbonic anhydrase and erythrocuprein. Catalase and proteins with lower mobilities did not carry any $210 \mathrm{~Pb}$. The question whether carbonic anhydrase or erythrocuprein, whose mobilities were close to that of $\mathrm{Hb}$, carried lead was later solved by a double tracer technique since both are metalloproteins. The major fraction of $210 \mathrm{pb}$ associated with the minor $\left(A_{2}\right)$ band comprising only $2 \%$ of the total hemoglobin. Only after saturation of this band was a greater fraction of $210 \mathrm{pb}$ found in the main band.

In Fig. 3 electrophoretic patterns of human RBC-cytosol are compared to canine $\mathrm{RBC}-\mathrm{cy}$ tosol and to the mobility of $210 \mathrm{~Pb}$ subjected to the same experimental conditions but without any protein. The $A_{2}$-band was missing in the dog and so was the corresponding peak of $210 \mathrm{pb}$ activity. In the beagle no difference was observed between cytosols tagged in vivo and in vitro, and results did not differ greatly when breeds other than the beagle were used. $210 \mathrm{pb}$ had always a slightly higher mobility than the corresponding hemoglobin but any modification in the mobility of the $\mathrm{Hb}$ also resulted in a corresponding shift in the appearance of $210 \mathrm{pb}$. Also, in the dog some lead remained unbound and was therefore found in the front band.

Since hemoglobin has free -SH groups, it seemed likely that these were involved. in lead binding. Consequently, the binding of lead was compared to that of mercury, which is known to interact with the thiol-. groups of hemoglobin (Fig. 4, left side). Two things became evident:

a) two of the ${ }^{203} \mathrm{Hg}$ peaks were positioned as $210 \mathrm{~Pb}$; b) $203 \mathrm{Hg}$ reacting 
with $\mathrm{Hb}$ was leading the hemoglobin peak just as $210 \mathrm{pb}$, indicating that both nuclides impart a higher mobility when combined to $\mathrm{Hb}$. Also there was more ${ }^{203} \mathrm{Hg}$ in the $\mathrm{HbA}_{2}$ area than in the main band.

Since mercury forms a strong bond with sulfhydryl groups, prior incubation of hemoglobin with $\mathrm{Hg}$ should block the uptake of $210 \mathrm{~Pb}$ if $-\mathrm{SH}$ groups are involved. As seen in the right half of Fig. 4, sulfhydryl inhibition with mercury blocked the uptake of $210 \mathrm{pb}$ completely. No difference was observed between cytosols whose thiol-groups were blocked by $\mathrm{Hb}^{++}$and subsequently incubated with $210 \mathrm{pb}$ while the red cells were intact as compared to those which were lysed before incubation. $210 \mathrm{pb}$ in both cases moved as unbound lead.

Purification of hemoglobin by crystallization in phosphate buffer and subsequent activation of thiol-groups with dithioerythrol did not greatly alter the pattern of lead uptake, except that more lead was found in the main $\mathrm{Hg}$ band. Thus, the availability of thiol-groups seems to be a necessary but not in itself a sufficient condition for the association of the metal with hemoglobin.

Carbonic anhydrase and erythrocuprein have electrophoretic mobilities similar to hemoglobin. Since both are metalloproteins, ( $\mathrm{n}$ and Cu, respectively), a double tracer study using $210 \mathrm{~Pb}$ and the metal associated with the respective protein was performed and the electrophoretic mobilities of $\mathrm{Zn}, \mathrm{Cu}$ and $210 \mathrm{~Pb}$ were compared. As seen on the left side of Fig. 5, the $\mathrm{HbA}_{2}$ compound was clearly separated from the carbonic anhydrase. $210 \mathrm{~Pb}$ appeared only in the $A_{2}$ area while $65 \mathrm{Zn}$ carbonic anhydrase had a lower mobility. Incubation of a semipurified preparation of human carbonic anhydrase with $210 \mathrm{~Pb}$ showed no association of the protein with lead. 
A similar experiment using ${ }^{64} \mathrm{Cu}$ and $210 \mathrm{~Pb}$ was carried out to determine the position of erythrocuprein. As seen on the right side of Fig. 5, ${ }^{64} \mathrm{Cu}$ after electrophoresis yielded a rather broad spectrum and the position or erythrocuprein could not be determined by this method. However, erythrocuprein separated from swine RBC and later from human $R B C$, when incubated with $210 \mathrm{pb}$ and separated, indicated a strong association of lead and protein, as was expected since lead is used as a precipitant in the preparation of erythrocuprein. (9)

\section{DISCUSSION}

In the red cell lead was associated with both stroma (10\%) and cytosol (90\%). The association of lead with the membranes causes basophilic stippling which was described years ago. This phenomenon occurs mainly when larger quantities of lead are available. The other is the interaction of lead with hemoglobin which is the main topic of this communication. This interaction may be the most important because when exposed to small quantities of the metal, as occurs when radon is inhaled by uranium workers, $9 / 10$ of the lead would be bound to Hb. In cases of pathological lead poisoning, the metal will be associated with the red cell membrane and the red cell cytosol.

Because of the high hemoglobin content of the cytosol, it would be very difficult to resolve any minor protein fractions having the same mobility as hemoglobin and a possible association of any such fractions with lead cannot be excluded at present. The high affinity of $210 \mathrm{pb}$ with the $\mathrm{HbA}_{2}$ component was surprising. It showed that small changes in the hemoglobin molecule ( $\beta$ and $\delta$ chains differ in six animo acid positions) may greatly alter the metál binding properties of $\mathrm{Hb}$. The small difference 
between the peaks of $210 \mathrm{~Pb}$ and hemoglobin is not inconsistent with a binding of the nuclide as has been observed by Charache et al. (10) as demonstrated by the identical behaviour of mercury tagged $\mathrm{Hb}$. Mercury however, is known to form a strong bond with hemoglobin. The stoichiometry of the reaction is difficult to establish. The fact that protein bound lead became dialysable in solutions of high salt or urea concentration indicates that the metal-protein bond is dependent on the steric configurations of the protein molecule. Inhibition by mercury ions proves that thiol-groups are involved in this binding. On the other hand, chemical activation of SH-groups did not change the pattern of lead binding drastically, which is not surprising since lead, despite its high activity for SH-groups is known to be an ineffective inhibitor of sulfhydryl proteins (those with only one thiol group). Chelate chemistry tells us that lead binding is much stronger when the metal interacts with with a second ligand such as another sterically available thiol-group or neighboring histidine. This would explain the sensitivity of the reaction of lead with proteins of red cell cytoplasm.

No attempt was made to assess or evaluate any of the consequences arising from such a bond between lead and hemoglobin.

The presence of lead in erythrocuprein may contribute to the diminished hemoglobin synthesis seen in lead poisoning.

\section{REFERENCES}

1. J. C. Aub, L. T. Fairhall, A. S. Minot, and P. Reznikoff; Lead Poisoning; Baltimore; Williams and Wilkins (1962).

2. F. W. Bruenger, W. Stevens, and Betsy J. Stover; The distribution of $210 \mathrm{pb}$ in canine blood after intravenous injection and the 
association of the nuclide with blood constituents in dogs and humans; Res. in Radiob., P. R. C00-119-242, 152, Univ. of Utah (1970).

3. C. W. Mays, R. D. Lloyd, F. W. Bruenger, D. R. Atherton, and J. L. Williams; $210 \mathrm{pb}$ metabolism in beagles; Meeting on biol. and ecol. of polonium and radiolead; Sutton, England (1970).

4. D. Barltrop and A. Smith; Interaction of lead with erythrocytes; Experientia 27: 92 (1971).

5. J. Schubert and M. R. White; Effect of sodium and zirconium citrate on distribution and excretion of radiolead; Arch. Biochem. 21: 224 (1949).

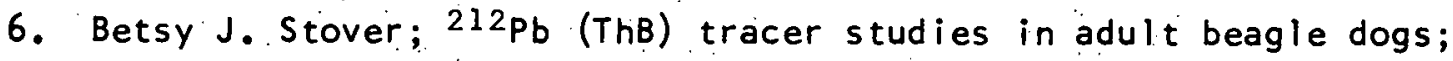
Proc. Soc. Exp. Biol. Med. 100: 269 (1959).

7. A. Haut, G. R. Tudhope, G. E. Cartwright, and M. M. Wintrobe; The nonhemoglobin erythrocytic proteins, studied by electrophores is on starch gel; J. Clin. Invest. 41: 579 (1962).

8. D. L. Drabkin; A simplified technique for a large scale crystalization of human oxyhemoglobin; Arch. Biochem. 21: 224 (1949).

9. J. R. Kimmel, H. Markowitz, and D. M. Brown; Some chemical and physical properties of erythrocuprein; J. Biol. Chem. 237: 47 (1959).

10. S. Charache and D. J. Weatherall; Fast hemoglobin in lead poisoning; Blood, Vol. 28, $\underline{3}: 337$ (1966). 


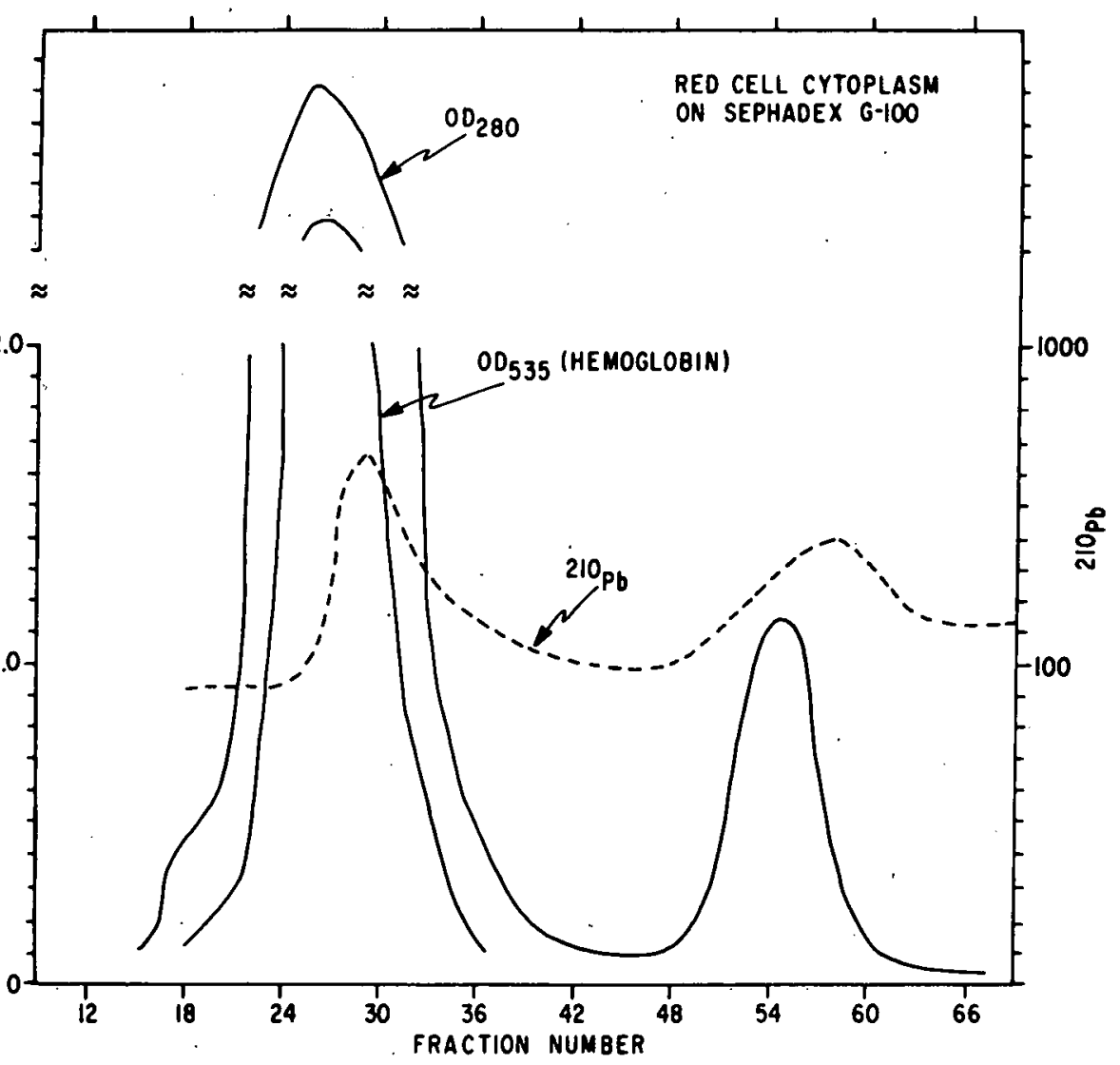

Fig. 1. Elution spectrum of dog red cell cytoplasm tagged with $210 \mathrm{~Pb}$ on Sephadex G-100: $210 \mathrm{~Pb}$ is associated with the Hb-peak and 'also' with low molecular weight components. "The lead content is presented on a logarithmic scale. The optical density is shown on the left side. 


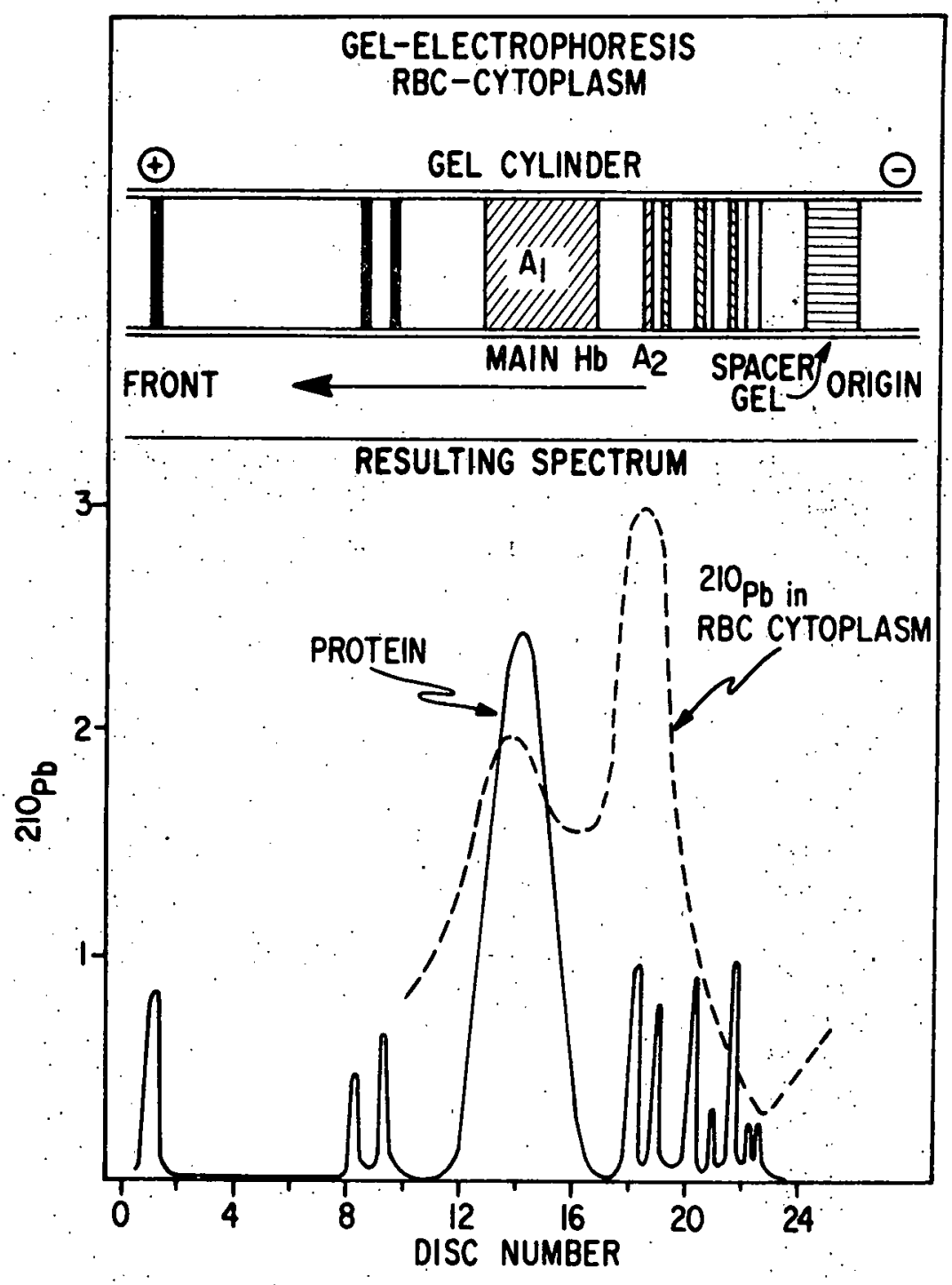

Fig. 2. The results of disc gel-electrophoresis of red cell cytosol. The top diagram represents the picture of a developed gel cylinder to which a human cytosol was applied. The solid curve on the bottom is the densitometric scan of the above gel and is a measure of the approximate protein content. The dashed ine is the $210 \mathrm{~Pb}$ content. 


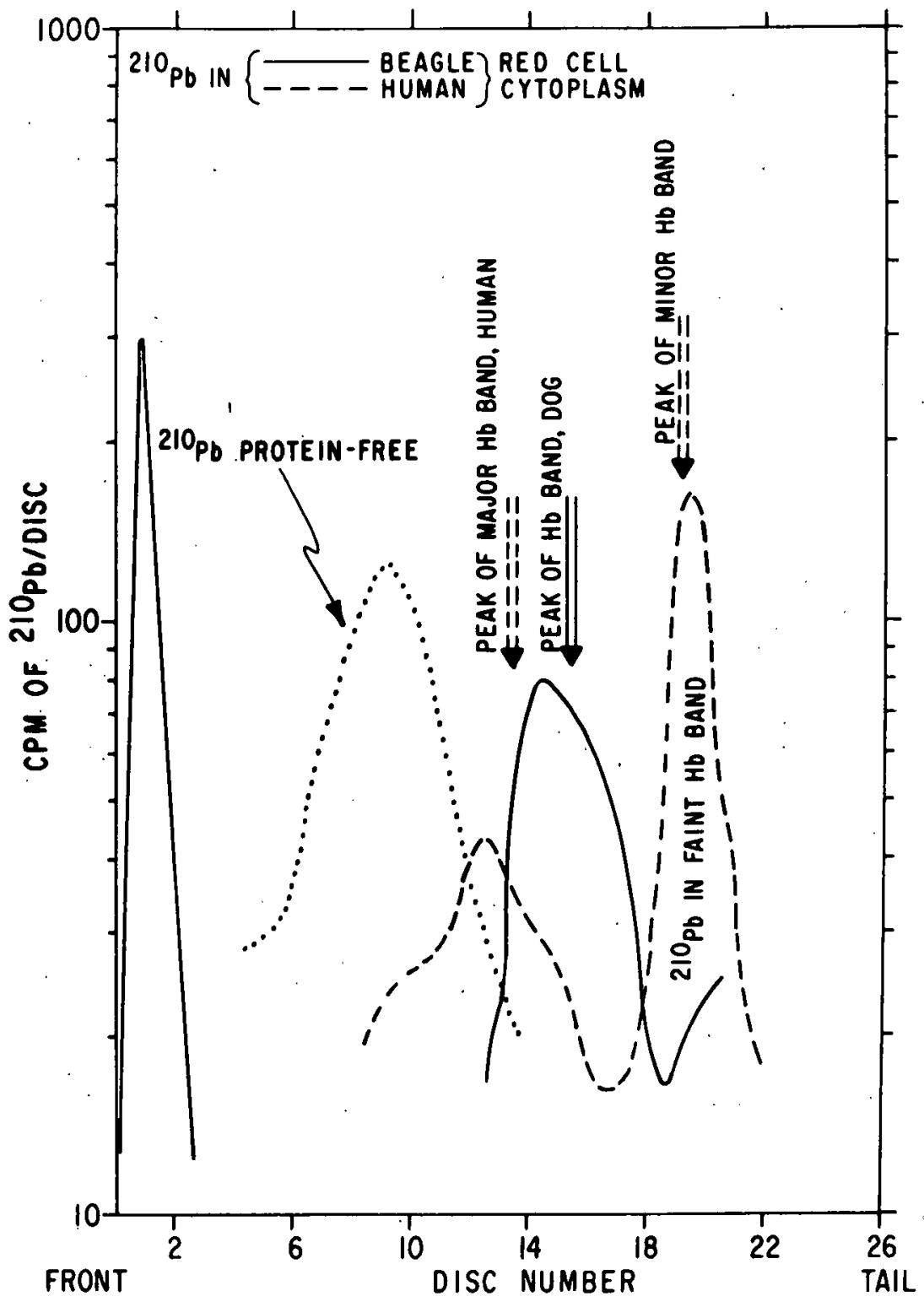

Fig. 3. Comparison of canine and human RBC-cytosol after separation by disc gel-electrophoresis. Canine Hb has a slightly higher mobility than human $\mathrm{Hb}$ and the $\mathrm{A}_{2}$-band is missing. The dotted line represents the position of protein-free $210 \mathrm{pb}$ subjected to electrophores is under the same conditions. 


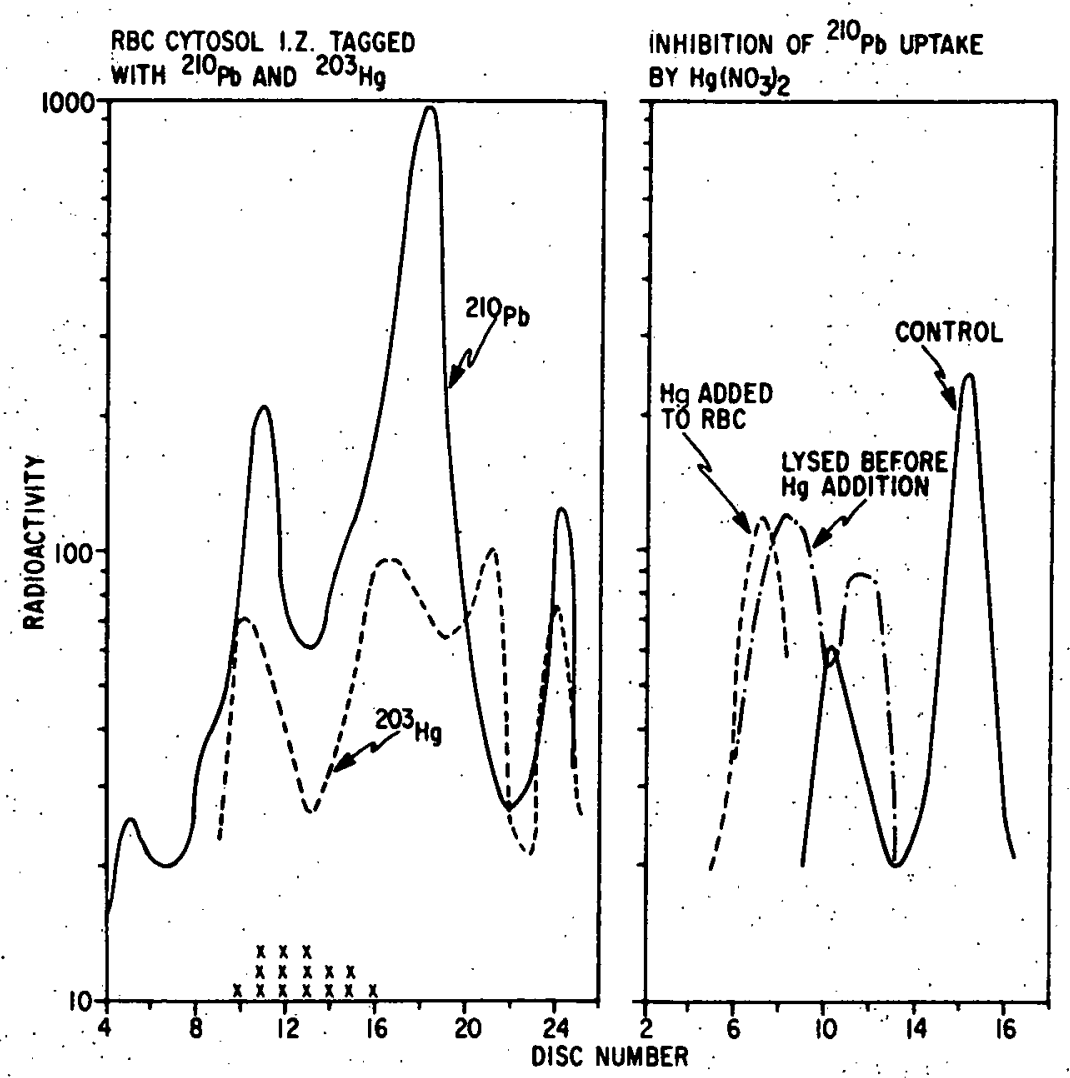

Fig. 4. Left: Spectrum of ${ }^{203} \mathrm{Hg}$ and $210 \mathrm{~Pb}$ activity after electrophoresis of two tagged human RBC-cytosols obtained from the same source. The position of the main Hb-band is indicated by $x^{\prime} s$.

Right: Comparison of electrophoretic mobilities of two human cytosols; one saturated with $\mathrm{Hg}$ and one that has no mercury (control). 


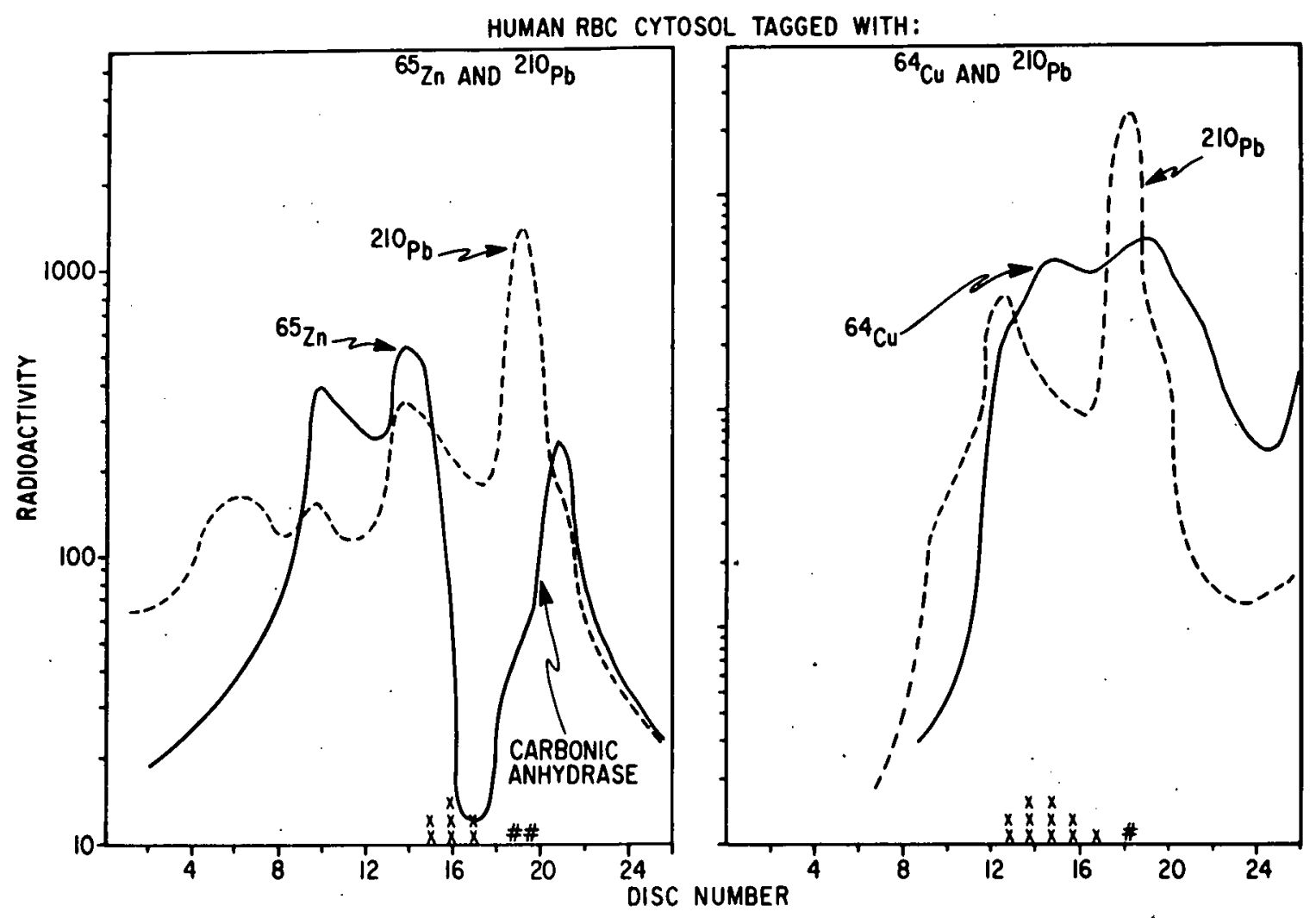

Fig. 5. Left: Result of a double tracer study using ${ }^{65} \mathrm{Zn}$ and $210 \mathrm{~Pb}$ tagged human RBC-cytosol. ${ }^{65} \mathrm{Zn}$ associated with carbonic anhydrase has a lower mobility than $\mathrm{HbA}_{2}$.

Right: A similar double tracer study using ${ }^{64} \mathrm{Cu}$ and $210 \mathrm{~Pb}$

- to determine the position of erythrocuprein. The spectrum of ${ }^{64} \mathrm{Cu}$ is rather broad and the position of erythrocuprein could. not be determined this way. Peaks of $\mathrm{HbA}$ and $\mathrm{HbA}_{2}$ are marked by $\mathrm{x}$ - and \#-marks, respectively. 
A NON-L INEAR INTERPRETATION

TO THE "DOUBLING DOSE" CONCEPT*

CHARLES W. MAYS

\section{ABSTRACT}

Radiation is known to induce cancer. If the increased incidence per additional rad is proportional to the total incidence existing. before each additional dose is received:

$$
I_{r}=I_{0}\left[e^{k x}-1\right]
$$

where $I_{r}$ is the incidence of a radiation-induced cancer, $I_{o}$ is its natural incidence, $x$ is the cumulative dose of radiation, and $k$ is a constant. The assumptions, derivation, and properties of this exponential, non-linear, equation are presented and compared with those of the traditional linear dose-response equation.

\section{INTRODUCT ION}

As applied to the radiation induction of a particular type of cancer, the doubling dose is defined as the quantity of radiation which will cause its total incidence to double. For example, if the natural incidence is $1 \%$, and 100 rads induces an additional $1 \%$ so that the total incidence is $2 \%$, then 100 rads is the first doubling dose. But what might be induced by a second doubling dose? Might it induce an additional $1 \%$ (equal to the original natural incidence) or might it induce an additional 2\% (equal to the total incidence following the first doubling dose)? Obviously, two different interpretations are possible, as has been pointed out by Brues (1970), and the purpose of this analysis is to explore them both. Much hinges on the factors which determine the so-called "natural" incidence, as will be examined

* Presented at the Conference on the Estimation of Low-Level Radiation Effects, Argonne National Laboratory, December 7-9, 1970. 
later in the discussion section.

\section{DER IVATION OF EQUATIONS}

let $I=$ tota 1 incidence $=I_{r}+I_{0}$

$I_{\mathrm{r}}=$ radiation induced incidence

$I_{\circ}=$ "natural" incidence, assumed constant for fixed conditions

$x=$ radiation dose

$\mathrm{b}$ and $\mathrm{k}$ are constants

(a) Linear Interpretation ("simple interest")

Assume that the additional incidence (dI) from additional

dose $(\mathrm{dx})$ is proportional to the natural incidence ( $\left.I_{0}\right)$.

$$
\frac{\mathrm{d} I}{\mathrm{~d} x}=\mathrm{b} \mathrm{I}_{\mathrm{o}} \mathrm{x}
$$

The solution to Eq. 1 is:

$$
I=b I_{0} x+I_{0}
$$

And since $\left[I=I_{r}+I_{0}\right]$ then:

$$
I_{r}=b \quad I_{0} X
$$

Thus, for the linear interpretation, the incidence of radiation induced cancer should be directly proportional to the amount of radiation. The doubling dose equals $1 / \mathrm{b}$. Therefore, the induced incidence should be $I_{\text {。 for }} 1$ doubling dose, $2 I_{0}$ for 2 times the doubling dose, $3 I_{\text {。 }}$ for 3 times the doubling dose, etc., for this model.

(b) Non-Linear Interpretation ("compound interest")

Assume that the additional incidence (dI) from additional dose $(\mathrm{dx})$ is proportional to the total incidence (I) existing just before the additional dose $(\mathrm{dx})$ is received:

$$
\frac{\mathrm{d} I}{\mathrm{dx}}=\mathrm{k} I
$$


The solution to $\mathrm{Eq} \cdot 4$ is:

$$
I=I_{0} e^{k x}
$$

And since $\left[I=I_{r}+I_{0}\right]$ then:

$$
I_{r}=I_{0}\left[e^{k x}-1\right]
$$

Thus, under the non-linear interpretation the incidence of radiation induced cancer should increase as an exponential function of dose.

\section{DISCUSS ION}

Equations 3 and 6 are compared in Fig. 1 where, as an illustrative example, both curves are fit through $I_{r}=10 \%$ at 1.000 rads.

Non-linear. Eq. 6 has interesting properties which will now be explored. As shown in Fig. 2, the higher the natural incidence, the more "linear" the "non-linear" model becomes. This prediction supports the impression stated by Albert (1970) that dose-incidence curves often tend to be non-linear for types of cancer having a low natural occurence. Similarly, during the recorded discussion of a paper by Finkel (1969), I suggested that the different shapes of the observed doseresponse relationships for radium in CFl mice (linear) and in humaris (non-linear) might be related to their different natural incidences \& 1 osteosarcoma/70 deaths in control mice vs. $\sim 1$ osteosarcoma/10,000 deaths in humans).

The slope of non-linear Eq. 6 is of interest, and can be obtained by differentiation:

$$
\frac{d I}{d x}=k I_{0} e^{k x}
$$

For small values of $x,\left[e^{k x} \approx 1\right]$ and $\left[\frac{d I_{r}}{d x} \approx k I_{0}\right]$, so that:

$$
I_{r} \simeq k I_{\circ} x \quad[\text { for small doses }]
$$

Thus, at small doses, "non-linear" Eq. 6 approaches a "linear" rela- 
tionship, but one whose slope is more shallow than that of the conventional linear relationship (see Figs, $1 \& 2$ and their captions). Traditionally, the conventional linear relationship (Eq - 3) has been used to express the "doubling dose" concept, but with perhaps insufficient thoughtgiven to the make-up of the so-called "natural" incidence. Recently Gofman and Tamplin (1969 \& 1970) have indicated that the natural incidence is not a fixed quantity, but can be influenced by various factors such as country of residence, cigarette smoking, exposure to asbestos, and background radiation. They claim that the average background of about 0.1 rad per year causes about $3 \%$ of the naturally-occurring cancers. If this were true and if the dose-response were linear, then in some regions of high background, well over half of the "natural" cancers should be radiation-induced, since the background in some inhabited parts of the world ranges up to about 10 rads per year, which is 100-fold higher than the average (Penna Franca et. al., 1965).

This raises an interesting point. Gofman and Tamplin (1969 \& 1970) claim that (a) the doubling dose for each type of cancer is similar and is about 100 rads for adults, (b) each type of cancer is induced in direct proportion to its natural incidence, and (c) the natural incidence is not a fixed quantity but is determined by a number of factors including background radiation. Suppose a prior dose of artificial radiation had been received. Then it would seem consistent to add its resulting incidence to the natural incidence, and to use this new total incidence in predicting the effect of a subsequent dose, as has been done in the derivation of Eq. 6. Obviously, cells cannot distinquish between radiations which differ only in their natural vs. artificial origin.

This suggests that non-linear Eq. 6 forms a more consistent model for cancer induction than does linear Eq. 3. In financial analogy, continually compounded interst (based on the accrued interest plus the original principal) is more fair than simple interest (based only on the principal). In fact, Eqs. $3 \& 6$ apply to banking when $I_{r}$ is the accrued interest, $I_{0}$ is the invested principal, $x$ is the time since the investment was made, and $b \& k$ are the simple and compound interest rates, respectively. 
But one must realize that the fundamental mechanisms by which cancer induces radiation ma be quite complex, and any relation as simple as Eg. 6 should not be expected to describe accurately the actual incidence over a wide dose range. For example, it must break down at very high doses due to the radiation-killing of potentially malignant cells. It may, however, prove useful in testing hypotheses, such as those by Gofman and Tamplin, against experimental data, and it may give insight into alternative models which hopefully may more closely approximate that elusive goal called reality.

\section{REFERENCES}

Albert, R. (1970). Unrecorded discussion, Conference on the Estimation of Low-Level Radiation Effects, Argonne National Laboratory, U.S.A. 7-9 Dec. 1970.

Brues, A. M. (1970). Ibid.

Finkel, M. P. Biskis, B. 0., and Jinkins, P. B. (1969). Toxicity of radium-226 in mice, in "Radiation-Induced Cancer;" pp." 369-391. (A. Ericson, ed.) Vienna: International Atomic Energy Agency.

Gofman, J.W. and Tamplin, A. H. (1969), Low dose radiation, chromosomes and cancer, in "Environmental Effects of Producing Electric Power," Hearings before the U.S. Congressional Joint Committee on Atomic Energy, Oct. 28-31 and Nov. 4-7, 1969, pp. 641-652.

Gofman, J. W., and Tamplin, A. H. (1970). Major fallacies in the AEC staff comments on the Gofman-Tamplin papers and congressional testimony, in "Environmental Effects of Producing Electric Power," Hearings of the U.S. Congressional Joint Committee on Atomic Energy, Part 2 (Vol II), Jan. 27-30 and Feb. 24-26, 1970, pp. 2113-2127.

Penna Franca, E., and 10.others (1965). Status of investigations in the Brazilian areas of high natural radioactivity, Health Physics 11:8 pp. $699-712$. 


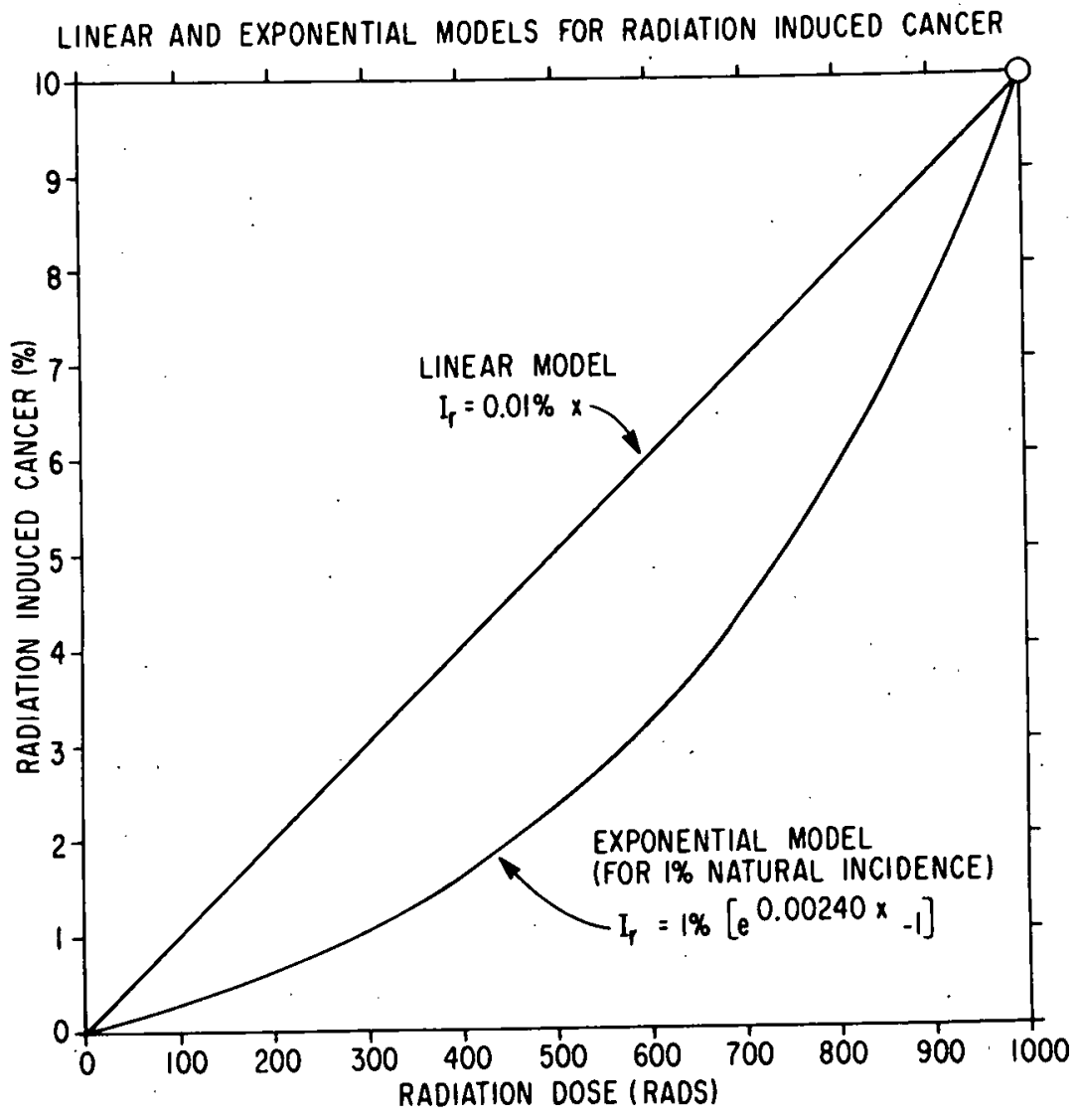

Fig. 1. Linear and exponential models for radiation induced cancer. Both of these illustrative models were fit through $0 \%$ induced cancer at zero dose and $10 \%$ induced cancer at 1000 rads. For a $1 \%$ natural incidence the initial slope of this particular exponential model (2:42\% per 1000 rads) is about $1 / 4$ of that for the linear model ( $10 \%$ per 1000 rads) 


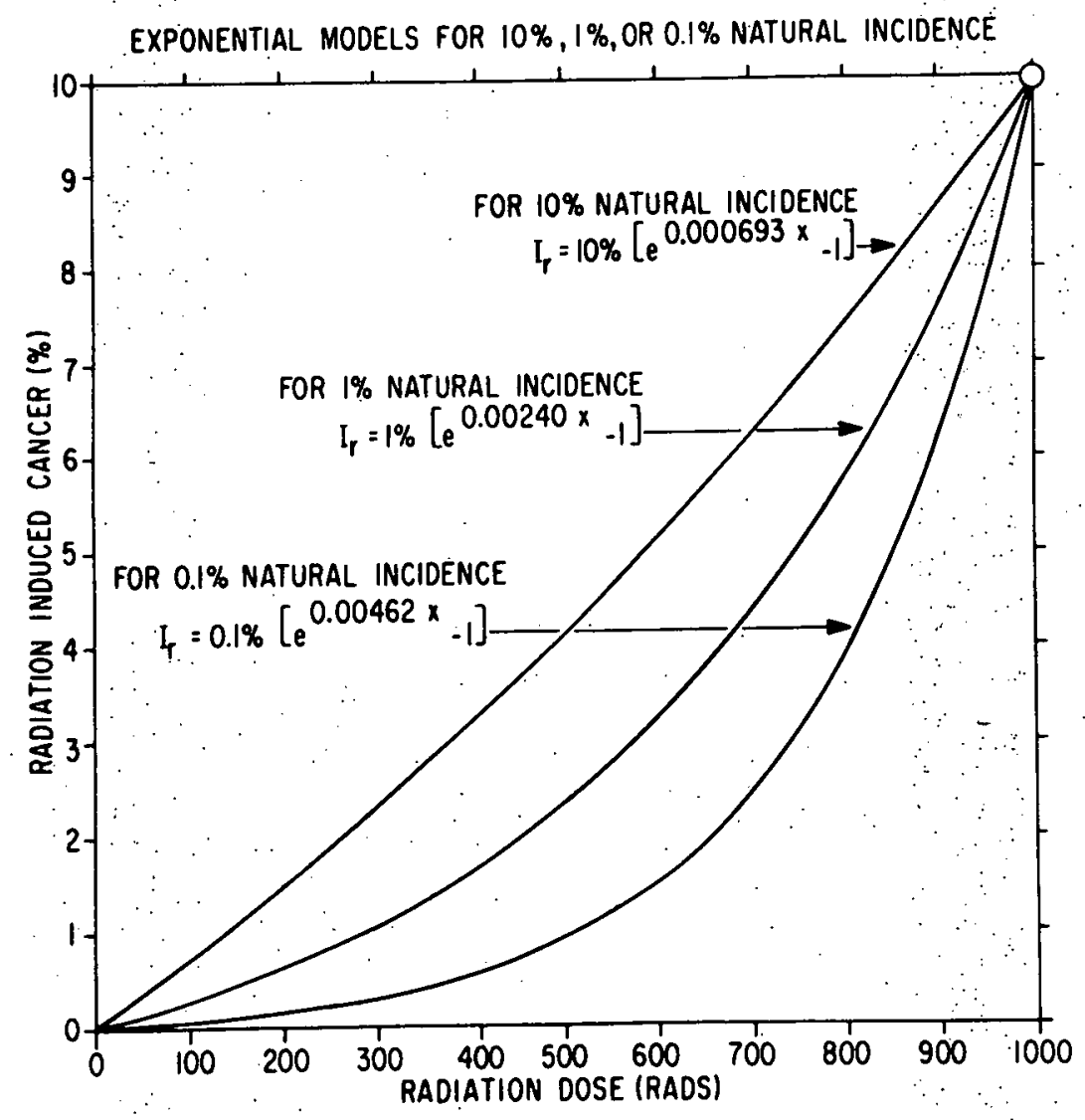

Fig. 2. Exponential models for $10 \%$, $1 \%$ or $0.1 \%$ natural incidence. Each of these illustrative models was fit through $0 \%$ induced" cancer at zero dose and $10 \%$ induced cancer at 1000 rads. The initial slopes of the 3 .curves are $6.93 \%$ per 1000 rads (for $10 \%$ natural incidence), $2.40 \%$ per 1000 rads (for $1 \%$ natural incidence) and $0.462 \%$ per 1000 rads (for $0.1 \%$ natural incidence). The higher the natural incidence, the more closely the exponential model approaches the linear model. 
ADDITIONS TO BIBLIOGRAPHY

(1 April 1970 through 31 March 1971)

\section{PUBLISHED ARTICLES}

1. Bartley, M. H. and W. S. S. Jee; Skeletal system/teeth and mandible; in The Beagle; edited by A. C. Andersen, lowa State U. Press, Ames, lowa; pp. 162-188 (1970).

2. Dewey, J.R., M. H. Bartley, Jr., and G. J. Armelagos; Rates of femoral cortical bone loss in two nubian populations; Clinical Orthaepics 65: 61-66 (1969).

3. Dougherty, J. H. and L. S. Rosenblatt; The comparative toxicity of ${ }^{226} \mathrm{Ra},{ }^{239} \mathrm{Pu},{ }^{228} \mathrm{Th},{ }^{228} \mathrm{Ra}$ and ${ }^{90} \mathrm{Sr}$ to leukocytes of beagles; Radiation Res. 43: 56-70 (1970).

4. Dougherty, T. F. and D. A. Dolowitz; Physiologic actions of heparin not related to blood clotting; in Chemical Dynamics; edited by Joseph 0. Hirschfelder and Douglas Henderson; Wiley-Interscience, a Division of John Wiley \& Sons, Inc., Pp. 633-646 (1971).

5. Eyring, Henry and Betsy J. Stover; The Dynamics of Life, 11. The steady-state theory of mutation rates; Proc. Natl. Acad. Sciences 66: 441-444 (1970).

6. Jee, W. S. S.; Bone seeking radionuclides and bones; in Pathology of Irradiation; edited by C. C. Berdjis; Williams and Wilkins, Baltimore; pp. 186-212 (1970).

7. Jee, W. S. S., M. H. Bartley, R. D. Cooper and N. L. Dockum; Skeletal system/bone structure; in The Beagle; edited by A. C. Andersen; lowa State U. Press, Ames, lowa, p. 162-188 (1970). 8. Jee, W. S. S., H. Z. Park, W. E. Roberts, E. L. Blackwood, and 
G. H. Kenner; Corticosteroid and bone; Amer. J. Anat., 129: $477-480(1970)$

9. Lloyd, R. D., C. W. Mays, B. W. Church, R. C. Pendleton, and Susan F. Mays; Does the elimination rate of cesium in humans change with the seasons; Health Physics 18:623-629 (1970).

10. Mays, C. W., T. F. Dougherty, B. J. Stover, W. S. S. Jee, W. R. Christensen, J.H. Dougherty, W. Stevens, and C. J. Nabors; Bone cancer induction by radionuclides: incidence vs. dose; in Environmental Effects of Producing Electric Power; Hearings before the Joint Committee on Atomic Energy, U. S. Congress Vol, 11, Part 2; pp. 2192-2210 (Jan. 27-30 and Feb. 24-26, 1970).

11. Mays, C. W., G. N. Taylor, W. S. S. Jee, and T. F. Dougherty; Speculated risk to bone and liver from $239 \mathrm{pu}$; Heal th Physics 19: $60.1-610(1970)$

12. Pendleton, R. C. and R. D. Lloyd; Zirconium-95 in Utah vegetation produced during the 1966 growing season; Radiological Health Data 11: 227-281 (1970).

13. Spiess, H. and C. W. Mays; Bone cancers induced by ${ }^{22}{ }^{4} \mathrm{Ra}$ (ThX) in children and adults; Health Physics 19: 713-729 (1970).

14. Stover, Betsy J., David R. Atherton and Dawn S: Buster; Protracted hepatic, splenic and renal retention of ${ }^{239} \mathrm{Pu}$ in the beagle; Health Phys. 20: 369-374 (1971).

15. Stover, Betsy J., F. W. Bruenger and W. Stevens; Association of americium with ferritin in the canine liver; Radiation Res. 43: $173-186(1970)$.

16. Stover, Betsy J.; The Dynamics of Life, IVa. Lenticular Cataracts induced by aging and irradiation; Chemical Dynamics; (Ed. 
by Hirschfelder); pp. 661-667, J. Wiley and Sons, New York (1971).

17. Stover, Betsy J. and Henry Eyring; The Dynamics of Life, 1.

Death from internal irradiation by ${ }^{239} \mathrm{Pu}$ and ${ }^{226} \mathrm{Ra}$, aging, cancer and other diseases; Proc. Natl. Acad. Sciences 66: 132139 (1970).

18. Stover, Betsy J. and Henry Eyring; The Dynamics of Life, 111 . Mechanisms of nonsurvival and the relation of dose size; Proc. Nat1. Acad. Sciences 66: 672-676 (1970). 


\section{PUBLISHED ABSTRACTS}

1. Atherton, D. R., F. W. Bruenger, and Betsy J. Stover; The interaction of some actinide elements with blood constituents; Abstracts of Papers for Nineteenth Annual Meeting of the Radiation Research Society, p. 97 (1971).

2. Bruenger, F.W., W. Stevens and Betsy J. Stover; The association of $210 \mathrm{~Pb}$ with constituents of erythrocytes; Abstracts of Papers for the Nineteenth Annual Meeting of the Radiation Research Society, p. 50 (1971).

3. Eyring, Henry and Betsy J. Stover; The Dynamics of Life, IV. The steady state theory of mutations causing cancer and other degenerative diseases; Abstracts of Papers for the Division of Physical Chemistry, American Chemical Society, 160th National Meeting, Chicago (1970).

4. Julian, G., H. Z. Park, W. E. Roberts, and W: S. S. Jee; Parathyroid-cortisol relationship measured by periodontal ligament labeling indices; 49th Annual Meeting Int. Assoc. for Dental Res:(I.A.D.R.); Abstracts of Papers, p. 259 (1971).

5. Kimmel, D., H. Z. Park, R. B. Dell, and W. S. S. Jee; Effects of calcitonin, cortisol and hypophysectomy upon $91 \mathrm{y}$ uptake; 49th Annual Meeting IADR; Abstracts of Papers, p. 258 (1971).

6. Kramer, M., W. E. Roberts, H. Z. Park, and W. S. S. Jee; Endogenous parathyroid hormone and the proliferation of periodontal ligament fibroblasts; 49th Annual Meeting. IADR; Abstracts of Papers, p. 259 (1971).

7. Lloyd, R. D., C. W. Mays, D. R. Atherton, F. W. Bruenger, and J. L. Williams, Retention and distribution of injected $210 \mathrm{~Pb}$ 
in beagles; Health Physics 19: 337 (1970).

8. Mays, C. W., R. D. Lloyd, F. W. Bruenger, D. R. Atherton, and J. L. Williams; $210 \mathrm{~Pb}$ metabolism in beagles; Published Abstracts of the Meeting on the Biology and Ecology of Polonium and Radiolead; Belmont, England, p. 24 (30 April-1 May, 1970).

9. Mays, C. W., G. N. Taylor, W. S. S. Jee, and T. F. Dougherty; Speculation on the risk to adult man from a permissible body. burden of ${ }^{239} \mathrm{Pu}(0.04 \mu \mathrm{Ci})$ equally divided between bone and liver; Book of Abstracts, 2nd International Congress of Radiation Protection, Brighton, England, p. 56 (3-8 May 1970) and also in Rad. Res. 43:1, p. 264 (July, 1970).

10. Nabors, C. J., Jr.; Altered corticosteroid biosynthes is in adrenals from cystic fibrosis patients; 12 th Annual Meeting of Cystic Fibrosis Club, Atlantic City, N. J., (April 1971).

11. Park, H. Z., J. M. Jurancich and W. S. S. Jee; Efflux of deep mineral store by parathyroid hormone and bone cells; 49 th Annual Meeting IADR; Abstracts of Papers, pp. 107 (1971).

12. Roberts, W. E. and W. S. S. Jee; Cortisol and the cellular kinetics of stimulated rat periodontal ligament; 49 th Annual Meeting IADR; Abstracts of Paper, p. 257 (1971).

13. Schafer, S., D. Higgenbottam, H. Z. Park, and E. I. Hashimoto; The distribution of ${ }^{3} \mathrm{H}$-tetracycline in young mouse bone; Anat. $\operatorname{Rec} \cdot 169: 418(1971)$.

14. Schafer, S., W. S. S. Jee, and R. B. Dell; The effect of cortisol on bone cell differentiation in vitro; 49th Annual Meeting IADR; Abstracts of Papers, p. 257 (1971). 
15. Stevens, W., F. W. Bruenger, D. R. Atherton and Betsy J. Stover; Subcellular distribution of ${ }^{241} \mathrm{Am}$ (III) and $239 \mathrm{Pu}$ (IV) in livers studied serially; Abstracts of Papers for the Nineteenth Annual Meeting of the Radiation Research Society; p 97 (1971).

16. Stover, Betsy J., D. R. Atherton, D. S. Buster and F. W. Bruenger; Retention of ${ }^{239} \mathrm{Pu}$ (IV) by the young adult beagle; Abstracts of Papers for the Nineteenth Annual Meeting of the Radiation Research Society, P. 99 (1971).

17. Taylor, G. N., R. D. Lloyd, D. R. Atherton, and C. W. Mays; Radium induced eye tumors; 4 th International Congress of Radiation Research, Evian, France; Livre des Resumes; P. 216 (1970).

18. Thurman, G. B., W. C. Mays, G. N. Taylor, and T. F. Dougherty; Growth dynamics of osteosarcomas induced in beagles by boneseeking radionuclides; Book of Abstract Preprints for 19th Annual Meeting of the Radiation Research Society, Boston; Abstract Ce-11, pg. 22 (1971).

19. Whitson, S. W.; Microtubules and tight junctions in bone; Anat. Rec. 169: 454 (1971).

20. Whitson, S. W., J. Yee, H. Z. Park; and W. S. S. Jee; Dose response studies of estradiol on growing rat bones; 49 th Annual Meeting IADR; Abstracts of Papers, pp. 106 (1971).

21. Yee, J.,D. W. Young, G. H. Kenner, H. Z. Park and W. S. S. Jee; Structural activity relationship of corticosteroids to growing rabbit bones; 47th Annual Meeting IADR; Abstracts of papers, pp. 106 (1971). 


\title{
COMPARATIVE EFFECTS OF $239 \mathrm{PU}$ AND ${ }^{241} \mathrm{Am}$ ON BIOCHEMICAL PARAMETERS EFFECTS OF DOSE AND RADIONUCLIDE BURDEN TIME
}

\author{
Charles J. Nabors, Jr., ${ }^{1}$ Walter Stevens and Richard E. Maxwell
}

Abstract: A comparison of the effects of ${ }^{239} \mathrm{Pu}$ and ${ }^{241} \mathrm{Am}$ on serum biochemical parameters has been made using the technique of multiple regression analysis. A separate analysis was made of data from male and female animals with plutonium animals also being separated into tumor and non-tumor groups. Two major differences were evident: $241 \mathrm{Am}$ appears to produce significant changes in SGPT and serum alkaline phosphatase at earlier times post-injection than ${ }^{239} \mathrm{Pu}$; male beagle dogs appear to be more susceptible to radiation induced changes in SGPT, SGOT and serum alkaline phosphatase than females. The significance of these findings and their possible relationship to carcinogenesis and hormonal effects is discussed.

\section{INTRODUCTION}

Changes in serum biochemistry due to injected radionuclides have been studied in this laboratory since its inception 20 years ago. Thus far, the most sensitive responses have been changes in serum transaminases and alkaline phosphatase. Of the nuclides in our long-term study group; $239 \mathrm{pu}$ has produced the most marked alterations in serum levels of these enzymes. More recently, ${ }^{241} \mathrm{Am}$ has been added to the nuclides under investigation in our laboratory. Preliminary observation showed that these nuclides have two common features: (1) both deposit large amounts in the liver (1) and (2) both elicit large increases in the same serum enzymes (2).

Increases in serum alkaline phosphatase correlate with both osteoblastic activity and liver function (3). Increased alkaline phosphatase activity precedes the onset of clinically detectable osteogenic sarcomas and correlates with the incidence of this tumor, which is also produced by a number of other

1. Markle Scholar in Academic Medicine. 
radionuclides $(4,5)$. Bone-seeking radionuclides produce osteogenic sarcomas as their major biologic end-point ${ }^{(6)}$.

Elevations in serum glutamic-pyruvic transaminase levels are specific indicators of hepatocellular necrosis in dogs $(7,8)$. Our laboratory has previously shown that changes in serum levels of this enzyme correlate with $239 \mathrm{pu}$ dosage ${ }^{(8)}$. In a preliminary report, we have also shown that 241 Am produces earlier post-injection rises in SGPT than ${ }^{239} \mathrm{Pu}$. Serum glutamic oxaloacetic transaminase activity is a less specific indicator of hepatic damage, but dogs bearing ${ }^{239} \mathrm{Pu}$ also have significant increases in SGOT (2).

Since ${ }^{241} \mathrm{Am}$ and $239 \mathrm{Pu}$ appear to be potentially harmful to our ecosystem, a comparative evaluation of the effects of the two nuclides was undertaken. This study includes an evaluation of the effects of these two nuclides with respect to the sex of the animal and also with respect to radionuclide burden time and dose.

\section{MATERIALS AND METHODS}

The dogs used were purebred Beagles born and reared in our laboratory. The animals were injected with either ${ }^{239} \mathrm{Pu}$ or ${ }^{241} \mathrm{Am}$ in young adulthood. Twelve or more ${ }^{239} \mathrm{Pu}$ dogs were injected at each dose level in our regular program (9). Five or more animals were injected as ${ }^{241} \mathrm{Am}$ test animals in a special study. While plutonium injected animals have been studied in this laboratory for 20 years, the more recent americium group has been, studied for the last five years. Each animal received a single intravenous injection of the soluble nuclide in sodium citrate-citric acid buffer, pH3.5. Blood samples were taken for biochemical analysis at 1 to 3 month intervals. All biochemical determinations 
were made using standard laboratory procedures. The control mean and $95 \%$ confidence limits used in this study were computed from data on zero level animals in our colony. The statistical technique used for the analysis of the data was multiple regression analysis. A similar technique has been reported previously ${ }^{(2)}$. Calculations for the statistical analysis were done on a Univac 1108 computer. The mathematical model for this analysis is: $z=a+b(\mu)+c(t)+d(\mu)(t)$, where $\mu$ is dose in $\mu c / k g, t$ is radionuclide burden time in months post-injection (MPI), and $Z$ is the parameter being approximated. This model constitutes a truncated biquadratic, as the squared terms $e\left(\mu^{2}\right)$ and $f\left(t^{2}\right)$ have been deleted. It was found that addition or deletion of these squared terms did not significantly $(p<.05)$ change the interpolatory character of this model for the data analyzed. Hence, this model was chosen for its simplicity and statistical significance. The equation can be rearranged to: $Z=(a+b \mu)+(c+d \mu) t$. For fixed values of $\mu$, the dose level, this equation is a linear function of $t$. The intercept slope of this line can be interpreted as follows:

The intercept $(a+b \mu)$ can be thought of as the immediate effect produced by an injected burden and the sign of the constant b determines whether an increase in dose will cause an increase $(+b)$ or a decrease (-b) in a particular parameter. If the constant $b$ does not differ significantly from zero, then the isotope in question does not have a significant immediate effect upon the parameter.

The slope $(c+d \mu)$ of the line is the time rate of change effect produced by the isotope burden $(\mu)$. Thus the effect measured by the slope becomes more 
pronounced as time increases, for the magnitude of the slope measures the effect per unit of time. As for the constant $d$, the signand magnitude of $d$ is important in determining the burden's effect upon the parameter as time after injection increases.

Since the multiple regression technique was used for this statistical analysis, the slope and intercept determined are the maximum likelihood estimators. The maximum likelihood estimator of slope is used to compare dose effects in Table 1 .

\section{RESUL:TS}

Figure 1 depicts the results obtained for SGPT measurements in male and female animals injected with ${ }^{239} \mathrm{Pu}$ and ${ }^{241} \mathrm{Am}$. The plutonium animals were further separated into tumor and non-tumor groups. Since only one osteosarcoma has been identified in americium animals, this distinction was not applicable. The regression lines on the graphs are solid where the data is actual and dashed where extraplations have been made. Note that as the dose increases from the 1 to the 3 to the 5 level, the effect of plutonium in female tumor animals appears to increase in terms of the slope of the regression line, while in males it is marked even at the 1 level. Some cross-over of the data appears between plutonium tumor and non-tumor animals in the females at 1 level, and in both sexes at the 3 and 5 levels. A rather interesting change occurs in americium male animals with the regression line changing from a negative slope at the 1 level to a positive slope in 5-level animals. A similar al though somewhat less marked change occurs in female animals. The 1 level slope for Am male dogs is more negative than for females. Plutonium non-tumor 
animals at the 1 and 3 levels show steeper slopes than the tumor animals. The negative slope obtained in 1 level americium animals is most prominent in male animals.

The results obtained from analysis of the data obtained by measuring serum glutamic oxaloacetic transaminase is presented in Figure 2. A tendency of the non-tumor plutonium injected animal to exhibit higher values than the tumor bearing plutonium animal is evident. This is true in all cases except for the 5 level male animal. The americium data shows some interesting results with the slope of the americium male regression line proceeding from a negative to a positive slope with increasing dose level. At level 5 , the male values are higher than female values. Also, 1 level values for female americium non-tumor animals are higher throughout than for the plutonium non-tumor animals with lower values obtained at the 3 and 5 level. This may indicate a more drastic effect of americium. In terms of overall effects, the male animal again appears to evidence greater radiation-induced changes at the 3 and 5 dose levels. Note that the values for SGOT units are generally higher than those obtained in females.

Figure 3 contains the data obtained for alkaline phosphatase measurements in plutonium tumor and non-tumor animals and in americium animals without tumors. Generally, the slopes of the regression lines for plutonium tumor animals are in all cases steeper than those for plutonium non-tumor animals in both sexes. It should be noted that in the 5 level group, many animals die due to other effects of the radiation prior to the onset of osteogenetic sarcoma, a pathology known to cause elevated alkaline phosphatase measurements. In male plutonium 
1 to 3 level animals, there is a cross-over of the tumor and non-tumor regression lines, while this is evident only in the 1 level female plutonium animals. The absolute values of the measurements at 120 days again increases in male animals as a function of increased dose. The same change occurs in female animals although the 120-day values are lower than in males. These findings taken along with those for SGPT and SGOT may mean a greater sensitivity to radionuclide induced changes in male animals than similar changes in females. The pattern observed in the americium-injected animals is that of a regression line that shows a negative slope which becomes increasingly positive in magnitude with increasing dose and actually positive in the 5 level male animals. Again, the change occurring in male americium-injected animals. is much more drastic than the change in female animals receiving this radionuclide. Table 1 shows the results obtained when the maximum likelihood estimator of slope of the line at various dose levels is calculated. Analysis of a maximum likelihood estimator in this fashion provides a comparison of the effect of dose. Two facts are most obvious from this table. First of all, the slope of the line increases with increasing dose level as we proceed from the 1 level figures on the left to the 5 level figures on the right. Secondly, the slope of the line is higher in male than in female animals within each test group compared ( 0.48 for.plutonium male tumor at the 1 level vs. 0.031 for plutonium female tumor). Generally the absolute values of the slopes for SGPT are higher than those for SGOT. One exception for this obtains in americium non-tumor animals at the 1 and 3 levels. This may be due to the fact that the slopes are generally negative in these groups and that this parameter is being measured at 
very early times in terms of months post-injection. This difference reverses for SGPT and SGOT values in the 5 level animals.

A difference obtains in alkaline phosphatase measurements where the plutonium injected female 1 level tumor animals show lower alkaline phosphatase values than female 1 level non-tumor animals. This difference reverses with the tumor animal's values being higher at the 3 and 5 levels where tumor incidence is higher. Again, the values for male animals are higher than for female with the exception of the 1 level non-tumor plutonium animals. The same sex difference obtains in americium-injected dogs for alkaline phosphatase. Also, these measurements in americium-injected dogs tend to become more positive with increasing dose level. These results show that dose level has a distinct effect on alkaline phosphatase values.

Table 2 shows the results obtained when the standard partial regression coefficients for the effects of $\mu \mathrm{Ci} / \mathrm{kg}$, months post-injection, and interaction are put into standard measure. The measurement with the smallest standard partial regression coefficient becomes the least common denominator, with a value of unity. The results show that the least effective variable in tumor animals tends to be months post-injection while $\mu \mathrm{Ci} / \mathrm{kg}$ and interaction $[\mu \mathrm{c} / \mathrm{kg}$ (MPI)] are generally much more effective in all three of the tests compared in this study. In both non-tumor and tumor animals, interaction tends to be the most potent variable of the three, indicating that both dose and radionuclide burden time interact to cause changes in SGPT, SGOT and alkaline phosphatase.

Table 3 shows the cumulative data on the incidence of osteosarcomas in beagle dogs injected with plutonium-239. With exception of the 1 and 5 levels, 
distribution of osteosarcomas is approximately equal between male and femal,e animals. The incidence of osteosarcomas is slightly lower in males at the 5 level and higher in males at the 1 level as compared to females. Insufficient data are available to draw any significance from these differences at this time. The 3 and 5 level animals have all expired, while some of the 1 level animals are still living. The over-all incidence of osteosarcomas is approximately equal between the two sexes.

Figure 4 shows the results for individual measurements of SGPT in two plutonium 5 level and two americium 5 level animals. The time scale on the abcissa is the same for both graphs. However, the ordinate scale differs for the two nuclides. The horizontal line across the graph indicates a $95 \%$ confidence level for control (0 level) dogs in our colony. The SGPT measurement in americium treated animals rises above the $95 \%$ confidence level at 5 months post-injection while the first detectable increase in plutonium animals does not occur until the eighth month post-injection. Also, the elevation of this value in americium dogs is from two to four times the highest elevation in animals injected with plutonium-239.

Figure 5 shows a similar comparison for animals injected with plutonium and americium for the measurement of alkaline phosphatase. Again, the horizontal line of the graph indicates a $95 \%$ confidence level obtained from measurements in zero level dogs. The earliest increase in americium treated animals is at 5 months post-injection while the earliest increase in plutonium injected animals occurs 14 months post-injection. Again, increases in serum alkaline phosphatase in americium injected animals are far greater than those obtained. 
in plutonium injected animals. Thus an earlier and more marked elevation in this serum biochemical perimeter appears to occur in americium injected beagle dogs.

\section{DISCUSSION}

The regression lines for transaminase measurements in animals bearing burdens of plutonium and americium show several distinct effects. The alterations in these serum enzymes are frequently the greatest in male animals. This is indicated by the slopes of the regression lines, where the curves for males tend to be more positive in ${ }^{239} \mathrm{Pu}$ animals and more negative in ${ }^{241} \mathrm{Am}$ males than females. The transaminases measure hepatocellular necrosis and there may be a tendency in female animals to resist this type of damage more than in males. The negative slope of the line describing the response to americium is quite surprising. Since this measurement indicates hepatocellular necrosis, this slope may be a reflection. of the shorter length of time that ${ }^{241} \mathrm{Am}$ has been studied. Only one osteogenic sarcoma tumor animal has been discovered in the americium study this far. Therefore, it was not possible to plot a line for americium tumor animals. Also, the 5-level americium animals died quite rapidly, precluding tumor development.

It is also interesting to note that in some instances the plutonium nontumor animals exhibited higher transaminase levels that in the tumor animals. This may be indicative of future tumor incidence or a precancerous condition. The individual dogs will have to be studied further to establish whether or not this observation is of biologic significance. Prior studies on alkaline phosphatase have shown that this parameter is elevated before the appearance of 
radiologically detectable disease ${ }^{(5)}$.

Changes observed in alkaline phosphatase measurements follow a pattern similar to that observed for transaminases. Again, the male animal exhibits a greater susceptibility to elevations of serum alkaline phosphatase activity. In this test, however, the slopes of the regression lines for plutonium tumor animals were higher than those for plutonium non-tumor animals. The slope of the regression line does not, however, reflect the elevation in serum alkaline phosphatase that occurs prior to the onset of clinically detectable osteosarcoma $(4,5)$. The slope of the regression line for americium.injected animals is again negative at lower dose levels and becomes positive:with a 5 level dose.

As another parameter of effect of dose level, we have calculated a maximum likelihood estimator for the slope of the regression line. These values, shown in Table 1 again indicate a more drastic response in male animals than in females and an increase in the response with increasing dose: Also, the response in the plutonium tumor animals is generally higher than that in non-tumor animals with some exceptions in the measurements made in female animals. Since. dose-time interaction is a very significant factor (Table 2 ), this may account for the fact that our maximum likelihood estimators for americium are lower than those for plutonium. Americium treated animals have been injected for only a short period of time and although drastic changes occurred as reflected in the slope of the regression 1 ine, the maximum likelihood estimator of dose effect is not higher than that obtained with plutonium. The negative figures obtained with americium are from groups of animals that showed a negative regression at 
lower dose levels.

When the standard partial regression coefficients from various groups of animals are put into standard measure, it appears that dose and dose-time interaction are the most significant factors for most of the plutonium tumor animals that we have studied. Radionuclide burden time tends to be more of a significant factor for changes in serum biochemical measurements in plutonium non-tumor animals than in tumor animals. Again, this may be due to the fact that we are dealing with a precancerous condition. Once pathology becomes clinically evident, dose becomes more statistically relevant. This is less true of americium treated animals, where the standard partial regression coefficient for dose is more prominent, particularly in the SGPT and alkaline phosphatase tests.

The comparison of tumor incidence in male and female plutonium injected animals shows no remarkable sex difference over the dose levels and time period that we have studied. This contrasts, of course, with the different responses in transaminases and alkaline phosphatase which we have observed in our study. Therefore, it appears that biochemical studies may reveal more subtle differences than clinically detectable carcinoma. Plutonium animals at level 1 and below are still surviving, and more obvious sex differences in the occurrence of osteosarcoma may appear in these animals.

One other indication of the differences between the effects of americium and plutonium on SGPT and alkaline phosphatase may be seen in Figures 4 and 5 where in both instances americium produced an earlier rise above the $95 \%$ confidence limit in the particular enzyme and also increased enzymatic activity to a 
far higher level than plutonium injection. These results are quite comparable since both plutonium and americium animals have been studied over these shorter periods of time. A possible explanation for the difference is the amount of injected nuclide initially deposited in the liver. Plutonium injection deposits $32.5 \%$ of an injected dose ${ }^{(10)}$, while $48.7 \%$ of an injected dose of americium deposits (1) at the 3 dose level. The larger initial deposition of ${ }^{241} \mathrm{Am}$ could be responsible for the early onset of enzymatic changes.

The sex difference in the degree of change induced by these two nuclides is perhaps the most interesting finding in this study. Previously, we have demonstrated radiation-induced impairment of adrenal cortical steroid production $^{(11,12)}$, hepatic steroid conjugation (13), and formation of androgens in the testes $(14,15)$ : All of these activities are intimately involved with the function of the reticuloendothelial system ${ }^{(16)}$. Fisher and Fisher have reported that substances that blockade the RES will produce an increase in serum transaminase (17). Estrogens have been shown to stimulate RES activity (18). It is possible that the presence of estrogen in the liver of female beagles contributes to the relative resistance to radiation reported here. Further studies on endocrine relationships will be the subject of future investigations.

\section{ACKNOWLEDGEMENT}

The authors wish to thank Miss R. Imelda Zizumbo, Mr. Robert Firmage and Miss Ann Bailey for their technical assistance. 


\section{REFERENCES}

1. Lloyd, R. D., C. W. Mays, G. N. Taylor and D. R. Atherton; Americium-241 retention in beagles; Research in Radiobiology, Univ. of Utah Report C00$119-241,123-134$ (1970).

2. Berliner, D. L., W. Stevens, C. J. Nabors, Jr. and R. E. Maxwell; Biochemical changes induced by internally deposited radionuclides in beagle dog blood. A statistical study. In: Delayed Effects of Bone-Seeking Radionuclides, C. W. Mays et al., Eds., Univ. of Utah Press, Salt Lake City, Utah, 471-488 (1969).

3. Dalgaard, J. B.; Serum and bile phosphatase in biliary fistula dogs; ACTA Physiol. Scandia. 16: 293-311 (1949).

4. Stevens, W., C. J. Nabors, Jr. and D. L. Berliner; A comparison of serum transaminase levels and other serum constituents in dogs burdened with ${ }^{239} \mathrm{Pu},{ }^{228} \mathrm{Th},{ }^{228} \mathrm{Ra}$ and ${ }^{226} \mathrm{Ra}$; Ann. N. Y. Acad. Sci. 145: 817-829, (1967).

5. Berliner, D. L., C. J. Nabors, Jr. and W. Stevens; Analysis of serum in beagles and possibilities of its use as predictors of radiation induced pathology. Bio-medical directors meeting of the A.E.C., Park City, Utah (1969).

6. Dougherty, T. F.; Incidence of bone cancer in internally irradiated dogs. In: Some Aspects of Internal Irradiation, T. F. Dougherty et al., Eds, Pergamon Press, New York, 47-57 (1962).

7. Zontine, W. J.; The transaminase test for liver necrosis in dogs; Can. Vet. J., 2: 9-19 (1961).

8. Stevens, W. and D. L. Berliner; Serum transaminase levels in beagle dogs burdened with plutonium-239; Radiation Res. 23: 420-429 (1964). 
9. Dougherty, T.F., B. J. Stover, J. H. Dougherty, W. S S. Jee, C.W. Mays, C. E. Rehfeld, W. R. Christensen and H. C. Goldthorpe; Studies of. the biological effects of ${ }^{226} \mathrm{Ra},{ }^{239} \mathrm{Pu},{ }^{228} \mathrm{Ra}$ (MsTh.), ${ }^{228} \mathrm{Th}$ (RdTh) and ${ }^{90} \mathrm{Sr}$ in adult beagles; Radiation Res. 17: 625-681 (1962).

1.0. Stover, B. J., D. R. Atherton and D. S. Buster; 239 pü(IV): Its retention in the skeleton of the beagle (in press, 1971).

11. Nabors, C. J., Jr., D. M: Cazes and D. L. Berliner; A model system for the study of radiation effects on adrenal steroidogenesis; Radiation Res. 16: $557(1962)$.

12. Berliner, D.: L., W. Stevens and T. F. Dougherty; The effects of ionizing radiation on the biosynthesis and biotransformation of corticosteroids. 'In: Effects of lonizing Radiation on the Reproductive System, W. D. Carlson and F. X. Gassner; Eds., Pergamon Press, New. York, 433-449 (1964).

13. Stevens, W. and D. L. Berliner; The effect of X-irradiation on the conjugation of steroids by mouse liver and kidney; Radiation Res. 20: 510-518 (1963).

14. Ellis, L. C. and D. L. Berliner; The effects of ionizing radiation on endocrine cells. 1. Steroid biotransformations and androgen. production by testes from irradiated mice; Radiation Res. 20: 549-563 (1963).

15. Ellis, L. C. and D. L. Berliner; The effects of ionizing radiations on endocrine cells. III. Restoration of testosterone production with a reduced nicotinamide adenine dinucleotide phosphate-generating system after localized irradiation to heads of rats; Radiation Res. $25: 156-194$ (1964).

16. Berliner, D. L., C. J. Nabors, Jr. and T. F. Dougherty; The role of hepatic and adrenal reticuloendothelial cells in steroid biotransformation; J. Reticuloendothelial Soc. 1: 1-1.7 (1964). 
17. Fisher, E. R. and B. Fisher; Hepatic damage by reticuloendothelial interference; Arch. Pathol. 75: 191-195 (1963).

18. Nicol, T. and D. L. J. Bilbey; The effect of various steroids on the phagocytic activity of the reticuloendothelial system. In: Reticuloendothelial Structure and Function, J. H. Heller, Ed., Ronald Press, New York; $301-320$ (1960). 
27

í.
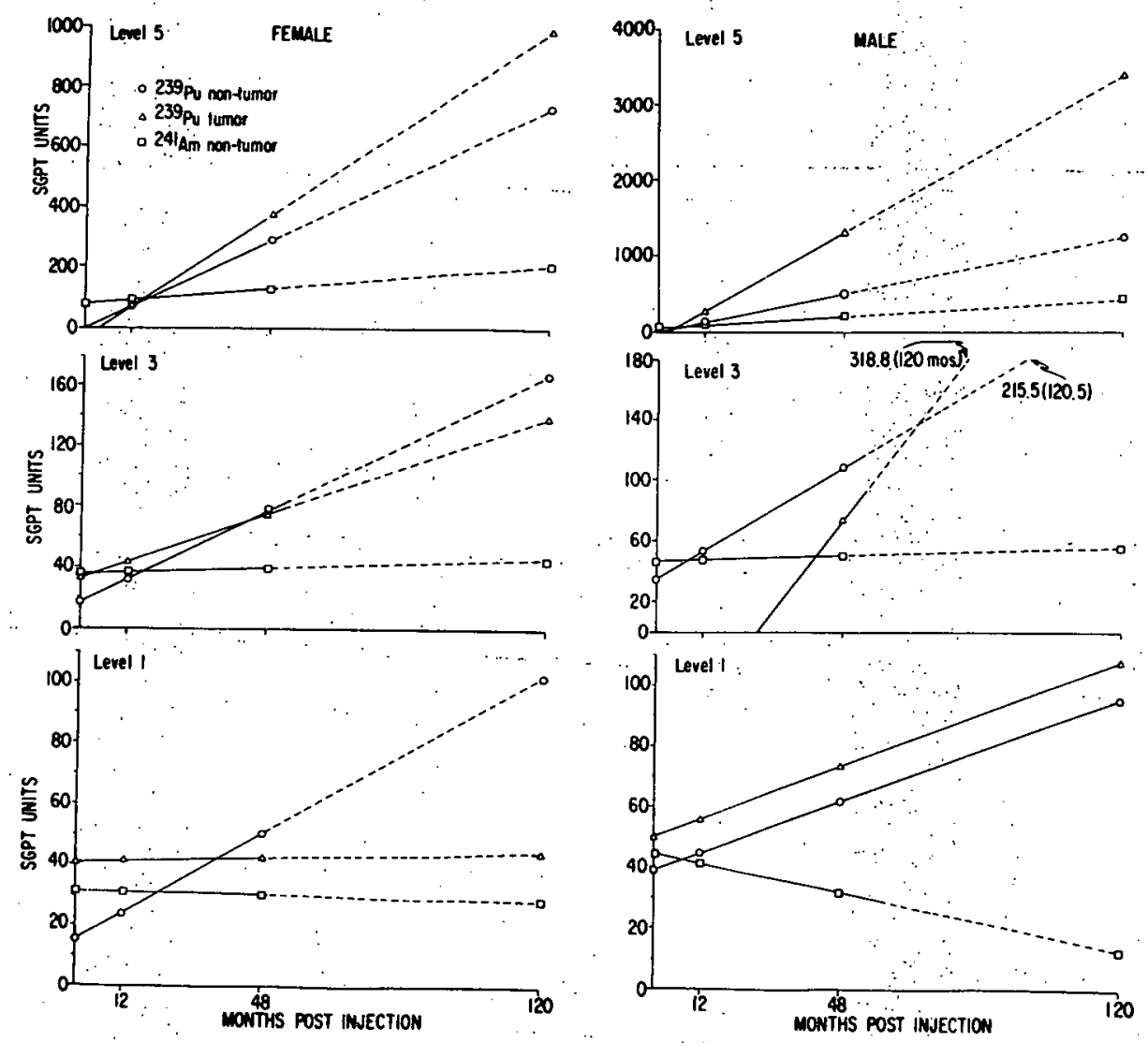

Figure 1. Regression lines for serum glutamic pyruvic transaminase levels in ${ }^{239} \mathrm{Pu}$ injected osteosarcoma tumor animals $(\Delta)$, non-tumor animals $(0)$ and $241_{A m}$ injected non-tumor animals ( $(0)$. The dashed portion of the lines represents an extrapolation of the data. Female animals injected with dose levels 1, 3 and 5 are on the left and males are on the right side of the page. The $95 \%$ confidence limit for elevated SGPT is 52 units. 

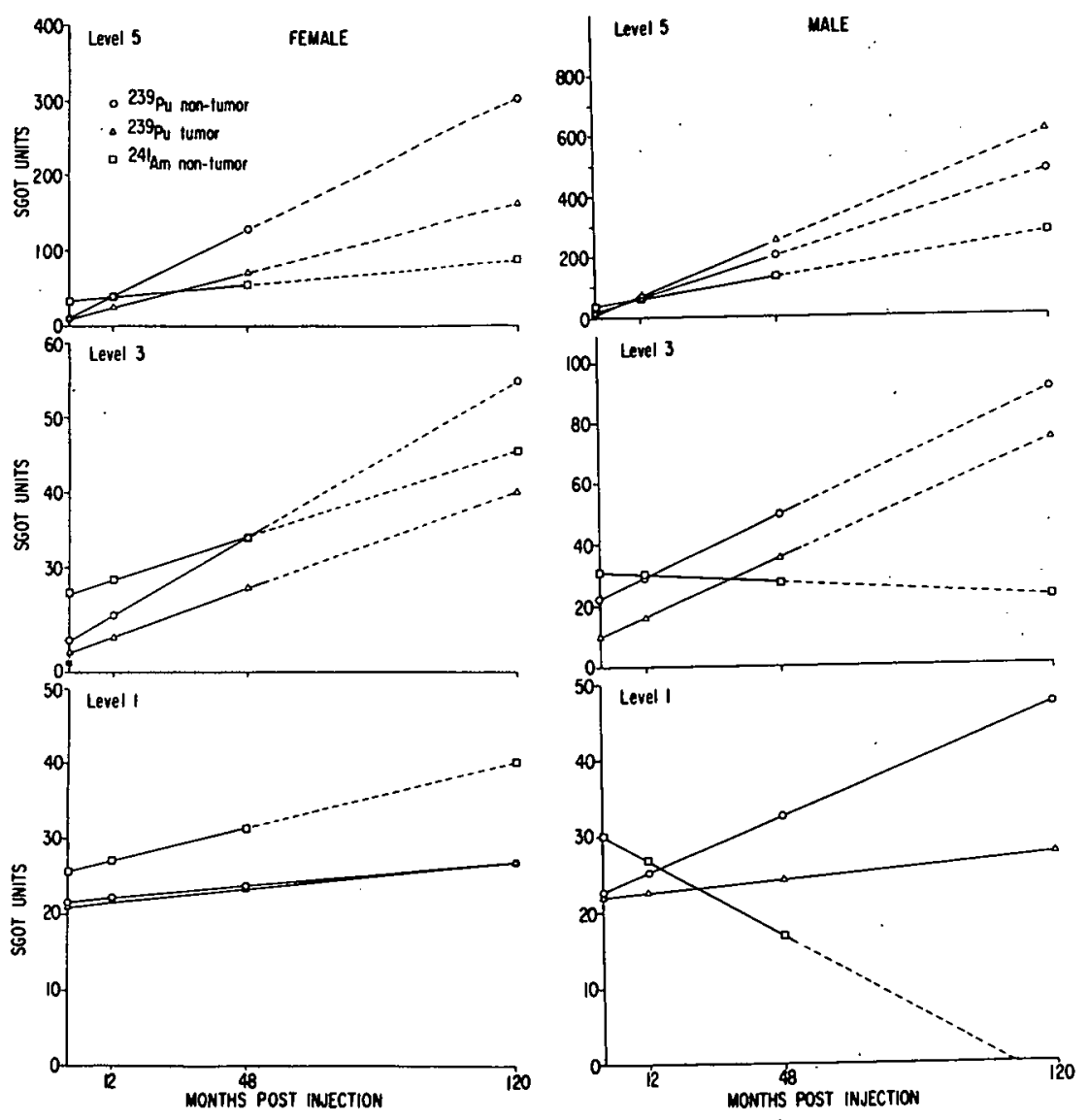

1

Figure 2. Serum glutamic oxaloacetic transaminase regression 1 ines for ${ }^{239} \mathrm{Pu}$ osteosarcoma animals $(\Delta)$, non-tumor animals $(0)$ and ${ }^{241}$ Am-injected non-tumor animals ( $\square)$. The dashed portion of the line represents extrapolated data. Female animals injected at dose levels 1, 3 and 5 are on the left, with comparable doses for males in the right hand column. The $95 \%$ confidence limit for elevated SGOT is 38 units. 

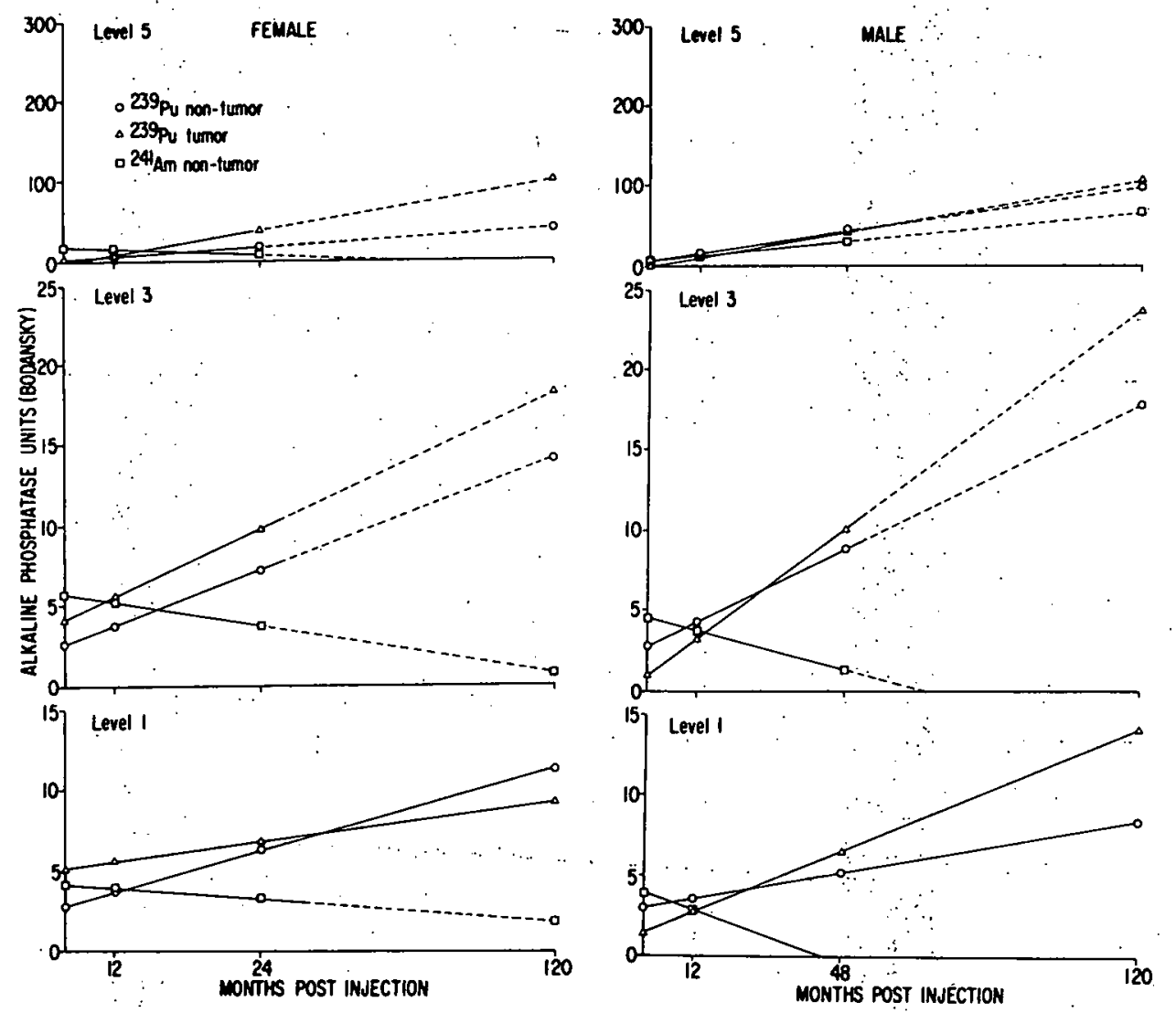

Figure 3. Regresșion lines for serum alkaline phosphatase measurements in beagles bearing $239 \mathrm{Pu}$ or ${ }^{241} \mathrm{Am}$ burdens. Data for ${ }^{239} \mathrm{Pu}$ osteosarcoma dogs $(\Delta)$, non-tumor dogs $(0)$ and ${ }^{241}$ Am non-tumor (D) animals were analyzed by multivariable regression analysis. The dashed portion of the line represents extrapolated data. Female animals bearing 1, 3 and 5 level doses are graphed on the left and comparable males on the right. 


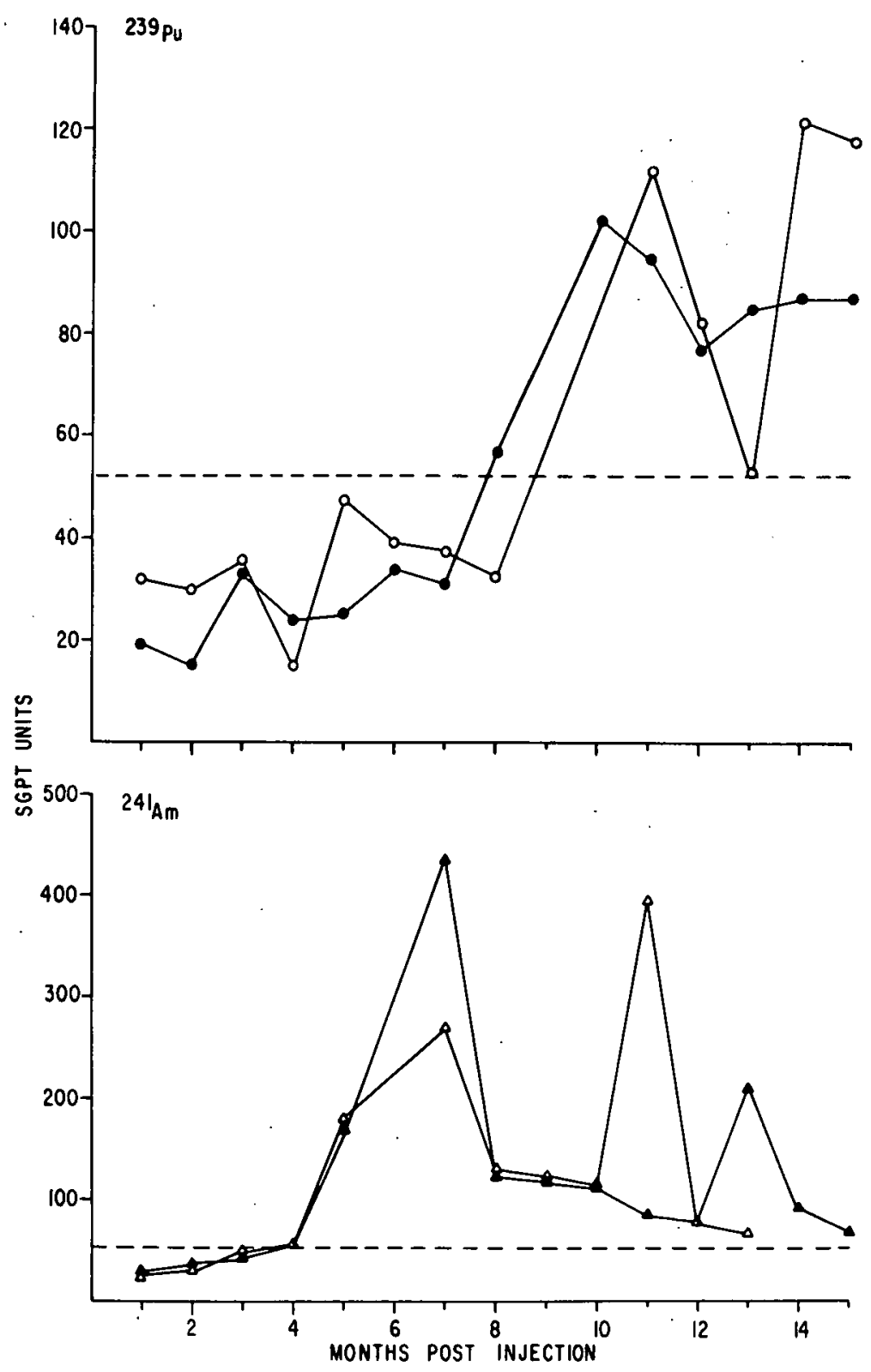

i.

1

Figure 4. Individual SGPT measurements for four 5 level dogs. The time scale on the abcissa is the same for both graphs, with the exception of the interruptions in the plutonium dogs' graph. Note the difference in the values for SGPT units on the ordinates of the two graphs. The horizontal lines represent the $95 \%$ confidence level for elevated measurements. The dogs, sexes and graph symbols are as follows: T41P5 $(q, 0) ; \operatorname{T53P5}\left(0^{7}, 0\right) ; \operatorname{TIW5}\left(0^{n}, \Delta\right) ; \operatorname{T2W5}\left(0^{\pi}, \Delta\right)$. 


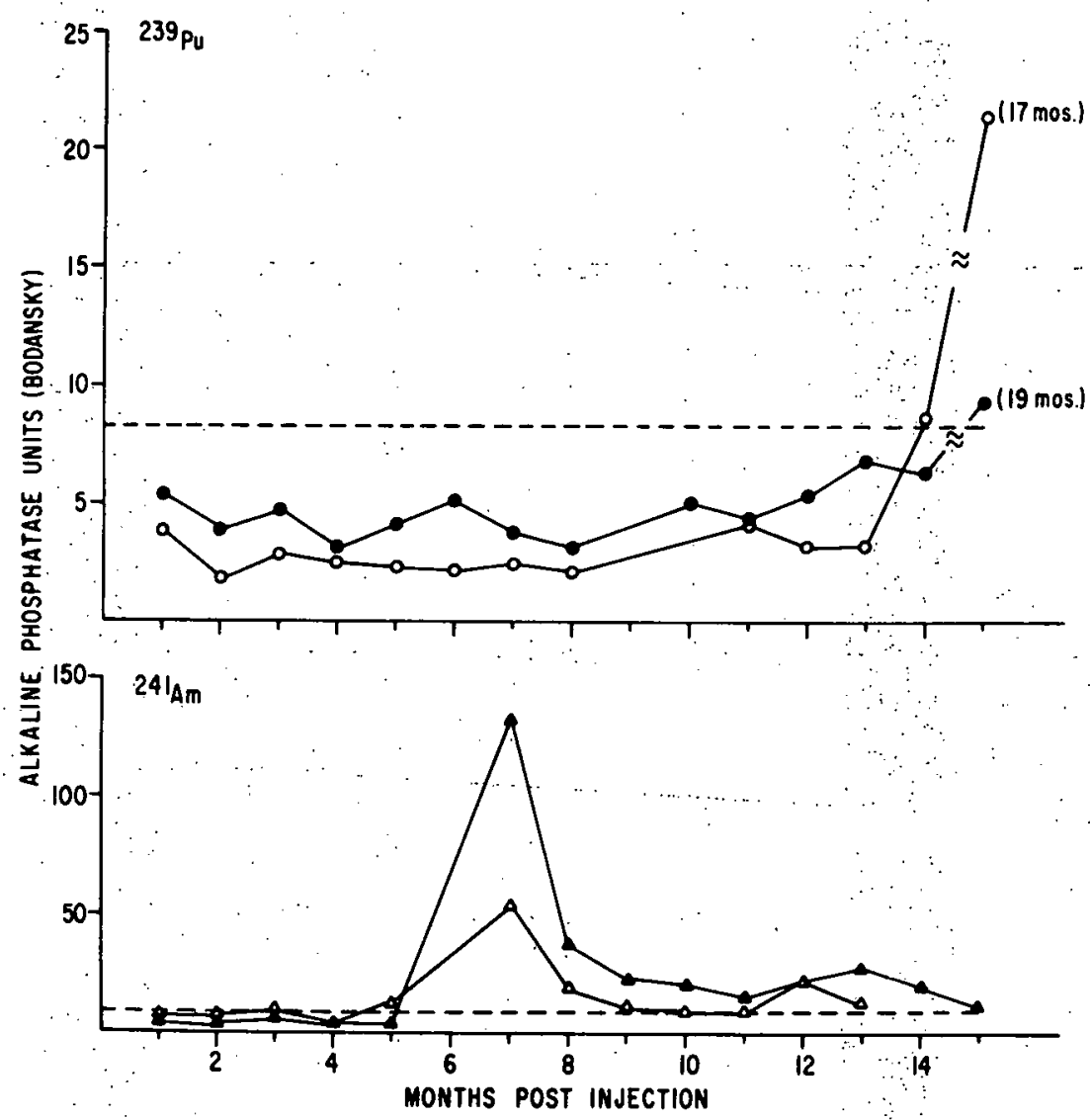

Figure 5. Serumalkaline phosphatase values in four 5 jevel animals measured for the first 15 months post-injection. Note the different values for alkaline phosphatase units on the ordinates of the two graphs: The horizontal lines represent $95 \%$ confidence levels for elevated measurements. The dogs, sexes and graph symbols are as follows: $\operatorname{T41P5}(q, 0) ; \operatorname{T53P5}\left(3^{\prime \prime}, 0\right) ; \operatorname{TIW}\left(0^{2}, \Delta\right) ; \operatorname{T2W5}\left(0^{3}, \Delta\right)$ 
Maximum likelihood estimators for slopes of regression lines

SLOPE $=c+d(\mu \mathrm{c} / \mathrm{kg})$

\begin{tabular}{|c|c|c|c|c|c|c|c|c|c|c|c|}
\hline \multicolumn{4}{|c|}{$\begin{array}{c}1 \text { LEVEL } \\
.016 \mu \mathrm{c} / \mathrm{kg}\end{array}$} & \multicolumn{4}{|c|}{$\begin{array}{l}3 \mathrm{LEVEL} \\
.30 \mathrm{\mu c} / \mathrm{kg}\end{array}$} & \multicolumn{4}{|c|}{$\begin{array}{c}5 \text { LEVEL } \\
2.8 \mathrm{\mu c} / \mathrm{kg}\end{array}$} \\
\hline TEST & $\frac{\text { TUMOR }}{\mathrm{Pu}}$ & \multicolumn{2}{|c|}{ NON TUMOR } & TEST & $\frac{\text { TUMOR }}{\mathrm{Pu}}$ & \multicolumn{2}{|c|}{ NON TUMOR } & TEST & $\frac{\text { TUMOR }}{\mathrm{Pu}}$ & PON T & $\frac{\text { JMOR }}{W}$ \\
\hline$\underline{\text { SGPT }}$ & & & & SGPT & & & & SGPT & & & \\
\hline $\begin{array}{l}\text { Female } \\
\text { Male }\end{array}$ & $\begin{array}{l}.031 \\
.480\end{array}$ & $\begin{array}{l}.722 \\
.469\end{array}$ & $\begin{array}{l}-.037 \\
-.285\end{array}$ & $\begin{array}{l}\text { Female } \\
\text { Male }\end{array}$ & $\begin{array}{r}.074 \\
3.396\end{array}$ & $\begin{array}{l}1.269 \\
1.50\end{array}$ & $\begin{array}{l}.077 \\
.080\end{array}$ & $\begin{array}{l}\text { Female } \\
\text { Male }\end{array}$ & $\begin{array}{c}8.4274 \\
29.063\end{array}$ & $\begin{array}{c}6.0782 \\
10.571\end{array}$ & $\begin{array}{l}1.0731 \\
3.2902\end{array}$ \\
\hline SGOT & & & & SGOT & & & & SGOT & & & \\
\hline $\begin{array}{l}\overline{\text { Female }} \\
\text { Male }\end{array}$ & $\begin{array}{l}.051 \\
.045\end{array}$ & $\begin{array}{l}.045 \\
.205\end{array}$ & $\begin{array}{r}.121 \\
-.308\end{array}$ & $\begin{array}{l}\text { Female } \\
\text { Male }\end{array}$ & $\begin{array}{l}.177 \\
.549\end{array}$ & $\begin{array}{l}.290 \\
.574\end{array}$ & $\begin{array}{r}.156 \\
-.076\end{array}$ & $\begin{array}{l}\text { Female } \\
\text { Male }\end{array}$ & $\begin{array}{l}1.2839 \\
4.9817\end{array}$ & $\begin{array}{l}2.4499 \\
3.82\end{array}$ & $\begin{array}{l}.4647 \\
1.967\end{array}$ \\
\hline Alk. $\mathrm{Ph}$ & os. & & & Alk. $\mathrm{Pr}$ & os. & & & Alk. Ph & os. & . & \\
\hline $\begin{array}{l}\text { Female } \\
\text { Male }\end{array}$ & $\begin{array}{l}.036 \\
.107\end{array}$ & $\begin{array}{l}.071 \\
.046\end{array}$ & $\begin{array}{l}-.018 \\
-.111\end{array}$ & $\begin{array}{l}\text { Female } \\
\text { Male }\end{array}$ & $\begin{array}{l}.120 \\
.189\end{array}$ & $\begin{array}{l}.096 \\
.122\end{array}$ & $\begin{array}{l}-.040 \\
-.049\end{array}$ & $\begin{array}{l}\text { Female } \\
\text { Male }\end{array}$ & $\begin{array}{l}.8623 \\
.9108\end{array}$ & $\begin{array}{l}.314 \\
.7885\end{array}$ & $\begin{array}{l}.23 \\
.499\end{array}$ \\
\hline
\end{tabular}

Table 1. The slopes of the regression lines for SGPT, SGOT and serum alkaline phosphatase, calculated for three dose levels. 